\title{
Hydrogeology Along the Southern Boundary of the Hanford Site Between the Yakima and Columbia Rivers, Washington
}

T. L. Liikala

September 1994

Prepared for

the U.S. Department of Energy

under Contract DE-AC06-76RLO 1830

Pacific Northwest Laboratory

Richland, Washington 99352 



\section{DISCLAIMER}

This report was prepared as an account of work sponsored by an agency of the United States Government. Neither the United States Government nor any agency thereof, nor any of their employees, make any warranty, express or implied, or assumes any legal liability or responsibility for the accuracy, completeness, or usefulness of any information, apparatus, product, or process disclosed, or represents that its use would not infringe privately owned rights. Reference herein to any specific commercial product, process, or service by trade name, trademark, manufacturer, or otherwise does not necessarily constitute or imply its endorsement, recommendation, or favoring by the United States Government or any agency thereof. The views and opinions of authors expressed herein do not necessarily state or reflect those of the United States Government or any agency thereof. 


\section{DISCLAIMER}

Portions of this document may be illegible in electronic image products. Images are produced from the best available original document. 


\section{Preface}

This report was originally published in May 1993 as a thesis for the degree of Master of Science with a major in hydrology through the University of Idaho. Research for the report was conducted between June 1989 and May 1990. The report contains valuable information on the hydrogeology along the southern boundary of the Hanford Site; therefore, the Ground-Water Surveillance Project agreed to publish it as a Pacific Northwest Laboratory technical report.

Because the report was published in 1993, references are made to activities, organizations, and/or previous investigations that were pertinent at the time, but may no longer be applicable, or have since been updated. Hence, the report remains essentially as it was originally written. 
, 


\section{Summary}

The 1100 and 3000 Areas are located along the southern boundary of the U.S. Department of Energy's (DOE) Hanford Site, near the city of Richland, Washington. Hazardous wastes have been discharged to the ground within the 1100 and 3000 Areas, and the city of Richland is considering annexing all or a portion of these areas.

The purpose of this study was to describe the hydrogeologic framework along the southern boundary of the Hanford Site as a basis for the Comprehensive Environmental Response, Compensation, and Liability Act (CERCLA) and Superfund Amendments and Reauthorization Act (SARA) of 1986 investigations and potential annexation by the city of Richland. The general objective was to characterize the unconfined ground-water flow system between the Columbia and Yakima rivers in support of future hazardous waste site investigations and ground-water and land-use management. Study activities were coordinated through the Hanford contractors to complement ongoing CERCLA/SARA investigations in the study area.

The 1100 and 3000 Areas and the adjacent lands are underlain by the Saddle Mountains Basalt Formation and sediments of the Ringold Formation and Hanford formation. An unconfined aquifer occurs within the Ringold and Hanford sediments. The North Richland well field, which serves as the secondary water-supply system for the city of Richland, taps the unconfined aquifer. Several of the disposal sites within the 1100 and 3000 Areas and other nearby industries are hydraulically upgradient of the well field.

The unconfined ground-water flow system between the Yakima and Columbia rivers was characterized in this study using site hydrogeology and spatial and temporal distribution of hydraulic head within the aquifer. An inventory of existing wells was made and water-level measurements were taken for a period of 1 year. Study results show that ground water in the unconfined aquifer flows generally west to east toward the Columbia River. Currently, the net recharge pumped to the North Richland well field has the most significant impact on water levels and hydraulic gradients for the unconfined aquifer; flow is altered by a ground-water mound beneath the well field. No impacts are evident at this time from farming west of the 1100 Area or farming and lawn irrigation in the 3000 Area. Ground-water levels near the Columbia River are influenced by fluctuations in river elevation.

Additional data needs for future hazardous waste site investigations and Richland corporate annexation of the 1100 and 3000 Areas have been identified. These needs are focused in four areas: 1) well maintenance and rehabilitation, 2) hydrogeologic characterization, 3) ground-water monitoring, and 4) ground-water management. 


\section{Acknowledgments}

I would like to thank the staff members from Pacific Northwest Laboratory and the Northwest College and University Association for Science who contributed their time and funding to this study. Special thanks go to George Last and Bob Bryce for their guidance and support throughout. I would like to thank Dr. Dale Ralston for his direction and persistence. I thank Drs. Roy Williams, Dennis Horn, and Frank Spane for their constructive reviews. Thanks also to Wayne Gorst and Georganne O'Connor for editorial review. 


\section{Contents}

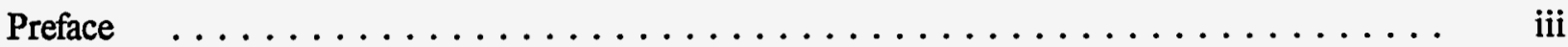

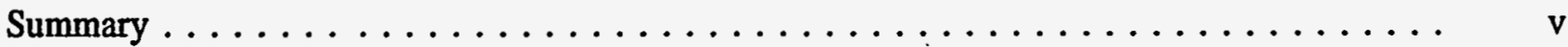

Acknowledgments $\quad \ldots \ldots \ldots \ldots \ldots \ldots \ldots \ldots \ldots \ldots \ldots \ldots \ldots$ vii

1.0 Introduction $\ldots \ldots \ldots \ldots \ldots \ldots \ldots \ldots \ldots \ldots \ldots \ldots \ldots \ldots \ldots \ldots \ldots$

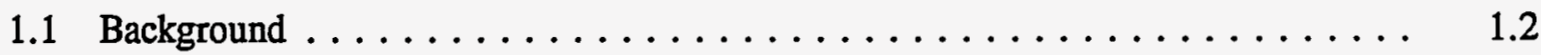

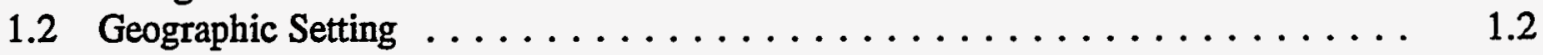

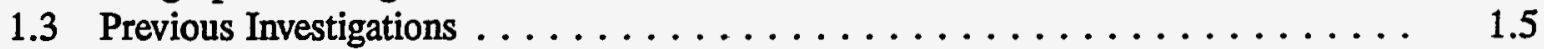

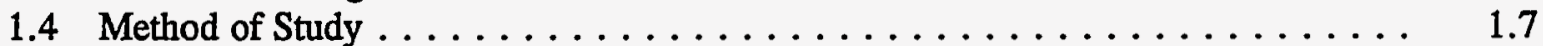

2.0 Regional Hydrogeology $\ldots \ldots \ldots \ldots \ldots \ldots \ldots \ldots \ldots \ldots \ldots \ldots \ldots \ldots \ldots$

2.1 Geology of the Pasco Basin $\ldots \ldots \ldots \ldots \ldots \ldots \ldots \ldots \ldots \ldots \ldots \ldots$

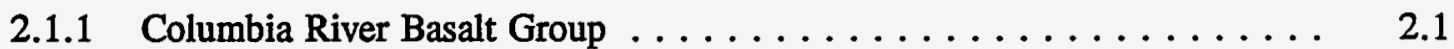

2.1 .2 Ringold Formation ...................... 2.1

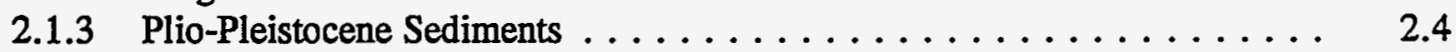

2.1.4 Hanford Formation ....................... 2.4

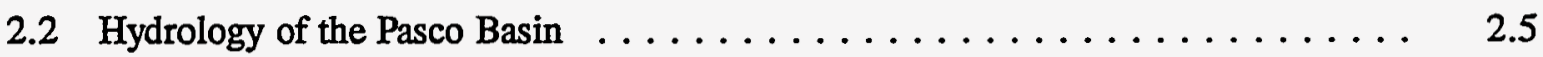

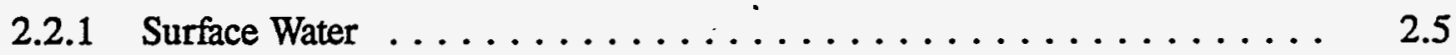

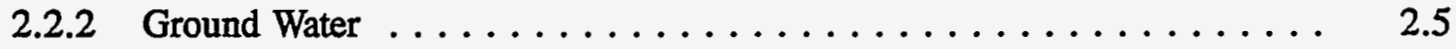

3.0 Study Area Hydrogeology $\ldots \ldots \ldots \ldots \ldots \ldots \ldots \ldots \ldots \ldots \ldots \ldots \ldots \ldots \ldots$

3.1 Existing Well Inventory $\ldots \ldots \ldots \ldots \ldots \ldots \ldots \ldots \ldots \ldots \ldots \ldots \ldots \ldots \ldots$

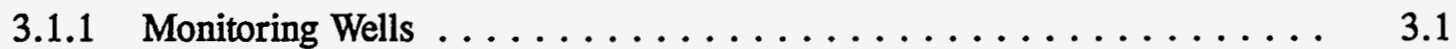

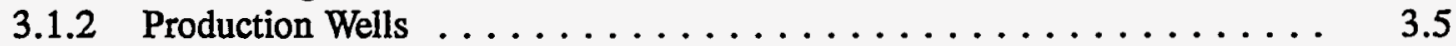

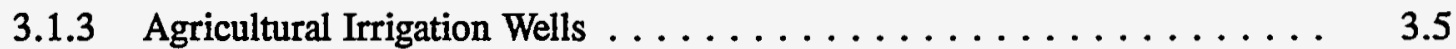

3.1 .4 Other Wells .......................... 3.5

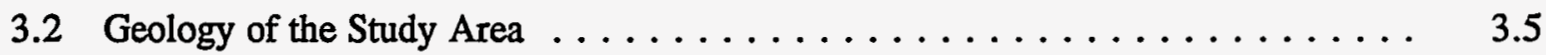

3.2.1 Saddle Mountains Basalt Formation $\ldots \ldots \ldots \ldots \ldots \ldots \ldots \ldots$

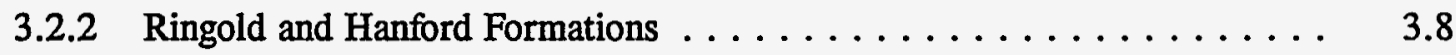


3.3 Hydrology of the Study Area $\ldots \ldots \ldots \ldots \ldots \ldots \ldots \ldots \ldots \ldots \ldots$

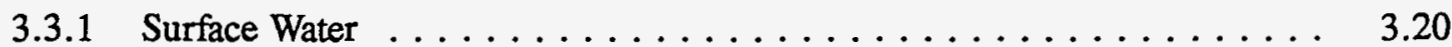

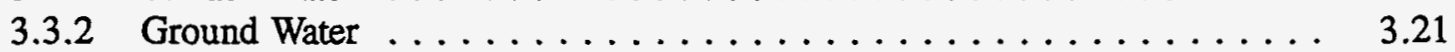

3.4 Hydrogeologic Conceptual Model of the Unconfined Ground-Water

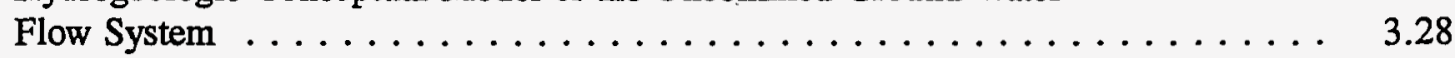

4.0 Hydraulic Head Distribution $\ldots \ldots \ldots \ldots \ldots \ldots \ldots \ldots \ldots \ldots \ldots \ldots$

4.1 Description of the Water-Level Monitoring Network $\ldots \ldots \ldots \ldots \ldots \ldots \ldots$

4.1 .1 Electric/Steel Tapes $\ldots \ldots \ldots \ldots \ldots \ldots \ldots \ldots \ldots \ldots \ldots . \ldots \ldots . \ldots \ldots$

4.1 .2 Continuous Water-Level Recorders . . . . . . . . . . . . . 4.5

4.1 .3 Transducers and Data Loggers . . . . . . . . . . . . . . . 4.5

4.1 .4 Other Water-Level Data . . . . . . . . . . . . . . . 4.7

4.2 Hydraulic Head Distribution $\ldots \ldots \ldots \ldots \ldots \ldots \ldots \ldots \ldots \ldots \ldots$

4.2.1 Spatial Distribution of Hydraulic Head . . . . . . . . . . . . . 4.7

4.2.2 Temporal Distribution of Hydraulic Head . . . . . . . . . . 4.9

4.3 Operations and Impacts of the North Richland Well Field . . . . . . . . . 4.11

4.4 Operations and Impacts of the Agricultural, Residential-Lawn, and Waste-Water

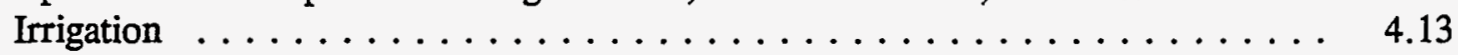

4.4.1 Farming West of the 1100 Area . . . . . . . . . . . . . . . 4.17

4.4 .23000 Area Farming and PNL Lawn Irrigation . . . . . . . . . . 4.20

4.4 .3 Residential-Lawn and Waste-Water Irrigation $\ldots \ldots \ldots \ldots \ldots \ldots . . \ldots .22$

4.5 Interrelationship with the Yakima and Columbia Rivers $\ldots \ldots \ldots \ldots \ldots . \ldots \ldots$

5.0 Discussion of Results and Additional Data Needs for CERCLA/SARA Investigations and Richland Corporate Annexation $\ldots \ldots \ldots \ldots \ldots \ldots \ldots \ldots \ldots \ldots \ldots \ldots \ldots \ldots$

5.1 Discussion of Results $\ldots \ldots \ldots \ldots \ldots \ldots \ldots \ldots \ldots \ldots \ldots \ldots \ldots$

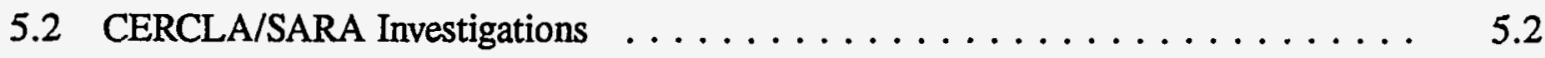

5.2 .1 Well Maintenance and Rehabilitation ................ 5.2

5.2 .2 Hydrogeologic Characterization . . . . . . . . . . . . . . 5.2

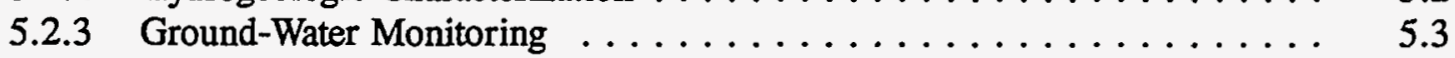

5.3 Richland Corporate Annexation $\ldots \ldots \ldots \ldots \ldots \ldots \ldots \ldots$

6.0 Conclusions $\ldots \ldots \ldots \ldots \ldots \ldots \ldots \ldots \ldots \ldots \ldots \ldots \ldots \ldots \ldots \ldots \ldots$ 
7.0 Additional Data Needs $\ldots \ldots \ldots \ldots \ldots \ldots \ldots \ldots \ldots \ldots \ldots \ldots \ldots \ldots$

8.0 References Cited $\ldots \ldots \ldots \ldots \ldots \ldots \ldots \ldots \ldots \ldots \ldots \ldots \ldots \ldots$

APPENDIX A - Well Construction and Lithologic Diagrams . . . . . . . . . . A.1

APPENDIX B - Water-Level Data $\ldots \ldots \ldots \ldots \ldots \ldots \ldots \ldots \ldots \ldots \ldots$

APPENDIX C - Water-Level Elevation Maps for June 1989 and August 1989

through May $1990 \ldots \ldots \ldots \ldots \ldots \ldots \ldots \ldots \ldots \ldots \ldots$ C. 1

APPENDIX D - Hydrographs for the Water-Level Monitoring Network $\ldots \ldots \ldots \ldots \ldots$. . . . .

Plates 1 Through $5 \ldots \ldots \ldots \ldots \ldots \ldots \ldots \ldots \ldots \ldots \ldots$ In Pocket 


\section{Figures}

1.1 Generalized Location Map of the Study Area $\ldots \ldots \ldots \ldots \ldots \ldots$

1.2 Map of the Study Area, June $1989 \ldots \ldots \ldots \ldots \ldots \ldots \ldots \ldots \ldots$

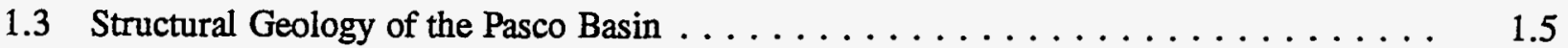

2.1 Generalized Geologic Cross Section Through the Central Pasco Basin $\ldots \ldots \ldots$. . . 2.2

2.2 Pasco Basin Stratigraphy $\ldots \ldots \ldots \ldots \ldots \ldots \ldots \ldots \ldots \ldots \ldots \ldots \ldots$

2.3 Distribution of Ringold Formation Section Types Within the

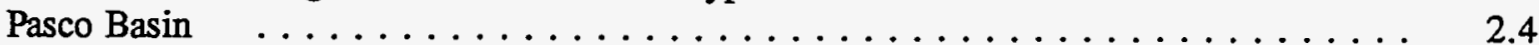

2.4 Major Surface-Water Features Within the Pasco Basin $\ldots \ldots \ldots \ldots \ldots \ldots$

2.5 Generalized Hydrologic Cross Section Through the

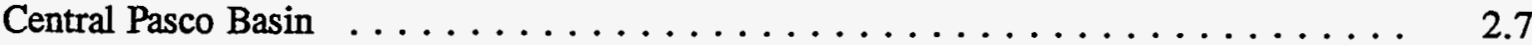

2.6 Hanford Site Water-Table Elevations, June $1989 \ldots \ldots \ldots \ldots \ldots \ldots$

3.1 Wells Used to Provide Hydrogeologic Data for the Study Area $\ldots \ldots \ldots \ldots \ldots . \ldots$

3.2 Potato Farming, 1989 Growing Season $\ldots \ldots \ldots \ldots \ldots \ldots$

3.3 Potato Farming, 1990 Growing Season $\ldots \ldots \ldots \ldots \ldots \ldots \ldots \ldots$

3.4 Generalized Geologic Column for the Study Area $\ldots \ldots \ldots \ldots \ldots$

3.5 Locations of the Study Area Cross Sections $\ldots \ldots \ldots \ldots \ldots \ldots \ldots \ldots$

3.6 Top of Basalt Map for the Study Area $\ldots \ldots \ldots \ldots \ldots \ldots \ldots \ldots \ldots$

3.7 Top of Silty Clay Lithofacies Map $\ldots \ldots \ldots \ldots \ldots \ldots \ldots \ldots \ldots \ldots$

3.8 Top of Gravelly Sand to Silty Clay Lithofacies Map $\ldots \ldots \ldots \ldots \ldots \ldots$

3.9 Top of Sandy Gravel Lithofacies Map $\ldots \ldots \ldots \ldots \ldots \ldots \ldots \ldots$

3.10 Generalized Hydrofacies Diagram for the Study Area $\ldots \ldots \ldots \ldots \ldots . \ldots \ldots$

3.11 Isopach Map for the Silty Clay Lens $\ldots \ldots \ldots \ldots \ldots \ldots \ldots \ldots \ldots \ldots$

3.12 Study Area Water-Level Elevations, July $1989 \ldots \ldots \ldots \ldots$. . . . . . . . . . . . . . 3.29 
3.13 Isopach Map for the Unsaturated Sediments $\ldots \ldots \ldots \ldots \ldots \ldots$

4.1 Water-Level Monitoring Network for the Study Area $\ldots \ldots \ldots \ldots \ldots \ldots$

4.2 Hydrographs for Selected Wells Across the Study Area $\ldots \ldots \ldots \ldots \ldots$

4.3 Recharge and Production Volumes for June 1989 to May $1990 \ldots \ldots \ldots \ldots$. . . . . . 42

4.4 Hydrologic Cross Section A-A' to the North of the Well Field . . . . . . . . . . . 4.14

4.5 Hydrologic Cross Section B-B' to the South of the Well Field . . . . . . . . . 4.15

4.6 Net Water-Level Changes Between July 1989 and January 1990 . . . . . . . . . 4.16

4.7 Minimum Depth to Water Below Land Surface for June 1989 to May $1990 \ldots \ldots$. . . . . 4.18

4.8 Potato Farming, 1991 Growing Season $\ldots \ldots \ldots \ldots \ldots \ldots \ldots \ldots \ldots \ldots \ldots$

\section{Tables}

2.1 Hydraulic Property Estimates for the Unconfined Aquifer Within the Pasco Basin $\ldots \ldots$ 2.8

3.1 Completion Data for the Study Area Wells $\ldots \ldots \ldots \ldots \ldots \ldots \ldots$

3.2 Formation Depths, Elevations, and Thicknesses Beneath the Study Area . . . . . . 3.10

3.3 General Characteristics of the Geologic Formations Beneath the Study Area . . . . . 3.12

3.4 Hydrofacies Depths, Elevations, and Thicknesses Beneath the Study Area . . . . . . 3.23

3.5 Hydraulic Property Estimates Within and Adjacent to the Study Area . . . . . . . 3.25

4.1 Completion Distribution for the Water-Level Monitoring Network . . . . . . . . . 4.2

4.2 Monthly Water-Level Elevations Used for Analysis and Interpretation . . . . . . . . . 4.3

4.3 Continuous Water-Level Recorder Inventory $\ldots \ldots \ldots \ldots \ldots \ldots \ldots$

4.4 Horizontal Hydraulic Gradients for the Unconfined Aquifer Beneath the

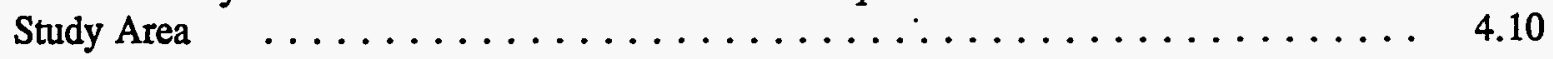

4.5 Horizontal Hydraulic Gradients for the Unconfined Aquifer Near the North Richland Well Field . . . . . . . . . . . . . . . . . . 4.17

4.6 Estimated Monthly Maximum Volumes of Irrigation Applied $\ldots \ldots \ldots \ldots \ldots$ 


\subsection{Introduction}

U.S. Department of Energy (DOE) operations at the Hanford Site, located in southeastern Washington, have generated large volumes of hazardous and radioactive wastes since 1944. Some of the hazardous wastes were discharged to the ground in the 1100 and 3000 Areas, near the city of Richland. The specific waste types and quantities are unknown; however, they probably include battery acid, antifreeze, hydraulic fluids, waste oils, solvents, degreasers, paints, and paint thinners.

Disposal sites within the 1100 and 3000 Areas are regulated by the Comprehensive Environmental Response, Compensation, and Liability Act (CERCLA) of 1980 as amended by the Superfund Amendments and Reauthorization Act (SARA) of 1986. This law requires hydrogeologic investigation, risk assessment, and cleanup of inactive hazardous waste disposal sịtes.

The city of Richland is considering annexing all or a portion of the 1100 and 3000 Areas. In addition, several of the disposal sites are hydraulically upgradient of the North Richland well field, which serves as the secondary water-supply system for the city of Richland. This water-supply system consists of a settling basin and two recharge basins adjacent to pumping wells completed in the unconfined aquifer. Water from the Columbia River is pumped into the settling basin, discharged through a flow divider into the recharge basins, allowed to infiltrate, and then pumped from the wells for use. Historical data indicate that operation of this system has a significant impact on water levels and hydraulic gradients in the area. ${ }^{\text {(a) }}$

Additional sites or features in the vicinity of the 1100 and 3000 Areas that may affect the groundwater quantity and/or quality include:

- city of Richland landfill

- Horn Rapids landfill

- Siemens Power Corp. facilities for producing commercial nuclear fuel

- Lamb-Weston Inc. potato processing plant

- Irrigated agricultural fields and lawns

- Yakima and Columbia rivers.

Collection, analysis, and documentation of hydrogeologic data near the 1100 and 3000 Areas are necessary to provide a basis for CERCLA/SARA investigations and ground-water and land-use management. Information on the unconfined aquifer is important in understanding ground-water flow and contaminant transport characteristics. Limited research has been conducted in these areas to define the distribution and concentrations of selected wastes in soil samples and the ground water.

The purpose of this study was to describe the hydrogeologic framework along the southern boundary of the Hanford Site as a basis for CERCLA/SARA investigations and Richland corporate annexation. The general objective was to characterize the unconfined ground-water flow system

(a) Freshley, M. D., M. P. Bergeron, and N. J. Aimo. 1989. Ground-Water Modeling Investigation of North Richland Well Field and the 1100 Area, Letter Report. Pacific Northwest Laboratory, Richland, Washington. 
between the Yakima and Columbia rivers in support of future hazardous waste site investigations and ground-water and land-use management. The specific objectives were to

- collect and review existing hydrogeologic data for the study area and establish a water-level monitoring network

- describe the regional and study area hydrogeology

- develop a hydrogeologic conceptual model of the unconfined ground-water flow system beneath the study area, based on available data

- describe the flow characteristics of the unconfined aquifer based on the spatial and temporal distribution of hydraulic head within the aquifer

- use the results of this study to delineate additional data needs in support of future Remedial Investigation/Feasibility Studies (RI/FS), Fate and Transport modeling, Baseline Risk Assessments (BRA), and ground-water and land-use management.

These activities were coordinated through the Hanford contractors to complement ongoing CERCLA/SARA investigations in the study area.

\subsection{Background}

The study area is located along the southern boundary of the Hanford Site in southeastern Washington (Figure 1.1) and covers approximately $25 \mathrm{mi}^{2}$ with a primary focus on the sediments overlying the basalt bedrock. The study area is bounded to the west and east by the Yakima and Columbia rivers, respectively (Figure 1.2). The northern boundary parallels Horn Rapids Road, and the southern boundary is near the city of Richland. The study area varies in elevation from approximately $515 \mathrm{ft}$ above mean sea level (msl) near the city of Richland landfill to $340 \mathrm{ft}$ above msl along the Columbia River.

\subsection{Geographic Setting}

The Hanford Site overlies the central Pasco Basin within the Columbia Basin physiographic subprovince of the Columbia Intermontane Province. The Hanford Site covers approximately $560 \mathrm{mi}^{2}$ and is used for reactor and fuel processing operations and waste storage and disposal. The adjacent lands to the north, west, and east are primarily range and agricultural lands. The Tri-Cities (Richland, Kennewick, and Pasco) constitute the nearest population center and are located southeast of the Site.

The Hanford Site is bounded to the north, west, and southwest by several structural anticlinal ridges (Figure 1.3). These large basaltic ridges trend to the east and southeast.' The Site is bounded to the east by the Columbia River and to the south by the Yakima River and city of Richland. Elevations vary from approximately $3580 \mathrm{ft}$ above msl on Rattlesnake Mountain at the southwestern border of the Site to $340 \mathrm{ft}$ above msl along the Columbia River within the study area.

The Hanford Site is located in the rain shadow formed by the Cascade Mountains. Precipitation on the Site averages 6.25 in. annually (Stone et al. 1983). More than $40 \%$ of this precipitation occurs from November to January, and approximately $38 \%$ occurs as snow from December to February. 


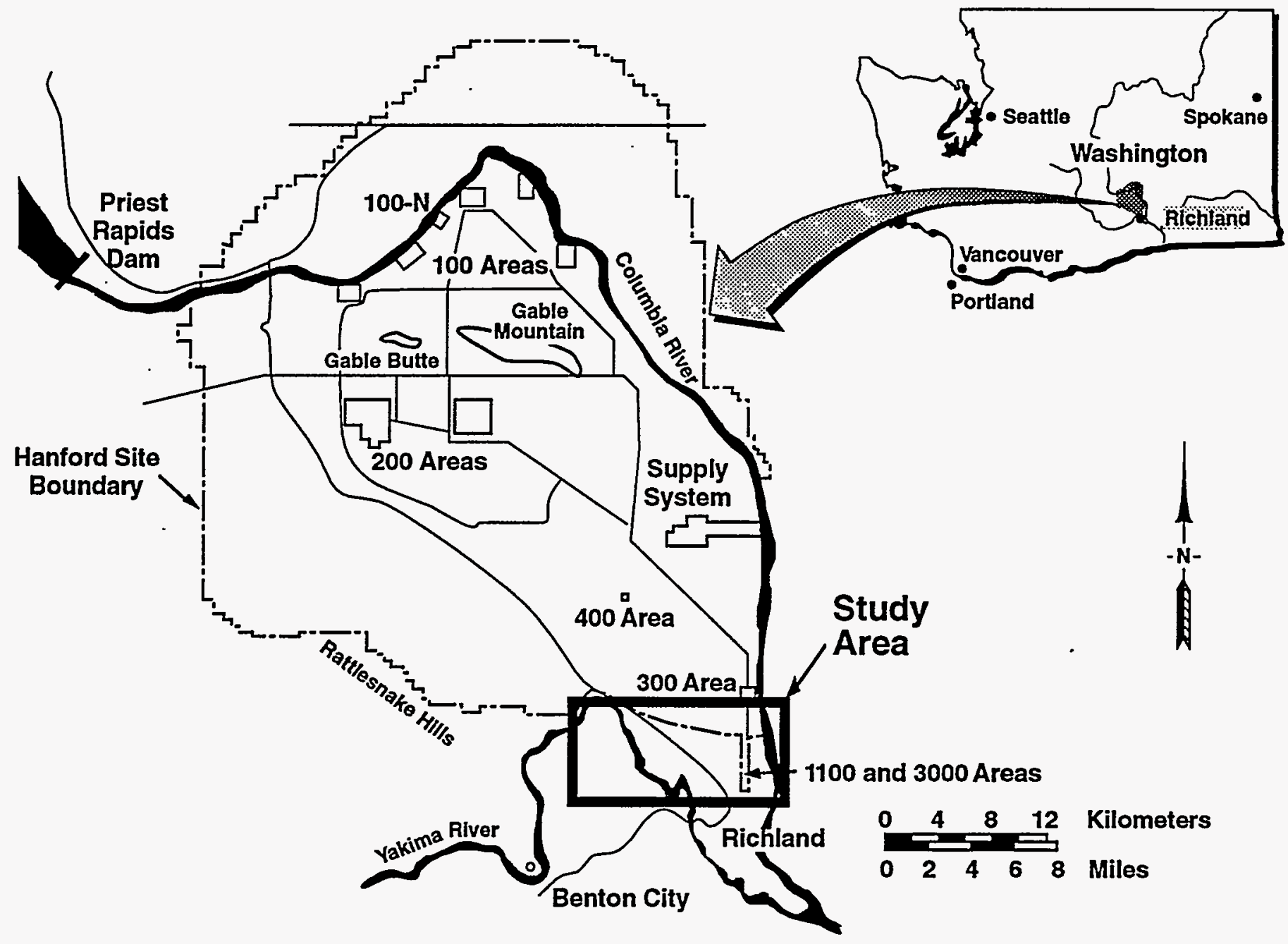

S9304073.10

Figure 1.1 Generalized Location Map of the Study Area

Prevailing winds at the Hanford Site are west-northwest and northwest year around. The Cascade Mountains serve as a source of cold air drainage and cause topographic wind channeling. Average hourly wind speeds in July vary from 5 to $13 \mathrm{mph}$, whereas the average hourly wind speed in January is $6 \mathrm{mph}$.

Temperature variations at the Hanford Site reflect the proximity to the Cascade Mountains. Colder temperatures occur in the winter and warmer temperatures in the summer than would occur without the mountains. Winter minima range from -27 to $22^{\circ} \mathrm{F}$ and summer maxima from 100 to $115^{\circ} \mathrm{F}$ (Stone et al. 1983). 


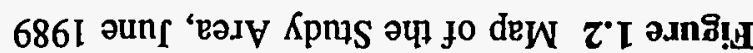

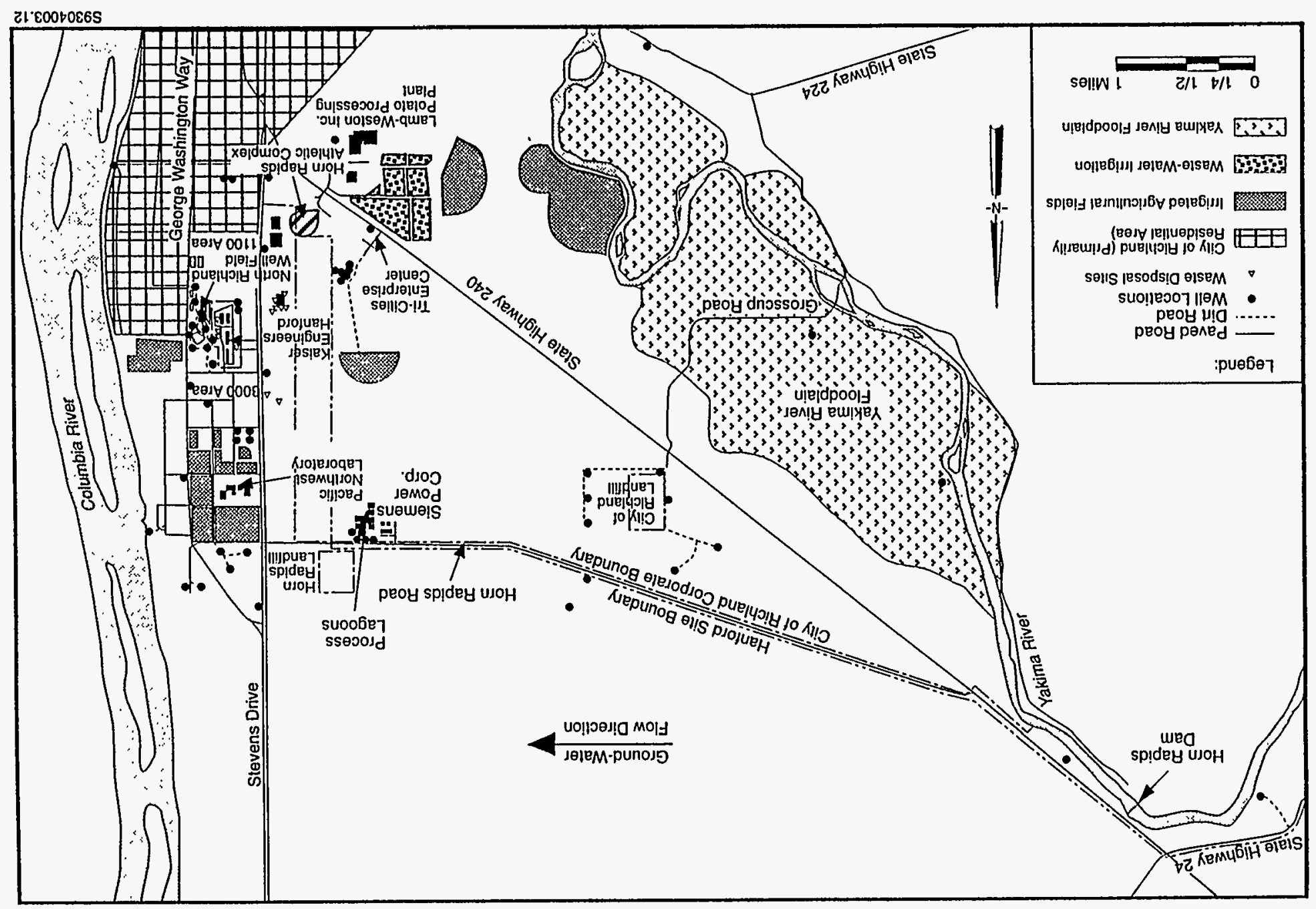




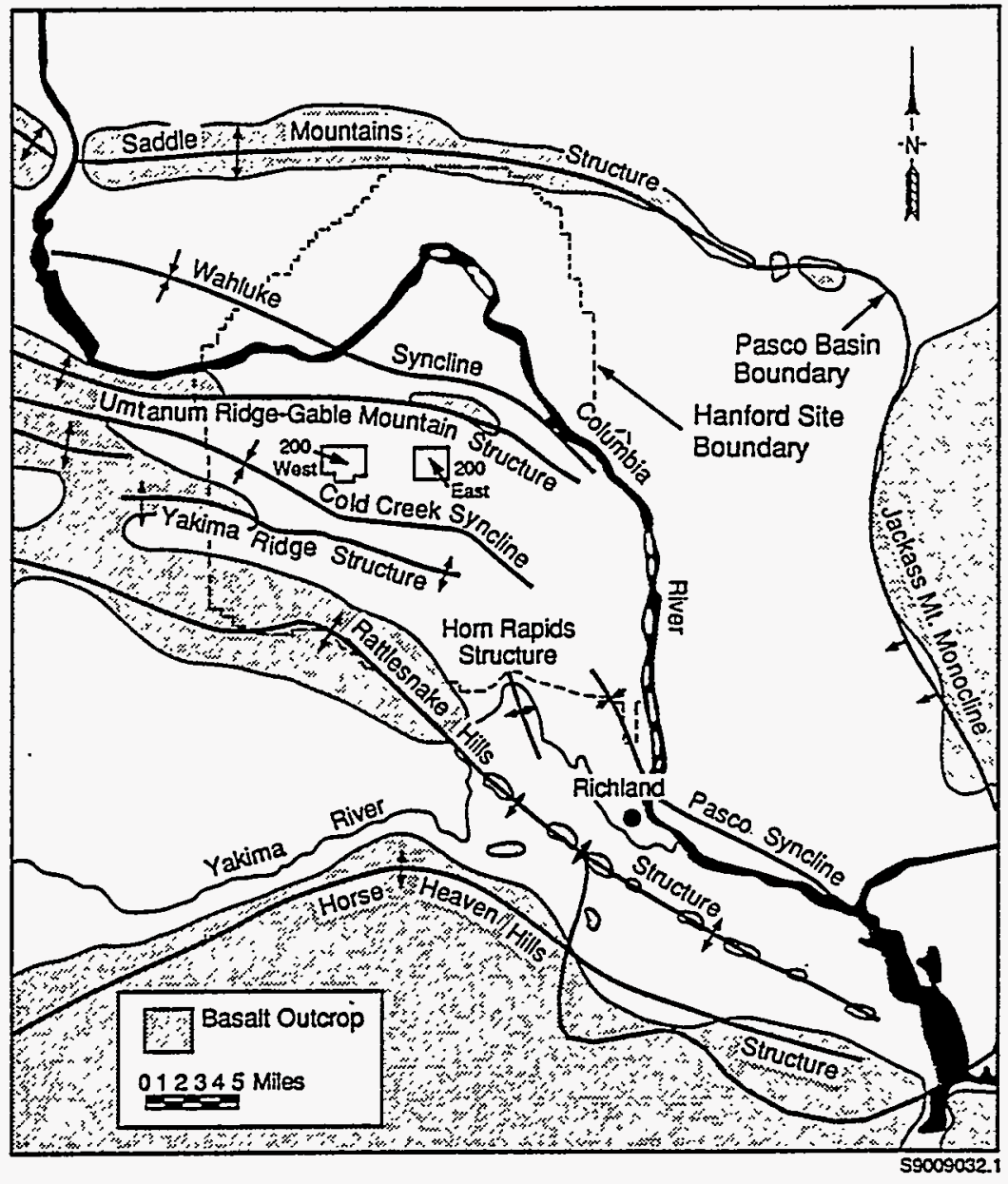

Figure 1.3 Structural Geology of the Pasco Basin (modified from DOE 1988a)

\subsection{Previous Investigations}

Numerous geologic and hydrogeologic reports and papers are published on the Columbia Intermontane Province, Columbia Basin subprovince, Pasco Basin, and Hanford Site. Research most relevant to this study is discussed below.

DOE $(1988 \mathrm{a}, \mathrm{b})$ provided a comprehensive description of the hydrogeologic setting for the Columbia Intermontane Province. This report was submitted as part of the process for siting a nuclear waste repository at the Hanford Site under the Basalt Waste Isolation Project.

Newcomb et al. (1972) described the general geologic and hydrologic conditions at the Hanford Site. Stratigraphic relations, direction and rate of ground-water movement, natural and artificial effects on the water table, aquifer coefficients, and contaminant migration were presented. 
Brown (1979) presented an overview of the Pasco Basin suprabasalt hydrogeology for areas adjacent to the Hanford Site. Lithostratigraphic units, hydraulic properties, and flow characteristics of the unconfined aquifer were discussed. Transmissivity values were tabulated for over 200 wells.

Lindberg and Bond (1979) assessed the ground-water flow and transport system beneath the 300 Area, located northeast of the study area. Ground-water flow directions, natural and artificial effects on the water table, water chemistry data, and numerical modeling results were presented.

Schalla et al. (1988) contains information on the Hazardous Waste Ground-Water Monitoring Compliance Program for the 300 Area Process Trenches. This document is a compilation of preliminary results including hydrogeologic characterization, ground-water monitoring, geochemistry, and numerical modeling. The process trenches are regulated by the Resource Conservation and Recovery Act (RCRA) of 1976 as amended by the Hazardous and Solid Waste Amendments of 1984.

Fecht and Lillie (1982) and McGhan (1989) provided lithologic logs and construction data, respectively, for several wells within the study area. Hard copy borehole and geophysical logs are maintained by Pacific Northwest Laboratory (PNL). Several logs are available in PNL's Hanford Ground-Water Data Base (HGWDB).

Bryce (1989) outlined the well installation and ground-water sampling plan for five monitoring wells in the 1100 Area. Bryce and Goodwin (1989) contains data collected during installation and initial sampling of the five wells including geologic and geophysical logs, survey data, and sample analyses.

DOE $(1990 \mathrm{~b}, \mathrm{c})$ documented the findings of the Phase I Remedial Investigation for the 1100-EM-1 Operable Unit. The findings included operational history, physical characteristics, nature and extent of contamination, and risk assessment for the unit. This unit is one of four 1100 Area operable units regulated by CERCLA/SARA.

ICF Northwest (1987) investigated and tested the North Richland well fieid and recharge basins. Borehole logs, hydraulic testing data, infiltration rates, and operational strategies were evaluated. Recommendations were made to reduce operational costs. Numerical modeling was used to determine the impact of the well field and recharge basins on ground-water flow in the 1100 Area. Simulation results indicated recharge to this system has a significant impact on hydraulic gradients and flow directions. ${ }^{(a)}$

J-U-B Engineers Inc. (1982) briefly discussed the hydrogeology near the Siemens Power Corp. facilities. Unit thicknesses, water-table maps, aquifer coefficients, and ground-water flow rates were given.

(a) Freshley, M. D., M. P. Bergeron, and N. J. Aimo. 1989. Ground-Water Modeling Investigation of North Richland Well Field and the 1100 Area, Letter Report. Pacific Northwest Laboratory, Richland, Washington. 


\subsection{Method of Study}

This study was conducted in four phases: 1) collection and review of existing hydrogeologic data, 2) establishment of a water-level monitoring network, 3) data analysis, and 4) interpretation of results.

Existing hydrogeologic data document general stratigraphic relations between geologic formations for several areas within and adjacent to the Hanford Site. Limited information on the unconfined ground-water flow system in the 1100 and 3000 Areas is available, but until now has not been compiled, analyzed, and published. Hydraulic head and soil and water chemistry data have been collected before this study.

A well network was established to characterize the hydrogeology and monitor water levels in the unconfined aquifer. Field activities included installation and maintenance of continuous water-level recorders, water-level measurements, and natural gamma and borehole television logging. Field activities were conducted between June 1989 and May 1990. Data analysis included defining the distribution of hydrogeologic units in the study area, developing a hydrogeologic conceptual model for the unconfined aquifer, and describing the spatial and temporal distribution of hydraulic head within the aquifer. Study results are used to delineate additional data needs in support of future hazardous waste site investigations and ground-water and land-use management.

Chapter 2.0 of this report contains information on the regional hydrogeology of the Pasco Basin; Chapter 3.0 describes the study area hydrogeology; Chapter 4.0 discusses the spatial and temporal distribution of hydraulic head including details on the water-level monitoring network, anthropogenic impacts to the water table, and the interrelationship with the Yakima and Columbia rivers; Chapters 5.0, 6.0, and 7.0 discuss results, conclusions, and additional data needs, respectively. The references cited throughout the text are presented in detail in Chapter 8.0. Four appendixes at the back of the report provide supporting data in the form of diagrams, tables, maps, and graphs. Five plates are included in the pocket. 


\subsection{Regional Hydrogeology}

This chapter provides information on the hydrogeology of the Pasco Basin as a preface to describing the study area hydrogeology. Summaries of the principal geologic and hydrologic units and the primary surface and ground-water features within the Pasco Basin are presented.

\subsection{Geology of the Pasco Basin}

The principal geologic units within the Pasco Basin are, in ascending stratigraphic order, 1) Columbia River Basalt Group with interbeds of the Ellensburg Formation, 2) Ringold Formation, 3) Plio-Pleistocene sediments, and 4) Hanford formation (informal name). Locally, Pleistocene/ Holocene alluvium, colluvium, and eolian deposits veneer the surface. A generalized geologic cross section through the central Pasco Basin is shown in Figure 2.1. Figure 2.2 summarizes the Pasco Basin stratigraphy.

\subsubsection{Columbia River Basalt Group}

Tholeiitic flood basalts of the Columbia River Basalt Group form the bedrock of the Pasco Basin. This Miocene basalt sequence was formed between 17 and 6 million years before present (mybp) (DOE 1988a) when large volumes of lava erupted from fissures in eastern Washington, western Idaho, and north-central and northeastern Oregon. The basalts cover more than $63,000 \mathrm{mi}^{2}$ with an estimated volume of $40,800 \mathrm{mi}^{3}$. They may be as much as $11,450 \mathrm{ft}$ thick beneath the Pasco Basin (DOE 1988a). The Columbia River Basalt Group is subdivided into five formations: Imnaha, Picture Gorge, Grande Ronde, Wanapum, and Saddle Mountains Basalts. The Grande Ronde, Wanapum, and Saddle Mountains Basalts are present in the Pasco Basin.

Miocene and locally Pliocene, epiclastic and volcaniclastic sediments of the Ellensburg Formation are intercalated between flows of the Columbia River Basalt Group. Areally extensive units include the Vantage, Mabton, Cold Creek, Selah, and Rattlesnake Ridge interbeds. These units are restricted primarily to the Wanapum and Saddle Mountains Basalts within the Pasco Basin.

\subsubsection{Ringold Formation}

The Columbia River Basalt Group is overlain by late Miocene to Pliocene sediments of the Ringold Formation. These sediments were deposited between 8.5 and 3.7 mybp (DOE 1988a) by the ancestral Columbia and Snake rivers in a fluvial-lacustrine environment, reaching a maximum thickness of more than $1200 \mathrm{ft}$ (Newcomb et al. 1972).

The Ringold Formation has generally been classified into three stratigraphic section types within the Pasco Basin. However, considerable variation in sediment types can occur, and lithofacies may not correlate across the entire basin. Section type I, located in the central Pasco Basin, is subdivided into four lithofacies: 1) basal sand and gravel unit, 2) lower clay, silt, and sand unit, 3) middle sand and gravel or conglomerate unit, and 4) upper clay, silt, and sand unit. These lithofacies represent mainstream deposits. Section type II consists of overbank-floodplain clay, silt, and sand with minor gravel lenses and is found north and east of Gable Mountain. Section type III is a fanglomerate, 


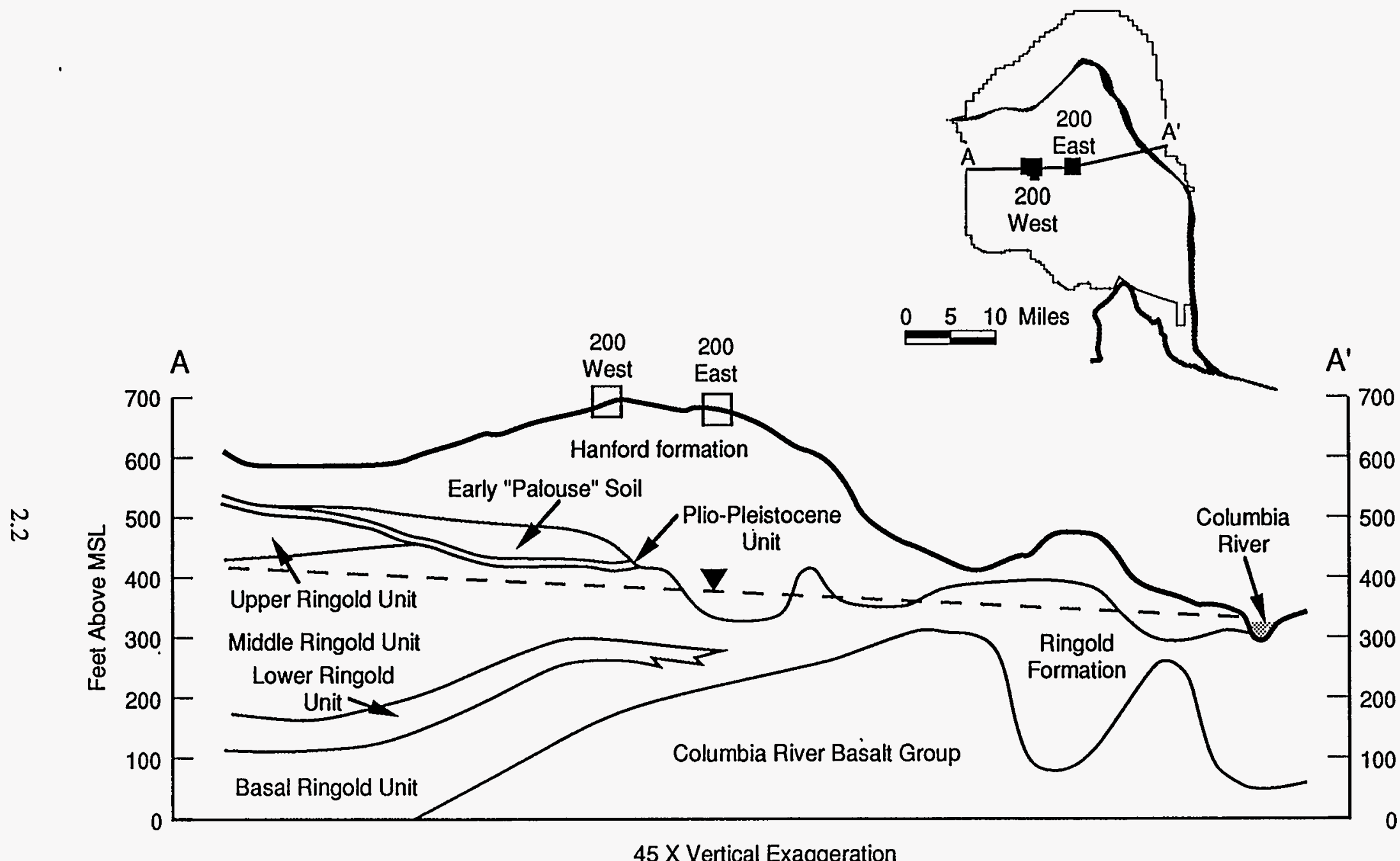

$\$ 9008050.1$

Figure 2.1 Generalized Geologic Cross Section Through the Central Pasco Basin (modified from Last et al. 1989) 


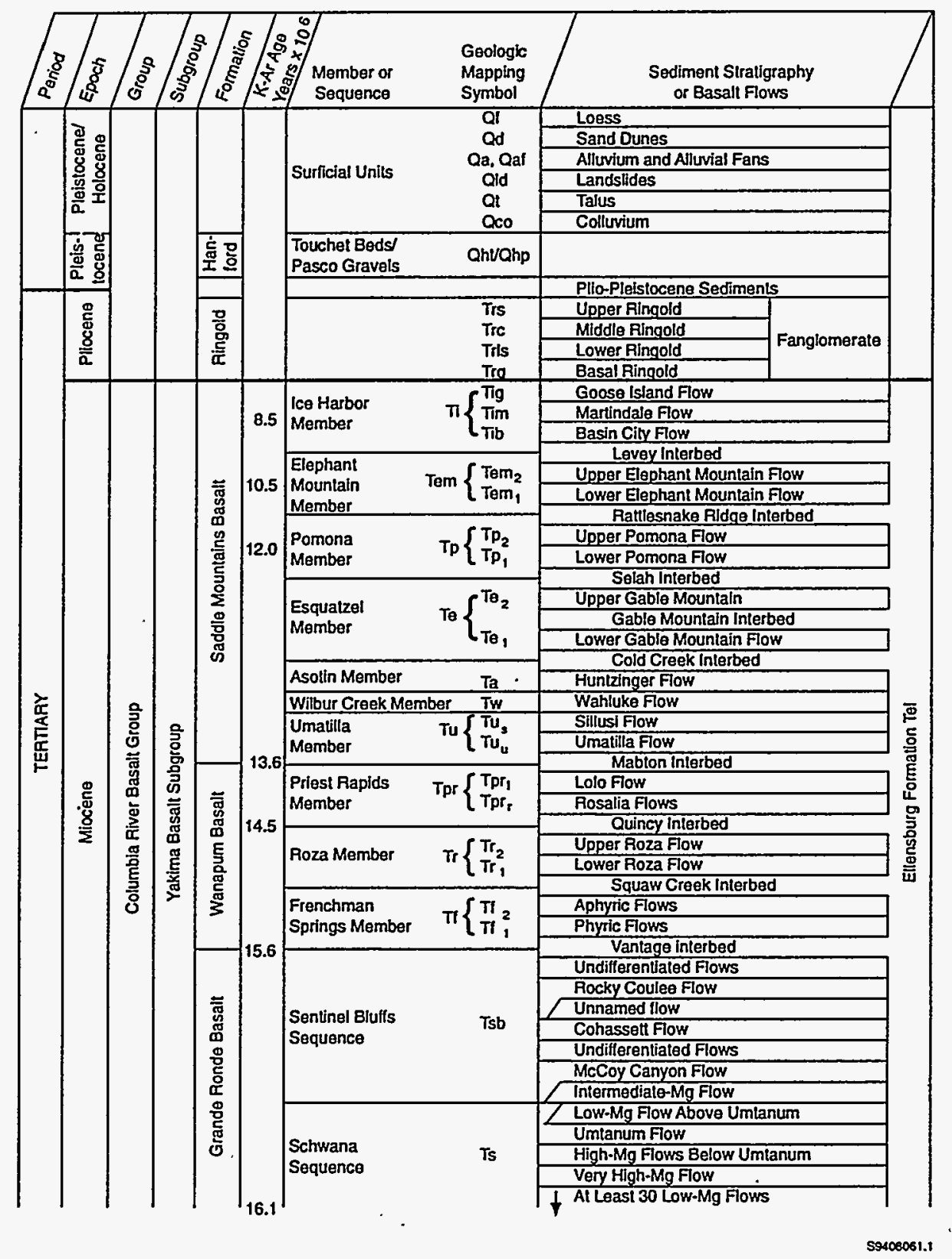

Figure 2.2 Pasco Basin Stratigraphy (modified from DOE 1984)

composed of talus, colluvium, and sidestream deposits that occur along the flanks of the anticlinal ridges and interfinger with the central basin deposits. Distribution of these section types is shown in Figure 2.3. 


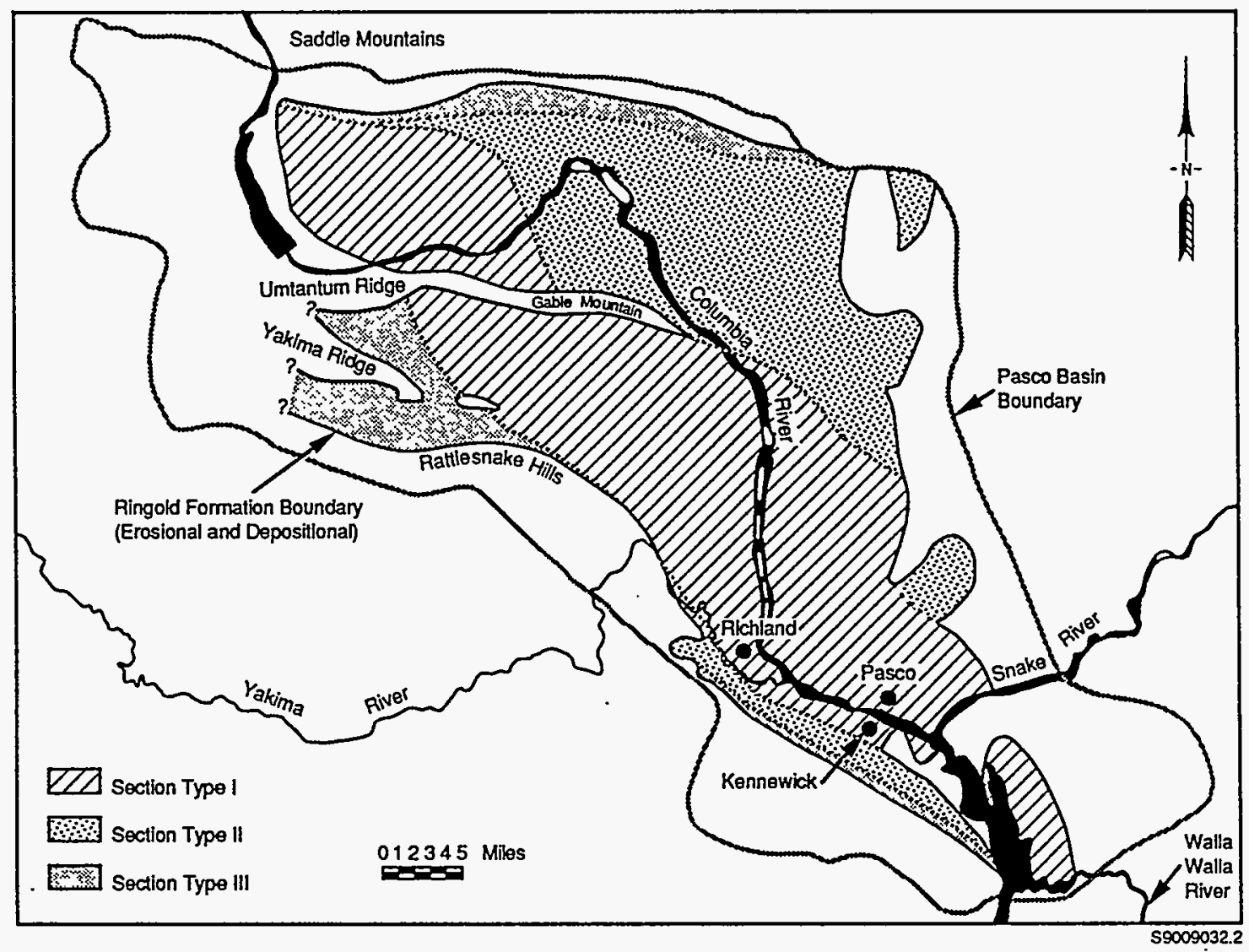

Figure 2.3 Distribution of Ringold Formation Section Types Within the Pasco Basin (modified from DOE 1988a)

\subsubsection{Plio-Pleistocene Sediments}

The late Pliocene to early Pleistocene is characterized by erosion of the uppermost Ringold Formation within the Pasco Basin. Localized deposition of the Plio-Pleistocene unit and early "Palouse" soil followed. Relatively high caliche content is found in the Plio-Pleistocene unit, and the early "Palouse" soil is thought to be an early Pleistocene loess. The Plio-Pleistocene sediments were probably deposited as reworked Ringold sediments.

\subsubsection{Hanford Formation}

The Hanford formation lies unconformably on the eroded surface of the Ringold Formation, PlioPleistocene sediments, and locally, Columbia River Basalt Group. The Hanford formation consists of catastrophic flood sediments that were deposited during the rapid draining of glacial Lake Missoula in western Montana and northern Idaho. Massive volumes of water spilled abruptly across eastern and central Washington scouring the land surface, locally eroding into the Ringold Formation, upper basalt flows, and interbeds. Thick sequences of glaciofluvial sediments were deposited by several episodes of Pleistocene flooding, with the last major flood sequence dated about 13,000 years before present (Myers and Price 1979). 
The Hanford formation has locally been divided into two lithofacies, termed the "Pasco Gravels facies" and the "Touchet Beds facies." The Pasco Gravels facies is composed of poorly sorted gravels and coarse sand indicative of a high-energy depositional environment. The Touchet Beds facies consists of rhythmically bedded sequences of graded silt, sand, and minor gravel lenses. These sediments are limited to areas where slack-water conditions existed.

Eolian sediments, including loess and active and stabilized sand dunes, locally veneer the surface of the Pasco Basin. Alluvium and colluvium occur along major river and stream courses and beneath moderate to high relief areas, respectively.

\subsection{Hydrology of the Pasco Basin}

The Pasco Basin contains several natural and artificial surface-water bodies, numerous semiconfined to confined aquifers, and an unconfined aquifer. The following discussion focuses on streamflow characteristics and ground-water occurrence, recharge, and discharge.

\subsubsection{Surface Water}

The primary surface-water feature within the Pasco Basin is the Columbia River and its major tributaries, the Yakima, Snake, and Walla Walla rivers. Cold Creek and its tributary, Dry Creek, are ephemeral streams draining areas along the western part of the basin. West Lake, located southwest of Gable Mountain, is the only natural lake. Artificial ponds and ditches are present on the Hanford Site and are generally associated with nuclear fuel reprocessing and waste disposal activities. Figure 2.4 shows the major surface-water features within the Pasco Basin.

The Columbia River enters the Pasco Basin at Sentinel Gap and exits at Wallula Gap. Flow along the Hanford reach averages 120,000 cubic feet per second (cfs) and is controlled by Priest Rapids Dam (DOE 1988b). River elevations range from $486 \mathrm{ft}$ above msl near Sentinel Gap to $340 \mathrm{ft}$ above msl near Wallula Gap. Several multipurpose water resource projects are located along this reach, including Hanford Site intakes for onsite use and irrigation outfalls for the Columbia Basin Irrigation Project. The Columbia River contributes $67 \%$ of the outflow from the Pasco Basin, the Snake River contributes $30 \%$, the Yakima River contributes $2 \%$, and the Walla Walla River contributes less than $1 \%$ (DOE 1988b).

\subsubsection{Ground Water}

Ground water within the Pasco Basin occurs under confined to unconfined conditions. Four principal hydrologic units have been identified in this multiaquifer system: 1) Grande Ronde Basalt, 2) Wanapum Basalt, 3) Saddle Mountains Basalt, and 4) Ringold and Hanford sediments. Figure 2.5 is a generalized hydrologic cross section through the central Pasco Basin.

\subsubsection{Semiconfined to Confined Aquifers}

Several semiconfined to confined aquifers are contained within the basalt flow tops, flow bottoms, and sedimentary interbeds of the Grande Ronde, Wanapum, and Saddle Mountains Basalts. Dense basalt flow interiors act as aquicludes and clay interbeds form aquitards between these aquifers. 


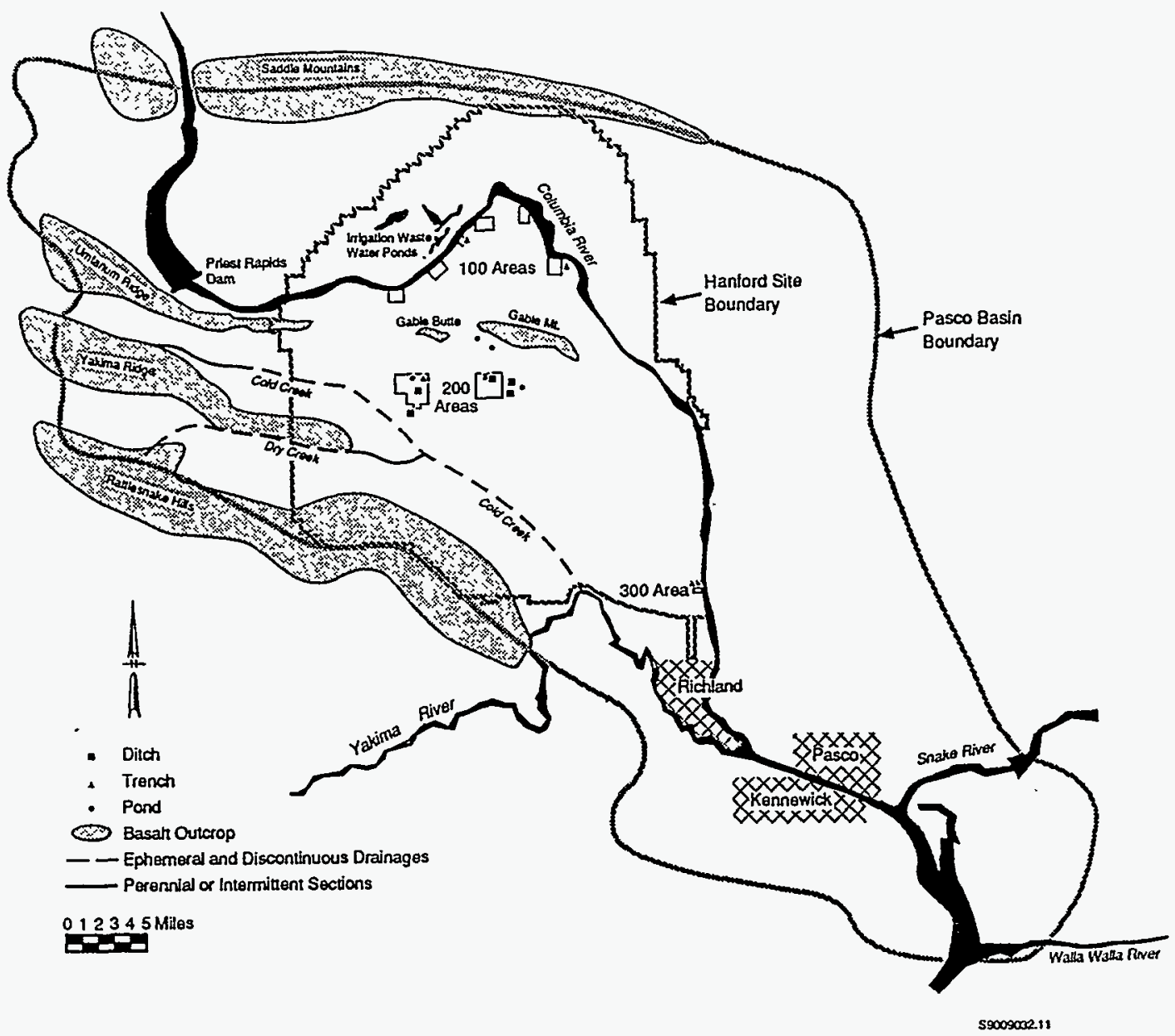

Figure 2.4 Major Surface-Water Features Within the Pasco Basin (modified from DOE 1988b)

Precipitation infiltration and interbasin runoff along the margins of the Pasco Basin locally recharge the semiconfined to confined aquifers. Additional recharge occurs outside the basin where the Grande Ronde and Wanapum Basalts crop out. Discharge from these aquifers occurs to the overlying unconfined aquifer and the Columbia River.

The potential for hydraulic connection between the uppermost confined and unconfined aquifers has been documented south of Gable Mountain extending to the 200 East Area (Graham et al. 1984). In this region, postglacial flood waters and the ancestral Columbia River eroded portions of the Elephant Mountain Basalt Member separating the two aquifers.

\subsubsection{Unconfined Aquifer}

The unconfined aquifer is the uppermost regionally extensive aquifer. It is contained within the fluvial-lacustrine sediments of the Ringold Formation and the glaciofluvial gravels and sands of the Hanford formation. Depth to water ranges from less than $1 \mathrm{ft}$ near the Yakima and Columbia rivers, 
to over $350 \mathrm{ft}$ near the center of the Hanford Site. The aquifer is approximately $500 \mathrm{ft}$ thick west of the 200 West Area (Last et al. 1989). The basalt surface, and locally, the lower clay, silt, and sand unit of the Ringold Formation, form the aquifer base. Areal hydraulic conductivity, transmissivity, and specific yield estimates for the unconfined aquifer are shown in Table 2.1.

Sources of natural recharge to the unconfined aquifer are rainfall and runoff from bordering elevations, ephemeral stream infiltration, and river water along influent reaches of the Yakima and Columbia rivers. Artificial recharge occurs from waste-water disposal on the Hanford Site and agricultural irrigation. Figure 2.6 shows water-table elevations beneath the Site for June 1989 . Ground water flows primarily from recharge areas in the west, eastward to discharge areas along the Columbia River. Flow is altered locally by ground-water mounds beneath the 200 Areas.

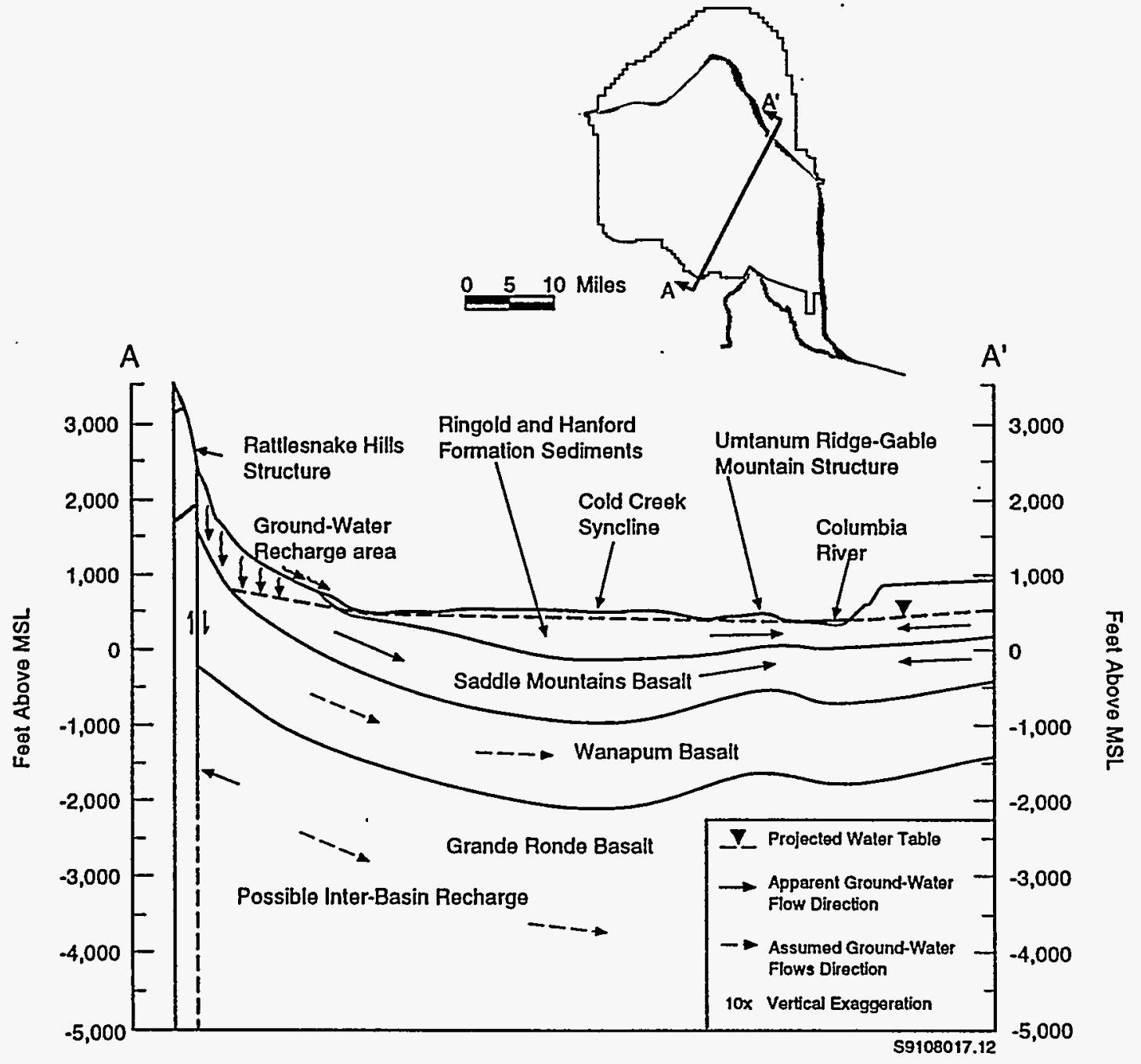

Figure 2.5 Generalized Hydrologic Cross Section Through the Central Pasco Basin (modified from DOE 1990b) 
Table 2.1 Hydraulic Property Estimates for the Unconfined Aquifer Within the Pasco Basin (modified from Gephart et al. 1979)

\begin{tabular}{|c|c|}
\hline $\begin{array}{l}\text { Hydrogeologic } \\
\text { Unit }\end{array}$ & $\begin{array}{l}\text { Hydraulic Conductivity } \\
\text { (ft/day) }\end{array}$ \\
\hline Hanford formation & $500-20,000$ \\
\hline $\begin{array}{l}\text { Undifferentiated Hanford formation } \\
\text { and middle Ringold unit }\end{array}$ & $100-7,000$ \\
\hline Middle Ringold unit & $20-600$ \\
\hline Lower Ringold unit & $0.11-10$ \\
\hline Area & $\begin{array}{l}\text { Transmissivity } \\
\text { (ft2/day) }\end{array}$ \\
\hline $\begin{array}{l}\text { North of Gable Butte and Gable } \\
\text { Mountain }\end{array}$ & $4,000-25,000$ \\
\hline $\begin{array}{l}\text { Paleochannels along flanks of Gable } \\
\text { Butte and Gable Mountain }\end{array}$ & $40,000-600,000$ \\
\hline Other areas on the Hanford Site & $2,000-40,000$ \\
\hline Area & Storage Coefficients \\
\hline
\end{tabular}

Throughout the unconfined aquifer $\quad 0.01-0.1$ 


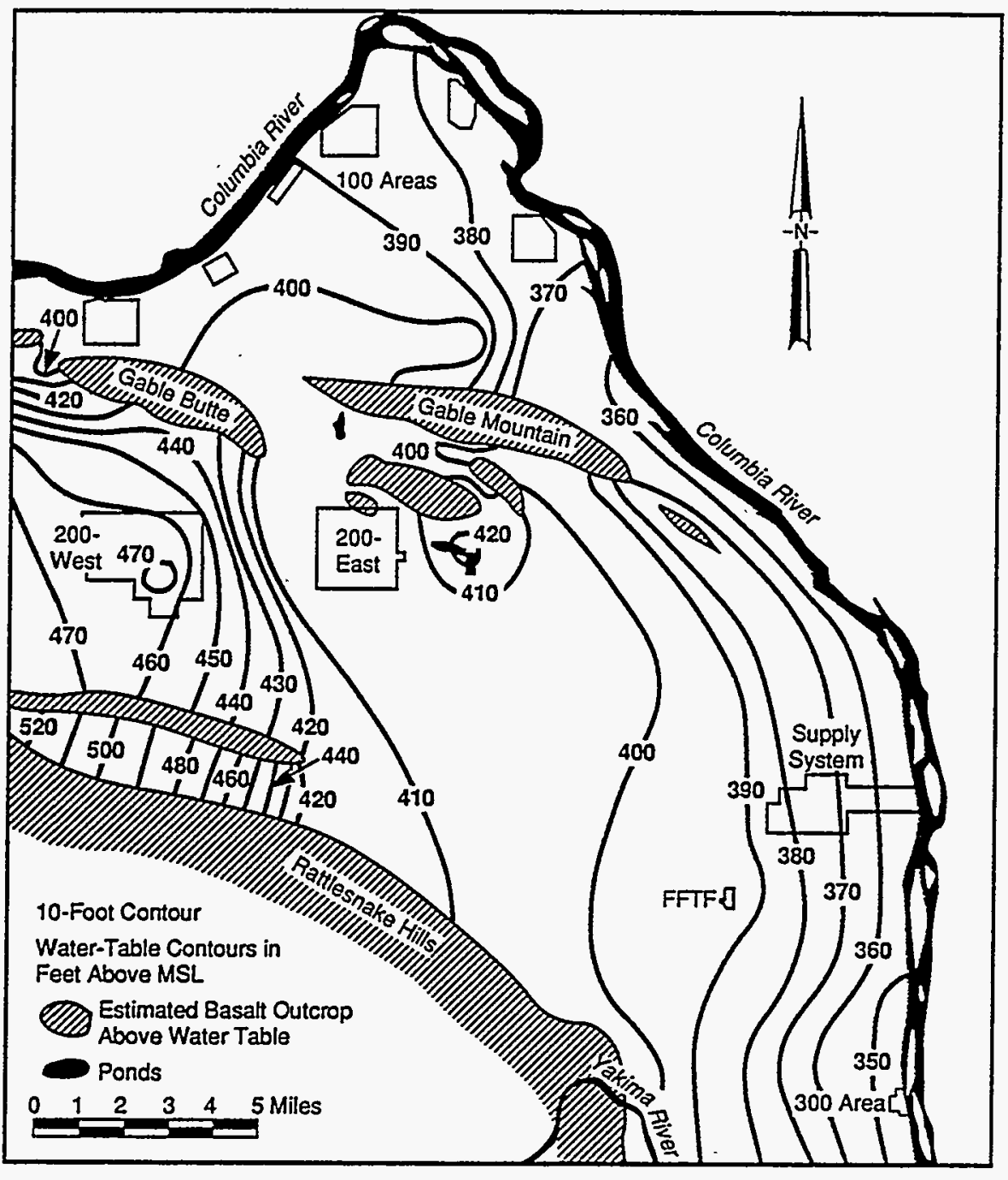

Figure 2.6 Hanford Site Water-Table Elevations, June 1989 (Newcomer et al. 1990) 


\subsection{Study Area Hydrogeology}

This chapter provides information on the study area hydrogeology. An inventory of existing wells and descriptions of the principal lithofacies and hydrofacies are presented. A hydrogeologic conceptual model for the unconfined ground-water flow system was developed based on these descriptions.

\subsection{Existing Well Inventory}

Existing wells within the study area from which hydrogeologic information was obtained include Hanford Site monitoring wells, city of Richland monitoring and production wells, agricultural irrigation wells, private monitoring and water-supply wells, and a hand-dug farm well. These well locations are shown in Figure 3.1. Well construction and lithologic diagrams are contained in Appendix A. Well completion data and recommended maintenance for several wells are summarized in Table 3.1.

Additional monitoring wells were drilled concurrent with and after this study as part of the RI/FS for the 1100-EM-1 Operable Unit. Information on most of these wells is discussed in DOE (1990b). Drilling logs (water well reports) for other wells within and adjacent to the study area are available from Westinghouse Hanford Company (WHC), Siemens Power Corp., Washington Department of Ecology, city of Richland, and local drilling companies.

\subsubsection{Monitoring Wells}

The Hanford Site monitoring wells used in this study are prefixed by 699-(Table 3.1 and Figure 3.1) and were drilled from 1944 to 1988 . Detailed information on the Hanford well numbering system is contained in McGhan (1989). These wells were drilled to monitor ground-water contamination resulting from Hanford Site activities. Generally, the wells drilled before 1986 are constructed of perforated carbon steel casing or carbon steel casing and stainless steel screen. Wells drilled after 1985 are constructed of stainless steel casing and screen. Of the 20 Hanford Site monitoring wells, 5 each are constructed of perforated carbon steel casing, carbon steel casing and stainless steel screen, and stainless steel casing and screen; 3 wells are open bottom completions; and 2 have unknown completions (Table 3.1).

Wells 699-S23-26 and 699-S24-19 were initially drilled as water-supply wells and later incorporated into the Hanford Site monitoring network. Well 699-S28-E0 supplies water to the Hanford Patrol Training Academy, and well 699-S51-2 supplies water to the city of West Richland. Well 699-S36E12A is used to supplement the PNL irrigation intake at the Port of Benton (D.R. Schielke, PNL, personal communication, 1990).

Other monitoring wells within the study area include those designated TW14 through TW18, owned by Siemens Power Corp., and EC-1 and Landfill Wells \#1 through \#4, owned by the city of Richland (Figure 3.1). Wells TW14 through TW18 monitor ground water adjacent to the Siemens Power Corp. process lagoons. Two of these wells are constructed of slotted polyvinyl chloride (PVC) casing; 1 is constructed of carbon steel casing and stainless steel screen; and 2 are open bottom . completions (Table 3.1). Well EC-1 is an open bottom PVC well (Table 3.1) installed to monitor 


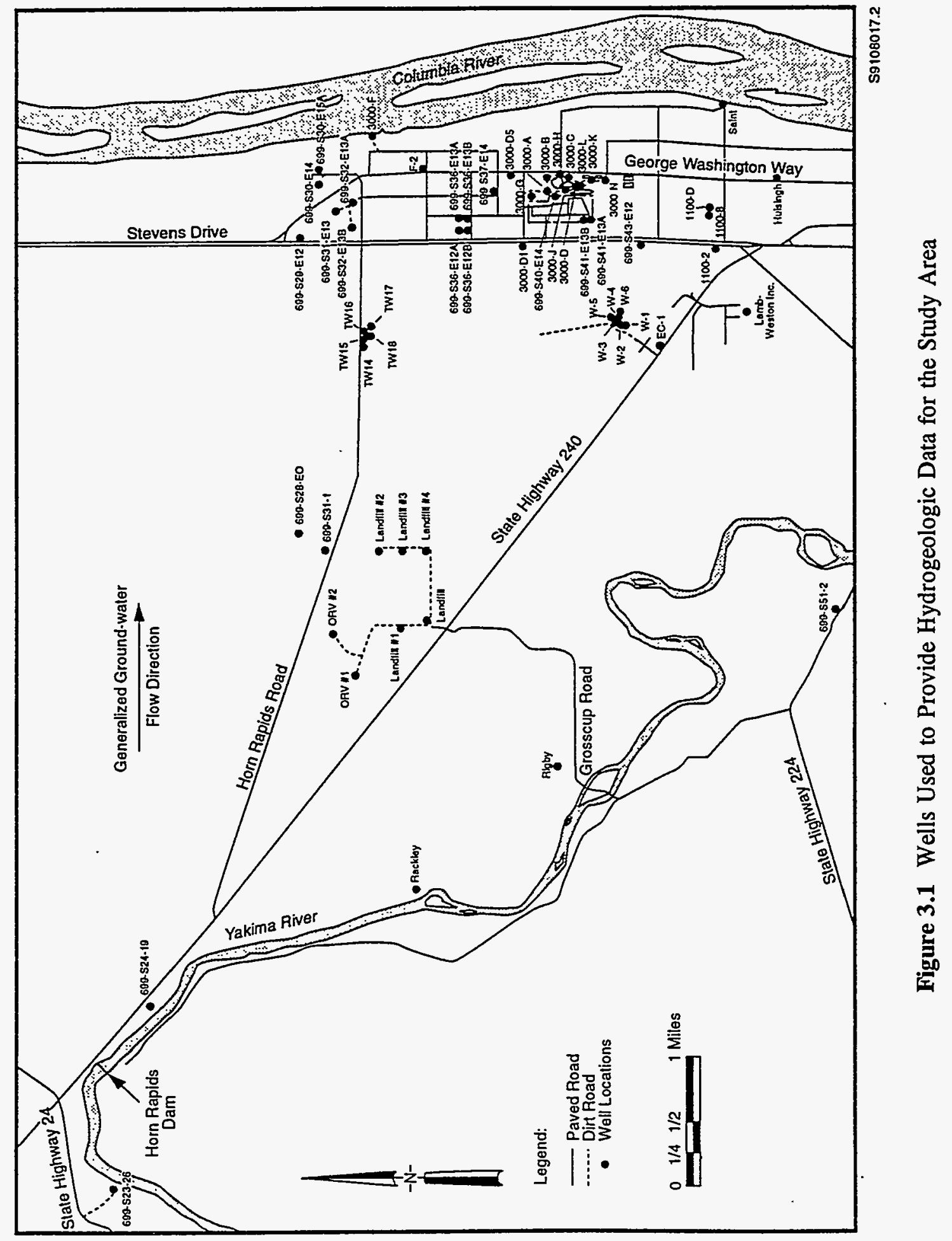


Table 3.1 Completion Data for the Study Area Wells

\begin{tabular}{|c|c|c|c|c|c|c|c|c|c|c|c|c|c|}
\hline $\begin{array}{c}\text { Woll } \\
\text { Numbor }\end{array}$ & \multicolumn{2}{|c|}{$\begin{array}{c}\text { Plant, } \\
\text { Richland } \\
\text { Coordinates }\end{array}$} & $\begin{array}{c}\text { Casing } \\
\text { Elev. } \\
\text { (ft) }\end{array}$ & $\begin{array}{c}\text { M.P. } \\
\text { Slov. } \\
\text { (ft) } \\
\end{array}$ & $\begin{array}{c}\text { Land } \\
\text { Surfaco } \\
\text { Elev. } \\
\text { (ft) }\end{array}$ & $\begin{array}{c}\text { Casing } \\
\text { Diam. } \\
\text { (in) }\end{array}$ & \multicolumn{2}{|c|}{$\begin{array}{c}\text { Construction } \\
\text { Materials } \\
\text { Casing Scroen }\end{array}$} & $\begin{array}{c}\text { Depth } \\
\text { to Btm. } \\
\text { (ft) }\end{array}$ & $\begin{array}{c}\text { W-L } \\
\text { Depth } \\
\text { (ft) }\end{array}$ & $\begin{array}{l}\text { Depth of } \\
\text { Screaned Interval } \\
\text { ( } f t)\end{array}$ & $\begin{array}{l}\text { Comp. } \\
\text { Date }\end{array}$ & $\begin{array}{l}\text { Recommended } \\
\text { Maintenance }\end{array}$ \\
\hline 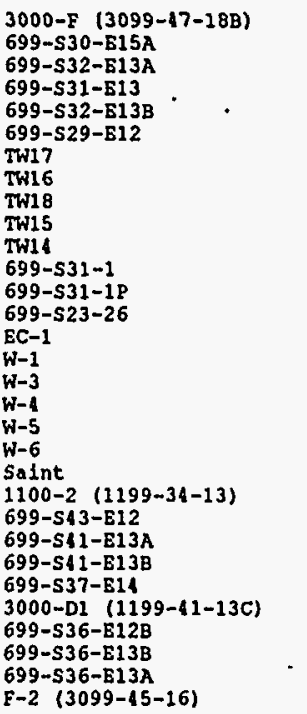 & $\begin{array}{ll}\text { RN } & 34026 \\
\text { PS } & 43060 \\
\text { PS } & 41004 \\
\text { PS } & 40970 \\
\text { PS } & 39745 \\
\text { RN } & 41030 \\
\text { PS } & 36182 \\
\text { PS } & 36195 \\
\text { RN } & 45108\end{array}$ & $\begin{array}{ll}\mathrm{RE} & 13203 \\
\mathrm{PE} & 11986 \\
\mathrm{PE} & 12811 \\
\mathrm{PE} & 12813 \\
\mathrm{PE} & 13980 \\
\mathrm{RE} & 13259 \\
\mathrm{PE} & 12350 \\
\mathrm{PE} & 12846 \\
& \\
\mathrm{RE} & 16386\end{array}$ & $\begin{array}{l}374.95 \\
400.14 \\
390.16 \\
394.06 \\
394.72 \\
387.96 \\
379.45 \\
376.73 \\
377.31 \\
370.60 \\
370.21 \\
460.00 \\
460.00 \\
424.70 \\
361.11 \\
359.78 \\
358.88 \\
361.50 \\
361.82 \\
361.70 \\
361.17 \\
394.78 \\
405.60 \\
410.56 \\
410.10 \\
408.28 \\
405.98 \\
399.07 \\
399.63 \\
399.30 \\
408.04\end{array}$ & $\begin{array}{l}362.57 \\
361.97 \\
360.87\end{array}$ & $\begin{array}{l}372.97 \\
397.67 \\
388.67 \\
392.29 \\
392.69 \\
383.71 \\
377.15 \\
375.41 \\
375.57 \\
368.88 \\
368.18 \\
158.09 \\
158.09 \\
118.32 \\
362.45 \\
358.87 \\
355.63 \\
360.00 \\
360.00 \\
360.00 \\
360.00 \\
392.03 \\
402.33 \\
407.21 \\
406.75 \\
404.88 \\
404.51 \\
397.44 \\
397.76 \\
398.34 \\
106.87\end{array}$ & $\begin{array}{c}17 \\
6 \\
8 \\
8 \\
8 \\
6 \\
3 \\
6 \\
3 \\
6 \\
6 \\
8 \\
1 \\
12 \\
10 \\
8 \\
6 \\
8 \\
11 \\
10 \\
8 \\
8 \\
4 \\
1 \\
4 \\
4 \\
20 \\
8 \\
8 \\
8 \\
36\end{array}$ & $\begin{array}{l}C \\
C S \\
C S \\
C S \\
C S \\
C S \\
\text { PVC } \\
C S \\
P V C \\
C S \\
C S \\
C S \\
C S \\
C S \\
P V C \\
C S \\
C S \\
\cdot C S \\
C S \\
C S \\
C S \\
C S \\
S S \\
S S \\
S S \\
S S \\
C S \\
C S \\
C S \\
C S \\
C\end{array}$ & $\begin{array}{l}\text { PC } \\
\text { SS } \\
\text { SS } \\
\text { SS } \\
\text { SS } \\
\text { PCS, SS } \\
\text { PVC } \\
\text { SS } \\
\text { PVC } \\
\\
\text { PCS } \\
\text { OH } \\
\text { OB } \\
\text { PCS } \\
\text { PCS } \\
\text { PCS? } \\
\text { PCS? } \\
\text { PCS } \\
\text { SS } \\
\text { PCS } \\
\text { SS } \\
\text { SS } \\
\text { SS } \\
\text { SS } \\
\text { OB } \\
\text { OB } \\
\text { SS } \\
\text { OB }\end{array}$ & $\begin{array}{l}71 \\
78 \\
75 \\
72 \\
74 \\
79 \\
34 \\
33 \\
34 \\
24 \\
22 \\
142 \\
228 \\
11 \\
8 \\
18 \\
24 \\
30 \\
67 \\
32 \\
47 \\
75 \\
58 \\
63 \\
87 \\
63 \\
74 \\
72 \\
81 \\
72 \\
65\end{array}$ & $\begin{array}{l}33.65 \\
58.64 \\
43.18 \\
17.11 \\
47.18 \\
41.95 \\
26.11 \\
23.43 \\
24.04 \\
17.26 \\
16.83 \\
84.33 \\
80.49 \\
10.13 \\
7.10 \\
7.09 \\
5.99 \\
5.07 \\
6.23 \\
5.92 \\
15.04 \\
41.63 \\
51.39 \\
55.69 \\
55.22 \\
54.61 \\
51.64 \\
45.25 \\
45.76 \\
45.70 \\
60.07\end{array}$ & $\begin{array}{c}93-103 \\
221-228 \\
\\
O B \\
5-30 \\
5-29 \\
P C S 3 \\
\text { PCS? } \\
17-27 \\
43-53 \\
45-90 \\
42-58 \\
47-63 \\
77-87 \\
44-63 \\
O B \\
O B \\
O B \\
52-72 \\
O B\end{array}$ & $\begin{array}{l}1 / 51 \\
1 / 51 \\
6 / 44 \\
1 / 83 \\
1 / 83 \\
1989 \\
4 / 89 \\
5 / 89 \\
7 / 76 \\
3 / 48 \\
10 / 88 \\
10 / 88 \\
10 / 88 \\
10 / 88 \\
3 / 14 \\
10 / 79 \\
10 / 79 \\
9 / 79\end{array}$ & $\begin{array}{l}\text { Cleanout/Dovolop } \\
\text { Cleanout/Devolop } \\
\text { Cleanout/Develop } \\
\text { Cleanout/Develop, Borehole TV TV } \\
\text { Cleanout/Develop, Borehole TV } \\
\text { Hydraullc Testing } \\
\text { Hydraulic Testing } \\
\text { Resurvey } \\
\text { Cleanout/Devolop } \\
\text { Cleanout/Develop } \\
\text { Survey, Borehole TV Log } \\
\text { Survey, Borehole TV Log } \\
\text { Survey } \\
\text { Resurvey } \\
\text { Cleanout/Develop }\end{array}$ \\
\hline Notes: & & & & & & & & & & & . & & \\
\hline 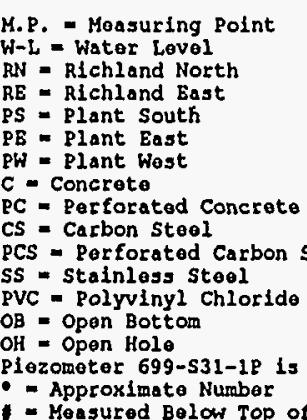 & eol & & & & & & & & & & . & & \\
\hline
\end{tabular}


Table 3.1 (cont'd)

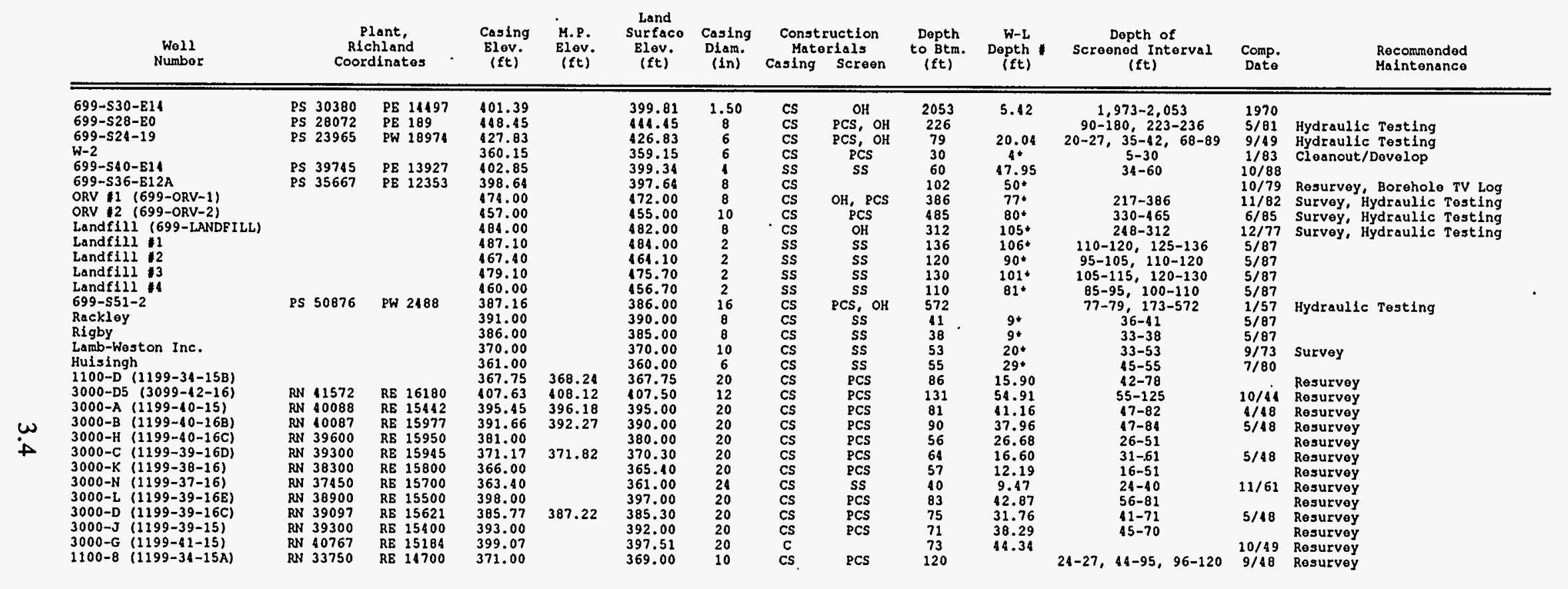

Notes:

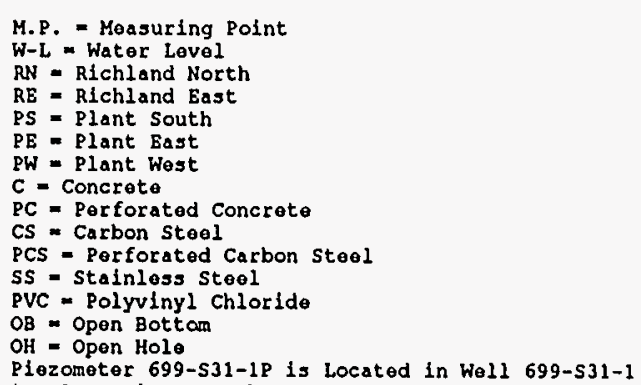

i: - Measured Below Top of Casing or Measuring Point in October 1989 
water-level fluctuations resulting from agricultural irrigation (S. Arlt, city of Richland, personal communication, 1989). Landfill Wells \#1 through \#4 were drilled per regulatory requirement in May 1987 and monitor ground water beneath the city of Richland landfill. These wells are constructed of stainless steel casing and screen (Table 3.1).

\subsubsection{Production Wells}

Wells prefixed by 1100 - and 3000- (Figure 3.1) are city of Richland production wells. Corresponding Hanford well numbers are given in parentheses (Table 3.1). Most of these wells were drilled in the 1940s and are constructed of perforated carbon steel casing (Table 3.1). Wells located in the North Richland well field are pumped as part of the secondary water-supply system for the city of Richland. Wells ORV \#1, ORV \#2, and the Landfill Well supply water to the city of Richland off-road vehicle park and landfill, respectively.

\subsubsection{Agricultural Irrigation Wells}

Wells W-4 through W-6 (Figure 3.1) were drilled in 1989 to supply water for agricultural irrigation. These wells are constructed of perforated carbon steel casing (Table 3.1) and were pumped by the Agricultural Engineering and Development Company (AEDC) to irrigate a half circle (approximately 250 acres) of potatoes west of the 1100 Area during the 1989 growing season (Figure 3.2). The farming was expanded to eight full circles (approximately 4000 acres) of potatoes before the 1990 growing season (Figure 3.3), and irrigation water was drawn from the AEDC intake at the Port of Benton. Wells W-4 through W-6 currently are used to supplement the river intake.

\subsubsection{Other Wells}

Wells W-1 through W-3 (Figure 3.1) are constructed of perforated carbon steel casing (Table 3.1). These wells were drilled in 1983 to determine if sufficient ground-water quantities existed at shallow depths to irrigate the planned Horn Rapids Triangle golf course.

The remaining wells in Figure 3.1 are private water-supply wells and a hand-dug farm well. The private water-supply wells are constructed of carbon steel casing and stainless steel screen (Table 3.1). Information on these wells was provided by the city of Richland and Onwego Drilling Company Inc. The hand-dug farm well (F-2) is constructed of concrete casing with an open-bottom completion (Table 3.1). A borehole television camera was used to help gather information on this well.

\subsection{Geology of the Study Area}

This section focuses on the principal lithofacies, occurrence, and thicknesses of the geologic formations beneath the study area. Lithofacies interpretation was based primarily on geologic sample descriptions, including texture, sorting, gross mineralogy, color, and consolidation. Natural gamma, neutron, and density logs were used qualitatively to indicate relative differences in lithology. Geologic, top of basalt contour, structural cross section, and stratigraphic correlation maps from Myers and Price (1979) were also used as input in the interpretation. Hydrogeologic data were obtained from the 61 wells shown in Figure 3.1. Well construction and lithologic diagrams for these wells are contained in Appendix A. 


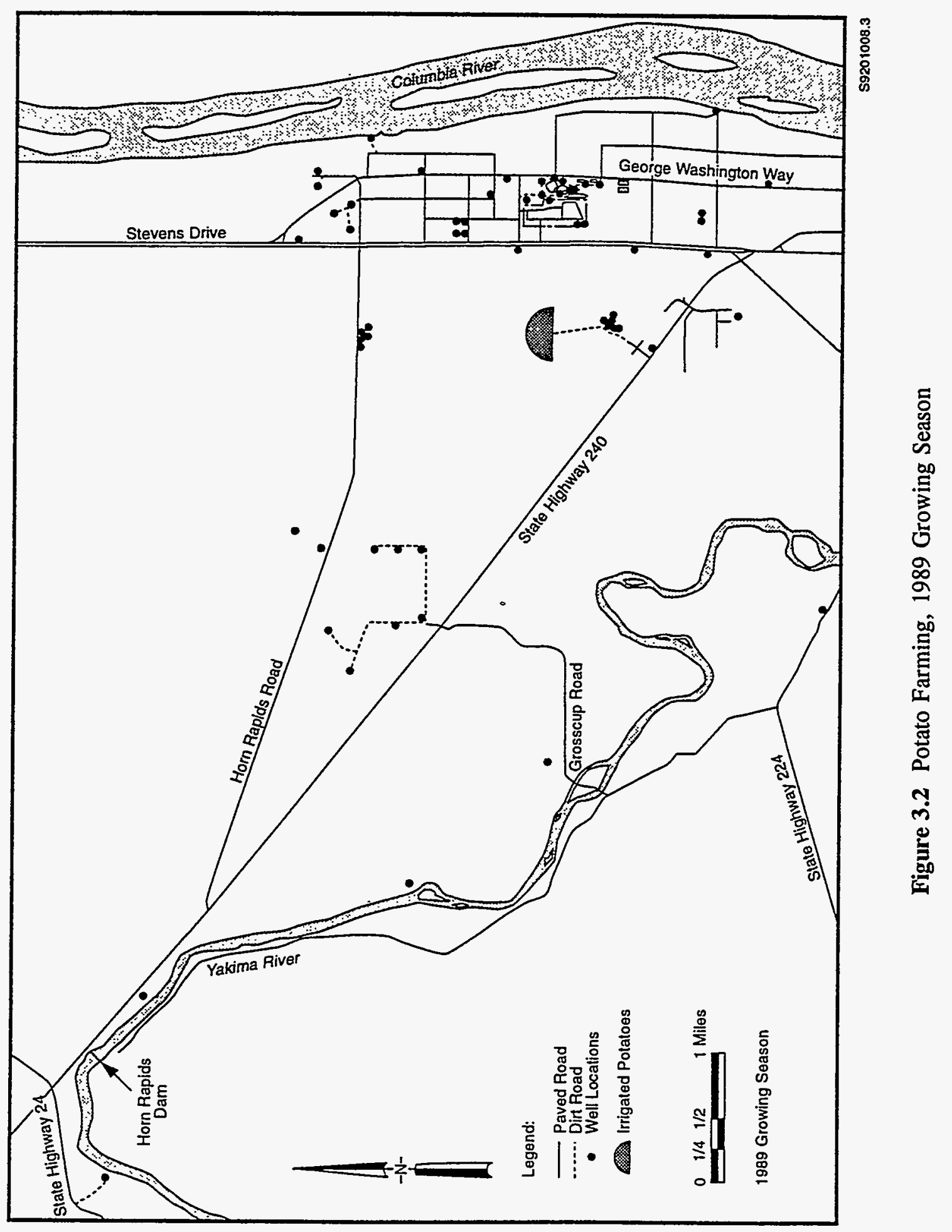




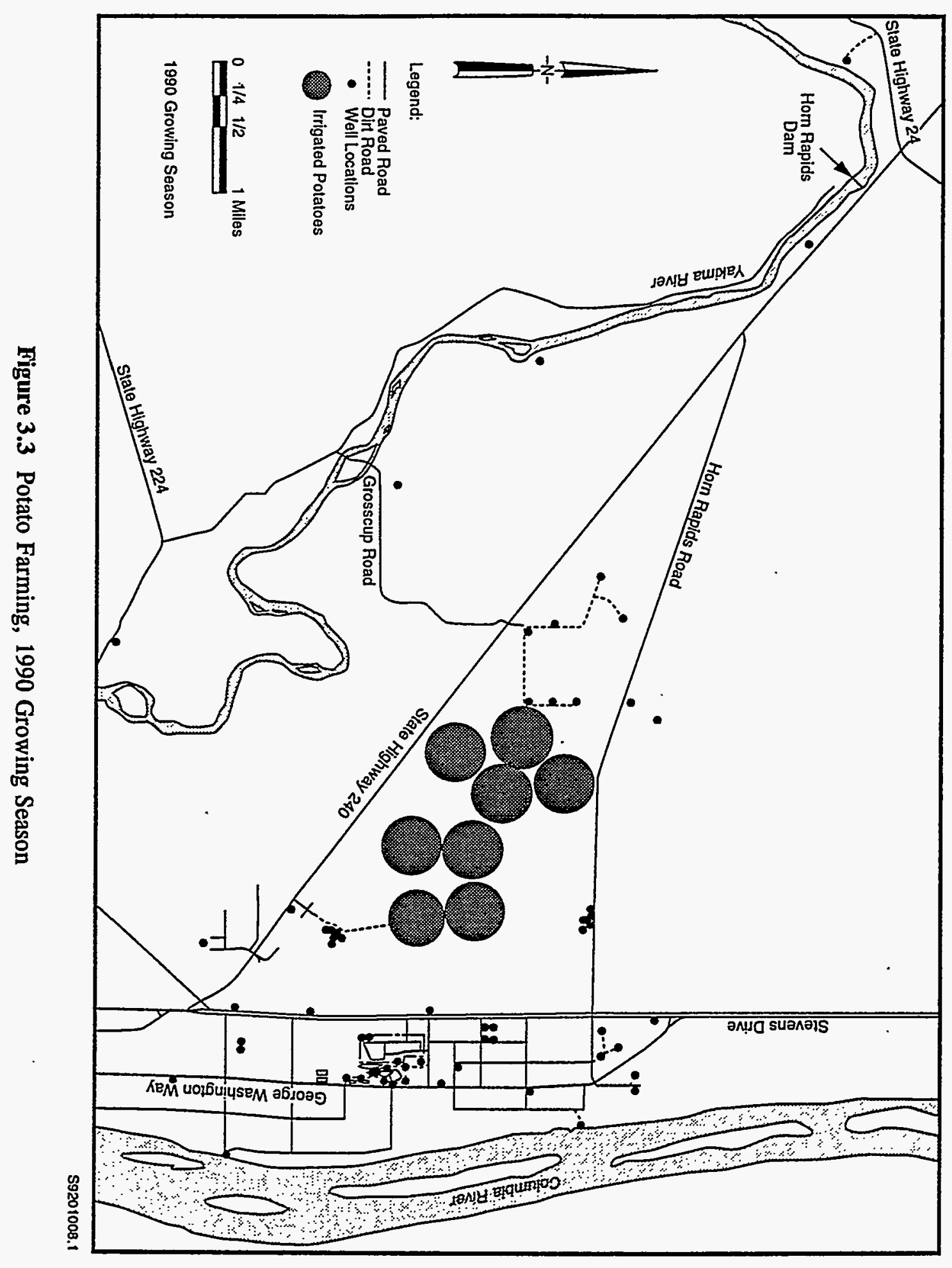


Five geologic formations, the Grande Ronde, Wanapum, and Saddle Mountains Basalts, and sediments of the Ringold Formation and Hanford formation, have been identified beneath the study area. Figure 3.4 is a generalized geologic column showing the order, principal lithofacies, and average elevation of the upper Saddle Mountains Basalt and Ringold Formations, and Hanford formation. The Grande Ronde and Wanapum Basalts are not considered further in this study. Table 3.2 lists formation depths, elevations, and thicknesses. General characteristics of each formation including texture, sorting, mineralogy, color, consolidation, and occurrence are given in Table 3.3. Figure 3.5 shows the location of five cross sections, parallel and perpendicular to ground-water flow. The cross sections are included as Plates 1 through 5. A detailed discussion of each formation follows. References to depth are given in feet below land surface (bls) with elevation in feet above msl in parentheses.

\subsubsection{Saddle Mountains Basalt Formation}

The Saddle Mountains Basalt Formation was encountered in eight wells at depths ranging from 52 to $248 \mathrm{ft}$ bls ( 375 to $191 \mathrm{ft}$ above msl) (Table 3.2). Geologic samples were characterized as fractured to dense gray and black basalt mixed with clay and sand. Structural cross section and stratigraphic correlation maps (Myers and Price 1979) show that the Ice Harbor Member (Ti) is the uppermost basalt throughout the study area. Drilling logs indicate the member ranges from 75 to $108 \mathrm{ft}$ thick (Table 3.2). The Ice Harbor Member crops out south of the Yakima River horn (Plates 1 through 3 and Figure 3.6).

The Levey Interbed (Tel), described as a tuffaceous sandstone to gray-green and blue clay, was noted in three wells below the Ice Harbor Member. Gray dense basalt from the Elephant Mountain Member (Tem) was noted below the Levey Interbed. The Elephant Mountain Member also crops out south of the Yakima River horn (Plates 1 through 3 and Figure 3.6).

Myers and Price (1979) reported that the Ice Harbor and Elephant Mountain Members erupted from fissures in southeastern Washington and adjacent Oregon and Idaho. The members erupted between 10.5 and 6 mybp near the end of the Columbia River Basalt volcanism. Plates 1 through 3 and Figure 3.6 show that the basalt surface dips to the east and southeast between the Horn Rapids Structure (anticline) and Pasco Syncline. Myers and Price (1979) concluded that basalt compression and uplift occurred from mid-Miocene to early Pliocene (15 to 5 mybp). Newcomb et al. (1972) suggested that in some areas, the lower Ringold sediments were deposited contemporaneously with basalt deformation. Relatively thinner accumulations of the overlying sediment along the Horn Rapids Structure and thicker accumulations near the Pasco Syncline (Plates 1 through 3) support these conclusions.

\subsubsection{Ringold and Hanford Formations}

The Saddle Mountains Basalt Formation is overlain by fluvial and overbank-floodplain sediments of the Ringold Formation and glaciofluvial sediments of the Hanford formation. These sediments exhibit varied texture, sorting, and consolidation within and between lithofacies. Gross mineralogy, sorting, and color distinctions typically used to delineate the contact between the Ringold Formation and Hanford formation are not evident or are inconsistent in the drilling logs and HGWDB. The formations may be interstratified or have gradational contacts beneath the study area. The uppermost Ringold sediments were probably eroded and redeposited with the Hanford sediments by the ancestral 


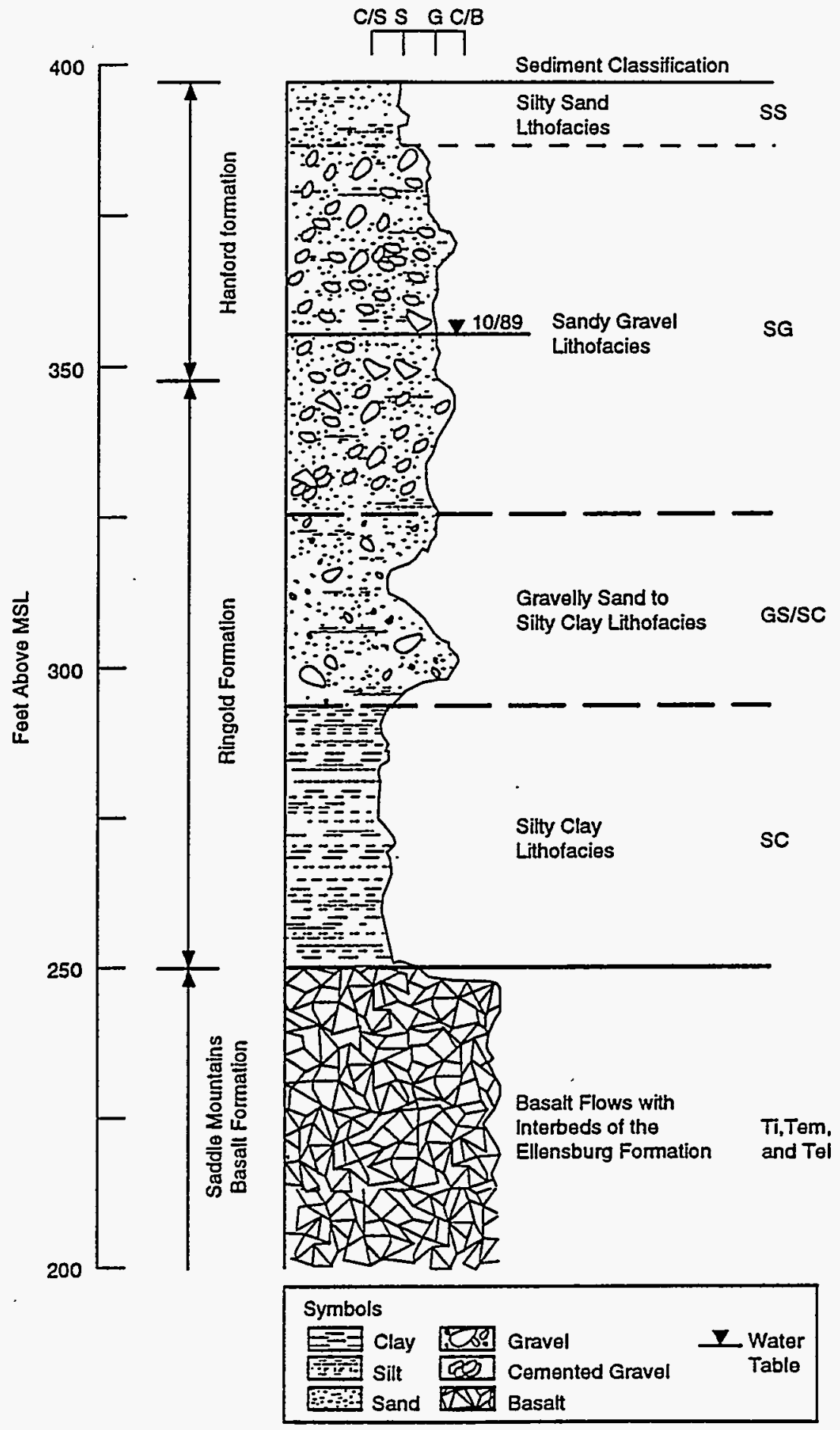

$\$ 9007059.30$

Figure 3.4 Generalized Geologic Column for the Study Area (after Liikala 1988; Compton 1967) 
Table 3.2 Formation Depths, Elevations, and Thicknesses Beneath the Study Area

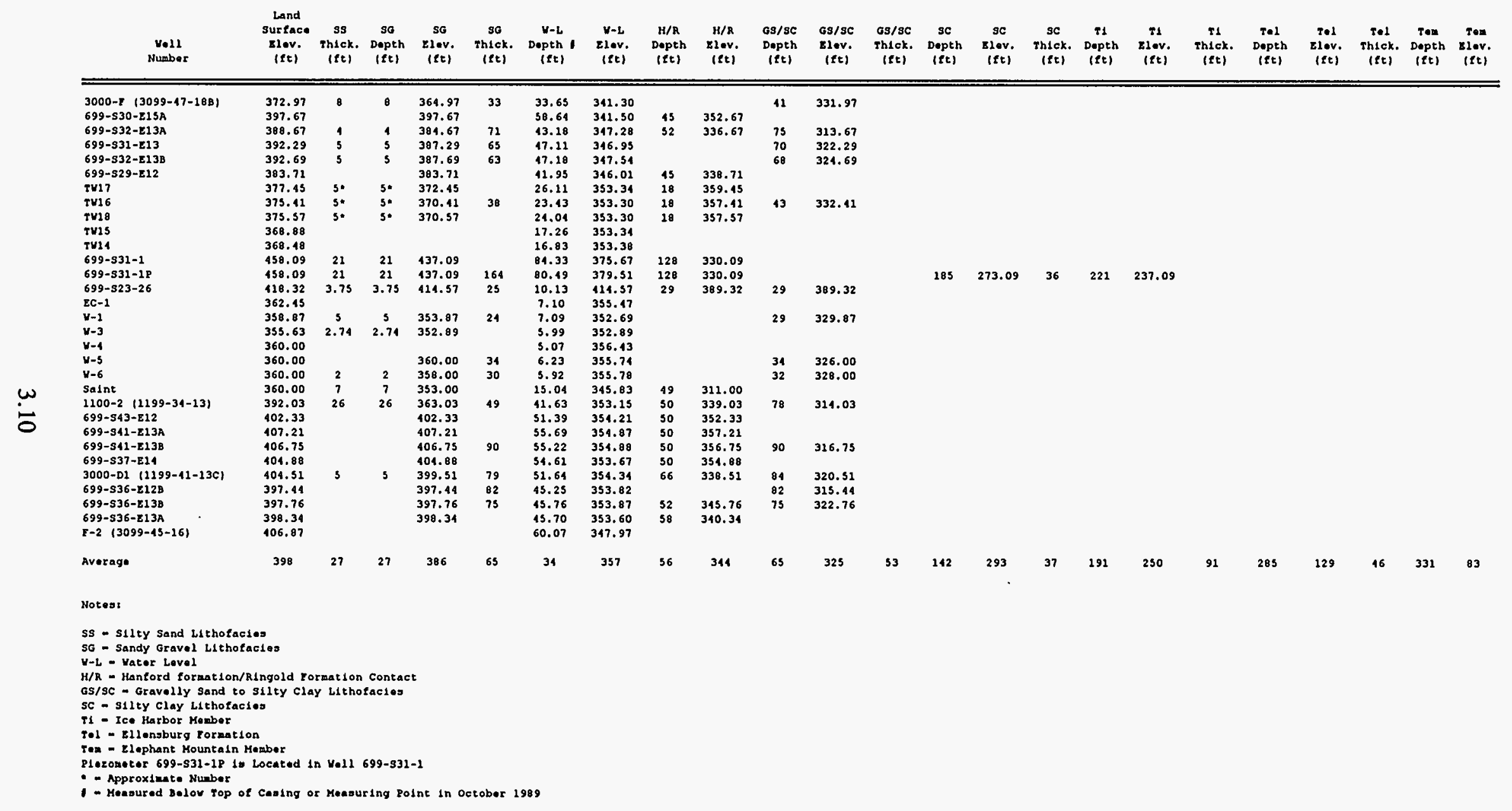


Table 3.2 (cont'd)

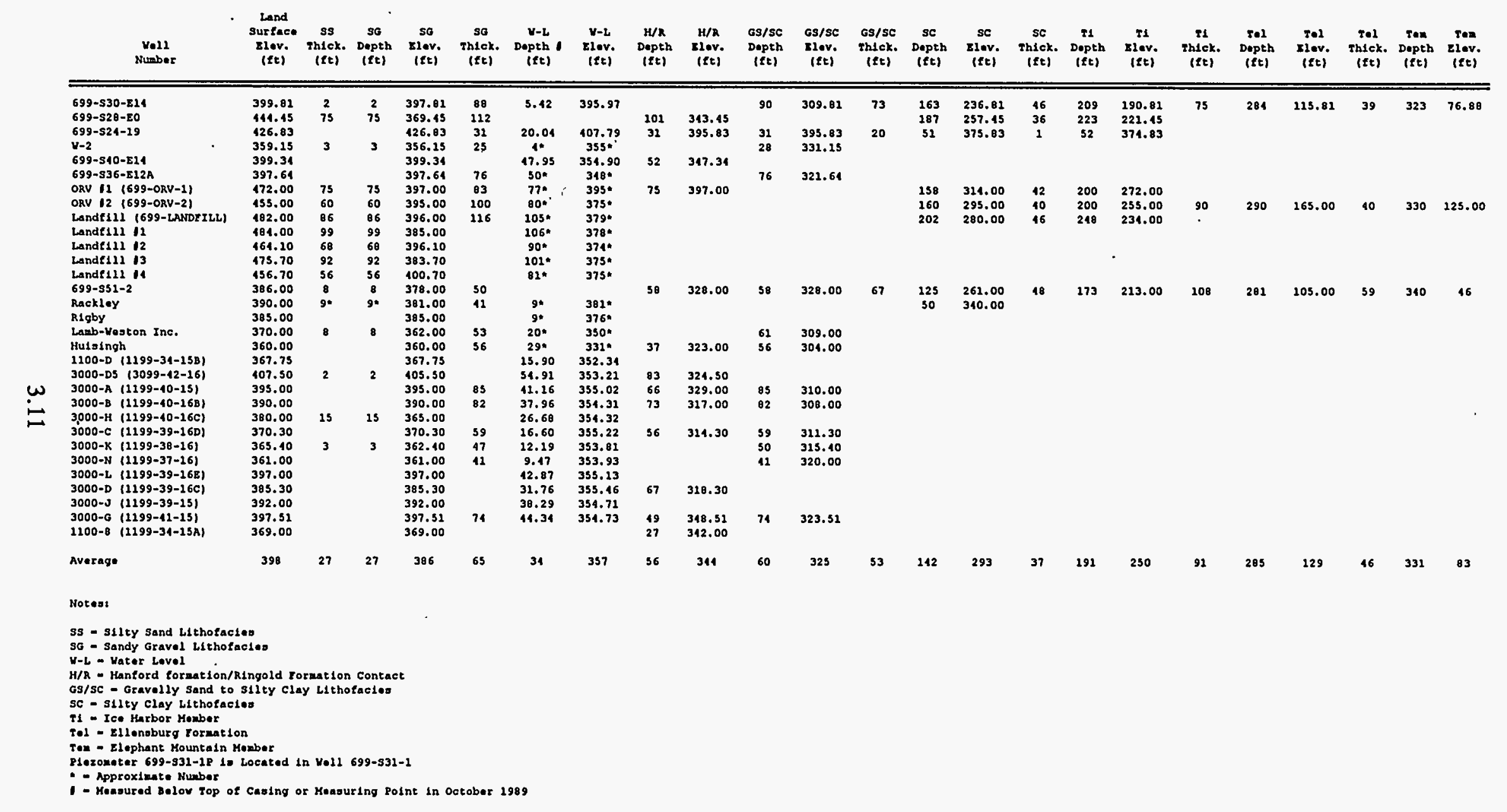


Table 3.3 General Characteristics of the Geologic Formations Beneath the Study Area

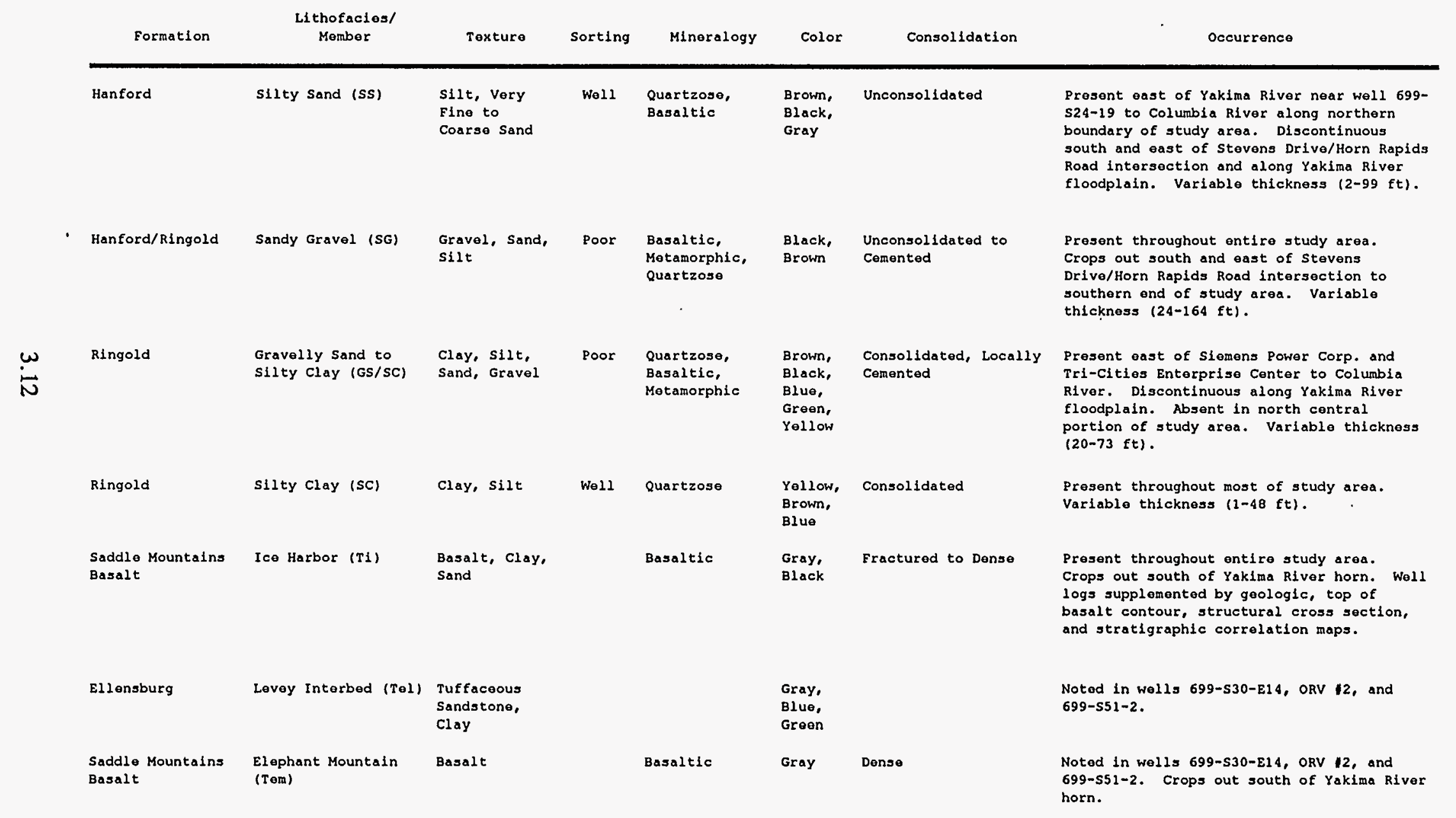




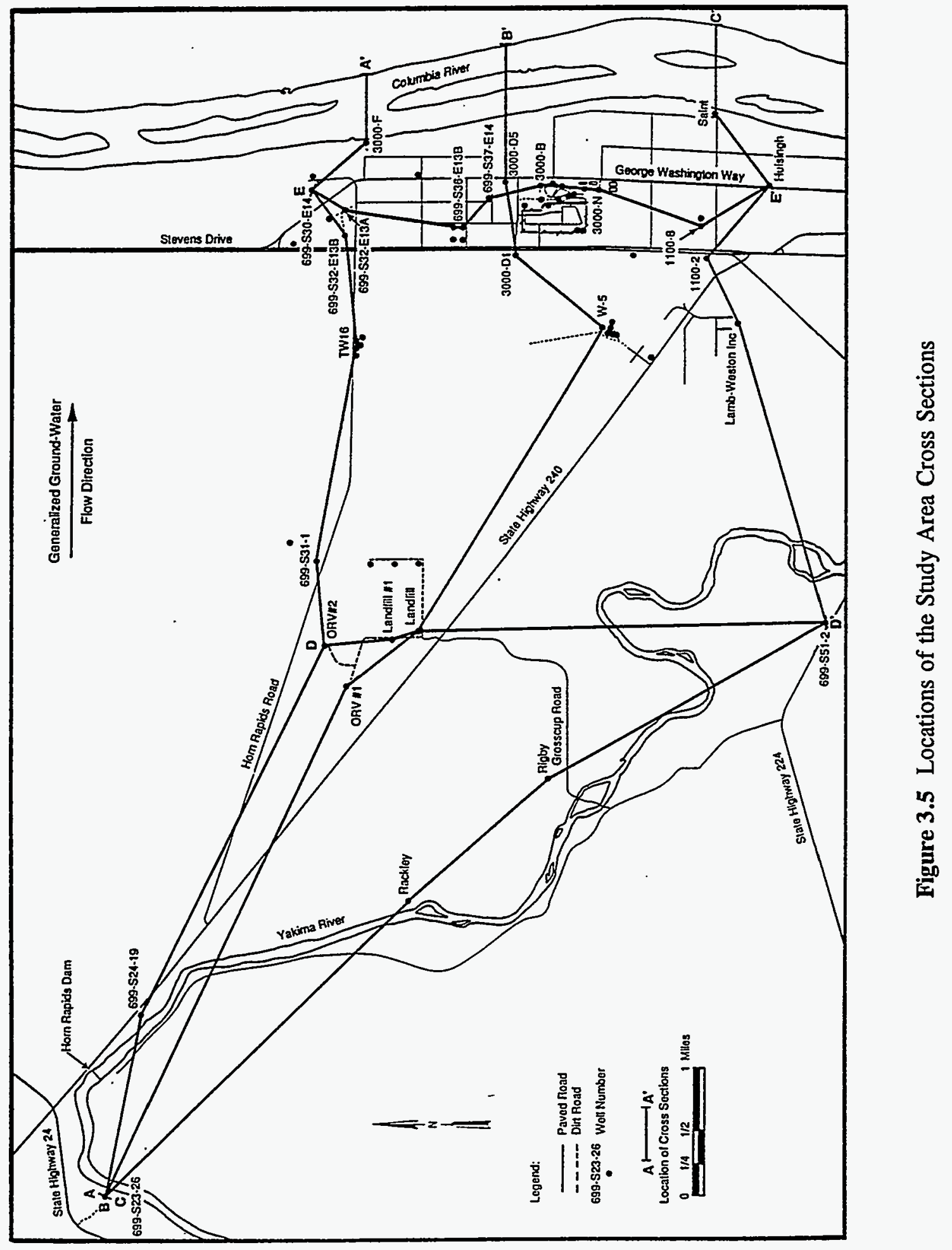




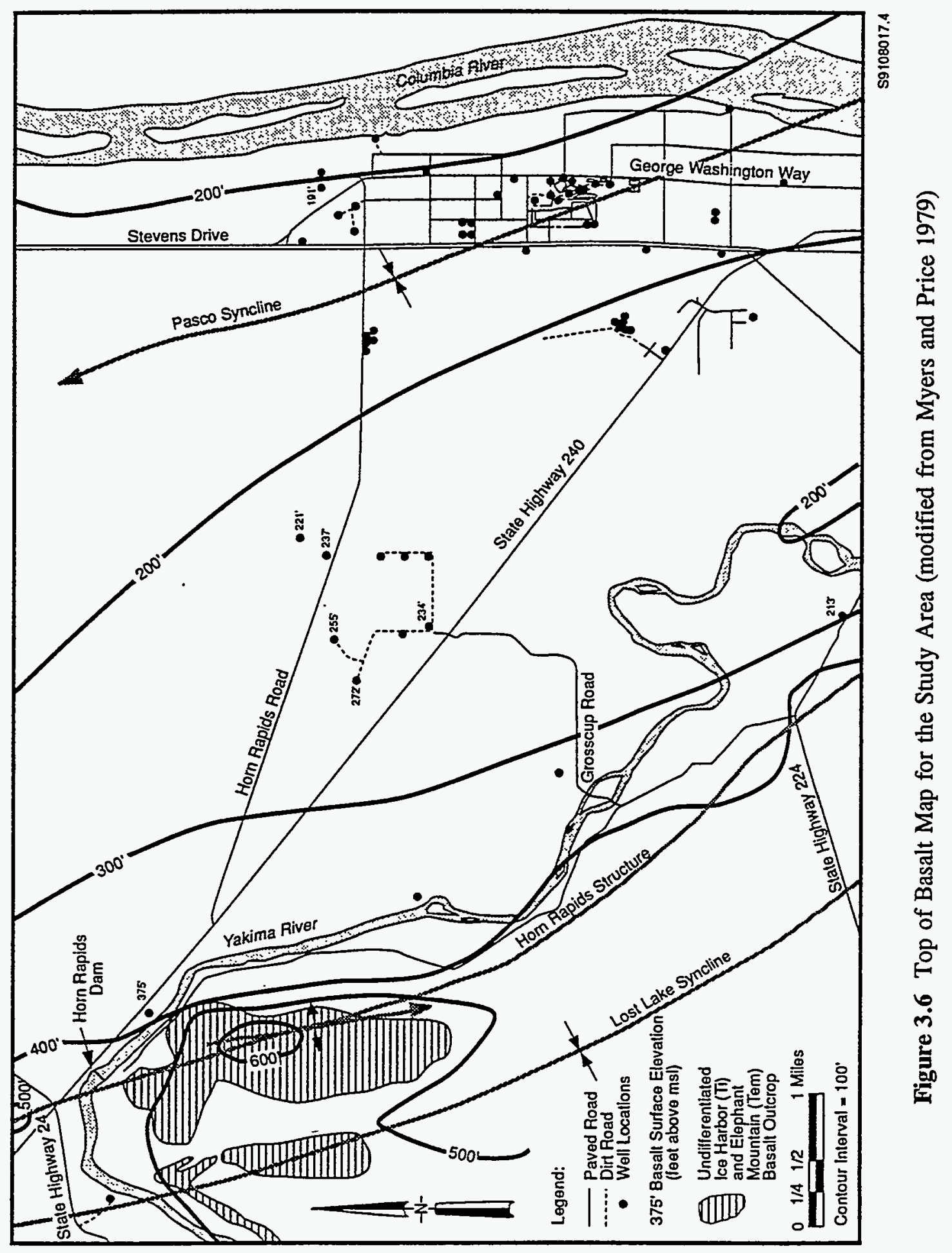


Columbia and Snake rivers and postglacial flooding. Future hydrogeologic investigations should include laboratory tests for bulk mineralogy and geochemistry to help delineate this contact.

For this study, the Ringold and Hanford sediments have been subdivided into four principal lithofacies. They are, in ascending order, 1) silty clay lithofacies (SC), 2) gravelly sand to silty clay lithofacies (GS/SC), 3) sandy gravel lithofacies (SG), and 4) silty sand lithofacies (SS). Predominant textural composition of these lithofacies is delineated in Figure 3.4 by clay/silt (C/S), sand (S), gravel (G), and cobble/boulder (C/B). Lindsey and Gaylord (1990) and Bjornstad (1990) suggested the use of lithofacies as the most accurate method for describing lithologic heterogeneities in fluvial depositional environments.

Delineation of these lithofacies was based on geologic sample descriptions from various sources and qualitative interpretation of geophysical logs. A small number of wells exist over a large study area. Both horizontal and vertical changes in sediment characteristics probably occur over short distances. The descriptions and occurrences of the lithofacies may require refinement as additional data are collected in future hydrogeologic investigations. Advanced borehole geophysical tools (e.g., commercial vendor sondes) should be run in several wells to provide more quantitative data on the properties of the suprabasalt sediments.

\subsubsection{Silty Clay Lithofacies}

The silty clay lithofacies occurs in nine wells ranging from 50 to $202 \mathrm{ft}$ bls (376 to $237 \mathrm{ft}$ above msl) (Table 3.2 and Figure 3.7). These sediments consist of well-sorted clay and silt with minor amounts of sand and weathered basalt fragments, suggesting low-energy deposition in an overbankfloodplain environment. The sediments are further characterized as quartzose and consolidated with variable colors, including yellow, brown, and blue. Geophysical logs show relatively higher natural gamma (higher clay content) and lower neutron neutron (higher porosity) and gamma gamma (lower density) counts in these sediments.

The silty clay lithofacies is present throughout most of the study area, ranging from 1 to $48 \mathrm{ft}$ thick (Table 3.2). The thickness appears to be relatively constant from the center of the study area eastward as the sediments slope about the same rate as the basalt surface (Plates 1 through 3 and Figure 3.7). The silty clay lithofacies probably correlates to the fine-grained Ringold sequence beneath the 300 Area described in DOE (1990a), the lower silt and clay of the Ringold Formation beneath the 300 Area in Lindberg and Bond (1979), and the lower Ringold unit beneath the 300 Area in (Schalla et al. 1988). Newcomb et al. (1972) noted blue clays in the lowest part of the Ringold Formation beneath the Richland area.

\subsubsection{Gravelly Sand to Silty Clay Lithofacies}

The silty clay lithofacies is overlain, in part, by a poorly sorted mixture of clay, silt, sand, and gravel. These sediments comprise the gravelly sand to silty clay lithofacies. This lithofacies contains several discontinuous sequences of fining upward sediments with a distinct silty clay lens forming the top. Webster and Crosby (1982) described fining upward cycles within the Ringold Formation elsewhere on the Hanford Site.

The sediments within the gravelly sand to silty clay lithofacies consist of quartzose, basaltic, and metamorphic grains. Color changes are common, including brown, black, blue, green, and yellow. 


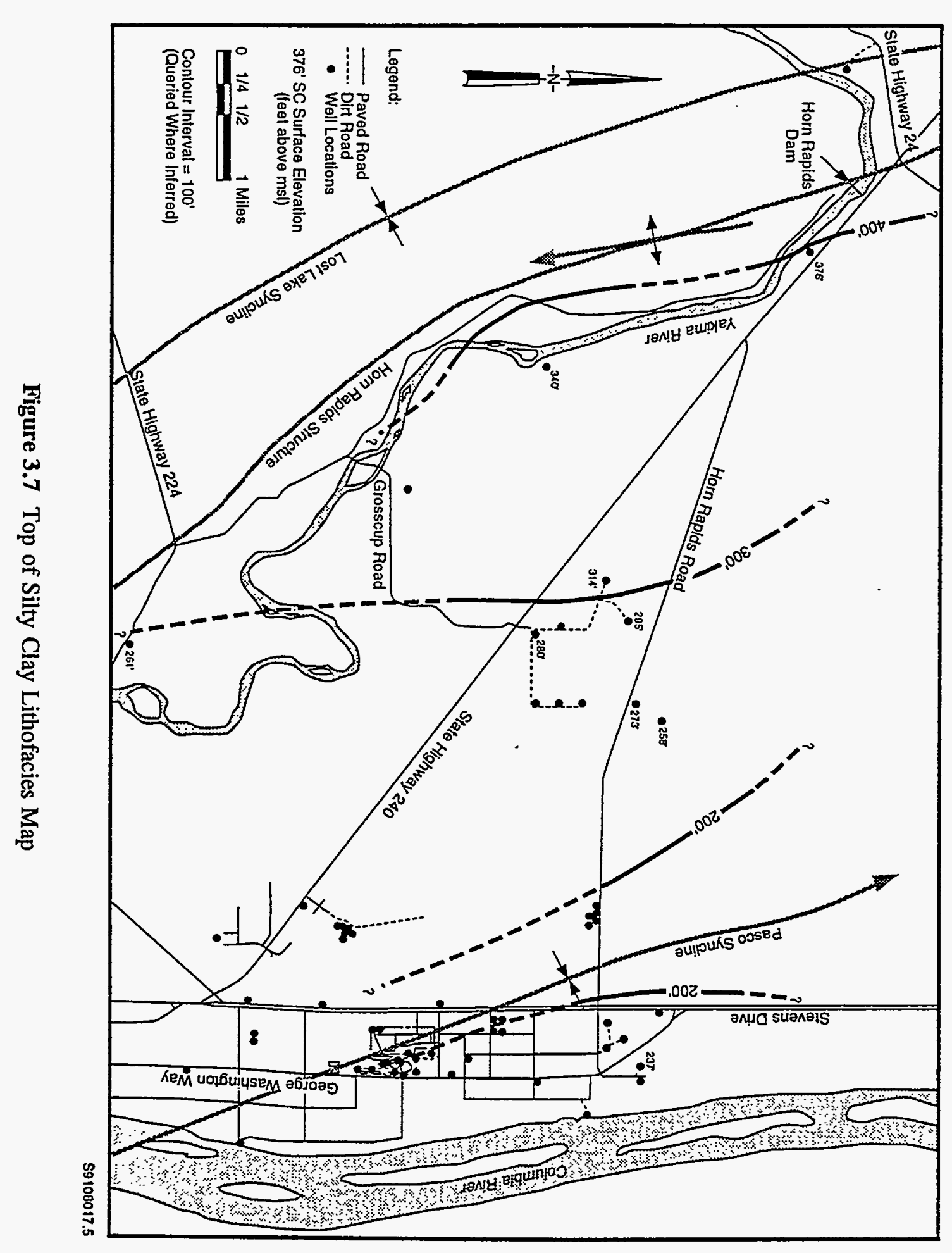


Drilling logs indicate the sediments are consolidated and locally cemented. Relatively higher natural gamma counts (higher clay content) were noted near the top of the lithofacies. Texture and sorting suggest several episodes of fluvial and slack-water deposition.

The gravelly sand to silty clay lithofacies occurs in 27 wells at depths of 28 to $90 \mathrm{ft}$ bls (396 to $304 \mathrm{ft}$ above msl) (Table 3.2 and Figure 3.8) and ranges in thickness from 20 to $73 \mathrm{ft}$ (Table 3.2). The sediments are present primarily in the eastern part of the study area and discontinuous along the Yakima River floodplain (Plates 1 through 5 and Figure 3.8). Future hydrogeologic investigations within the study area should include test holes between the city of Richland landfill and 1100 Area to further characterize the distribution of these sediments.

The silty clay lens at the top of the gravelly sand to silty clay lithofacies appears to be an erosional unconformity with peak elevations east of George Washington Way and west of Stevens Drive (Figure 3.8). Thickness of the silty clay lens ranges from $8 \mathrm{ft}$ in well 699-S32-E13B to $45 \mathrm{ft}$ in well W-5. The silty clay lens correlates to the uppermost fine-grained Ringold Formation facies beneath the 1100-EM-1 Operable Unit described in DOE (1990b). DOE (1990b) also noted an ash layer east of the Horn Rapids landfill (Figure 1.2), which is laterally continuous with the uppermost fine-grained Ringold Formation facies. The ash layer is interpreted to be originally an airfall deposit of limited extent, transported to its present location by the ancestral Yakima River.

\subsubsection{Sandy Gravel Lithofacies}

The sandy gravel lithofacies is present throughout the entire study area. The sandy gravel lithofacies overlies the silty clay lithofacies in the western part of the study area and the gravelly sand to silty clay lithofacies in the eastern part of the study area. The sediments crop out south and east of the Stevens Drive/Horn Rapids Road intersection to the southern end of the study area (Plates 1 through 5 and Figure 3.9).

The sandy gravel lithofacies was partially or fully penetrated in all 61 wells at depths ranging from land surface to $99 \mathrm{ft}$ bls ( $437 \mathrm{fo} 353 \mathrm{ft}$ above msl) (Table 3.2 and Figure 3.9). Thickness of the lithofacies varies between 24 and $164 \mathrm{ft}$ (Table 3.2), with the thickest accumulation in piezometer 699-S31-1P. The sediments are poorly sorted, consisting of fine to coarse gravel with a sand and silt matrix. The gravels consist mainly of basalt with some metamorphic and quartzose clasts. The sands and silts consist of black and brown basaltic and quartzose grains. The sediments range from unconsolidated to cemented. Backfill materials from construction activities are found locally at or near the surface and are generally indistinguishable from the in situ gravels and sands. Texture and sorting suggest high-energy deposition, resulting from both fluvial and glaciofluvial processes.

The sandy gravel lithofacies correlates to the coarse-grained Ringold Formation facies and Hanford formation beneath the 1100-EM-1 Operable Unit described in DOE (1990b). These sediments also appear to correlate to the coarse-grained Ringold sequence and Hanford formation beneath the 300 Area in DOE (1990a) and the middle Ringold unit and Hanford formation beneath the 300 Area in (Schalla et al. 1988).

\subsubsection{Silty Sand Lithofacies}

The silty sand lithofacies is the uppermost lithofacies in the study area except where the sandy gravel lithofacies crops out (Plates 1 through 5 and Figure 3.9). The silty sand lithofacies was 


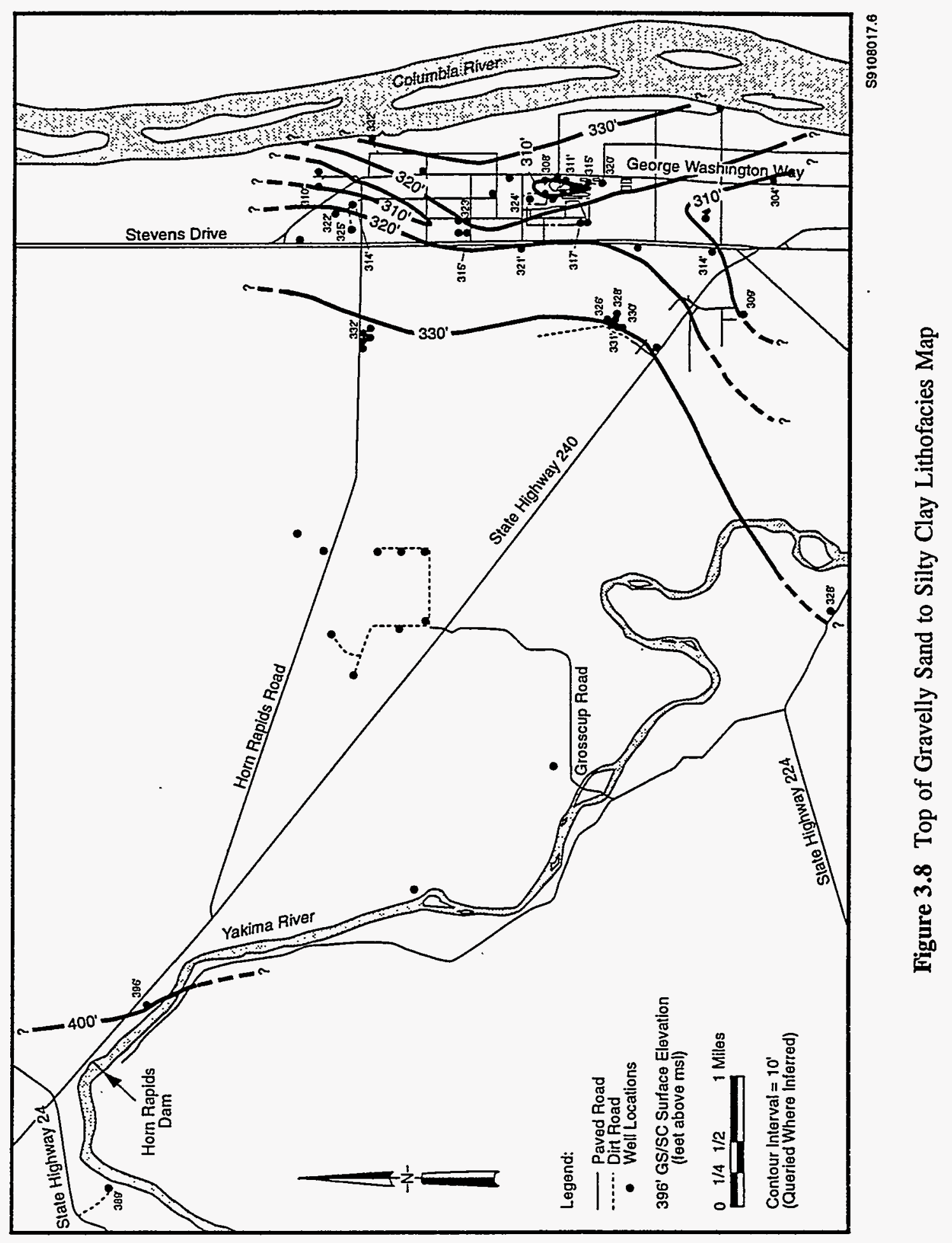




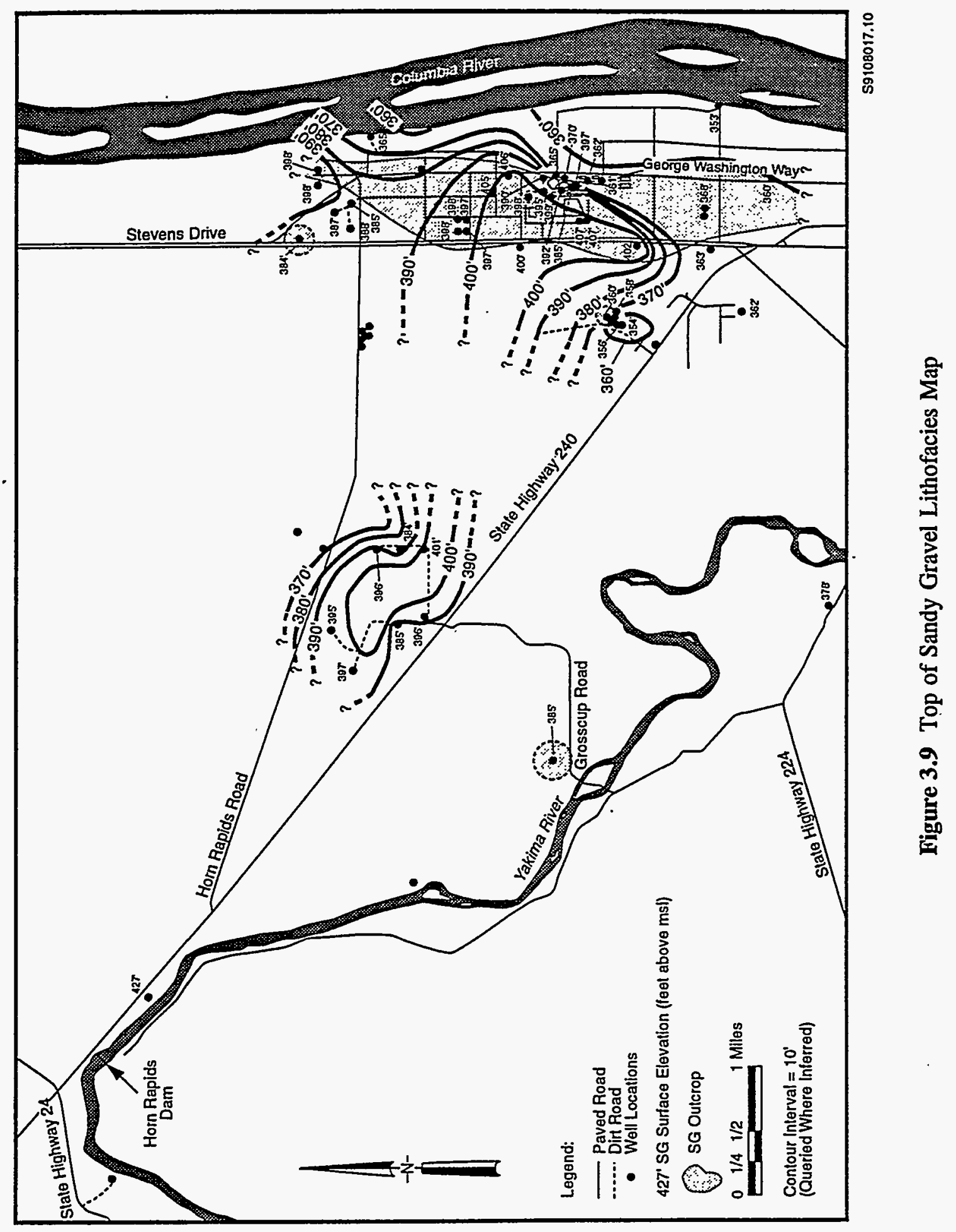


probably removed during construction activities in these areas. The silty sand lithofacies consists of unconsolidated and well-sorted silt and very fine to coarse sand. The grains are described as both quartzose and basaltic and brown, black, and gray. Minor gravel lenses are noted in wells ORV \#1, ORV \#2, the Landfill Well, and 699-S31-1 (Plates 1, 2, and 4). The sediments range in thickness from 2 to $99 \mathrm{ft}$ (Table 3.2), with the thickest accumulation near the city of Richland landfill (Figure 1.2).

The silty sand lithofacies was probably derived from two sources. The coarse-grained sands and minor gravel lenses probably represent a transitional facies between the flood deposits of the Pasco Gravels facies and the slack-water deposits of the Touchet Beds facies. The silt and fine sands, evident in the form of northeast-trending sand dunes, are probably eolian deposits derived from reworked Hanford sediments. The silt and fine sands correlate to the surficial deposits at the 1100-EM-1 Operable Unit described in DOE (1990b) and the eolian deposits at the 300 Area in DOE (1990a), Lindberg and Bond (1979), and Schalla et al. (1988).

\subsection{Hydrology of the Study Area}

Several natural and artificial surface-water bodies, a confined aquifer, and an unconfined aquifer are present within the study area. This discussion focuses on the surface-water types, locations, and uses, and ground-water occurrence, recharge, and discharge.

\subsubsection{Surface Water}

The primary surface-water features within the study area are the Yakima and Columbia rivers (Figure 1.2). The Yakima River bounds the study area to the west from approximately State Highway 24 to State Highway 224. The Columbia River forms the eastern boundary from approximately Horn Rapids Road to Saint Street. Flows along these reaches are controlled primarily by the Horn Rapids irrigation diversion dam in the Yakima River and Priest Rapids and McNary hydroelectric dams in the Columbia River.

Surface runoff to the Yakima and Columbia rivers within the study area contributes little to total gaged flows (DOE 1988b). Low-intensity precipitation events combined with high evapotranspiration rates and soil infiltration capacities are insufficient to generate runoff. Seeps have been documented within the study area along the Columbia River shoreline (McCormack and Carlile 1984). The seeps flow intermittently, primarily as a result of fluctuating river levels.

The Columbia River is used as a source for drinking water, agricultural and lawn irrigation, and recreational activities. The city of Richland pumping station at Snyder Street supplies the municipal water-treatment plant and North Richland well field. Irrigation intakes include the AEDC and PNL at the Port of Benton and Washington State University Tri-Cities at Sprout Road. The Yakima River is used for irrigation and recreational activities.

Ponded water is present in low-lying areas of the Yakima River floodplain (Figure 1.2). Ponded water was also noted near wells W-1 through W-6 (Figure 3.1) from February through April 1990, when ground-water levels rose above land surface. Ground water also discharges year-round to several drainage ditches south of the study area in the city of Richland. 
Artificial surface-water features within the study area include the settling and recharge basins within the North Richland well field, Siemens Power Corp. process lagoons, and Horn Rapids ditch, which diverts water from the Yakima River at Horn Rapids Dam (Figure 1.2).

\subsubsection{Ground Water}

Both confined and unconfined aquifers occur beneath the study area. For this study, four principal hydrofacies have been identified. Hydrofacies are defined here as laterally continuous units of hydrologic significance. Hydrologic significance is indicated by a change in water level with depth and/or a hydraulic conductivity contrast between units. No hydrochemical data are available from this study. The hydrofacies are, in ascending order, 1) a confined aquifer (CA) within the Ice Harbor Member, 2) an aquitard (A) formed by the silty clay lithofacies, 3 ) the unconfined aquifer (UA) within the gravelly sand to silty clay and sandy gravel lithofacies, and 4) the unsaturated sediments (US) within the sandy gravel and silty sand lithofacies. Figure 3.10 is a generalized hydrofacies diagram showing the average water-level elevations available for the study area. Table 3.4 lists hydrofacies depths, elevations, and thicknesses. Hydraulic property estimates for hydrologic units within and adjacent to the study area are available from several sources. These estimates are shown in Table 3.5.

Interpretation of these hydrofacies was based on geologic sample descriptions, primarily texture, sorting, and consolidation. Natural gamma, neutron, and density logs were used qualitatively to indicate relative differences in hydraulic conductivity and porosity. Hydraulic head measurements were used to calculate horizontal and vertical gradients. However, as mentioned previously, only a few wells exist over a large study area. Most of these wells are completed in the unconfined aquifer. Changes in sediment characteristics probably occur over short distances resulting in heterogeneous and

anisotropic conditions. Refinement of the hydrofacies descriptions and occurrences may be required as new hydrogeologic data become available. As additional monitoring wells are completed at discrete intervals, water levels should be measured concurrently across the study area. A flow net should be constructed to analyze the hydraulic heads within and between hydrofacies.

\subsubsection{Confined Aquifer}

A confined aquifer occurs within the Ice Harbor Member of the Saddle Mountains Basalt Formation and is monitored in two of the eight wells penetrating basalt. Drilling logs describe the aquifer as water-bearing, black, porous, or vesicular basalt with some sand. Aquifer thickness ranges from 1 to $22 \mathrm{ft}$ (Table 3.4); however, the lateral continuity of the confined aquifer is unknown. The distribution and continuity of the aquifer should be further characterized to better understand ground-water flow and contaminant transport. Schalla et al. (1988) noted an uppermost confined aquifer beneath the 300 Area within the Ice Harbor Member and basal Ringold unit with horizontal hydraulic conductivities of 2 to $260 \mathrm{ft} /$ day and transmissivities of 60 to $1300 \mathrm{ft}^{2} /$ day (Table 3.5).

Local recharge to the confined aquifer probably occurs near the Yakima River horn where the Ice Harbor Member crops out adjacent to the Yakima River (Plates 1 through 3 and Figure 3.6). Increasing hydraulic head with depth was noted in drilling logs for well ORV \#1 (Figure 3.1). Schalla et al. (1988) reported hydraulic heads for the uppermost confined aquifer beneath the 300 Area approximately 20 to $35 \mathrm{ft}$ higher than the unconfined aquifer, resulting in an upward hydraulic gradient of 0.15 to $0.27 \mathrm{ft} / \mathrm{ft}$. Discharge occurs to the unconfined aquifer and Columbia River. 


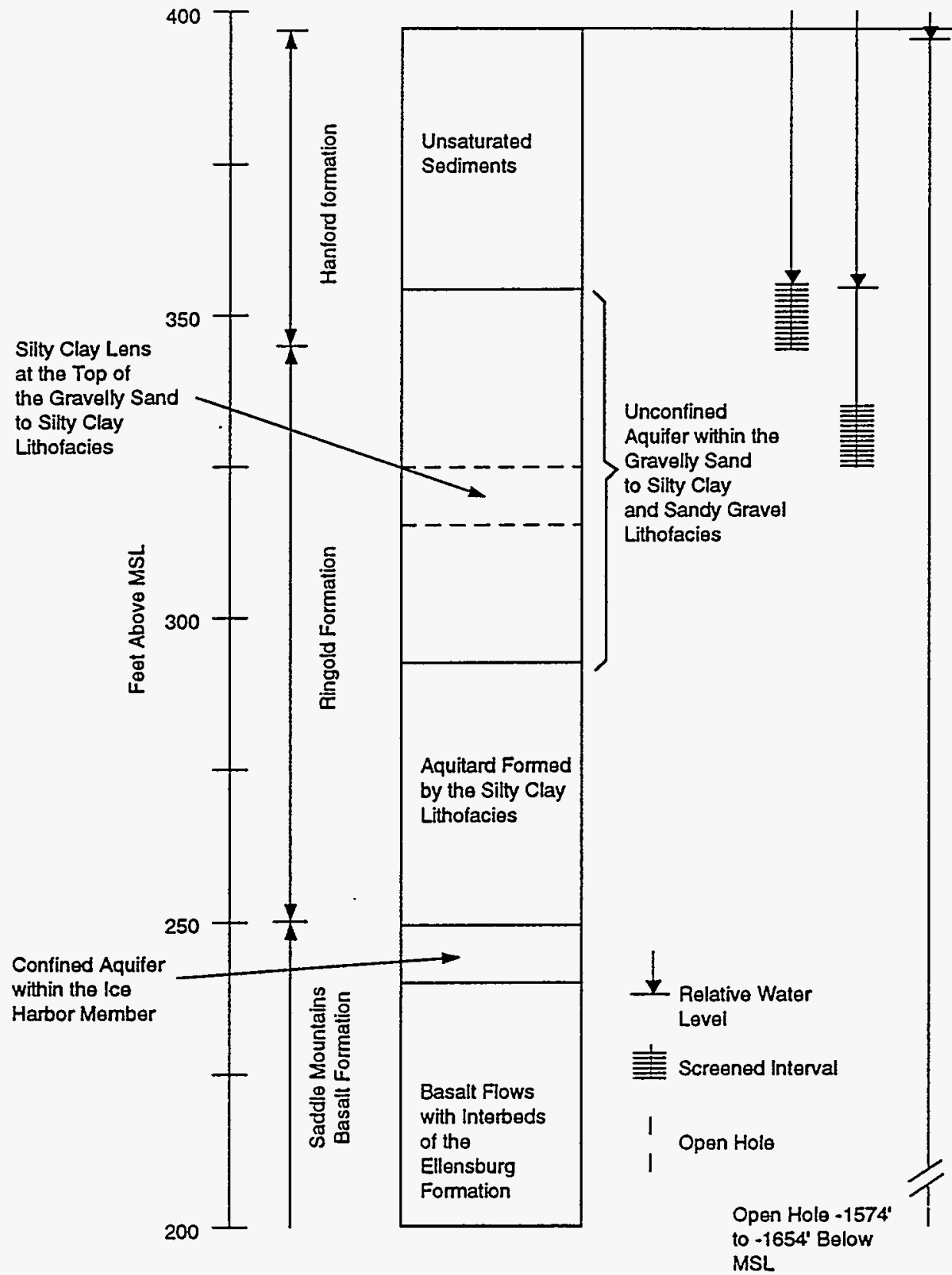

$\$ 9007059.36$

Figure 3.10 Generalized Hydrofacies Diagram for the Study Area 
Table 3.4 Hydrofacies Depths, Elevations, and Thicknesses Beneath the Study Area

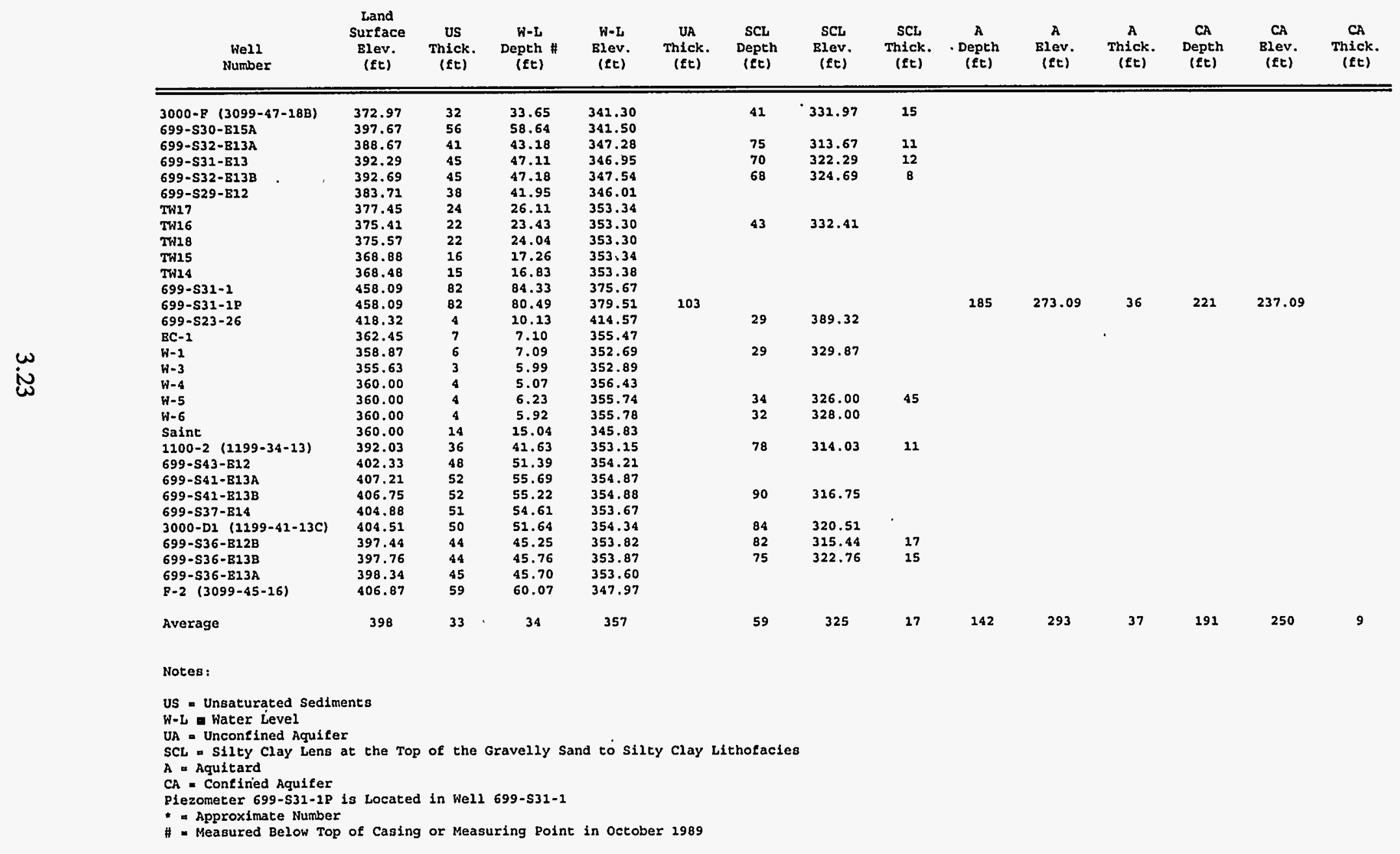


Table 3.4 (cont'd)

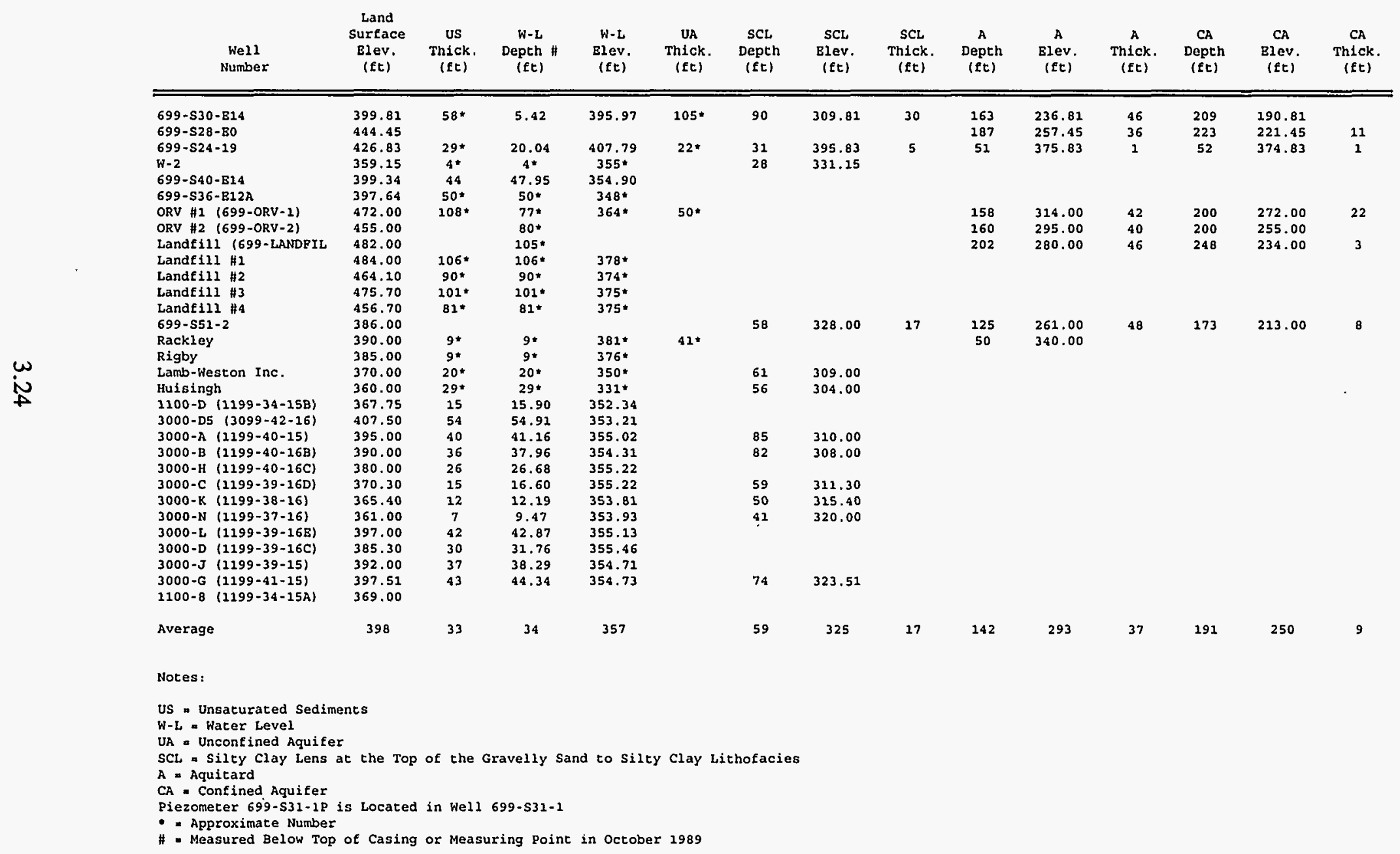


Table 3.5 Hydraulic Property Estimates Within and Adjacent to the Study Area

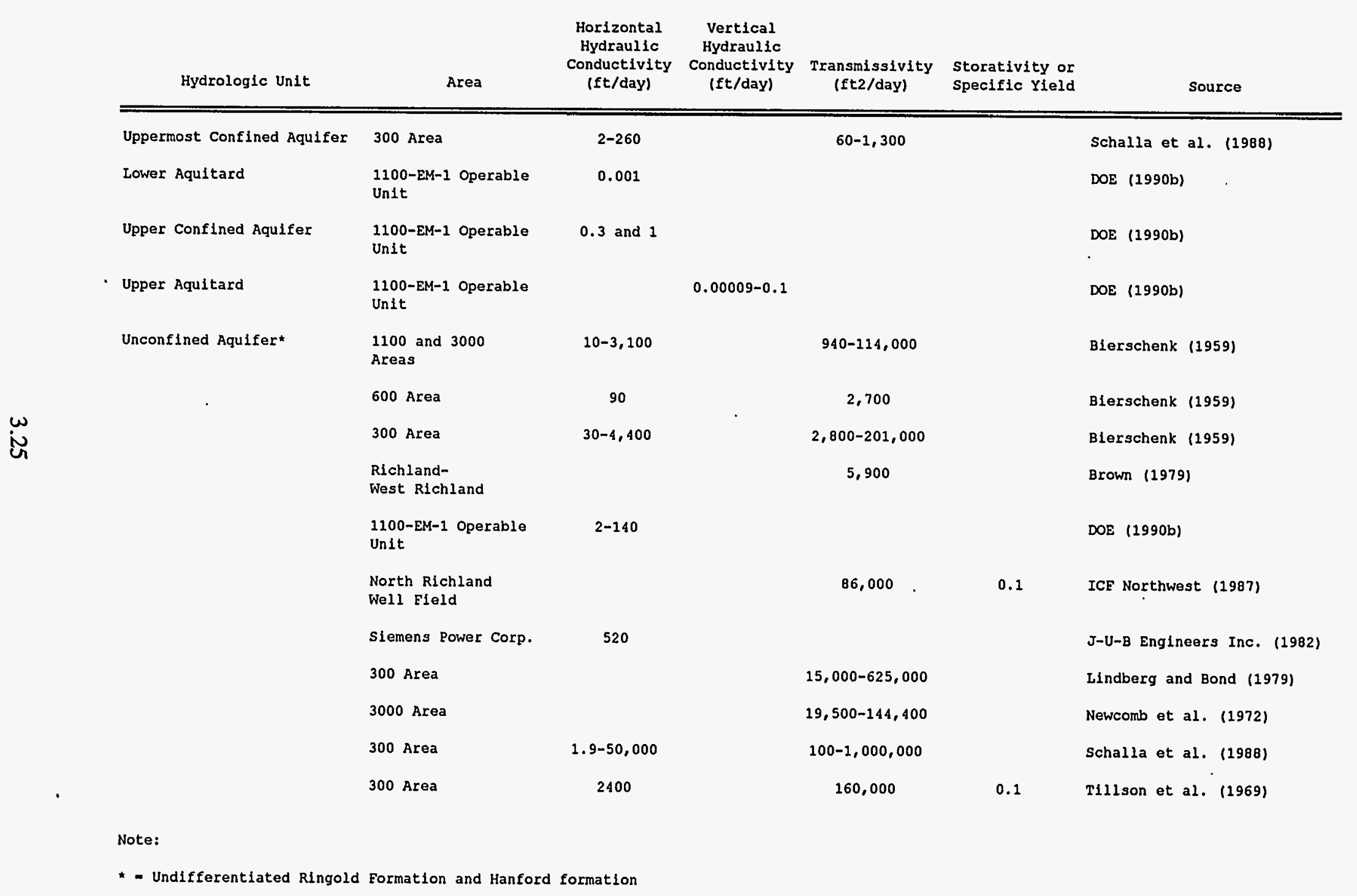


Hydraulic head data collected in this study for both wells monitoring the confined aquifer (piezometer 699-S31-1P and well 699-S24-19) are questionable. Drilling logs indicate potential hydraulic connection between the confined and unconfined aquifers. Annular seals between the aquifers are not evident in the logs. Potential hydraulic connection is also noted for five of the six other wells penetrating basalt. Hydraulic testing should be done at these wells to assess these potential connections.

\subsubsection{Aquitard}

An aquitard is formed by the silty clay lithofacies overlying the Ice Harbor Member. The aquitard ranges in thickness from 1 to $48 \mathrm{ft}$ (Table 3.4) and appears to be laterally continuous within and beyond the study area, extending north to the 300 Area and south to the city of Richland. Beneath the $1100-$ EM-1 Operable Unit, DOE (1990b) reported a silt layer overlying the basalt with estimated horizontal hydraulic conductivity of $0.001 \mathrm{ft} /$ day (Table 3.5 ). Geophysical logs show relatively higher natural gamma (higher clay content) and lower neutron neutron (higher porosity) and gamma gamma (lower density) counts in these sediments.

\subsubsection{Unconfined Aquifer}

The unconfined aquifer is the uppermost areally extensive aquifer beneath the study area and is contained within the gravelly sand to silty clay and sandy gravel lithofacies. The unconfined aquifer is laterally continuous within the Ringold Formation and Hanford formation beneath the Hanford Site. Fifty six of the 61 wells used in this study are completed in the unconfined aquifer. Depth to water ranges from near land surface in wells W-1 through W-6 to approximately $100 \mathrm{ft}$ in the city of Richland landfill wells (Figure 3.1). Perched water is found locally in north Richland during the summer irrigation season (J.R. Raymond, PNL, personal communication, 1990).

Thickness of the unconfined aquifer is varied, ranging from approximately 22 to $105 \mathrm{ft}$ (Table 3.4). The minimum thickness occurs in well 699-S24-19, where the basalt has been uplifted and the overlying sediments are generally thinner (Plate 1 and Figure 3.6). Thickness increases to a maximum in the central part of the study area in piezometer 699-S31-1P and again in the northeastern part of the study area in well 699-S30-E14. Ground-water mounding occurs beneath the settling and recharge basins within the North Richland well field.

The base of the unconfined aquifer is formed, at least in part, by the aquitard overlying the Ice Harbor Member. The silty clay lens at the top of the gravelly sand to silty clay lithofacies may divide the aquifer into two parts in the eastern part of the study area. The silty clay lens ranges from 8 to $45 \mathrm{ft}$ thick (Table 3.4 and Figure 3.11). The surface of the silty clay lens appears to be an erosional unconformity (Figure 3.8) and discontinuities may occur. The silty clay lens may also cause local semiconfined to confined conditions within the unconfined aquifer. DOE (1990b) noted a silt aquitard of similar thickness ( 4 to $33 \mathrm{ft}$ ) beneath the 1100-EM-1 Operable Unit that correlates to the silty clay lens. Vertical hydraulic conductivities for this aquitard range from 0.00009 to $0.1 \mathrm{ft} /$ day (Table 3.5). DOE (1990b) further noted an upper confined aquifer beneath the silt aquitard with horizontal hydraulic conductivities of 0.3 and $1 \mathrm{ft} /$ day (Table 3.5). A hydraulic head in the upper confined aquifer approximately $6 \mathrm{ft}$ higher than the unconfined aquifer was measured near the Horn Rapids landfill (Figure 1.2). This results in an upward hydraulic gradient of $0.36 \mathrm{ft} / \mathrm{ft}$. 


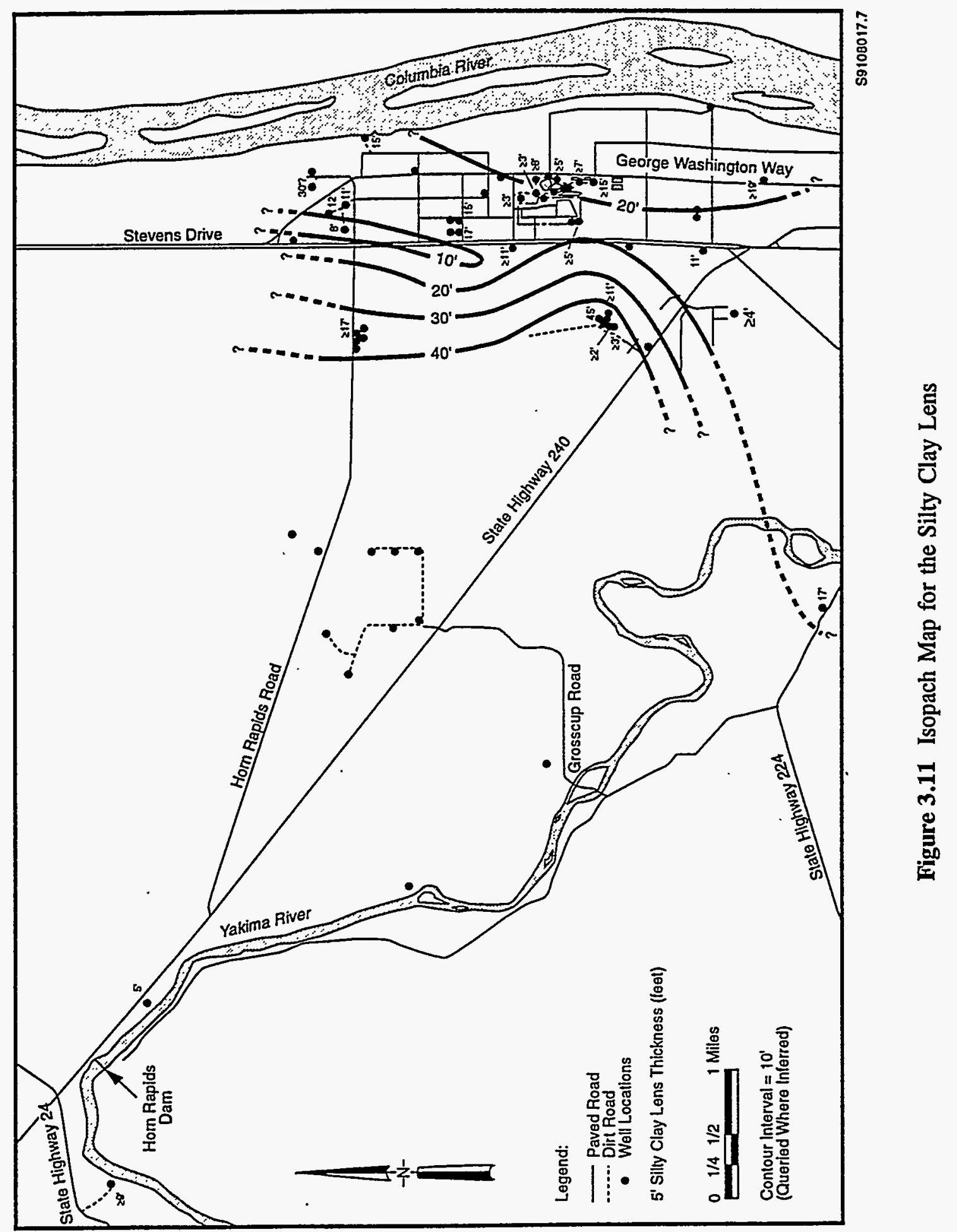


No water-level data are available from this study to evaluate the hydrologic significance of the silty clay lens. Recent water-level measurements in the HGWDB from well 699-S41-E13C, adjacent to wells 699-S41-E13A and 699-S41-E13B (Figure 3.1), indicate a downward hydraulic gradient near these wells. The silty clay lens appears to be locally significant enough to produce hydraulic head differences. The unconfined aquifer probably acts as a heterogeneous hydrofacies on a small scale over a short time and a homogeneous hydrofacies on a large scale over a long time. The distribution and continuity of the silty clay lens should be further characterized as it may have a marked effect on ground-water flow and contaminant transport in the unconfined aquifer.

Hydraulic property estimates for the unconfined aquifer within and adjacent to the study area are available from several sources, including Bierschenk (1959), Brown (1979), DOE (1990b), ICF Northwest (1987), J-U-B Engineers Inc. (1982), Lindberg and Bond (1979), Newcomb et al. (1972), Schalla et al. (1988), and Tillson et al. (1969). A summary of these estimates is provided in Table 3.5. The hydraulic conductivity and transmissivity values range over several orders of magnitude, probably as a result of aquifer heterogeneity, well design and construction, and/or aquifer test methods.

Local sources of natural recharge to the unconfined aquifer are river water along influent reaches of the Yakima River and precipitation infiltration. Significant artificial recharge occurs from the settling and recharge basins within the North Richland well field. Additional recharge occurs from agricultural, lawn, and waste-water irrigation (Figure 1.2). Discharge occurs primarily to the Columbia River. Lesser discharge occurs to production wells in the North Richland well field, agricultural irrigation wells, monitoring wells, and private wells in north Richland. Figure 3.12 shows water-level elevations for the unconfined aquifer in July 1989. This month was chosen because a complete set of water-level data exists for all of the monitoring wells. Ground water flows generally from west to east. Detailed information on the spatial and temporal distribution of hydraulic head in the unconfined aquifer is provided in Chapter 4.0.

\subsubsection{Unsaturated Sediments}

The unsaturated sediments consist of the upper part of the sandy gravel lithofacies and all of the silty sand lithofacies. The unsaturated sediments range from 3 to $108 \mathrm{ft}$ thick (Table 3.4 and Figure 3.13). The thinnest accumulation occurs in wells $W-1$ through $W-6$, where the water table is near land surface. The unsaturated sediments are also thin immediately downgradient of the settling and recharge basins within the North Richland well field. The unsaturated sediments are thickest beneath the city of Richland landfill.

The unsaturated sediments correspond to the vadose zone beneath the 1100-EM-1 Operable Unit described in DOE (1990b). DOE (1990b) reported moisture contents ranging from 1.09 to $7.28 \%$ in this zone.

\subsection{Hydrogeologic Conceptual Model of the Unconfined Ground-Water Flow System}

The remainder of this study focuses on ground-water flow characteristics within the unconfined aquifer beneath the study area. Analysis of existing hydrogeologic data has resulted in the development of the following conceptual model for the unconfined aquifer. 
$6 \tau^{\circ} \varepsilon$

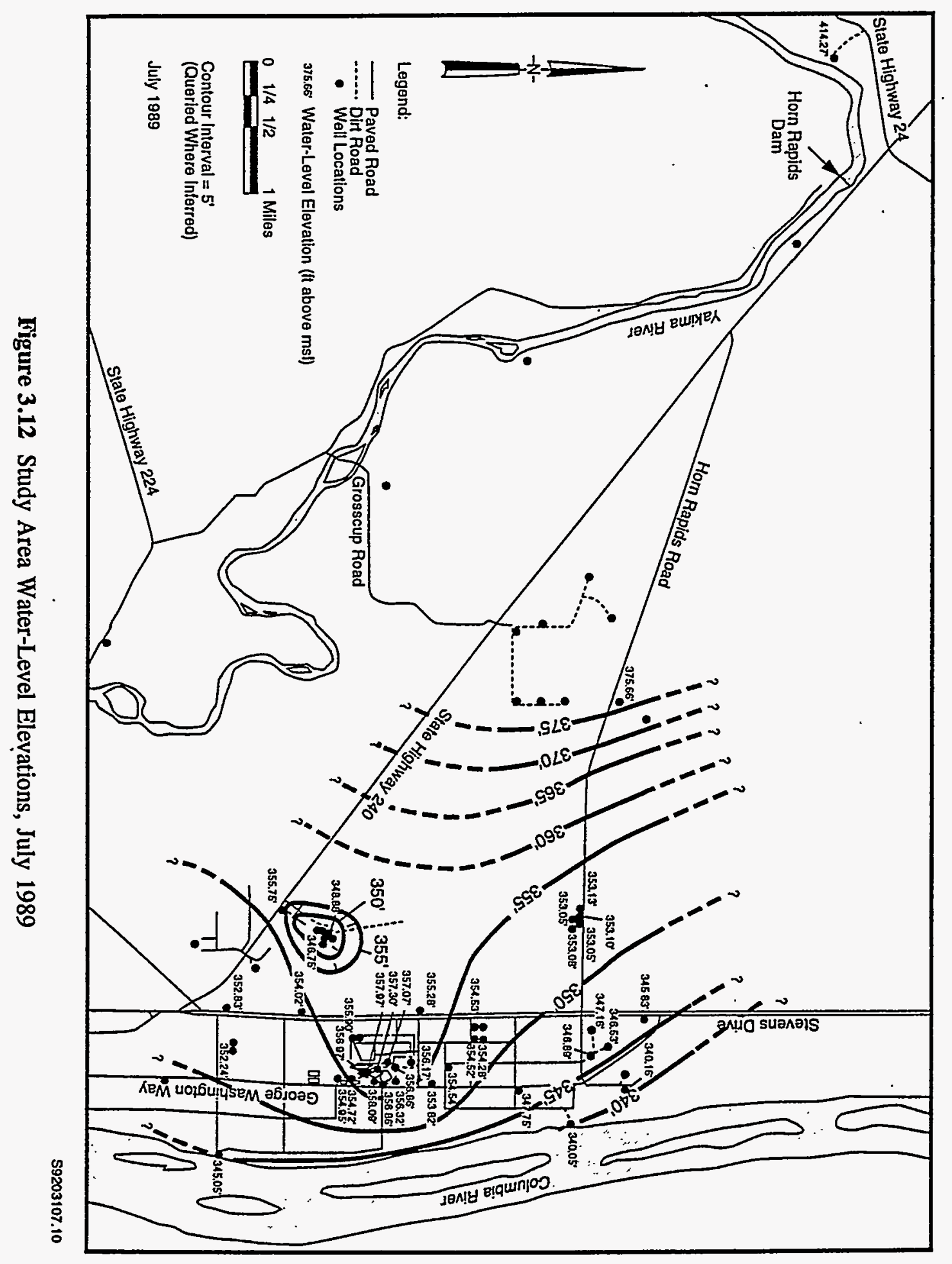




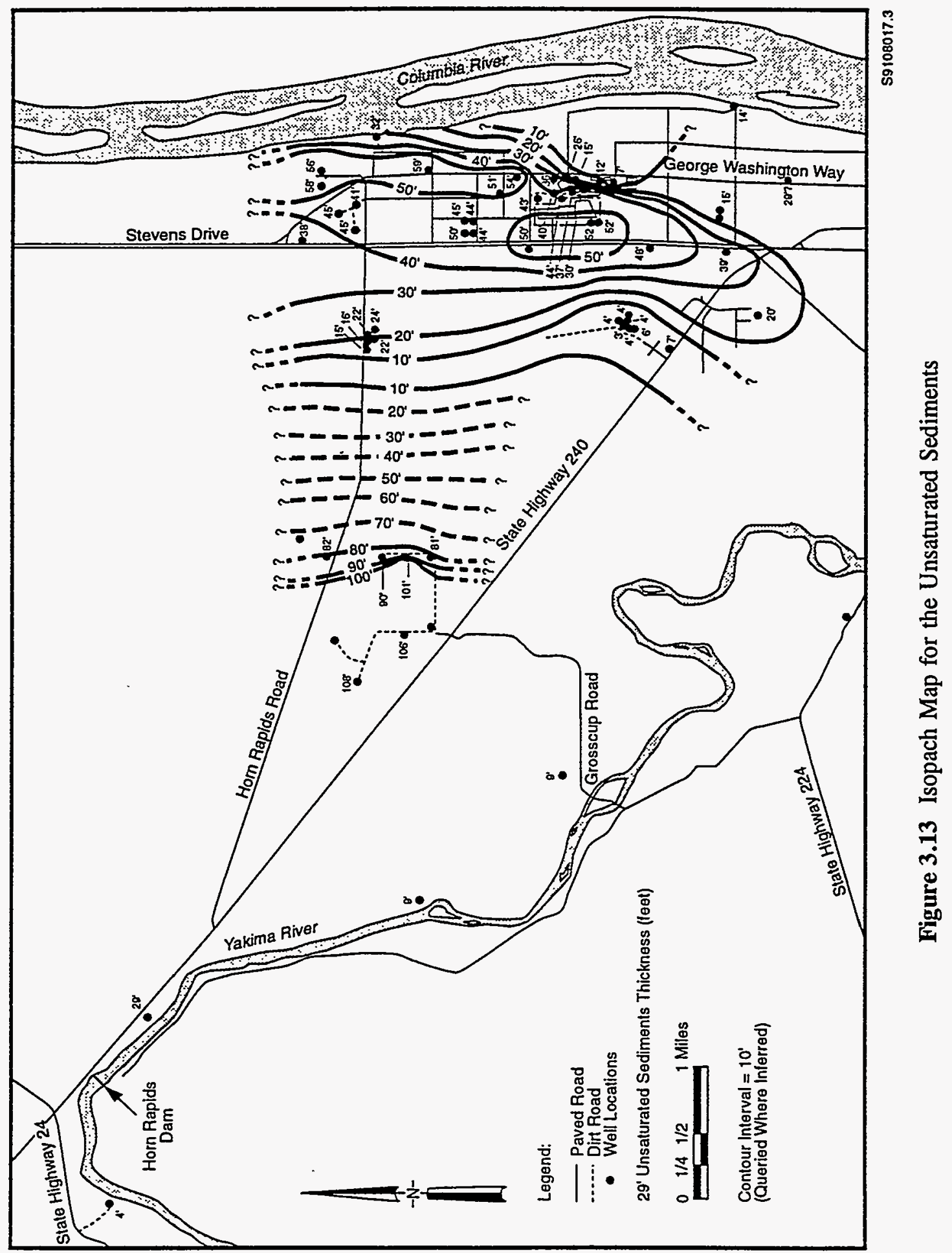


The hydrogeology of the unconfined aquifer beneath the study area is very complex. Sediments of the Ringold Formation and Hanford formation, which constitute the aquifer, were derived from both fluvial and glaciofluvial processes. Depositional environments ranged from high to low energy. The fluvial sediments were deposited by the ancestral Columbia and Snake rivers. These river courses varied significantly over time, changing as the Columbia River Basalts continued to be uplifted. Sediments range from main stream to overbank-floodplain deposits. The glaciofluvial sediments were deposited by catastrophic floods. Floods eroded portions of the underlying sediments and redeposited them with the flood sediments. These sediments range from massive flood to slack-water deposits.

The depositional history of the Ringold and Hanford sediments has resulted in an unconfined aquifer that is both heterogeneous and anisotropic. The unconfined aquifer occurs within the gravelly sand to silty clay and sandy gravel lithofacies. Aquifer thickness and undoubtedly, hydraulic properties, are varied. The silty clay lithofacies serves as the aquifer bottom in the western part of the study area. In the eastern part of the study area, the silty clay lens at the top of the gravelly sand to silty clay lithofacies may divide the aquifer into two parts. Local semiconfined to confined conditions within the unconfined aquifer may be caused by the silty clay lens. The unconfined aquifer probably acts as a heterogeneous hydrofacies on a small scale over a short time and a homogeneous hydrofacies on a large scale over a long time. Ground water flows generally west to east, from the Yakima River to the Columbia River. The aquifer is recharged by the Yakima River and discharges to the Columbia River. 


\subsection{Hydraulic Head Distribution}

This chapter describes the flow characteristics of the unconfined aquifer beneath the study area based on the spatial and temporal distribution of hydraulic head within the aquifer. A description of the water-level monitoring network is provided. The operations and impacts of the North Richland well field and agricultural, lawn, and waste-water irrigation are discussed as well as the interrelationship with the Yakima and Columbia rivers.

\subsection{Description of the Water-Level Monitoring Network}

The water-level monitoring network for this study included 46 wells and two gaging stations on the Columbia River. Wells were selected based on their completion interval (primarily within the unconfined aquifer) and whether routine access to the well site was permitted. Well completion distribution is shown in Table 4.1. Water-level data were collected using electric/steel tapes, continuous waterlevel recorders, and transducers and data loggers. Additional river-elevation and North Richland well field data were collected from the city of Richland at the municipal water-treatment plant on Saint Street.

Water-level data were collected from June 1989 to May 1990. Measurement frequencies varied with collection method and included continuous, every half hour, every 6 hours, weekly, monthly, and biannually. The monthly measurements shown in Table 4.2 and other frequencies where appropriate, were used for analysis and interpretation. The complete water-level data set is contained in Appendix B. Figure 4.1 shows the locations and collection methods for the network.

\subsubsection{Electric/Steel Tapes}

Thirty nine of the 46 wells in the water-level monitoring network were measured using electric/ steel tapes (Figure 4.1). All 39 of these wells are completed in the unconfined aquifer (Table 4.1). An electric tape was used initially to measure the approximate depth to water with steel tape measurements used thereafter.

Hydraulic heads in the monitoring, agricultural irrigation, and other wells were measured on a weekly basis from June to August 1989 and monthly from September 1989 to May 1990, except for the wells completed in basalt. Heads in these wells were measured infrequently during the year because of the focus on the unconfined aquifer. Hydraulic heads in the production wells were measured on a monthly basis from June 1989 to January 1990. Field data including date, procedure, measuring device, initials, well number, time, held value, cut value, depth to water, casing elevation, water-level elevation, and comments were recorded in a bound notebook and transferred to computer spreadsheets for analysis and interpretation. The water levels were measured per PNL technical procedure WL-1, "Water-Level Measurement Procedure" (PNL 1989). The steel tapes are calibrated on an annual basis per PNL technical procedure WL-2, "Procedure for Standardizing Steel Tapes" (PNL 1989). 
Table 4.1 Completion Distribution for the Water-Level Monitoring Network

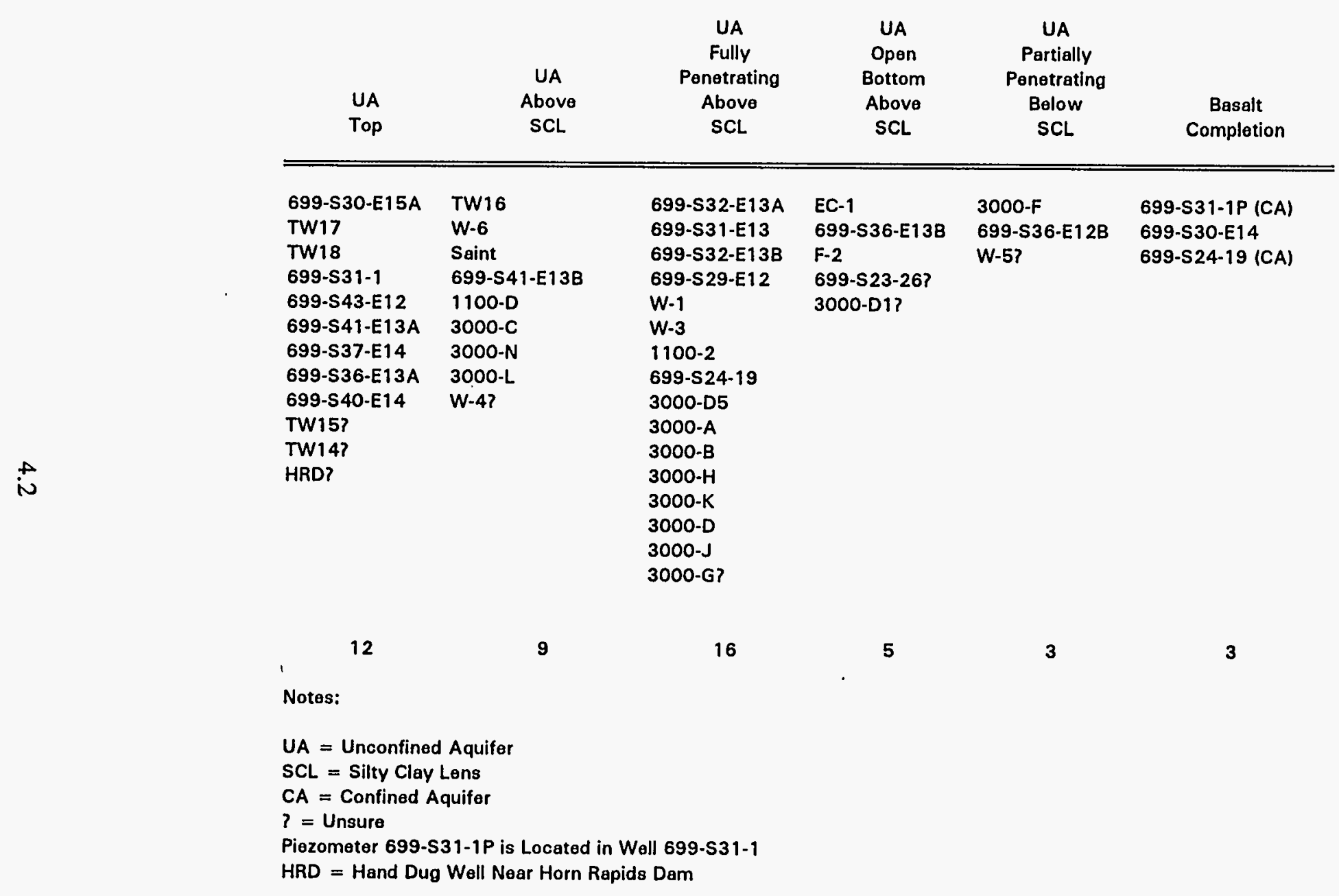


Table 4.2 Monthly Water-Level Measurements Used for Analysis and Interpretation

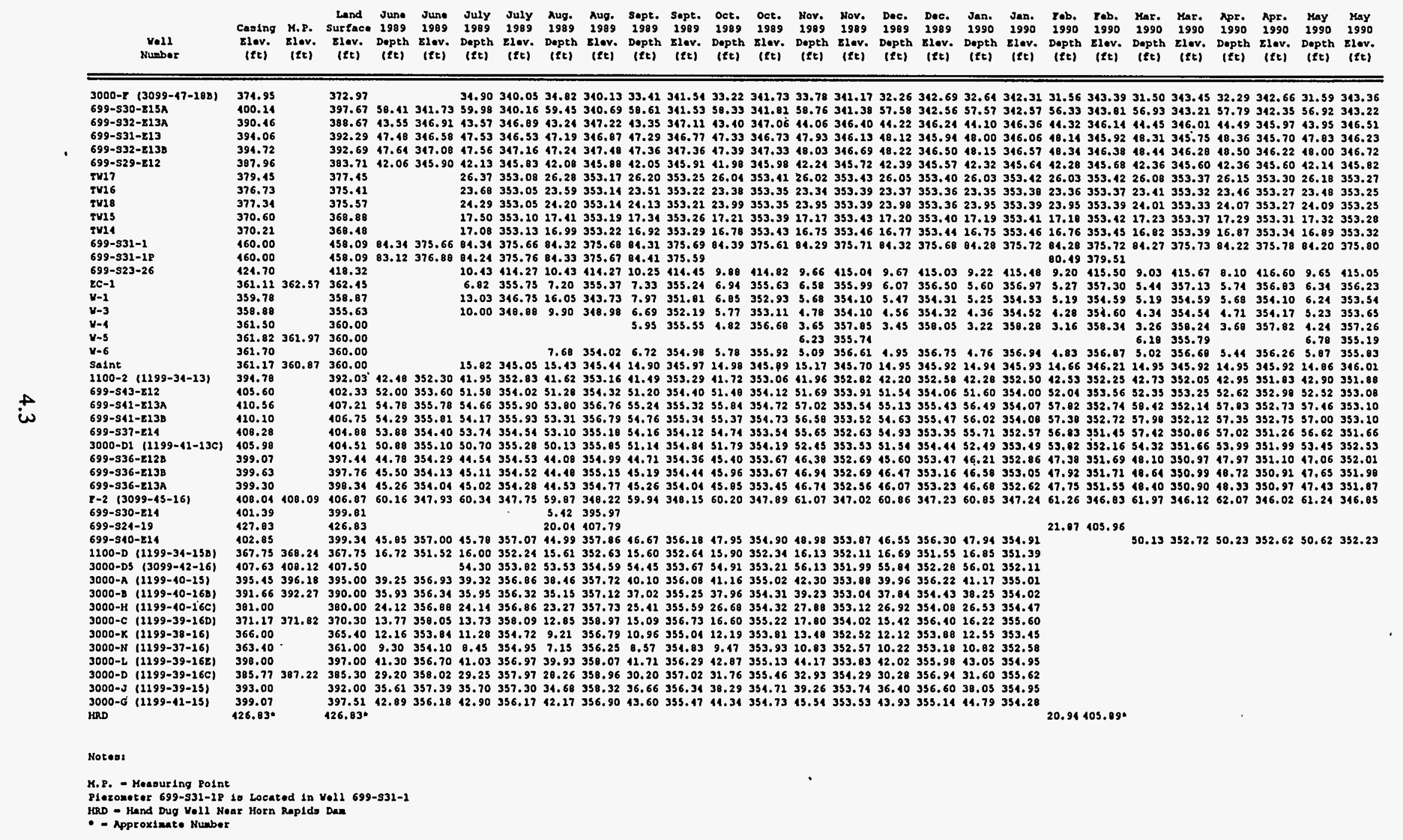




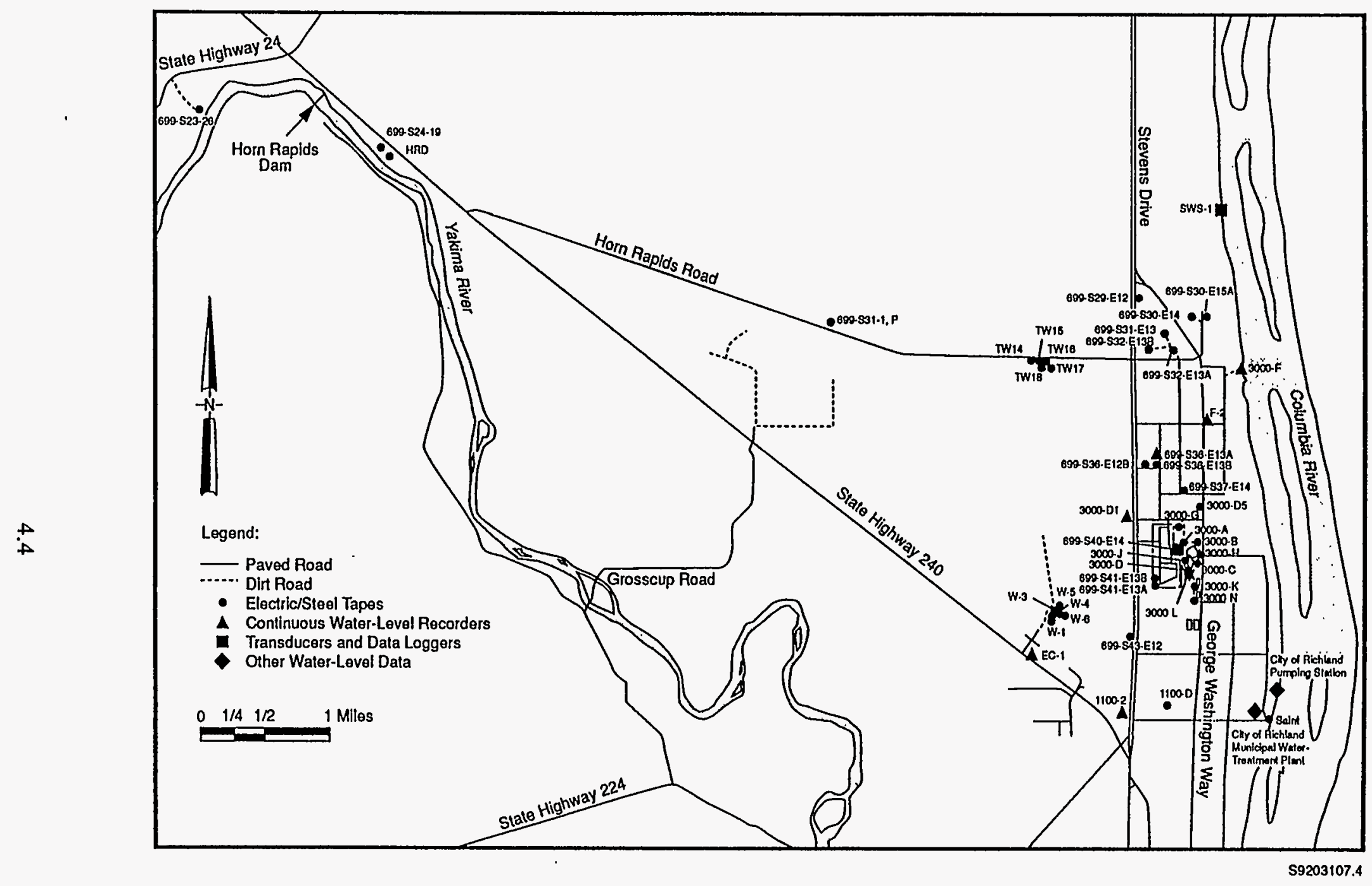

Figure 4.1 Water-Level Monitoring Network for the Study Area 


\subsubsection{Continuous Water-Level Recorders}

Six of the 46 wells in the water-level monitoring network were measured using continuous waterlevel recorders (Figure 4.1). Five of these six wells were selected based on the following criteria: 1) the wells are completed in the unconfined aquifer (Table 4.1),2) the casing diameters are sufficient to accept 6-in. floats, and 3) the wells are located adjacent to a waste disposal site, agricultural field, or the Columbia River. Well 3000-D1 was initially monitored as part of an ongoing Hanford Site project. Stevens Type F recorders were installed per manufacturer's instructions on the wells. Table 4.3 lists the well number, recorder serial number, clock type, drum and clock gears, and starting and ending dates.

Five of the six wells were set up with drum gears of $1 \mathrm{ft}$ per revolution. Well 3000-F was set up with drum gears of $5 \mathrm{ft}$ per revolution because of its proximity to the Columbia River (Figure 4.1). The recorder charts were changed on a weekly basis from June to August 1989 and monthly from September 1989 to May 1990: The well number, clock type, feet per revolution, date, time, measuring device, initials, and starting and ending depths to water were recorded on the chart. The starting and ending depths to water were measured using a steel tape per PNL technical procedure WL-1, "WaterLevel Measurement Procedure" (PNL 1989). The recorders were cleaned, oiled, and the batteries replaced monthly. Field data including date, well number, time, held value, cut value, depth to water, casing elevation, measuring point elevation, water-level elevation, comments, procedure, measuring device, and initials were recorded in a bound notebook. The recorder charts were digitized, with the $1200 \mathrm{hrs}$ reading for each day transferred to computer spreadsheet for analysis and interpretation.

\subsubsection{Transducers and Data Loggers}

One of the 46 wells in the water-level monitoring network and 1 Columbia River gaging station were measured using transducers and data loggers (Figure 4.1). These devices were installed initially as part of other ongoing Hanford Site projects.

A Keller 10-psi transducer and Terra 8D data logger were installed in well 699-S40-E14 in November 1988. The transducer and data logger were set up to monitor fluctuations in the unconfined aquifer adjacent to the North Richland well field. Well 699-S40-E14 is located immediately west of the well field (Figure 4.1). Historical data indicate that operation of the well field has a significant impact on water levels and hydraulic gradients in this area. ${ }^{\text {(a) }}$

Hydraulic head measurements during this study were recorded every half hour from June 1,1989 , to January 26, 1990, and then every 6 hours through May 31, 1990. The data were downloaded monthly to a computer in the field. Steel tape measurements were used to calibrate the transducer and data logger for instrument drift after downloading. Rechargeable batteries were installed every month. Field data including date, well number, depth to water, time, measuring device, filename, comments, and initials were recorded in a bound notebook. The field data were converted to ascii files and transferred to computer spreadsheet. The actual and daily average water-level elevations were used for analysis and interpretation.

(a) Freshley, M. D., M. P. Bergeron, and N. J. Aimo. 1989. Ground-Water Modeling Investigation of North Richland Well Field and the 1100 Area, Letter Report. Pacific Northwest Laboratory, Richland, Washington. 
Table 4.3 Continuous Water-Level Recorder Inventory

\begin{tabular}{|c|c|c|c|c|c|c|}
\hline $\begin{array}{l}\text { Well } \\
\text { Number }\end{array}$ & $\begin{array}{c}\text { Recorder } \\
\text { Serial } \\
\text { Number }\end{array}$ & $\begin{array}{l}\text { Clock } \\
\text { Type }\end{array}$ & $\begin{array}{l}\text { Drum } \\
\text { Gears }\end{array}$ & $\begin{array}{l}\text { Clock } \\
\text { Gears }\end{array}$ & $\begin{array}{l}\text { Starting } \\
\text { Date }\end{array}$ & $\begin{array}{l}\text { Ending } \\
\text { Date }\end{array}$ \\
\hline $3000-F$ & $\begin{array}{l}99994-81 \\
\mathrm{~J}-024400\end{array}$ & $\begin{array}{l}\text { PNL Wind Up } \\
\text { UI Battery }\end{array}$ & $110 / 33$ & $\begin{array}{l}128 / 16 \\
128 / 16\end{array}$ & $\begin{array}{l}06-26-89 \\
10-05-89\end{array}$ & $\begin{array}{l}10-05-89 \\
05-17-90\end{array}$ \\
\hline EC-1 & $\begin{array}{l}92654-79 \\
\text { B-9580 }\end{array}$ & $\begin{array}{l}\text { PNL Wind Up } \\
\text { WHC Battery }\end{array}$ & $84 / 56$ & $\begin{array}{l}128 / 16 \\
128 / 16\end{array}$ & $\begin{array}{l}07-13-89 \\
08-22-89\end{array}$ & $\begin{array}{l}08-22-89 \\
05-17-90\end{array}$ \\
\hline $1100-2$ & 99993-81 & PNL Battery & $84 / 56$ & $\begin{array}{c}96 / 48 \\
128 / 16\end{array}$ & $\begin{array}{l}06-14-89 \\
08-16-89\end{array}$ & $\begin{array}{l}08-16-89 \\
05-17-90\end{array}$ \\
\hline 3000-D1 & $\begin{array}{l}92655-79 \\
J-024391 \\
130510\end{array}$ & $\begin{array}{l}\text { PNL Wind Up } \\
\text { UI Battery } \\
\text { UI QMT }\end{array}$ & $84 / 56$ & $\begin{array}{c}128 / 16 \\
128 / 16 \\
\text { N/A }\end{array}$ & $\begin{array}{l}06-21-89 \\
09-09-89 \\
03-03-90\end{array}$ & $\begin{array}{l}09-09-89 \\
02-23-90 \\
05-17-90\end{array}$ \\
\hline 699-S36-E13A & $99995-81$ & PNL Battery & $84 / 56$ & $\begin{array}{c}96 / 48 \\
128 / 16\end{array}$ & $\begin{array}{l}06-26-89 \\
08-16-89\end{array}$ & $\begin{array}{l}08-16-89 \\
05-17-90\end{array}$ \\
\hline$F-2$ & $92653-79$ & PNL Battery & $84 / 56$ & $\begin{array}{c}96 / 48 \\
128 / 16\end{array}$ & $\begin{array}{l}06-14-89 \\
08-16-89\end{array}$ & $\begin{array}{l}08-16-89 \\
05-17-90\end{array}$ \\
\hline
\end{tabular}

Notes:

PNL = Pacific Northwest Laboratory

$\mathrm{UI}=$ University of Idaho

WHC $=$ Westinghouse Hanford Company

OMT = Quartz Multispeed Timer

A Keller 10-psi transducer and Terra 8D data logger were also installed at the Surface Water Monitoring Station (SWS-1) adjacent to the 300 Area (Figure 4.1). The transducer and data logger were set up to monitor fluctuations in the Columbia River downgradient from the 300 Area Process Trenches.

River-elevation measurements were recorded every half hour. Data were collected for this study from June 1, 1989, through May 31, 1990. The data were downloaded monthly to a computer in the field. Staff-gage measurements were used to calibrate the transducer and data logger for instrument drift after downloading. Rechargeable batteries were installed every month. Field data including date, station number, river elevation, time, filename, comments, and initials were recorded in a bound notebook. The field data were converted to ascii files and transferred to computer spreadsheet. The actual, daily average, and 10-day average river elevations were used for analysis and interpretation. 


\subsubsection{Other Water-Level Data}

Other water-level data collected for this study include Columbia River elevations at the city of Richland pumping station on Snyder Street (Figure 4.1). Daily staff-gage readings were recorded in a monthly Richland Water System Report. Data were collected for the period June 1, 1989, to May 31, 1990. These reports also provided the daily and monthly volumes of recharge and production water pumped to and from the North Richland well field, respectively. The well field serves as the secondary water-supply system for the city of Richland.

\subsection{Hydraulic Head Distribution}

The spatial and temporal distribution of hydraulic head in the unconfined aquifer is based on hydraulic head measurements from the water-level monitoring network described above. The analysis and interpretation of these measurements focuses on ground-water flow directions, horizontal and vertical hydraulic gradients, and well and river hydrographs. Water-level elevations for July 1989 are shown in Figure 3.12. This month was chosen because a complete set of water-level data exists for all of the monitoring wells. Water-level elevation maps for June 1989 and August 1989 through May 1990 are included in Appendix C. Figure 4.2 shows hydrographs for selected wells and the Columbia River at SWS-1. Hydrographs for the remaining wells, in both collective (for adjacent wells) and individual format, and the city of Richland pumping station at Snyder Street are contained in Appendix D.

\subsubsection{Spatial Distribution of Hydraulic Head}

Ground water in the unconfined aquifer beneath the study area flows generally west to east toward the Columbia River year around (Figure 3.12 and Appendix C). This flow direction is altered locally by the ground-water mound beneath the North Richland well field and to a lesser extent by pumping from wells W-4 through W-6. The ground-water mound results from the net recharge (volume of recharge minus production water) pumped to the well field. The impacts of this mound are evident across the eastern part of the study area. Ground-water flow is directed to the northeast and southeast of the well field.

A cone of depression forms near wells W-4 through W-6 when these wells are pumped to irrigate the potatoes west of the 1100 Area (Figure 3.12 and Appendix C). The cone of depression extends outward approximately $0.25 \mathrm{mi}$ and is noted to the southwest in well EC-1.

Ground-water levels near the Columbia River are influenced by fluctuations in the river elevation. Responses to these fluctuations are most pronounced along the river shore near well $3000-\mathrm{F}$ and can be seen at least $1500 \mathrm{ft}$ inland in the northeastern part of the study area. The fluctuations are dampened significantly to the south, within approximately $500 \mathrm{ft}$ of the river, near the Saint Well.

Ground-water levels in the north central part of the study area appear to reflect natural conditions. No influence from human activities is evident at this time. 


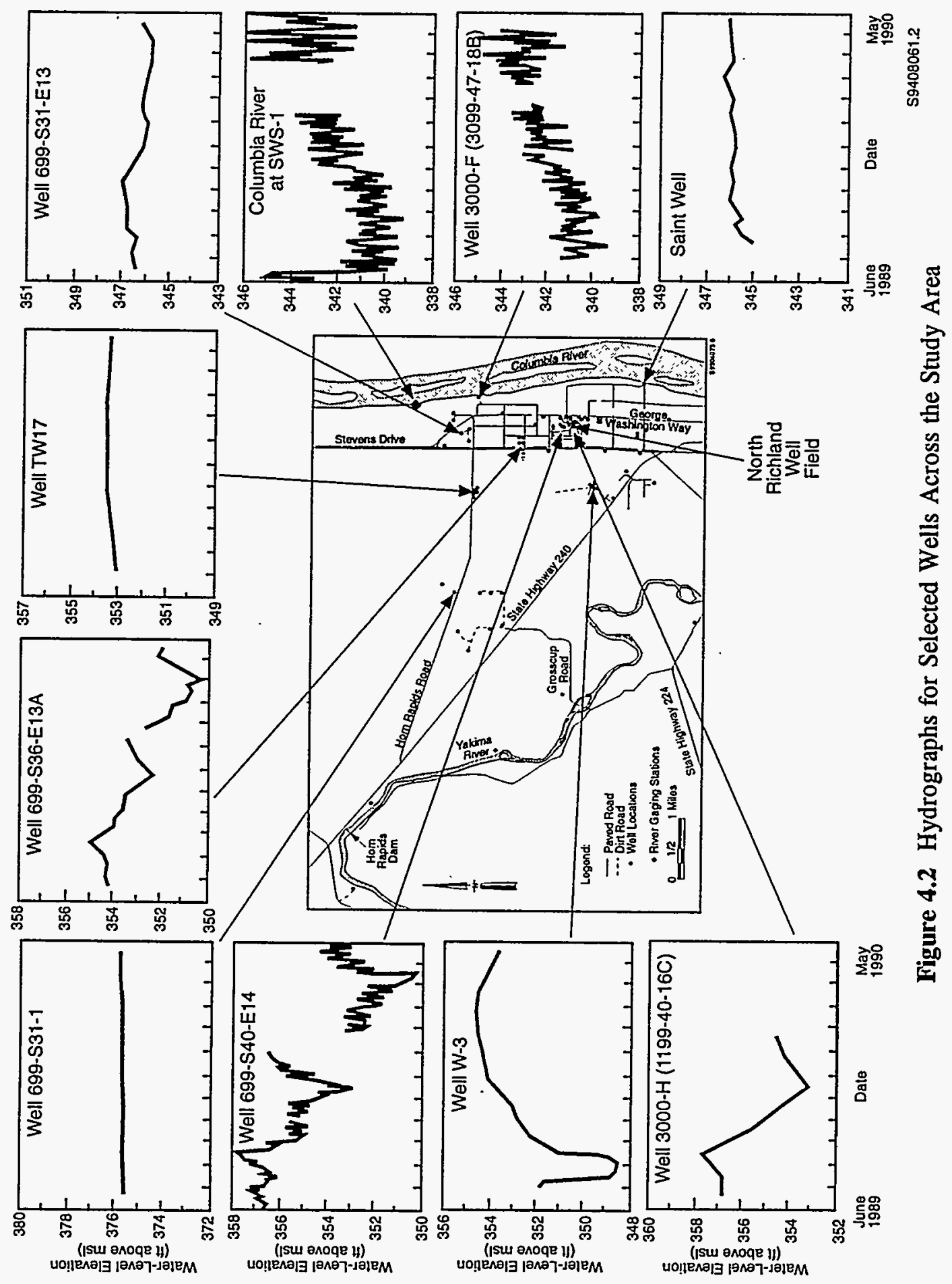


Horizontal hydraulic gradients for the unconfined aquifer were calculated and generally refiect the eastward sloping topography of the study area. The monthly and average gradients for three west to east transects, using hydraulic head data from wells 699-S23-26, 3000-F, 699-S37-E14, and the Saint Well, are shown in Table 4.4. The hydraulic gradients range from approximately 6 to $8 \mathrm{ft} / \mathrm{mi}$ and are consistent between the three transects over time.

No data from this study are available on the vertical hydraulic gradients between the unconfined and confined aquifers. Gradient calculations were attempted using hydraulic head data from well 699-S31-1 and piezometer 699-S31-1P, and a hand-dug well (HRD) completed in the unconfined aquifer near Horn Rapids Dam and well 699-S24-19 (Figure 4.1). The gradients indicate no vertical flow in these areas, probably as a result of poor well construction. Drilling logs for well 699-S31-1 and piezometer 699-S31-1P, and well 699-S24-19 indicate potential hydraulic connections between the unconfined and confined aquifers. Annular seals between the two hydrofacies are not evident in the logs, so the resultant heads probably are combined. Hydraulic testing should be done in well 699-S31-1 and piezometer 699-S31-1P, and well 699-S24-19 to assess these potential connections.

Vertical hydraulic gradients were calculated within the unconfined aquifer in the eastern part of the study area. Hydraulic head measurements from wells 699-S41-E13A and 699-S41-E13B (Figure 4.1) indicate no vertical flow in this area. Well 699-S41-E13A is completed at the top of the unconfined aquifer (Table 4.1). Well 699-S41-E13B is completed just above the silty clay lens at the top of the gravelly sand to silty clay lithofacies. Both wells are located within the ground-water mound beneath the North Richland well field, where a downward gradient would be expected. However, these wells are located approximately $25 \mathrm{ft}$ apart and monitor intervals with a vertical displacement of only $30 \mathrm{ft}$.

No wells in the water-level monitoring network are completed in the silty clay lens or aquitard overlying the Ice Harbor Member. Two wells, drilled concurrent with this study as part of the RI/FS for the 1100-EM-1 Operable Unit, are completed below the silty clay lens. However, the limited and varied information on the vertical hydraulic gradients from this study, DOE (1990b), and Schalla et al. (1988) accentuates the need for further characterization. The vertical distribution of hydraulic head between the unconfined and confined aquifers and across the silty clay lens is necessary to better understand ground-water recharge and discharge areas, flow directions, and contaminant transport among these aquifers.

\subsubsection{Temporal Distribution of Hydraulic Head}

The temporal distribution of hydraulic head in the unconfined aquifer can be divided into several distinct periods. The frequency and length of these periods vary with location. In the eastern part of the study area, 27 wells in the water-level monitoring network respond to the net recharge pumped to the North Richland well field. Hydrographs for these wells generally peak in August to October 1989 and reach lows in November 1989 and April.1990 (Figure 4.2 and Appendix D).

Wells EC-1, W-1, and W-3, located in the southcentral part of the study area, respond to the seasonal pumping of wells W-4 through W-6. Hydrographs for these six wells show a drawdown period from June to August 1989, followed by a recovery period from August to December 1989 (Figure 4.2 and Appendix D). The recovery period appears to be enhanced by seasonal recharge as 
Table 4.4 Horizontal Hydraulic Gradients for the Unconfined Aquifer Beneath the Study Area

\begin{tabular}{lccccc}
\multicolumn{1}{c}{ Month } & Year & $\begin{array}{c}\text { Horizontal } \\
\text { Gydraulic } \\
\text { Gradient }\end{array}$ & $\begin{array}{c}\text { Horizontal } \\
\text { Hydraulic } \\
\text { Gradient \# } \\
\text { (ft/mi) }\end{array}$ & $\begin{array}{c}\text { Horizontal } \\
\text { Hydraulic } \\
\text { Gradient @ } \\
\text { (ft/mi) }\end{array}$ & $\begin{array}{c}\text { Average } \\
\text { Gradient } \\
\text { (ft/mi) }\end{array}$ \\
\hline \hline June & 1989 & & & & \\
July & 1989 & 8.4 & 6.9 & 6.9 & 7.4 \\
August & 1989 & 8.4 & 6.8 & 6.9 & 7.4 \\
September & 1989 & 8.3 & 6.9 & 6.8 & 7.3 \\
October & 1989 & 8.3 & 7.0 & 6.8 & 7.4 \\
November & 1989 & 8.4 & 7.1 & 6.9 & 7.4 \\
December & 1989 & 8.2 & 7.0 & 6.8 & 7.4 \\
January & 1990 & 8.3 & 7.1 & 6.8 & 7.4 \\
February & 1990 & 8.2 & 7.2 & 6.8 & 7.4 \\
March & 1990 & 8.2 & 7.3 & 6.8 & 7.4 \\
April & 1990 & 8.4 & 7.2 & 6.8 & 7.5 \\
May & 1990 & 8.1 & 7.2 & 6.8 & 7.4
\end{tabular}

Notes:

- Horizontal Hydraulic Gradient Between Wells 699-S23-26 and 3000-F

\# = Horizontal Hydraulic Gradient Between Wells 699-S23-26 and 699-S37-E14

@ = Horizontal Hydraulic Gradient Between Wells 699-\$23-26 and Saint

water levels continue to rise until the beginning of the 1990 growing season. Ground water was noted above land surface from February to April 1990 near these wells. The water levels begin to decline again as the wells are used to supplement the AEDC intake at the Port of Benton.

Water-level data for wells EC-1, W-1, and W-3 through W-6 (Appendix D) indicate a horizontal gradient between wells W-4 through W-6 during the recovery period. This gradient is probably an artifact of the casing elevations being estimated from the Richland quadrangle, Washington map (USGS 1978). Horizontal and vertical control for wells W-4 through W-6 should be resurveyed to provide more accurate lithofacies, hydrofacies, and water-level elevations.

Wells 3000-F, 699-S30-E15A, and the Saint Well, located near the Columbia River, respond to fluctuations in the river level. Hydrographs for these wells and the river are lowest in July 1989 and peak in April to May 1990 (Figure 4.2 and Appendix D). The amplitude of the peak in the river hydrograph for the city of Richland pumping station at Snyder Street is somewhat lower than at SWS-1. This probably reflects the differences in data collection methods. The data at SWS-1 were collected every half hour using a transducer and data logger. Daily staff-gage readings were recorded at the pumping station. The hydrograph for well 699-\$23-26 shows a similar profile to the wells near the Columbia River but indicates a response to elevation changes in the Yakima River. 
Water levels in well 699-S31-1, located in the northcentral part of the study area, reflect groundwater flow conditions away from recharge or discharge areas. The hydrograph for this well is relatively flat, varying less than $0.2 \mathrm{ft}$ during the entire data collection period (Figure 4.2 and Appendix D). Hydrographs for wells TW14 through TW18 have less than $0.4 \mathrm{ft}$ of change. The slight increase in water-level elevation from August 1989 to January 1990 may be a distant effect of the North Richland well field or related to activities at the Siemens Power Corp. process lagoons (Figure 1.2).

\subsection{Operations and Impacts of the North Richland Well Field}

The North Richland well field serves as the secondary water-supply system for the city of Richland. This water-supply system consists of a settling basin and two recharge basins located adjacent to 12 production wells completed in the unconfined aquifer. Columbia River water is pumped from the city of Richland pumping station at Snyder Street into the south end of the settling basin. The water infiltrates or flows through a weir at the north end of the basin into a flow divider and is discharged to the recharge basins. The water infiltrates from the recharge basins and is then pumped from the adjacent production wells using line shaft turbine pumps. The production water is treated by a central chlorinator system before being dispensed to city lines for use.

The settling and recharge basins are wide, shallow depressions, designed to enhance infiltration. ICF Northwest (1987) recommended lining the basins with sand, repairing the dike between the recharge basins, and relocating the largest pumps to the wells with the highest yield to improve production of this system. The sediments beneath the basins act as a natural filter to remove the turbidity from the Columbia River water. The river water also serves to reduce the hardness of the ground water.

Since the time of construction of the city of Richland municipal water-treatment plant until 1987, volumes ranging from zero to 16 million gallons per day (mgd) have been pumped to the settling basin (ICF Northwest 1987). From November 1988 to May 1990, an average volume of 7.0 mgd was pumped to the settling basin. The North Richland well field is operated year-round with peak usage occurring during the summer irrigation months and again in December and January, when the watertreatment plant is shut down for annual maintenance. Figure 4.3 shows the monthly total volume of recharge and production water pumped to and from the well field, respectively, during this study. The ratio of recharge to production water varied from $2: 1$ to $11: 1$ with an average ratio of $4: 1$. The monthly average net recharge for this period was 134.9 million gallons (mg). Historical data indicate that the ratio has ranged from 2:1 to 4:1. (a) Reasons for this operational history are unknown. The current strategy used by the city of Richland is based, in a large part, on mitigating the potential for any ground-water contamination to migrate from upgradient disposal sites within the 1100-EM-1 Operable Unit to the well field. During periods of high net recharge, a mound develops causing

(a) Freshley, M. D., M. P. Bergeron, and N. J. Aimo. 1989. Ground-Water Modeling Investigation of North Richland Well Field and the 1100 Area, Letter Report. Pacific Northwest Laboratory, Richland, Washington. 


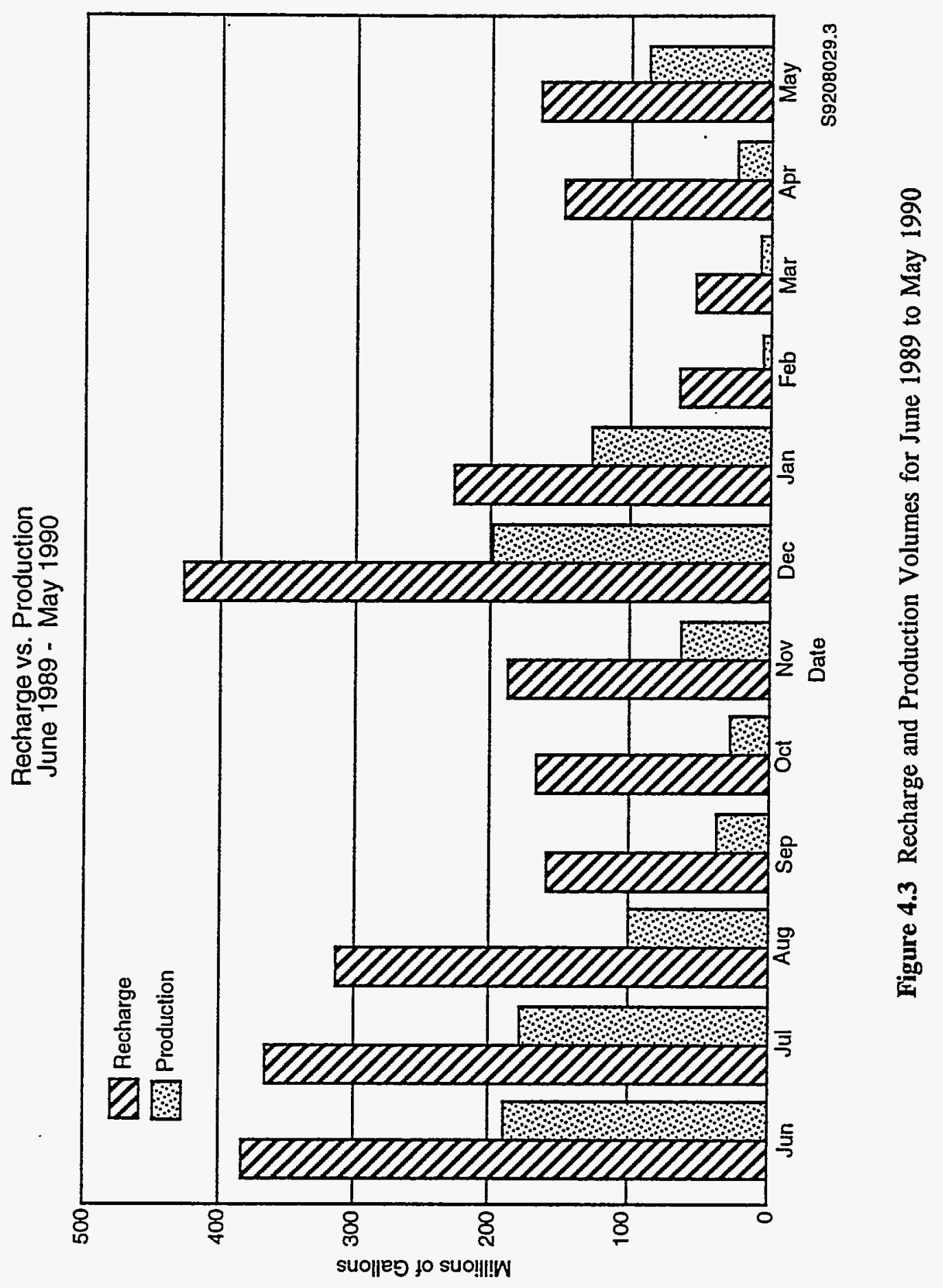


ground-water flow to be diverted around the well field. ${ }^{(a)}$ No net recharge produces a small localized mound, but ground water from the 1100 Area can move toward the well field.

Currently, the net recharge pumped to the well field has the most significant impact on water levels and hydraulic gradients for the unconfined aquifer beneath the study area. Twenty seven, and possibly 32 , of the 46 wells in the water-level monitoring network respond to this recharge. Two north-south hydrologic cross sections, with hydrographs for several wells located within and adjacent to the well field, are shown in Figures 4.4 and 4.5. The hydrographs in these figures have similar profiles to that of Figure 4.3 for at least a mile to the north and south of the well field. Figure 4.6 shows the net water-level changes that occurred in each well and the Columbia River between July 1989 and January 1990. This period was chosen because a complete set of monthly water-level data exists for all 46 wells in the monitoring network. Wells affected by the net recharge to the well field showed a net water-level decrease. The magnitude of change in these wells varied from approximately 2.5 to less than $1 \mathrm{ft}$ and generally decreased with increased distance from the well field. Responses were noted farther to the north and south than west and east. Water-level responses to the west and east probably are dampened by the horizontal hydraulic gradient.

Horizontal hydraulic gradients were calculated for three west to east transects at or near the well field, using hydraulic head data from wells 3000-D1, 3000-D5, 699-S40-E14, 3000-H, 699-S41-E13A, and 3000-K. The monthly and average gradients for June 1989 through January 1990 are shown in Table 4.5. The gradients range from less than 1 to approximately $11 \mathrm{ft} / \mathrm{mi}$ and vary significantly with the net recharge pumped to the well field. Generally, the steepest gradients occurred in June and December where high monthly net recharge was preceded by low monthly net recharge. A reverse gradient occurred in August 1989 between wells 699-S41-E13A and 3000-K as a result of three successive months of high net recharge. Gradients were not calculated for February through May 1990 because water levels were not measured in wells 3000-D5, 3000-H, and 3000-K during these months. Overall, the net recharge to the North Richland well field probably has increased water levels in the unconfined aquifer significantly within and adjacent to the well field and will continue to do so under the current operational strategy. This effect may eventually become a concern near wells $3000-\mathrm{N}$, $3000-\mathrm{K}$, and $3000-\mathrm{C}$, where the minimum depth to water during this study ranged from approximately 5 to $11 \mathrm{ft}$ bls (Figure 4.7). Monitoring of water-level elevations and ground-water quality should continue in this area to assess the long-term effects of the net recharge.

\subsection{Operations and Impacts of the Agricultural, Residential-Lawn, and Waste-Water Irrigation}

Agricultural, residential-lawn, and waste-water irrigation occurs at several locations within and adjacent to the study area (Figure 1.2). Table 4.6 lists the estimated monthly maximum volumes of irrigation applied. The estimated volumes are based primarily on total pumping capacities for each

(a) Freshley, M. D., M. P. Bergeron, and N. J. Aimo. 1989. Ground-Water Modeling Investigation of North Richland Well Field and the 1100 Area, Letter Report. Pacific Northwest Laboratory, Richland, Washington. 

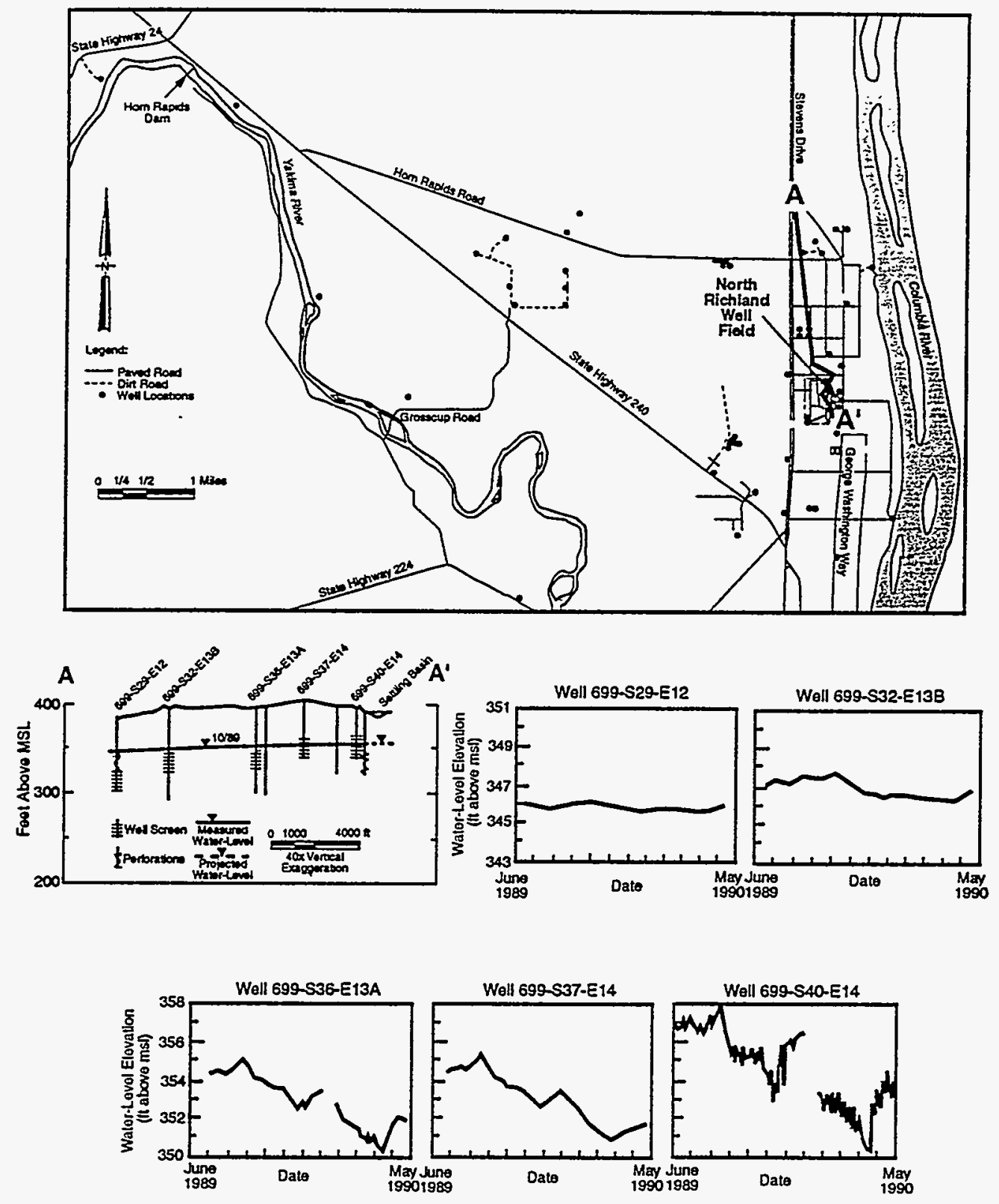

\$9304073.8

Figure 4.4 Hydrologic Cross Section A-A' to the North of the Well Field 


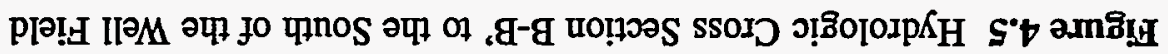
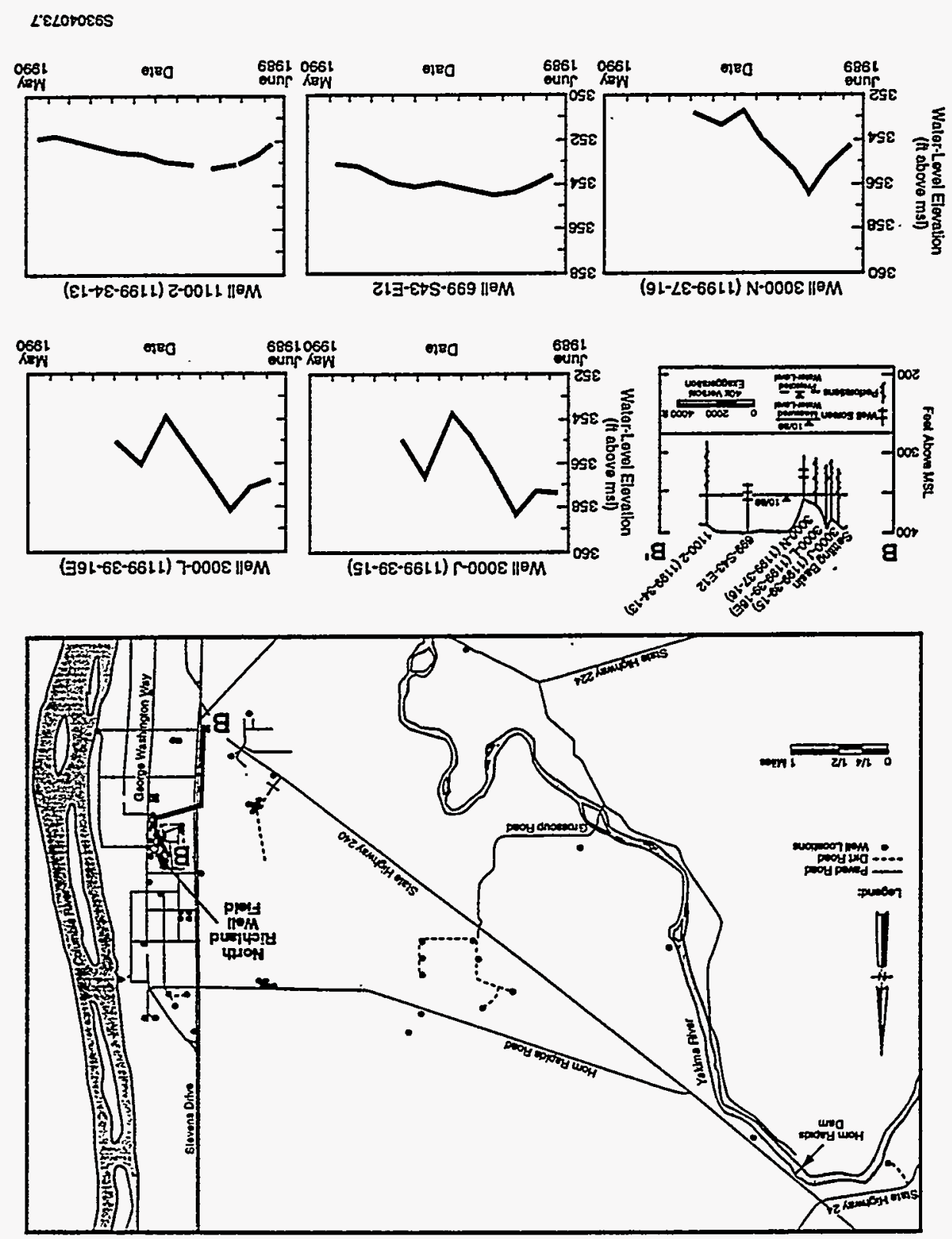


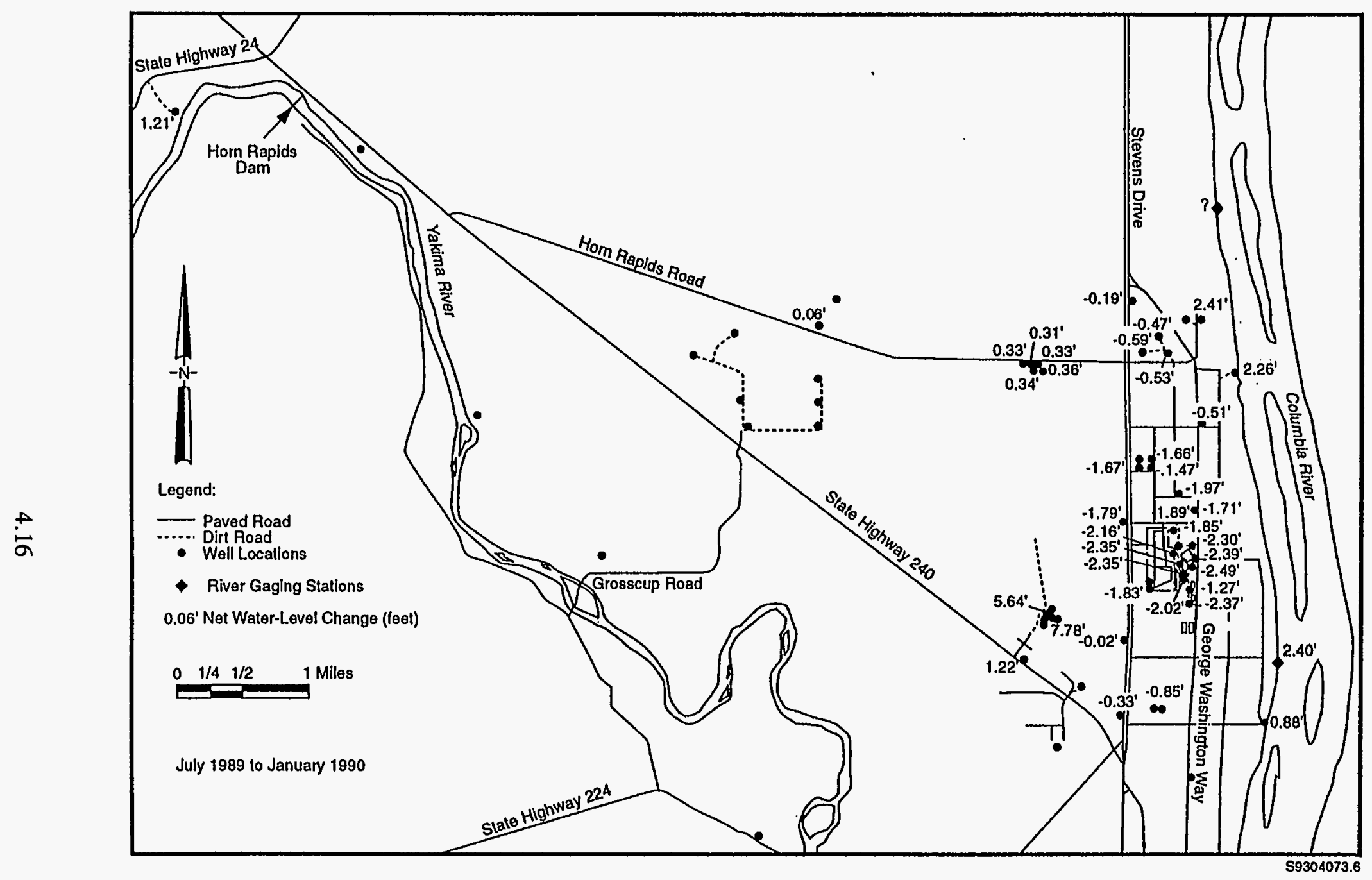

Figure 4.6 Net Water-Level Changes Between July 1989 and January 1990 
Table 4.5 Horizontal Hydraulic Gradients for the Unconfined Aquifer Near the North Richland Well Field

\begin{tabular}{lccccc}
\multicolumn{1}{c}{ Month } & Year & $\begin{array}{c}\text { Horizontal } \\
\text { Hydraulic } \\
\text { Gradient } \\
\text { (ft/mi) }\end{array}$ & $\begin{array}{c}\text { Horizontal } \\
\text { Hydraulic } \\
\text { Gradient \# } \\
\text { (ft/mi) }\end{array}$ & $\begin{array}{c}\text { Horizontal } \\
\text { Hydraulic } \\
\text { Gradient @ } \\
\text { (ft/mi) }\end{array}$ & $\begin{array}{c}\text { Average } \\
\text { Gradient } \\
\text { (ft/mi) }\end{array}$ \\
\hline \hline June & 1989 & & & & \\
July & 1989 & 2.2 & 1.0 & 3.9 & 3.2 \\
August & 1989 & 1.9 & 0.6 & -0.1 & 2.3 \\
September & 1989 & 1.7 & 3.0 & 0.8 & 1.8 \\
October & 1989 & 1.5 & 2.9 & 2.8 & 2.4 \\
November & 1989 & 2.3 & 3.8 & 3.1 & 3.0 \\
December & 1989 & 3.2 & 11.1 & 4.7 & 6.3 \\
January & 1990 & 2.1 & 2.2 & 1.9 & 2.0
\end{tabular}

Notes:

- = Horizontal Hydraulic Gradient Between Wells 3000-D1 and 3000-D5

\# = Horizontal Hydraulic Gradient Between Wells 699-S40-E14 and 3000-H

@ = Horizontal Hydraulic Gradient Between Wells 699-S41-E13A and 3000-K

system. The actual volumes may vary significantly depending on local requirements/conditions. The two most significant locations are the farming west of the 1100 Area and the farming and PNL lawn irrigation in the 3000 Area.

\subsubsection{Farming West of the 1100 Area}

The AEDC has leased much of the land east of the city of Richland landfill and west of the 1100 Area, informally known as the Horn Rapids Triangle. The lease runs for 20 years with an option to buy. A half circle (approximately 250 acres) of potatoes was irrigated in 1989 (Figure 3.2).

Wells W-4 through W-6 (Figure 4.1) were pumped continuously during the growing season (as conditions permitted) at combined rate of approximately $500 \mathrm{gpm}$ to irrigate the half circle (T. Wiser, AEDC, personal communication, 1989). This rate results in an estimated monthly maximum volume of $21.6 \mathrm{mg}$ (Table 4.6). However, the pumps in wells W-4 and W-6 became sand locked several times. 


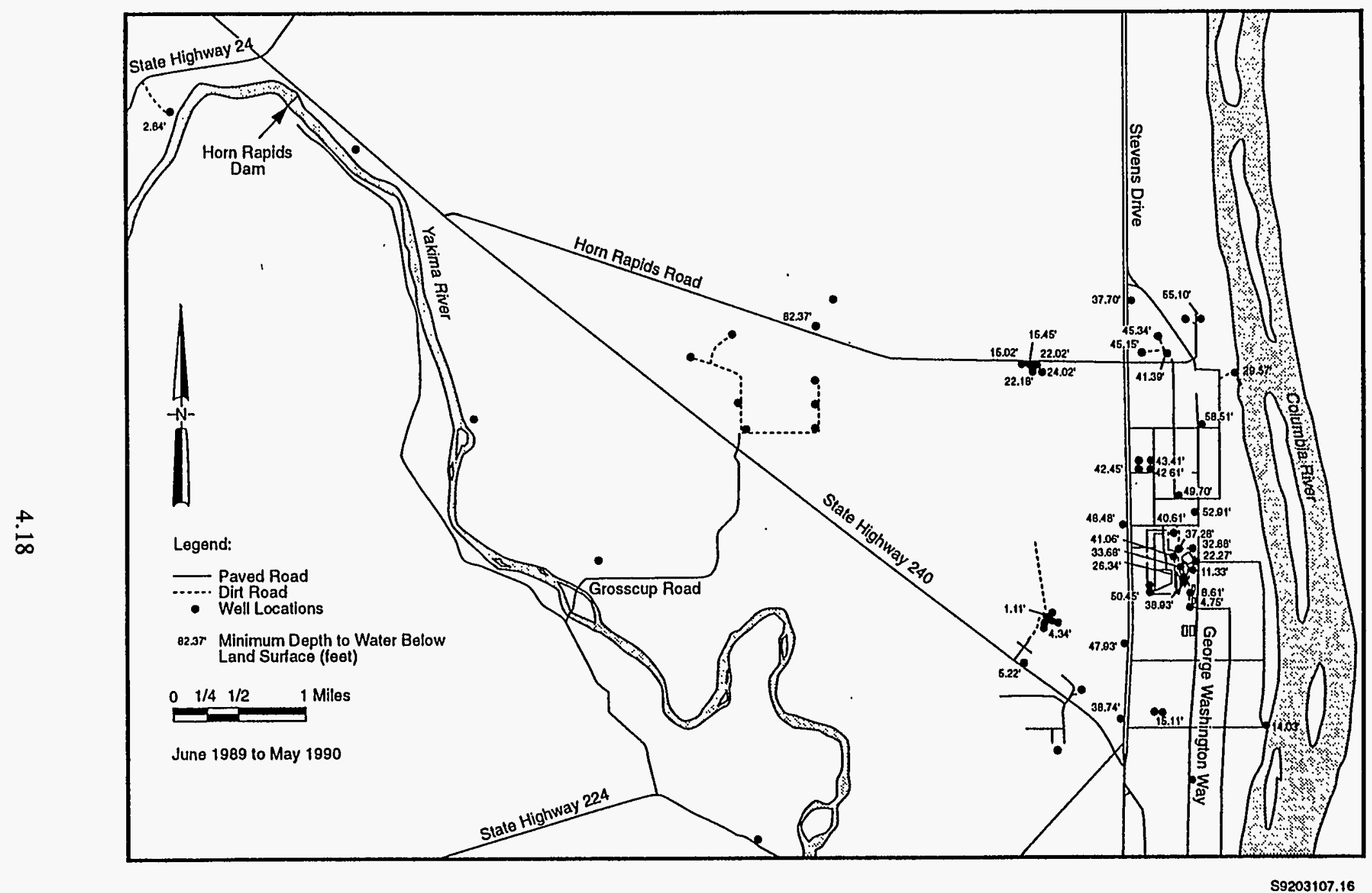

Figure 4.7 Minimum Depth to Water Below Land Surface for June 1989 to May 1990 
Table 4.6 Estimated Monthly Maximum Volumes of Irrigation Applied

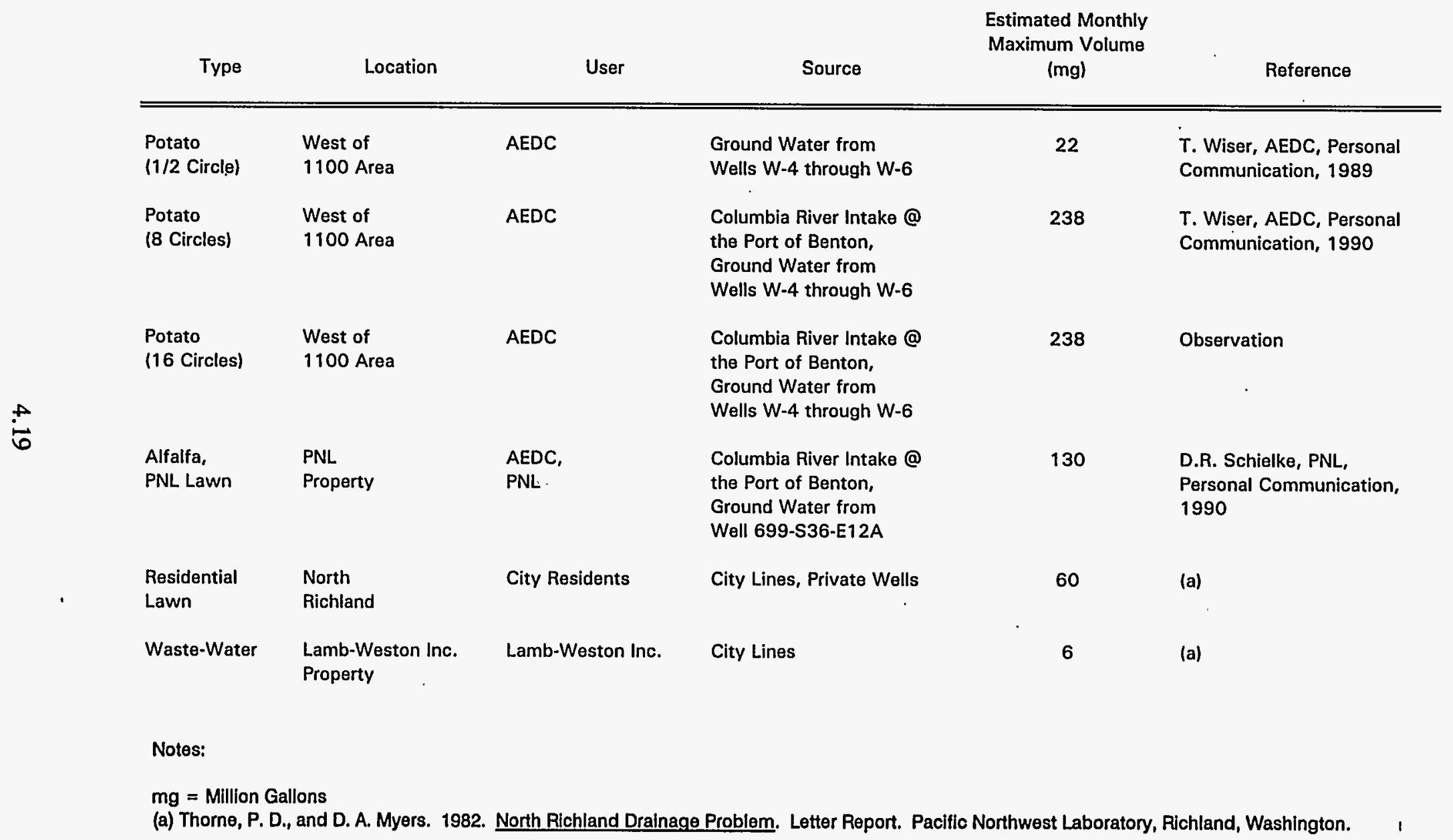


The farming was expanded to eight full circles (approximately 4000 acres) of potatoes before the 1990 growing season (Figure 3.3) and 16 full circles (approximately 7500 acres) of potatoes before the 1991 growing season (Figure 4.8). Irrigation water is drawn primarily from the Columbia River at the Port of Benton, where the AEDC installed five 1000-gpm capacity, line shaft turbine pumps. The water is pumped through a 36-in. line and distributed using two pumping stations, 50 and $150 \mathrm{hp}$, located south of Siemens Power Corp. Wells W-4 through W-6 are pumped intermittently to supplement the river intake and lower water levels near these wells. Pumping both systems at full capacity would result in an estimated monthly maximum volume of $238 \mathrm{mg}$ (Table 4.6). This volume is approximately $75 \%$ greater than the monthly average net recharge to the North Richland well field. The actual total pumping rate and volume of water applied are unknown (T. Wiser, AEDC, personal communication, 1990). However, the rate and volume are known to vary with soil conditions, crop type and growth, temperature, wind velocity, and precipitation.

The cone of depression, which forms when wells W-4 through W-6 are pumped for irrigation, is of limited extent. Drawdowns were noted only in wells EC-1, W-1, and W-3 through W-6 and ranged from 1 up to at least $11 \mathrm{ft}$. No other impacts from the farming west of the 1100 Area are evident on water levels and hydraulic gradients for the unconfined aquifer beneath the study area at this time. This lack of impact may be the result of several factors, including 1) the water-level data from this study were collected during the initial farming operations and are too preliminary to assess any impacts, 2) the pumping rates and volume of water applied are significantly less than capacity, 3) an insufficient number of monitoring wells exist in key locations to assess any impacts, 4) the irrigation occurs over a large area, 5) the irrigation is seasonal, 6) the irrigation is masked by or combined with the impacts from the North Richland well field (Figure 4.6), and/or 7 ) most of the water applied evapotranspires with little drainage below the root zone.

In the long term, irrigation of the fields west of the 1100 Area probably will contribute to changes in water levels in the unconfined aquifer beneath the study area. Potatoes require a relatively large amount of moisture. Precipitation for this area averages less than 7 in. annually. The crops are planted in the well-sorted silt and very fine to coarse sand of the silty sand lithofacies. These sediments are relatively porous and have high infiltration capacities. The silty sand lithofacies becomes increasingly thinner east of the city of Richland landfill and reaches a minimum in wells W-1 through W-6. Irrigation water will recharge the unconfined aquifer much faster where the water table is nearer land surface (Figure 4.7). Potatoes also require the application of nitrate for fertilization and diquot or sulfuric acid to kill the vines before harvesting. Monitoring of water-level elevations and ground-water quality west of the 1100 Area should continue to assess the long-term effects of the farming on the unconfined aquifer.

\subsubsection{Area Farming and PNL Lawn Irrigation}

The farming and PNL lawn irrigation in the 3000 Area is another significant location of irrigation within the study area. The AEDC has leased the land surrounding the main PNL complex from PNL to grow alfalfa. This crop was chosen because of its ability to grow in the poorly sorted gravels and sands of the sandy gravel lithofacies. The PNL complex is landscaped with lawns, shrubs, and trees. Irrigation water is drawn primarily from the Columbia River at the Port of Benton, where three 1000-gpm capacity, line shaft turbine pumps have been installed. Well 699-S36-E12A (Figure 3.1) is equipped with a 500-gpm capacity, $40 \mathrm{hp}$, submersible pump and is used to supplement the PNL intake during peak irrigation periods. The pump raises the pressure on the southern part this irrigation system 


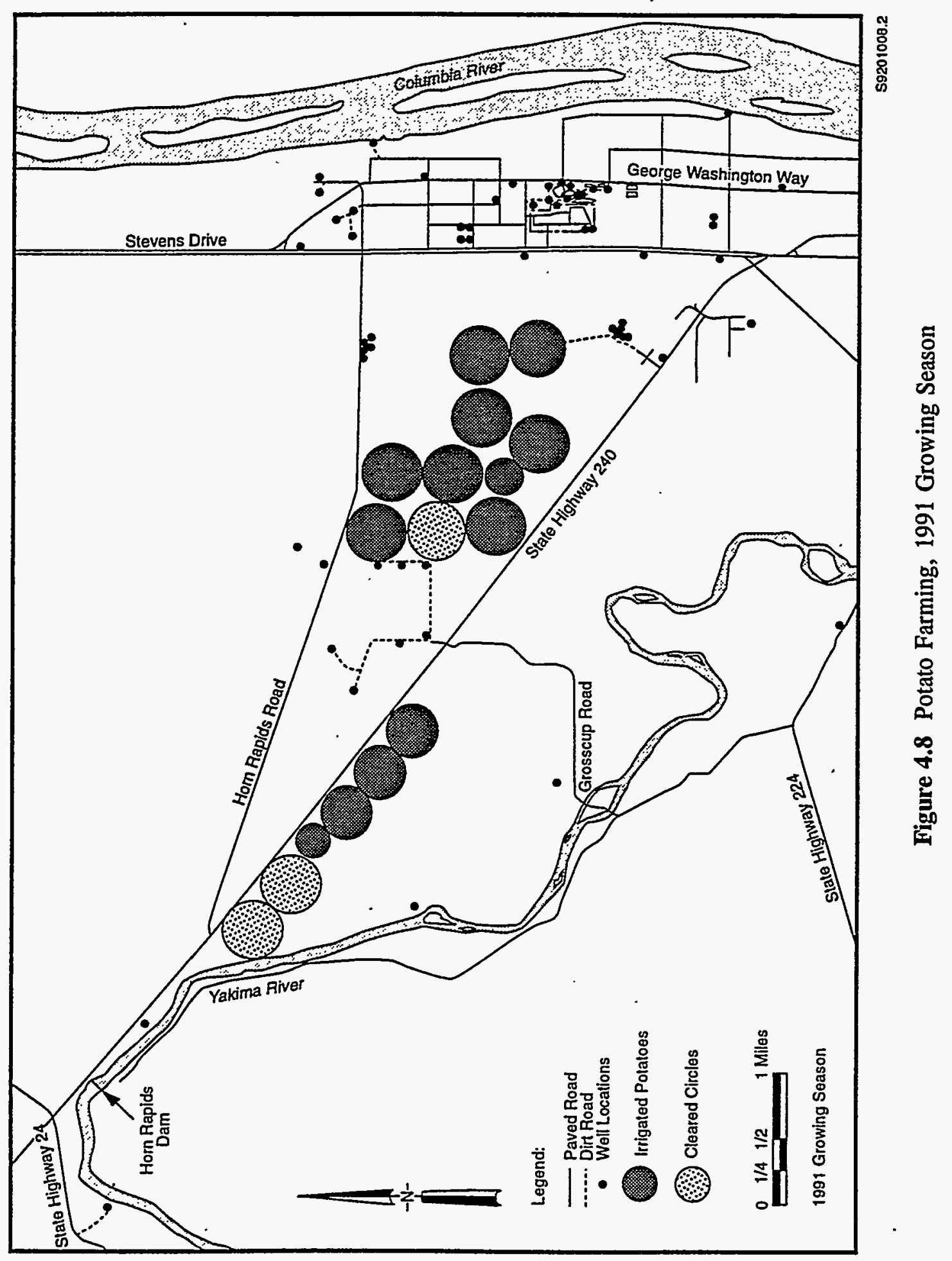


(D.R. Schielke, PNL, personal communication, 1990). At full capacity, the estimated monthly maximum volume of irrigation for this system is $130 \mathrm{mg}$ (Table 4.6). The actual rate and volume of irrigation applied are unknown; however, the alfalfa is irrigated continuously during the growing season, except during the four to five harvests.

No impacts are evident on water levels and hydraulic gradients for the unconfined aquifer beneath the study area from the 3000 Area farming and PNL lawn irrigation. Water levels in wells F-2, 699-S32-E13A, 699-S31-E13, 699-S32-E13B, 699-S36-E12B, 699-S36-E13B, and 699-S36-E13A, which surround the farming and lawn irrigation, respond to the net recharge pumped to the North Richland well field. A local cone of depression may form near well 699-S36-E12A during pumping; however, no responses are noted in wells within $500 \mathrm{ft}$. Possible explanations for these observations are that 1) the pumping rates and volume of water applied are significantly less than capacity, 2) the farming and lawn irrigation are seasonal, 3) the farming and lawn irrigation are masked by or combined with the impacts from the North Richland well field (Figure 4.6), 4) the alfalfa and lawn uptake are a significant portion of the irrigation applied, 5) any recharge is retained in the unsaturated sediments as the minimum depth to water in this area is approximately 45 to $60 \mathrm{ft}$ bls (Figure 4.7), and/or 6) the unconfined aquifer is relatively more transmissive in this area and any recharge rapidly dissipates or is discharged to the nearby Columbia River.

In general, the alfalfa farming and PNL lawn irrigation probably will continue to contribute little, if any, to changes in water levels in the unconfined aquifer beneath the study area. The farming and lawn irrigation have been operated consistently for several years. Additionally, PNL has plans for further expansion of facilities on the leased land.

\subsubsection{Residential-Lawn and Waste-Water Irrigation}

Lesser amounts of irrigation are applied to residential areas within north Richland and the LambWeston Inc. property (Figure 1.2). This irrigation includes lawn, shrub, and tree irrigation in the residential areas and waste-water irrigation on the Lamb-Weston Inc. property. City lines are the primary water source for these irrigation systems although some residents use private wells for lawn irrigation.

Seasonally high ground-water levels and drainage problems in North Richland were investigated for

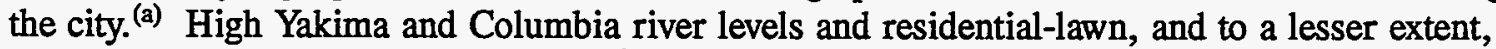
waste-water irrigation were cited as contributing factors to these problems. Ground water was noted less than $1 \mathrm{ft}$ bls in May 1982, approximately $1 \mathrm{mi}$ south of the study area. Monthly maximum volumes of irrigation were estimated at $60 \mathrm{mg}$ in the residential areas and $6 \mathrm{mg}$ on the Lamb-Weston Inc. property. ${ }^{(a)}$ These numbers probably have increased significantly with the continued development of North Richland and the expansion of Lamb-Weston Inc. operations. A perforated drain pipe was installed to mitigate the high ground-water levels and drainage problems; however, the problems have recurred (S. Arlt, city of Richland, personal communication, 1990). Similar problems probably will occur elsewhere in North Richland where the ground water is shallow, especially if combined with the

(a) Thorne, P. D., and D. A. Myers. 1982. North Richland Drainage Problem, Letter Report. Pacific Northwest Laboratory, Richland, Washington. 
net recharge from the North Richland well field. Routine monitoring of water-level elevations should be initiated to assess the long-term effects of the residential-lawn and waste-water irrigation.

\subsection{Interrelationship with the Yakima and Columbia Rivers}

The Yakima and Columbia rivers have significant influence on ground-water flow in the unconfined aquifer beneath the study area. The aquifer is recharged along influent reaches of the Yakima River; ground water flows generally eastward, discharging to the Columbia River. River flows along these reaches are controlled primarily by the Horn Rapids irrigation diversion dam on the Yakima River, and Priest Rapids and McNary hydroelectric dams on the Columbia River. Flows adjacent to the study area average $3300 \mathrm{css}$ in the Yakima River and $120,000 \mathrm{cfs}$ in the Columbia River. During this study, flows averaged 2500 and $102,500 \mathrm{cfs}$ in the two rivers, respectively. Fluctuations in the river elevations affect the horizontal hydraulic gradients in the aquifer near the rivers. Near the Yakima River, increases in river elevation locally steepen the hydraulic gradients in the aquifer, whereas decreases flatten the gradients locally. In contrast, near the Columbia River, increases in elevation decrease the hydraulic gradients and cause water levels in the aquifer to rise, whereas decreases in elevation steepen the gradients.

Annual fluctuations in the Yakima River are thought to be less than $3 \mathrm{ft}$ based on the hydrograph for well 699-S23-26 (Appendix D). This well is located approximately $80 \mathrm{ft}$ from the river. Well 699-S23-26 had a net water-level increase of $1.21 \mathrm{ft}$ (Figure 4.6). The minimum depth to water was $2.84 \mathrm{ft}$ bls (Figure 4.7). Overbank flooding may occur during peak runoff years; however, this should not be a major concern given the remoteness of the area.

The Columbia River fluctuates up to $5 \mathrm{ft}$ per day. Well 3000-F is located approximately $180 \mathrm{ft}$ from the river and fluctuates up to $3.5 \mathrm{ft}$ per day. Between July 1989 and January 1990, net waterlevel increases of approximately 1 to $2.5 \mathrm{ft}$ were noted in wells responding to the Columbia River, with the higher magnitude changes occurring closer to the river (Figure 4.6). Hydrographs for wells 3000-F and 699-S30-E15A exhibit similar profiles to the Columbia River at SWS-1 (Figure 4.2 and Appendix D). Net water-level increases in these wells were 2.26 and $2.41 \mathrm{ft}$, respectively. The hydrograph for the Saint Well has a somewhat similar profile; however, the river-level fluctuations appear to be dampened significantly. This well is located approximately $500 \mathrm{ft}$ from the river but the water level varied less than $1 \mathrm{ft}$. Possible reasons for this profile include 1) north-south channeling of the Ringold and Hanford sediments near the river (Brown 1979) has formed an erosional boundary between the well and river, 2) a hydraulic conductivity contrast occurs within the sandy gravel lithofacies between the well and river, 3) the unconfined aquifer is much thicker near the Saint Well than wells 3000-F and 699-S30-E15A, and/or 4) water levels in the Saint Well may be influenced by elevation changes in the McNary pool [Lake Wallula extends upriver as far as the city of Richland (USGS 1978)], whereas wells 3000-F and 699-S30-E15A reflect control by Priest Rapids Dam. The minimum depth to water for wells 3000-F, 699-S30-E15A, and the Saint Well ranges from approximately 14 to $55 \mathrm{ft}$ bls (Figure 4.7).

Sufficient data have been gathered in this study to further analyze the unconfined aquifer/Columbia River interrelationship. The similarity of changes in timing and magnitude with distance from the river should be analyzed to determine the hydraulic diffusivity (i.e., transmissivity/storativity) for the aquifer 
between well 3000-F and the river at SWS-1. Short- (i.e., several days) and long-term (i.e., several months) fluctuations should be compared. Similar analyses could be done on the unconfined aquifer/ Yakima River interrelationship by correlating continuous water-level data from well 699-S23-26 with river elevation data from the U.S. Geological Survey gaging station at Kiona, Washington. 


\subsection{Discussion of Results and Additional Data Needs for CERCLA/SARA Investigations and Richland Corporate Annexation}

This chapter summarizes the results of this study of the unconfined ground-water flow system between the Yakima and Columbia rivers. The results are used to delineate additional data needs in support of future CERCLA/SARA investigations and Richland Corporate annexation of the 1100 and 3000 Areas.

\subsection{Discussion of Results}

The hydrogeology of the unconfined aquifer beneath the study area is very complex. The Ringold Formation and Hanford formation sediments, which form the hydrogeologic framework of the unconfined aquifer, were derived from both fluvial and glaciofluvial processes. These processes have resulted in an aquifer that is both heterogeneous and anisotropic.

The unconfined aquifer is contained within the gravelly sand to silty clay and sandy gravel lithofacies. These sediments vary in occurrence, distribution, texture, and sorting across the study area. The unconfined aquifer exhibits varied thickness, and undoubtedly, varied hydraulic properties. The silty clay lithofacies serves as the aquifer bottom in the western part of the study area. In the eastern part of the study area, the silty clay lens at the top of the gravelly sand to silty clay lithofacies may divide the aquifer into two parts, causing local semiconfined to confined conditions within the unconfined aquifer. The unconfined aquifer probably acts as a heterogeneous hydrofacies on a small scale over a short time and a homogeneous hydrofacies on a large scale over a long time.

Ground water in the unconfined aquifer flows generally west to east beneath the study area. The aquifer is recharged by the Yakima River and discharges to the Columbia River. Flow is altered locally by the ground-water mound beneath the North Richland well field and to a lesser extent by pumping from wells W-4 through W-6. Ground-water levels near the Columbia River are influenced by fluctuations in the river elevation. Responses to fluctuations can be seen at least $1500 \mathrm{ft}$ inland in the northeastern part of the study area. Levels in the north central part of the study area appear to reflect natural conditions.

Currently, the net recharge pumped to the North Richland well field has the most significant impact on water levels and hydraulic gradients for the unconfined aquifer beneath the study area. The net recharge probably has increased water levels in the aquifer significantly over the past several years and will continue to do so under the current operational strategy. With the exception of the cone of depression that forms near wells W-1 through W-6, no other impacts from the farming west of the 1100 Area are evident at this time. In the long term, the irrigation probably will contribute to changes in water levels in the unconfined aquifer. No impacts are evident from the 3000 Area farming and PNL lawn irrigation. In general, the farming and PNL lawn irrigation probably will continue to contribute little, if any, to changes in water levels in the unconfined aquifer. A local cone of depression may form near well 699-S36-E12A during pumping. 
Previously estimated monthly maximum volumes of residential-lawn and waste-water irrigation probably have increased significantly with the continued development of North Richland and the expansion of Lamb-Weston Inc. operations. Seasonally high ground-water levels and drainage problems resulting from this irrigation probably will occur elsewhere in North Richland where the ground water is shallow, especially if combined with the net recharge from the well field.

\subsection{CERCLA/SARA Investigations}

Hazardous wastes have been discharged to the ground in the 1100 and 3000 Areas. These disposal sites are contained within the 1100-EM-1 Operable Unit, which is regulated by CERCLA/SARA. The results of this study can be used to delineate additional data needs in support of future CERCLA/SARA activities at the 1100-EM-1 Operable Unit. The additional data needs are focused in three areas: 1) well maintenance and rehabilitation, 2) hydrogeologic characterization, and 3) ground-water monitoring. Following through with these activities will provide a more quantitative data set for use in the RI/FS, Fate and Transport modeling, and the BRA and reduce costs by maximizing use of existing structures.

\subsubsection{Well Maintenance and Rehabilitation}

Inconsistencies exist between the drilling logs and the WELL DATA files in the HGWDB. These inconsistencies should be corrected to help prevent misinterpretation of well construction details. Several wells should be surveyed (resurveyed) for horizontal and vertical control to provide more accurate lithofacies, hydrofacies, and water-level elevations. These wells include EC-1, W-4, W-5, W-6, the Saint Well, F-2, ORV \#1, ORV \#2, the Landfill Well, the Lamb-Weston Inc. Well, 1100-D, 3000-D5, 3000-A, 3000-B, 3000-H, 3000-C, 3000-K, 3000-N, 3000-L, 3000-D, 3000-J, 3000-G, and 1100-8.

A borehole television camera should be used to help gather completion information on wells TW15, TW14, W-4, W-5, and 699-S36-E12A. Hydraulic testing should be done in wells 699-S31-1 and piezometer 699-S31-1P, 699-S28-E0, 699-S24-19, ORV \#1, ORV \#2, the Landfill Well, and 699-S51-2 to assess the potential connections between the confined and unconfined aquifers.

Wells TW14 through TW18, W-1 through W-3, and 1100-2 should be cleaned out and developed to provide more accurate and representative water-level elevations and ground-water samples, respectively. Several other wells should be rehabilitated to improve construction and provide more accurate and representative ground-water samples. These wells include 699-S23-26, EC-1, 1100-2, 699-S36E12B, 699-S36-E13B, 3000-G, and possibly 3000-D1.

\subsubsection{Hydrogeologic Characterization}

A catalog of borehole lithologic logs (after Fecht and Lillie 1982) and a catalog of borehole geophysical logs (after Blair et al. 1981) from the study area should be published to summarize existing hydrogeologic data. Inconsistencies between the drilling logs and the GEODAT DATA files in the HGWDB should be corrected to help prevent misinterpretation of the hydrogeology. 
Future hydrogeologic investigations within and adjacent to the study area should include laboratory tests for bulk mineralogy and geochemistry to help delineate the contact between the Ringold Formation and Hanford formation. Future investigations should also include test holes between the city of Richland landfill and 1100 Area to further characterize the distribution of the gravelly sand to silty clay lithofacies. Advanced borehole geophysical tools (e.g., commercial vendor sondes) should be run in several wells to provide more quantitative data on the properties of the suprabasalt sediments.

The distribution and continuity of the confined aquifer should be further characterized to better understand ground-water flow and contaminant transport in this aquifer. The distribution and continuity of the silty clay lens at the top of the gravelly sand to silty clay lithofacies should also be further characterized as it may have a marked effect on ground-water flow and contaminant transport in the unconfined aquifer. The vertical distribution of hydraulic head between the unconfined and confined aquifers and across the silty clay lens should be further characterized to better understand ground-water recharge and discharge areas, flow directions, and contaminant transport among these aquifers. As additional monitoring wells are drilled within the study area, water levels should be measured concurrently across the study area to construct a flow net.

The unconfined aquifer/Columbia River interrelationship beneath the study area should be further analyzed to determine the hydraulic diffusivity for the aquifer between well $3000-\mathrm{F}$ and the river at SWS-1. Short- and long-term fluctuations should be compared. Similar analyses could be done on the unconfined aquifer/Yakima River interrelationship by correlating continuous water-level data from well 699-S23-26 with river elevation data from the U.S. Geological Survey gaging station at Kiona, Washington.

Sufficient data have been gathered herein to construct a ground-water flow model for the unconfined aquifer near the North Richland well field. The physical configuration of the aquifer including location, areal extent, thickness, and location of surface water features have been presented. Hydraulic property estimates are contained in Table 3.6. Water-level elevation maps have been constructed for the period June 1989 to May 1990 (Figure 3.12 and Appendix C). Production and recharge volumes for the North Richland well field and estimated irrigation volumes are available in Appendix B and Table 3.11, respectively. The model should be used to simulate regional changes in hydraulic head caused by the well field and farming west of the 1100 Area.

\subsubsection{Ground-Water Monitoring}

Wells within the study area selected for routine water-level monitoring and ground-water sampling should be added to the PNL and WHC well maintenance programs. Monitoring of water-level elevations and ground-water quality in and adjacent to the North Richland well field should continue to assess the long-term effects of the net recharge to the well field on the unconfined aquifer. Monitoring of water-level elevations and ground-water quality west of the 1100 Area should also continue to assess the long-term effects of the farming on the aquifer. Routine monitoring of water-level elevations should be initiated to assess the long-term effects of the residential-lawn and waste-water irrigation on the unconfined aquifer. 


\subsection{Richland Corporate Annexation}

The city of Richland is considering annexing all or a portion of the 1100 and 3000 Areas to within its corporate boundary. These areas and the surrounding land have been designated as the "Tri-Cities Science and Technology Park" and are zoned for non-DOE industrial development. A number of these developments probably will be located hydraulically upgradient of the North Richland well field, given the current availability of land.

Several of the disposal sites within the 1100-EM-1 Operable Unit are also hydraulically upgradient of the well field. Additional sites or features in the vicinity of the 1100 and 3000 Areas that may affect the ground-water quantity and/or quality include 1) city of Richland landfill, 2) Horn Rapids landfill, 3) Siemens Power Corp. facilities for producing commercial nuclear fuel, 4) Lamb-Weston Inc. potato processing plant, and 5) irrigated agricultural fields and lawns.

The potential ground-water quantity and/or quality impacts to the North Richland well field from the planned development of the Tri-Cities Science and Technology Park and existing sites may be very significant. A ground-water management plan should be developed for the city of Richland to address these potential problems. The plan should also address issues such as management potential, artificial recharge, and conjunctive use of ground-water and surface water. The plan should be a cooperative effort between the city of Richland and DOE and its contractors. Other contributors/reviewers may include Siemens Power Corp., AEDC, and Lamb-Weston Inc. The plan should be modeled after successful existing ground-water management plans (e.g., Pullman-Moscow, and some communities in Colorado). The plan would serve as a proactive management/development tool for the city of Richland. 


\subsection{Conclusions}

The conclusions from this study are as follows.

1. The study area is underlain by the Saddle Mountains Basalt Formation with interbeds of the Ellensburg Formation and sediments of the Ringold Formation and Hanford formation. Four principal lithofacies were identified within the Ringold and Hanford sediments. They are, in ascending order, silty clay lithofacies, gravelly sand to silty clay lithofacies, sandy gravel lithofacies, and silty sand lithofacies. The descriptions and occurrences of the lithofacies may require refinement as additional data are collected in future hydrogeologic investigations.

2. Ground water beneath the study area occurs as both confined and unconfined aquifers. Four principal hydrofacies have been identified in this study. They are, in ascending order, a confined aquifer within the Ice Harbor Member, an aquitard formed by the silty clay lithofacies, the unconfined aquifer within the gravelly sand to silty clay and sandy gravel lithofacies, and the unsaturated sediments. Refinement of the hydrofacies descriptions and occurrences may be required as additional hydrogeologic data become available.

3. No water-level data are available from this study to evaluate the hydrologic significance of the silty clay lens at the top of the gravelly sand to silty clay lithofacies. Recent water-level measurements in the HGWDB from well 699-S41-E13C, adjacent to wells 699-S41-E13A and 699-S41-E13B, indicate a downward hydraulic gradient near these wells. The silty clay lens appears to be locally significant enough to produce hydraulic head differences. The unconfined aquifer probably acts as a heterogeneous hydrofacies on a small scale over a short time and a homogeneous hydrofacies on a large scale over a long time.

4. Ground water in the unconfined aquifer flows generally from west to east beneath the study area. The aquifer is recharged along influent reaches of the Yakima River and discharges to the Columbia River. Flow is altered locally by the ground-water mound beneath the North Richland well field and to a lesser extent, by pumping from wells W-4 through W-6. Ground-water levels near the Columbia River are influenced by fluctuations in the river elevation. Levels in the north central part of the study area appear to reflect natural conditions.

5. Currently, the net recharge pumped to the North Richland well field has the most significant impact on water levels and hydraulic gradients for the unconfined aquifer beneath the study area. Twenty seven, and possibly 32, of the 46 wells in the water-level monitoring network respond to this recharge.

6. The net recharge pumped to the North Richland well field probably has increased water levels in the unconfined aquifer beneath the study area significantly over the past several years and will continue to do so under the current operational strategy. This may eventually become a concern near wells $3000-\mathrm{N}, 3000-\mathrm{K}$, and $3000-\mathrm{C}$. 
7. With the exception of the cone of depression that forms near wells W-1 through W-6, no other impacts from the farming west of the 1100 Area are evident on water levels and hydraulic gradients for the unconfined aquifer beneath the study area at this time. In the long term, the irrigation probably will contribute to changes in water levels in the unconfined aquifer.

8. No impacts are evident on water levels and hydraulic gradients for the unconfined aquifer beneath the study area from the 3000 Area farming and PNL lawn irrigation. In general, the farming and PNL lawn irrigation probably will continue to contribute little, if any, to changes in water levels in the unconfined aquifer. A local cone of depression may form near well 699-S36-E12A during pumping.

9. Previously estimated monthly maximum volumes of residential-lawn and waste-water irrigation probably have increased significantly with the continued development of North Richland and the expansion of Lamb-Weston Inc. operations. Seasonally high ground-water levels and drainage problems resulting from this irrigation probably will occur elsewhere in North Richland where the ground water is shallow, especially if combined with the net recharge from the North Richland well field.

10. Fluctuations in the Yakima and Columbia rivers have significant influence on water levels and hydraulic gradients in the unconfined aquifer beneath the study area. Responses to fluctuations in the Columbia River can be seen at least $1500 \mathrm{ft}$ inland in the northeastern part of the study area. 


\subsection{Additional Data Needs}

The additional data needs identified in this study are as follows.

1. A catalog of borehole lithologic logs from the study area should be published to summarize existing hydrogeologic data.

2. A catalog of borehole geophysical logs from the study area should be published to summarize existing hydrogeologic data.

3. Inconsistencies between the drilling logs and GEODAT DATA and WELL DATA files in the HGWDB should be corrected to help prevent misinterpretation.

4. Wells EC-1, W-4, W-5, W-6, the Saint Well, F-2, ORV \#1, ORV \#2, the Landfill Well, the Lamb-Weston Inc. Well, 1100-D, 3000-D5, 3000-A, 3000-B, 3000-H, 3000-C, 3000-K, 3000-N, $3000-\mathrm{L}, 3000-\mathrm{D}, 3000-\mathrm{J}, 3000-\mathrm{G}$, and 1100-8 should be surveyed (resurveyed) for horizontal and vertical control to provide more accurate lithofacies, hydrofacies, and water-level elevations.

5. A borehole television camera should be used to help gather completion information on wells TW15, TW14, W-4, W-5, and 699-S36-E12A.

6. Future hydrogeologic investigations within and adjacent to the study area should include laboratory tests for bulk mineralogy and geochemistry to help delineate the contact between the Ringold Formation and Hanford formation.

7. Advanced borehole geophysical tools (e.g., commercial vendor sondes) should be run in several wells to provide more quantitative data on the properties of the suprabasalt sediments beneath the study area.

8. Future hydrogeologic investigations within the study area should include test holes between the city of Richland landfill and 1100 Area to further characterize the distribution of the gravelly sand to silty clay lithofacies.

9. As additional monitoring wells are drilled within the study area, water levels should be measured concurrently across the study area to construct a flow net.

10. The distribution and continuity of the confined aquifer should be further characterized to better understand ground-water flow and contaminant transport in this aquifer.

11. Hydraulic testing should be done in wells 699-S31-1 and piezometer 699-S31-1P, 699-S28-E0, 699-S24-19, ORV \#1, ORV \#2, the Landfill Well, and 699-S51-2 to assess the potential connections between the confined and unconfined aquifers.

12. The distribution and continuity of the silty clay lens at the top of the gravelly sand to silty clay lithofacies should be further characterized as it may have a marked effect on ground-water flow and contaminant transport in the unconfined aquifer. 
13. Wells TW14 through TW18, W-1 through W-3, and 1100-2 should be cleaned out and developed to provide more accurate and representative water-level elevations and ground-water samples, respectively.

14. Wells within the study area selected for routine water-level monitoring and ground-water sampling should be added to the PNL and WHC well-maintenance programs.

15. The vertical distribution of hydraulic head between the unconfined and confined aquifers and across the silty clay lens at the top of the gravelly sand to silty clay lithofacies should be further characterized to better understand ground-water recharge and discharge areas, flow directions, and contaminant transport among these aquifers.

16. Monitoring of water-level elevations and ground-water quality in and adjacent to the North Richland well field should continue to assess the long-term effects of the net recharge to the well field on the unconfined aquifer.

17. Monitoring of water-level elevations and ground-water quality west of the 1100 Area should continue to assess the long-term effects of the farming on the unconfined aquifer.

18. Routine monitoring of water-level elevations should be initiated in the southern and southwestern parts of the study area to assess the long-term effects of the residential-lawn and waste-water irrigation on the unconfined aquifer.

19. The unconfined aquifer/Columbia River interrelationship beneath the study area should be further analyzed to determine the hydraulic diffusivity for the aquifer between well 3000-F and the river at SWS-1. Short- and long-term fluctuations should be compared. Similar analyses could be done on the unconfined aquifer/Yakima River interrelationship by correlating continuous water-level data from well 699-S23-26 with river elevation data from the U.S. Geological Survey gaging station at Kiona, Washington.

20. A ground-water flow model for the unconfined aquifer near the North Richland well field should be constructed using the data gathered herein. The model should be used to simulate regional changes in hydraulic head caused by the well field and farming west of the 1100 Area.

21. Wells 699-S23-26, EC-1, 1100-2, 699-S36-E12B, 699-S36-E13B, 3000-G, and possibly 3000-D1 should be rehabilitated to improve construction and provide more accurate and representative ground-water samples.

22. A ground-water management plan should be developed for the city of Richland to address potential ground-water quantity and/or quality problems resulting from existing sites and the planned development of the Tri-Cities Science and Technology Park. The plan should also address issues such as management potential, artificial recharge, and conjunctive use of ground-water and surface water. The plan should be a cooperative effort between the city of Richland and DOE and its contractors. Other contributors/reviewers may include Siemens Power Corp., AEDC, and LambWeston Inc. The plan should be modeled after successful existing ground-water management plans (e.g., Pullman-Moscow, and some communities in Colorado). The plan would serve as a proactive management/development tool for the city of Richland. 


\subsection{References Cited}

Bierschenk, W. H. 1959. Aquifer Characteristics and Ground-Water Movement at Hanford. HW-60601, General Electric, Richland, Washington.

Bjornstad, B. N. 1990. Geohydrology of the 218-W-5 Burial Ground, 200-West Area, Hanford Site. PNL-7336, Pacific Northwest Laboratory, Richland, Washington.

Blair, S. C., L. S. Law, and J. W. Lindberg. 1981. A Catalog of Borehole Geophysics on the Hanford Site, 1958 to 1980. PNL-3504, Pacific Northwest Laboratory, Richland, Washington.

Brown, R. E. 1979. A Review of Water-Well Data from the Unconfined Aquifer in the Eastern and Southern Parts of the Pasco Basin. RHO-BWI-C-56, Rockwell Hanford Operations, Richland, Washington.

Bryce, R. W. 1989. Well Installation and Ground-Water Sampling Plan for 1100 Area Environmental Monitoring Wells. PNL-6815, Pacific Northwest Laboratory, Richland, Washington.

Bryce, R. W., and S.M. Goodwin. 1989. Borehole Summary Report for Five Ground-Water Monitoring Wells Constructed in the 1100 Area. PNL-6824, Pacific Northwest Laboratory, Richland, Washington.

Compton, R. R. 1967. Manual of Field Geology. John Wiley and Sons, Inc., New York.

Fecht, K. R., and J. T. Lillie. 1982. A Catalog of Borehole Lithologic Logs from the 600 Area, Hanford Site. RHO-LD-158, Rockwell Hanford Operations, Richland, Washington.

Gephart, R. E., R. C. Arnett, R. G. Baca, L. S. Leonhart, and F. A. Spane, Jr. 1979. Hydrologic Studies Within the Columbia Plateau, Washington: An Integration of Current Knowledge. RHO-BWIST-5, Rockwell Hanford Operations, Richland, Washington.

Graham, M. J., G. V. Last, and K. R. Fecht. 1984. An Assessment of Aquifer Intercommunication in the B Pond-Gable Mountain Pond Area of the Hanford Site. RHO-RE-ST-12P, Rockwell Hanford Operations, Richland, Washington.

ICF Northwest. 1987. Hydrogeologic Study of North Richland Well Field and Groundwater Recharge Basins. ICF Northwest, Richland, Washington.

J-U-B Engineers Inc. 1982. Ground-Water Quality and Flow Characteristics in the Vicinity of the Exxon Nuclear Company Inc. Fuel Fabrication Facility. XN-JUB-82-86, J-U-B Engineers Inc., Kennewick, Washington.

Last, G. V., B. N. Bjornstad, M. P. Bergeron, D. W. Wallace, D. R. Newcomer, J. A. Schramke, M. A. Chamness, C. S. Cline, S. P. Airhart, and J. S. Wilbur. 1989. Hydrogeology of the 200 Areas Low-Level Burial Grounds-An Interim Report. PNL-6820, Vol. 1. Pacific Northwest Laboratory, Richland, Washington. 
Liikala, T. L. 1988. Geohydrologic Characterization of the Area Surrounding the 183-H Solar Evaporation Basins. PNL-6728, Pacific Northwest Laboratory, Richland, Washington.

Lindberg, J. W., and F. W. Bond. 1979. Geohydrology and Ground-Water Quality Beneath the 300 Area, Hanford Site, Washington. PNL-2949, Pacific Northwest Laboratory, Richland, Washington.

Lindsey, K. A., and D. R. Gaylord. 1990. "Lithofacies and Sedimentology of the Miocene-Pliocene Ringold Formation, Hanford Site, South-Central Washington." Northw Sci., 64(3):165-180.

McCormack, W. D., and J.M.V. Carlile. 1984. Investigation of Ground-Water Seepage from the Hanford Shoreline of the Columbia River. PNL-5289, Pacific Northwest Laboratory, Richland, Washington.

McGhan, V. L. 1989. Hanford Hells. PNL-6907, Pacific Northwest Laboratory, Richland, Washington.

Myers, C. W., and S. M. Price. 1979. Geologic Studies of the Columbia Plateau: A Status Report. RHO-BWI-ST-4, Rockwell Hanford Operations, Richland, Washington.

Newcomb, R. C., J. R. Stand, and F. J. Frank. 1972. Geology and Ground-Water Characteristics of the Hanford Reservation of the U.S. Atomic Energy Commission, Washington. U.S. Geological Survey Professional Paper 717, U.S. Geological Survey, Washington, D.C.

Newcomer, D. R., J. P. McDonald, and S. M. Goodwin. 1990. Water-Table Elevations on the Hanford Site, June 1989. PNL-7282, Pacific Northwest Laboratory, Richland, Washington.

Pacific Northwest Laboratory (PNL). 1989. Procedures for Ground-Water Investigations. PNL-6894, Pacific Northwest Laboratory, Richland, Washington.

Schalla, R., R. W. Wallace, R. L. Aaberg, S. P. Airhart, D. J. Bates, J.M.V. Carlile, C. S. Cline, D. I. Dennison, M. D. Freshley, P. R. Heller, E. J. Jensen, K. B. Olsen, R. G. Parkhurst, J. T. Rieger, and E. J. Westergard. 1988. Interim Characterization Report for the 300 Area Process Trenches. PNL-6716, Pacific Northwest Laboratory, Richland, Washington.

Stone, W. A., J. M. Thorp, O. P. Gifford, and D. J. Hoitink. 1983. Climatological Summary for the Hanford Area. PNL-4622, Pacific Northwest Laboratory, Richland, Washington.

Tillson, D. D., D. J. Brown, and J. R. Raymond. 1969. River Water-Ground Water Relationships Along a Section of the Columbia River Valley. Meeting Preprint 823, American Society of Civil Engineers Annual Meeting and National Meeting on Water Resources Engineering, New Orleans, Louisiana.

U.S. Department of Energy (DOE). 1984. Draft Environmental Assessment, Reference Repository Location, Hanford Site, Washington. DOE/RW-0017, U.S. Department of Energy, Washington, D.C. 
U.S. Department of Energy (DOE). 1988a. Consultation Draft, Site Characterization Plan, Reference Repository Location, Hanford Site, Washington. DOE/RW-0164, Vol. 1, U.S. Department of Energy, Washington, D.C.

U.S. Department of Energy (DOE). 1988b. Consultation Draft, Site Characterization Plan, Reference Repository Location, Hanford Site, Washington. DOE/RW-0164, Vol. 2, U.S. Department of Energy, Washington, D.C.

U.S. Department of Energy (DOE). 1990a. Remedial Investigation/Feasibility Study Work Plan for the 300-FF-5 Operable Unit, Hanford Site, Richland, Washington. DOE/RL 89-14, Draft C, U.S. Department of Energy, Richland, Washington.

U.S. Department of Energy (DOE). 1990b. Phase I Remedial Investigation Report for the Hanford Site 1100-EM-1 Operable Unit. DOE/RL-90-18, Vol. 1, U.S. Department of Energy, Richland, Washington.

U.S. Department of Energy (DOE). 1990c. Phase I Remedial Investigation Report for the Hanford Site 1100-EM-1 Operable Unit. DOE/RL-90-18, Vol. 2, U.S. Department of Energy, Richland, Washington.

U.S. Geological Survey (USGS). 1978. Richland Quadrangle, Washington. 7.5 minute Series (topographic), U.S. Geological Survey, Denver, Colorado.

Webster, G. D., and J. W. Crosby III. 1982. Stratigraphic Investigation of the Skagit/Hanford Nuclear Project, Skagit/Hanford Nuclear Project Preliminary Safety Analysis Report. Puget Sound Power and Light Company, Bellevue, Washington. 
Appendix A

Well Construction and Lithologic Diagrams 
WELL NUMBER 3000-F (3099-47-188)

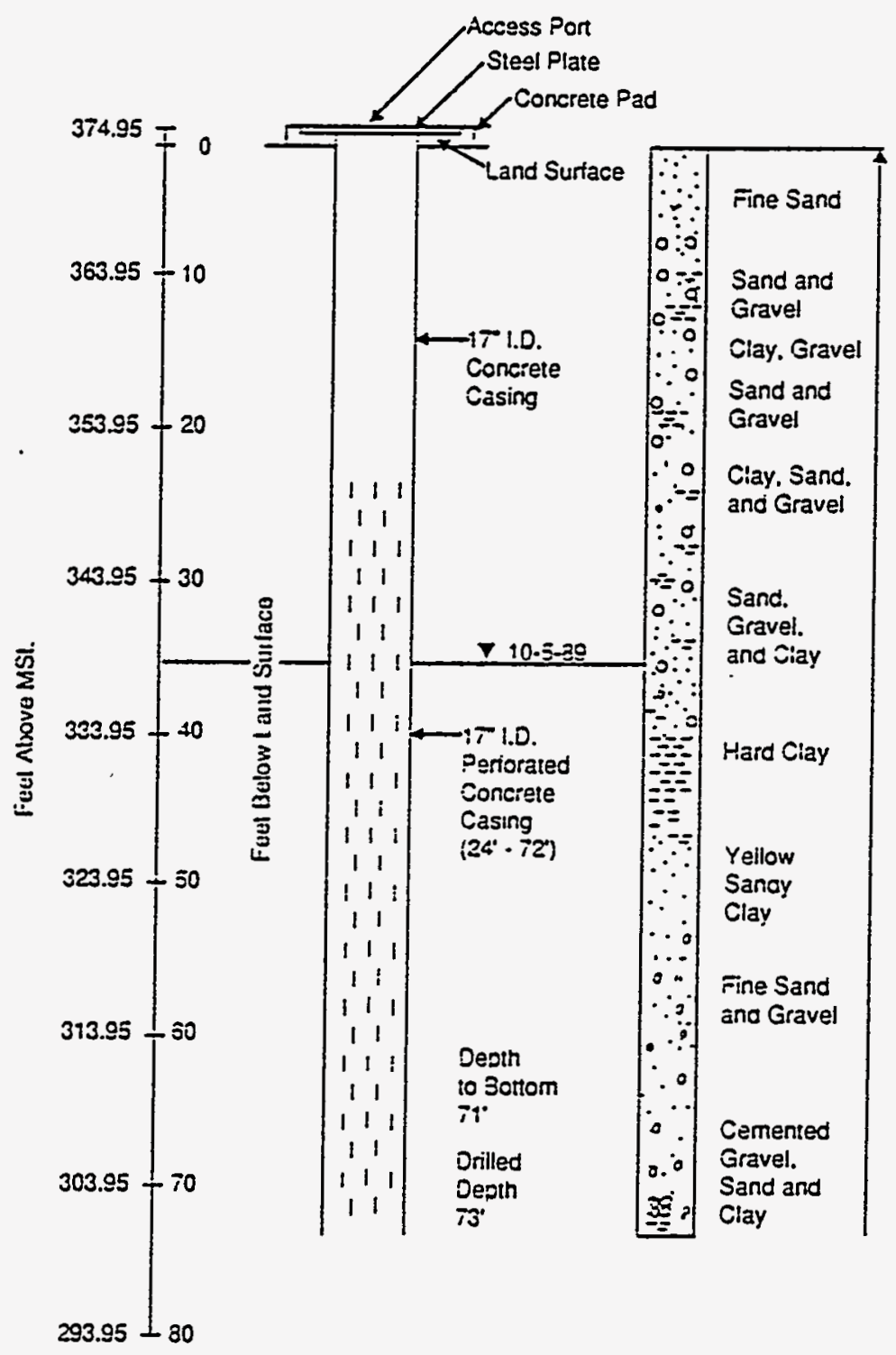

Well Completed 8/48

59007059.2

A. 1 
WELL NUMBER 699-S30-E15A

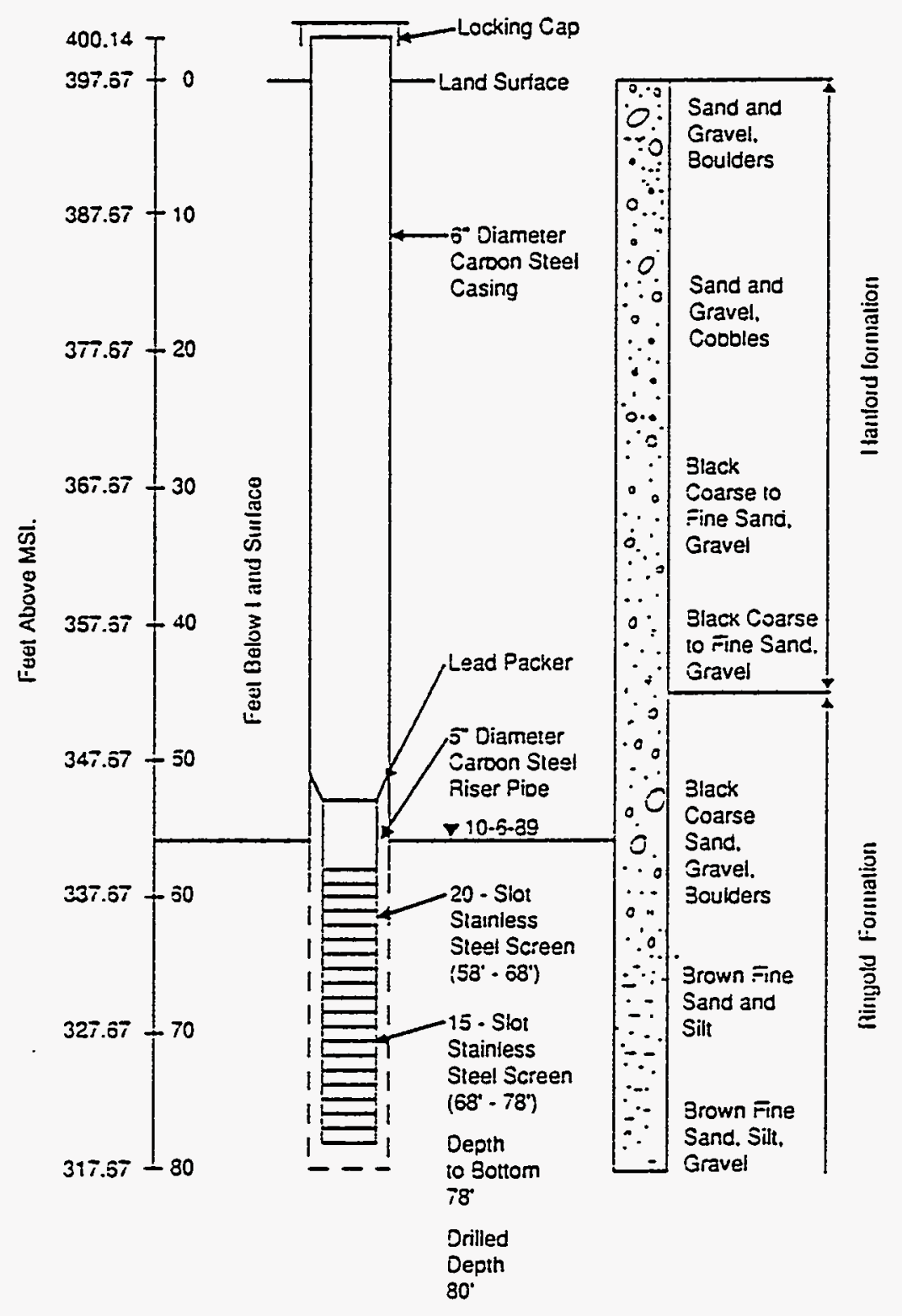

Well Completed $10 / 71$

\$s007059.1 
WELL NUMBER 699-S32-E13A

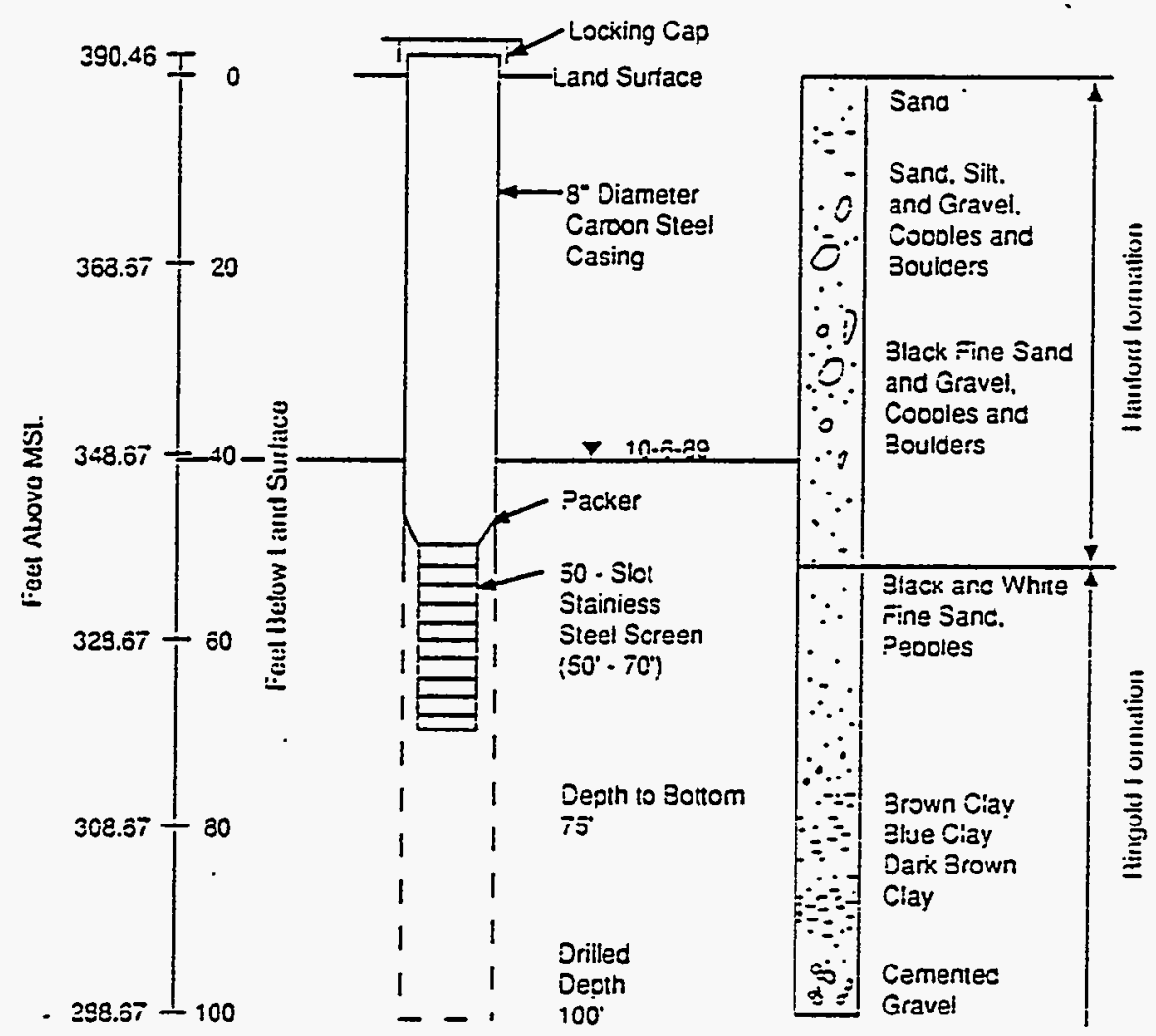

Well Comoleted 9/79

ssocicss: 
WELL NUMBER ด९9-S31-E13

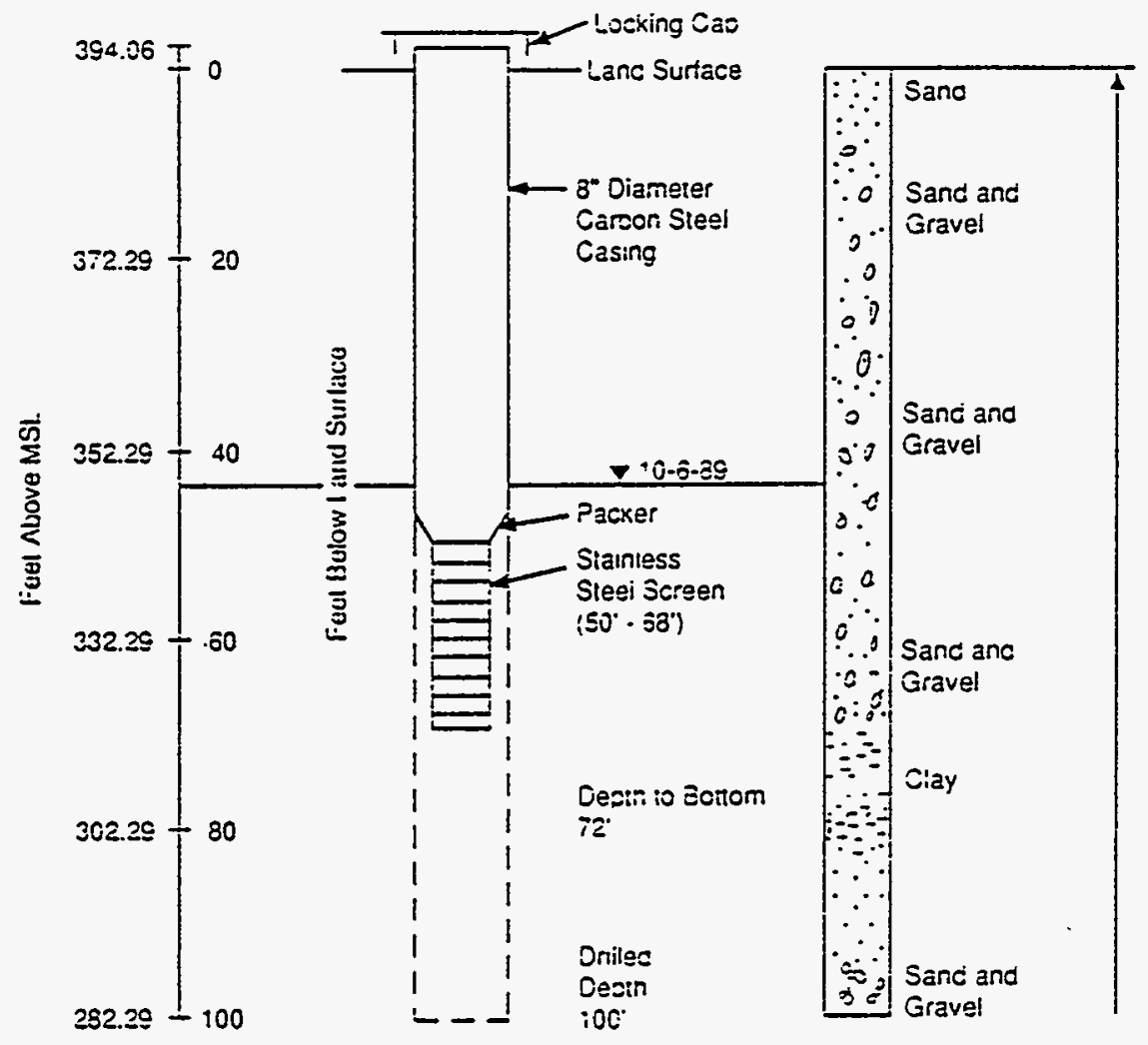

Well Comoieted 10r9

$\$ 5007059.5$ 
WEIL NUMBER 699-S32-E13B

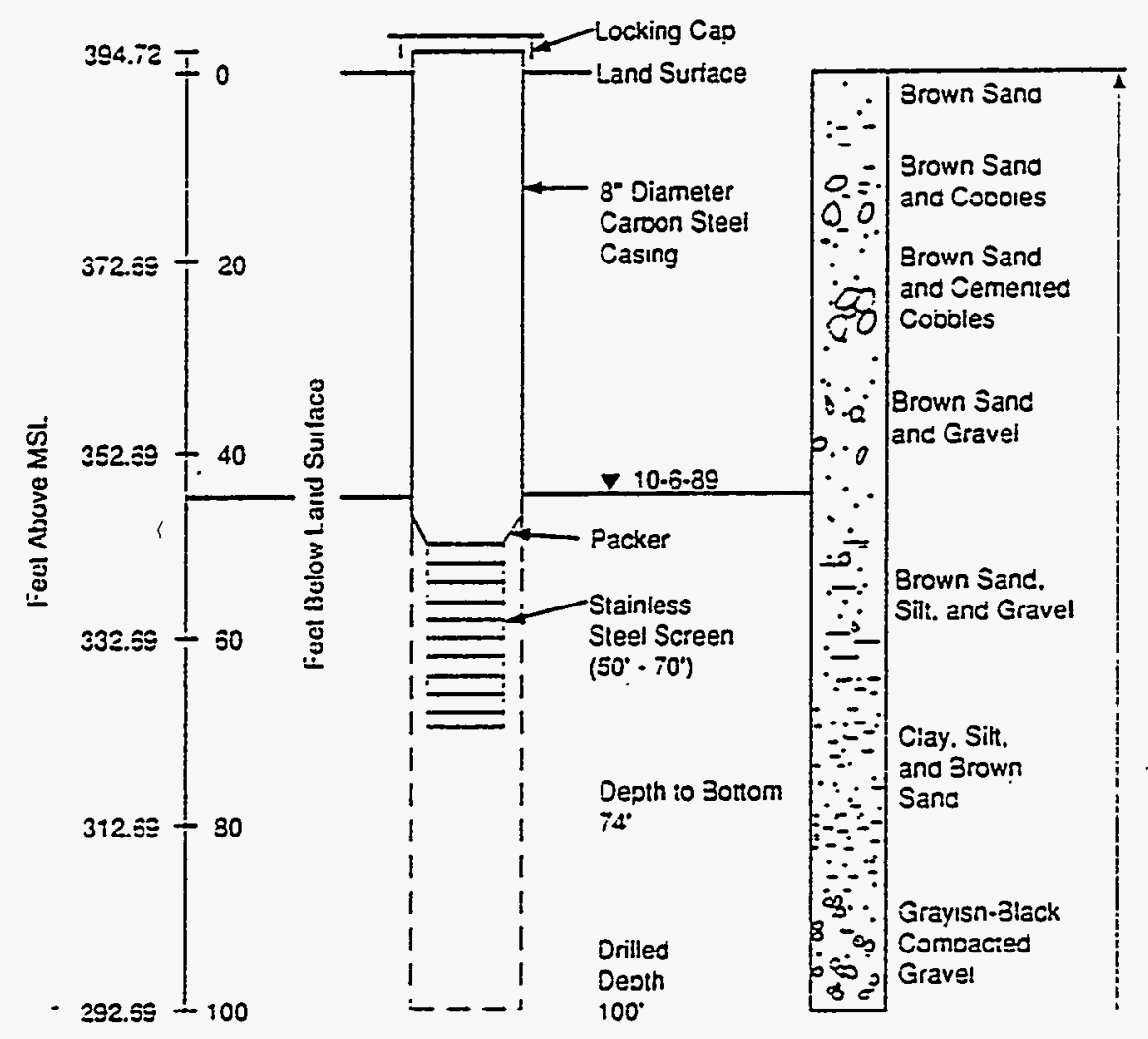

Well Comcieted iong

S500705s.: 1 
WELL NUMBER G99-S29-E12

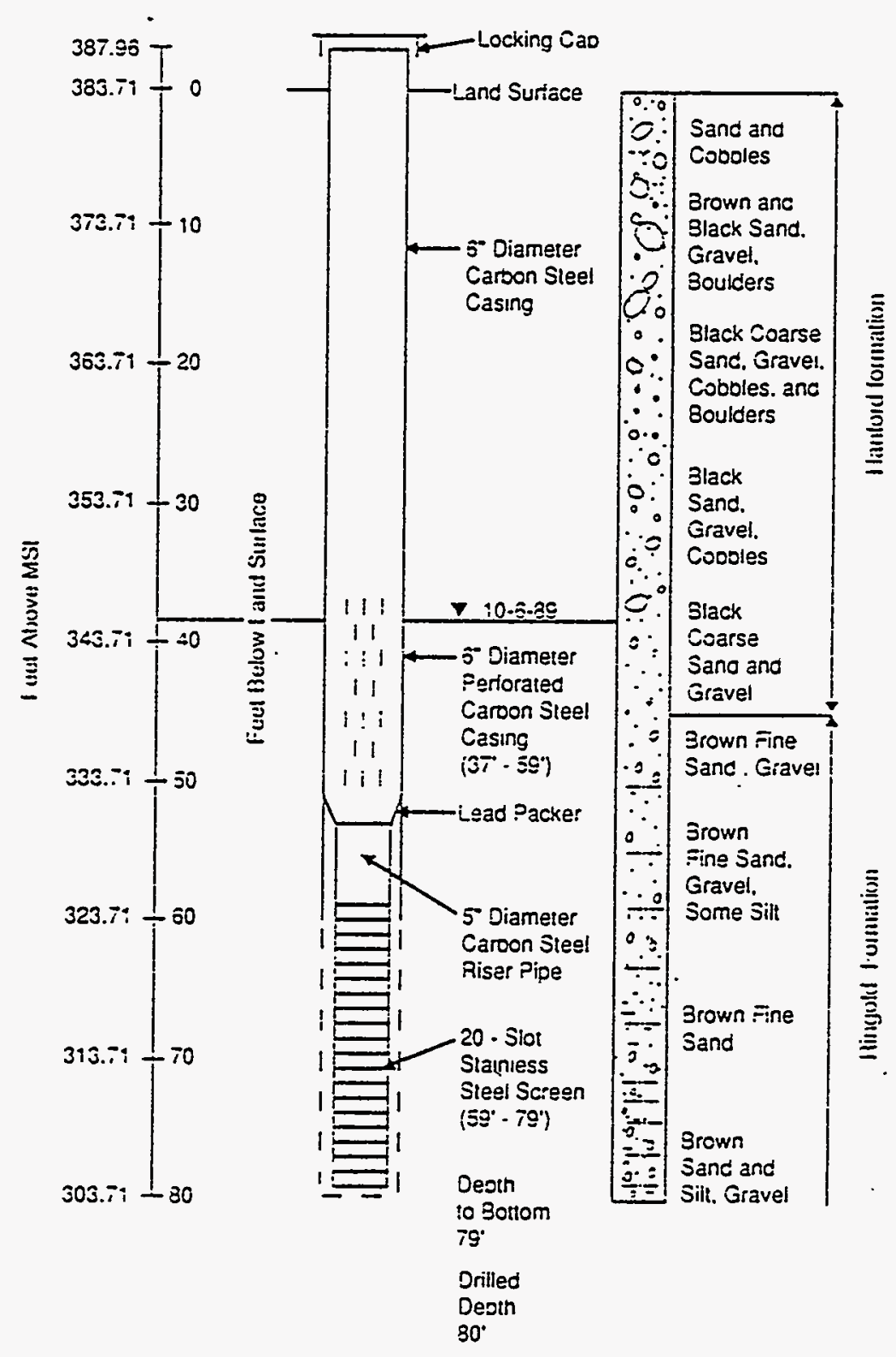

Well Comoleted iriti

590070s9 3 
WELL NUMBER TW17

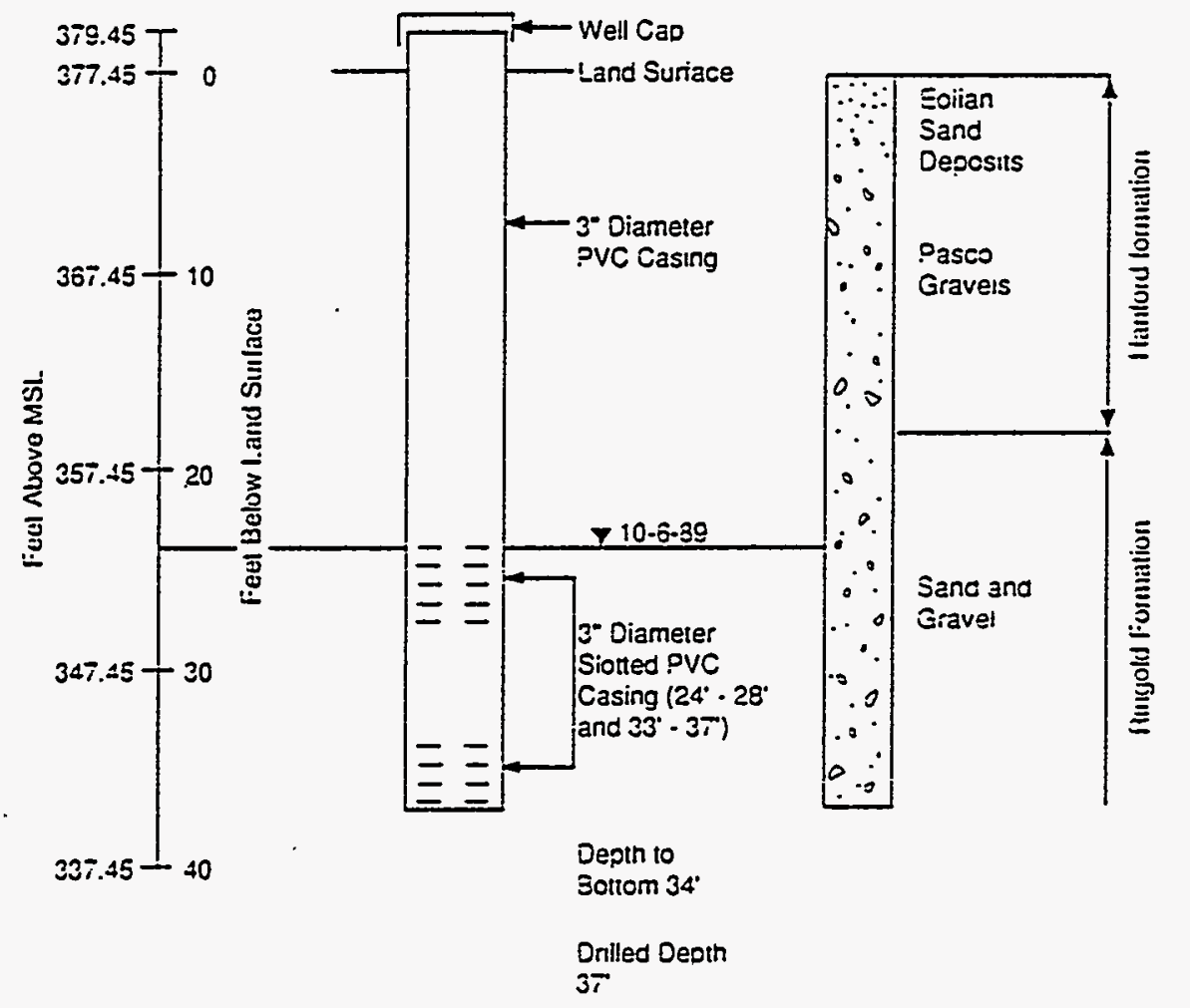

Well Completed 1982

S5007059.0

A. 7 
WELL NUMBER TW16

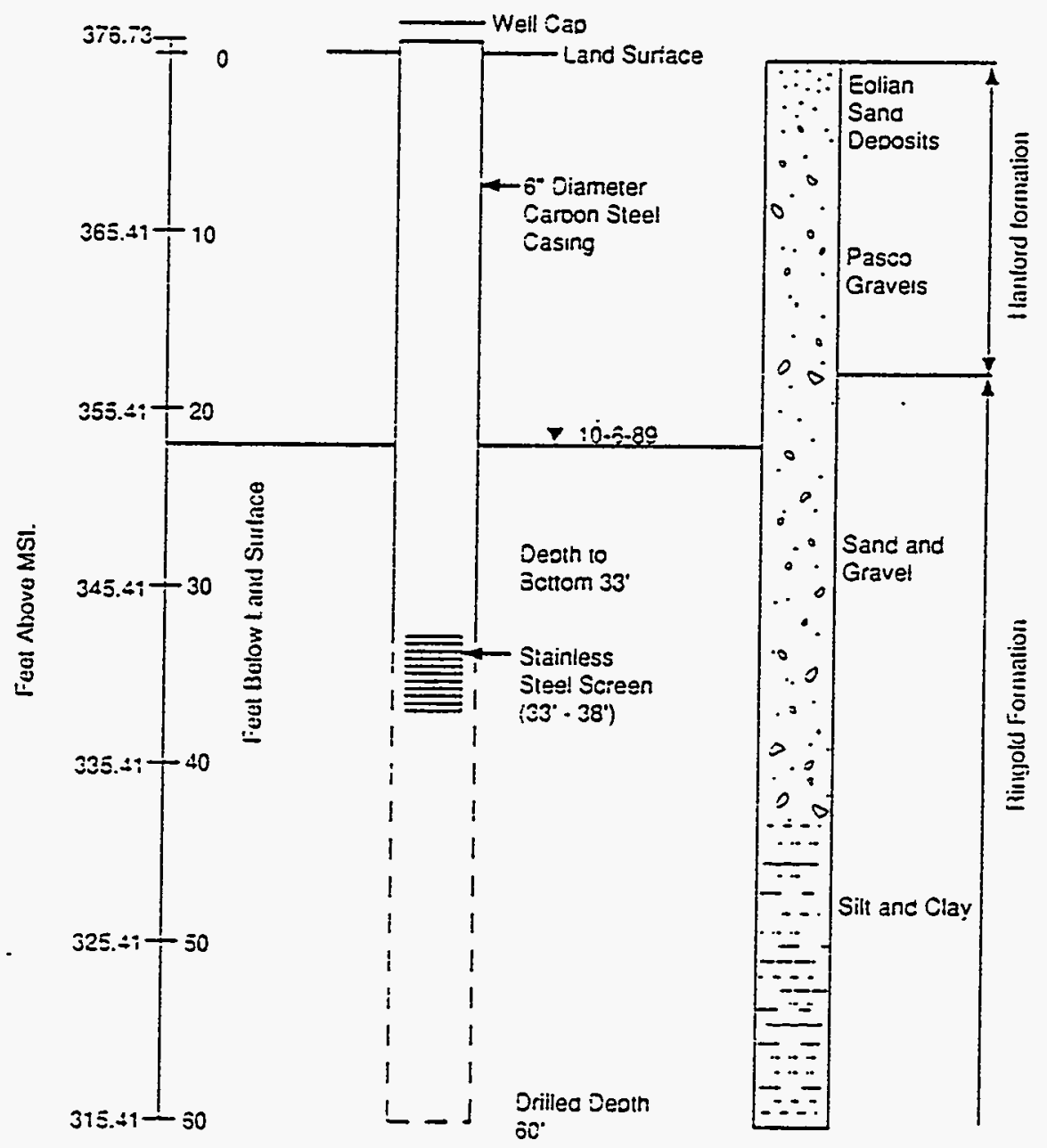

Well Compoleted :982

59007059.:- 
WELL NUMBER TW18

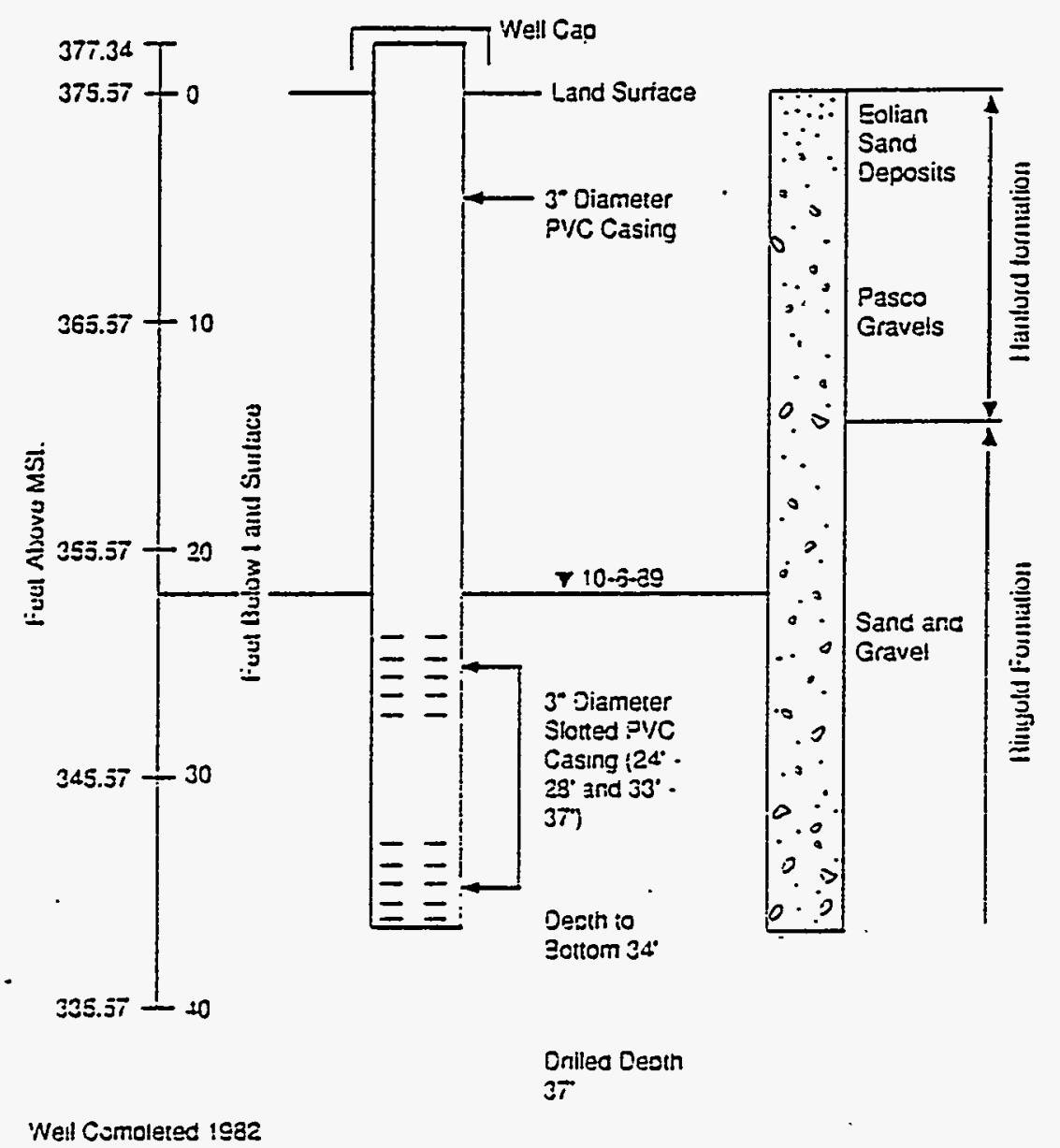

5\$007059.3 
WELL NUMBER TW15

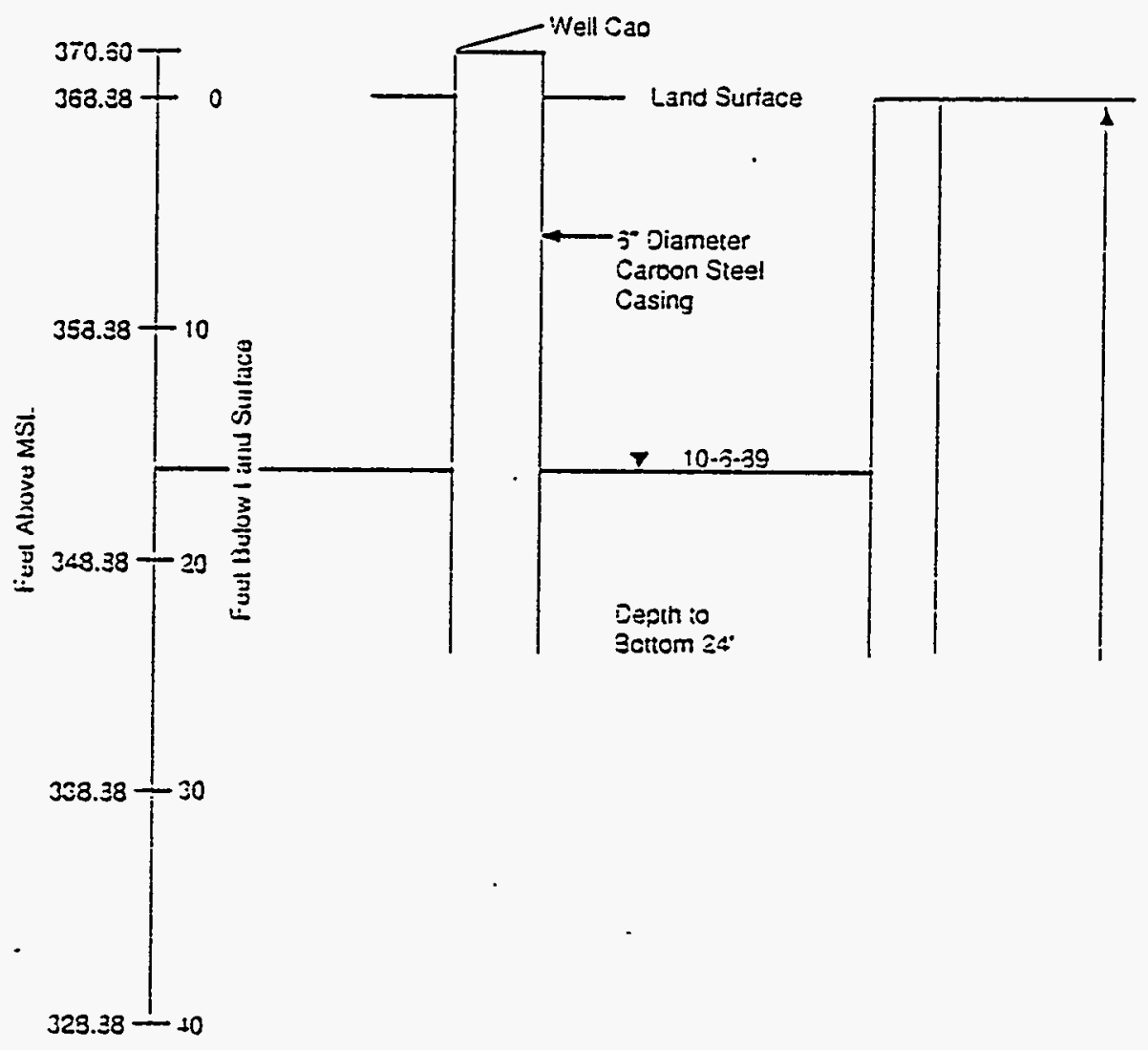

350070S9. 0

A.10 
WELL NUMBER TW14

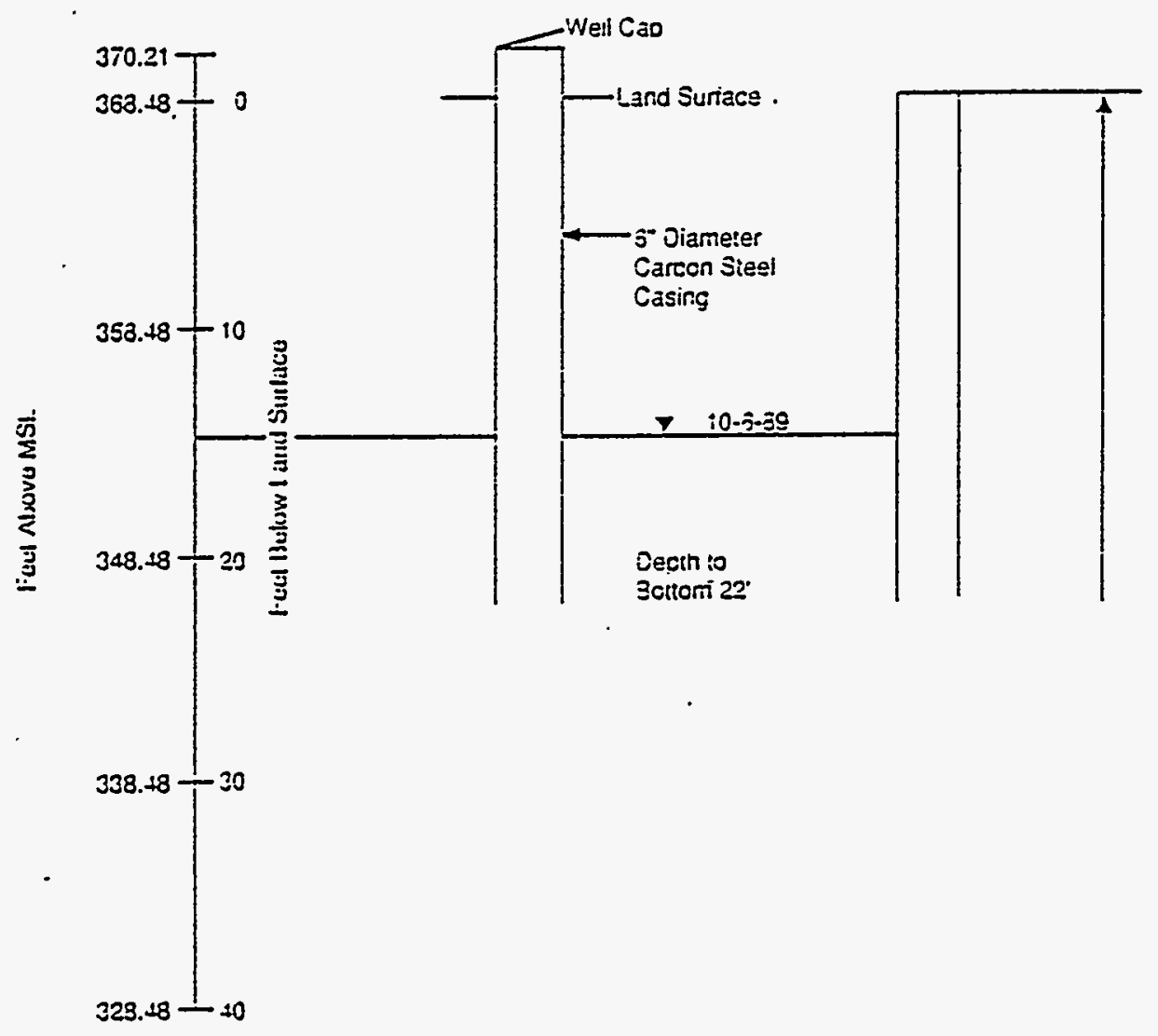

S50070s9. 25

A. 11 


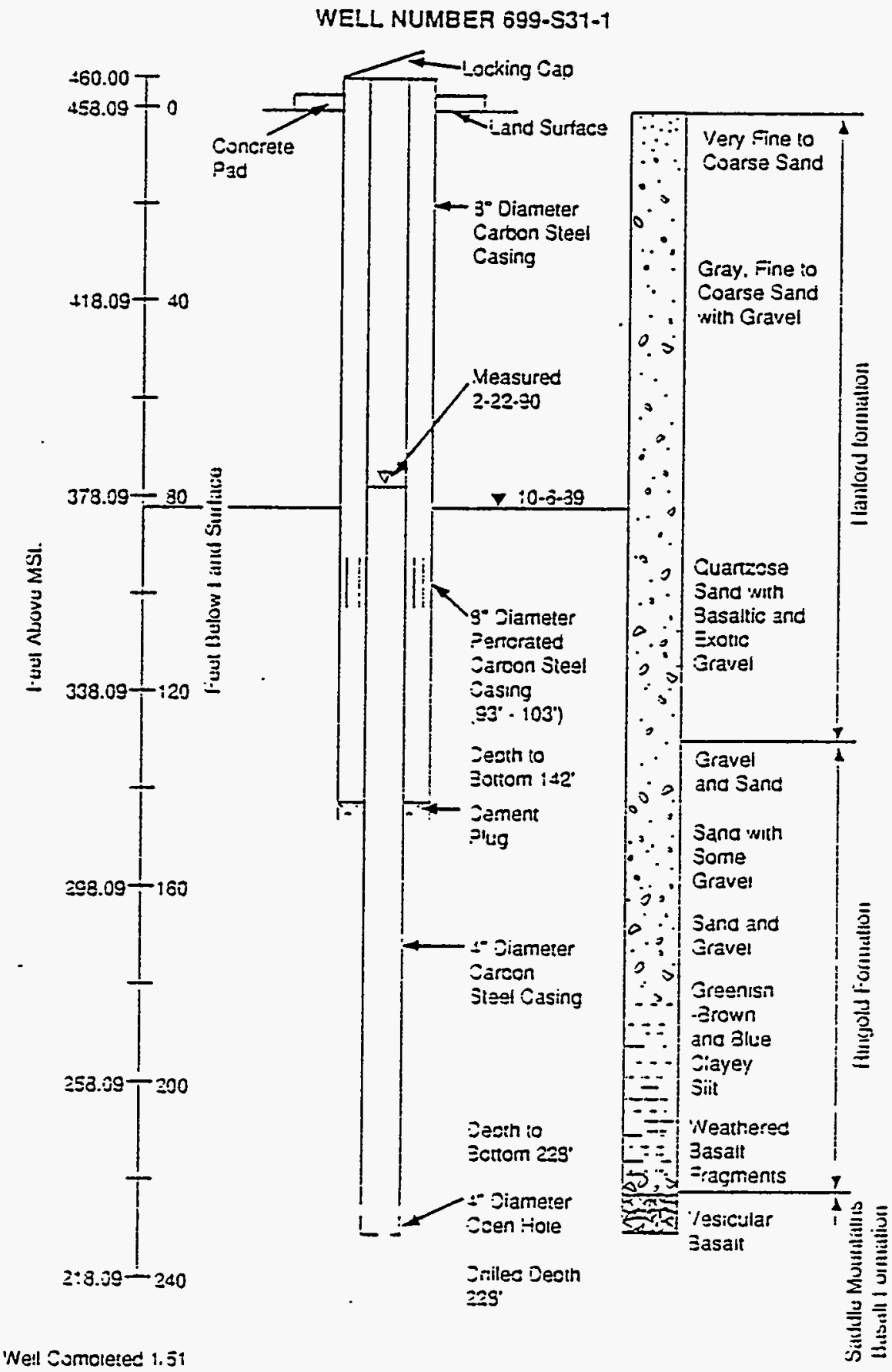

'Ne!l Comcleted 1. 51

s9coress ; 
WELL NUMBER 699-S23-26

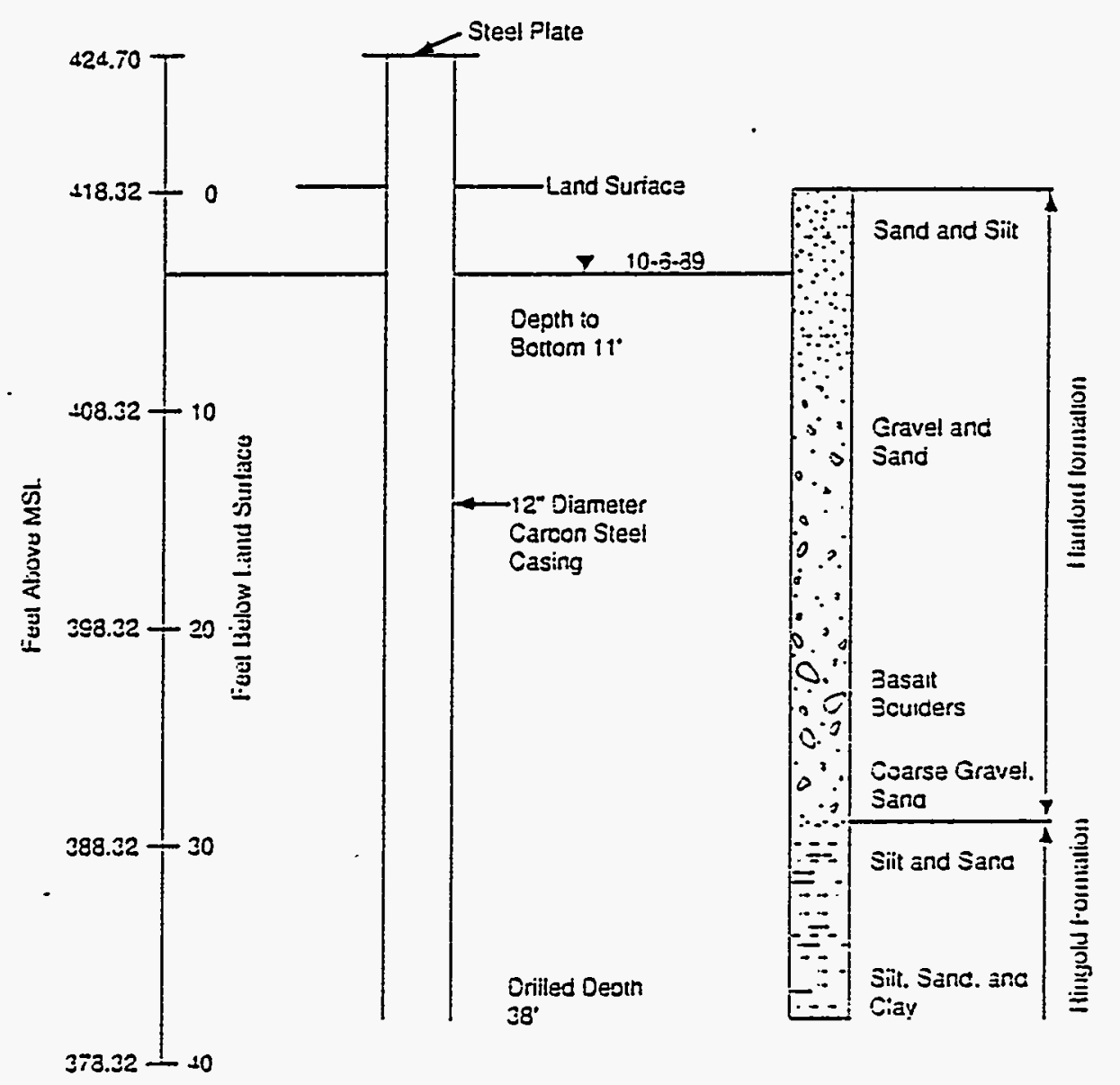

Nell Conctered jiss

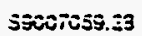


WELL NUMBER EC-1

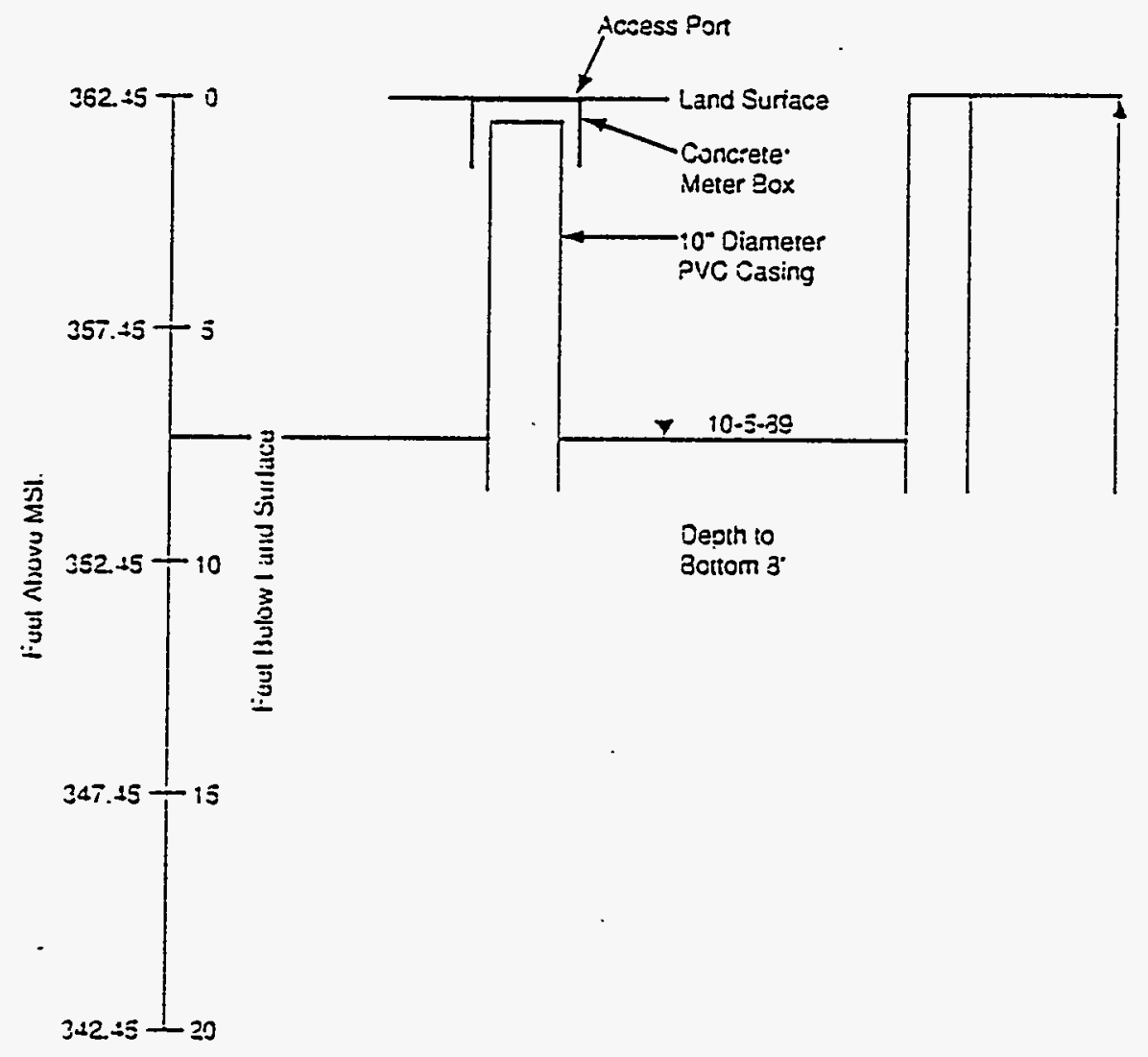

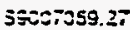

A. 14 


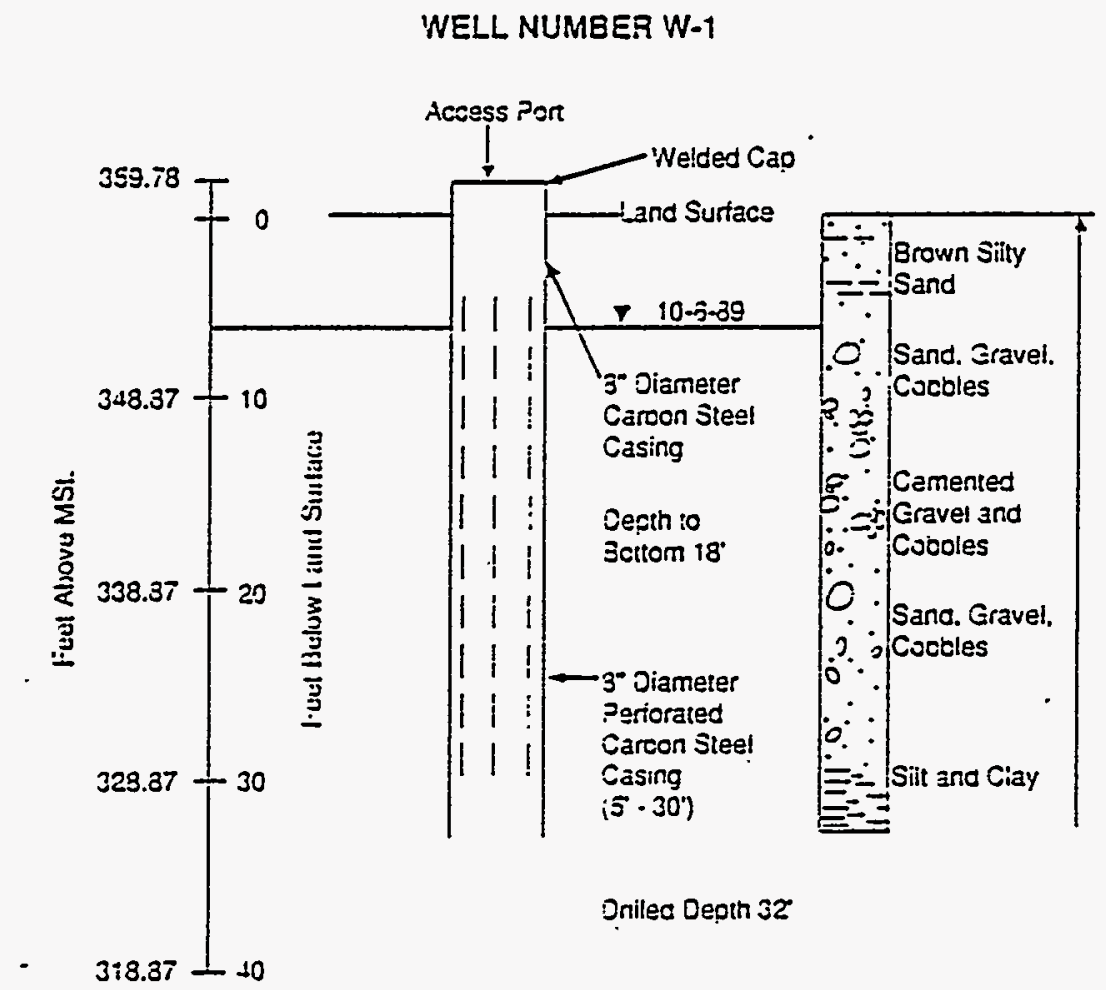

Well Completes 1/83

$S \leq 007059.35$ 
WELL NUMBER $N-3$

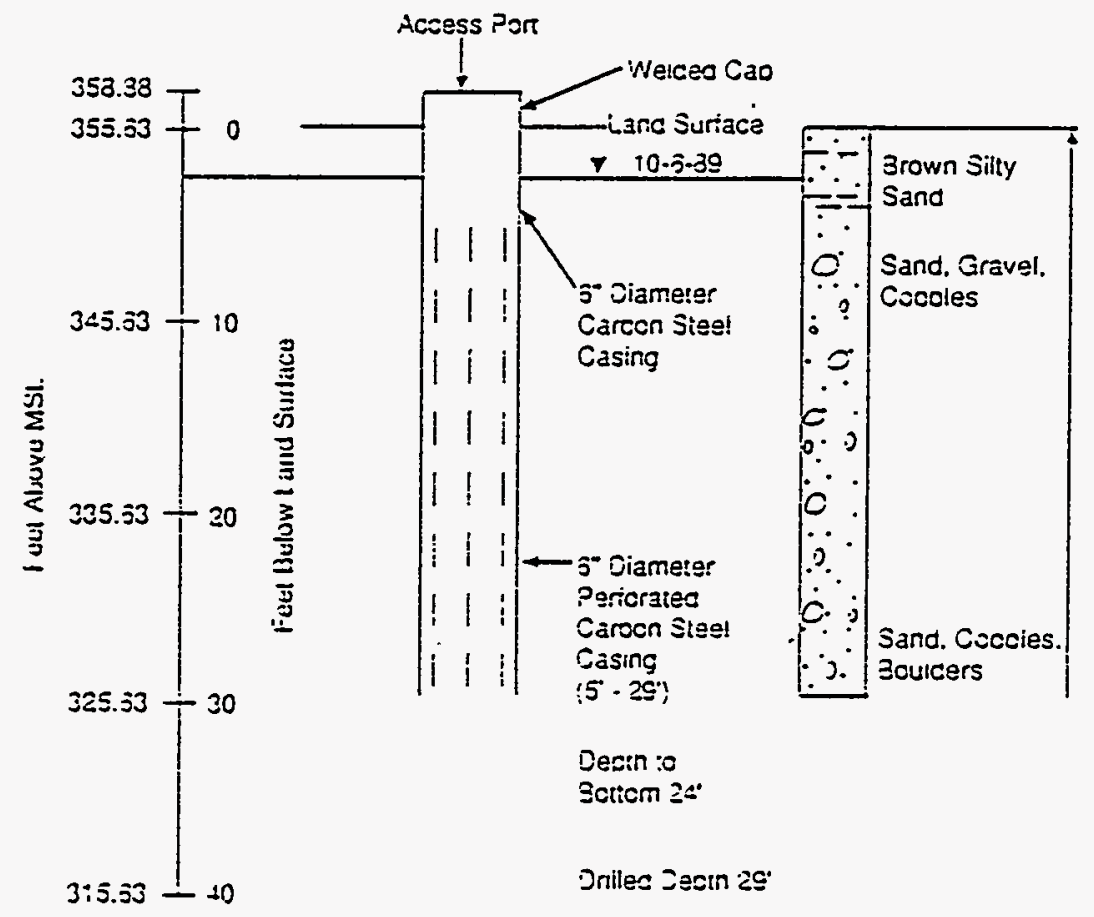

Wetl Comcleted i/83

S9C07.59.ม? 


\section{WELL NUMBER W-4}

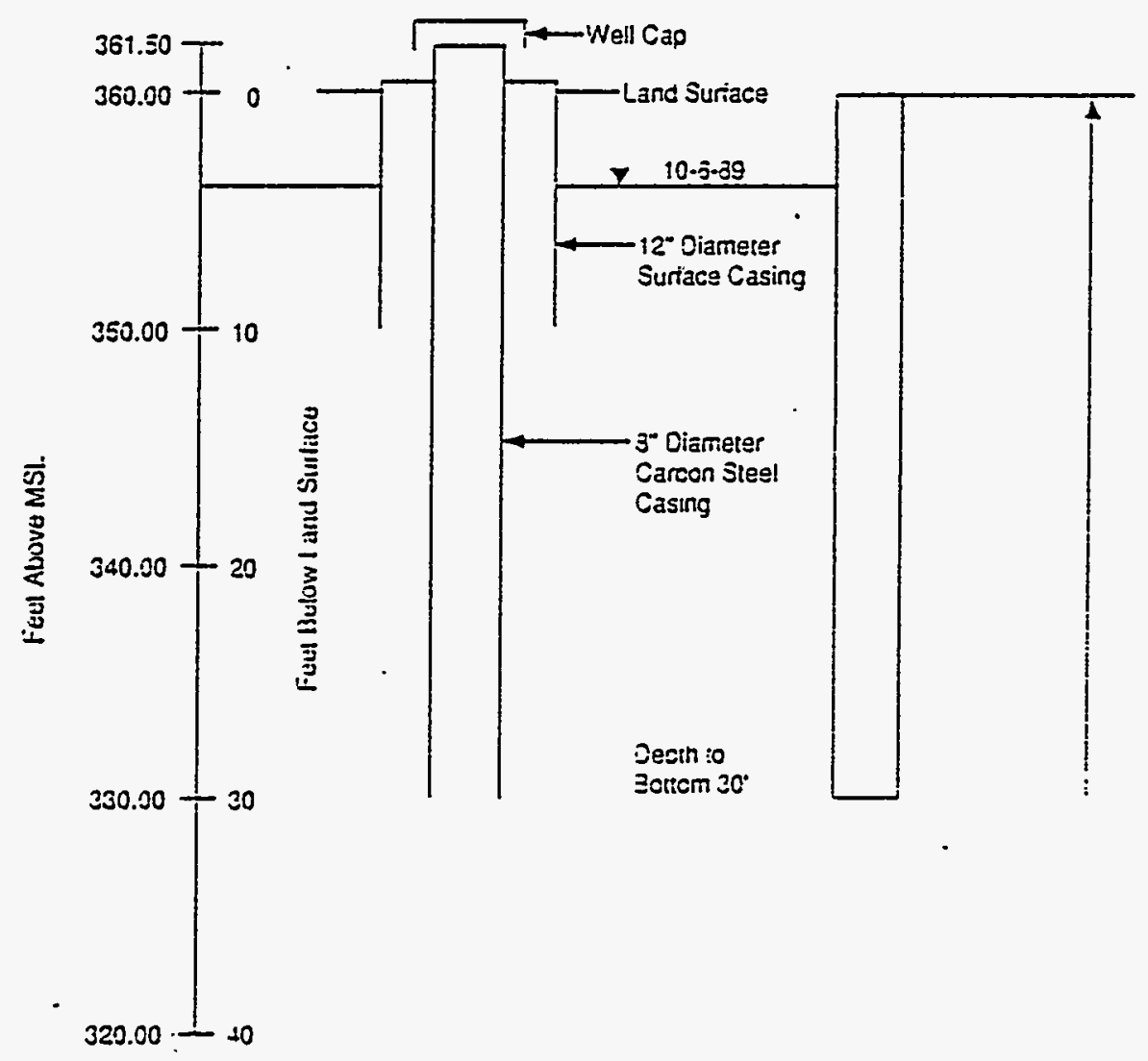

Wetl Completed 1989

3soctcss

A. 17 


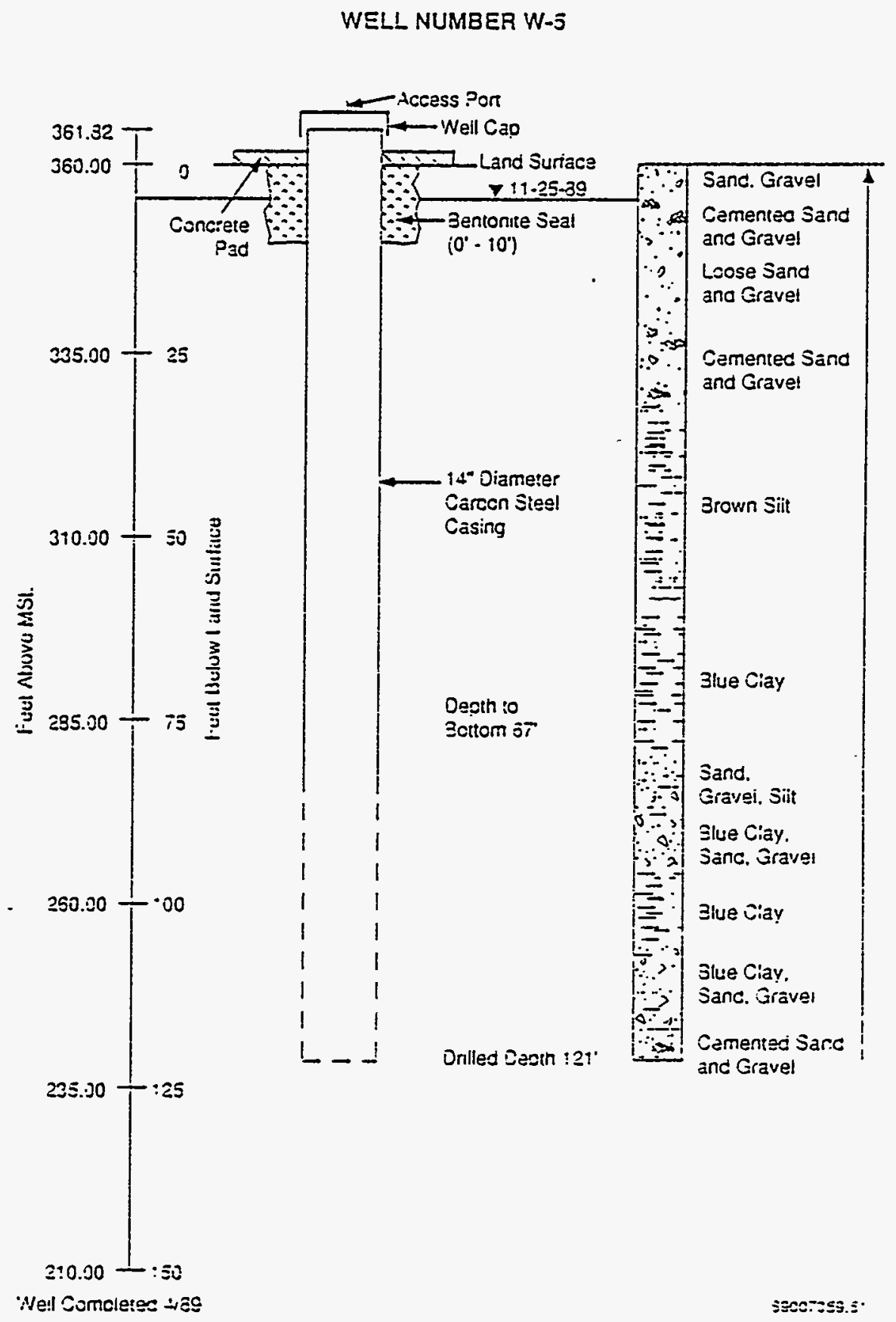

A. 18 


\section{$6 I^{\circ} \mathrm{V}$}

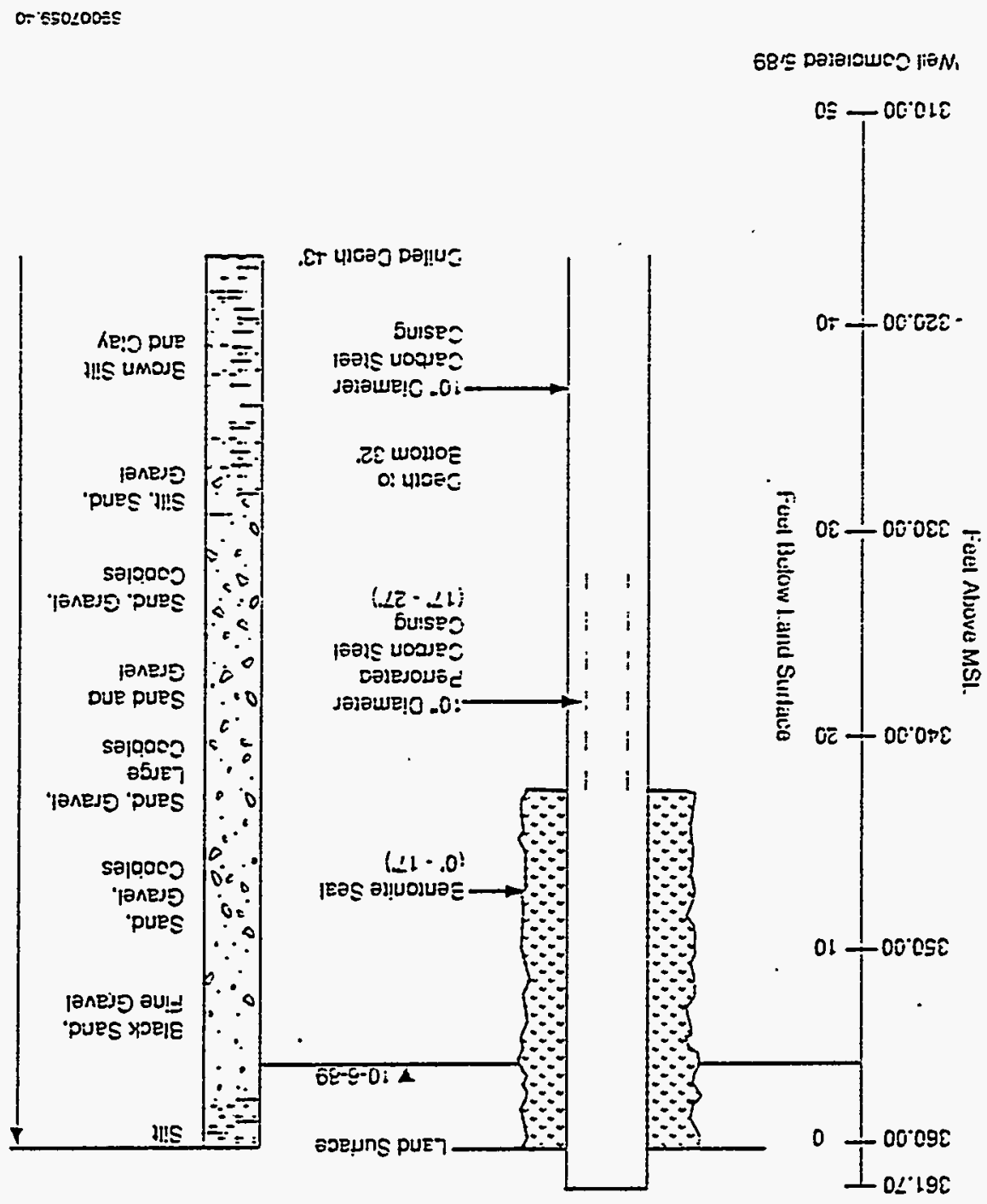

9-N \&38WกN 773M 


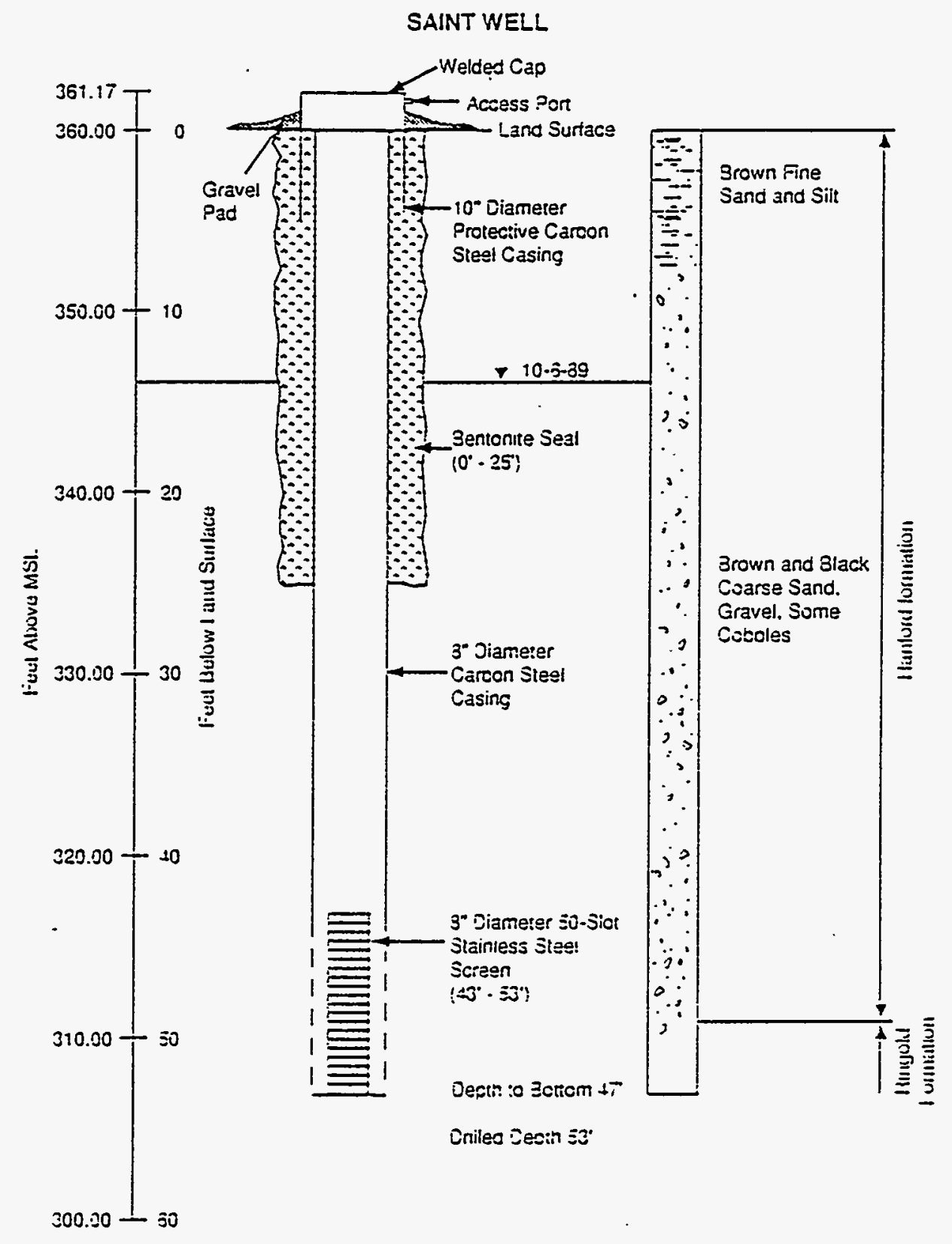

$55007055=2$ 
WELL NUM8ER 1100-2 (1199-34-13)

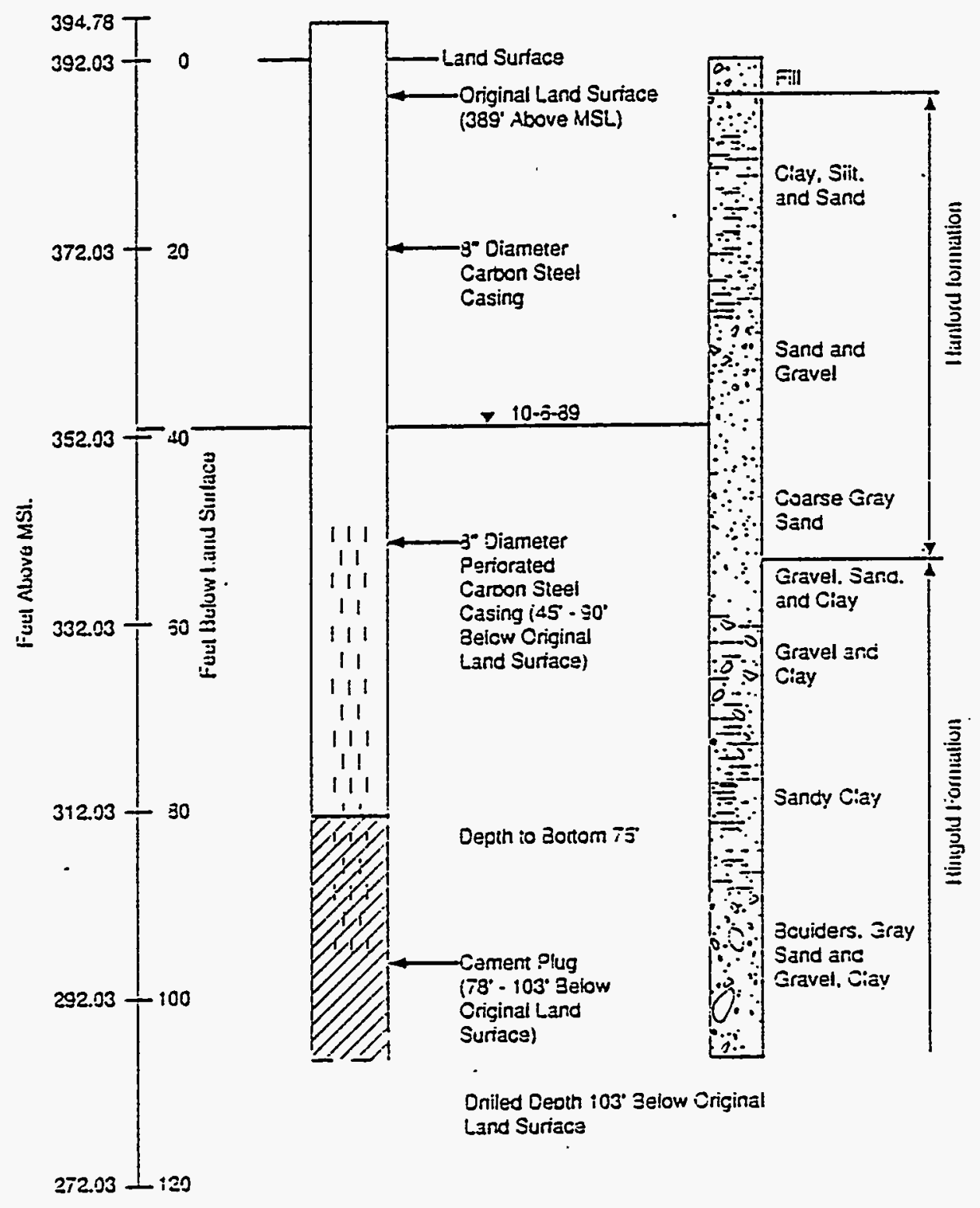

Well Completes 3/48 


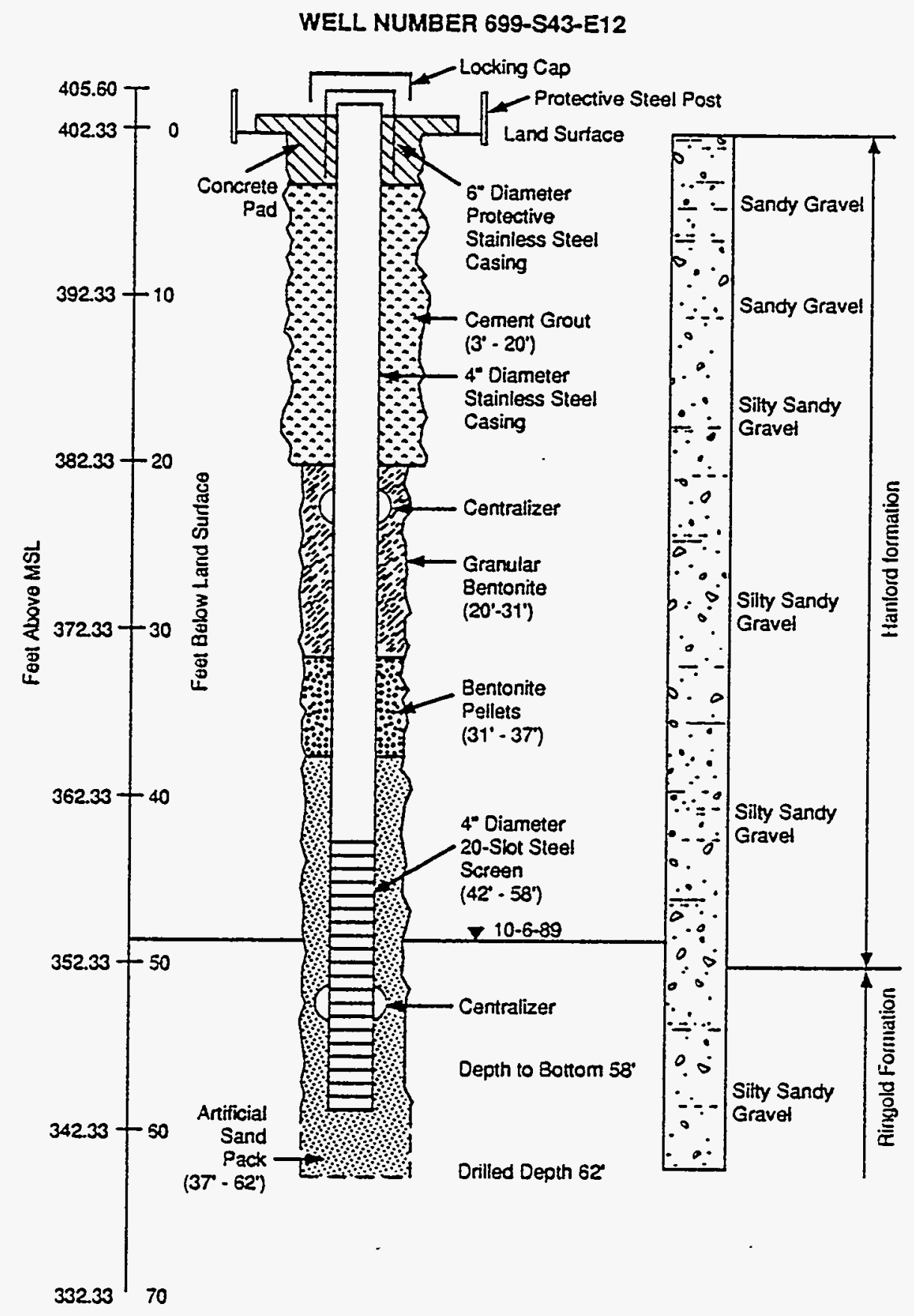

Well Completed 10/88

59007050.39 


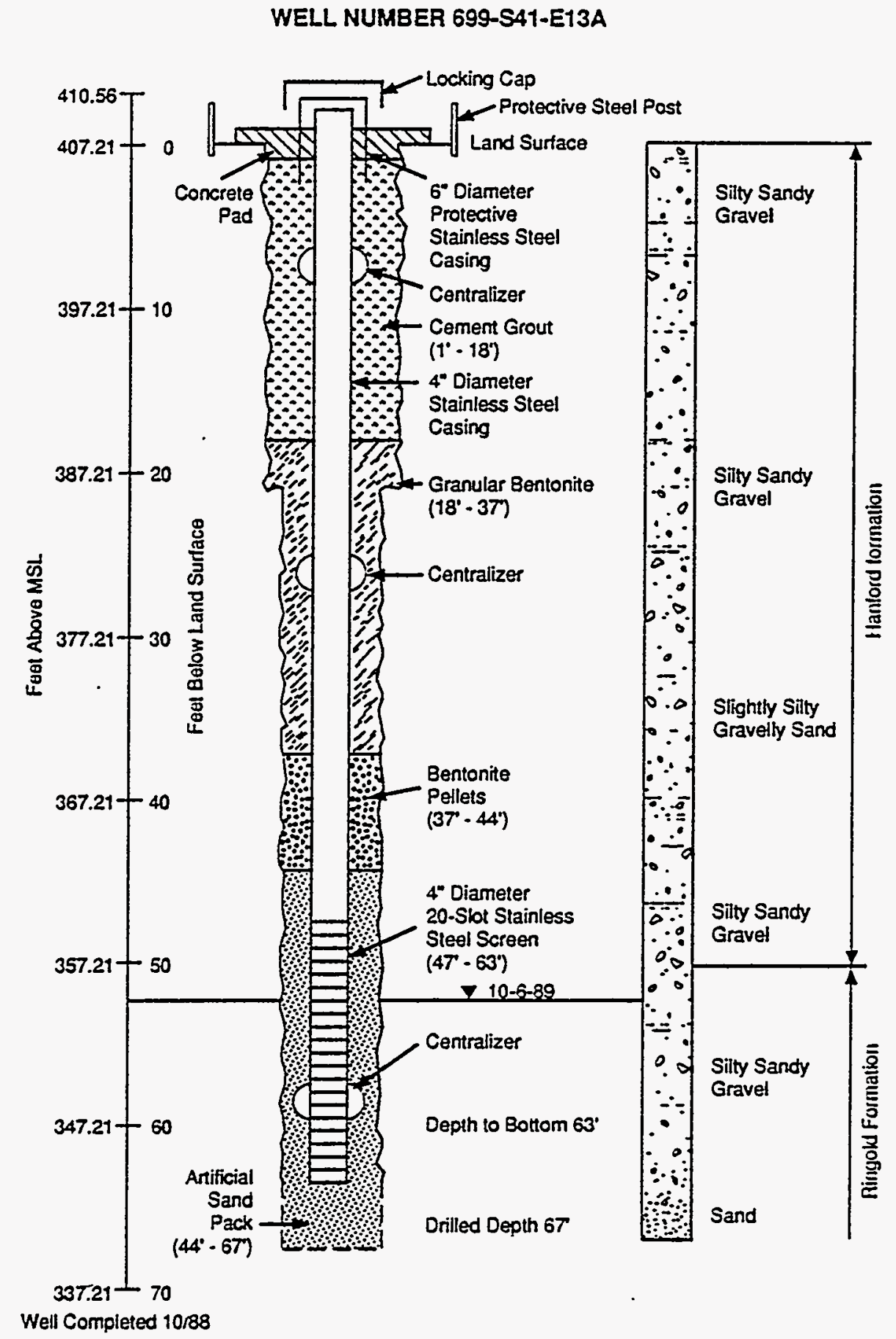

59007059.38 
WELL NUMBER 699-S41-E138

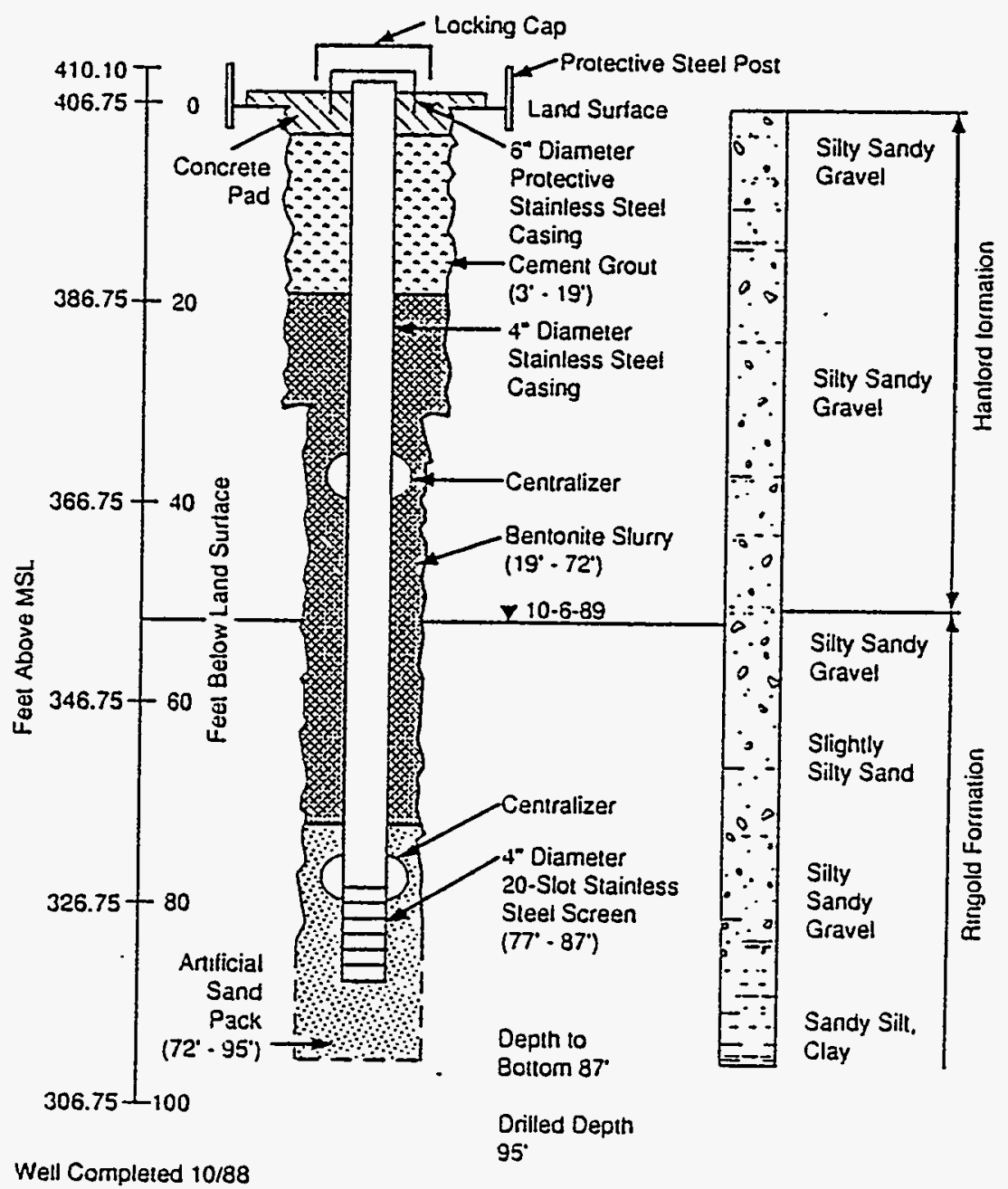

$\$ \$ 007059.37$ 
WELL NUMBER 699-S37-E14

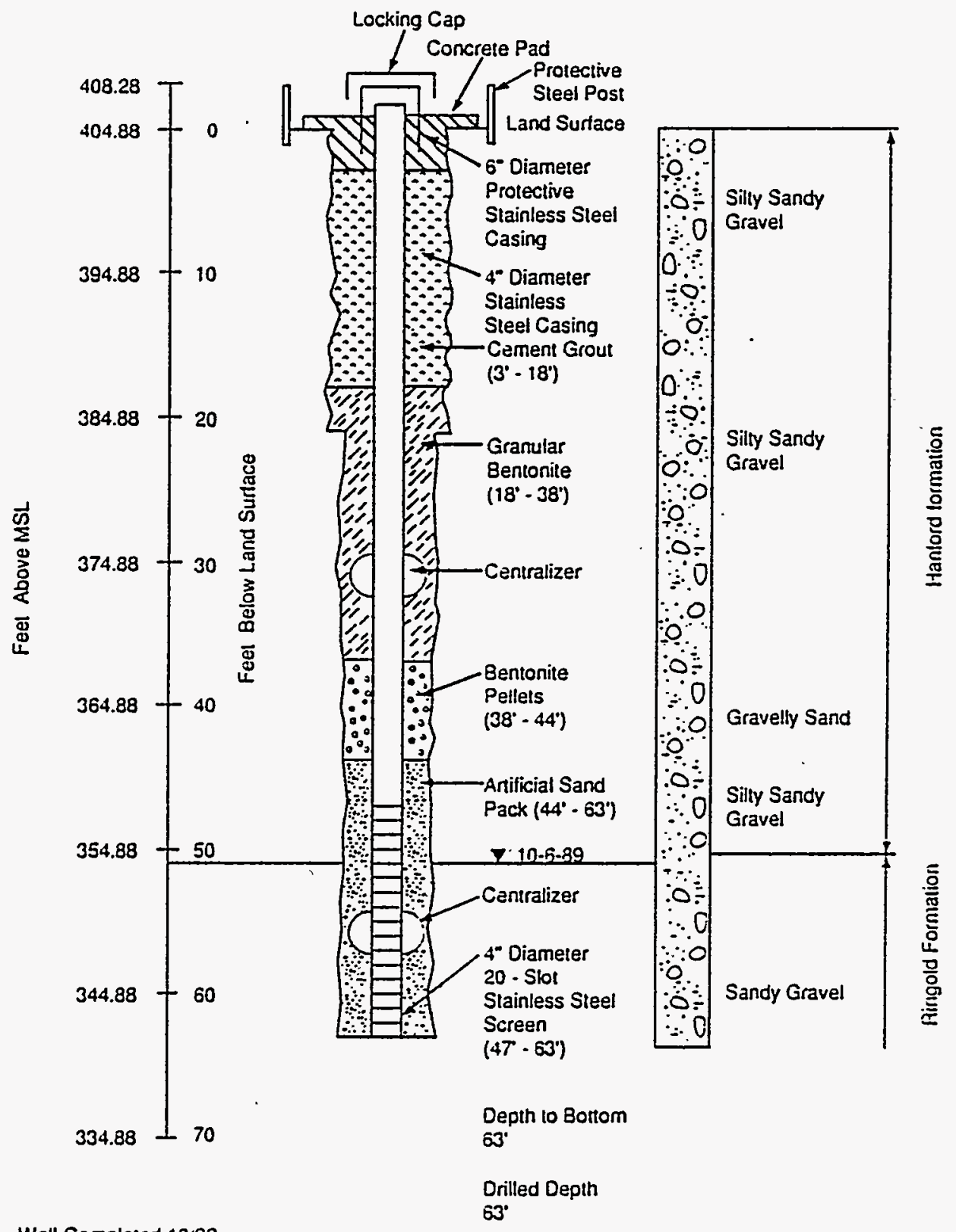

Well Completed 10/88

$\$ 500705912$ 
WELL NUMBER 3000-D1 (1199-41-13C)

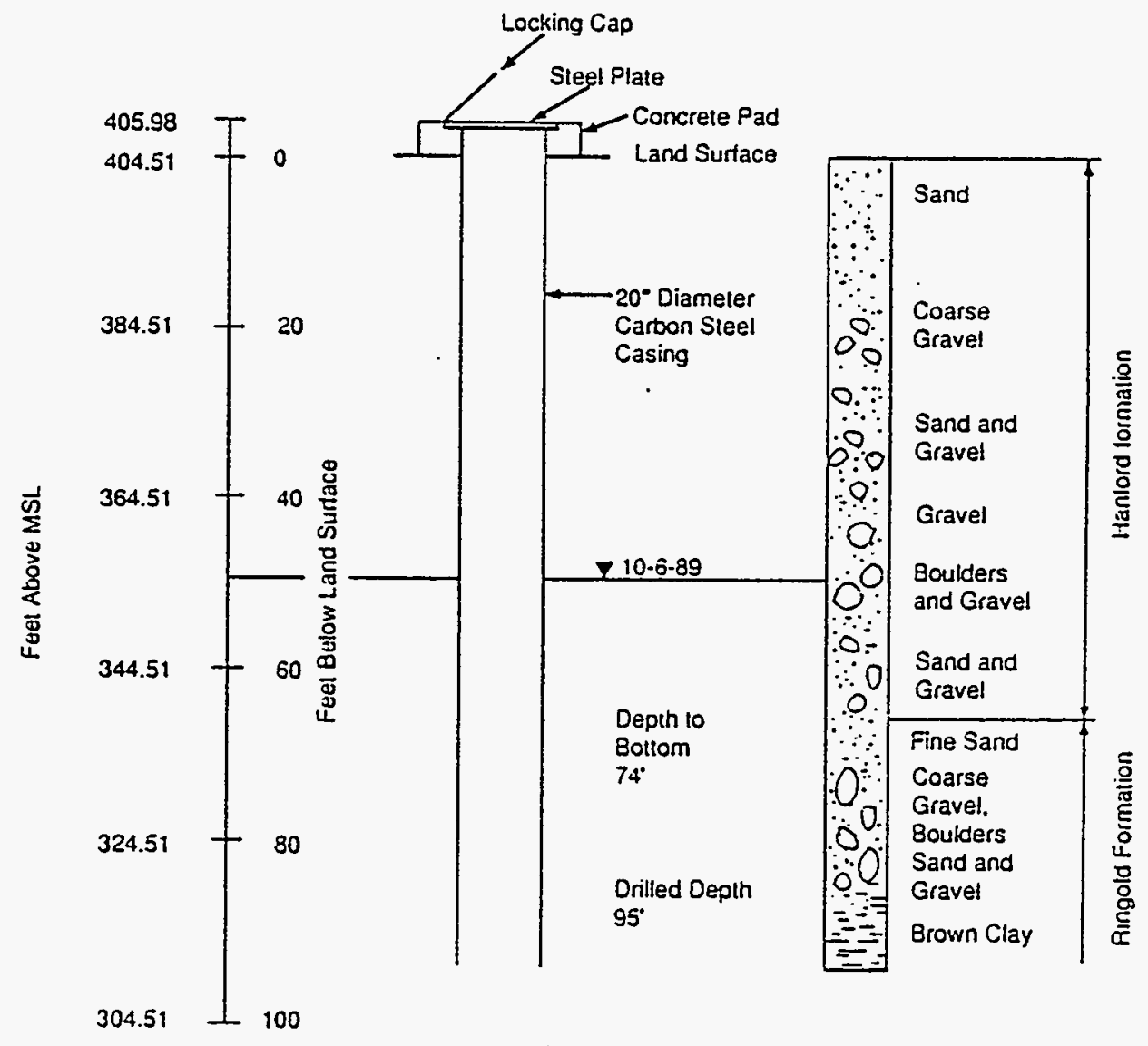

Well Completed 3/44

59007059.13 
WELL NUMBER 699-S36-E12B

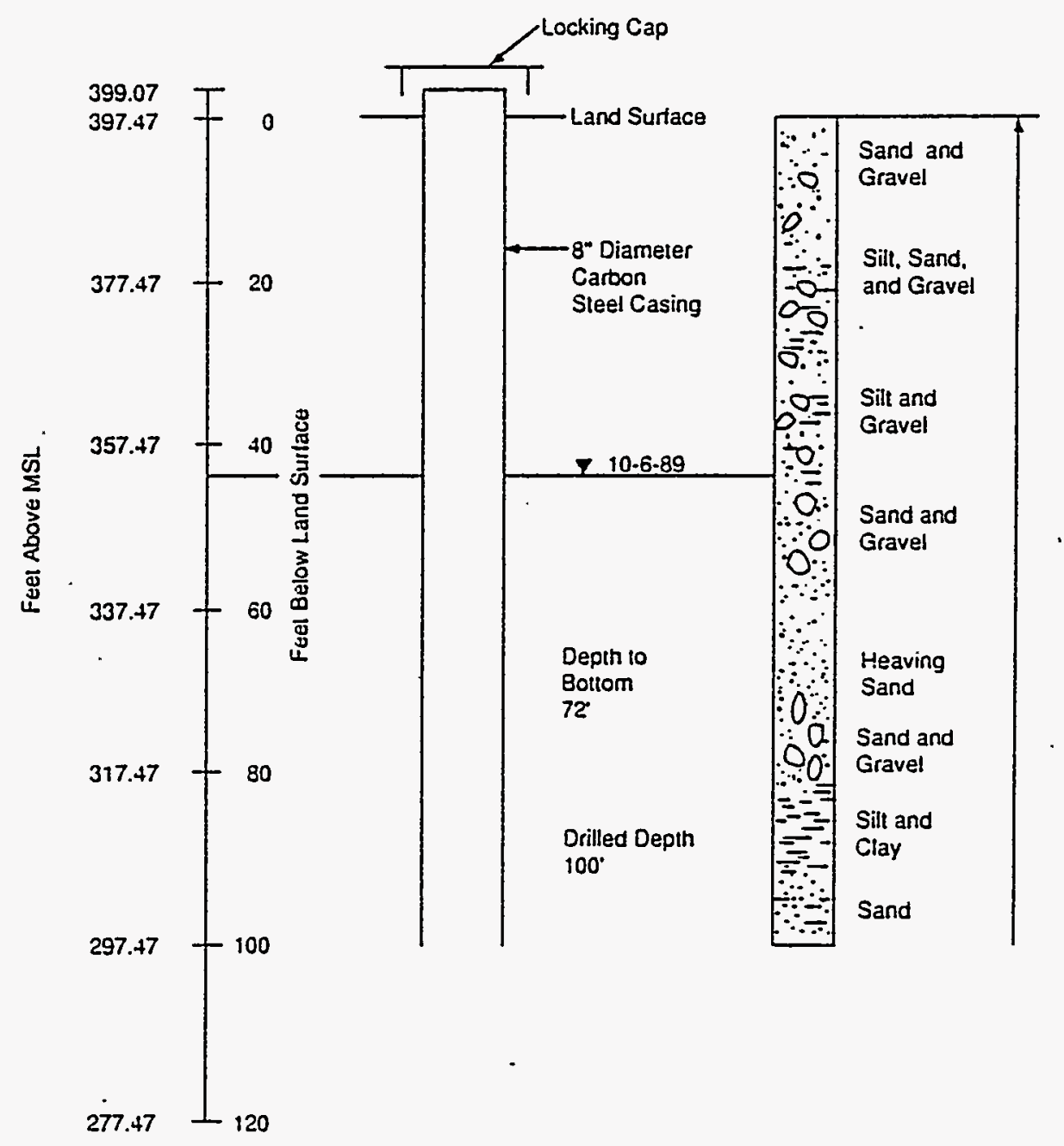

Well Completed 10/79

5900705914 


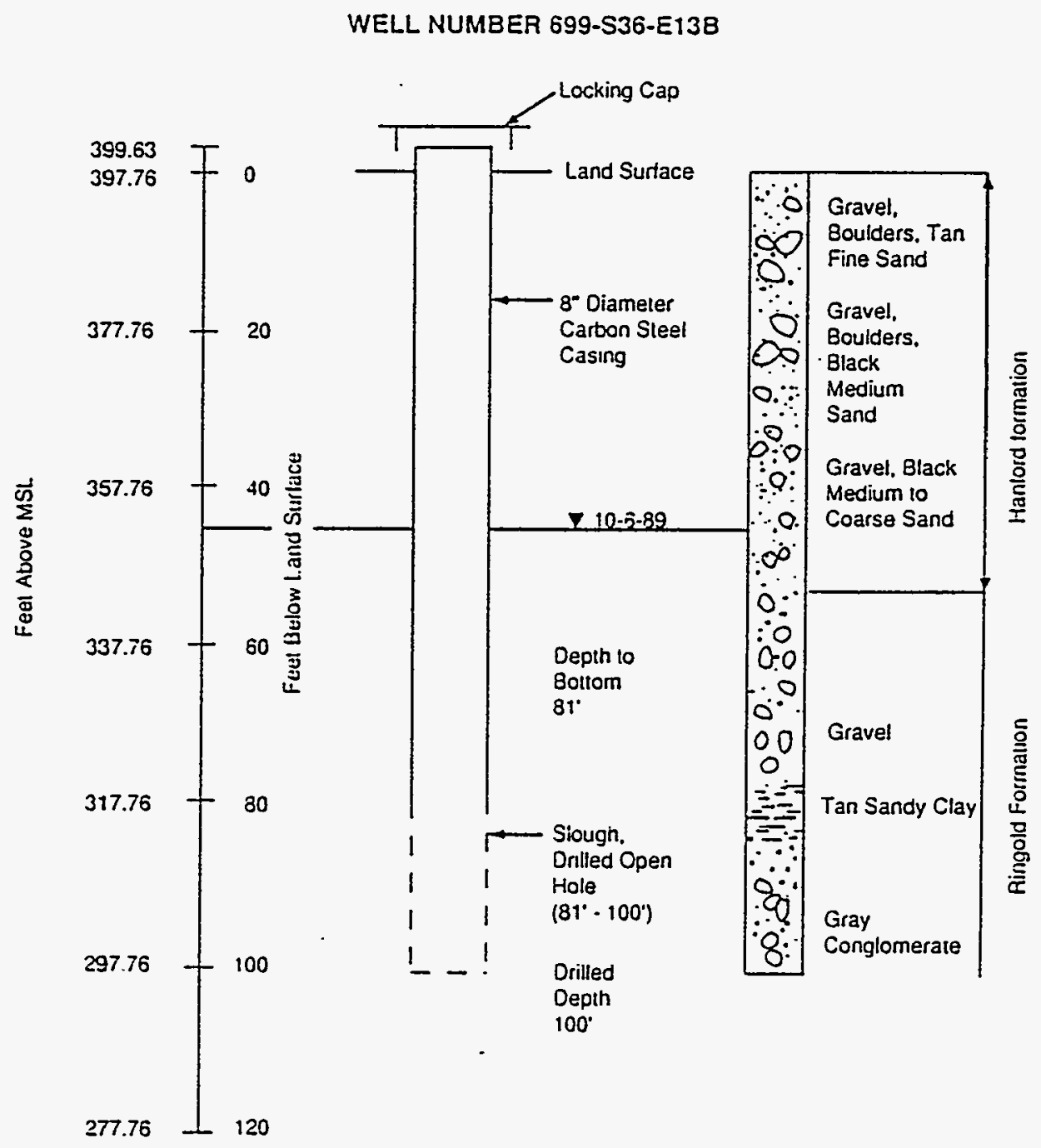

Well Completed 10/79

$\$ 9007059.15$ 
WELL NUMBER 699-S36-E13A

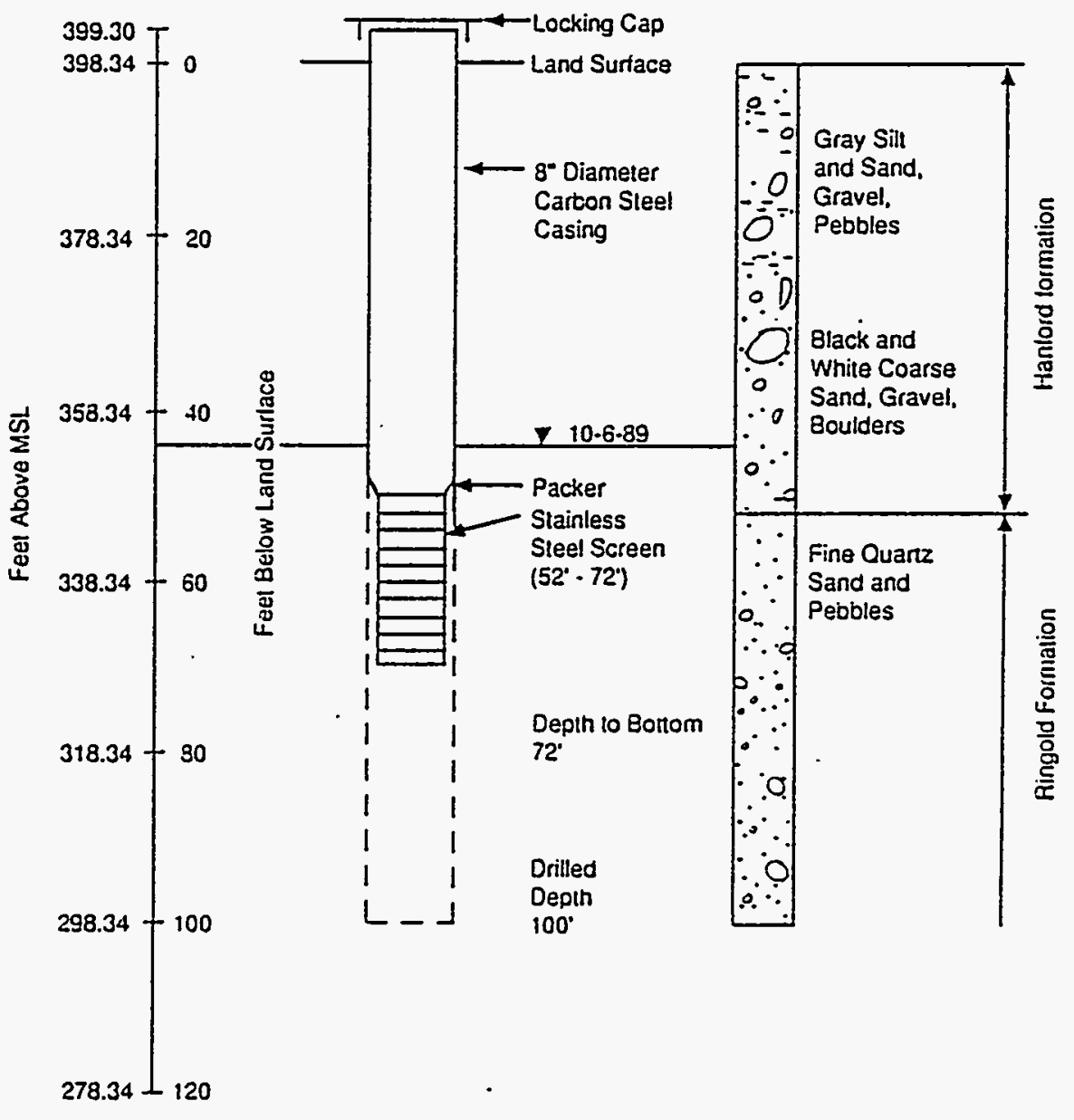

Well Completed 9/79

\$9007059.17 


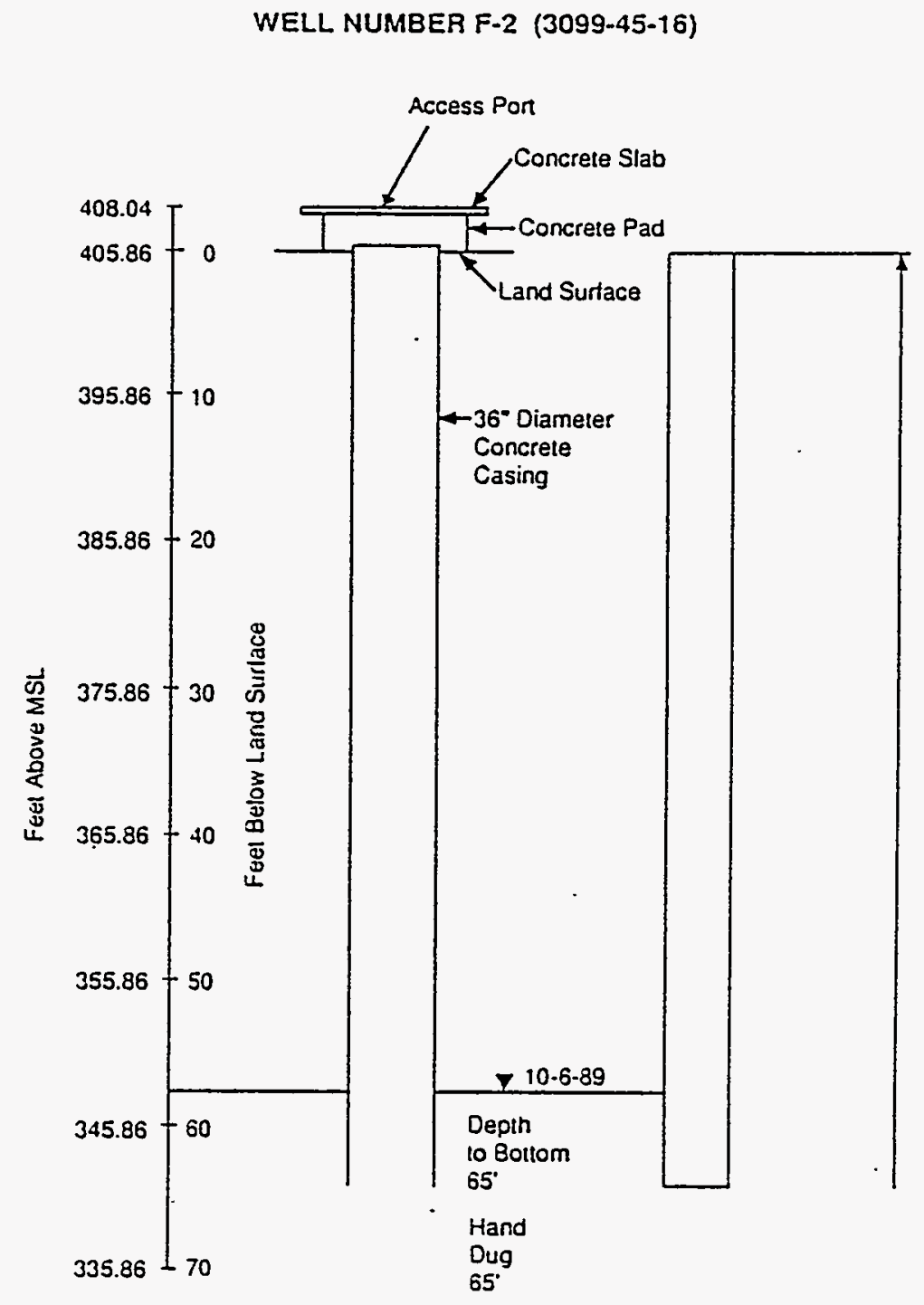

\$5007059.16 
WELL NUMBER 699-S30-E14

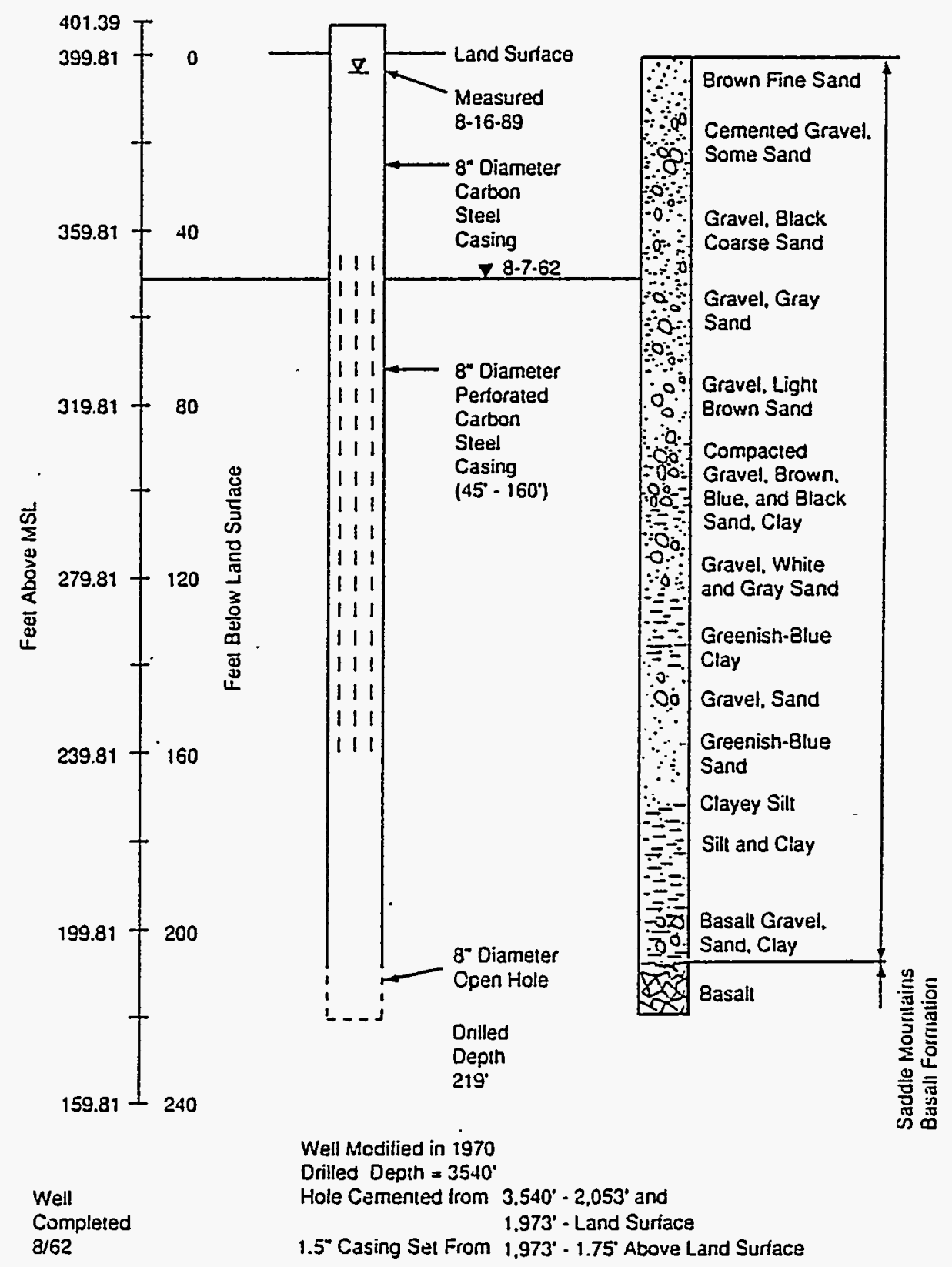

5900705921 
WELL NUMBER 699-\$28-E0

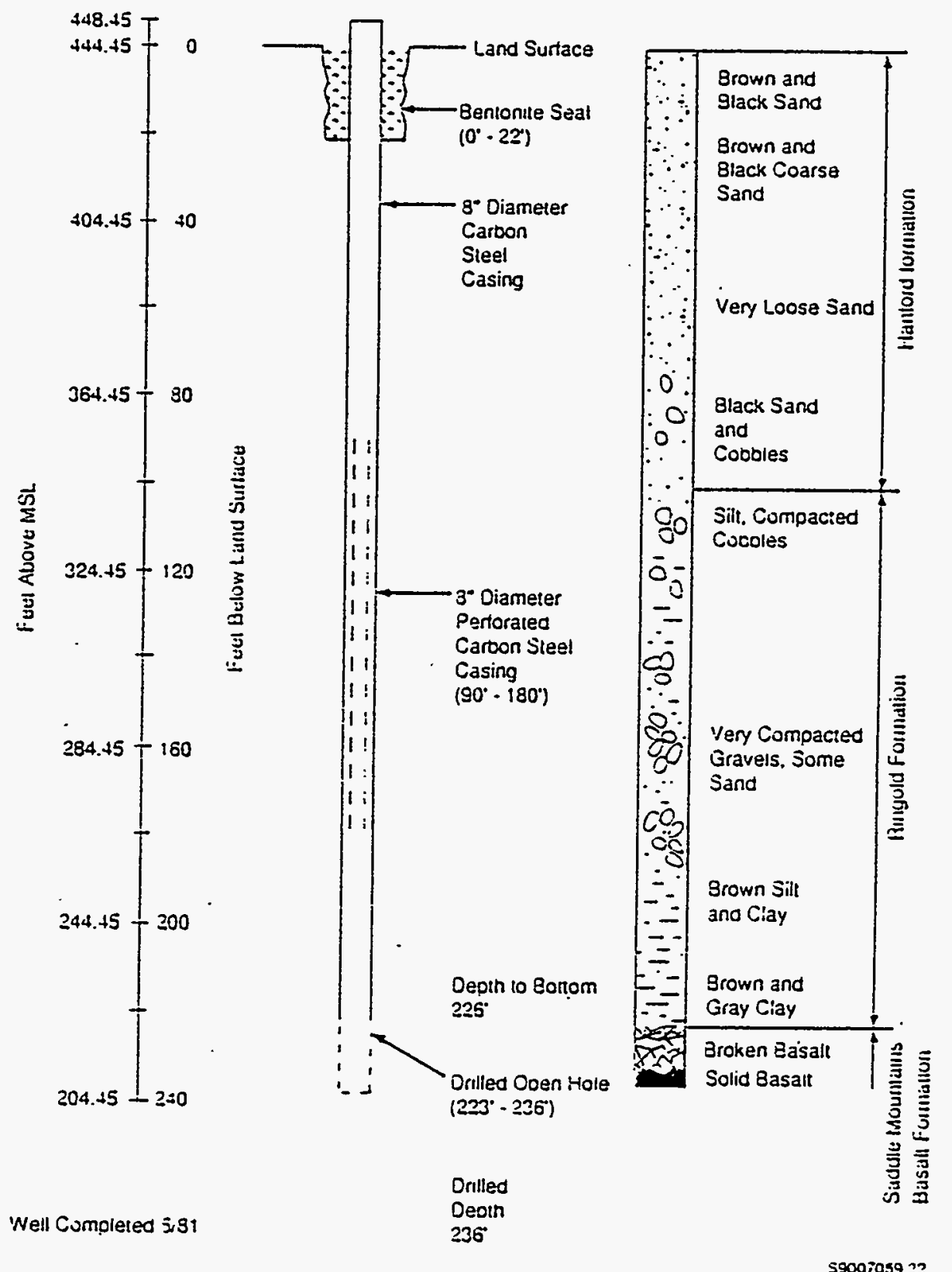


WELL NUMBER 699-S24-19

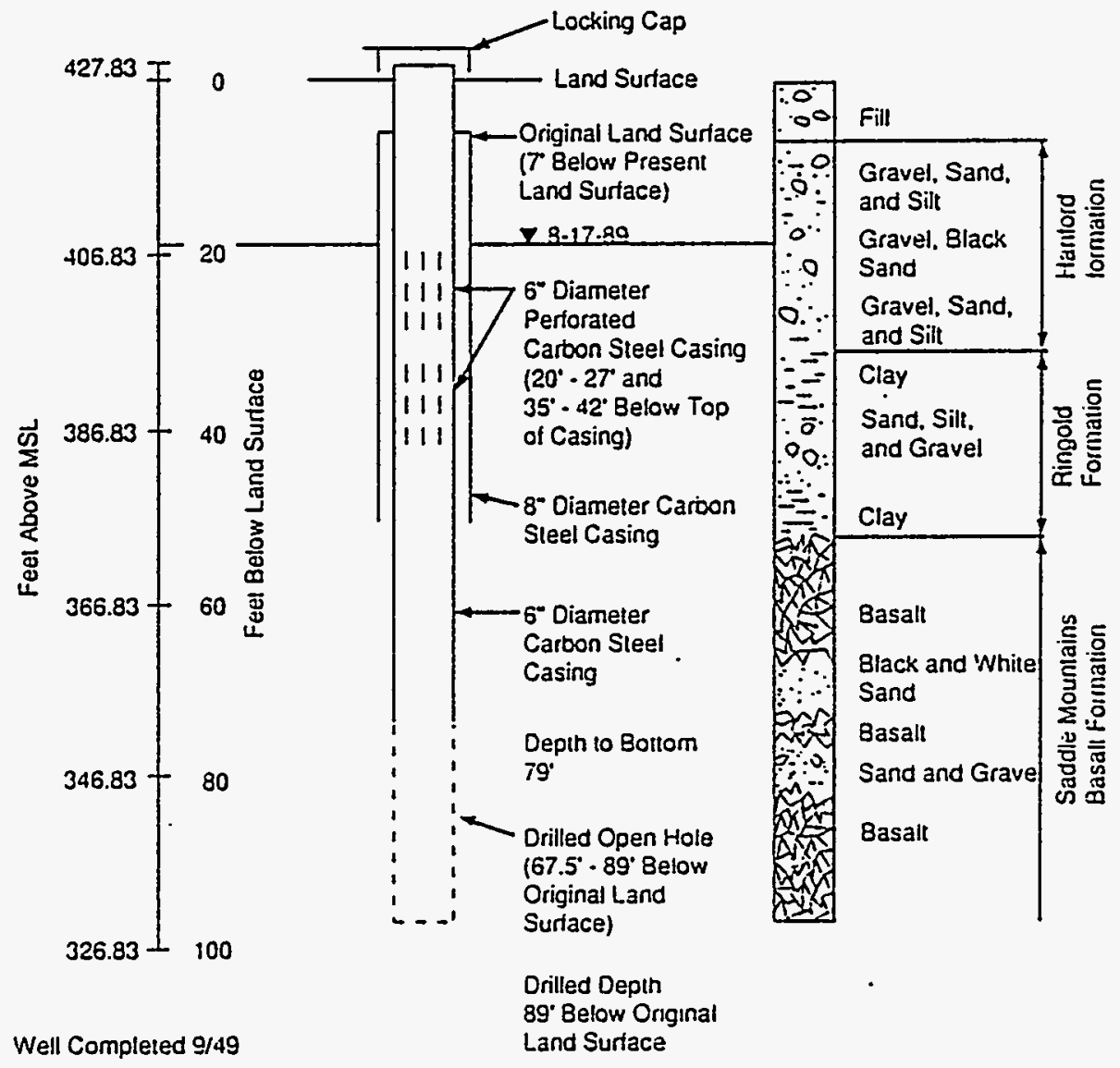

59007059.23 
WELL NUMBER W-2

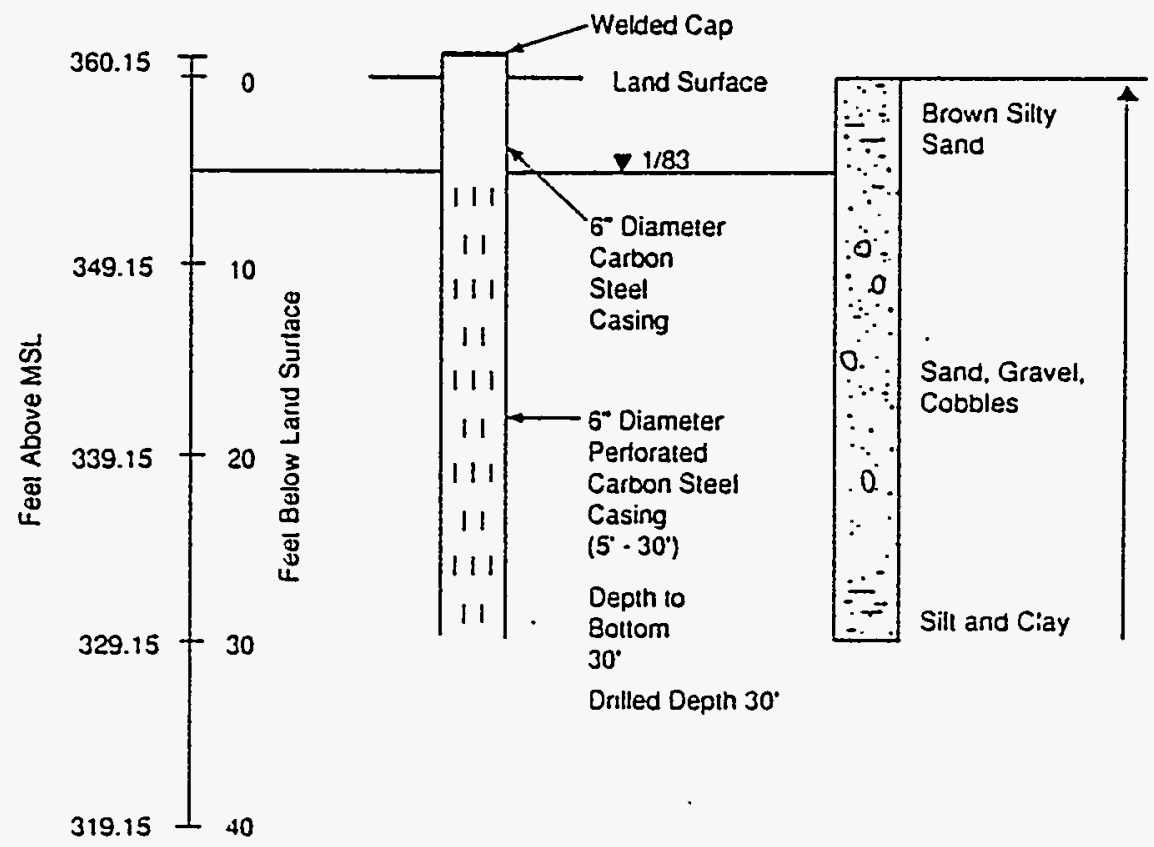

Well Completed 1/83

$\$ 900705924$ 


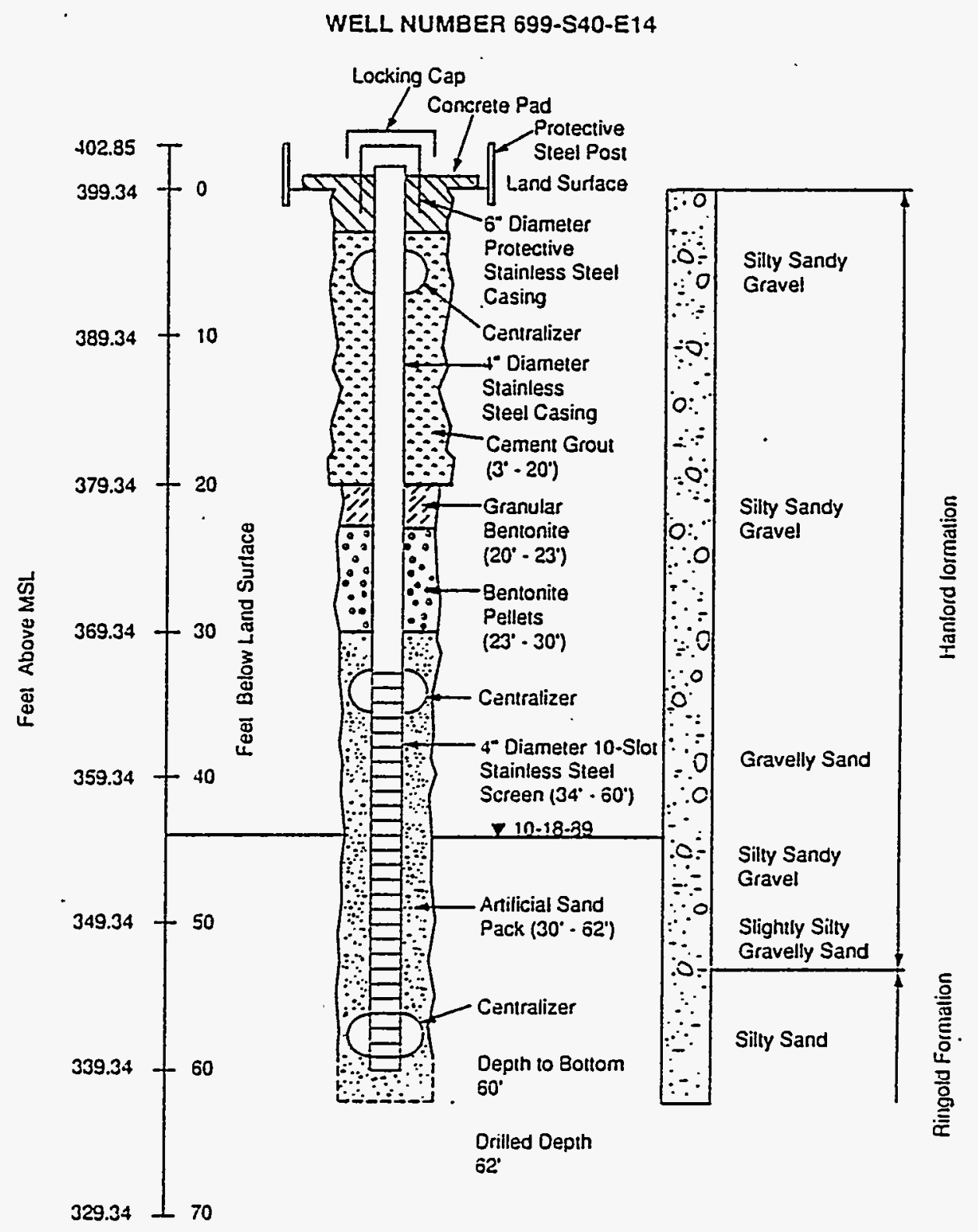

Well Completed 10/88

S9007059 25 
WELL NUMBER 699-S36-E12A

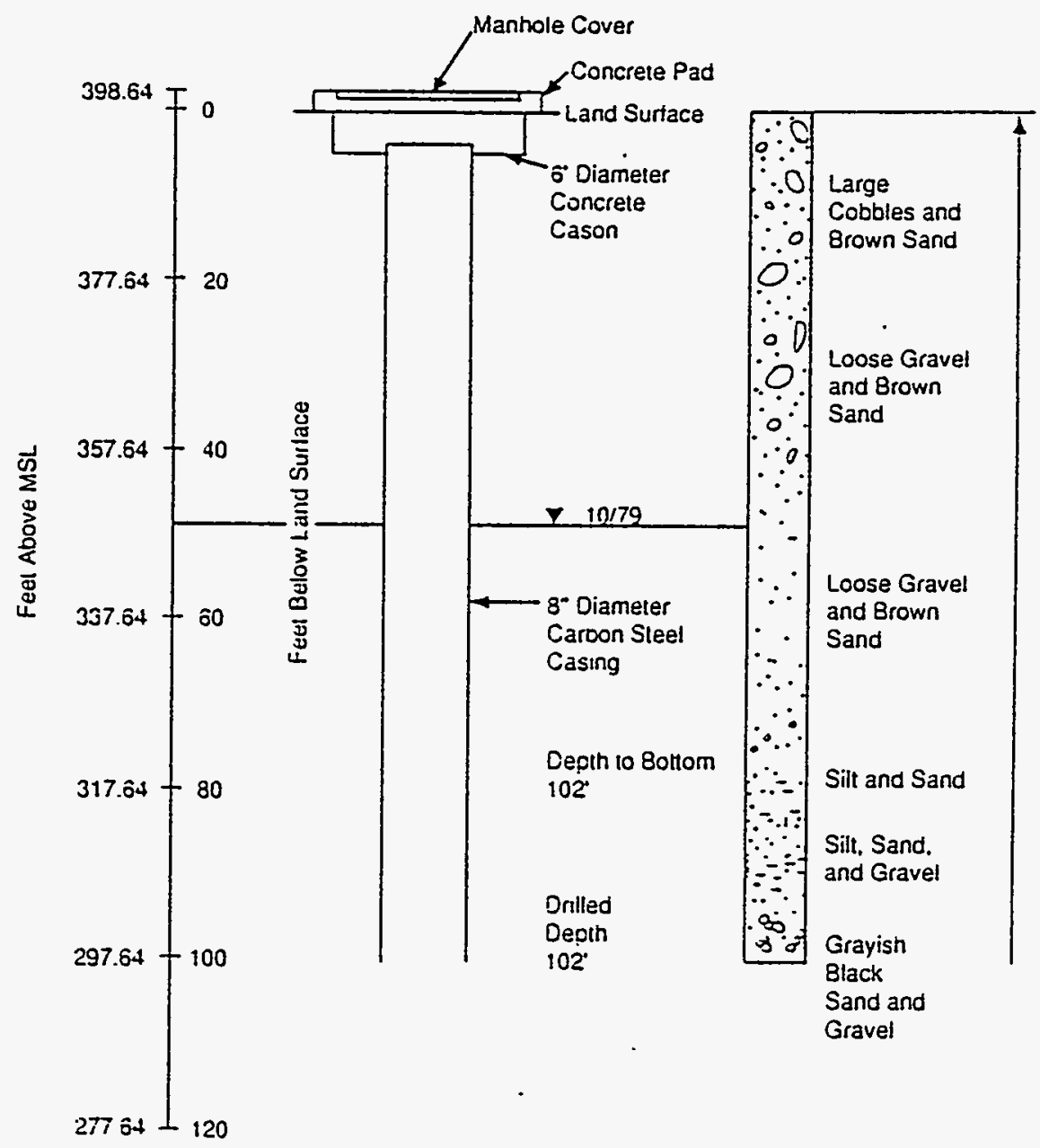

Well Completed10179

5900705931 
WELL NUMBER ORV \#1 (699-ORV-1)

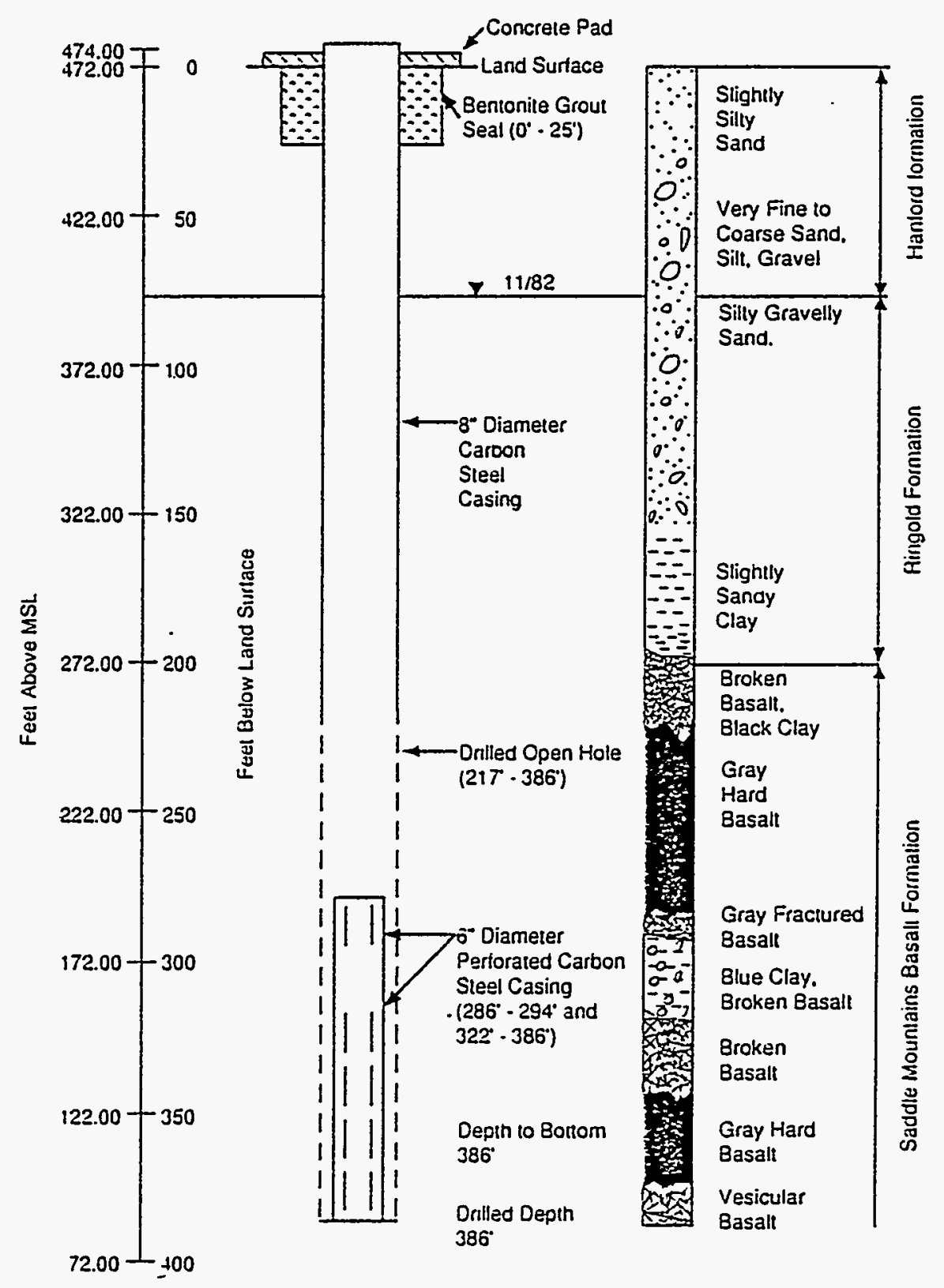

Well Completed 1182

$\$ 9007059+1$ 
WELL NUMBER ORV \#2 (699-ORV-2)

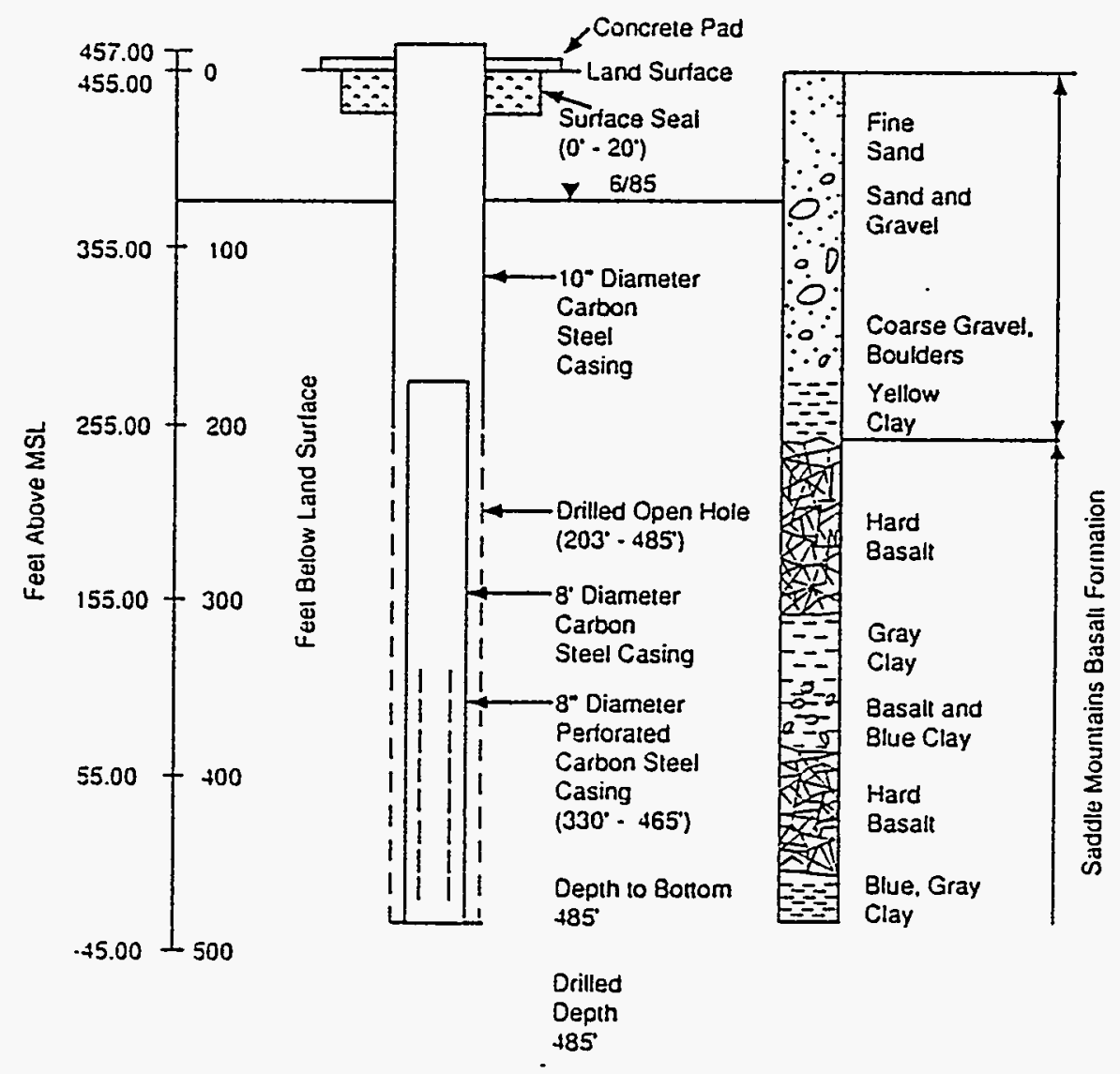

Well Completed a/85

5900705932 


\section{LANDFILL WELL (699-LANDFILL)}

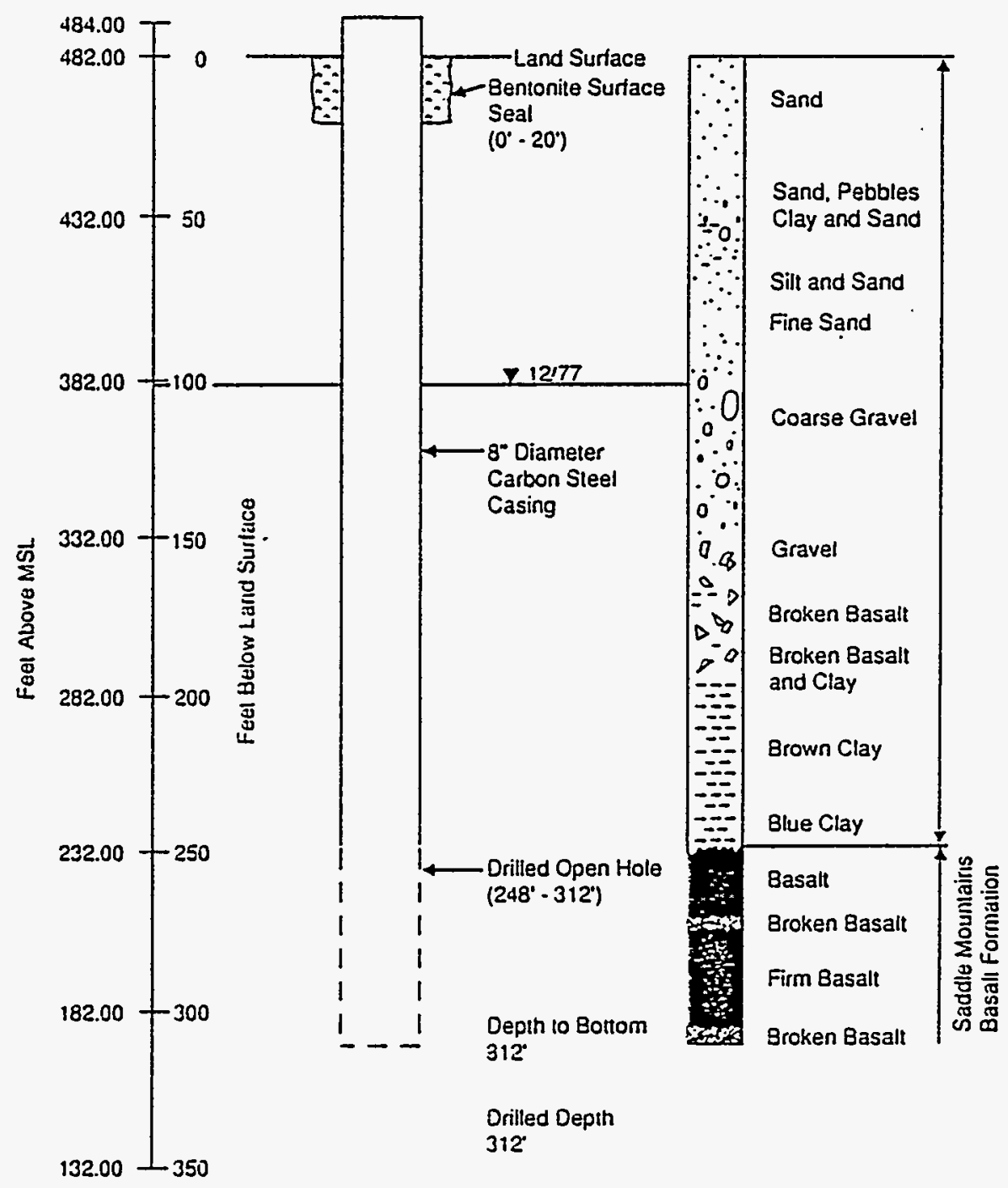




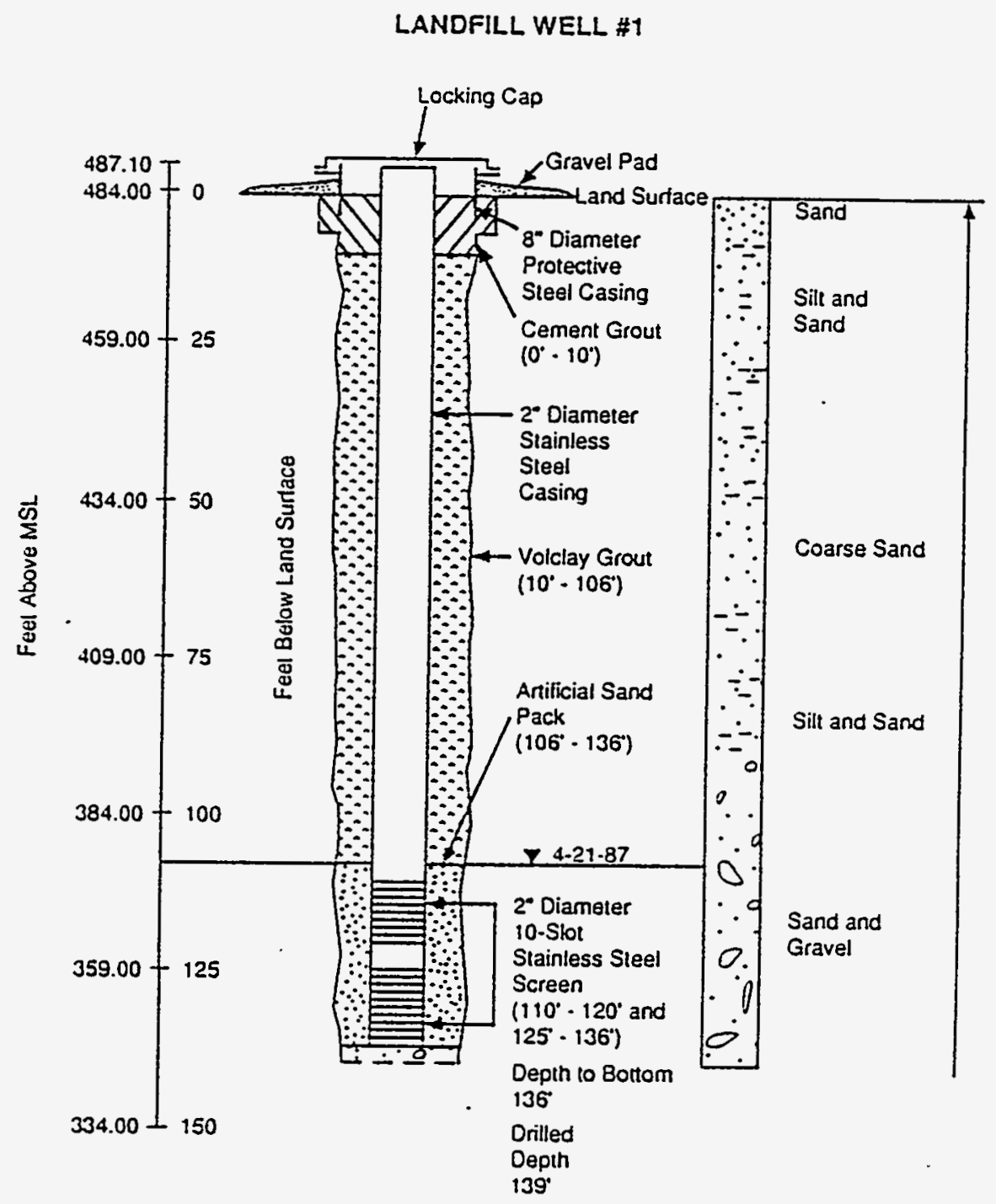

Well Completed 5/87

$\$ 900705933$ 
LANDFILL WELL \#2

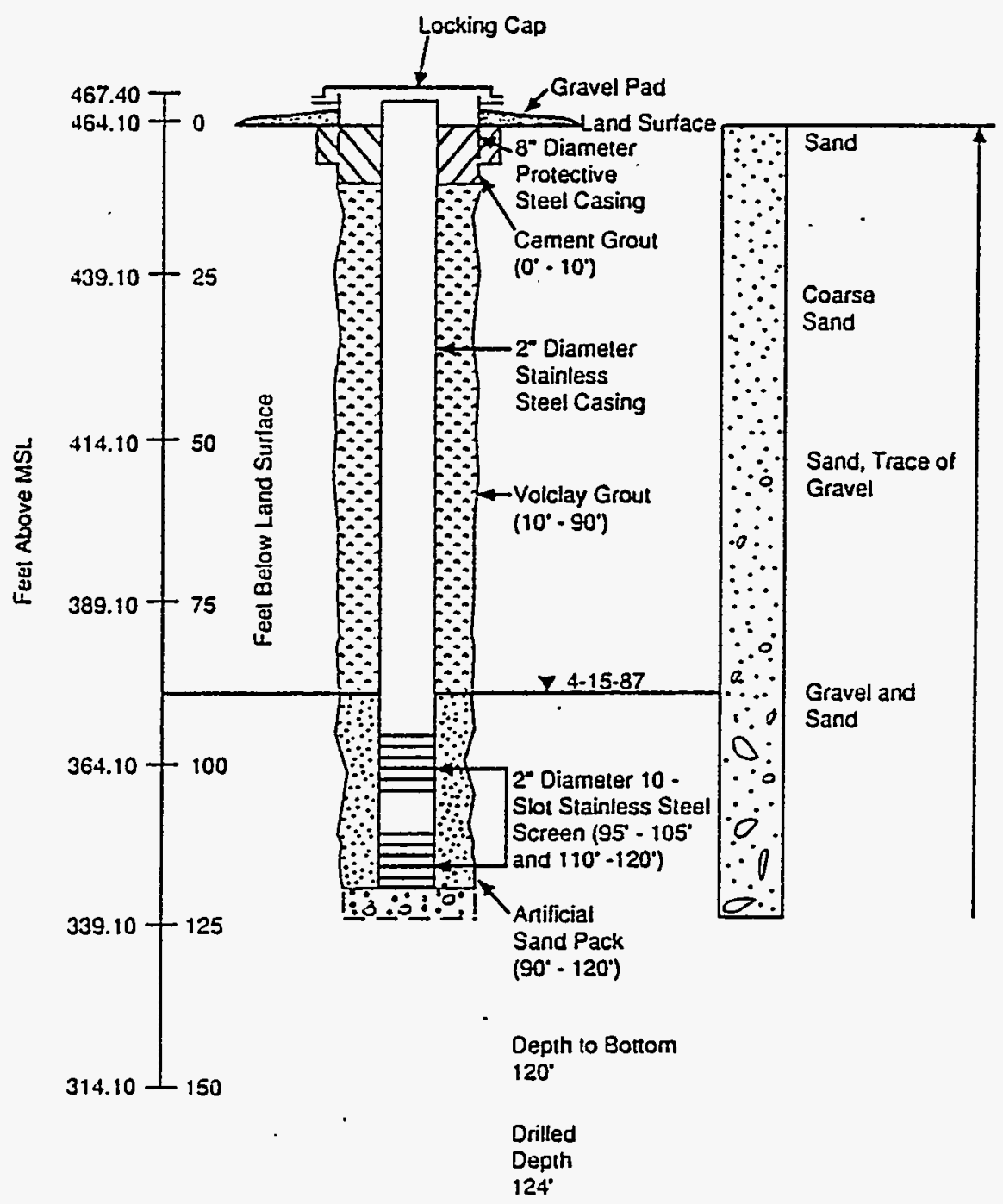

Well Compleled $5 / 87$

59007059.12 
LANDFILL WELL \#3

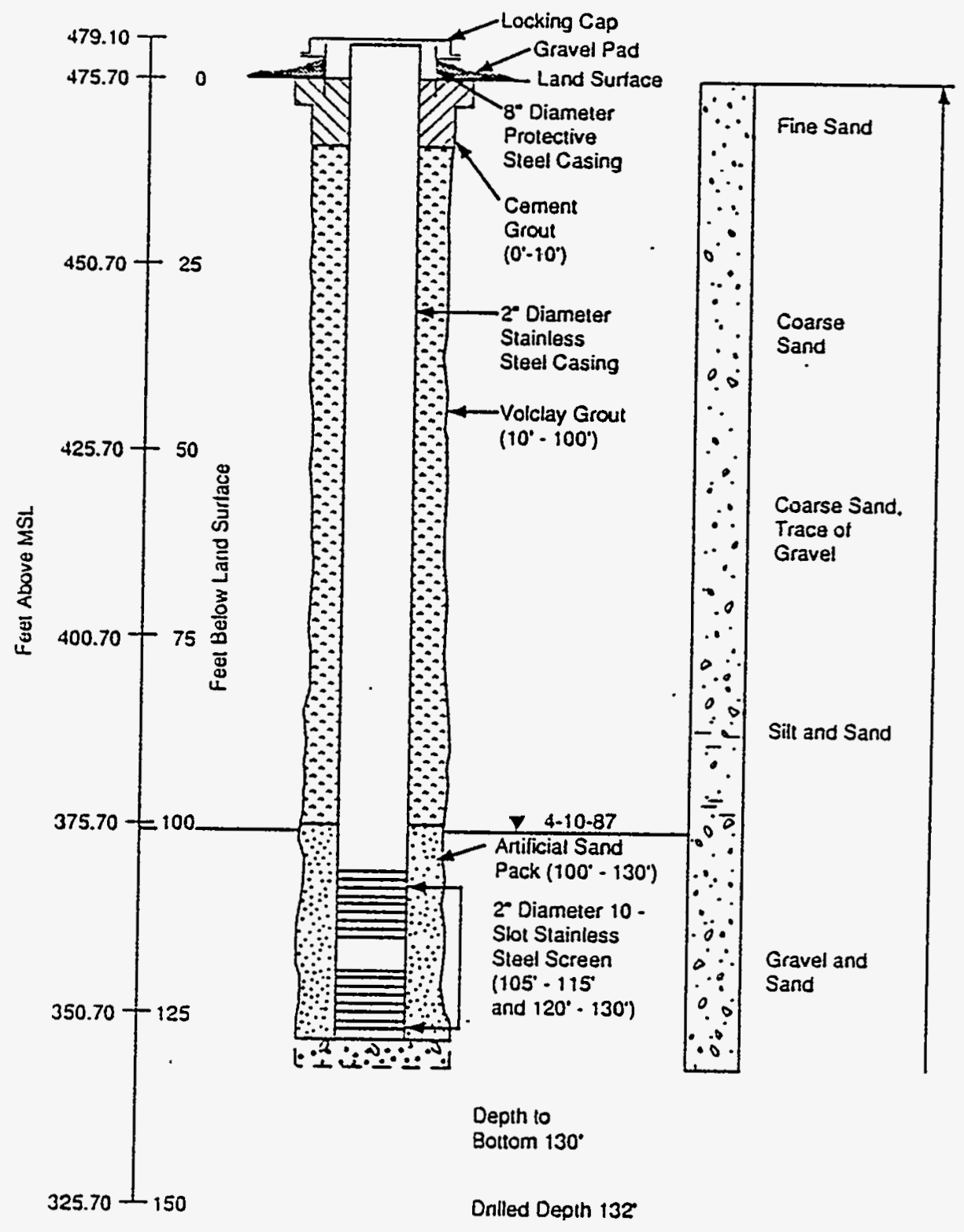

Well Completed 5/87

$\$ 9007059 .+3$ 


\section{LANDFILL WELL \#4}

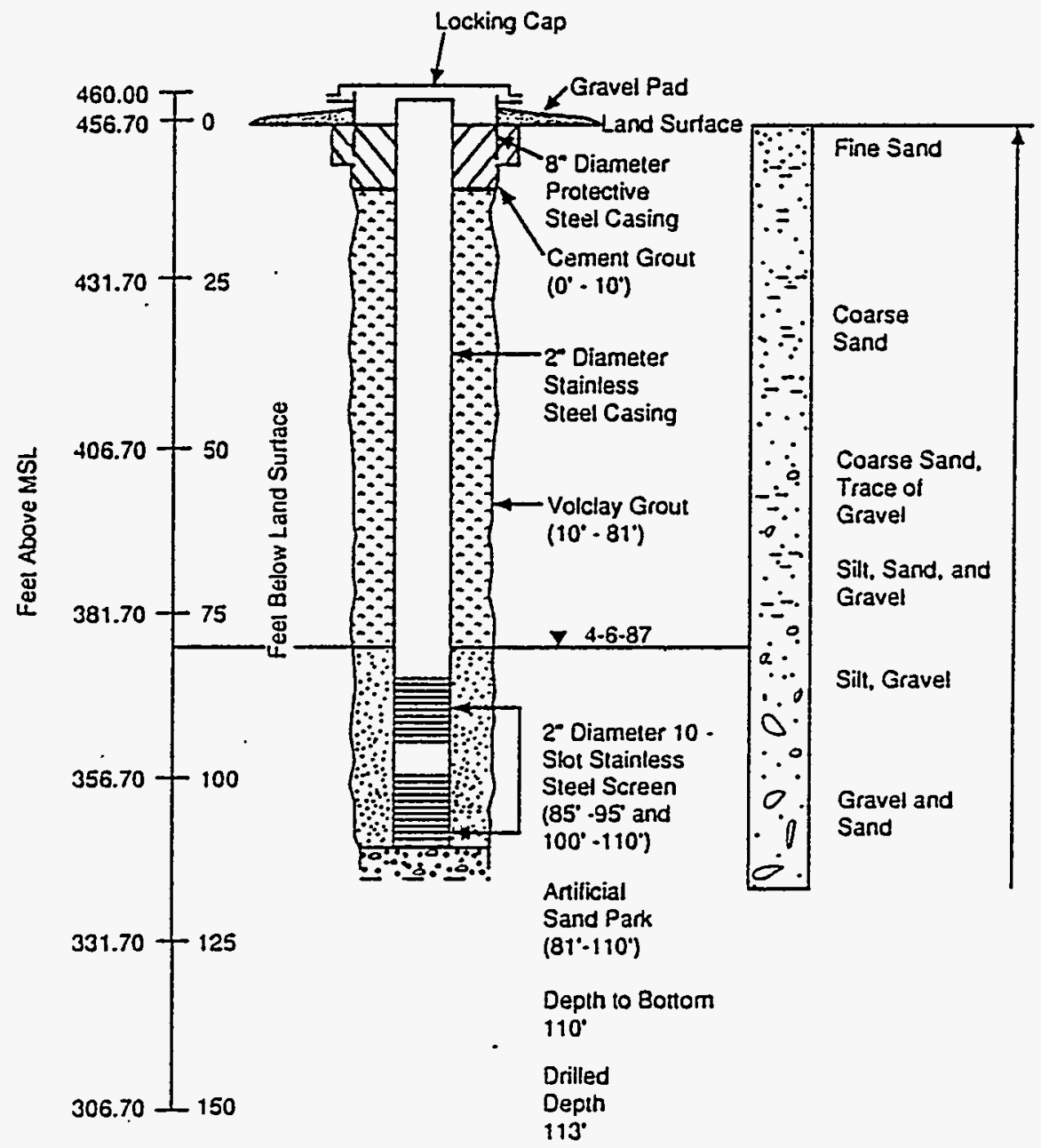

Well Completed 5/87

59007059.4 
WELL NUMBER 699-S51-2

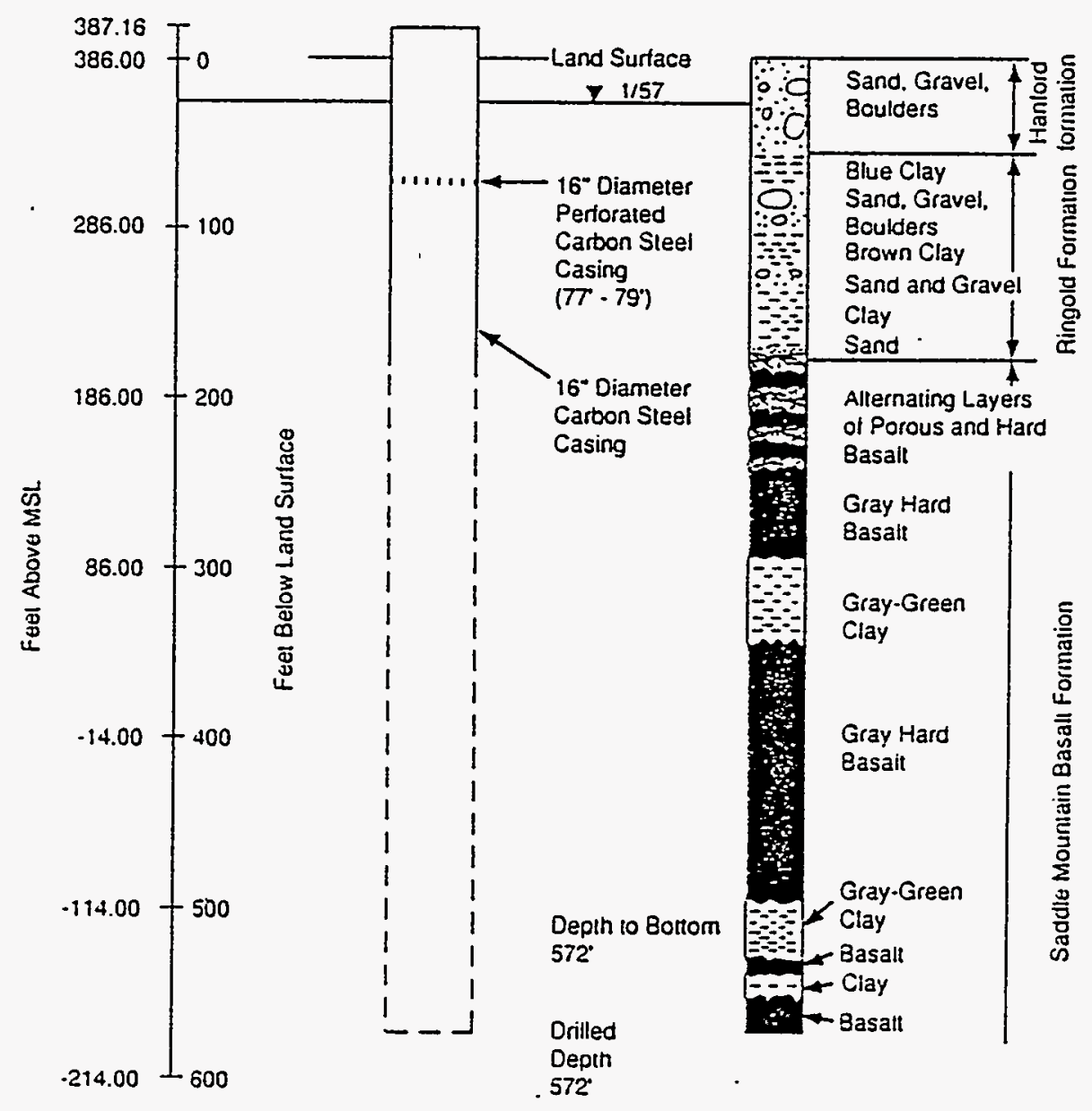

Well Completed 1/57

5900705935 
RACKLEY WELL

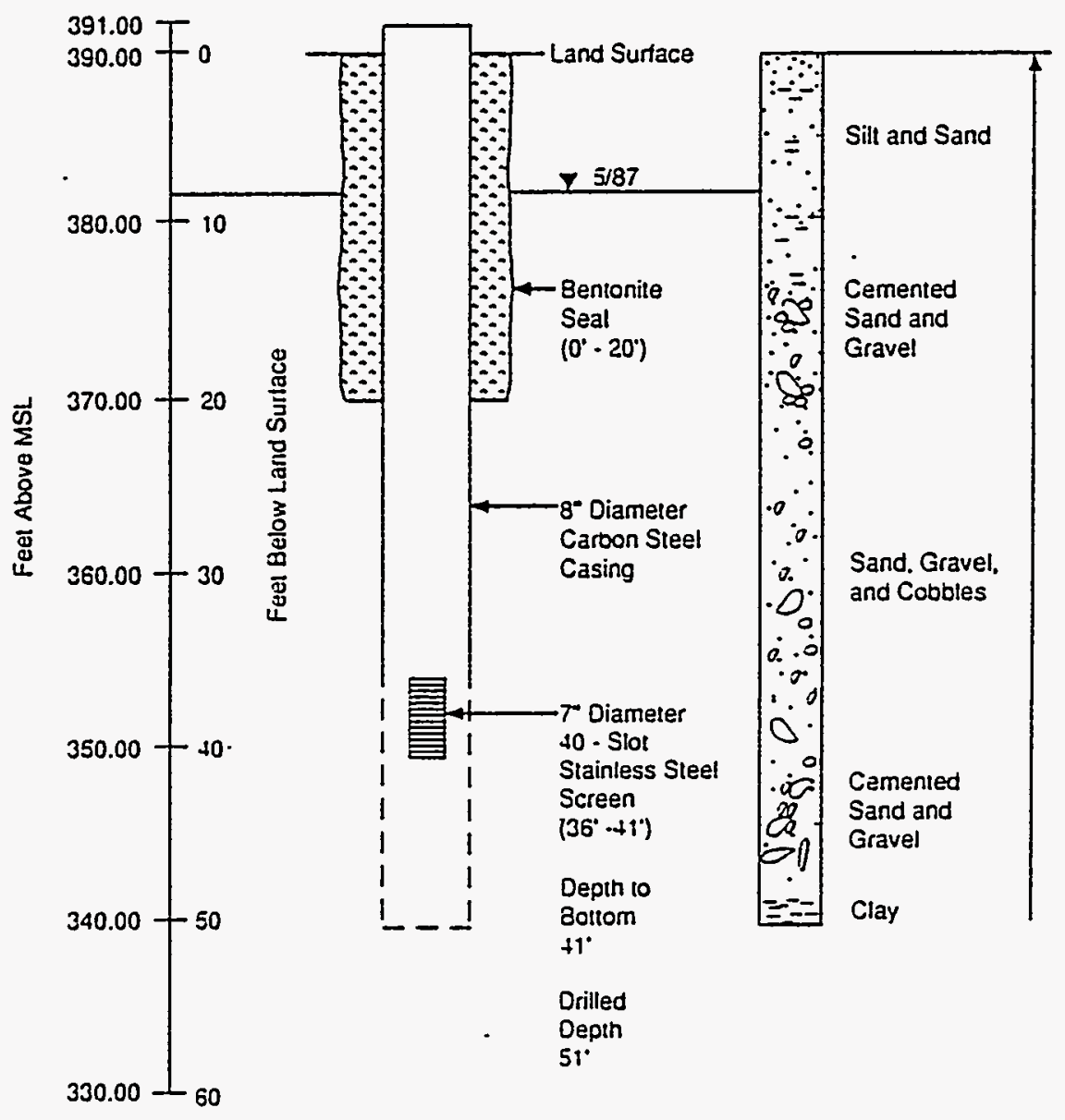

Well Completed $5 j 87$

55007059 45 
RIGBY WELL

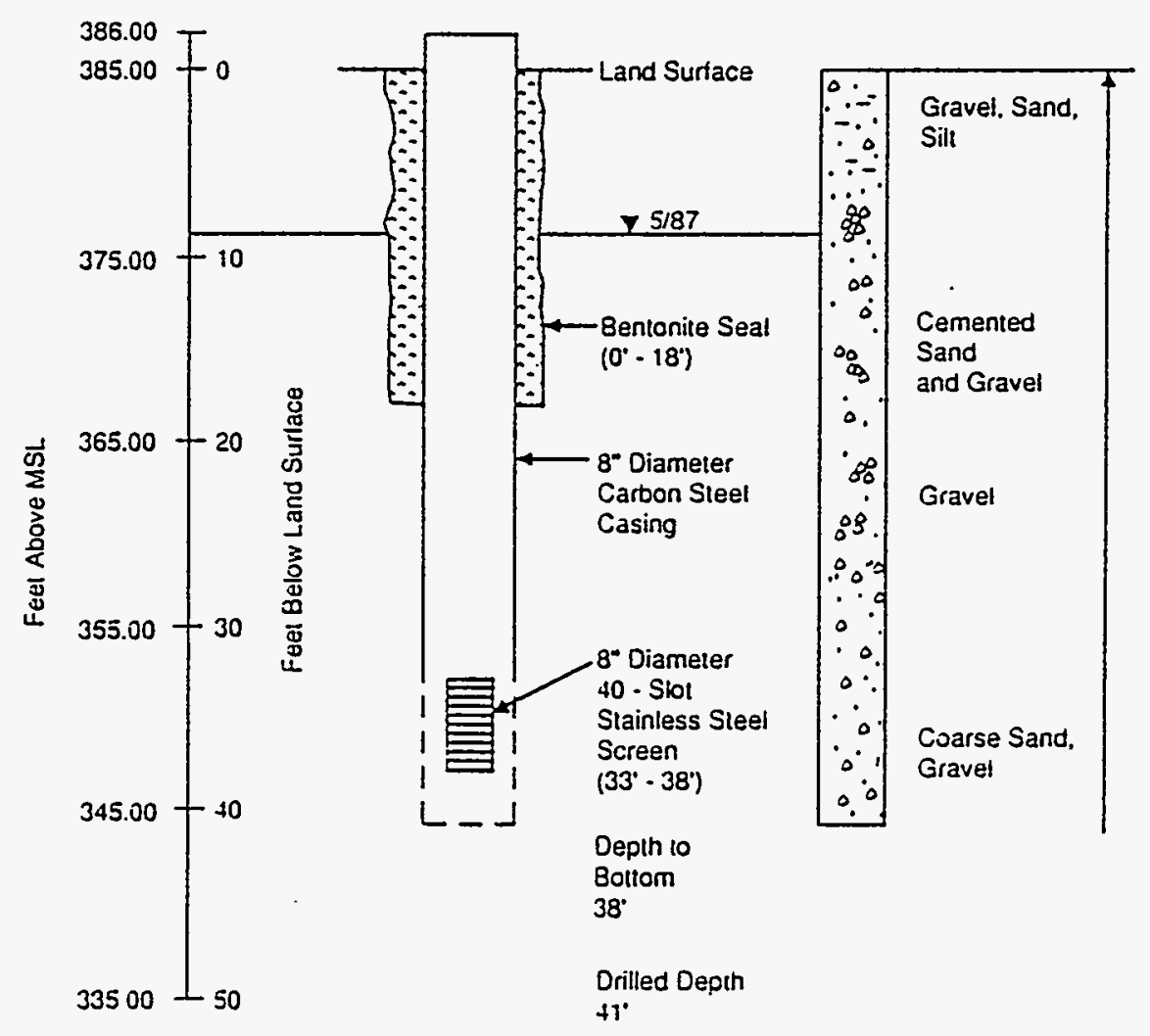

Well Completed 5/87

5900705934 
LAMB - WESTON INC. WELL

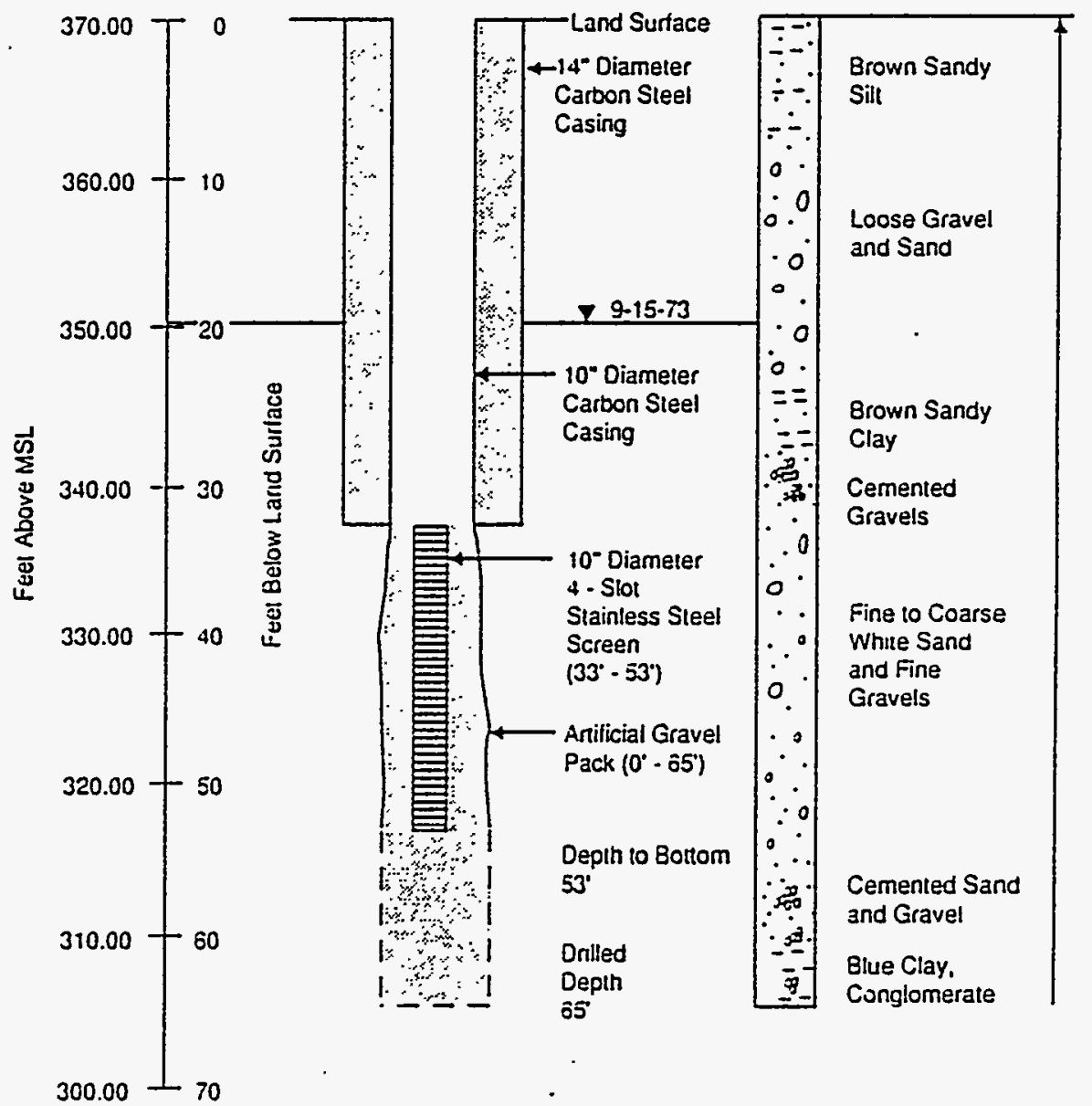

Well Completed 9/73 


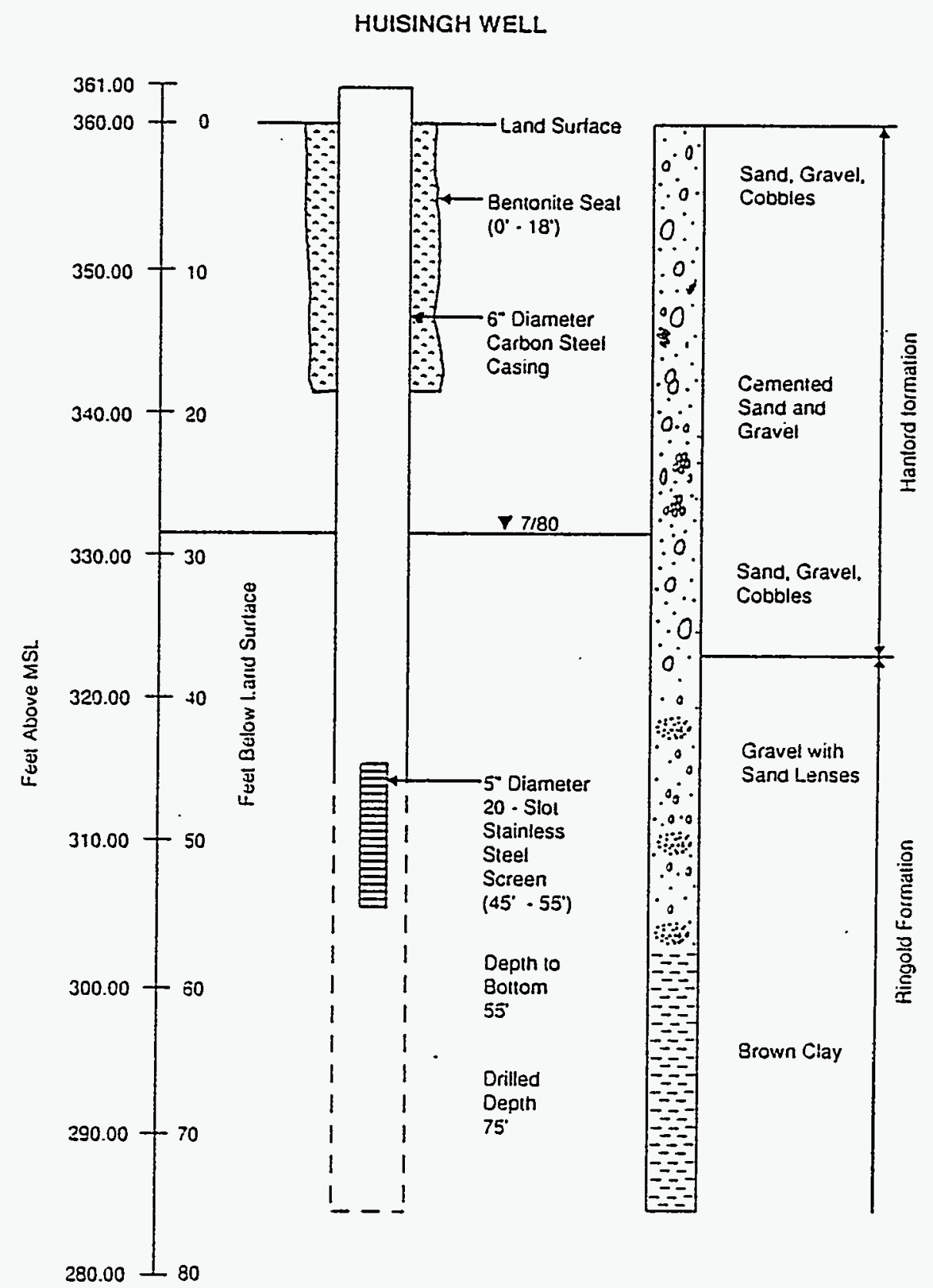

Well Cornpleted 7/80

5900705948 
WELL NUMBER 1100-D (1799-34-158)

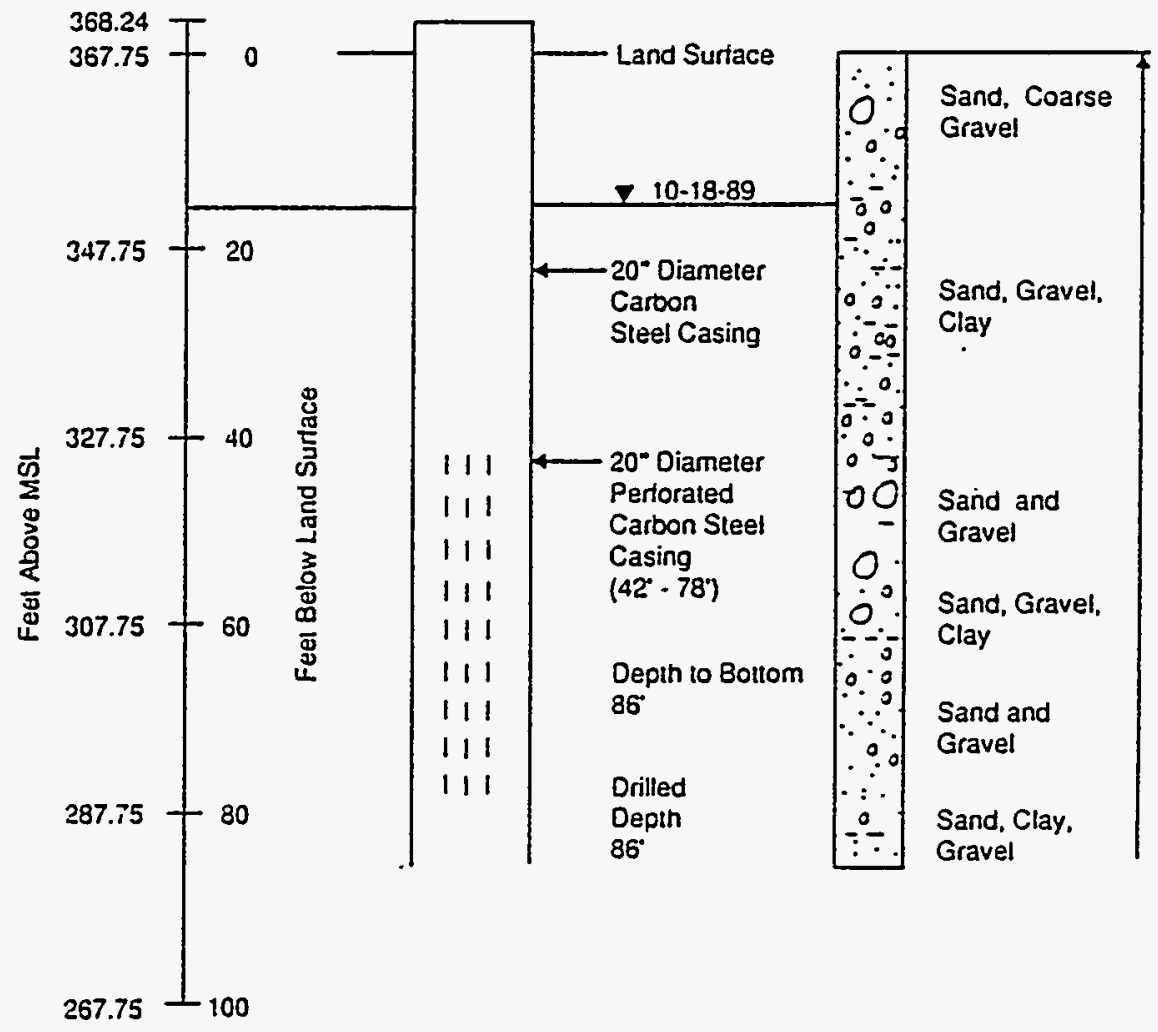

$59007059+7$ 
WELL NUMBER 3000-D5 (3099-42-16)

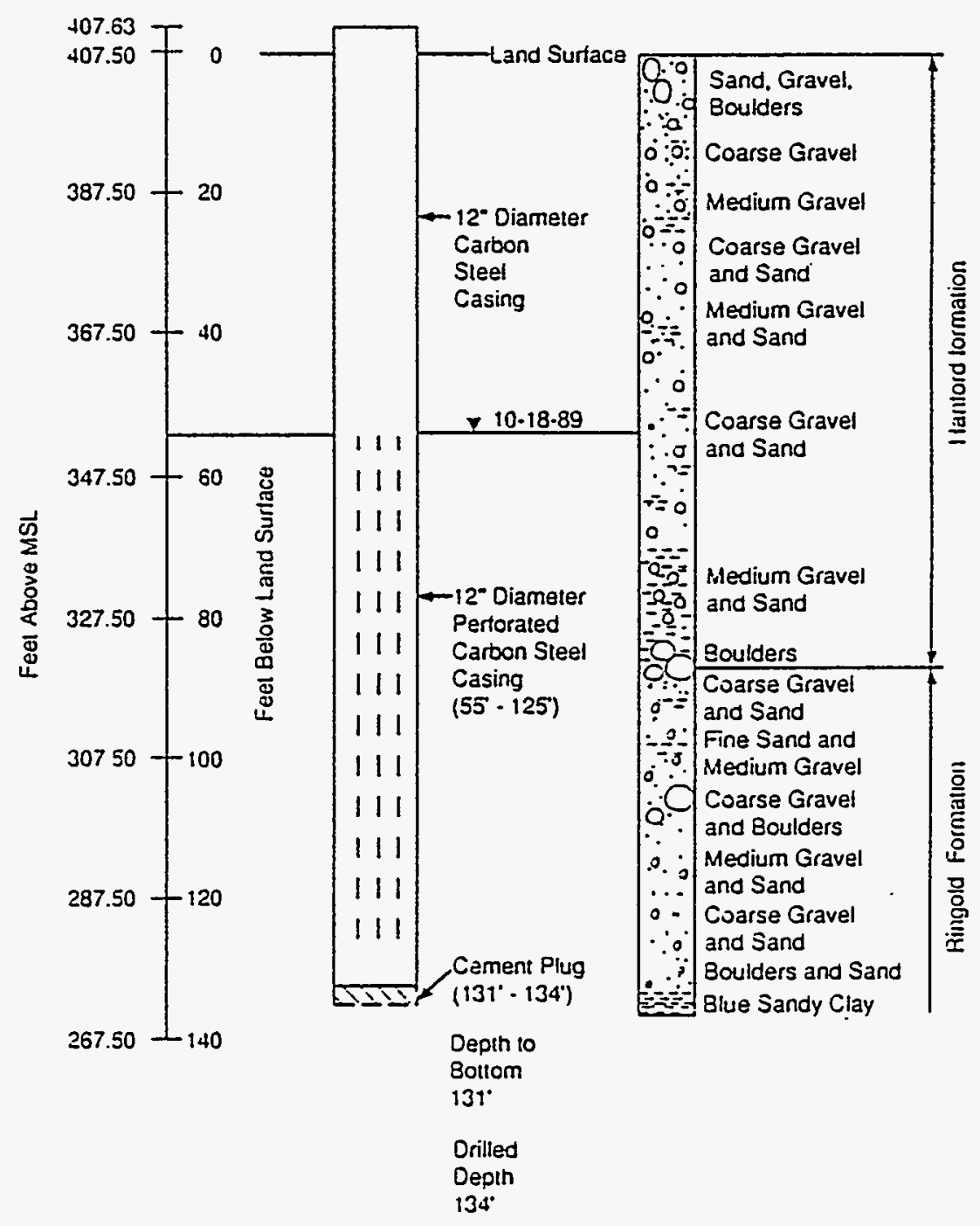

Well Completed 10/44 
WELL NUMBER 3000-A (1199-40-15)

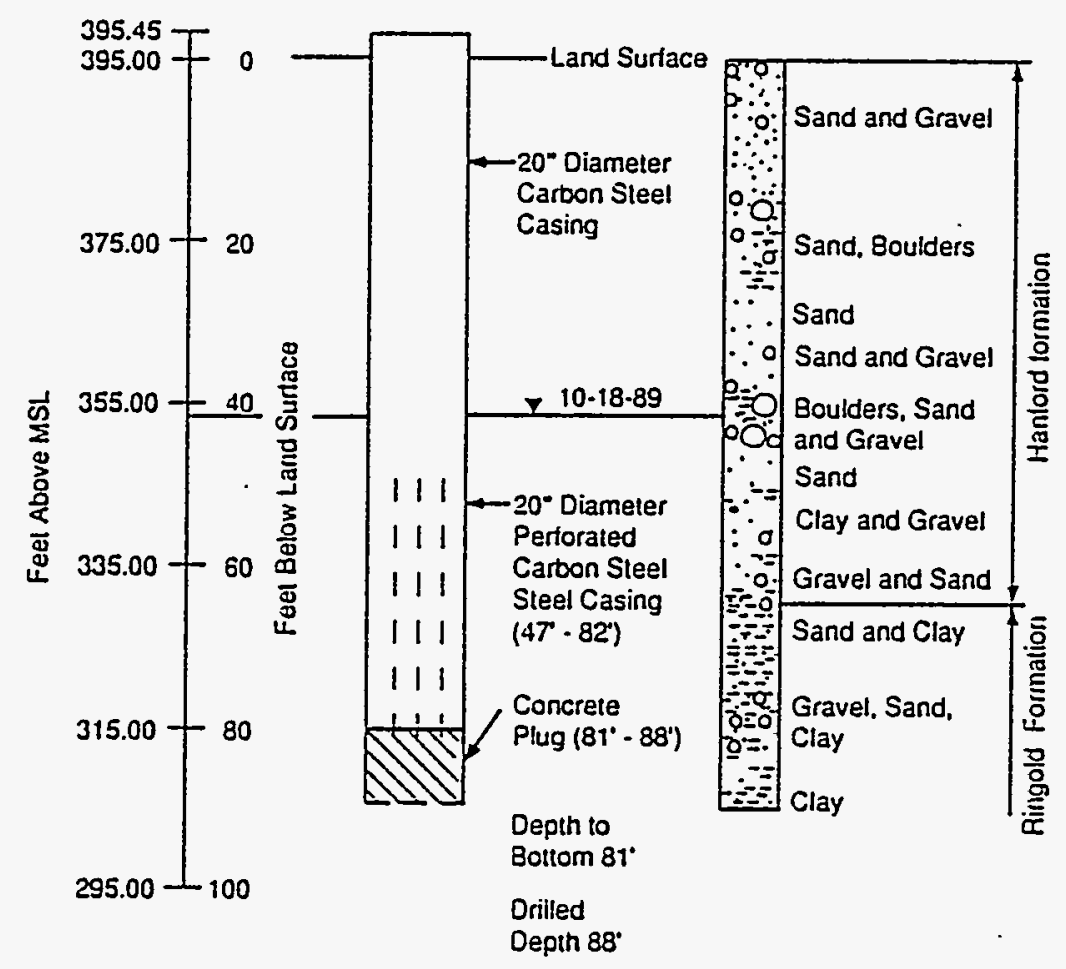

Well Completed $4 / 48$

\$5007059.57 
WELL NUMBER 3000-B (1199-40-168)

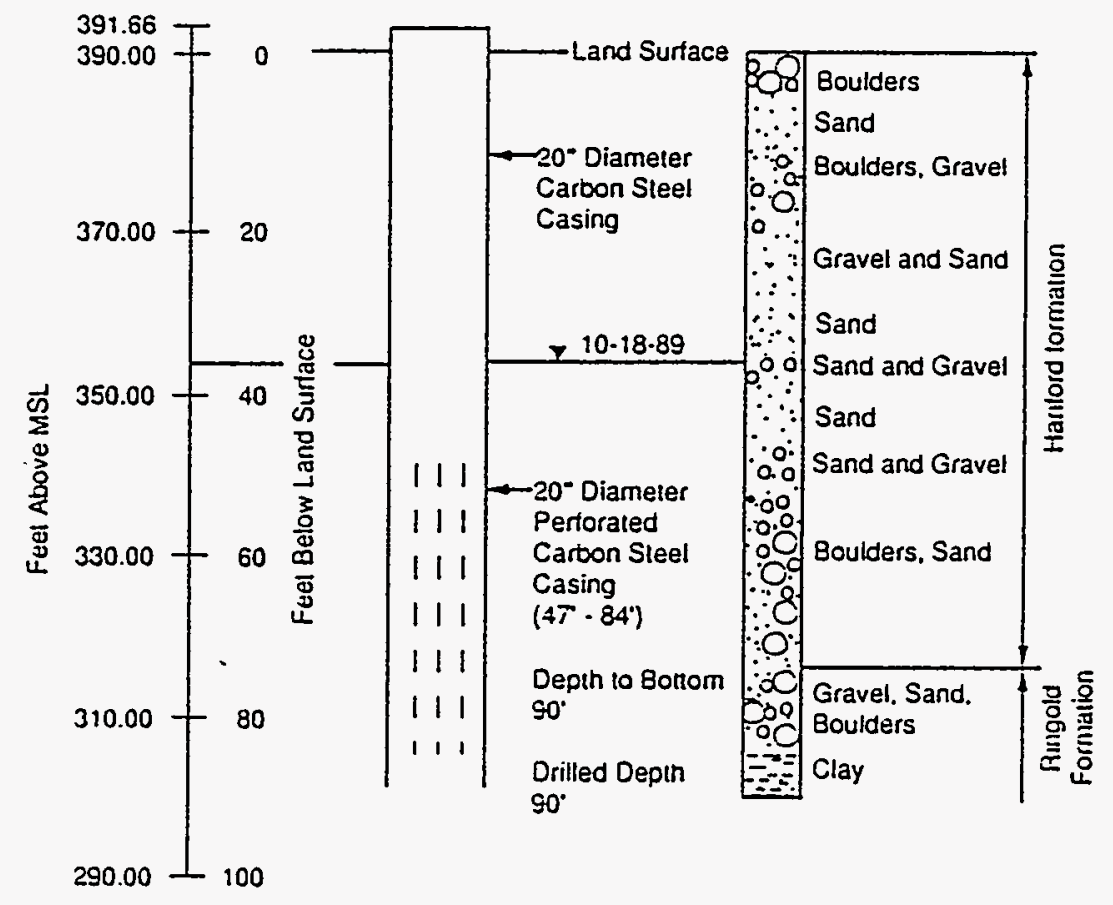

Well Completed 5/48

590070s9 58 


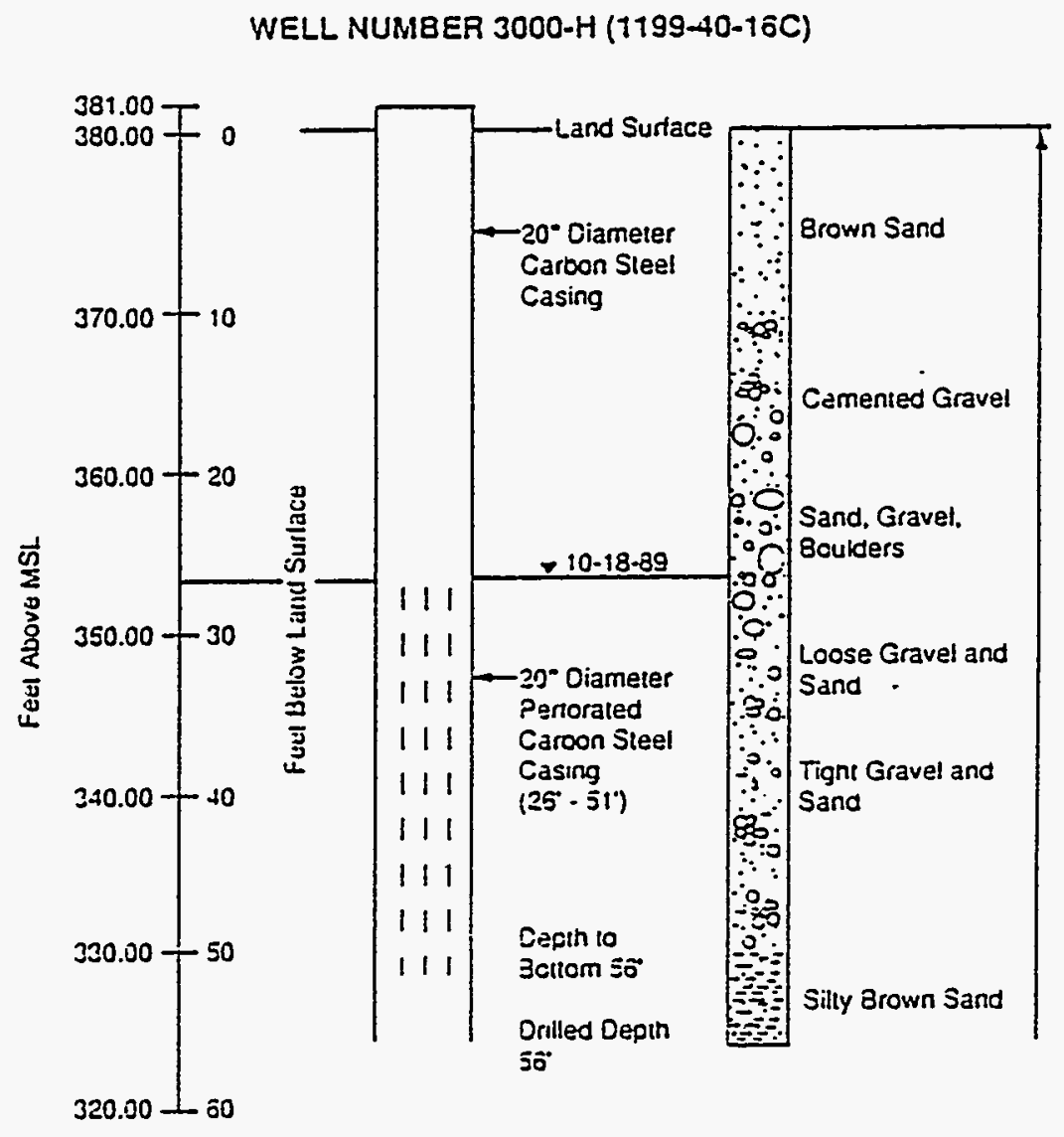

59007059.59

\section{A.53}




\section{WELL NUMBER 3000-C (1199-39-16D)}

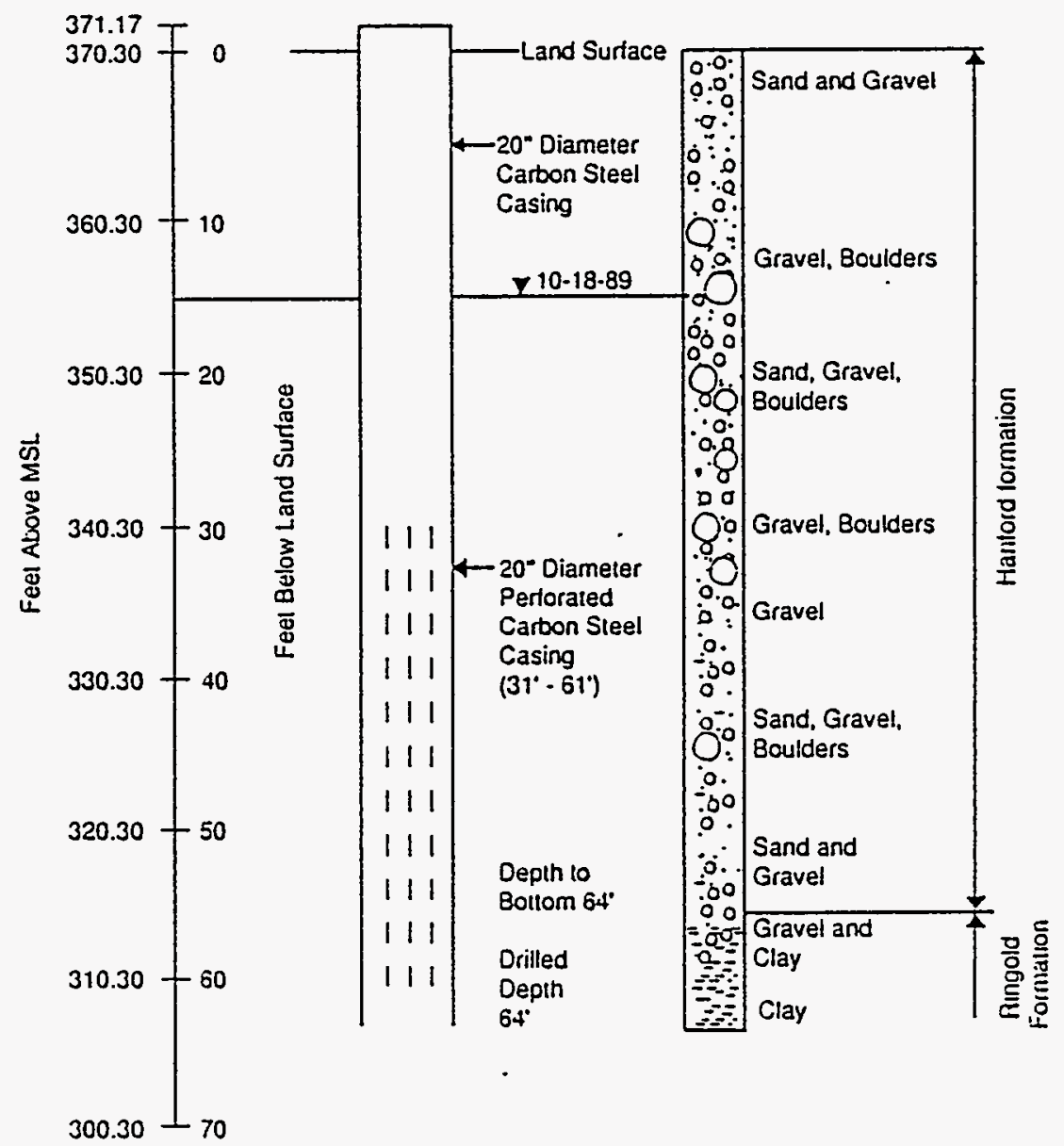

Well Completed 5/48

$\$ 9007059.60$ 
WELL NUMBER 3000-K (1199-38-16)

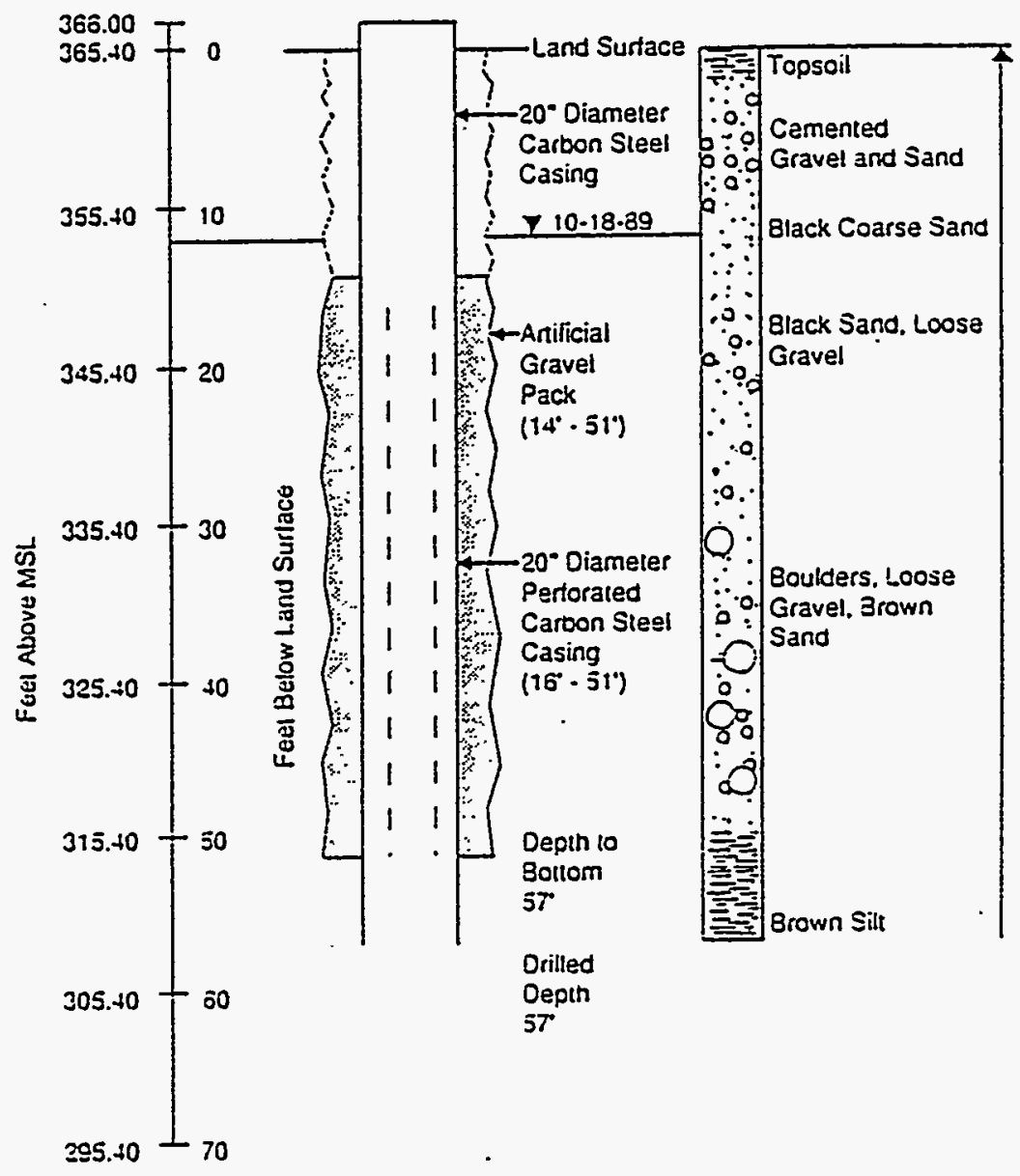

\$9007059.ة0 
WELL NUMBER 3000-N (1199-37-16)

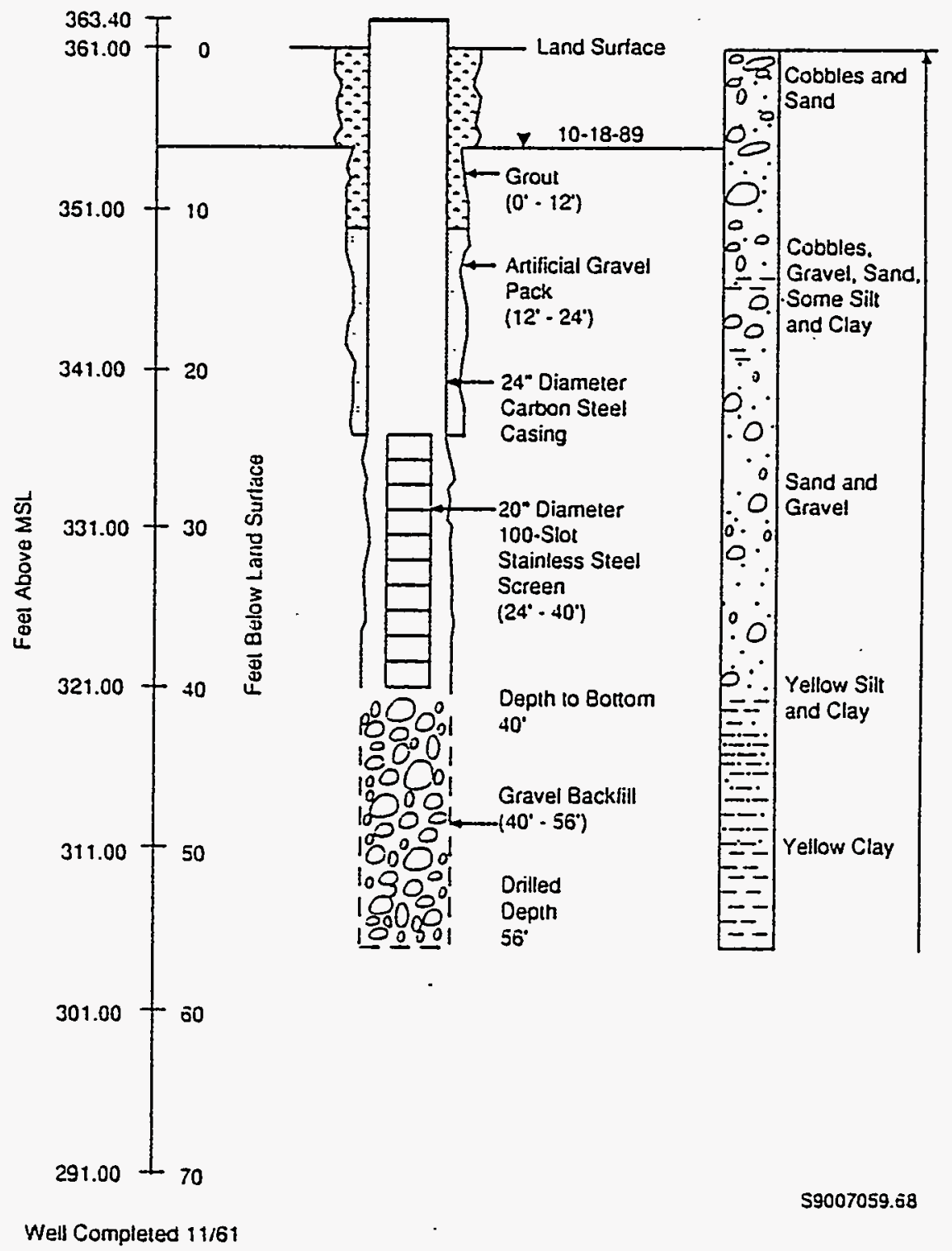


WELL NUMBER 3000-L (1799-39-16E)

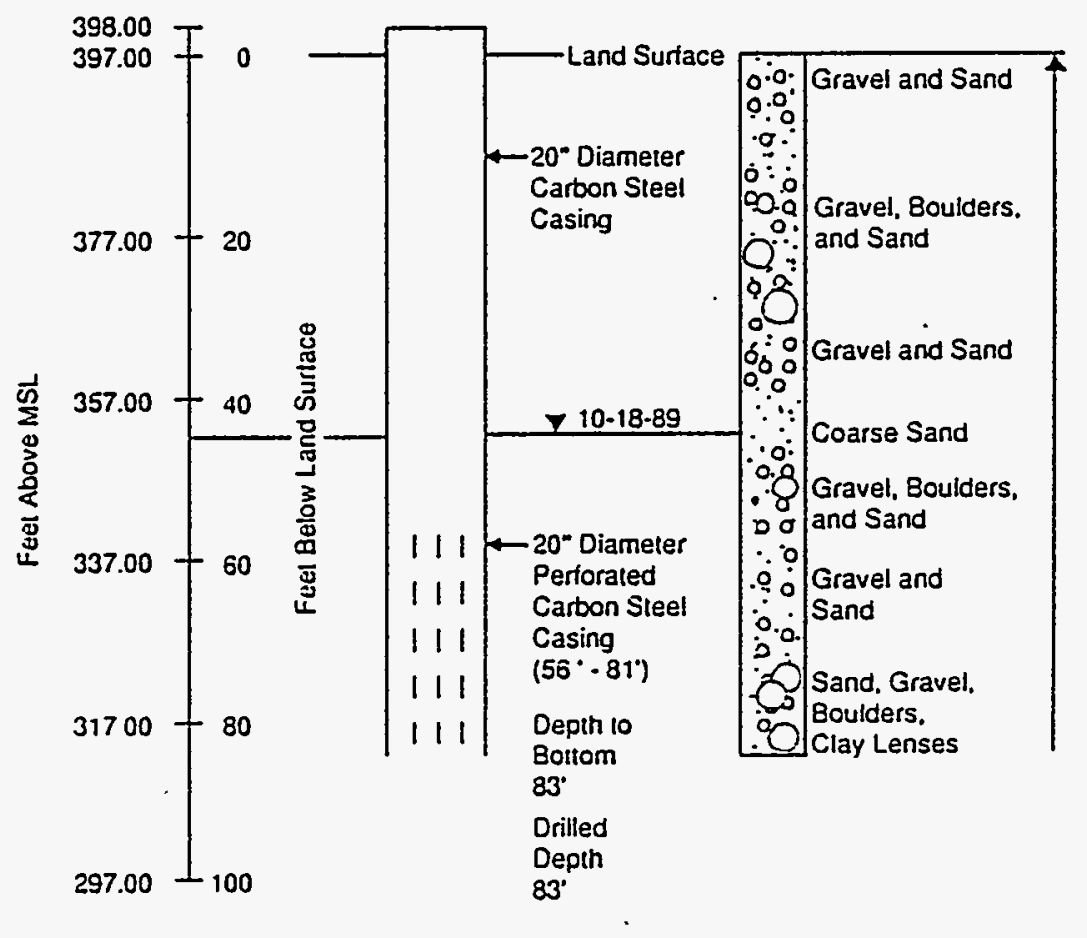

59007059.61 
WELL NUMBER 3000-D (1199-39-16C)

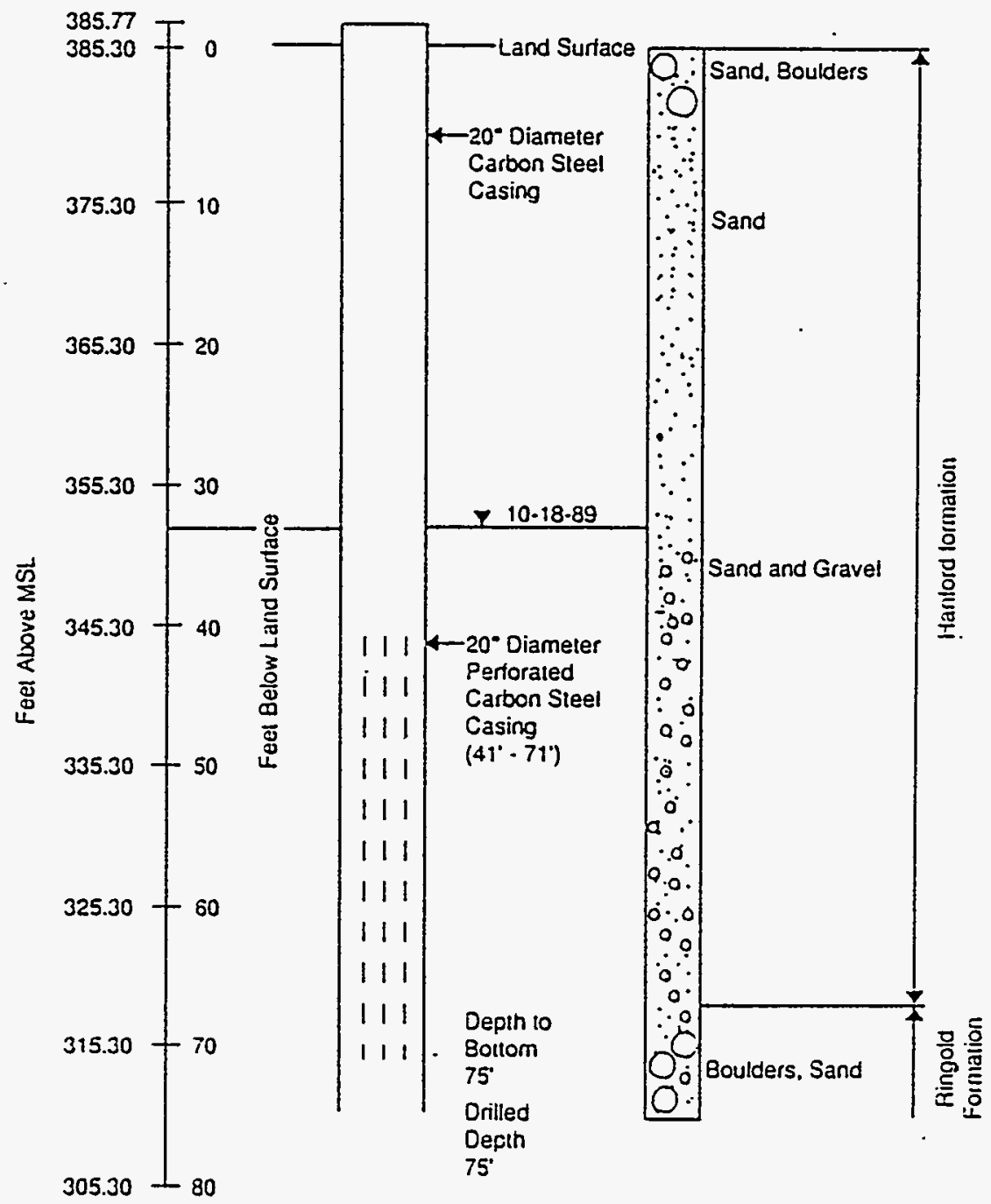

Well Completed 5/48

S9007059 62 
WELL NUMBER 3000-J (1199-39-15)

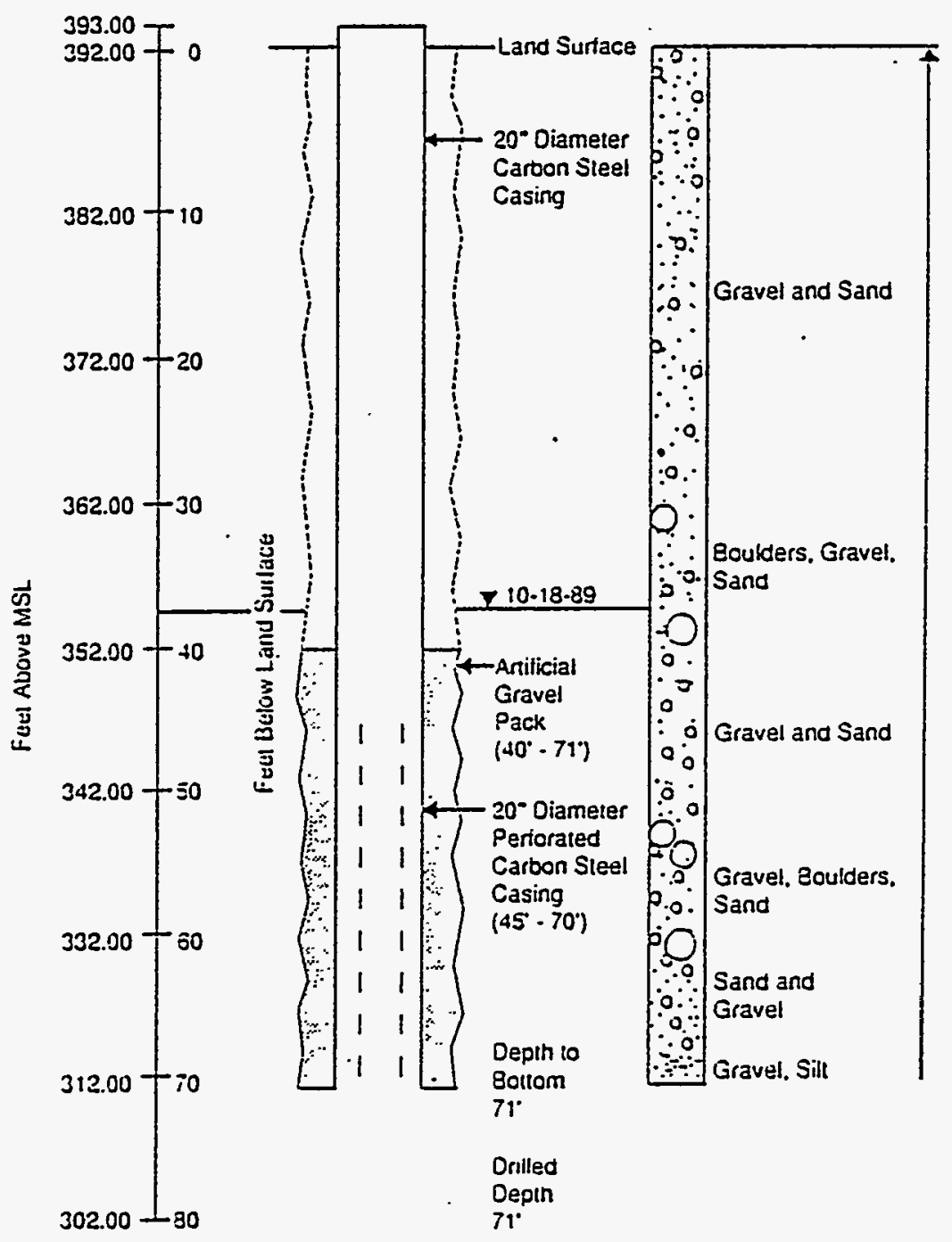

55007059 t3 


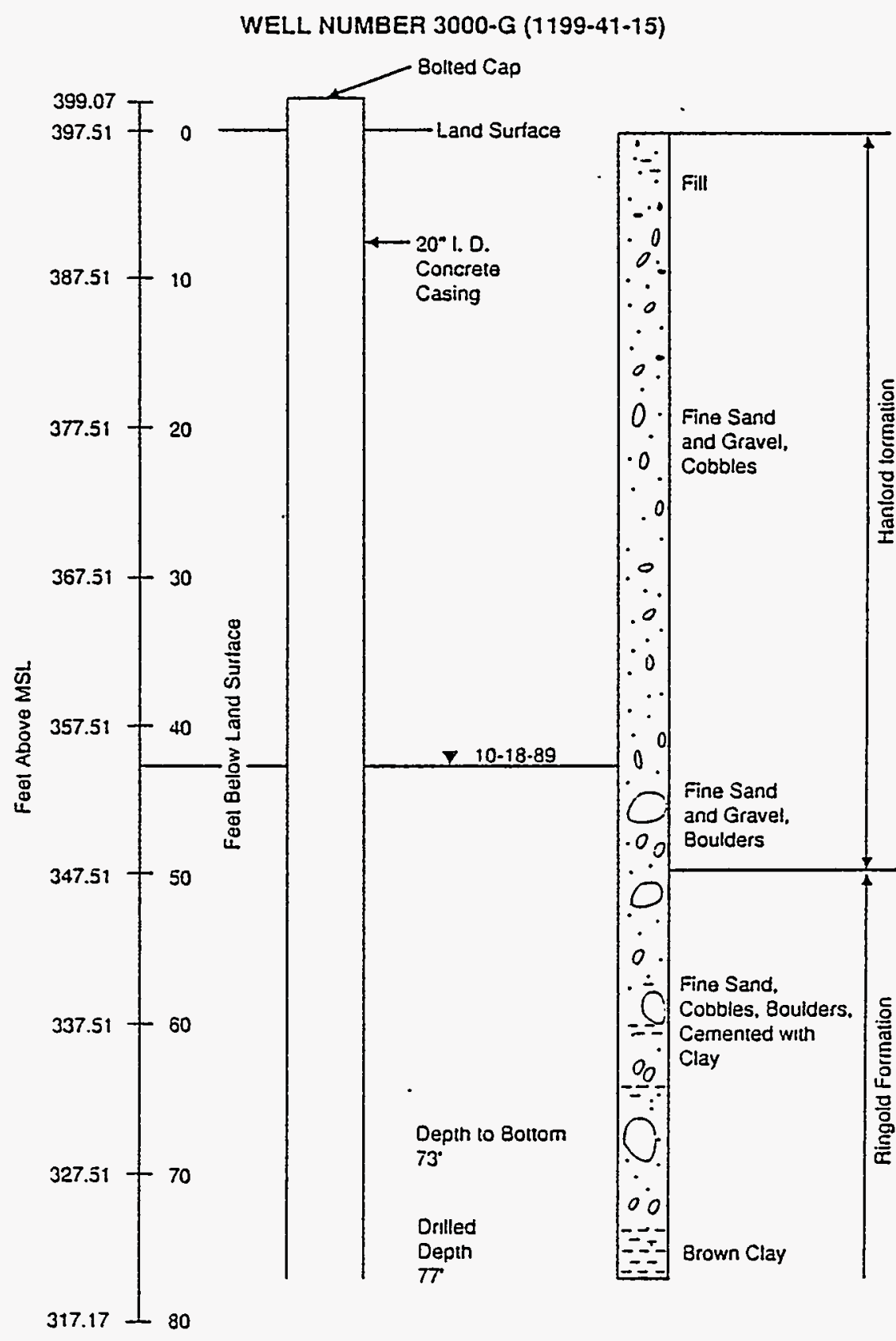

Well Completed 10/49 
WELL NUMBER 1100-8 (1199-34-15A)

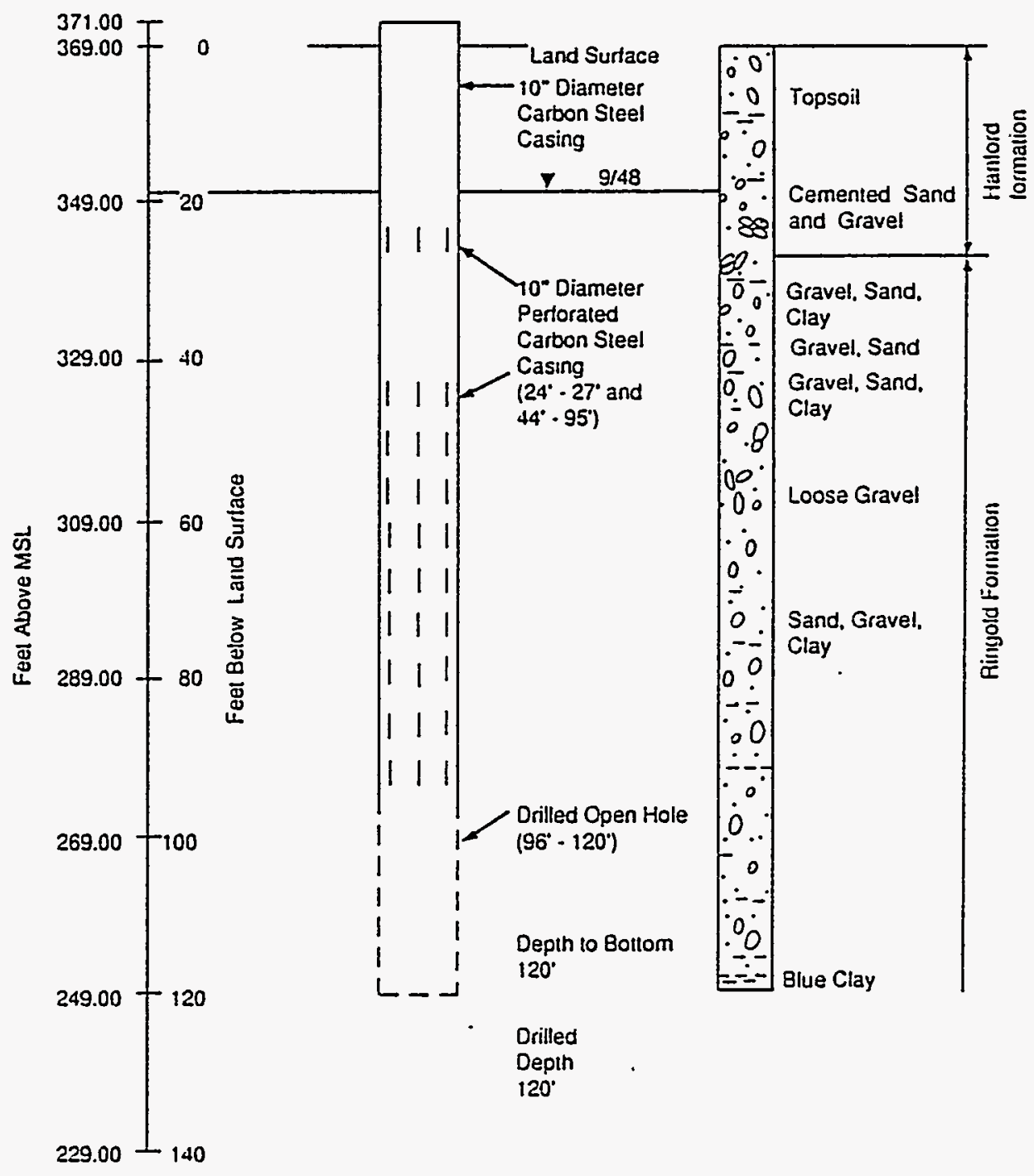

Well Completed 9/48

$\$ 9007059$ od 
Appendix B

\author{
Water-Level Data
}


Electric/Steel Tape Wells

699-530-E15A

\begin{tabular}{cc} 
Date & $\begin{array}{c}\text { W-I Elev. } \\
\text { (ft) }\end{array}$ \\
\hline & \\
$06 / 15 / 89$ & 344.17 \\
$06 / 21 / 89$ & 341.73 \\
$06 / 27 / 89$ & 341.15 \\
$07 / 05 / 89$ & 340.57 \\
$07 / 11 / 89$ & 340.79 \\
$07 / 18 / 89$ & 340.16 \\
$07 / 25 / 89$ & 341.20 \\
$08 / 01 / 89$ & 340.98 \\
$08 / 08 / 89$ & 341.08 \\
$08 / 16 / 89$ & 340.69 \\
$09 / 07 / 89$ & 341.53 \\
$10 / 06 / 89$ & 341.50 \\
$10 / 20 / 89$ & 341.81 \\
$11 / 25 / 89$ & 341.38 \\
$12 / 28 / 89$ & 342.56 \\
$01 / 22 / 90$ & 342.57 \\
$02 / 22 / 90$ & 343.81 \\
$03 / 22 / 90$ & 343.21 \\
$04 / 18 / 90$ & 342.35 \\
$05 / 17 / 90$ & 343.22
\end{tabular}

699-S32-EI3A

W-I Elev.

Date (ft)

\begin{tabular}{ll}
\hline \hline \\
$06 / 15 / 89$ & 346.79 \\
$06 / 21 / 89$ & 346.91 \\
$06 / 27 / 89$ & 346.89 \\
$07 / 05 / 89$ & 346.98 \\
$07 / 11 / 89$ & 346.87 \\
$07 / 18 / 89$ & 346.89 \\
$07 / 25 / 89$ & 346.80 \\
$08 / 01 / 89$ & 346.94 \\
$08 / 08 / 89$ & 347.10 \\
$08 / 16 / 89$ & 347.22 \\
$09 / 07 / 89$ & 347.11 \\
$10 / 06 / 89$ & 347.28 \\
$10 / 20 / 89$ & 347.06 \\
$11 / 25 / 89$ & 346.40 \\
$12 / 28 / 89$ & 346.24 \\
$01 / 22 / 90$ & 346.36 \\
$02 / 22 / 90$ & 346.14 \\
$03 / 22 / 90$ & 346.01 \\
$04 / 18 / 90$ & 345.97 \\
$05 / 17 / 90$ & 346.51
\end{tabular}

$699-531-E 13$

-I Elev. Date (ft)

\begin{tabular}{ll}
\hline \hline & \\
$06 / 15 / 89$ & 346.47 \\
$06 / 21 / 89$ & 346.58 \\
$06 / 27 / 89$ & 346.53 \\
$07 / 05 / 89$ & 346.62 \\
$07 / 11 / 89$ & 346.61 \\
$07 / 18 / 89$ & 346.53 \\
$07 / 25 / 89$ & 346.44 \\
$08 / 01 / 89$ & 346.57 \\
$08 / 08 / 89$ & 346.71 \\
$08 / 16 / 89$ & 346.87 \\
$09 / 07 / 89$ & 346.77 \\
$10 / 06 / 89$ & 346.95 \\
$10 / 20 / 89$ & 346.73 \\
$11 / 25 / 89$ & 346.13 \\
$12 / 28 / 89$ & 345.94 \\
$01 / 22 / 90$ & 346.06 \\
$02 / 22 / 90$ & 345.92 \\
$03 / 22 / 90$ & 345.75 \\
$04 / 18 / 90$ & 345.70 \\
$05 / 17 / 90$ & 346.23
\end{tabular}

$699-532-513 B$

W-L Elev. Date (Et)

\begin{tabular}{ll}
\hline \hline \\
$06 / 15 / 89$ & 346.90 \\
$06 / 21 / 89$ & 347.08 \\
$06 / 27 / 89$ & 347.16 \\
$07 / 05 / 89$ & 347.24 \\
$07 / 11 / 89$ & 347.24 \\
$07 / 18 / 89$ & 347.16 \\
$07 / 25 / 89$ & 347.08 \\
$08 / 01 / 89$ & 347.20 \\
$08 / 08 / 89$ & 347.34 \\
$08 / 16 / 89$ & 347.48 \\
$09 / 07 / 89$ & 347.36 \\
$10 / 06 / 89$ & 347.54 \\
$10 / 20 / 89$ & 347.33 \\
$11 / 25 / 89$ & 346.69 \\
$12 / 28 / 89$ & 346.50 \\
$01 / 22 / 90$ & 346.57 \\
$02 / 22 / 90$ & 346.38 \\
$03 / 22 / 90$ & 346.28 \\
$04 / 18 / 90$ & 346.22 \\
$05 / 17 / 90$ & 346.72
\end{tabular}

$699-529-512$

\begin{tabular}{cc} 
Date & $\begin{array}{c}W \text { Elev. } \\
\text { (ft) }\end{array}$ \\
\hline & \\
$06 / 21 / 89$ & 345.90 \\
$06 / 27 / 89$ & 345.89 \\
$07 / 05 / 89$ & 345.87 \\
$07 / 11 / 89$ & 345.86 \\
$07 / 18 / 89$ & 345.83 \\
$07 / 25 / 89$ & 345.78 \\
$08 / 01 / 89$ & 345.76 \\
$08 / 08 / 89$ & 345.80 \\
$08 / 16 / 89$ & 345.88 \\
$09 / 07 / 89$ & 345.91 \\
$10 / 06 / 89$ & 346.01 \\
$10 / 20 / 89$ & 345.98 \\
$11 / 25 / 89$ & 345.72 \\
$12 / 28 / 89$ & 345.57 \\
$01 / 22 / 90$ & $345: 64$ \\
$02 / 22 / 90$ & 345.68 \\
$03 / 22 / 90$ & 345.60 \\
$04 / 18 / 90$ & 345.60 \\
$05 / 17 / 90$ & 345.82
\end{tabular}

TW17

\begin{tabular}{cc} 
Date & $\begin{array}{c}\text { NIev. } \\
\text { (ft) }\end{array}$ \\
\hline & \\
$07 / 11 / 89$ & 353.07 \\
$07 / 18 / 89$ & 353.08 \\
$07 / 25 / 89$ & 353.10 \\
$08 / 01 / 89$ & 353.12 \\
$08 / 08 / 89$ & 353.15 \\
$08 / 16 / 89$ & 353.17 \\
$09 / 07 / 89$ & 353.25 \\
$10 / 06 / 89$ & 353.34 \\
$10 / 21 / 89$ & 353.41 \\
$11 / 25 / 89$ & 353.43 \\
$12 / 28 / 89$ & 353.40 \\
$01 / 22 / 90$ & 353.42 \\
$02 / 22 / 90$ & 353.42 \\
$03 / 22 / 90$ & 353.37 \\
$04 / 18 / 90$ & 353.30 \\
$05 / 17 / 90$ & 353.27
\end{tabular}


Tพ16

\begin{tabular}{cc} 
Date & $\begin{array}{c}W-L \text { Elev. } \\
\text { (ft) }\end{array}$ \\
\hline \hline & \\
$07 / 11 / 89$ & 353.04 \\
$07 / 18 / 89$ & 353.05 \\
$07 / 25 / 89$ & 353.07 \\
$08 / 01 / 89$ & 353.09 \\
$08 / 08 / 89$ & 353.11 \\
$08 / 16 / 89$ & 353.14 \\
$09 / 07 / 89$ & 353.22 \\
$10 / 06 / 89$ & 353.30 \\
$10 / 21 / 89$ & 353.35 \\
$11 / 25 / 89$ & 353.39 \\
$12 / 28 / 89$ & 353.36 \\
$01 / 22 / 90$ & 353.38 \\
$02 / 22 / 90$ & 353.37 \\
$03 / 22 / 90$ & 353.32 \\
$04 / 18 / 90$ & 353.27 \\
$05 / 17 / 90$ & 353.25
\end{tabular}

TW18

\begin{tabular}{cc} 
Date & $\begin{array}{c}\text { W-L Elev. } \\
\text { (ft) }\end{array}$ \\
\hline & \\
$07 / 11 / 89$ & 353.04 \\
$07 / 18 / 89$ & 353.05 \\
$07 / 25 / 89$ & 353.06 \\
$08 / 01 / 89$ & 353.08 \\
$08 / 08 / 89$ & 353.11 \\
$08 / 16 / 89$ & 353.14 \\
$09 / 07 / 89$ & 353.21 \\
$10 / 06 / 89$ & 353.30 \\
$10 / 21 / 89$ & 353.35 \\
$11 / 25 / 89$ & 353.39 \\
$12 / 28 / 89$ & 353.36 \\
$01 / 22 / 90$ & 353.39 \\
$02 / 22 / 90$ & 353.39 \\
$03 / 22 / 90$ & 353.33 \\
$04 / 18 / 90$ & 353.27 \\
$05 / 17 / 90$ & 353.25
\end{tabular}

TW15

\begin{tabular}{cc} 
Date & $\begin{array}{c}\text { W-L Elev. } \\
\text { (ft) }\end{array}$ \\
\hline & \\
$07 / 11 / 89$ & 353.09 \\
$07 / 18 / 89$ & 353.10 \\
$07 / 25 / 89$ & 353.12 \\
$08 / 01 / 89$ & 353.13 \\
$08 / 08 / 89$ & 353.15 \\
$08 / 16 / 89$ & 353.19 \\
$09 / 07 / 89$ & 353.26 \\
$10 / 06 / 89$ & 353.34 \\
$10 / 21 / 89$ & 353.39 \\
$11 / 25 / 89$ & 353.43 \\
$12 / 28 / 89$ & 353.40 \\
$01 / 22 / 90$ & 353.41 \\
$02 / 22 / 90$ & 353.42 \\
$03 / 22 / 90$ & 353.37 \\
$04 / 18 / 90$ & 353.31 \\
$05 / 17 / 90$ & 353.28
\end{tabular}

TN14

W-L Elev. Date (ft)

\begin{tabular}{ll}
\hline \hline & \\
$07 / 11 / 89$ & 353.11 \\
$07 / 18 / 89$ & 353.13 \\
$07 / 25 / 89$ & 353.15 \\
$08 / 01 / 89$ & 353.17 \\
$08 / 08 / 89$ & 353.18 \\
$08 / 16 / 89$ & 353.22 \\
$09 / 07 / 89$ & 353.29 \\
$10 / 06 / 89$ & 353.38 \\
$10 / 21 / 89$ & 353.43 \\
$11 / 25 / 89$ & 353.46 \\
$12 / 28 / 89$ & 353.44 \\
$01 / 22 / 90$ & 353.46 \\
$02 / 22 / 90$ & 353.45 \\
$03 / 22 / 90$ & 353.39 \\
$04 / 18 / 90$ & 353.34 \\
$05 / 17 / 90$ & 353.32
\end{tabular}

$699-531-1$

\begin{tabular}{|c|c|}
\hline Date & (Et) \\
\hline $06 / 21 / 89$ & 375.66 \\
\hline $06 / 27 / 89$ & 375.67 \\
\hline $07 / 05 / 89$ & 375.66 \\
\hline $07 / 11 / 89$ & 375.66 \\
\hline $07 / 18 / 89$ & 375.66 \\
\hline $07 / 25 / 89$ & 375.68 \\
\hline $08 / 01 / 89$ & 375.69 \\
\hline $08 / 08 / 89$ & 375.70 \\
\hline $08 / 17 / 89$ & 375.68 \\
\hline $09 / 07 / 89$ & 375.69 \\
\hline $10 / 06 / 89$ & 375.67 \\
\hline $10 / 21 / 89$ & 375.61 \\
\hline $11 / 25 / 89$ & 375.71 \\
\hline $12 / 28 / 89$ & 375.68 \\
\hline $01 / 22 / 90$ & 375.72 \\
\hline $02 / 22 / 90$ & 375.72 \\
\hline $03 / 22 / 90$ & 375.73 \\
\hline $04 / 18 / 90$ & 375.78 \\
\hline $05 / 17 / 90$ & 375.80 \\
\hline
\end{tabular}

$699-523-26$

Date $\quad \begin{gathered}W-I \text { Elev. } \\ (E t)\end{gathered}$

\begin{tabular}{ll}
\hline & \\
$06 / 27 / 89$ & 414.44 \\
$07 / 05 / 89$ & 414.47 \\
$07 / 11 / 89$ & 414.34 \\
$07 / 18 / 89$ & 414.27 \\
$07 / 25 / 89$ & 414.22 \\
$08 / 01 / 89$ & 414.18 \\
$08 / 08 / 89$ & 414.17 \\
$08 / 17 / 89$ & 414.27 \\
$09 / 07 / 89$ & 414.45 \\
$10 / 06 / 89$ & 414.57 \\
$10 / 21 / 89$ & 414.82 \\
$11 / 25 / 89$ & 415.04 \\
$12 / 28 / 89$ & 415.03 \\
$01 / 22 / 90$ & 415.48 \\
$02 / 22 / 90$ & 415.50 \\
$03 / 22 / 90$ & 415.67 \\
$04 / 18 / 90$ & 416.60 \\
$05 / 17 / 90$ & 415.05
\end{tabular}


พ-1

\begin{tabular}{cc} 
Date & $\begin{array}{c}\text { W-I Elev. } \\
\text { (ft) }\end{array}$ \\
\hline \hline $07 / 05 / 89$ & 351.54 \\
$07 / 11 / 89$ & 351.50 \\
$07 / 18 / 89$ & 346.75 \\
$07 / 25 / 89$ & 343.42 \\
$08 / 01 / 89$ & 343.39 \\
$08 / 08 / 89$ & 343.39 \\
$08 / 17 / 89$ & 343.73 \\
$08 / 22 / 89$ & 350.69 \\
$09 / 08 / 89$ & 351.81 \\
$10 / 06 / 89$ & 352.69 \\
$10 / 21 / 89$ & 352.93 \\
$11 / 25 / 89$ & 354.10 \\
$12 / 28 / 89$ & 354.31 \\
$01 / 22 / 90$ & 354.53 \\
$02 / 22 / 90$ & 354.59 \\
$03 / 22 / 90$ & 354.59 \\
$04 / 18 / 90$ & 354.10 \\
$05 / 17 / 90$ & 353.54
\end{tabular}

พ-3

W-L Elev.

Date (ft)

\begin{tabular}{ll}
\hline \hline \\
$07 / 05 / 89$ & 351.80 \\
$07 / 11 / 89$ & 351.74 \\
$07 / 18 / 89$ & 348.88 \\
$07 / 25 / 89$ & 348.62 \\
$08 / 01 / 89$ & 348.54 \\
$08 / 08 / 89$ & 348.54 \\
$08 / 17 / 89$ & 348.98 \\
$08 / 22 / 89$ & 351.14 \\
$09 / 08 / 89$ & 352.19 \\
$10 / 06 / 89$ & 352.89 \\
$10 / 21 / 89$ & 353.11 \\
$-11 / 25 / 89$ & 354.10 \\
$12 / 28 / 89$ & 354.32 \\
$01 / 22 / 90$ & 354.52 \\
$02 / 22 / 90$ & 354.60 \\
$03 / 22 / 90$ & 354.54 \\
$04 / 18 / 90$ & 354.17 \\
$05 / 17 / 90$ & 353.65
\end{tabular}

พ-4

\begin{tabular}{cr} 
Date & $\begin{array}{c}\text { W-L Elev. } \\
\text { (ft) }\end{array}$ \\
\hline \hline $07 / 05 / 89$ & 355.34 \\
$07 / 11 / 89$ & 355.29 \\
$09 / 08 / 89$ & 355.55 \\
$10 / 06 / 89$ & 356.43 \\
$10 / 21 / 89$ & 356.68 \\
$11 / 25 / 89$ & 357.85 \\
$12 / 28 / 89$ & 358.05 \\
$01 / 22 / 90$ & 358.28 \\
$02 / 22 / 90$ & 358.34 \\
$03 / 22 / 90$ & 358.24 \\
$04 / 18 / 90$ & 357.82 \\
$05 / 17 / 90$ & 357.26
\end{tabular}

w-5

\begin{tabular}{cr} 
Date & $\begin{array}{c}\text { W-I Elev. } \\
\text { (ft) }\end{array}$ \\
\hline $11 / 25 / 89$ & 355.74 \\
$03 / 22 / 90$ & 355.79 \\
$05 / 17 / 90$ & 355.19
\end{tabular}

พ-6

\begin{tabular}{cc} 
Date & $\begin{array}{c}\text { W-I Elev. } \\
\text { (Et) }\end{array}$ \\
\hline $07 / 25 / 89$ & 353.72 \\
$08 / 01 / 89$ & 353.76 \\
$08 / 08 / 89$ & 353.82 \\
$08 / 17 / 89$ & 354.02 \\
$08 / 22 / 89$ & 354.33 \\
$09 / 08 / 89$ & 354.98 \\
$10 / 06 / 89$ & 355.78 \\
$10 / 21 / 89$ & 355.92 \\
$11 / 25 / 89$ & 356.61 \\
$12 / 28 / 89$ & 356.75 \\
$01 / 22 / 90$ & 356.94 \\
$02 / 22 / 90$ & 356.87 \\
$03 / 22 / 90$ & 356.68 \\
$04 / 18 / 90$ & 356.26 \\
$05 / 17 / 90$ & 355.83
\end{tabular}

Saint

\begin{tabular}{cc} 
Date & $\begin{array}{c}W-i \text { Elev. } \\
\text { (Et) }\end{array}$ \\
\hline \hline $07 / 11 / 89$ & 345.05 \\
$07 / 18 / 89$ & 345.05 \\
$07 / 25 / 89$ & 345.36 \\
$08 / 01 / 89$ & 345.49 \\
$08 / 08 / 89$ & 345.58 \\
$08 / 17 / 89$ & 345.44 \\
$09 / 08 / 89$ & 345.97 \\
$10 / 06 / 89$ & 345.83 \\
$10 / 21 / 89$ & 345.89 \\
$11 / 25 / 89$ & 345.70 \\
$12 / 28 / 89$ & 345.92 \\
$01 / 24 / 90$ & 345.93 \\
$02 / 23 / 90$ & 346.21 \\
$03 / 22 / 90$ & 345.92 \\
$04 / 18 / 90$ & 345.92 \\
$05 / 17 / 90$ & 346.01
\end{tabular}


699-543-E12

\begin{tabular}{cc} 
Date & $\begin{array}{c}\text { W-I Elev. } \\
\text { (ft) }\end{array}$ \\
\hline \hline $06 / 21 / 89$ & 353.60 \\
$07 / 13 / 89$ & 353.96 \\
$07 / 18 / 89$ & 354.02 \\
$07 / 25 / 89$ & 354.06 \\
$08 / 01 / 89$ & 354.11 \\
$08 / 08 / 89$ & 354.20 \\
$08 / 17 / 89$ & 354.32 \\
$09 / 08 / 89$ & 354.40 \\
$10 / 06 / 89$ & 354.21 \\
$10 / 22 / 89$ & 354.12 \\
$11 / 25 / 89$ & 353.91 \\
$12 / 28 / 89$ & 354.06 \\
$01 / 24 / 90$ & 354.00 \\
$02 / 23 / 90$ & 353.56 \\
$03 / 22 / 90$ & 353.25 \\
$04 / 18 / 90$ & 352.98 \\
$05 / 17 / 90$ & 353.08
\end{tabular}

699-S41-E13A

\begin{tabular}{cc} 
Date & $\begin{array}{c}\text { W-I Elev. } \\
\text { (Et) }\end{array}$ \\
\hline & \\
\hline $06 / 21 / 89$ & 355.78 \\
$07 / 13 / 89$ & 355.91 \\
$07 / 18 / 89$ & 355.90 \\
$07 / 25 / 89$ & 355.86 \\
$08 / 01 / 89$ & 356.09 \\
$08 / 08 / 89$ & 356.17 \\
$08 / 17 / 89$ & 356.76 \\
$09 / 08 / 89$ & 355.32 \\
$10 / 06 / 89$ & 354.87 \\
$10 / 18 / 89$ & 354.72 \\
$11 / 13 / 89$ & 353.54 \\
$01 / 02 / 90$ & 355.43 \\
$01 / 22 / 90$ & 354.07 \\
$02 / 23 / 90$ & 352.74 \\
$03 / 22 / 90$ & 352.14 \\
$04 / 13 / 90$ & 352.73 \\
$05 / 17 / 90$ & 353.10
\end{tabular}

$699-\$ 41-E 13 B$

\begin{tabular}{cc} 
Date & $\begin{array}{c}W-L \text { Elev. } \\
\text { (ft) }\end{array}$ \\
\hline \hline $06 / 21 / 89$ & 355.81 \\
$07 / 13 / 89$ & 355.94 \\
$07 / 18 / 89$ & 355.93 \\
$07 / 25 / 89$ & 355.89 \\
$08 / 01 / 89$ & 356.12 \\
$08 / 08 / 89$ & 356.21 \\
$08 / 17 / 89$ & 356.79 \\
$09 / 08 / 89$ & 355.34 \\
$10 / 06 / 89$ & 354.88 \\
$10 / 18 / 89$ & 354.73 \\
$11 / 13 / 89$ & 353.52 \\
$01 / 02 / 90$ & 355.47 \\
$01 / 22 / 90$ & 354.08 \\
$02 / 23 / 90$ & 352.72 \\
$03 / 22 / 90$ & 352.12 \\
$04 / 18 / 90$ & 352.75 \\
$05 / 17 / 90$ & 353.10
\end{tabular}

699-537-E14

\begin{tabular}{cc} 
Date & $\begin{array}{c}W-L \text { Elev. } \\
\text { (ft) }\end{array}$ \\
\hline \hline $06 / 21 / 89$ & 354.40 \\
$07 / 13 / 89$ & 354.61 \\
$07 / 18 / 89$ & 354.54 \\
$07 / 25 / 89$ & 354.54 \\
$08 / 01 / 89$ & 354.72 \\
$08 / 08 / 89$ & 354.85 \\
$08 / 17 / 89$ & 355.18 \\
$09 / 08 / 89$ & 354.12 \\
$10 / 06 / 89$ & 353.67 \\
$10 / 22 / 89$ & 353.54 \\
$11 / 25 / 89$ & 352.63 \\
$12 / 28 / 89$ & 353.35 \\
$01 / 24 / 90$ & 352.57 \\
$02 / 23 / 90$ & 351.45 \\
$03 / 22 / 90$ & 350.86 \\
$04 / 18 / 90$ & 351.26 \\
$05 / 17 / 90$ & 351.66
\end{tabular}

699-\$36-E12B

\begin{tabular}{cc} 
Date & $\begin{array}{c}\text { W-I Elev. } \\
\text { (ft) }\end{array}$ \\
\hline \hline $06 / 15 / 89$ & 354.03 \\
$06 / 21 / 89$ & 354.29 \\
$06 / 27 / 89$ & 354.43 \\
$07 / 05 / 89$ & 354.59 \\
$07 / 11 / 89$ & 354.61 \\
$07 / 18 / 89$ & 354.53 \\
$07 / 26 / 89$ & 354.50 \\
$08 / 01 / 89$ & 354.58 \\
$08 / 08 / 89$ & 354.73 \\
$08 / 17 / 89$ & 354.99 \\
$09 / 08 / 89$ & 354.36 \\
$10 / 06 / 89$ & 353.82 \\
$10 / 22 / 89$ & 353.67 \\
$11 / 25 / 89$ & 352.69 \\
$12 / 28 / 89$ & 353.47 \\
$01 / 24 / 90$ & 352.86 \\
$02 / 23 / 90$ & 351.69 \\
$03 / 22 / 90$ & 350.97 \\
$04 / 18 / 90$ & 351.10 \\
$05 / 17 / 90$ & 352.01
\end{tabular}

$699-536-E 13 B$

\begin{tabular}{cc} 
Date & $\begin{array}{c}\text { W-L Elev. } \\
\text { (ft) }\end{array}$ \\
\hline \hline $06 / 14 / 89$ & 354.01 \\
$06 / 21 / 89$ & 354.13 \\
$06 / 26 / 89$ & 354.31 \\
$06 / 27 / 89$ & 354.36 \\
$07 / 05 / 89$ & 354.51 \\
$07 / 11 / 89$ & 354.51 \\
$07 / 18 / 89$ & 354.52 \\
$07 / 26 / 89$ & 354.49 \\
$08 / 01 / 89$ & 354.49 \\
$08 / 08 / 89$ & 354.54 \\
$08 / 17 / 89$ & 355.15 \\
$09 / 08 / 89$ & 354.44 \\
$10 / 06 / 89$ & 353.87 \\
$10 / 22 / 89$ & 353.67 \\
$11 / 25 / 89$ & 352.59 \\
$12 / 28 / 89$ & 353.16 \\
$01 / 24 / 90$ & 353.05 \\
$02 / 23 / 90$ & 351.71 \\
$03 / 22 / 90$ & 350.99 \\
$04 / 18 / 90$ & 350.91 \\
$05 / 17 / 90$ & 351.98
\end{tabular}

B.4 
Continuous Water-Level Recorder Wells

\begin{tabular}{|c|c|c|c|c|}
\hline \multirow[b]{2}{*}{ Month } & \multirow[b]{2}{*}{ Date } & \multirow[b]{2}{*}{ Year } & \multicolumn{2}{|c|}{$\begin{array}{c}3000-F \\
(3099-47-18 B)\end{array}$} \\
\hline & & & $\begin{array}{c}\text { Depth } \\
\text { (ft) }\end{array}$ & $\begin{array}{c}\text { Elev. } \\
\text { (ft) }\end{array}$ \\
\hline \multirow[t]{30}{*}{ June } & 1 & \multirow[t]{29}{*}{1989} & & \\
\hline & 2 & & & \\
\hline & 3 & & & \\
\hline & 4 & & & \\
\hline & 5 & & & \\
\hline & 6 & & & \\
\hline & 7 & & & \\
\hline & 8 & & & \\
\hline & 9 & & & \\
\hline & 10 & & & \\
\hline & 11 & & & \\
\hline & 12 & & & \\
\hline & 13 & & & \\
\hline & 14 & & & \\
\hline & 15 & & & \\
\hline & 16 & & & \\
\hline & 17 & & & \\
\hline & 18 & & & \\
\hline & 19 & & & \\
\hline & 20 & & & \\
\hline & 21 & & & \\
\hline & 22 & & & \\
\hline & 23 & & & \\
\hline & 24 & & & \\
\hline & 25 & & & \\
\hline & 26 & & 34.73 & 340.22 \\
\hline & 27 & & 33.50 & 341.45 \\
\hline & 28 & & 33.90 & 341.05 \\
\hline & 29 & & 33.74 & 341.21 \\
\hline & 30 & & & \\
\hline
\end{tabular}

\begin{tabular}{|c|c|c|c|c|}
\hline \multirow[b]{2}{*}{ Month } & \multirow[b]{2}{*}{ Date } & \multirow[b]{2}{*}{ Year } & \multicolumn{2}{|c|}{$\begin{array}{c}3000-F \\
(3099-47-18 B)\end{array}$} \\
\hline & & & $\begin{array}{l}\text { Depth } \\
\text { (ft) }\end{array}$ & $\begin{array}{c}\text { Elev. } \\
(\mathrm{ft})\end{array}$ \\
\hline \multirow[t]{31}{*}{ July } & 1 & 1989 & & \\
\hline & 2 & & & \\
\hline & 3 & & & \\
\hline & 4 & & 34.39 & 340.56 \\
\hline & 5 & & 34.86 & 340.09 \\
\hline & 6 & & 34.23 & 340.72 \\
\hline & 7 & & 33.93 & 341.02 \\
\hline & 8 & & 33.78 & 341.17 \\
\hline & 9 & & 34.39 & 340.56 \\
\hline & 10 & & 34.79 & 340.16 \\
\hline & 11 & & 34.15 & 340.80 \\
\hline & 12 & & 33.65 & 341.30 \\
\hline & 13 & & 34.34 & 340.61 \\
\hline & 14 & & 34.38 & 340.57 \\
\hline & 15 & & 35.05 & 339.90 \\
\hline & 16 & & 35.64 & 339.31 \\
\hline & 17 & & 35.63 & 339.32 \\
\hline & 18 & & 34.90 & 340.05 \\
\hline & 19 & & 34.89 & 340.06 \\
\hline & 20 & & 34.38 & 340.57 \\
\hline & 21 & & 34.27 & 340.68 \\
\hline & 22 & & 33.71 & 341.24 \\
\hline & 23 & & 34.28 & 340.67 \\
\hline & 24 & & 34.25 & 340.70 \\
\hline & 25 & & 33.48 & 341.47 \\
\hline & 26 & & 33.15 & 341.80 \\
\hline & 27 & & 33.67 & 341.28 \\
\hline & 28 & & 33.92 & 341.03 \\
\hline & 29 & & 33.45 & 341.50 \\
\hline & 30 & & 33.92 & 341.03 \\
\hline & 31 & & 34.38 & 340.57 \\
\hline
\end{tabular}




\begin{tabular}{|c|c|c|c|c|}
\hline \multirow[b]{2}{*}{ Month } & \multirow[b]{2}{*}{ Date } & \multirow[b]{2}{*}{ Year } & \multicolumn{2}{|c|}{$\begin{array}{c}3000-F \\
(3099-47-18 B)\end{array}$} \\
\hline & & & $\begin{array}{l}\text { Depth } \\
\text { (ft) }\end{array}$ & $\begin{array}{l}\text { Elev. } \\
\text { (ft) }\end{array}$ \\
\hline \multirow{31}{*}{ August } & 1 & 1989 & 34.24 & 340.71 \\
\hline & 2 & & 34.79 & 340.16 \\
\hline & 3 & & 35.24 & 339.71 \\
\hline & 4 & & 34.27 & 340.68 \\
\hline & 5 & & 33.63 & 341.32 \\
\hline & 6 & & 34.13 & 340.82 \\
\hline & 7 & & 34.22 & 340.73 \\
\hline & 8 & & 33.75 & 341.20 \\
\hline & 9 & & 33.68 & 341.27 \\
\hline & 10 & & 33.78 & 341.17 \\
\hline & 11 & & 34.10 & 340.85 \\
\hline & 12 & & 34.10 & 340.85 \\
\hline & 13 & & 34.34 & 340.61 \\
\hline & 14 & & 34.53 & 340.42 \\
\hline & 15 & & & \\
\hline & 16 & & 34.82 & 340.13 \\
\hline & 17 & & 34.69 & 340.26 \\
\hline & 18 & & 33.79 & 341.16 \\
\hline & 19 & & 33.82 & 341.13 \\
\hline & 20 & & 34.27 & 340.68 \\
\hline & 21 & & 33.95 & 341.00 \\
\hline & 22 & & 34.77 & 340.18 \\
\hline & 23 & & 35.21 & 339.74 \\
\hline & 24 & & 35.10 & 339.85 \\
\hline & 25 & & 34.64 & 340.31 \\
\hline & 26 & & $34: 69$ & 340.26 \\
\hline & 27 & & 35.05 & 339.90 \\
\hline & 28 & & 35.22 & 339.73 \\
\hline & 29 & & 34.56 & 340.39 \\
\hline & 30 & & 34.44 & 340.51 \\
\hline & 31 & & 33.62 & 341.33 \\
\hline
\end{tabular}

\begin{tabular}{|c|c|c|c|c|}
\hline & & & $\begin{array}{r}300 \\
13099\end{array}$ & $\begin{array}{l}F \\
-18 B)\end{array}$ \\
\hline Month & Date & Year & $\begin{array}{c}\text { Depth } \\
\text { (ft) }\end{array}$ & $\begin{array}{c}\text { Elev. } \\
(\mathrm{ft})\end{array}$ \\
\hline September & 1 & 1989 & 33.91 & 341.04 \\
\hline & 2 & & 33.96 & 340.99 \\
\hline & 3 & & 34.41 & 340.54 \\
\hline & 4 & & 34.53 & 340.42 \\
\hline & 5 & & 34.51 & 340.44 \\
\hline & 6 & & 33.72 & 341.23 \\
\hline & 7 & & 33.41 & 341.54 \\
\hline & 8 & & 33.71 & 341.24 \\
\hline & 9 & & 33.99 & 340.96 \\
\hline & 10 & & 34.52 & 340.43 \\
\hline & 11 & & 34.82 & 340.13 \\
\hline & 12 & & 34.62 & 340.33 \\
\hline & 13 & & 34.28 & 340.67 \\
\hline & 14 & & 33.95 & 341.00 \\
\hline & 15 & & 33.96 & 340.99 \\
\hline & 16 & & 34.06 & 340.89 \\
\hline & 17 & & 34.41 & 340.54 \\
\hline & 18 & & 34.87 & 340.08 \\
\hline & 19 & & 34.18 & 340.77 \\
\hline & 20 & & 33.58 & 341.37 \\
\hline & 21 & & 33.73 & 341.22 \\
\hline & 22 & & 34.01 & 340.94 \\
\hline & 23 & & 33.55 & 341.40 \\
\hline & 24 & & 34.18 & 340.77 \\
\hline & 25 & & 34.74 & 340.21 \\
\hline & 26 & & 33.93 & 341.02 \\
\hline & 27 & & 33.74 & 341.21 \\
\hline & 28 & & 33.63 & 341.32 \\
\hline & 29 & & 33.69 & 341.26 \\
\hline & 30 & & 33.83 & 341.12 \\
\hline
\end{tabular}




\begin{tabular}{|c|c|c|c|c|}
\hline \multirow[b]{2}{*}{ Month } & \multirow[b]{2}{*}{ Date } & \multirow[b]{2}{*}{ Year } & \multicolumn{2}{|c|}{$\begin{array}{c}3000-F \\
(3099-47-18 B)\end{array}$} \\
\hline & & & $\begin{array}{l}\text { Depth } \\
\text { (ft) }\end{array}$ & $\begin{array}{c}\text { Elev. } \\
\text { (ft) }\end{array}$ \\
\hline \multirow[t]{31}{*}{ October } & 1 & 1989 & 34.58 & 340.37 \\
\hline & 2 & & 34.42 & 340.53 \\
\hline & 3 & & 33.56 & 341.39 \\
\hline & 4 & & 33.12 & 341.83 \\
\hline & 5 & & 33.65 & 341.30 \\
\hline & 6 & & 34.10 & 340.85 \\
\hline & 7 & & 33.46 & 341.49 \\
\hline & 8 & & 33.75 & 341.20 \\
\hline & 9 & & 34.72 & 340.23 \\
\hline & 10 & & 33.80 & 341.15 \\
\hline & 11 & & 33.58 & 341.37 \\
\hline & 12 & & 32.99 & 341.96 \\
\hline & 13 & & 32.78 & 342.17 \\
\hline & 14 & & 33.20 & 341.75 \\
\hline & 15 & & 34.05 & 340.90 \\
\hline & 16 & & 34.13 & 340.82 \\
\hline & 17 & & 33.38 & 341.57 \\
\hline & 18 & & 33.20 & 341.75 \\
\hline & 19 & & 33.10 & 341.85 \\
\hline & 20 & & 33.22 & 341.73 \\
\hline & 21 & & 32.98 & 341.97 \\
\hline & 22 & & 33.45 & 341.50 \\
\hline & 23 & & 33.74 & 341.21 \\
\hline & 24 & & 34.17 & 340.78 \\
\hline & 25 & & 33.90 & 341.05 \\
\hline & 26 & & 33.65 & 341.30 \\
\hline & 27 & & 33.43 & 341.52 \\
\hline & 28 & & 33.39 & 341.56 \\
\hline & 29 & & 33.24 & 341.71 \\
\hline & 30 & & 33.67 & 341.28 \\
\hline & 31 & & 33.72 & 341.23 \\
\hline
\end{tabular}

\begin{tabular}{|c|c|c|c|c|}
\hline \multirow[b]{2}{*}{ Month } & \multirow[b]{2}{*}{ Date } & \multirow[b]{2}{*}{ Year } & \multicolumn{2}{|c|}{$\begin{array}{c}3000-F \\
(3099-47-18 B)\end{array}$} \\
\hline & & & $\begin{array}{c}\text { Depth } \\
\text { (ft) }\end{array}$ & $\begin{array}{c}\text { Elev. } \\
\text { (ft) }\end{array}$ \\
\hline \multirow[t]{30}{*}{ November } & 1 & 1989 & 33.52 & 341.43 \\
\hline & 2 & & 33.25 & 341.70 \\
\hline & 3 & & 33.51 & 341.44 \\
\hline & 4 & & 33.50 & 341.45 \\
\hline & 5 & & 33.10 & 341.85 \\
\hline & 6 & & 33.38 & 341.57 \\
\hline & 7 & & 33.00 & 341.95 \\
\hline & 8 & & 32.37 & 342.58 \\
\hline & 9 & & 32.37 & 342.58 \\
\hline & 10 & & 32.40 & 342.55 \\
\hline & 11 & & 32.52 & 342.43 \\
\hline & 12 & & 32.69 & 342.26 \\
\hline & 13 & & 32.84 & 342.11 \\
\hline & 14 & . & 32.60 & 342.35 \\
\hline & 15 & & 32.04 & 342.91 \\
\hline & 16 & & 31.73 & 343.22 \\
\hline & 17 & & 32.10 & 342.85 \\
\hline & 18 & & 32.19 & 342.76 \\
\hline & 19 & & 32.38 & 342.57 \\
\hline & 20 & & 32.90 & 342.05 \\
\hline & 21 & & 32.67 & 342.28 \\
\hline & 22 & & & \\
\hline & 23 & & & \\
\hline & 24 & & 34.17 & 340.78 \\
\hline & 25 & & 33.78 & 341.17 \\
\hline & 26 & & 33.37 & 341.58 \\
\hline & 27 & & 33.28 & 341.67 \\
\hline & 28 & & 32.91 & 342.04 \\
\hline & 29 & & 32.46 & 342.49 \\
\hline & 30 & & 32.09 & 342.86 \\
\hline
\end{tabular}




\begin{tabular}{|c|c|c|c|c|}
\hline \multirow[b]{2}{*}{ Month } & \multirow[b]{2}{*}{ Date } & \multirow[b]{2}{*}{ Year } & \multicolumn{2}{|c|}{$\begin{array}{c}3000-F \\
(3099-47-18 B)\end{array}$} \\
\hline & & & $\begin{array}{c}\text { Depth } \\
(\mathrm{ft})\end{array}$ & $\begin{array}{c}\text { Elev. } \\
\text { (ft) }\end{array}$ \\
\hline \multirow[t]{31}{*}{ December } & 1 & 1989 & 32.80 & 342.15 \\
\hline & 2 & & 33.03 & 341.92 \\
\hline & 3 & & 33.30 & 341.65 \\
\hline & 4 & & 33.73 & 341.22 \\
\hline & 5 & & 34.08 & 340.87 \\
\hline & 6 & & 33.82 & 341.13 \\
\hline & 7 & & 32.68 & 342.27 \\
\hline & 8 & & 32.28 & 342.67 \\
\hline & 9 & & 32.48 & 342.47 \\
\hline & 10 & & 33.03 & 341.92 \\
\hline & 11 & & 32.47 & 342.48 \\
\hline & 12 & & 32.40 & 342.55 \\
\hline & 13 & & 32.74 & 342.21 \\
\hline & 14 & & 32.36 & 342.59 \\
\hline & 15 & & 32.25 & 342.70 \\
\hline & 16 & & 32.82 & 342.13 \\
\hline & 17 & & 32.51 & 342.44 \\
\hline & 18 & & 32.90 & 342.05 \\
\hline & 19 & & 32.50 & 342.45 \\
\hline & 20 & & 32.14 & 342.81 \\
\hline & 21 & & 32.11 & 342.84 \\
\hline & 22 & & 32.64 & 342.31 \\
\hline & 23 & & 32.64 & 342.31 \\
\hline & 24 & & 33.14 & 341.81 \\
\hline & 25 & & 33.51 & 341.44 \\
\hline & 26 & & 33.83 & 341.12 \\
\hline & 27 & & 32.52 & 342.43 \\
\hline & 28 & & 32.26 & 342.69 \\
\hline & 29 & & 32.00 & 342.95 \\
\hline & 30 & & 32.65 & 342.30 \\
\hline & 31 & & 32.45 & 342.50 \\
\hline
\end{tabular}

\begin{tabular}{|c|c|c|c|c|}
\hline \multirow[b]{2}{*}{ Month } & \multirow[b]{2}{*}{ Date } & \multirow[b]{2}{*}{ Year } & \multicolumn{2}{|c|}{$\begin{array}{c}3000-F \\
(3099-47-18 B)\end{array}$} \\
\hline & & & $\begin{array}{l}\text { Depth } \\
(f t)\end{array}$ & $\begin{array}{l}\text { Elev. } \\
\text { (ft) }\end{array}$ \\
\hline \multirow[t]{31}{*}{ January } & 1 & 1990 & 32.98 & 341.97 \\
\hline & 2 & & 32.86 & 342.09 \\
\hline & 3 & & 32.68 & 342.27 \\
\hline & 4 & & 31.64 & 343.31 \\
\hline & 5 & & 31.62 & 343.33 \\
\hline & 6 & & 32.23 & 342.72 \\
\hline & 7 & & 32.62 & 342.33 \\
\hline & 8 & & 32.94 & 342.01 \\
\hline & 9 & & 32.74 & 342.21 \\
\hline & 10 & & 31.80 & 343.15 \\
\hline & 11 & & 31.56 & 343.39 \\
\hline & 12 & & 32.32 & 342.63 \\
\hline & 13 & & 32.34 & 342.61 \\
\hline & 14 & & 32.82 & 342.13 \\
\hline & 15 & & 33.14 & 341.81 \\
\hline & 16 & & 32.49 & 342.46 \\
\hline & 17 & & 32.29 & 342.66 \\
\hline & 18 & & 32.51 & 342.44 \\
\hline & 19 & & 32.64 & 342.31 \\
\hline & 20 & & 32.72 & 342.23 \\
\hline & 21 & & 32.34 & 342.61 \\
\hline & 22 & & 32.64 & 342.31 \\
\hline & 23 & & 32.69 & 342.26 \\
\hline & 24 & & 32.23 & 342.72 \\
\hline & 25 & & & \\
\hline & 26 & & & \\
\hline & 27 & & & \\
\hline & 28 & & & \\
\hline & 29 & & & \\
\hline & 30 & & & \\
\hline & 31 & & & \\
\hline
\end{tabular}




\begin{tabular}{|c|c|c|c|c|}
\hline \multirow[b]{2}{*}{ Month } & \multirow[b]{2}{*}{ Date } & \multirow[b]{2}{*}{ Year } & \multicolumn{2}{|c|}{$\begin{array}{c}3000-F \\
(3099-47-18 B)\end{array}$} \\
\hline & & & $\begin{array}{l}\text { Depth } \\
(f t)\end{array}$ & $\begin{array}{l}\text { Elev. } \\
\text { (ft) }\end{array}$ \\
\hline \multirow[t]{27}{*}{ February } & 1 & 1990 & & \\
\hline & 2 & & & \\
\hline & 3 & & & \\
\hline & 4 & & & \\
\hline & 5 & & & \\
\hline & 6 & & & \\
\hline & 8 & & & \\
\hline & 9 & & - & \\
\hline & 10 & & & \\
\hline & 11 & & & \\
\hline & 12 & & & \\
\hline & 13 & & & \\
\hline & 14 & & & \\
\hline & 15 & & & \\
\hline & 16 & & & \\
\hline & 17 & & & \\
\hline & 18 & & & \\
\hline & 19 & & & \\
\hline & 20 & & & \\
\hline & 21 & & & \\
\hline & 22 & & 31.56 & 343.39 \\
\hline & 23 & & 32.04 & 342.91 \\
\hline & 24 & & 32.37 & 342.58 \\
\hline & 25 & & 32.29 & 342.66 \\
\hline & 26 & & 32.23 & 342.72 \\
\hline & 27 & & 32.39 & 342.56 \\
\hline & 28 & & 32.42 & 342.53 \\
\hline
\end{tabular}

\begin{tabular}{|c|c|c|c|c|}
\hline & & & $\begin{array}{r}300 \\
13099\end{array}$ & $\begin{array}{l}-F \\
7-18 B)\end{array}$ \\
\hline Month & Date & Year & $\begin{array}{l}\text { Depth } \\
\text { (ft) }\end{array}$ & $\begin{array}{c}\text { Elev. } \\
\text { (ft) }\end{array}$ \\
\hline March & 1 & 1990 & 32.00 & 342.95 \\
\hline & 2 & & 31.40 & 343.55 \\
\hline & 3 & & 32.24 & 342.71 \\
\hline & 4 & & 32.23 & 342.72 \\
\hline & 5 & & 32.75 & 342.20 \\
\hline & 6 & & 32.28 & 342.67 \\
\hline & 7 & & 32.19 & 342.76 \\
\hline & 8 & & 32.20 & 342.75 \\
\hline & 9 & & 31.22 & 343.73 \\
\hline & 10 & & 30.93 & 344.02 \\
\hline & 11 & & 32.12 & 342.83 \\
\hline & 12 & & 32.20 & 342.75 \\
\hline & 13 & & 32.33 & 342.62 \\
\hline & 14 & & 32.74 & 342.21 \\
\hline & 15 & & 32.79 & 342.16 \\
\hline & 16 & & 32.26 & 342.69 \\
\hline & 17 & . & 31.81 & 343.14 \\
\hline & 18 & & 32.00 & 342.95 \\
\hline & 19 & & 32.08 & 342.87 \\
\hline & 20 & & 32.45 & 342.50 \\
\hline & 21 & & 32.27 & 342.68 \\
\hline & 22 & & 31.50 & 343.45 \\
\hline & 23 & & 31.35 & 343.60 \\
\hline & 24 & & 31.06 & 343.89 \\
\hline & 25 & & 31.18 & 343.77 \\
\hline & 26 & & 31.37 & 343.58 \\
\hline & 27 & & 31.73 & 343.22 \\
\hline & 28 & & 31.46 & 343.49 \\
\hline & 29 & & 30.72 & 344.23 \\
\hline & 30 & & 32.10 & 342.85 \\
\hline & 31 & & 32.92 & 342.03 \\
\hline
\end{tabular}




\begin{tabular}{|c|c|c|c|c|}
\hline \multirow[b]{2}{*}{ Month } & \multirow[b]{2}{*}{ Date } & \multirow[b]{2}{*}{ Year } & \multicolumn{2}{|c|}{$\begin{array}{c}3000-F \\
(3099-47-18 B)\end{array}$} \\
\hline & & & $\begin{array}{l}\text { Depth } \\
(\mathrm{ft})\end{array}$ & $\begin{array}{l}\text { Elev. } \\
\text { (ft) }\end{array}$ \\
\hline \multirow[t]{30}{*}{ April } & 1 & 1990 & 33.01 & 341.94 \\
\hline & 2 & & 32.05 & 342.90 \\
\hline & 3 & & $30: 22$ & 344.73 \\
\hline & 4 & & 31.07 & 343.88 \\
\hline & 5 & & 32.03 & 342.92 \\
\hline & 6 & & 32.34 & 342.61 \\
\hline & 7 & & 32.30 & 342.65 \\
\hline & 8 & & 31.14 & 343.81 \\
\hline & 9 & & 32.20 & 342.75 \\
\hline & 10 & & 31.92 & 343.03 \\
\hline & 11 & & 31.77 & 343.18 \\
\hline & 12 & & 31.82 & 343.13 \\
\hline & 13 & & 32.13 & 342.82 \\
\hline & 14 & & 31.99 & 342.96 \\
\hline & 15 & & 32.96 & 341.99 \\
\hline & 16 & & 33.73 & 341.22 \\
\hline & 17 & & 33.12 & 341.83 \\
\hline & 18 & & 32.29 & 342.66 \\
\hline & 19 & & 32.01 & 342.94 \\
\hline & 20 & & 31.52 & 343.43 \\
\hline & 21 & & 31.85 & 343.10 \\
\hline & 22 & & 32.78 & 342.17 \\
\hline & 23 & & 33.33 & 341.62 \\
\hline & 24 & & 31.45 & 343.50 \\
\hline & 25 & & 31.98 & 342.97 \\
\hline & 26 & & 30.02 & 344.93 \\
\hline & 27 & & 30.55 & 344.40 \\
\hline & 28 & & 31.90 & 343.05 \\
\hline & 29 & & 32.58 & 342.37 \\
\hline & 30 & & 33.45 & 341.50 \\
\hline
\end{tabular}

\begin{tabular}{|c|c|c|c|c|}
\hline \multirow[b]{2}{*}{ Month } & \multirow[b]{2}{*}{ Date } & \multirow[b]{2}{*}{ Year } & \multicolumn{2}{|c|}{$\begin{array}{c}3000-F \\
(3099-47-18 B)\end{array}$} \\
\hline & & & $\begin{array}{c}\text { Depth } \\
(\mathrm{ft})\end{array}$ & $\begin{array}{c}\text { Elev. } \\
(\mathrm{ft})\end{array}$ \\
\hline May & 1 & 1990 & 32.29 & 342.66 \\
\hline & 2 & & 32.36 & 342.59 \\
\hline & 3 & & 30.85 & 344.10 \\
\hline & 4 & & & \\
\hline & 5 & & & \\
\hline & 6 & & & \\
\hline & 7 & & & \\
\hline & 8 & & & \\
\hline & 9 & & & \\
\hline & 10 & & & \\
\hline & 11 & & & \\
\hline & 12 & & & \\
\hline & 13 & & & \\
\hline & 14 & & & \\
\hline & 15 & & & \\
\hline & 16 & & & \\
\hline & 17 & & 31.59 & 343.36 \\
\hline & 18 & & & \\
\hline & 19 & & & \\
\hline & 20 & & & \\
\hline & 21 & & & \\
\hline & 22 & & & \\
\hline & 23 & & & \\
\hline & 24 & & & \\
\hline & 25 & & & \\
\hline & 26 & & & \\
\hline & 27 & & & \\
\hline & 28 & & & \\
\hline & 29 & & & \\
\hline & 30 & & & \\
\hline & 31 & & & \\
\hline
\end{tabular}




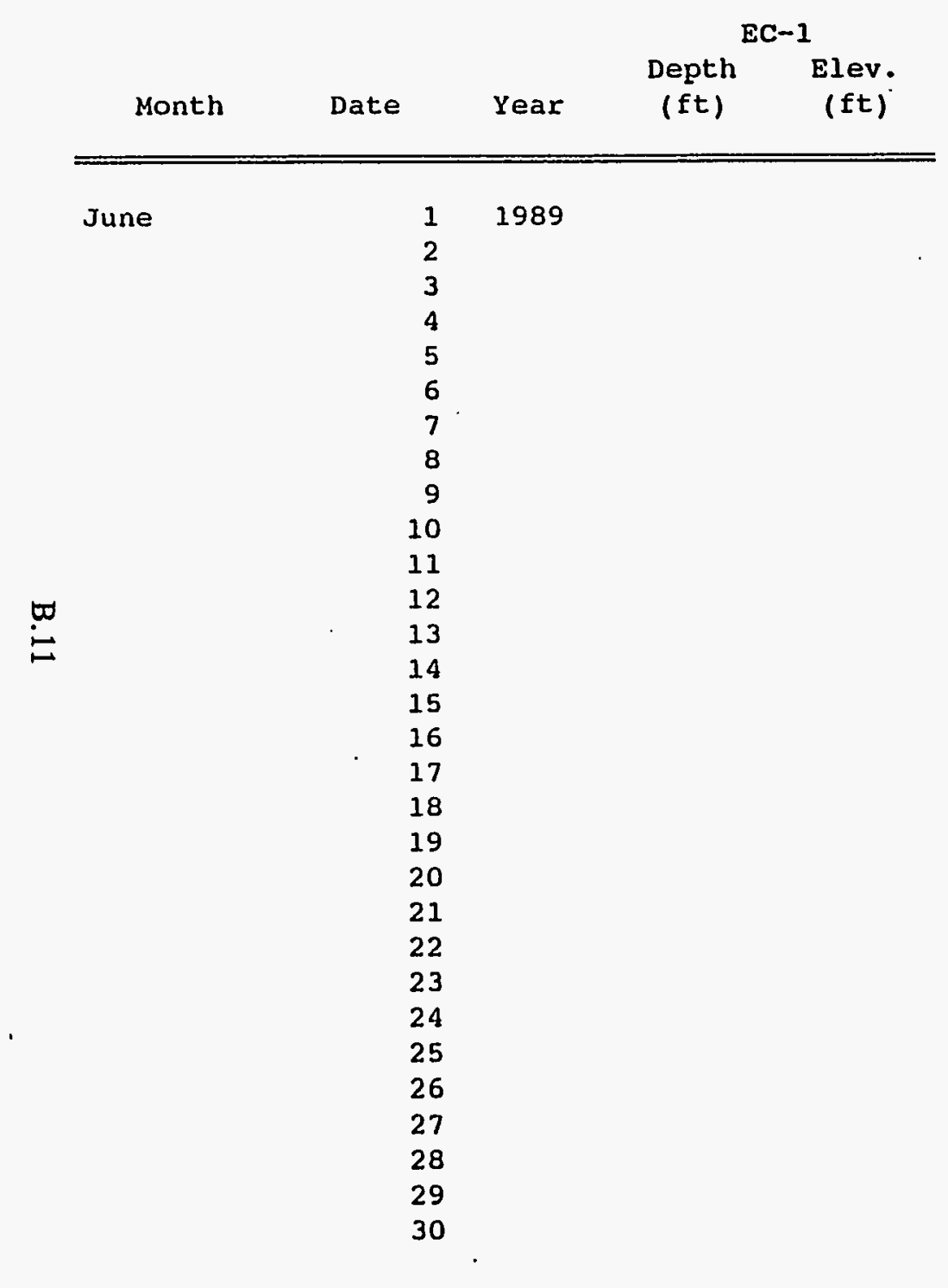

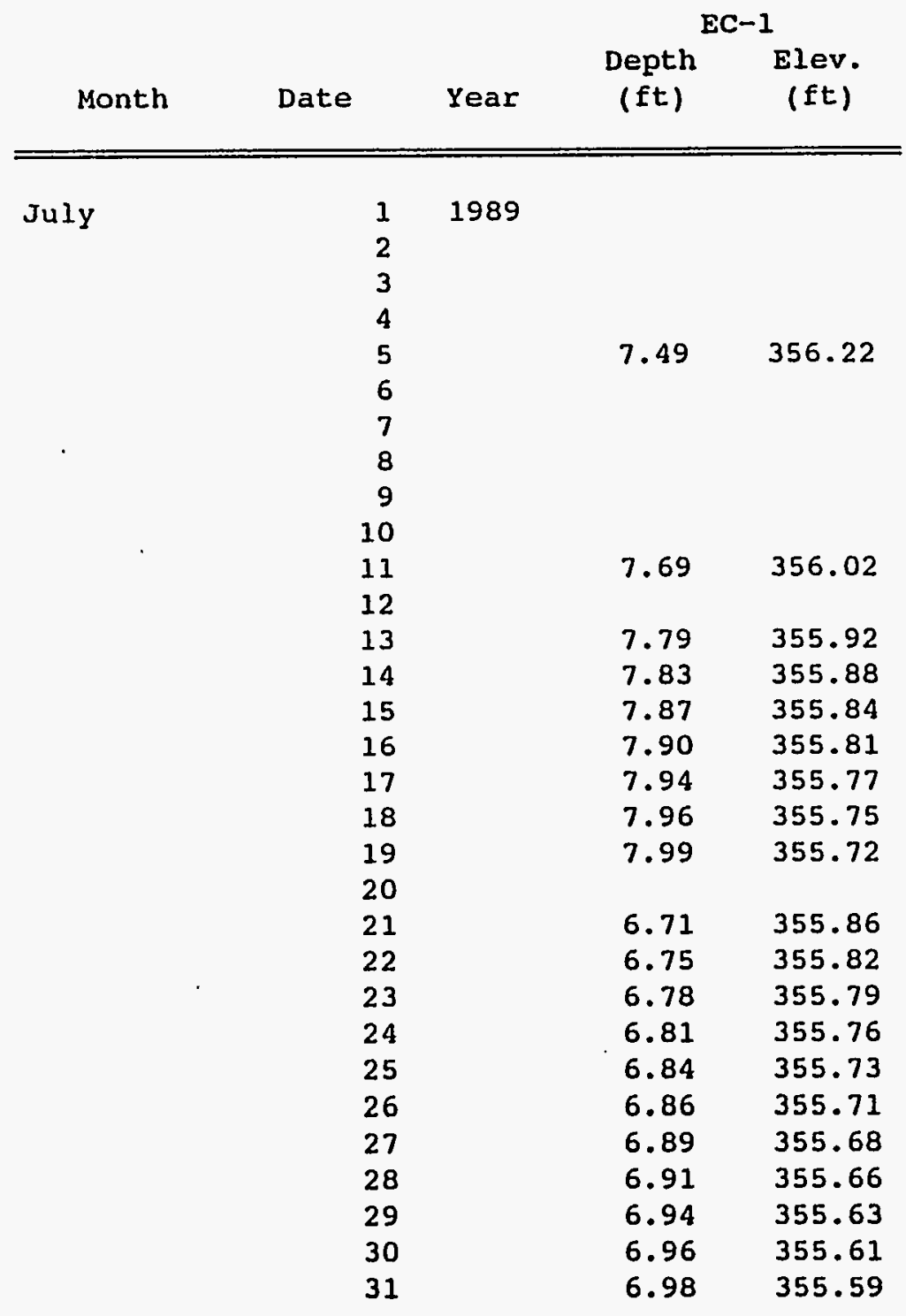




\begin{tabular}{|c|c|c|c|c|}
\hline & & & & \\
\hline Month & Date & Year & $\begin{array}{l}\text { Depth } \\
\text { (ft) }\end{array}$ & $\begin{array}{c}\text { Elev. } \\
\text { (ft) }\end{array}$ \\
\hline August & 1 & 1989 & 7.00 & 355.57 \\
\hline & 2 & & 7.02 & 355.55 \\
\hline & 3 & & 7.04 & 355.53 \\
\hline & 4 & & 7.06 & 355.51 \\
\hline & 5 & & 7.08 & 355.49 \\
\hline & 6 & & 7.10 & 355.47 \\
\hline & 7 & & 7.11 & 355.46 \\
\hline & 8 & & 7.12 & 355.45 \\
\hline & 9 & & 7.13 & 355.44 \\
\hline & 10 & & 7.14 & 355.43 \\
\hline & 11 & & 7.15 & 355.42 \\
\hline & 12 & & 7.16 & 355.41 \\
\hline & 13 & & & \\
\hline & 14 & & & \\
\hline & 15 & & & \\
\hline & 16 & & 7.20 & 355.37 \\
\hline & 17 & & & \\
\hline & 18 & & & \\
\hline & 19 & & & \\
\hline & 20 & & & \\
\hline & 21 & & & \\
\hline & 22 & & 7.27 & 355.30 \\
\hline & 23 & & 7.27 & 355.30 \\
\hline & 24 & & 7.28 & 355.29 \\
\hline & 25 & & 7.28 & 355.29 \\
\hline & 26 & & 7.29 & 355.28 \\
\hline ' & 27 & & 7.30 & 355.27 \\
\hline & 28 & & 7.30 & 355.27 \\
\hline & 29 & & 7.30 & 355.27 \\
\hline & 30 & & 7.30 & 355.27 \\
\hline & 31 & & 7.31 & 355.26 \\
\hline
\end{tabular}

\begin{tabular}{|c|c|c|c|c|}
\hline \multirow[b]{2}{*}{ Month } & \multirow[b]{2}{*}{ Date } & \multirow[b]{2}{*}{ Year } & \multicolumn{2}{|c|}{ EC-1 } \\
\hline & & & $\begin{array}{c}\text { Depth } \\
\text { (ft) }\end{array}$ & $\begin{array}{c}\text { Elev. } \\
(\mathrm{ft})\end{array}$ \\
\hline \multirow[t]{30}{*}{ September } & 1 & 1989 & 7.31 & 355.26 \\
\hline & 2 & & 7.32 & 355.25 \\
\hline & 3 & & 7.33 & 355.24 \\
\hline & 4 & & 7.33 & 355.24 \\
\hline & 5 & & 7.33 & 355.24 \\
\hline & 6 & & 7.33 & 355.24 \\
\hline & 7 & & 7.33 & 355.24 \\
\hline & 8 & & 7.33 & 355.24 \\
\hline & 9 & & 7.34 & 355.23 \\
\hline & 10 & & 7.35 & 355.22 \\
\hline & 11 & & 7.35 & 355.22 \\
\hline & 12 & & 7.36 & 355.21 \\
\hline & 13 & & 7.36 & 355.21 \\
\hline & 14 & & 7.36 & 355.21 \\
\hline & 15 & & 7.37 & 355.20 \\
\hline & 16 & & 7.37 & 355.20 \\
\hline & 17 & & 7.35 & 355.22 \\
\hline & 18 & & 7.33 & 355.24 \\
\hline & 19 & & 7.30 & 355.27 \\
\hline & 20 & & 7.27 & 355.30 \\
\hline & 21 & & 7.25 & 355.32 \\
\hline & 22 & & 7.24 & 355.33 \\
\hline & 23 & & 7.22 & 355.35 \\
\hline & 24 & & 7.20 & 355.37 \\
\hline & 25 & & 7.19 & 355.38 \\
\hline & 26 & & 7.18 & 355.39 \\
\hline & 27 & & 7.17 & 355.40 \\
\hline & 28 & & 7.17 & 355.40 \\
\hline & 29 & & 7.17 & 355.40 \\
\hline & 30 & & 7.17 & 355.40 \\
\hline
\end{tabular}




\begin{tabular}{|c|c|c|c|c|}
\hline & & & & \\
\hline Month & Date & Year & $\begin{array}{c}\text { Depth } \\
\text { (ft) }\end{array}$ & $\begin{array}{c}\text { Elev. } \\
\text { (ft) }\end{array}$ \\
\hline October & 1 & 1989 & 7.17 & 355.40 \\
\hline & 2 & & 7.16 & $355 . .41$ \\
\hline & 3 & & 7.15 & 355.42 \\
\hline & 4 & & 7.13 & 355.44 \\
\hline & 5 & & 7.10 & 355.47 \\
\hline & 6 & & 7.09 & 355.48 \\
\hline & 7 & & 7.07 & 355.50 \\
\hline & 8 & & 7.05 & 355.52 \\
\hline & 9 & & 7.04 & 355.53 \\
\hline & 10 & & 7.02 & 355.55 \\
\hline & 11 & & 7.01 & 355.56 \\
\hline & 12 & & 7.01 & 355.56 \\
\hline & 13 & & 7.00 & 355.57 \\
\hline & 14 & & 7.00 & 355.57 \\
\hline & 15 & & 6.99 & 355.58 \\
\hline & 16 & & 6.99 & 355.58 \\
\hline . & 17 & & 6.99 & 355.58 \\
\hline & 18 & & 6.97 & 355.60 \\
\hline & 19 & & 6.97 & 355.60 \\
\hline & 20 & & 6.96 & 355.61 \\
\hline & 21 & & 6.94 & 355.63 \\
\hline & 22 & & 6.93 & 355.64 \\
\hline & 23 & & 6.92 & 355.65 \\
\hline & 24 & & 6.90 & 355.67 \\
\hline & 25 & & 6.89 & 355.68 \\
\hline & 26 & & 6.87 & 355.70 \\
\hline & 27 & & 6.86 & 355.71 \\
\hline & 28 & - & 6.85 & 355.72 \\
\hline & 29 & & 6.83 & 355.74 \\
\hline & 30 & & 6.82 & 355.75 \\
\hline & 31 & & 6.81 & 355.76 \\
\hline
\end{tabular}

\begin{tabular}{|c|c|c|c|c|}
\hline & & & & \\
\hline Month & Date & Year & $\begin{array}{c}\text { Depth } \\
\text { (ft) }\end{array}$ & $\begin{array}{c}\text { Elev. } \\
\text { (ft) }\end{array}$ \\
\hline November- & 1 & 1989 & 6.80 & 355.77 \\
\hline & 2 & & 6.79 & 355.78 \\
\hline & 3 & & 6.78 & 355.79 \\
\hline & 4 & & 6.78 & 355.79 \\
\hline & 5 & & 6.78 & 355.79 \\
\hline & 6 & & 6.77 & 355.80 \\
\hline & 7 & & 6.77 & 355.80 \\
\hline & 8 & & 6.76 & 355.81 \\
\hline & 9 & & 6.76 & 355.81 \\
\hline & 10 & & 6.75 & 355.82 \\
\hline & 11 & & 6.75 & 355.82 \\
\hline & 12 & & 6.74 & 355.83 \\
\hline & 13 & & 6.74 & 355.83 \\
\hline & 14 & & 6.74 & 355.83 \\
\hline & 15 & & 6.73 & 355.84 \\
\hline & 16 & & 6.72 & 355.85 \\
\hline & 17 & & 6.72 & 355.85 \\
\hline & 18 & & 6.70 & 355.87 \\
\hline & 19 & & 6.69 & 355.88 \\
\hline & 20 & & 6.67 & 355.90 \\
\hline & 21 & & 6.66 & 355.91 \\
\hline & 22 & & 6.65 & 355.92 \\
\hline & 23 & & 6.63 & 355.94 \\
\hline & 24 & & 6.60 & 355.97 \\
\hline & 25 & & 6.58 & 355.99 \\
\hline & 26 & & 6.56 & 356.01 \\
\hline & 27 & & 6.54 & 356.03 \\
\hline & 28 & & 6.52 & 356.05 \\
\hline & 29 & & 6.49 & 356.08 \\
\hline & 30 & & 6.47 & 356.10 \\
\hline
\end{tabular}




\begin{tabular}{|c|c|c|c|c|}
\hline & & & & \\
\hline Month & Date & Year & $\begin{array}{c}\text { Depth } \\
\text { (ft) }\end{array}$ & $\begin{array}{c}\text { Elev. } \\
\text { (ft) }\end{array}$ \\
\hline December & 1 & 1989 & 6.45 & 356.12 \\
\hline & 2 & & 6.43 & 356.14 \\
\hline & 3 & & 6.42 & 356.15 \\
\hline & 4 & & 6.40 & 356.17 \\
\hline & 5 & & 6.40 & 356.17 \\
\hline & 6 & & 6.39 & 356.18 \\
\hline & 7 & & 6.38 & 356.19 \\
\hline & 8 & & 6.36 & 356.21 \\
\hline & 9 & & 6.35 & 356.22 \\
\hline & 10 & & 6.35 & 356.22 \\
\hline & 11 & & 6.35 & 356.22 \\
\hline & 12 & & 6.35 & 356.22 \\
\hline & 13 & & 6.35 & 356.22 \\
\hline & 14 & & 6.35 & 356.22 \\
\hline & 15 & & 6.35 & 356.22 \\
\hline & 16 & & 6.35 & 356.22 \\
\hline & 17 & & 6.35 & 356.22 \\
\hline & 18 & & 6.34 & 356.23 \\
\hline & 19 & & 6.33 & 356.24 \\
\hline & 20 & & 6.32 & 356.25 \\
\hline & 21 & & 6.31 & 356.26 \\
\hline & 22 & & 6.30 & 356.27 \\
\hline & 23 & & 6.27 & 356.30 \\
\hline & 24 & & 6.25 & 356.32 \\
\hline & 25 & & 6.20 & 356.37 \\
\hline & .26 & & 6.15 & 356.42 \\
\hline & 27 & & 6.10 & 356.47 \\
\hline & 28 & & 6.07 & 356.50 \\
\hline & 29 & & 6.04 & 356.53 \\
\hline & 30 & & 6.01 & 356.56 \\
\hline & 31 & & 5.97 & 356.60 \\
\hline
\end{tabular}

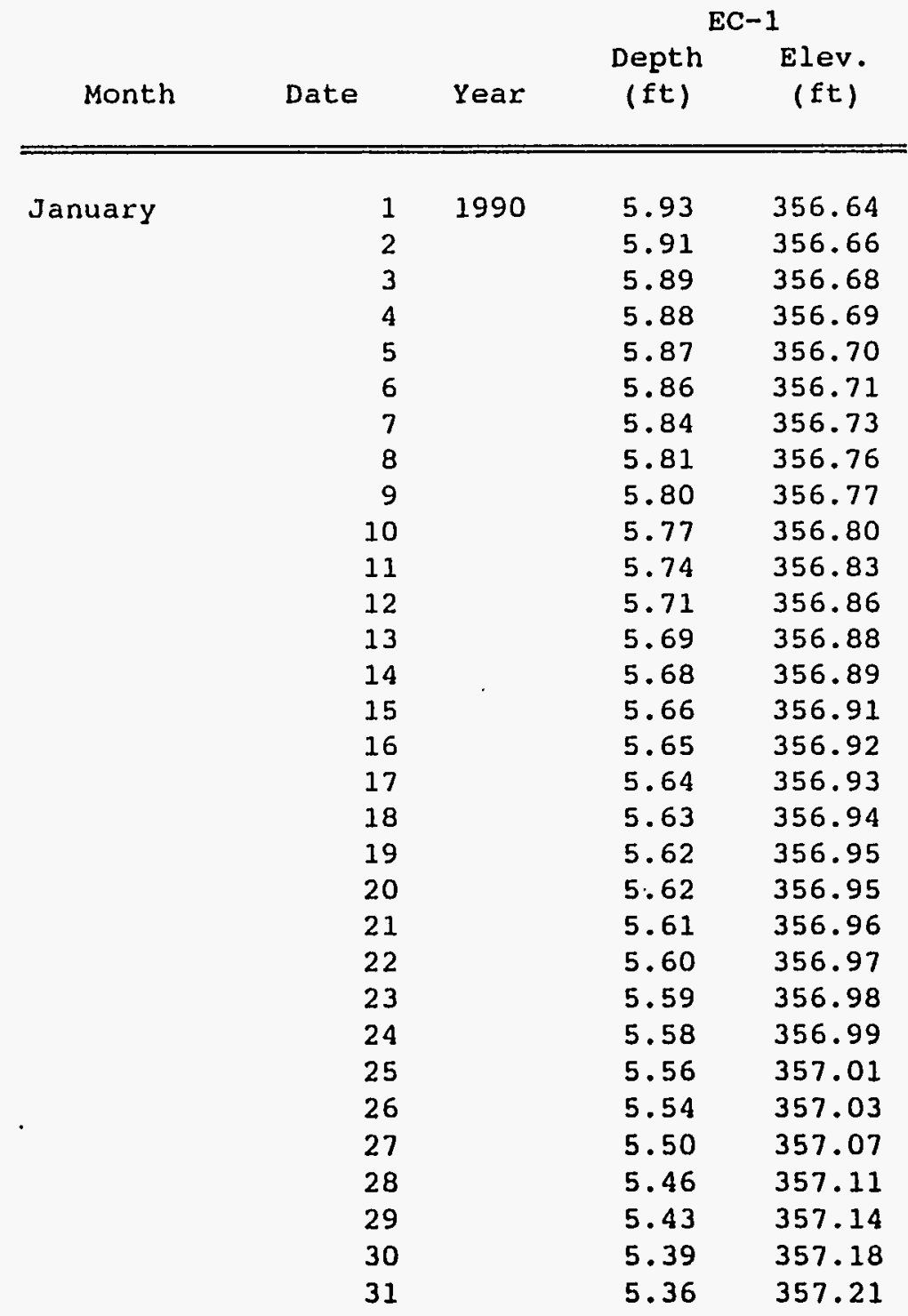




\begin{tabular}{|c|c|c|c|c|}
\hline & & & & \\
\hline Month & Date & Year & $\begin{array}{c}\text { Depth } \\
\text { (ft) }\end{array}$ & $\begin{array}{c}\text { Elev. } \\
(\mathrm{ft})\end{array}$ \\
\hline February & 1 & 1990 & 5.33 & 357.24 \\
\hline & 2 & & 5.31 & 357.26 \\
\hline & 3 & & 5.29 & 357.28 \\
\hline & 4 & & 5.28 & 357.29 \\
\hline & 5 & & 5.27 & 357.30 \\
\hline & 6 & & 5.26 & 357.31 \\
\hline & 7 & & 5.25 & 357.32 \\
\hline & 8 & & 5.24 & 357.33 \\
\hline . & 9 & & 5.24 & 357.33 \\
\hline & 10 & & 5.25 & 357.32 \\
\hline & 11 & & 5.25 & 357.32 \\
\hline & 12 & & 5.25 & 357.32 \\
\hline & 13 & & 5.27 & 357.30 \\
\hline & 14 & & 5.28 & 357.29 \\
\hline & 15 & & 5.26 & 357.31 \\
\hline & 16 & & 5.28 & 357.29 \\
\hline & 17 & & 5.30 & 357.27 \\
\hline & 18 & & 5.32 & 357.25 \\
\hline & 19 & & 5.30 & 357.27 \\
\hline & 20 & & 5.27 & 357.30 \\
\hline & 21 & & 5.28 & 357.29 \\
\hline & 22 & & 5.27 & 357.30 \\
\hline & 23 & & 5.28 & 357.29 \\
\hline & 24 & & 5.29 & 357.28 \\
\hline & 25 & & 5.29 & 357.28 \\
\hline & 26 & & 5.30 & 357.27 \\
\hline & 27 & & 5.30 & 357.27 \\
\hline & 28 & & 5.28 & 357.29 \\
\hline
\end{tabular}

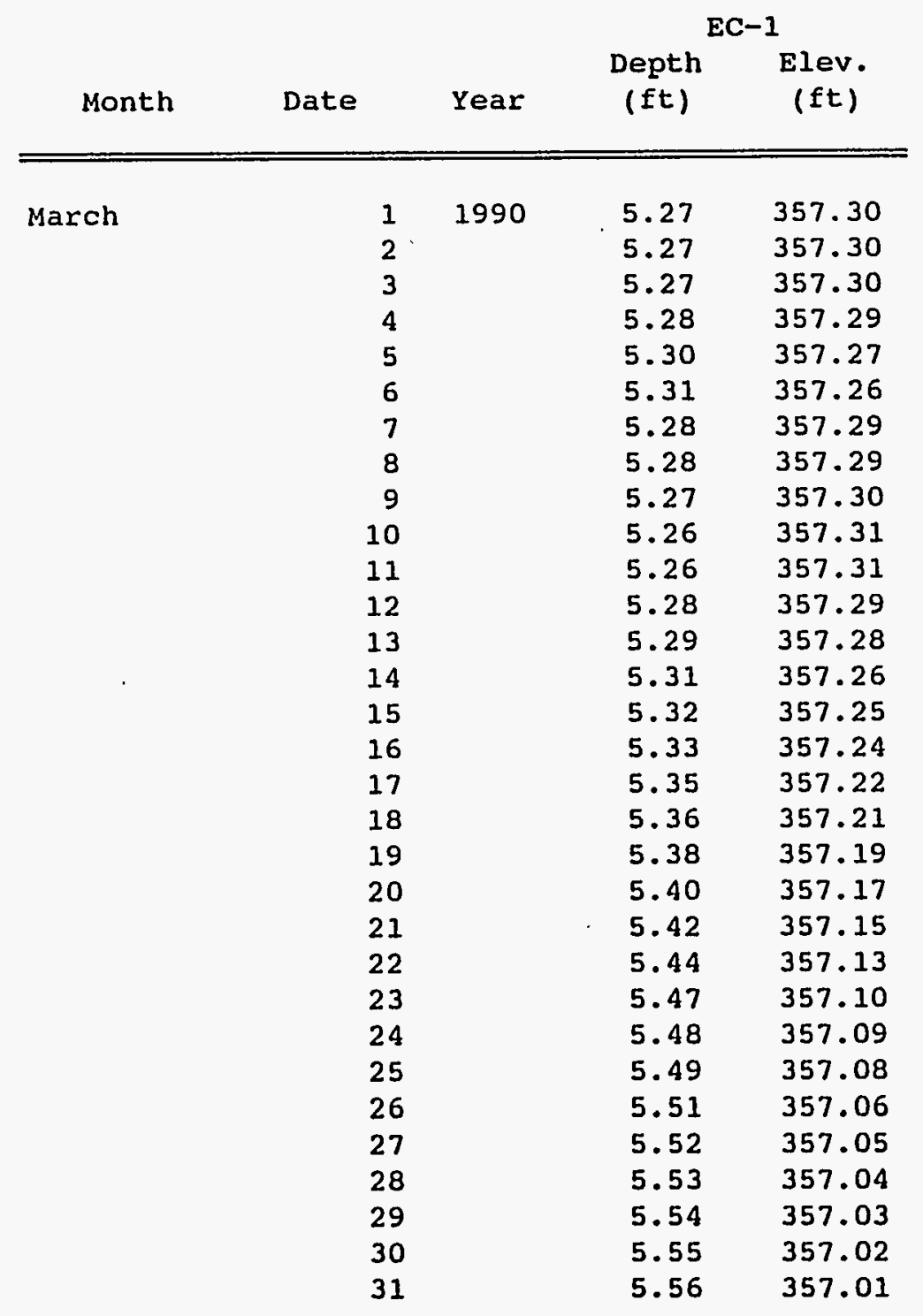




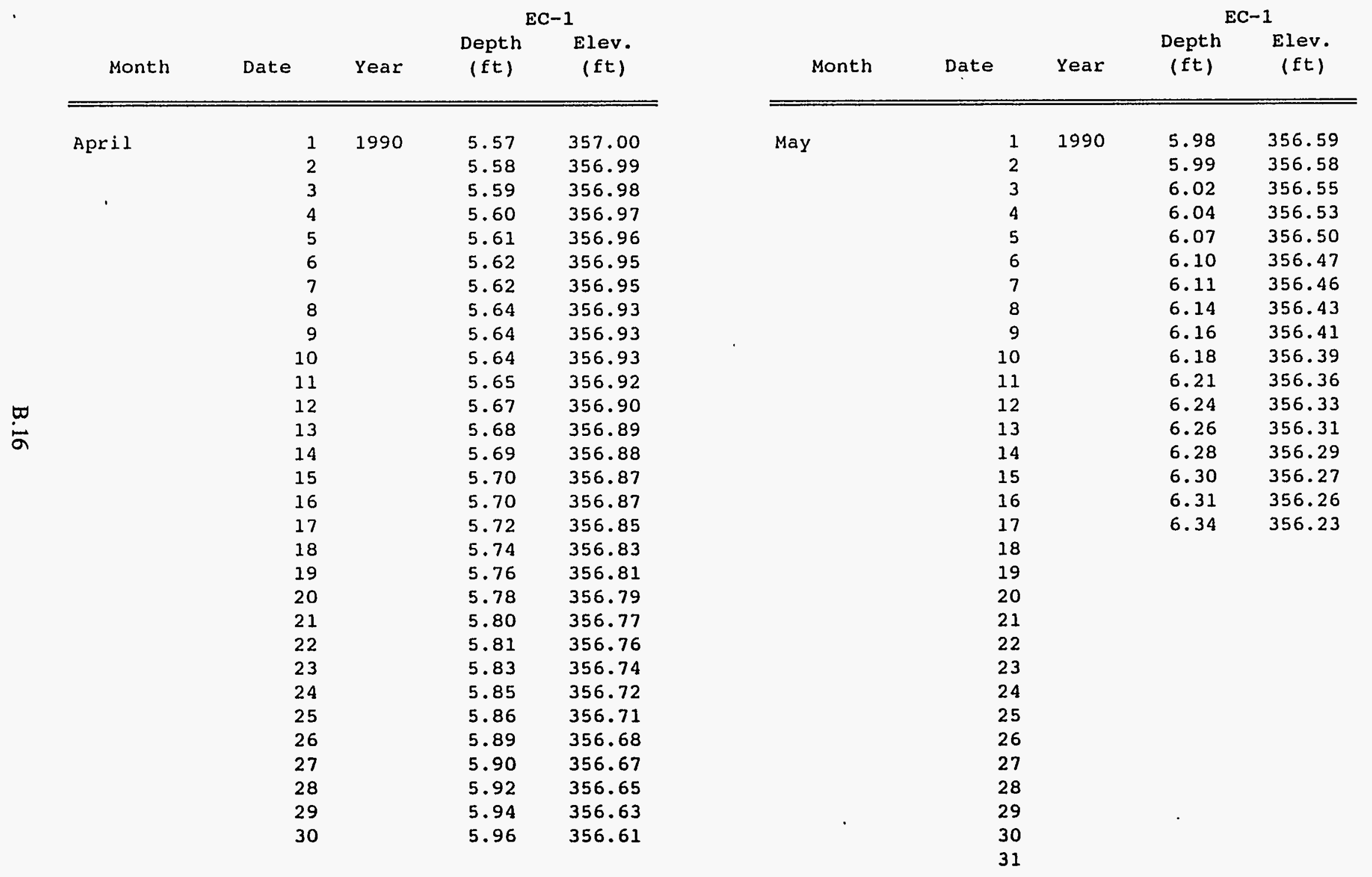




\begin{tabular}{|c|c|c|c|c|}
\hline & & & $\begin{array}{r}11 \\
(1199\end{array}$ & $\begin{array}{l}2 \\
-13)\end{array}$ \\
\hline Month & Date & Year & $\begin{array}{l}\text { Depth } \\
\text { (ft) }\end{array}$ & $\begin{array}{c}\text { Elev. } \\
(\mathrm{ft})\end{array}$ \\
\hline June & 1 & 1989 & & \\
\hline & 2 & & & \\
\hline & 3 & & & - \\
\hline & 4 & & & \\
\hline & 5 & & & \\
\hline & 6 & & & \\
\hline & 7 & & & \\
\hline & 8 & & & \\
\hline & 19 & & & \\
\hline & 10 & & & \\
\hline & 11 & & & \\
\hline & 12 & & & \\
\hline & 13 & & & \\
\hline & 14 & & 42.64 & 352.14 \\
\hline & 15 & & 42.62 & 352.16 \\
\hline & 16 & & 42.60 & 352.18 \\
\hline & 17 & & 42.58 & 352.20 \\
\hline & 18 & & 42.55 & 352.23 \\
\hline & 19 & & 42.52 & 352.26 \\
\hline & 20 & & 42.51 & 352.27 \\
\hline & 21 & & 42.48 & 352.30 \\
\hline & 22 & & 42.45 & 352.33 \\
\hline & 23 & & 42.43 & 352.35 \\
\hline & 24 & & 42.41 & 352.37 \\
\hline & 25 & & 42.39 & 352.39 \\
\hline & 26 & & 42.36 & 352.42 \\
\hline & 27 & & 42.34 & 352.44 \\
\hline & 28 & & 42.33 & 352.45 \\
\hline & 29 & & 42.30 & 352.48 \\
\hline & 30 & & 42.28 & 352.50 \\
\hline
\end{tabular}

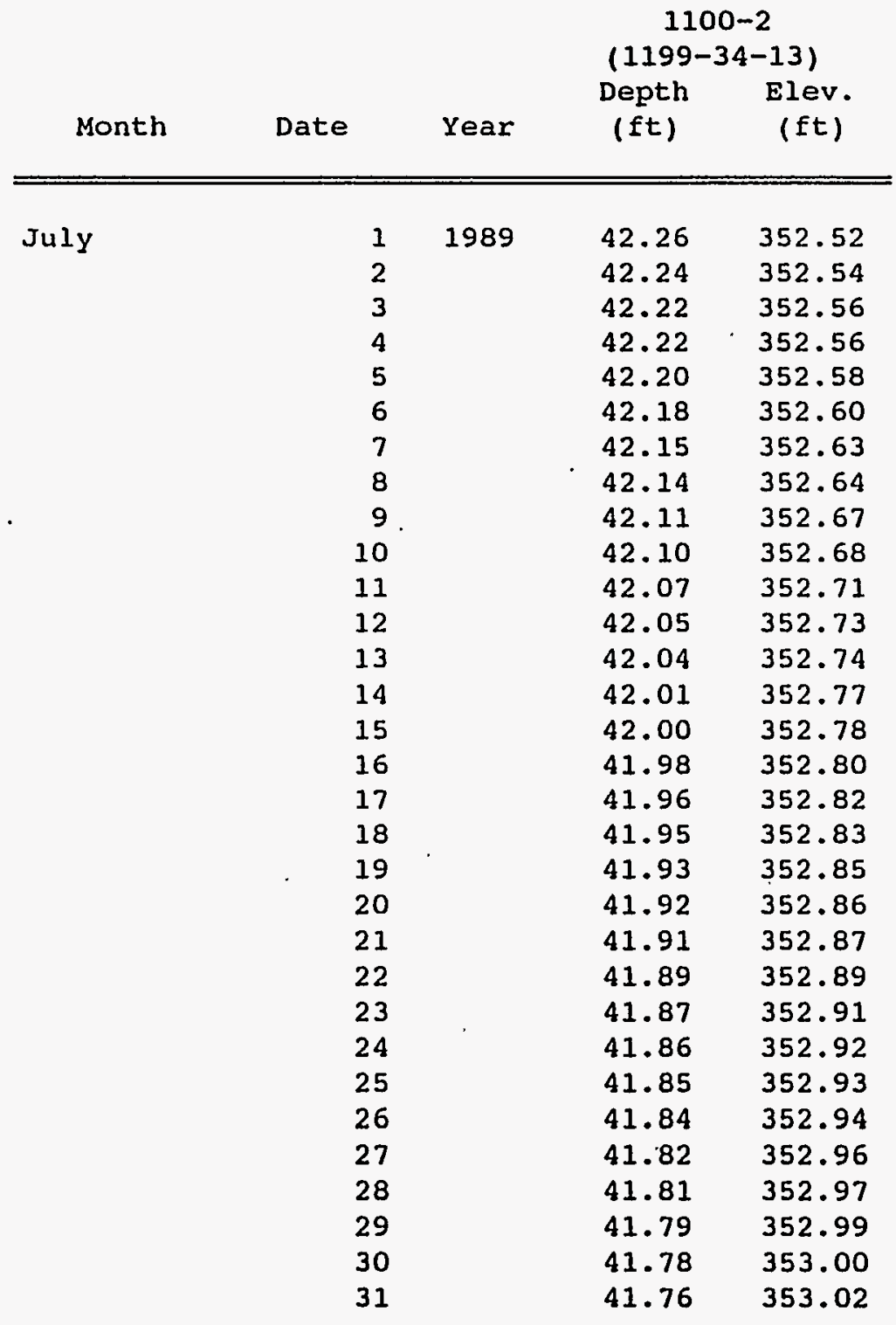




\begin{tabular}{|c|c|c|c|c|}
\hline & & & $\begin{array}{r}11 \\
\text { (1199. }\end{array}$ & $\begin{array}{l}-2 \\
-13)\end{array}$ \\
\hline Month & Date & Year & $\begin{array}{c}\text { Depth } \\
\text { (ft) }\end{array}$ & $\begin{array}{c}\text { Elev. } \\
\text { (ft) }\end{array}$ \\
\hline August & 1 & 1989 & 41.75 & 353.03 \\
\hline & 2 & & 41.72 & 353.06 \\
\hline & 3 & & 41.71 & 353.07 \\
\hline & 4 & & 41.70 & 353.08 \\
\hline & 5 & & 41.69 & 353.09 \\
\hline & 6 & & & \\
\hline & 7 & & & \\
\hline & 8 & & 41.69 & 353.09 \\
\hline & 9 & & 41.68 & 353.10 \\
\hline & 10 & & 41.67 & 353.11 \\
\hline & 11 & & 41.67 & 353.11 \\
\hline & 12 & & 41.66 & 353.12 \\
\hline & 13 & & 41.65 & 353.13 \\
\hline & 14 & & 41.64 & 353.14 \\
\hline & 15 & & 41.63 & 353.15 \\
\hline & 16 & & 41.62 & 353.16 \\
\hline & 17 & & 41.62 & 353.16 \\
\hline & 18 & & 41.61 & 353.17 \\
\hline & 19 & & 41.61 & 353.17 \\
\hline & 20 & & 41.60 & 353.18 \\
\hline & 21 & & 41.59 & 353.19 \\
\hline & 22 & & 41.57 & 353.21 \\
\hline & 23 & & 41.56 & 353.22 \\
\hline & 24 & & 41.55 & 353.23 \\
\hline & 25 & & 41.54 & 353.24 \\
\hline & 26 & & 41.53 & 353.25 \\
\hline & 27 & & 41.53 & 353.25 \\
\hline & 28 & & 41.52 & 353.26 \\
\hline & 29 & & 41.51 & 353.27 \\
\hline & 30 & & 41.50 & 353.28 \\
\hline & 31 & & 41.50 & 353.28 \\
\hline
\end{tabular}

\begin{tabular}{|c|c|c|c|c|}
\hline & & & $\begin{array}{r}11 \\
(1199\end{array}$ & $\begin{array}{l}2 \\
-13)\end{array}$ \\
\hline Month & Date & Year & $\begin{array}{c}\text { Depth } \\
(\mathrm{ft})\end{array}$ & $\begin{array}{c}\text { Elev. } \\
(f t)\end{array}$ \\
\hline September & 1 & 1989 & 41.50 & 353.28 \\
\hline & 2 & & 41.50 & 353.28 \\
\hline & 3 & & 41.50 & 353.28 \\
\hline & 4 & & 41.49 & 353.29 \\
\hline & 5 & & 41.50 & 353.28 \\
\hline & 6 & & 41.49 & 353.29 \\
\hline & 7 & & 41.49 & 353.29 \\
\hline & 8 & & 41.49 & 353.29 \\
\hline & 9 & & 41.50 & 353.28 \\
\hline & 10 & & 41.50 & 353.28 \\
\hline & 11 & & & \\
\hline & 12 & & & \\
\hline & 13 & & & \\
\hline & 14 & & & \\
\hline & 15 & & & \\
\hline & 16 & & & \\
\hline & 17 & & & \\
\hline & 18 & & & \\
\hline & 19 & & & \\
\hline & 20 & & & \\
\hline & 21 & & & \\
\hline & 22 & & & \\
\hline & 23 & & & \\
\hline & 24 & & & \\
\hline & 25 & & & \\
\hline & 26 & & & \\
\hline & 27 & & & \\
\hline & 28 & & & \\
\hline & 29 & & & \\
\hline & 30 & & & \\
\hline
\end{tabular}




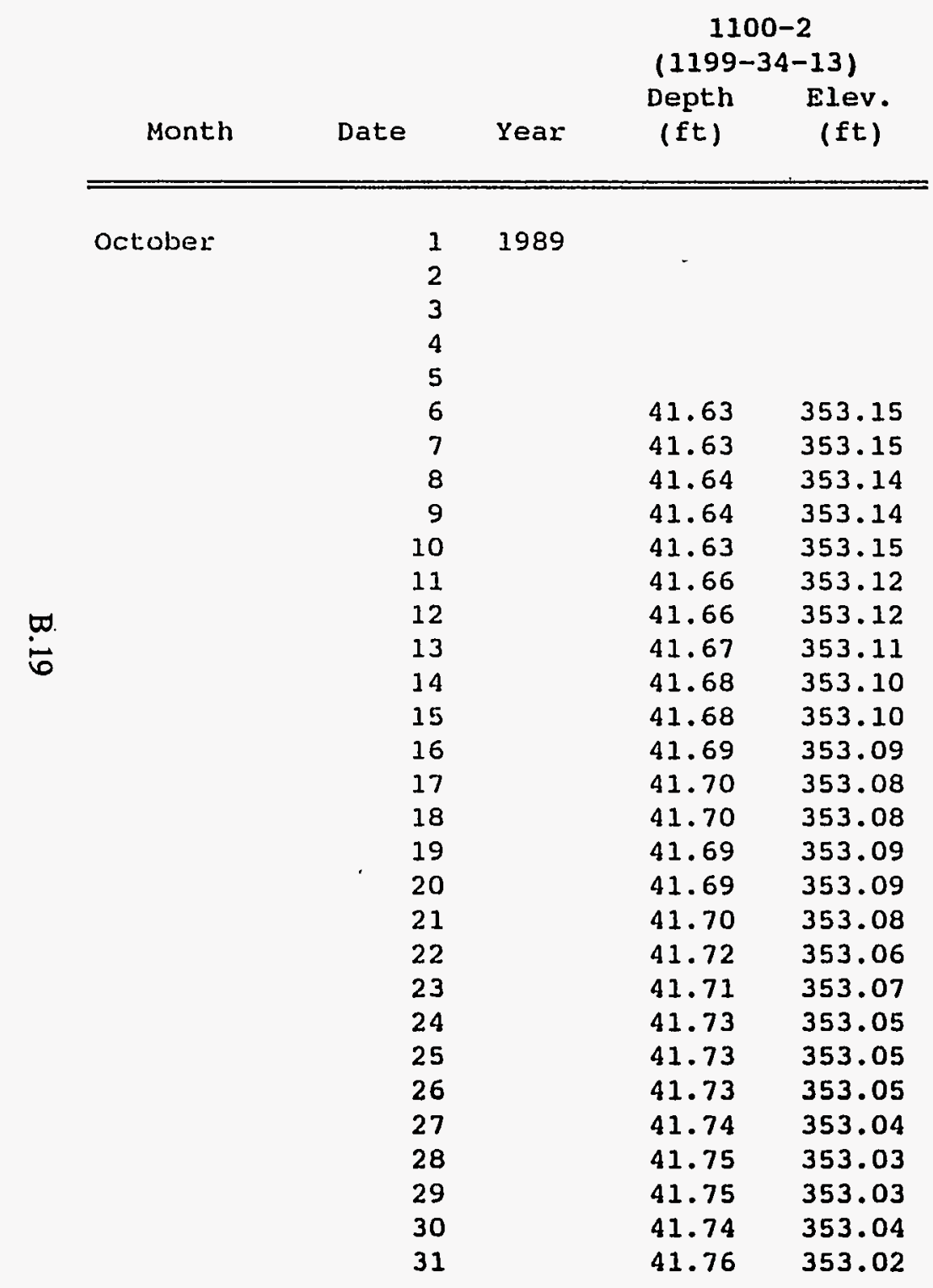

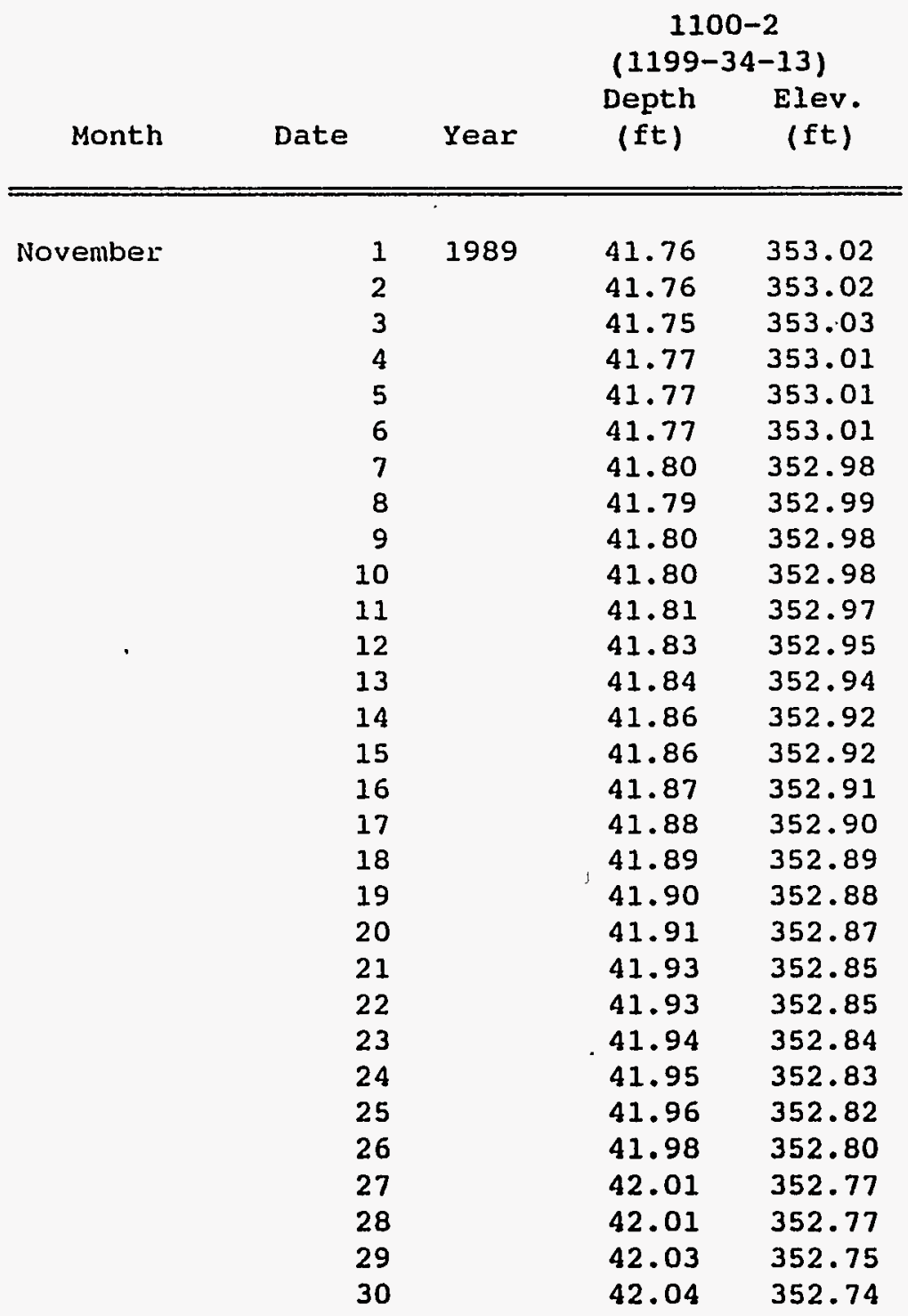


$1100-2$

(1199-34-13)

Depth Elev

Month Date Year (ft) (ft)

is

\begin{tabular}{llll}
\hline \hline & & & \\
December & 1 & 42.05 & 352.73 \\
2 & 42.05 & 352.73 \\
3 & 42.06 & 352.72 \\
4 & 42.06 & 352.72 \\
5 & 42.08 & 352.70 \\
6 & 42.09 & 352.69 \\
7 & 42.09 & 352.69 \\
8 & 42.10 & 352.68 \\
9 & 42.12 & 352.66 \\
10 & 42.13 & 352.65 \\
11 & 42.12 & 352.66 \\
12 & 42.13 & 352.65 \\
13 & 42.14 & 352.64 \\
14 & 42.14 & 352.64 \\
15 & 42.15 & 352.63 \\
16 & 42.15 & 352.63 \\
17 & 42.16 & 352.62 \\
18 & 42.16 & 352.62 \\
19 & 42.17 & 352.61 \\
20 & 42.17 & 352.61 \\
21 & 42.18 & 352.60 \\
22 & 42.19 & 352.59 \\
23 & 42.20 & 352.58 \\
24 & 42.19 & 352.59 \\
25 & 42.19 & 352.59 \\
26 & 42.18 & 352.60 \\
27 & 32.18 & 352.60 \\
28 & 352.58 \\
29 & 352.58 \\
30 & 352.58 \\
31 & 352.59
\end{tabular}

$1100-2$

(1199-34-13)

Depth Elev.

(ft) (ft)

\begin{tabular}{llll}
\hline January & & & \\
& 1 & & \\
2 & 42.19 & 352.59 \\
3 & 42.21 & 352.57 \\
4 & 42.21 & 352.57 \\
5 & 42.21 & 352.57 \\
6 & 42.20 & 352.58 \\
7 & 42.20 & 352.58 \\
8 & 42.20 & 352.58 \\
9 & 42.22 & 352.56 \\
10 & 42.20 & 352.58 \\
11 & 42.23 & 352.55 \\
12 & 42.22 & 352.56 \\
13 & 42.20 & 352.58 \\
14 & 42.21 & 352.57 \\
15 & 42.23 & 352.55 \\
16 & 42.22 & 352.56 \\
17 & 42.23 & 352.55 \\
18 & 42.24 & 352.54 \\
19 & 42.24 & 352.54 \\
20 & 42.25 & 352.53 \\
21 & 42.25 & 352.53 \\
22 & 42.24 & 352.54 \\
23 & 42.25 & 352.53 \\
24 & 42.27 & 352.51 \\
25 & 42.28 & 352.50 \\
26 & 352.51 \\
27 & 352.48 \\
28 & 352.49 \\
29 & 352.50 \\
30 & 352.48 \\
& & 352.47 \\
& & 352.46
\end{tabular}


1100-2

(1199-34-13)

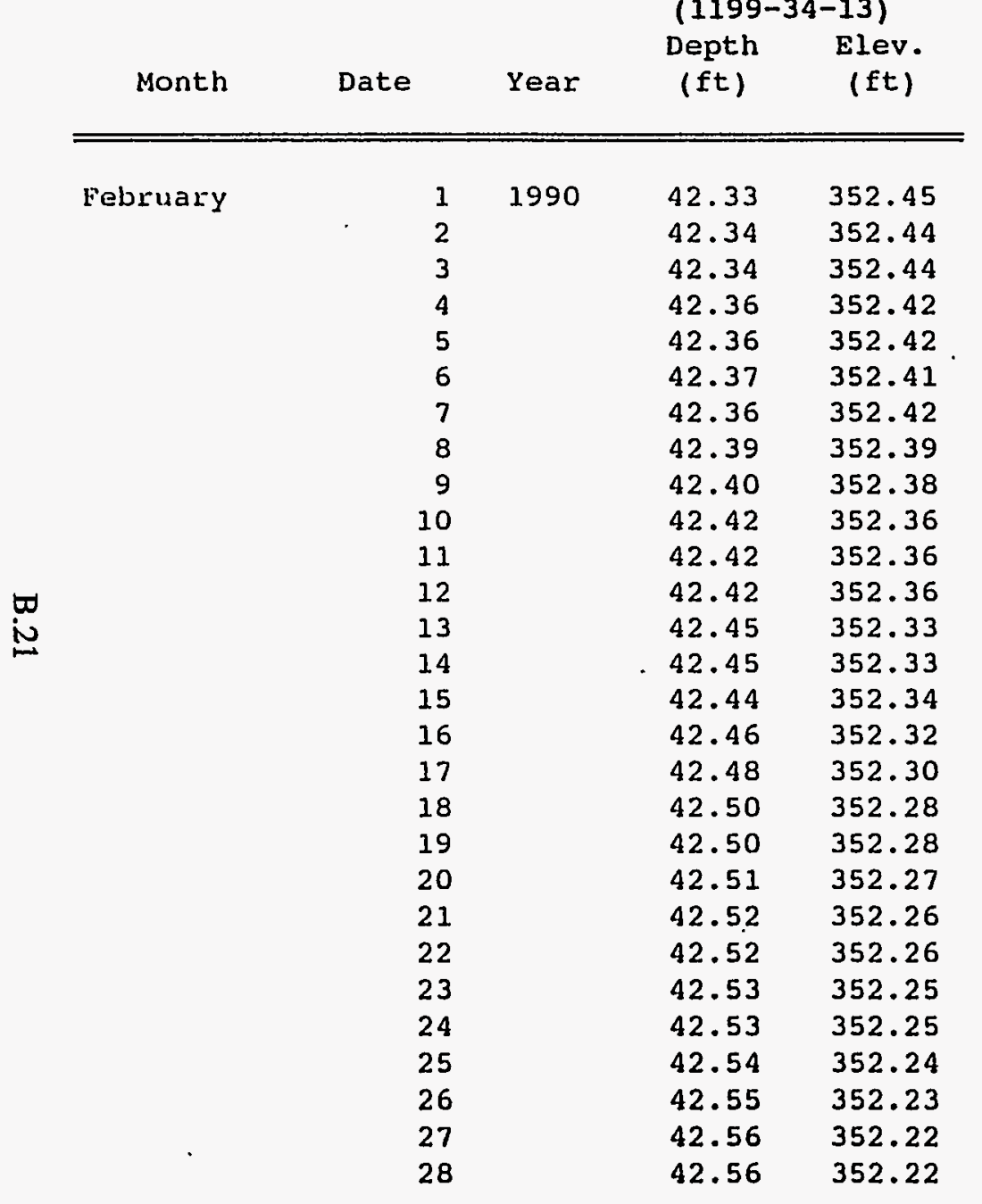

1100-2

(1199-34-13)

Depth Elev.

(ft) (ft)

\begin{tabular}{cccc}
\hline March & & & \\
& 1 & & \\
2 & 42.57 & 352.21 \\
3 & 42.57 & 352.21 \\
4 & 42.58 & 352.20 \\
5 & 42.58 & 352.20 \\
6 & 42.60 & 352.18 \\
7 & 42.61 & 352.17 \\
8 & 42.61 & 352.17 \\
9 & 42.62 & 352.16 \\
10 & 42.62 & 352.16 \\
11 & 42.63 & 352.15 \\
12 & 42.65 & 352.13 \\
13 & 42.66 & 352.12 \\
14 & 42.67 & 352.11 \\
15 & 42.68 & 352.10 \\
16 & 42.69 & 352.09 \\
17 & 42.69 & 352.09 \\
18 & 42.70 & 352.08 \\
19 & 42.70 & 352.08 \\
20 & 42.71 & 352.07 \\
21 & 42.72 & 352.06 \\
22 & 42.73 & 352.05 \\
23 & 42.73 & 352.05 \\
24 & 42.75 & 352.03 \\
25 & 42.75 & 352.03 \\
26 & 42.75 & 352.03 \\
27 & 42.76 & 352.02 \\
28 & 42.77 & 352.01 \\
29 & 42.78 & 352.00 \\
30 & 32.79 & 351.99 \\
31 & 351.99 \\
& 351.97
\end{tabular}


$1100-2$

(1199-34-13) Depth Elev.

Month Date Year (ft) (ft)

\begin{tabular}{|c|c|c|c|c|}
\hline \multirow[t]{30}{*}{ April } & 1 & 1990 & 42.82 & 351.96 \\
\hline & 2 & & 42.83 & 351.95 \\
\hline & 3 & & 42.84 & 351.94 \\
\hline & 4 & & 42.85 & 351.93 \\
\hline & 5 & & 42.85 & 351.93 \\
\hline & 6 & & 42.86 & 351.92 \\
\hline & 7 & & 42.87 & 351.91 \\
\hline & 8 & & 42.89 & 351.89 \\
\hline & 9 & & 42.90 & 351.88 \\
\hline & 10 & & 42.90 & 351.88 \\
\hline & 11 & & 42.91 & 351.87 \\
\hline & 12 & & 42.92 & 351.86 \\
\hline & 13 & & 42.92 & 351.86 \\
\hline & 14 & & 42.93 & 351.85 \\
\hline & 15 & & 42.93 & 351.85 \\
\hline & 16 & & 42.94 & 351.84 \\
\hline & 17 & & 42.95 & 351.83 \\
\hline & 18 & & 42.95 & 351.83 \\
\hline & 19 & & 42.96 & 351.82 \\
\hline & 20 & & 42.96 & 351.82 \\
\hline & 21 & & 42.96 & 351.82 \\
\hline & 22 & & 42.96 & 351.82 \\
\hline & 23 & & 42.97 & 351.81 \\
\hline & 24 & & 42.97 & 351.81 \\
\hline & 25 & & 42.96 & 351.82 \\
\hline & 26 & & 42.97 & 351.81 \\
\hline & 27 & & 42.96 & 351.82 \\
\hline & 28 & & 42.96 & 351.82 \\
\hline & 29 & & 42.97 & 351.81 \\
\hline & 30 & & 42.98 & 351.80 \\
\hline
\end{tabular}

$1100-2$

(1199-34-13)

Depth Elev.

(ft) (ft)

\begin{tabular}{|c|c|c|c|c|}
\hline \multirow[t]{17}{*}{ May } & 1 & 1990 & 42.96 & 351.82 \\
\hline & 2 & & 42.96 & 351.82 \\
\hline & 3 & & 42.98 & 351.80 \\
\hline & 4 & & 42.97 & 351.81 \\
\hline & 5 & & 42.95 & 351.83 \\
\hline & 6 & & 42.95 & 351.83 \\
\hline & 7 & & 42.94 & 351.84 \\
\hline & 8 & & 42.95 & 351.83 \\
\hline & 9 & & 42.93 & 351.85 \\
\hline & 10 & & 42.93 & 351.85 \\
\hline & 11 & & 42.92 & 351.86 \\
\hline & 12 & & 42.92 & 351.86 \\
\hline & 13 & & 42.91 & 351.87 \\
\hline & 14 & & 42.91 & 351.87 \\
\hline & 15 & & 42.91 & 351.87 \\
\hline & 16 & & 42.90 & 351.88 \\
\hline & 17 & & 42.90 & 351.88 \\
\hline
\end{tabular}




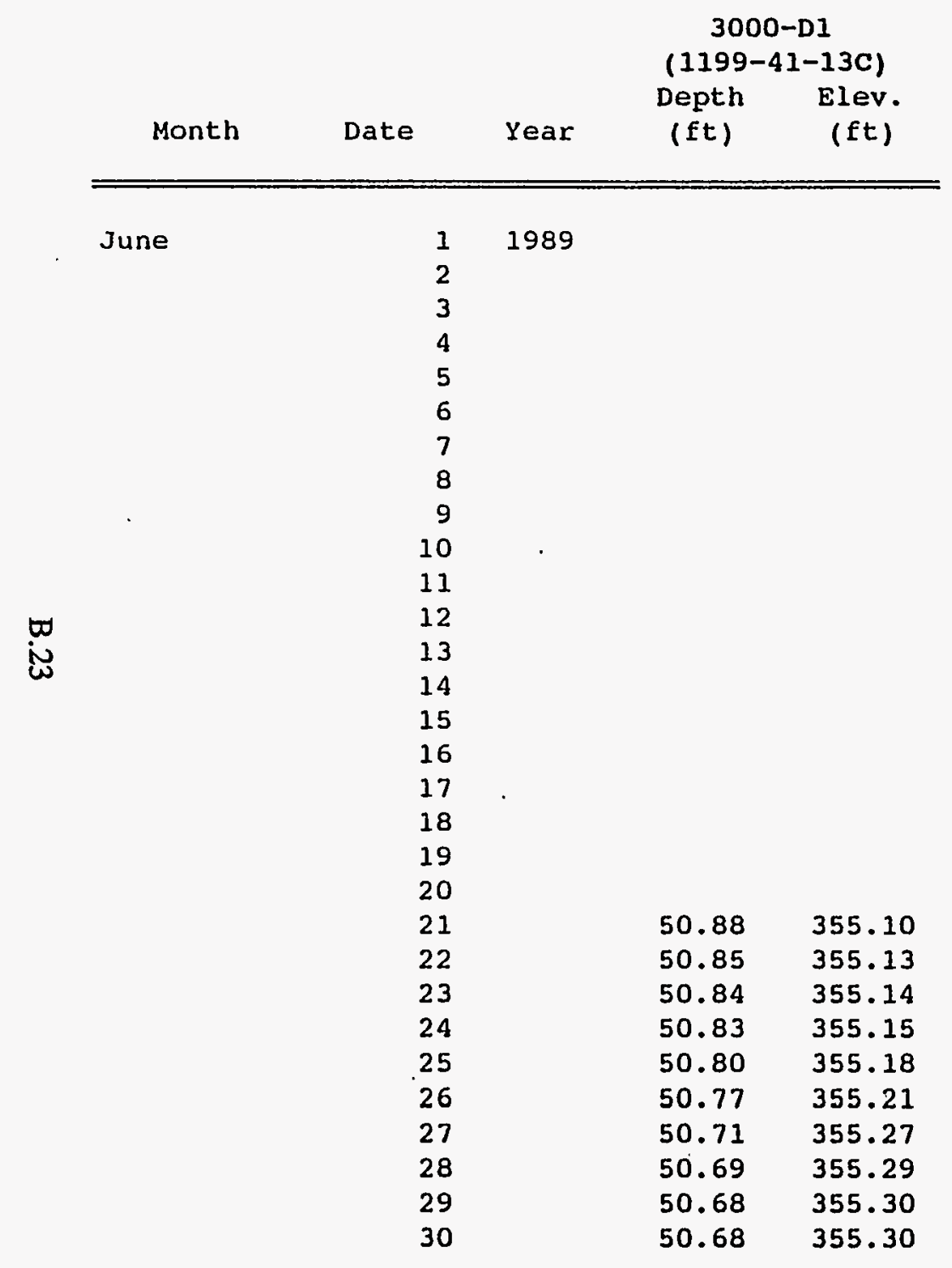

3000-D1

(1199-41-13C)

Depth Elev.

(ft) (ft)

\begin{tabular}{|c|c|c|c|c|}
\hline \multirow[t]{31}{*}{ July } & 1 & 1989 & 50.68 & 355.30 \\
\hline & 2 & & 50.63 & 355.35 \\
\hline & 3 & & 50.61 & 355.37 \\
\hline & 4 & & 50.64 & 355.34 \\
\hline & 5 & & 50.67 & 355.31 \\
\hline & 6 & & 50.69 & 355.29 \\
\hline & 7 & & 50.70 & 355.28 \\
\hline & 8 & & 50.72 & 355.26 \\
\hline & 9 & & 50.70 & 355.28 \\
\hline & 10 & & 50.67 & 355.31 \\
\hline & 11 & & 50.64 & 355.34 \\
\hline & 12 & & 50.63 & 355.35 \\
\hline & 13 & & 50.65 & 355.33 \\
\hline & 14 & & 50.67 & 355.31 \\
\hline & 15 & & 50.77 & 355.21 \\
\hline & 16 & & 50.82 & 355.16 \\
\hline & 17 & & 50.74 & 355.24 \\
\hline & 18 & & 50.70 & 355.28 \\
\hline & 19 & & 50.71 & 355.27 \\
\hline & 20 & & 50.75 & 355.23 \\
\hline & 21 & & 50.80 & 355.18 \\
\hline & 22 & & 50.81 & 355.17 \\
\hline & 23 & & 50.77 & 355.21 \\
\hline & 24 & & 50.7 .4 & 355.24 \\
\hline & 25 & & 50.72 & 355.26 \\
\hline & 26 & & 50.73 & 355.25 \\
\hline & 27 & & 50.75 & 355.23 \\
\hline & 28 & & 50.74 & 355.24 \\
\hline & 29 & & 50.72 & 355.26 \\
\hline & 30 & & 50.68 & 355.30 \\
\hline & 31 & & 50.64 & 355.34 \\
\hline
\end{tabular}




\begin{tabular}{|c|c|c|c|c|}
\hline & & & $\begin{array}{r}300 \\
(1199-\end{array}$ & $\begin{array}{l}D 1 \\
-13 C)\end{array}$ \\
\hline Month & Date & Year & $\begin{array}{l}\text { Depth } \\
(\mathrm{ft})\end{array}$ & $\begin{array}{c}\text { Elev. } \\
\text { (ft) }\end{array}$ \\
\hline August & 1 & 1989 & 50.61 & 355.37 \\
\hline & 2 & & 50.57 & 355.41 \\
\hline & 3 & & 50.53 & 355.45 \\
\hline & 4 & & 50.55 & 355.43 \\
\hline & 5 & & 50.55 & 355.43 \\
\hline & 6 & & 50.52 & 355.46 \\
\hline & 7 & & 50.50 & 355.48 \\
\hline & 8 & & 50.48 & 355.50 \\
\hline & 9 & & 50.50 & 355.48 \\
\hline & 10 & & 50.42 & 355.56 \\
\hline & 11 & & 50.37 & 355.61 \\
\hline & 12 & & 50.35 & 355.63 \\
\hline & 13 & & 50.31 & 355.67 \\
\hline & 14 & & 50.27 & 355.71 \\
\hline & 15 & & 50.24 & 355.74 \\
\hline & 16 & & 50.16 & 355.82 \\
\hline & 17 & & 50.13 & 355.85 \\
\hline & 18 & & 50.11 & 355.87 \\
\hline & 19 & & 50.08 & 355.90 \\
\hline & 20 & & 50.07 & 355.91 \\
\hline & 21 & & 50.03 & 355.95 \\
\hline & 22 & & 50.00 & 355.98 \\
\hline & 23 & & 50.10 & 355.88 \\
\hline & 24 & & 50.24 & 355.74 \\
\hline & 25 & & 50.36 & 355.62 \\
\hline & 26 & & 50.44 & 355.54 \\
\hline & 27 & & 50.50 & 355.48 \\
\hline & 28 & & 50.52 & 355.46 \\
\hline & 29 & & 50.51 & 355.47 \\
\hline & 30 & & 50.57 & 355.41 \\
\hline & 31 & & 50.63 & 355.35 \\
\hline
\end{tabular}

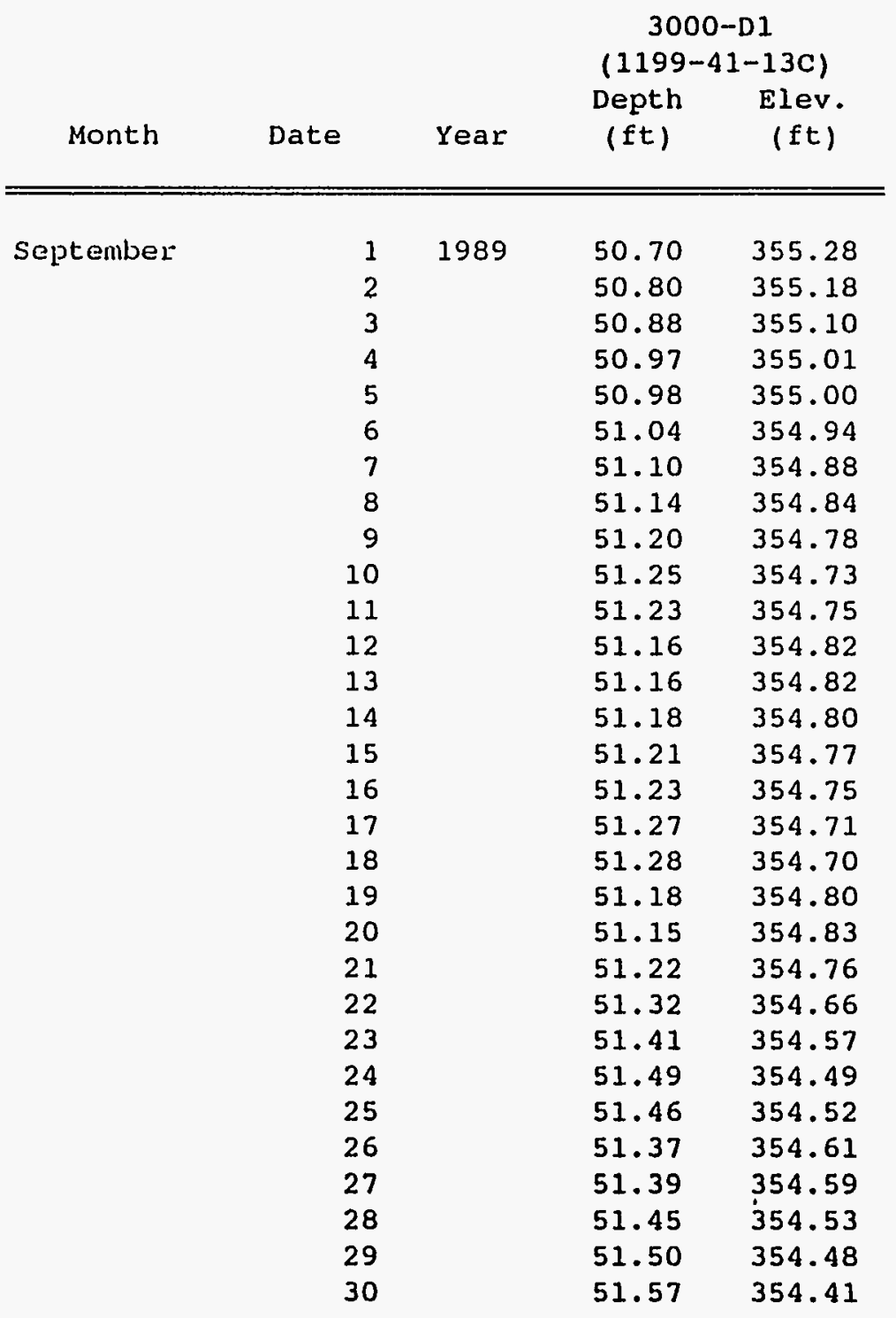




\begin{tabular}{|c|c|c|c|c|}
\hline \multirow[b]{2}{*}{ Month } & \multirow[b]{2}{*}{ Date } & \multirow[b]{2}{*}{ Year } & \multicolumn{2}{|c|}{$\begin{array}{c}3000-D 1 \\
(1199-41-13 C)\end{array}$} \\
\hline & & & $\begin{array}{l}\text { Depth } \\
\text { (ft) }\end{array}$ & $\begin{array}{l}\text { Elev. } \\
\text { (ft) }\end{array}$ \\
\hline \multirow[t]{30}{*}{ October } & 1 & 1989 & 51.66 & 354.32 \\
\hline & 2 & & & \\
\hline & 3 & & & \\
\hline & $\begin{array}{l}4 \\
5\end{array}$ & & & \\
\hline & 6 & & 51.64 & 354.34 \\
\hline & 7 & & 51.66 & 354.32 \\
\hline & 8 & & 51.67 & 354.31 \\
\hline & 9 & & 51.66 & 354.32 \\
\hline & 10 & & 51.58 & 354.40 \\
\hline & 11 & & 51.57 & 354.41 \\
\hline & 12 & & 51.59 & 354.39 \\
\hline & 13 & & 51.65 & 354.33 \\
\hline & 14 & & 51.72 & 354.26 \\
\hline & 15 & & 51.77 & 354.21 \\
\hline & 16 & & 51.75 & 354.23 \\
\hline & 17 & & 51.70 & 354.28 \\
\hline & 18 & & 51.74 & 354.24 \\
\hline & 19 & & 51.75 & 354.23 \\
\hline & 20 & & 51.75 & 354.23 \\
\hline & 21 & & 51.77 & 354.21 \\
\hline & 22 & & 51.79 & 354.19 \\
\hline & 23 & & 51.75 & 354.23 \\
\hline & 24 & & 51.65 & 354.33 \\
\hline & 25 & & 51.66 & 354.32 \\
\hline & 26 & & 51.72 & 354.26 \\
\hline & 27 & & 51.77 & 354.21 \\
\hline & 28 & & 51.84 & 354.14 \\
\hline & 29 & & 51.90 & 354.08 \\
\hline & 30 & & 51.96 & 354.02 \\
\hline & 31 & & 51.95 & 354.03 \\
\hline
\end{tabular}

3000-D1

(1199-41-13C)

Depth Elev.

(ft) (ft)

\begin{tabular}{llll}
\hline November & & & \\
\hline & 1 & 52.02 & 353.96 \\
2 & 52.05 & 353.93 \\
3 & 52.10 & 353.88 \\
4 & 52.20 & 353.78 \\
& 5 & 52.29 & 353.69 \\
6 & 52.36 & 353.62 \\
7 & 52.28 & 353.70 \\
8 & 52.28 & 353.70 \\
9 & 52.36 & 353.62 \\
10 & 52.46 & 353.52 \\
11 & 52.57 & 353.41 \\
12 & 52.69 & 353.29 \\
13 & 52.82 & 353.16 \\
14 & 52.77 & 353.21 \\
15 & 52.80 & 353.18 \\
16 & 52.87 & 353.11 \\
17 & 52.95 & 353.03 \\
18 & 52.97 & 353.01 \\
19 & 52.98 & 353.00 \\
20 & 52.92 & 353.06 \\
21 & 52.76 & 353.22 \\
22 & 52.76 & 353.22 \\
23 & 52.65 & 353.33 \\
24 & 52.54 & 353.44 \\
25 & 52.45 & 353.53 \\
26 & 353.65 \\
27 & 353.73 \\
28 & 353.78 \\
29 & 353.76 \\
30 & 353.55
\end{tabular}


3000-D1

$(1199-41-13 \mathrm{C})$

Depth Elev.

Month Date Year (ft) (ft)

\begin{tabular}{|c|c|c|c|c|}
\hline \multirow[t]{31}{*}{ December } & 1 & 1989 & 52.63 & 353.35 \\
\hline & 2 & & 52.57 & 353.41 \\
\hline & 3 & & 52.44 & 353.54 \\
\hline & 4 & & 52.31 & 353.67 \\
\hline & 5 & & 52.22 & 353.76 \\
\hline & 6 & & 52.14 & 353.84 \\
\hline & 7 & & 52.07 & 353.91 \\
\hline & 8 & & 52.02 & 353.96 \\
\hline & 9 & & 51.98 & 354.00 \\
\hline & 10 & & 51.94 & 354.04 \\
\hline & 11 & & 51.90 & 354.08 \\
\hline & 12 & & 51.87 & 354.11 \\
\hline & 13 & & 51.88 & 354.10 \\
\hline & 14 & & 51.90 & 354.08 \\
\hline & 15 & & 51.88 & 354.10 \\
\hline & 16 & & 51.85 & 354.13 \\
\hline & 17 & & 51.81 & 354.17 \\
\hline & 18 & & 51.80 & 354.18 \\
\hline & 19 & & 51.77 & 354.21 \\
\hline & 20 & & 51.74 & 354.24 \\
\hline & 21 & & 51.72 & 354.26 \\
\hline & 22 & & 51.70 & 354.28 \\
\hline & 23 & & 51.68 & 354.30 \\
\hline & 24 & & 51.65 & 354.33 \\
\hline & 25 & & 51.63 & 354.35 \\
\hline & 26 & & 51.58 & 354.40 \\
\hline & 27 & & 51.55 & 354.43 \\
\hline & 28 & & 51.54 & 354.44 \\
\hline & 29 & & 51.54 & 354.44 \\
\hline & 30 & & 51.53 & 354.45 \\
\hline & 31 & & 51.52 & 354.46 \\
\hline
\end{tabular}

3000-D1

(1199-41-13C)

Depth Elev.

Month Date Year (ft) (ft)

\begin{tabular}{cccc}
\hline \hline & & & \\
January & 1 & 51.48 & 354.50 \\
2 & 51.45 & 354.53 \\
3 & 51.41 & 354.57 \\
4 & 51.39 & 354.59 \\
5 & 51.39 & 354.59 \\
6 & 51.37 & 354.61 \\
7 & 51.35 & 354.63 \\
8 & 51.34 & 354.64 \\
9 & 51.32 & 354.66 \\
10 & 51.35 & 354.63 \\
11 & 51.33 & 354.65 \\
12 & 51.31 & 354.67 \\
13 & 51.36 & 354.62 \\
14 & 51.60 & 354.38 \\
15 & 51.93 & 354.05 \\
16 & 52.15 & 353.83 \\
17 & 52.21 & 353.77 \\
18 & 52.20 & 353.78 \\
19 & 52.33 & 353.65 \\
20 & 52.45 & 353.53 \\
21 & 52.53 & 353.45 \\
22 & 52.44 & 353.54 \\
23 & 52.40 & 353.58 \\
24 & 52.49 & 353.49 \\
25 & 52.55 & 353.43 \\
26 & 52.69 & 353.29 \\
27 & 52.81 & 353.17 \\
28 & 53.03 & 353.05 \\
29 & 352.93 \\
30 & 352.90 \\
31 & 352.83
\end{tabular}




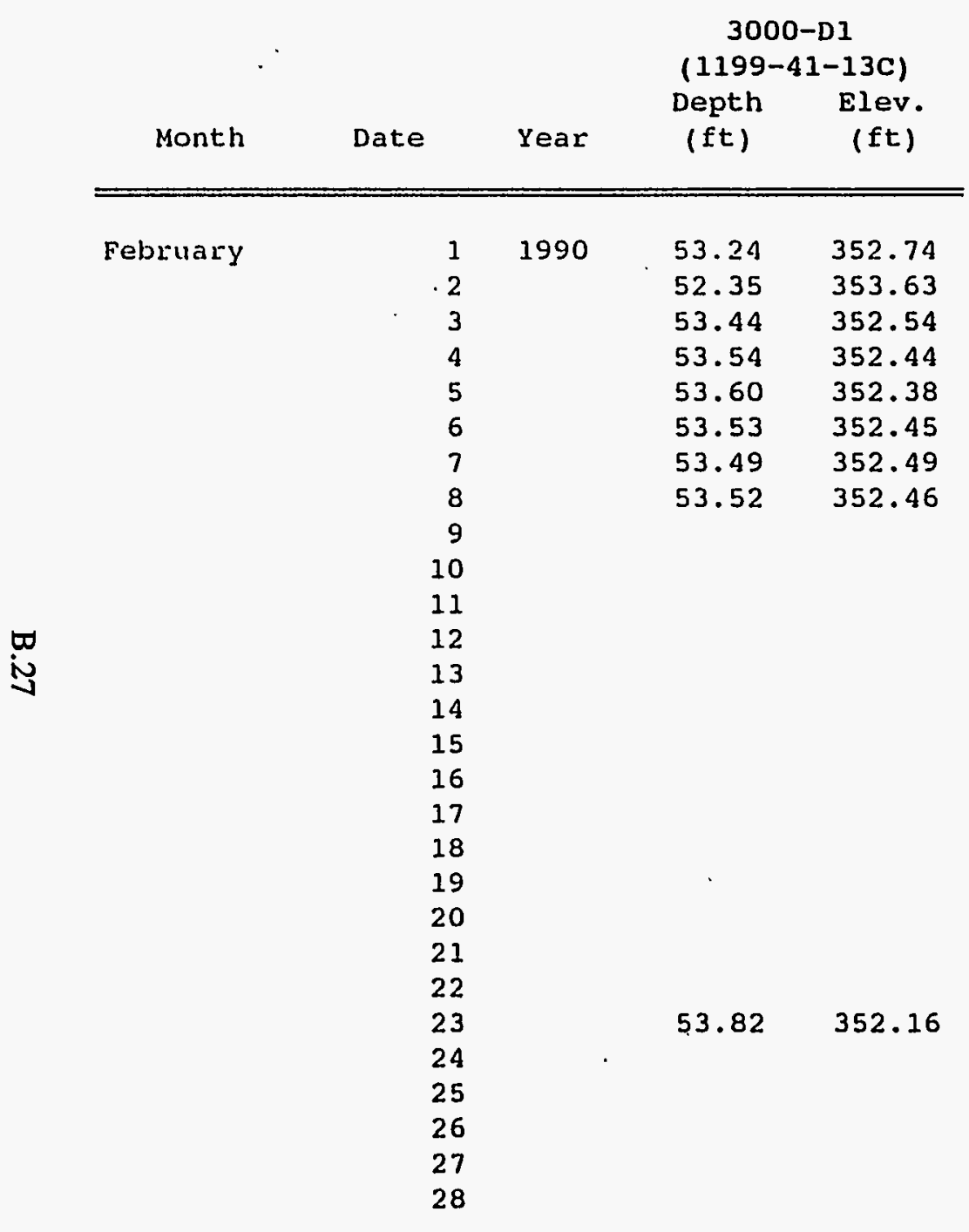

\begin{tabular}{|c|c|c|c|c|}
\hline \multirow[b]{2}{*}{ Month } & \multirow[b]{2}{*}{ Date } & \multirow[b]{2}{*}{ Year } & \multicolumn{2}{|c|}{$\begin{array}{c}3000-D 1 \\
(1199-41-13 \mathrm{C})\end{array}$} \\
\hline & & & $\begin{array}{c}\text { Depth } \\
\text { (ft) }\end{array}$ & $\begin{array}{c}\text { Elev. } \\
\text { (ft) }\end{array}$ \\
\hline \multirow[t]{30}{*}{ March } & $\begin{array}{l}1 \\
2\end{array}$ & 1990 & & \\
\hline & 3 & & 53.99 & 351.99 \\
\hline & 4 & & 54.02 & 351.96 \\
\hline & 5 & & & \\
\hline & 6 & & & \\
\hline & 7 & & & \\
\hline & 8 & & & \\
\hline & 9 & & & \\
\hline & 10 & & & - \\
\hline & 11 & & & \\
\hline & 12 & & & \\
\hline & 13 & & & \\
\hline & 14 & & & \\
\hline & 15 & & & \\
\hline & 16 & & & \\
\hline & 17 & & & \\
\hline & 18 & & & \\
\hline & 19 & & & \\
\hline & 20 & & & \\
\hline & 21 & & & \\
\hline & 22 & & 54.32 & 351.66 \\
\hline & 23 & & & \\
\hline & 24 & & & \\
\hline & 25 & & & \\
\hline & 26 & & & \\
\hline & 27 & & & \\
\hline & 28 & & & \\
\hline & 29 & & & \\
\hline & 30 & & & \\
\hline & 31 & & & \\
\hline
\end{tabular}


3000-D1

(1199-41-13C)

Depth Elev.

Month Date Year (ft) (ft)

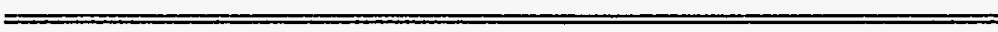

53.99

351.99

\begin{tabular}{llll} 
& & \multicolumn{2}{c}{$3000-D 1$} \\
& & $(1199-41-13 C)$ \\
Mepth & Elev. \\
Denth & Date $\quad$ Year & (ft) & (ft) \\
\hline
\end{tabular}

May

53.45

352.53 


\begin{tabular}{|c|c|c|c|c|}
\hline & & & 699-5 & $-E 13 A$ \\
\hline Month & Date & Year & $\begin{array}{c}\text { Depth } \\
\text { (ft) }\end{array}$ & $\begin{array}{c}\text { Elev. } \\
\text { (ft) }\end{array}$ \\
\hline June & 1 & 1989 & & \\
\hline & 2 & & & \\
\hline & 3 & & & \\
\hline & 4 & & & \\
\hline & 5 & & & \\
\hline & 6 & & & \\
\hline & 7 & & & \\
\hline & 8 & & & \\
\hline & 9 & & & \\
\hline & 10 & & & \\
\hline & 11 & & & \\
\hline & 12 & & & \\
\hline & 13 & & & \\
\hline & 14 & & & \\
\hline & 15 & & & \\
\hline & 16 & & 45.44 & 353.86 \\
\hline & 17 & & & \\
\hline & 18 & & & \\
\hline & 19 & & & \\
\hline & 20 & & & \\
\hline & 21 & & 45.26 & 354.04 \\
\hline & 22 & & & \\
\hline & 23 & & & \\
\hline & 24 & & & \\
\hline & 25 & & & \\
\hline & 26 & & 45.14 & 354.16 \\
\hline & 27 & & 45.12 & 354.18 \\
\hline & 28 & & 45.08 & 354.22 \\
\hline & 29 & & 45.05 & 354.25 \\
\hline & 30 & & 45.04 & 354.26 \\
\hline
\end{tabular}

\begin{tabular}{|c|c|c|c|c|}
\hline \multirow[b]{2}{*}{ Month } & \multirow[b]{2}{*}{ Date } & \multirow[b]{2}{*}{ Year } & \multicolumn{2}{|c|}{$699-S 36-E 13 A$} \\
\hline & & & $\begin{array}{c}\text { Depth } \\
\text { (ft) }\end{array}$ & $\begin{array}{c}\text { Elev. } \\
\text { (ft) }\end{array}$ \\
\hline \multirow[t]{31}{*}{ July } & 1 & 1989 & 45.04 & 354.26 \\
\hline & 2 & & 45.02 & 354.28 \\
\hline & 3 & & 44.98 & 354.32 \\
\hline & 4 & & 44.96 & 354.34 \\
\hline & 5 & & 44.97 & 354.33 \\
\hline & 6 & & 44.98 & 354.32 \\
\hline & 7 & & 44.98 & 354.32 \\
\hline & 8 & & 45.00 & 354.30 \\
\hline & 9 & & 44.98 & 354.32 \\
\hline & 10 & & 44.96 & 354.34 \\
\hline & 11 & & 44.94 & 354.36 \\
\hline & 12 & & 44.93 & 354.37 \\
\hline & 13 & & 44.95 & 354.35 \\
\hline & 14 & & 44.96 & 354.34 \\
\hline & 15 & & 45.02 & 354.28 \\
\hline & 16 & & 45.07 & 354.23 \\
\hline & 17 & & 45.07 & 354.23 \\
\hline & 18 & & 45.02 & 354.28 \\
\hline & 19 & & 45.02 & 354.28 \\
\hline & 20 & & 45.05 & 354.25 \\
\hline & 21 & & 45.08 & 354.22 \\
\hline & 22 & & 45.10 & 354.20 \\
\hline & 23 & & 45.10 & 354.20 \\
\hline & 24 & & 45.09 & 354.21 \\
\hline & 25 & & 45.05 & 354.25 \\
\hline & 26 & & 45.02 & 354.28 \\
\hline & 27 & & 45.05 & 354.25 \\
\hline & 28 & & 45.04 & 354.26 \\
\hline & 29 & & 45.03 & 354.27 \\
\hline & 30 & & 45.02 & 354.28 \\
\hline & 31 & & 44.98 & 354.32 \\
\hline
\end{tabular}




\begin{tabular}{|c|c|c|c|c|}
\hline & & & 699-5 & -E13A \\
\hline Month & Date & Year & $\begin{array}{c}\text { Depth } \\
\text { (ft) }\end{array}$ & $\begin{array}{c}\text { Elev. } \\
(\mathrm{ft})\end{array}$ \\
\hline August & 1 & 1989 & 44.95 & 354.35 \\
\hline & 2 & & 44.93 & 354.37 \\
\hline & 3 & & 44.89 & 354.41 \\
\hline & 4 & & 44.88 & 354.42 \\
\hline & 5 & & 44.88 & 354.42 \\
\hline & 6 & & 44.88 & 354.42 \\
\hline & 7 & & 44.85 & 354.45 \\
\hline & 8 & & 44.81 & 354.49 \\
\hline & 9 & & 44.81 & $354: 49$ \\
\hline & 10 & & 44.91 & 354.39 \\
\hline & 11 & & 44.80 & 354.50 \\
\hline & 12 & & 44.75 & 354.55 \\
\hline & 13 & & 44.72 & 354.58 \\
\hline & 14 & & 44.68 & 354.62 \\
\hline & 15 & & 44.64 & 354.66 \\
\hline & 16 & & 44.55 & 354.75 \\
\hline & 17 & & 44.53 & 354.77 \\
\hline & 18 & & 44.50 & 354.80 \\
\hline & 19 & & 44.48 & 354.82 \\
\hline & 20 & & 44.46 & 354.84 \\
\hline & 21 & & 44.43 & 354.87 \\
\hline & 22 & & 44.38 & 354.92 \\
\hline & 23 & & 44.40 & 354.90 \\
\hline & 24 & & 44.47 & 354.83 \\
\hline & 25 & & 44.55 & 354.75 \\
\hline & 26 & & 44.62 & 354.68 \\
\hline & 27 & & 44.66 & 354.64 \\
\hline & 28 & & 44.70 & 354.60 \\
\hline & 29 & & 44.68 & 354.62 \\
\hline & 30 & & 44.71 & 354.59 \\
\hline & 31 & & 44.77 & 354.53 \\
\hline
\end{tabular}

\begin{tabular}{|c|c|c|c|c|}
\hline & & & $699-$ & $-E 13 A$ \\
\hline Month & Date & Year & $\begin{array}{c}\text { Depth } \\
(f t)\end{array}$ & $\begin{array}{c}\text { Elev. } \\
(\mathrm{ft})\end{array}$ \\
\hline September & 1 & 1989 & 44.81 & 354.49 \\
\hline & 2 & & 44.89 & 354.41 \\
\hline & 3 & & 44.95 & 354.35 \\
\hline & 4 & & 45.01 & 354.29 \\
\hline & 5 & & 45.04 & 354.26 \\
\hline & 6 & & 45.07 & 354.23 \\
\hline & 7 & & 45.11 & 354.19 \\
\hline & 8 & & 45.26 & 354.04 \\
\hline & 9 & & 45.30 & 354.00 \\
\hline & 10 & & 45.35 & 353.95 \\
\hline & 11 & & 45.38 & 353.92 \\
\hline & 12 & & 45.36 & 353.94 \\
\hline & 13 & & 45.36 & 353.94 \\
\hline & 14 & & 45.36 & 353.94 \\
\hline & 15 & & 45.37 & 353.93 \\
\hline & 16 & & 45.39 & 353.91 \\
\hline & 17 & & 45.41 & 353.89 \\
\hline & 18 & & 45.42 & 353.88 \\
\hline & 19 & & 45.36 & 353.94 \\
\hline & 20 & & 45.33 & 353.97 \\
\hline & 21 & & 45.34 & 353.96 \\
\hline & 22 & & 45.41 & 353.89 \\
\hline & 23 & & 45.46 & 353.84 \\
\hline & 24 & & 45.51 & 353.79 \\
\hline & 25 & & 45.51 & 353.79 \\
\hline & 26 & & 45.47 & 353.83 \\
\hline & 27 & & 45.46 & 353.84 \\
\hline & 28 & & 45.48 & 353.82 \\
\hline & 29 & & 45.51 & 353.79 \\
\hline & 30 & & 45.55 & 353.75 \\
\hline
\end{tabular}




\begin{tabular}{|c|c|c|c|c|}
\hline & & & $699-5$ & $-E 13 A$ \\
\hline Month & Date & Year & $\begin{array}{c}\text { Depth } \\
\text { (ft) }\end{array}$ & $\begin{array}{c}\text { Elev. } \\
\text { (ft) }\end{array}$ \\
\hline October & 1 & 1989 & 45.62 & 353.68 \\
\hline & 2 & & 45.70 & 353.60 \\
\hline & 3 & & 45.69 & 353.61 \\
\hline & 4 & & 45.68 & 353.62 \\
\hline & 5 & & 45.68 & 353.62 \\
\hline & 6 & & 45.70 & 353.60 \\
\hline & 7 & & 45.72 & 353.58 \\
\hline & 8 & & 45.73 & 353.57 \\
\hline & 9 & & 45.74 & 353.56 \\
\hline & 10 & & 45.69 & 353.61 \\
\hline & 11 & & 45.69 & 353.61 \\
\hline & 12 & & 45.70 & 353.60 \\
\hline & 13 & & 45.73 & 353.57 \\
\hline & 14 & & 45.77 & 353.53 \\
\hline & 15 & & 45.81 & 353.49 \\
\hline & 16 & & 45.82 & 353.48 \\
\hline & 17 & & 45.79 & 353.51 \\
\hline & 18 & & 45.79 & 353.51 \\
\hline & 19 & & 45.82 & 353.48 \\
\hline & 20 & & 45.82 & 353.48 \\
\hline & 21 & & 45.83 & 353.47 \\
\hline & 22 & & 45.85 & 353.45 \\
\hline & 23 & & 45.84 & 353.46 \\
\hline & 24 & & 45.82 & 353.48 \\
\hline & 25 & & 45.82 & 353.48 \\
\hline & 26 & & 45.85 & 353.45 \\
\hline & 27 & & 45.88 & 353.42 \\
\hline & 28 & & 45.93 & 353.37 \\
\hline & 29 & & 45.99 & 353.31 \\
\hline & 30 & & 46.03 & 353.27 \\
\hline & 31 & & 46.06 & 353.24 \\
\hline
\end{tabular}

\begin{tabular}{|c|c|c|c|c|}
\hline \multirow[b]{2}{*}{ Month } & \multirow[b]{2}{*}{ Date } & \multirow[b]{2}{*}{ Year } & \multicolumn{2}{|c|}{ 699-S36-E13A } \\
\hline & & & $\begin{array}{l}\text { Depth } \\
\text { (ft) }\end{array}$ & $\begin{array}{c}\text { Elev. } \\
\text { (ft) }\end{array}$ \\
\hline \multirow[t]{30}{*}{ November } & 1 & 1989 & 46.11 & 353.19 \\
\hline & 2 & & 46.14 & 353.16 \\
\hline & 3 & & 46.18 & 353.12 \\
\hline & 4 & & 46.23 & 353.07 \\
\hline & 5 & & 46.30 & 353.00 \\
\hline & 6 & & 46.36 & 352.94 \\
\hline & 7 & & 46.37 & 352.93 \\
\hline & 8 & & 46.37 & 352.93 \\
\hline & 9 & & 46.41 & 352.89 \\
\hline & 10 & & 46.47 & .352 .83 \\
\hline & 11 & & 46.55 & 352.75 \\
\hline & 12 & & 46.63 & 352.67 \\
\hline & 13 & & 46.73 & 352.57 \\
\hline & 14 & & 46.77 & 352.53 \\
\hline & 15 & & 46.78 & 352.52 \\
\hline & 16 & & 46.82 & 352.48 \\
\hline & 17 & & 46.89 & 352.41 \\
\hline & 18 & & 46.91 & 352.39 \\
\hline & 19 & & 46.91 & 352.39 \\
\hline & 20 & & 46.91 & 352.39 \\
\hline & 21 & & 46.90 & 352.40 \\
\hline & 22 & & 46.89 & 352.41 \\
\hline & 23 & & 46.85 & 352.45 \\
\hline & 24 & & 46.80 & 352.50 \\
\hline & 25 & & 46.74 & 352.56 \\
\hline & 26 & & 46.68 & 352.62 \\
\hline & 27 & & 46.62 & 352.68 \\
\hline & 28 & & 46.58 & 352.72 \\
\hline & 29 & & 46.56 & 352.74 \\
\hline & 30 & & 46.63 & 352.67 \\
\hline
\end{tabular}


$699-S 36-E 13 A$

\begin{tabular}{|c|c|c|c|c|}
\hline & & & 699- & $j-E 13 A$ \\
\hline Month & Date & Year & $\begin{array}{c}\text { Depth } \\
(\mathrm{ft})\end{array}$ & $\begin{array}{c}\text { Elev. } \\
\text { (ft) }\end{array}$ \\
\hline December & 1 & 1989 & 46.77 & 352.53 \\
\hline & 2 & & 46.79 & 352.51 \\
\hline & 3 & & 46.74 & 352.56 \\
\hline & 4 & & 46.67 & 352.63 \\
\hline & 5 & & 46.61 & 352.69 \\
\hline & 6 & & 46.56 & 352.74 \\
\hline & 7 & & 46.50 & 352.80 \\
\hline & 8 & & 46.46 & 352.84 \\
\hline & 9 & & 46.44 & 352.86 \\
\hline & 10 & & 46.40 & 352.90 \\
\hline & 11 & & 46.36 & 352.94 \\
\hline & 12 & & 46.33 & 352.97 \\
\hline & 13 & & 46.32 & 352.98 \\
\hline & 14 & & 46.32 & 352.98 \\
\hline & 15 & & 46.31 & 352.99 \\
\hline & 16 & & 46.29 & 353.01 \\
\hline & 17 & & 46.27 & 353.03 \\
\hline & 18 & & 46.26 & 353.04 \\
\hline & 19 & & 46.23 & 353.07 \\
\hline & 20 & & 46.21 & 353.09 \\
\hline & 21 & & 46.19 & 353.11 \\
\hline & 22 & & 46.18 & 353.12 \\
\hline & 23 & & 46.16 & 353.14 \\
\hline & 24 & & 46.15 & 353.15 \\
\hline & 25 & & 46.14 & 353.16 \\
\hline & 26 & & 46.11 & 353.19 \\
\hline & 27 & & 46.08 & 353.22 \\
\hline & 28 & & 46.07 & 353.23 \\
\hline & 29 & & 46.06 & 353.24 \\
\hline & 30 & & 46.05 & 353.25 \\
\hline & 31 & & 46.04 & 353.26 \\
\hline
\end{tabular}

$699-536-E 13 A$

Depth Elev.

Month Date Year (ft) (ft)

\begin{tabular}{lllll}
\hline January & & & & \\
& 1 & 1990 & 46.01 & 353.29 \\
2 & & 46.00 & 353.30 \\
3 & & 45.97 & 353.33 \\
4 & & 45.94 & 353.36 \\
5 & & 45.93 & 353.37 \\
6 & & 45.92 & 353.38 \\
& 7 & 45.89 & 353.41
\end{tabular}

$\begin{array}{ll}46.68 & 352.62 \\ 46.71 & 352.59 \\ 46.79 & 352.51 \\ 46.87 & 352.43 \\ 46.96 & 352.34 \\ 47.05 & 352.25 \\ 47.10 & 352.20 \\ 47.16 & 352.14\end{array}$




\begin{tabular}{|c|c|c|c|c|}
\hline & & & & $-E 13 A$ \\
\hline Month & Date & Year & $\begin{array}{c}\text { Depth } \\
\text { (ft) }\end{array}$ & $\begin{array}{c}\text { Elev. } \\
(\mathrm{ft})\end{array}$ \\
\hline February & 1. & 1990 & 47.21 & 352.09 \\
\hline & 2 & & 47.30 & 352.00 \\
\hline & 3 & & 47.37 & 351.93 \\
\hline & 4 & & 47.46 & 351.84 \\
\hline & 5 & & 47.53 & 351.77 \\
\hline & 6 & & 47.55 & 351.75 \\
\hline & 7 & & 47.53 & 351.77 \\
\hline & 8 & & 47.53 & 351.77 \\
\hline & 9 & & 47.58 & 351.72 \\
\hline & 10 & & 47.63 & 351.67 \\
\hline & 11 & & 47.68 & 351.62 \\
\hline & 12 & & 47.73 & 351.57 \\
\hline & 13 & & 47.70 & 351.60 \\
\hline & 14 & & 47.67 & 351.63 \\
\hline & 15 & & 47.65 & 351.65 \\
\hline & 16 & & 47.69 & 351.61 \\
\hline & $17^{\circ}$ & & 47.75 & 351.55 \\
\hline & 18 & & 47.80 & 351.50 \\
\hline & 19 & & 47.83 & 351.47 \\
\hline & 20 & & 47.79 & 351.51 \\
\hline & 21 & & 47.75 & 351.55 \\
\hline & 22 & & 47.74 & 351.56 \\
\hline & 23 & & 47.75 & 351.55 \\
\hline & 24 & & 47.78 & 351.52 \\
\hline & 25 & & 47.83 & 351.47 \\
\hline & 26 & & 47.90 & 351.40 \\
\hline & 27 & & 47.90 & 351.40 \\
\hline & 28 & & 47.89 & 351.41 \\
\hline
\end{tabular}

\begin{tabular}{|c|c|c|c|c|}
\hline \multirow[b]{2}{*}{ Month } & \multirow[b]{2}{*}{ Date } & \multirow[b]{2}{*}{ Year } & \multicolumn{2}{|c|}{$699-S 36-E 13 A$} \\
\hline & & & $\begin{array}{c}\text { Depth } \\
\text { (ft) }\end{array}$ & $\begin{array}{c}\text { Elev. } \\
\text { (ft) }\end{array}$ \\
\hline \multirow[t]{31}{*}{ March } & 1 & 1990 & 47.88 & 351.42 \\
\hline & 2 & & 47.99 & 351.31 \\
\hline & 3 & & 48.18 & 351.12 \\
\hline & 4 & & 48.29 & 351.01 \\
\hline & 5 & & 48.38 & 350.92 \\
\hline & 6 & & 48.41 & 350.89 \\
\hline & 7 & & 48.37 & 350.93 \\
\hline & 8 & & 48.33 & 350.97 \\
\hline & 9 & & 48.38 & 350.92 \\
\hline & 10 & & 48.44 & 350.86 \\
\hline & 11 & & 48.50 & 350.80 \\
\hline & 12 & & 48.55 & 350.75 \\
\hline & 13 & & 48.49 & 350.81 \\
\hline & 14 & & 48.43 & 350.87 \\
\hline & 15 & & 48.40 & 350.90 \\
\hline & 16 & & 48.43 & 350.87 \\
\hline & 17 & & 48.58 & 350.72 \\
\hline & 18 & & 48.63 & 350.67 \\
\hline & 19 & & 48.63 & 350.67 \\
\hline & 20 & & 48.59 & .350 .71 \\
\hline & 21 & & 48.51 & 350.79 \\
\hline & 22 & & 48.40 & 350.90 \\
\hline & 23 & & 48.40 & 350.90 \\
\hline & 24 & & 48.41 & 350.89 \\
\hline & 25 & & 48.42 & 350.88 \\
\hline & 26 & & 48.45 & 350.85 \\
\hline & 27 & & 48.71 & 350.59 \\
\hline & 28 & & 48.77 & 350.53 \\
\hline & 29 & & 48.84 & 350.46 \\
\hline & 30 & & 48.91 & 350.39 \\
\hline & 31 & & 48.81 & 350.49 \\
\hline
\end{tabular}




\begin{tabular}{|c|c|c|c|c|c|c|c|c|c|}
\hline & & & \multicolumn{2}{|c|}{$699-S 36-E 13 A$} & \multirow[b]{2}{*}{ Month } & \multirow[b]{2}{*}{ Date } & \multirow[b]{2}{*}{ Year } & \multicolumn{2}{|c|}{ 699-S36-E13A } \\
\hline Month & Date & Year & $\begin{array}{c}\text { Depth } \\
\text { (ft) }\end{array}$ & $\begin{array}{c}\text { Elev. } \\
(\mathrm{ft})\end{array}$ & & & & $\begin{array}{c}\text { Depth } \\
\text { (ft) }\end{array}$ & $\begin{array}{c}\text { Elev. } \\
\text { (ft) }\end{array}$ \\
\hline \multirow[t]{31}{*}{ April } & 1 & 1990 & 48.80 & 350.50 & May & 1 & 1990 & 47.43 & 351.87 \\
\hline & 2 & & 48.81 & 350.49 & & 2 & & 47.34 & 351.96 \\
\hline & 3 & & 48.82 & 350.48 & & 3 & & 47.31 & 351.99 \\
\hline & 4 & & 48.97 & 350.33 & & 4 & & 47.28 & 352.02 \\
\hline & 5 & & 49.08 & 350.22 & & 5 & & 47.30 & 352.00 \\
\hline & 6 & & 49.14 & 350.16 & & 6 & & 47.36 & 351.94 \\
\hline & 7 & & 49.19 & 350.11 & & 7 & & 47.40 & 351.90 \\
\hline & 8 & & 49.19 & 350.11 & & 8 & & 47.32 & 351.98 \\
\hline & 9 & & 49.01 & 350.29 & & 9 & & 47.26 & 352.04 \\
\hline & 10 & & 48.82 & 350.48 & & 10 & & 47.27 & 352.03 \\
\hline & 11 & & 48.72 & 350.58 & & 11 & & 47.32 & 351.98 \\
\hline & 12 & & 48.58 & 350.72 & & 12 & & 47.40 & 351.90 \\
\hline & 13 & & 48.48 & 350.82 & & 13 & & 47.46 & 351.84 \\
\hline & 14 & & 48.40 & 350.90 & & 14 & & 47.49 & .351 .81 \\
\hline & 15 & & 48.34 & 350.96 & & 15 & & 47.41 & 351.89 \\
\hline & 16 & & 48.42 & 350.88 & & 16 & & 47.39 & 351.91 \\
\hline & 17 & & 48.40 & 350.90 & & 17 & & 47.43 & 351.87 \\
\hline & 18 & & 48.33 & 350.97 & & 18 & & & \\
\hline & 19 & & 48.33 & 350.97 & & 19 & & & \\
\hline & 20 & & 48.29 & 351.01 & & 20 & & & \\
\hline & 21 & & 48.15 & 351.15 & & 21 & & & \\
\hline & 22 & & 48.09 & 351.21 & & 22 & & & \\
\hline & 23 & & 48.02 & 351.28 & & 23 & & & \\
\hline & 24 & & 47.87 & 351.43 & & 24 & & & \\
\hline & 25 & & 47.75 & 351.55 & & 25 & & & \\
\hline & 26 & & 47.71 & 351.59 & - & 26 & & & \\
\hline & 27 & & 47.66 & 351.64 & & 27 & & & \\
\hline & 28 & & 47.61 & 351.69 & & 28 & & & \\
\hline & 29 & & 47.58 & 351.72 & & 29 & & & \\
\hline & 30 & & 47.54 & 351.76 & & 30 & & & \\
\hline & & & & & & 31 & & & \\
\hline
\end{tabular}




\begin{tabular}{|c|c|c|c|c|}
\hline & & & $\begin{array}{r}F \\
\text { (3099. }\end{array}$ & $-16)$ \\
\hline Month & Date & Year & $\begin{array}{c}\text { Depth } \\
\text { (ft) }\end{array}$ & $\begin{array}{c}\text { Elev. } \\
\text { (ft) }\end{array}$ \\
\hline June & 1 & 1989 & & \\
\hline & 2 & & & \\
\hline & 3 & & & \\
\hline & 4 & & & \\
\hline & 5 & & & \\
\hline & 6 & & & \\
\hline & 7 & & & \\
\hline & 8 & & & \\
\hline & 9 & & & \\
\hline & 10 & & & \\
\hline & 11 & & & \\
\hline & 12 & & & \\
\hline & 13 & & & \\
\hline & 14 & & 60.17 & 347.92 \\
\hline & 15 & & 60.11 & 347.98 \\
\hline & 16 & & 60.05 & 348.04 \\
\hline & 17 & & 60.06 & 348.03 \\
\hline & 18 & & 60.11 & 347.98 \\
\hline & 19 & & 60.17 & 347.92 \\
\hline & 20 & & 60.21 & 347.88 \\
\hline & 21 & & 60.16 & 347.93 \\
\hline & 22 & & 60.17 & 347.92 \\
\hline & 23 & & 60.20 & 347.89 \\
\hline & 24 & & 60.23 & 347.86 \\
\hline & 25 & & 60.25 & 347.84 \\
\hline & 26 & & 60.27 & 347.82 \\
\hline & 27 & & 60.27 & $347: 82$ \\
\hline & 28 & & 60.25 & 347.84 \\
\hline & 29 & & 60.24 & 347.85 \\
\hline & 30 & & 60.22 & 347.87 \\
\hline
\end{tabular}

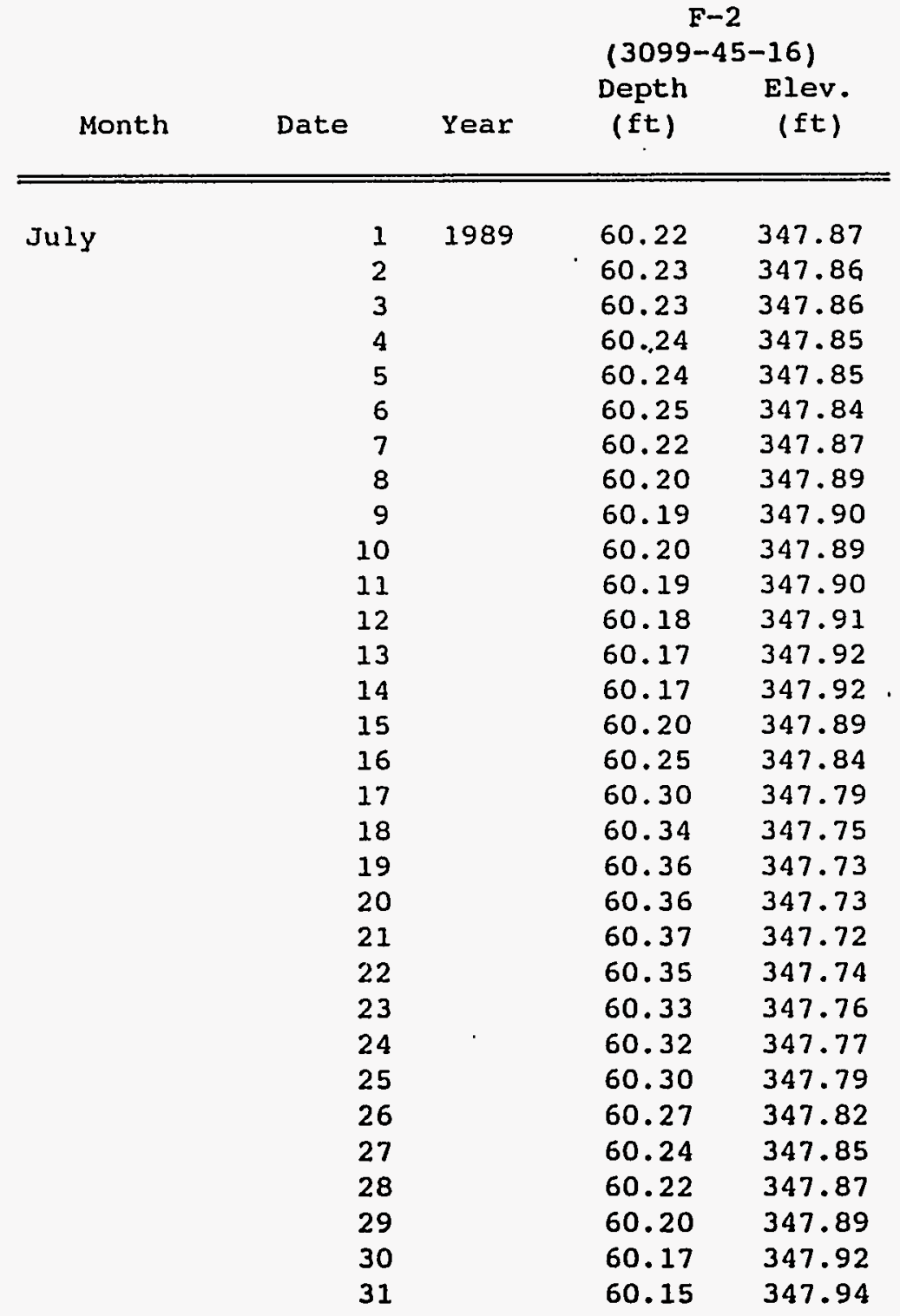


F-2

(3099-45-16) Depth Elev.

Month Date Year (ft) (ft)

\begin{tabular}{|c|c|c|c|c|}
\hline \multirow[b]{2}{*}{ Month } & \multirow[b]{2}{*}{ Date } & \multirow[b]{2}{*}{ Year } & \multicolumn{2}{|c|}{$(3099-45-16)$} \\
\hline & & & $\begin{array}{l}\text { Depth } \\
(f t)\end{array}$ & $\begin{array}{c}\text { Elev. } \\
\text { (ft) }\end{array}$ \\
\hline August & 1 & 1989 & 60.14 & 347.95 \\
\hline & 2 & & 60.14 & 347.95 \\
\hline & 3 & & 60.15 & 347.94 \\
\hline & 4 & & 60.15 & 347.94 \\
\hline & 5 & & 60.12 & 347.97 \\
\hline & 6 & & 60.08 & 348.01 \\
\hline & 7 & & 60.05 & 348.04 \\
\hline & 8 & & 60.02 & 348.07 \\
\hline & 9 & & 60.00 & 348.09 \\
\hline & 10 & & 59.97 & 348.12 \\
\hline & 11 & & 59.94 & 348.15 \\
\hline & 12 & & 59.91 & 348.18 \\
\hline & 13 & & 59.90 & 348.19 \\
\hline & 14 & & 59.88 & 348.21 \\
\hline & 15 & & 59.88 & 348.21 \\
\hline & 16 & & 59.87 & 348.22 \\
\hline & 17 & & 59.87 & 348.22 \\
\hline & 18 & & 59.85 & 348.24 \\
\hline & 19 & & 59.81 & 348.28 \\
\hline & 20 & & 59.78 & 348.31 \\
\hline & 21 & & 59.76 & 348,33 \\
\hline & 22 & & 59.74 & 348.35 \\
\hline & 23 & & 59.74 & 348.35 \\
\hline & 24 & & 59.75 & 348.34 \\
\hline & 25 & & 59.76 & 348.33 \\
\hline & 26 & & 59.78 & 348.31 \\
\hline & 27 & & 59.80 & 348.29 \\
\hline & 28 & & 59.83 & 348.26 \\
\hline & 29 & & 59.84 & 348.25 \\
\hline$\cdot$ & 30 & & 59.85 & 348.24 \\
\hline & 31 & & 59.84 & 348.25 \\
\hline
\end{tabular}




\begin{tabular}{|c|c|c|c|c|}
\hline \multirow[b]{2}{*}{ Month } & \multirow[b]{2}{*}{ Date } & \multirow[b]{2}{*}{ Year } & \multicolumn{2}{|c|}{$\begin{array}{c}F-2 \\
(3099-45-16)\end{array}$} \\
\hline & & & $\begin{array}{l}\text { Depth } \\
\text { (ft) }\end{array}$ & $\begin{array}{l}\text { Elev. } \\
\text { (ft) }\end{array}$ \\
\hline \multirow[t]{31}{*}{ october } & 1 & 1989 & 60.02 & 348.07 \\
\hline & 2 & & 60.06 & 348.03 \\
\hline & 3 & & 60.08 & 348.01 \\
\hline & 4 & & 60.08 & 348.01 \\
\hline & 5 & & 60.06 & 348.03 \\
\hline & 6 & & 60.07 & 348.02 \\
\hline & 7 & & 60.09 & 348.00 \\
\hline & 8 & & 60.10 & 347.99 \\
\hline & 9 & & 60.12 & 347.97 \\
\hline & 10 & & 60.15 & 347.94 \\
\hline & 11 & & 60.17 & 347.92 \\
\hline & 12 & & 60.17 & 347.92 \\
\hline & 13 & & 60.14 & 347.95 \\
\hline & 14 & & 60.11 & 347.98 \\
\hline & 15 & & 60.13 & 347.96 \\
\hline & 16 & & 60.17 & 347.92 \\
\hline & 17 & & 60.20 & 347.89 \\
\hline & 18 & & 60.21 & 347.88 \\
\hline & 19 & & 60.21 & 347.88 \\
\hline & 20 & & 60.19 & 347.90 \\
\hline & 21 & & 60.19 & 347.90 \\
\hline & 22 & & 60.20 & 347.89 \\
\hline & 23 & & 60.21 & 347.88 \\
\hline & 24 & & 60.25 & 347.84 \\
\hline & 25 & & 60.28 & 347.81 \\
\hline & 26 & & 60.31 & 347.78 \\
\hline & 27 & & 60.34 & 347.75 \\
\hline & 28 & & 60.37 & 347.72 \\
\hline & 29 & & 60.39 & 347.70 \\
\hline & 30 & & 60.40 & 347.69 \\
\hline & 31 & & 60.44 & 347.65 \\
\hline
\end{tabular}

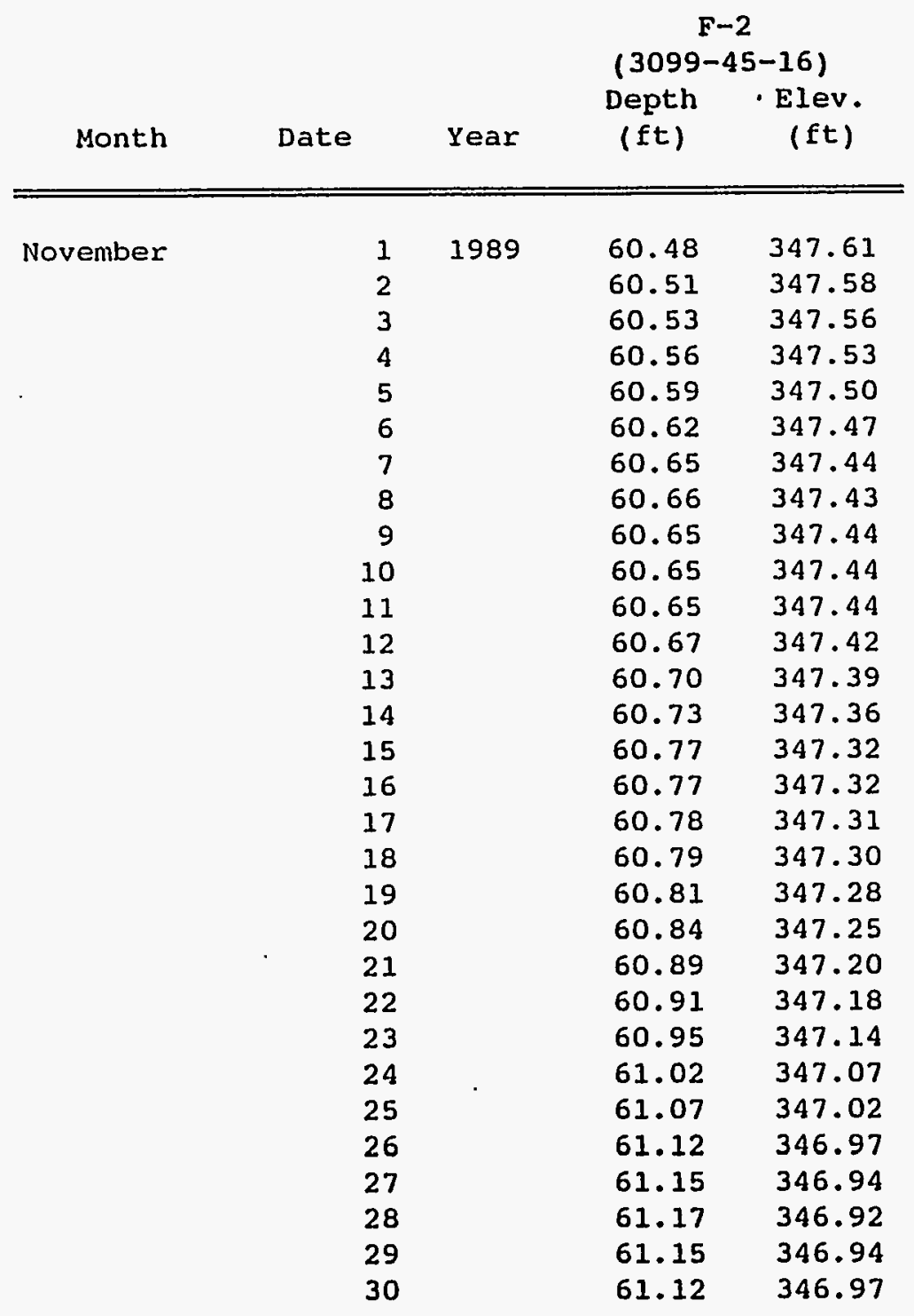


F-2

$(3099-45-16)$

Depth Elev.

Month Date Year ( $f$ ) (ft)

December

\begin{tabular}{|c|c|c|c|c|}
\hline & & & (3099 & $-16)$ \\
\hline Month & Date & Year & $\begin{array}{c}\text { Depth } \\
(\mathrm{ft})\end{array}$ & $\begin{array}{c}\text { Elev. } \\
\text { (ft) }\end{array}$ \\
\hline December & 1 & 1989 & 61.09 & 347.00 \\
\hline & 2 & & 61.11 & 346.98 \\
\hline & 3 & & 61.14 & 346.95 \\
\hline & 4 & & 61.17 & 346.92 \\
\hline & 5 & & 61.20 & 346.89 \\
\hline & 6 & & 61.23 & 346.86 \\
\hline & 7 & & 61.24 & 346.85 \\
\hline & 8 & & 61.21 & 346.88 \\
\hline & 9 & & 61.16 & 346.93 \\
\hline & 10 & & 61.11 & 346.98 \\
\hline & 11 & & 61.09 & 347.00 \\
\hline & 12 & & 61.05 & 347.04 \\
\hline & 13 & & 61.02 & 347.07 \\
\hline & 14 & & 60.99 & 347.10 \\
\hline & 15 & & 60.97 & 347.12 \\
\hline & 16 & & 60.94 & 347.15 \\
\hline & 17 & & 60.91 & 347.18 \\
\hline & 18 & & 60.91 & 347.18 \\
\hline & 19 & & 60.92 & 347.17 \\
\hline & 20 & & 60.90 & 347.19 \\
\hline & 21 & & 60.88 & 347.21 \\
\hline & 22 & & 60.84 & 347.25 \\
\hline & 23 & & 60.83 & 347.26 \\
\hline & 24 & & 60.82 & 347.27 \\
\hline & 25 & & 60.84 & 347.25 \\
\hline & 26 & & 60.87 & 347.22 \\
\hline & 27 & & 60.88 & 347.21 \\
\hline & 28 & & 60.86 & 347.23 \\
\hline & 29 & & 60.82 & 347.27 \\
\hline & 30 & & 60.79 & 347.30 \\
\hline & 31 & & 60.77 & 347.32 \\
\hline
\end{tabular}

F-2

$(3099-45-16)$

Depth Elev.

Month Date Year (ft) (ft)

\begin{tabular}{|c|c|c|c|c|}
\hline \multirow[t]{31}{*}{ January } & 1 & 1990 & 60.76 & 347.33 \\
\hline & 2 & & 60.77 & 347.32 \\
\hline & 3 & & 60.77 & 347.32 \\
\hline & 4 & & 60.75 & 347.34 \\
\hline & 5 & & 60.71 & 347.38 \\
\hline & 6 & & 60.67 & 347.42 \\
\hline & 7 & & 60.65 & 347.44 \\
\hline & 8 & & 60.64 & 347.45 \\
\hline & 9 & & 60.63 & 347.46 \\
\hline & 10 & & 60.63 & 347.46 \\
\hline & 11 & & 60.58 & 347.51 \\
\hline & 12 & & 60.53 & 347.56 \\
\hline & 13 & & 60.51 & 347.58 \\
\hline & 14 & & 60.51 & 347.58 \\
\hline & 15 & & 60.54 & 347.55 \\
\hline & 16 & & 60.59 & 347.50 \\
\hline & 17 & & 60.63 & 347.46 \\
\hline & 18 & & 60.65 & 347.44 \\
\hline & 19 & & 60.68 & 347.41 \\
\hline & 20 & & 60.72 & 347.37 \\
\hline & 21 & & 60.75 & 347.34 \\
\hline & 22 & & 60.78 & 347.31 \\
\hline & 23 & & 60.83 & 347.26 \\
\hline & 24 & & 60.85 & 347.24 \\
\hline & 25 & & 60.84 & 347.25 \\
\hline & 26 & & 60.85 & 347.24 \\
\hline & 27 & & 60.85 & 347.24 \\
\hline & 28 & & 60.85 & 347.24 \\
\hline & 29 & & 60.86 & 347.23 \\
\hline & 30 & & 60.89 & 347.20 \\
\hline & 31 & & 60.94 & 347.15 \\
\hline
\end{tabular}




\begin{tabular}{|c|c|c|c|c|}
\hline & & & (3099. & $-16)$ \\
\hline Month & Date & Year & $\begin{array}{c}\text { Depth } \\
\text { (ft) }\end{array}$ & $\begin{array}{c}\text { Elev. } \\
(\mathrm{ft})\end{array}$ \\
\hline February & 1 & 1990 & 60.97 & 347.12 \\
\hline & 2 & & 60.97 & 347.12 \\
\hline & 3 & & 61.00 & 347.09 \\
\hline & 4 & & 61.04 & 347.05 \\
\hline . & 5 & & 61.09 & 347.00 \\
\hline & 6 & & 61.15 & 346.94 \\
\hline & 7 & & 61.23 & 346.86 \\
\hline & 8 & & 61.26 & 346.83 \\
\hline & 9 & & 61.22 & 346.87 \\
\hline & 10 & & 61.19 & 346.90 \\
\hline & 11 & & 61.22 & 346.87 \\
\hline & 12 & & 61.27 & 346.82 \\
\hline & 13 & & 61.32 & 346.77 \\
\hline & 14 & & 61.35 & 346.74 \\
\hline & 15 & & 61.37 & 346.72 \\
\hline & 16 & & 61.34 & 346.75 \\
\hline & 17 & & 61.28 & 346.81 \\
\hline & 18 & & 61.25 & 346.84 \\
\hline & 19 & & 61.29 & 346.80 \\
\hline & 20 & & 61.31 & 346.78 \\
\hline & 21 & & 61.30 & 346.79 \\
\hline & 22 & & 61.26 & 346.83 \\
\hline & 23 & & 61.26 & 346.83 \\
\hline & 24 & & 61.31 & 346.78 \\
\hline & 25 & & 61.36 & 346.73 \\
\hline & 26 & & 61.40 & 346.69 \\
\hline & 27 & & 61.45 & 346.64 \\
\hline & 28 & & 61.49 & 346.60 \\
\hline
\end{tabular}

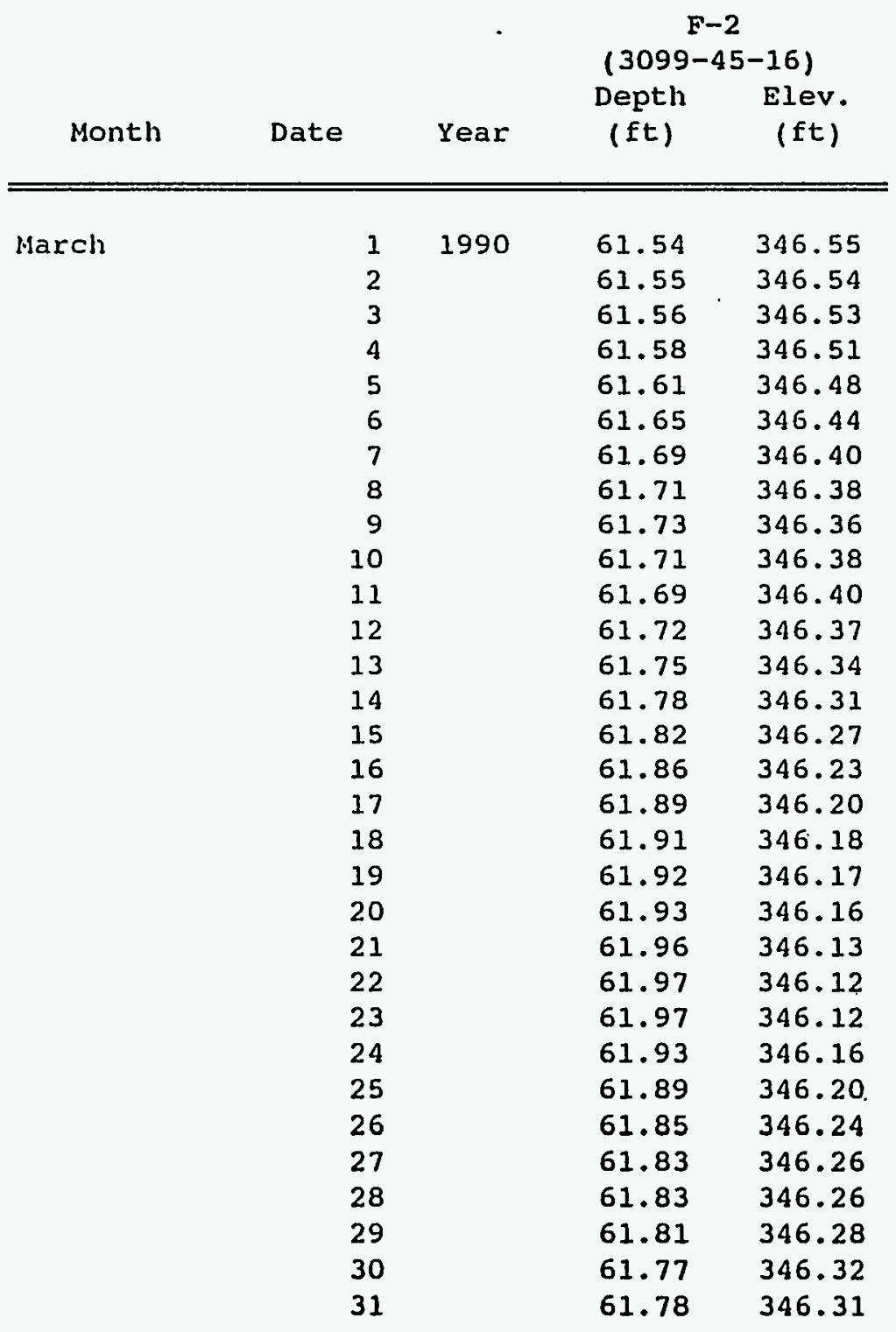




\begin{tabular}{|c|c|c|c|c|}
\hline \multirow[b]{2}{*}{ Month } & \multirow[b]{2}{*}{ Date } & \multirow[b]{2}{*}{ Year } & \multicolumn{2}{|c|}{$\begin{array}{c}F-2 \\
(3099-45-16)\end{array}$} \\
\hline & & & $\begin{array}{l}\text { Depth } \\
(f t)\end{array}$ & $\begin{array}{l}\text { Elev. } \\
\text { (ft.) }\end{array}$ \\
\hline \multirow[t]{30}{*}{$A p r i .1$} & 1 & 1990 & 61.86 & 346.23 \\
\hline & 2 & & 61.95 & 346.14 \\
\hline & 3 & & 61.99 & 346.10 \\
\hline & 4 & & 61.92 & 346.17 \\
\hline & 5 & & 61.88 & 346.21 \\
\hline & 6 & & 61.91 & 346.18 \\
\hline & 7 & & 61.97 & 346.12 \\
\hline & 8 & & 62.01 & 346.08 \\
\hline & 9 & & 61.99 & 346.10 \\
\hline & 10 & & 62.01 & 346.08 \\
\hline & 11 & & 62.03 & 346.06 \\
\hline & 12 & & 62.02 & 346.07 \\
\hline & 13 & & 62.00 & 346.09 \\
\hline & 14 & & 62.00 & 346.09 \\
\hline & 15 & & 61.98 & 346.11 \\
\hline & 16 & & 62.00 & 346.09 \\
\hline & 17 & & 62.03 & 346.06 \\
\hline & 18 & & 62.07 & 346.02 \\
\hline & 19 & & 62.07 & 346.02 \\
\hline & 20 & & 62.04 & 346.05 \\
\hline & 21 & & 61.98 & 346.11 \\
\hline & 22 & & 61.94 & 346.15 \\
\hline & 23 & & 61.95 & 346.14 \\
\hline & 24 & & 61.96 & 346.13 \\
\hline & 25 & & 61.90 & 346.19 \\
\hline & 26 & & 61.84 & 346.25 \\
\hline & 27 & & 61.70 & 346.39 \\
\hline & 28 & & 61.57 & 346.52 \\
\hline & 29 & & 61.50 & 346.59 \\
\hline & 30 & & 61.48 & 346.61 \\
\hline
\end{tabular}

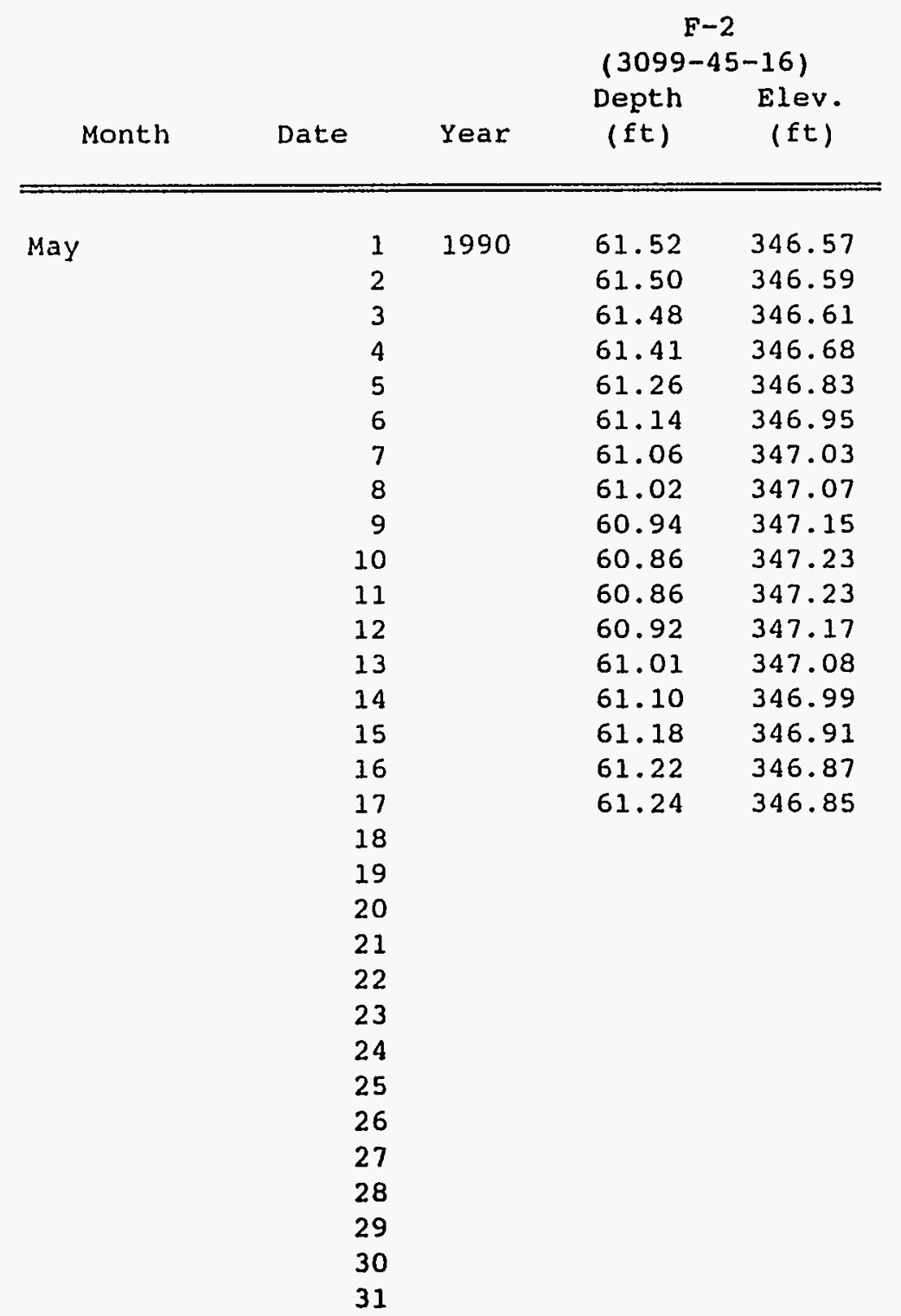




\section{We11 699-S40-E14}

\begin{tabular}{|c|c|c|c|}
\hline Month & Day & Year & $\begin{array}{c}\text { Average } \\
\text { W-L Elev. } \\
\text { (ft) }\end{array}$ \\
\hline June & 1 & 1989 & 357.19 \\
\hline & 2 & & 357.17 \\
\hline & 3 & & 356.83 \\
\hline${ }^{\circ}$ & 4 & & 356.81 \\
\hline & 5 & & 356.67 \\
\hline & 6 & & 356.62 \\
\hline & 7 & & 356.69 \\
\hline & 8 & & 356.63 \\
\hline & 9 & & 356.64 \\
\hline & 10 & & 356.71 \\
\hline & 11 & & 356.66 \\
\hline $\boldsymbol{\sigma}$ & 12 & & 356.64 \\
\hline 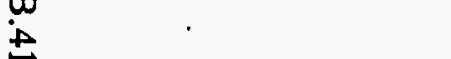 & 13 & & 356.74 \\
\hline & 14 & & 356.78 \\
\hline & 15 & & 356.94 \\
\hline & 16 & & 357.09 \\
\hline & 17 & & 357.03 \\
\hline & 18 & & 356.75 \\
\hline & 19 & & 356.78 \\
\hline & 20 & & 356.81 \\
\hline & 21 & & 356.92 \\
\hline & 22 & & 356.99 \\
\hline & 23 & & 356.94 \\
\hline & 24 & & 357.00 \\
\hline & 25 & & 357.00 \\
\hline & 26 & & 357.28 \\
\hline & 27 & & 357.18 \\
\hline & 28 & & 357.07 \\
\hline & 29 & & 357.00 \\
\hline & 30 & & 356.93 \\
\hline
\end{tabular}

\begin{tabular}{|c|c|c|c|}
\hline Month & - Day & Year & $\begin{array}{c}\text { Average } \\
\text { W-L Elev. } \\
\text { (ft) }\end{array}$ \\
\hline \multirow[t]{31}{*}{ July } & 1 & 1989 & 357.09 \\
\hline & 2 & & 357.29 \\
\hline & 3 & & 356.94 \\
\hline & 4 & & 356.83 \\
\hline & 5 & & 356.72 \\
\hline & 6 & & 356.68 \\
\hline & 7 & & 356.64 \\
\hline & 8 & & 356.59 \\
\hline & 9 & & 356.75 \\
\hline & 10 & & 356.81 \\
\hline & 11 & . & 356.76 \\
\hline & 12 & & 356.67 \\
\hline & 13 & & 356.62 \\
\hline & 14 & & 356.18 \\
\hline & 15 & & 356.17 \\
\hline & 16 & & 356.45 \\
\hline & 17 & & 356.87 \\
\hline & 18 & & 356.74 \\
\hline & 19 & & 356.59 \\
\hline & 20 & & 356.51 \\
\hline & 21 & & 356.46 \\
\hline & 22 & & 356.58 \\
\hline & 23 & & 356.69 \\
\hline & 24 & & 356.80 \\
\hline & 25 & & 356.63 \\
\hline & 26 & & 356.58 \\
\hline & 27 & & 356.70 \\
\hline & 28 & & 356.63 \\
\hline & 29 & & 356.78 \\
\hline & 30 & & 356.90 \\
\hline & 31 & & 356.96 \\
\hline
\end{tabular}




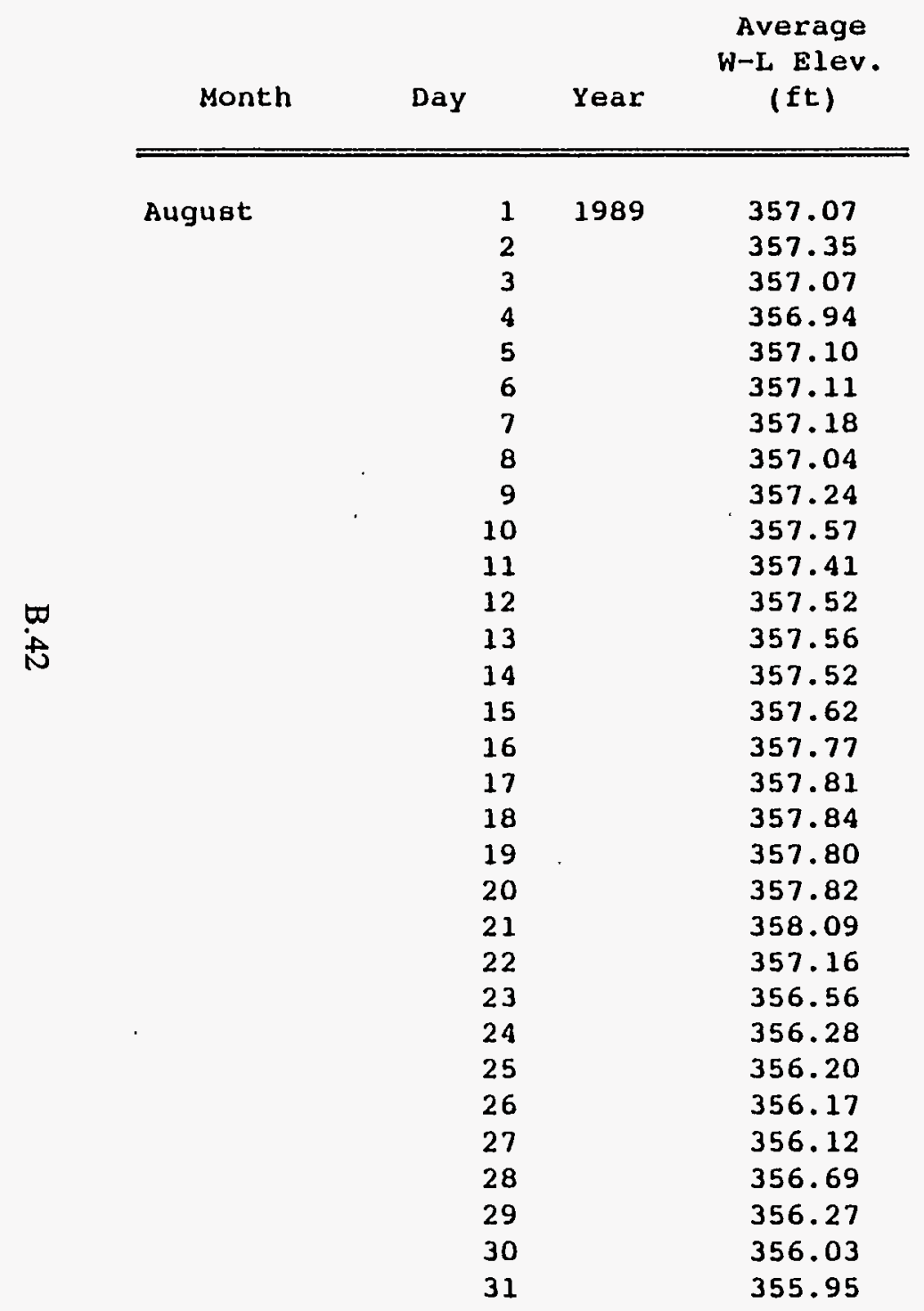

\begin{tabular}{|c|c|c|c|}
\hline Month & Day & Year & $\begin{array}{c}\text { Average } \\
\text { W-L Elev. } \\
\text { (ft) }\end{array}$ \\
\hline \multirow[t]{30}{*}{ September } & 1 & 1989 & 355.61 \\
\hline & 2 & & 355.51 \\
\hline & 3 & & 355.35 \\
\hline & 4 & & 355.87 \\
\hline & 5 & & 355.48 \\
\hline & 6 & & 355.34 \\
\hline & 7 & & 355.15 \\
\hline & 8 & & 355.07 \\
\hline & 9 & & 354.99 \\
\hline & 10 & & 355.19 \\
\hline & 11 & & 355.72 \\
\hline & 12 & & 355.49 \\
\hline & 13 & & 355.35 \\
\hline & 14 & & 355.25 \\
\hline & 15 & & 355.15 \\
\hline & 16 & & 355.11 \\
\hline & 17 & & 355.13 \\
\hline & 18 & & 355.91 \\
\hline & 19 & & 355.96 \\
\hline & 20 & & 355.67 \\
\hline & 21 & & 355.21 \\
\hline & 22 & & 355.01 \\
\hline & 23 & & 354.82 \\
\hline & 24 & & 355.08 \\
\hline & 25 & & 355.74 \\
\hline & 26 & & 355.41 \\
\hline & 27 & & 355.16 \\
\hline & 28 & & 354.95 \\
\hline & 29 & & \\
\hline & 30 & & \\
\hline
\end{tabular}




\begin{tabular}{|c|c|c|c|}
\hline Month & Day & Year & $\begin{array}{c}\text { Average } \\
\text { W-L Elev. } \\
\text { (ft) }\end{array}$ \\
\hline \multirow[t]{31}{*}{ october } & 1 & 1989 & \\
\hline & 2 & & \\
\hline & 3 & & \\
\hline & 4 & & \\
\hline & 5 & & \\
\hline & 6 & & 355.17 \\
\hline & 7 & & 355.15 \\
\hline & 8 & & 355.21 \\
\hline & 9 & & 355.71 \\
\hline & 10 & & 355.48 \\
\hline & 11 & & 355.40 \\
\hline & 12 & & 355.23 \\
\hline & 13 & & 354.97 \\
\hline & 14 & & 354.93 \\
\hline & 15 & & 354.88 \\
\hline & 16 & & 355.50 \\
\hline & 17 & & 355.19 \\
\hline & 18 & & 354.92 \\
\hline & 19 & & 354.96 \\
\hline & 20 & & 354.95 \\
\hline & 21 & & 354.92 \\
\hline & 22 & & 354.97 \\
\hline & 23 & & 355.68 \\
\hline & 24 & & 355.31 \\
\hline & 25 & & 355.03 \\
\hline & 26 & & 354.91 \\
\hline & 27 & & .354 .79 \\
\hline & 28 & & 354.55 \\
\hline & 29 & & 354.46 \\
\hline & 30 & & 354.77 \\
\hline & 31 & & 354.44 \\
\hline
\end{tabular}

\begin{tabular}{|c|c|c|c|c|}
\hline Month & & Day & Year & $\begin{array}{c}\text { Average } \\
\text { W-L Elev. } \\
\text { (ft) }\end{array}$ \\
\hline \multirow{30}{*}{\multicolumn{2}{|c|}{ November }} & 1 & 1989 & 354.49 \\
\hline & & 2 & & 354.32 \\
\hline & & 3 & & 354.03 \\
\hline & & 4 & & 353.77 \\
\hline & & 5 & & 353.67 \\
\hline & & 6 & & 354.45 \\
\hline & & 7 & & 354.32 \\
\hline & & 8 & & 353.90 \\
\hline & & 9 & & 353.55 \\
\hline & & 10 & & 353.32 \\
\hline & & 11 & & 353.11 \\
\hline & & 12 & & 352.84 \\
\hline & & 13 & & 353.65 \\
\hline & & 14 & & 353.79 \\
\hline & & 15 & & 353.40 \\
\hline & & 16 & & 353.25 \\
\hline & & 17 & & 353.30 \\
\hline & & 18 & & 353.43 \\
\hline & & 19 & & 353.61 \\
\hline & & 20 & & 354.60 \\
\hline & & 21 & & 354.21 \\
\hline & & 22 & & 354.70 \\
\hline & & 23 & & 355.18 \\
\hline & & 24 & & 355.55 \\
\hline & & 25 & & 355.77 \\
\hline & & 26 & & 355.84 \\
\hline & & 27 & & 355.69 \\
\hline & & 28 & & 355.32 \\
\hline & & 29 & & 354.27 \\
\hline & & .30 & & 353.61 \\
\hline
\end{tabular}




\begin{tabular}{|c|c|c|c|}
\hline Month & Day & Year & $\begin{array}{c}\text { Average } \\
W-L \text { Elev. } \\
\text { (ft) }\end{array}$ \\
\hline \multirow[t]{31}{*}{ December } & 1 & 1989 & 354.67 \\
\hline & 2 & & 355.43 \\
\hline & 3 & & 355.76 \\
\hline & 4 & & 355.87 \\
\hline & 5 & & 355.92 \\
\hline & 6 & & 356.01 \\
\hline & 7 & & 356.02 \\
\hline & 8 & & 356.03 \\
\hline & 9 & & 356.10 \\
\hline & 10 & & 356.14 \\
\hline & 11 & & 356.11 \\
\hline & 12 & & 356.02 \\
\hline & 13 & & 355.67 \\
\hline & 14 & & 355.87 \\
\hline & 15 & & 355.99 \\
\hline & 16 & & 356.05 \\
\hline & 17 & & 355.95 \\
\hline & 18 & & 356.05 \\
\hline & 19 & & 356.15 \\
\hline & 20 & & 356.24 \\
\hline & 21 & & 356.32 \\
\hline & 22 & & 356.34 \\
\hline & 23 & & 356.34 \\
\hline & 24 & & 356.34 \\
\hline & 25 & & 356.52 \\
\hline & 26 & & 356.53 \\
\hline & 27 & & 356.50 \\
\hline & 28 & & 356.40 \\
\hline & 29 & & 356.39 \\
\hline & 30 & & 356.37 \\
\hline & 31 & & 356.49 \\
\hline
\end{tabular}

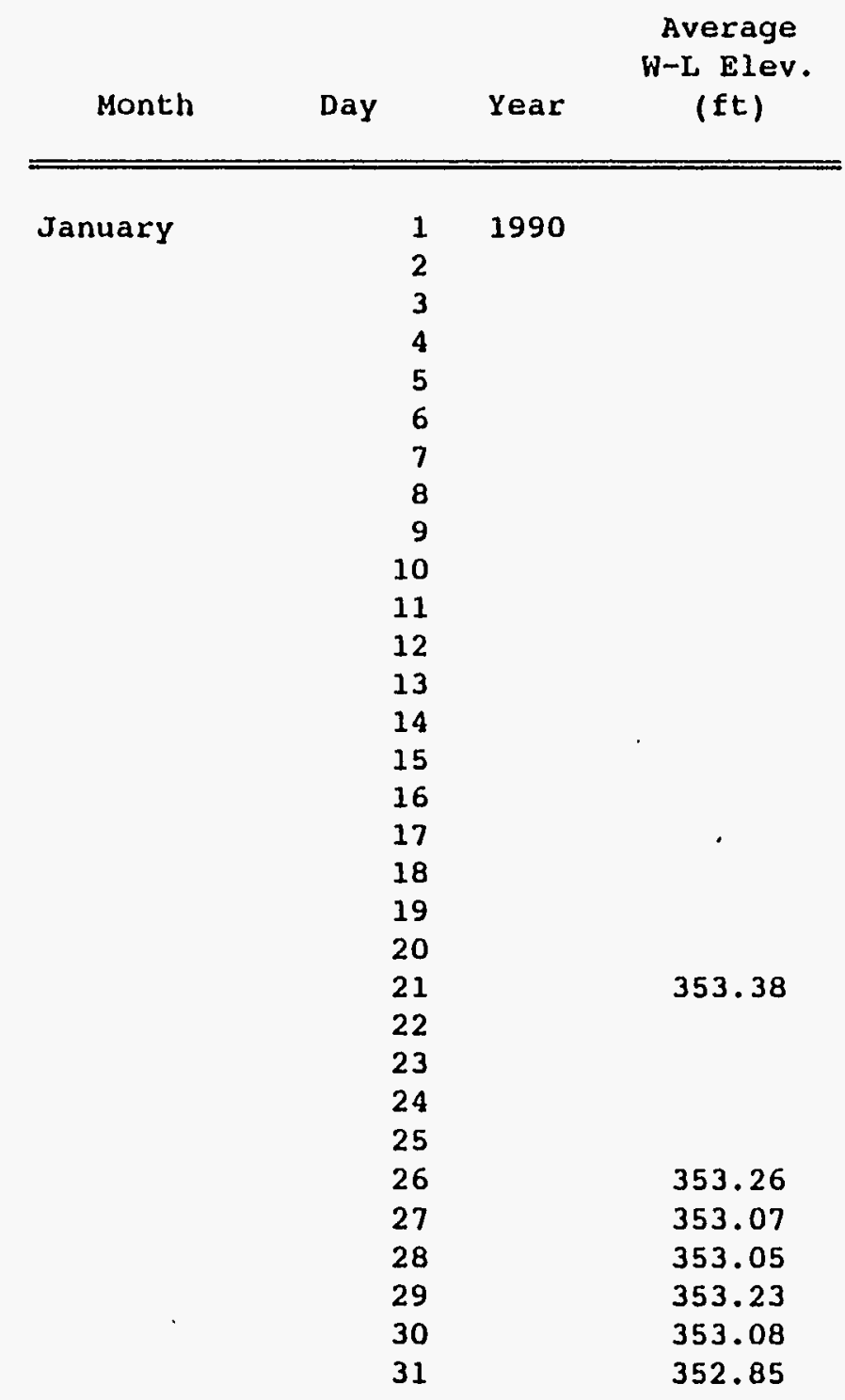




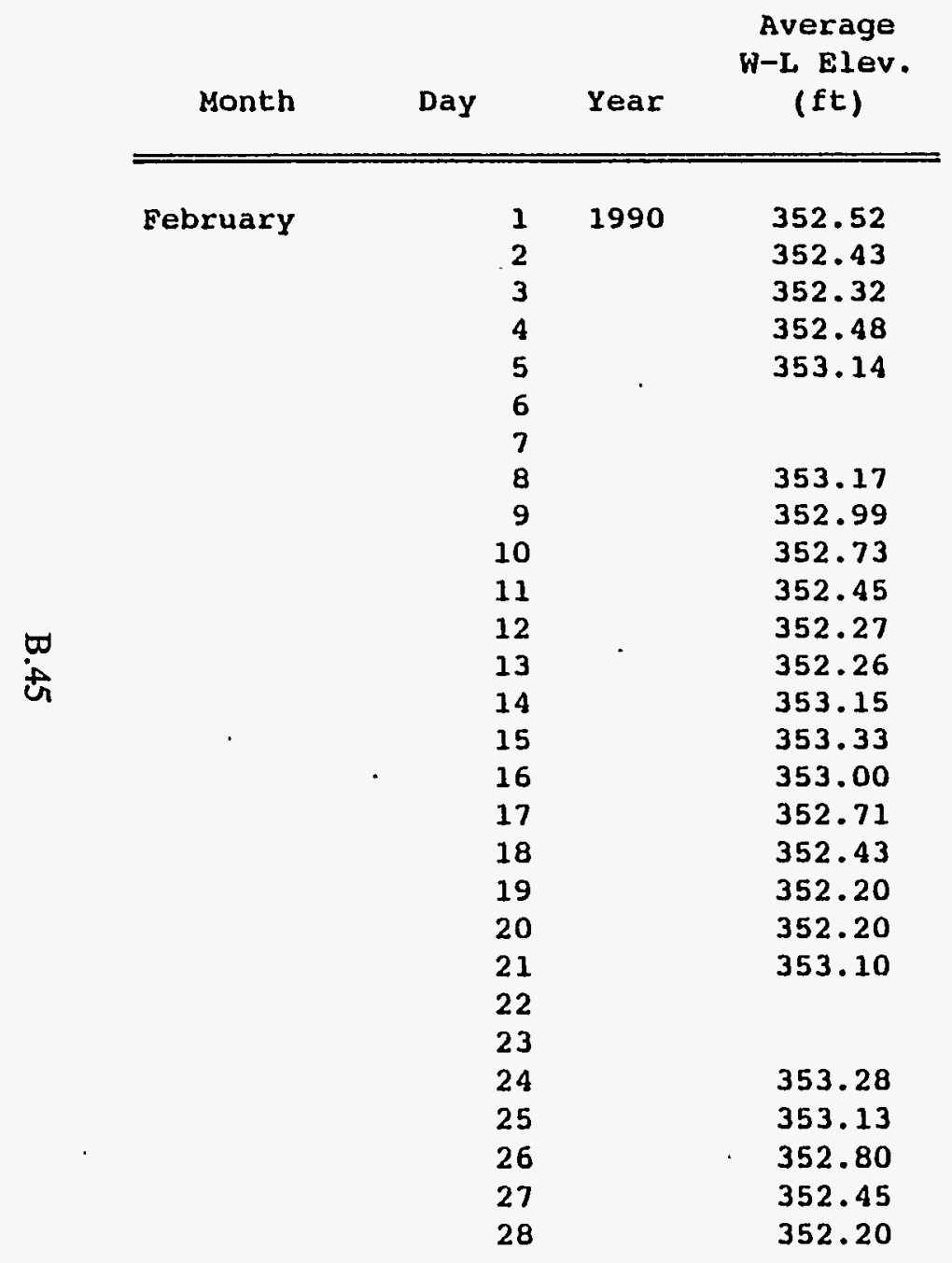

\begin{tabular}{|c|c|c|c|}
\hline Month & Day & Year & $\begin{array}{c}\text { Average } \\
\text { W-L Elev. } \\
\text { (ft) }\end{array}$ \\
\hline \multirow[t]{31}{*}{ March } & 1 & 1990 & 352.00 \\
\hline & 2 & & 352.14 \\
\hline & 3 & & 352.88 \\
\hline & 4 & & 352.71 \\
\hline & 5 & & 352.43 \\
\hline & 6 & & 352.12 \\
\hline & 7 & & 351.90 \\
\hline & 8 & & 351.71 \\
\hline & 9 & & 351.92 \\
\hline & 10 & & 352.67 \\
\hline & 11 & & \\
\hline & 12 & & \\
\hline & 13 & & 352.61 \\
\hline & 14 & & 352.40 \\
\hline & 15 & & 352.07 \\
\hline & 16 & & 351.78 \\
\hline & 17 & & 351.58 \\
\hline & 18 & & 351.47 \\
\hline & 19 & & 352.22 \\
\hline & 20 & & 352.51 \\
\hline & 21 & & 352.28 \\
\hline & 22 & & 351.98 \\
\hline & 23 & & 351.67 \\
\hline & 24 & & 351.48 \\
\hline & 25 & & 351.25 \\
\hline & 26 & & 351.75 \\
\hline & 27 & . & \\
\hline & 28 & $\cdot$ & \\
\hline & 29 & & 352.20 \\
\hline & 30 & & 352.03 \\
\hline & 31 & & 351.86 \\
\hline
\end{tabular}




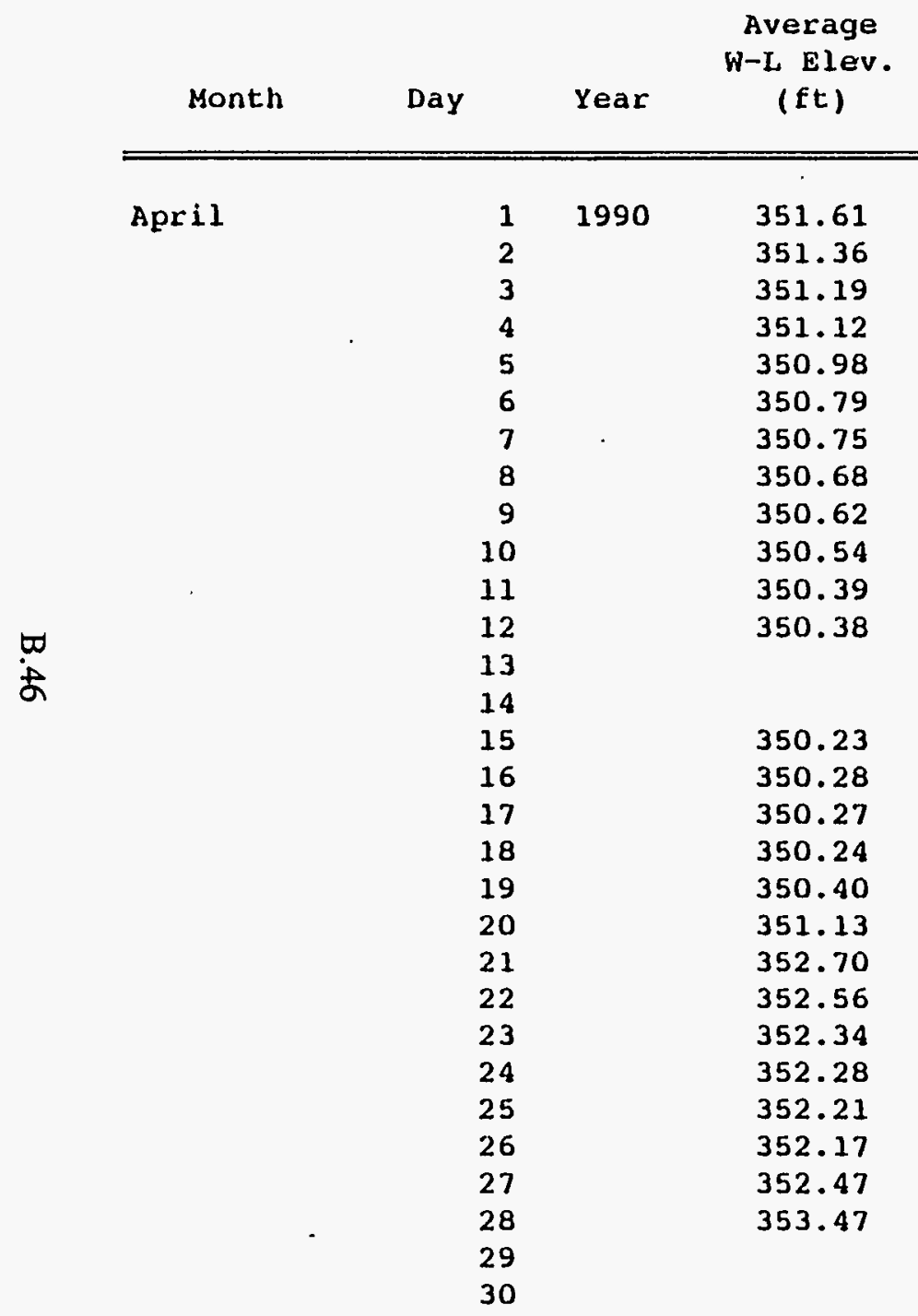

\begin{tabular}{|c|c|c|c|}
\hline Month & Day & Year & $\begin{array}{c}\text { Average } \\
W-L \text { Elev. } \\
\text { (ft) }\end{array}$ \\
\hline \multirow[t]{31}{*}{ May } & 1 & 1990 & 353.00 \\
\hline & 2 & & 352.87 \\
\hline & 3 & & 352.62 \\
\hline & 4 & & 352.47 \\
\hline & 5 & & 352.44 \\
\hline & 6 & & 352.51 \\
\hline & 7 & & 353.59 \\
\hline & 8 & & 354.01 \\
\hline & 9 & & 353.41 \\
\hline & 10. & & 353.23 \\
\hline & 11 & & 353.27 \\
\hline & 12 & & 353.32 \\
\hline & 13 & & 353.32 \\
\hline & 14 & & 353.77 \\
\hline & 15 & & 354.34 \\
\hline & 16 & & \\
\hline & 17 & & \\
\hline & 18 & & 353.99 \\
\hline & 19 & & 353.64 \\
\hline & 20 & & 353.54 \\
\hline & 21 & & 353.16 \\
\hline & 22 & & 352.96 \\
\hline & 23 & & 352.92 \\
\hline & 24 & & 353.96 \\
\hline & 25 & & 353.65 \\
\hline & 26 & & 353.10 \\
\hline & 27 & & 352.82 \\
\hline & 28 & & 352.49 \\
\hline & 29 & & 352.43 \\
\hline & 30 & & 352.61 \\
\hline & 31 & & 353.73 \\
\hline
\end{tabular}




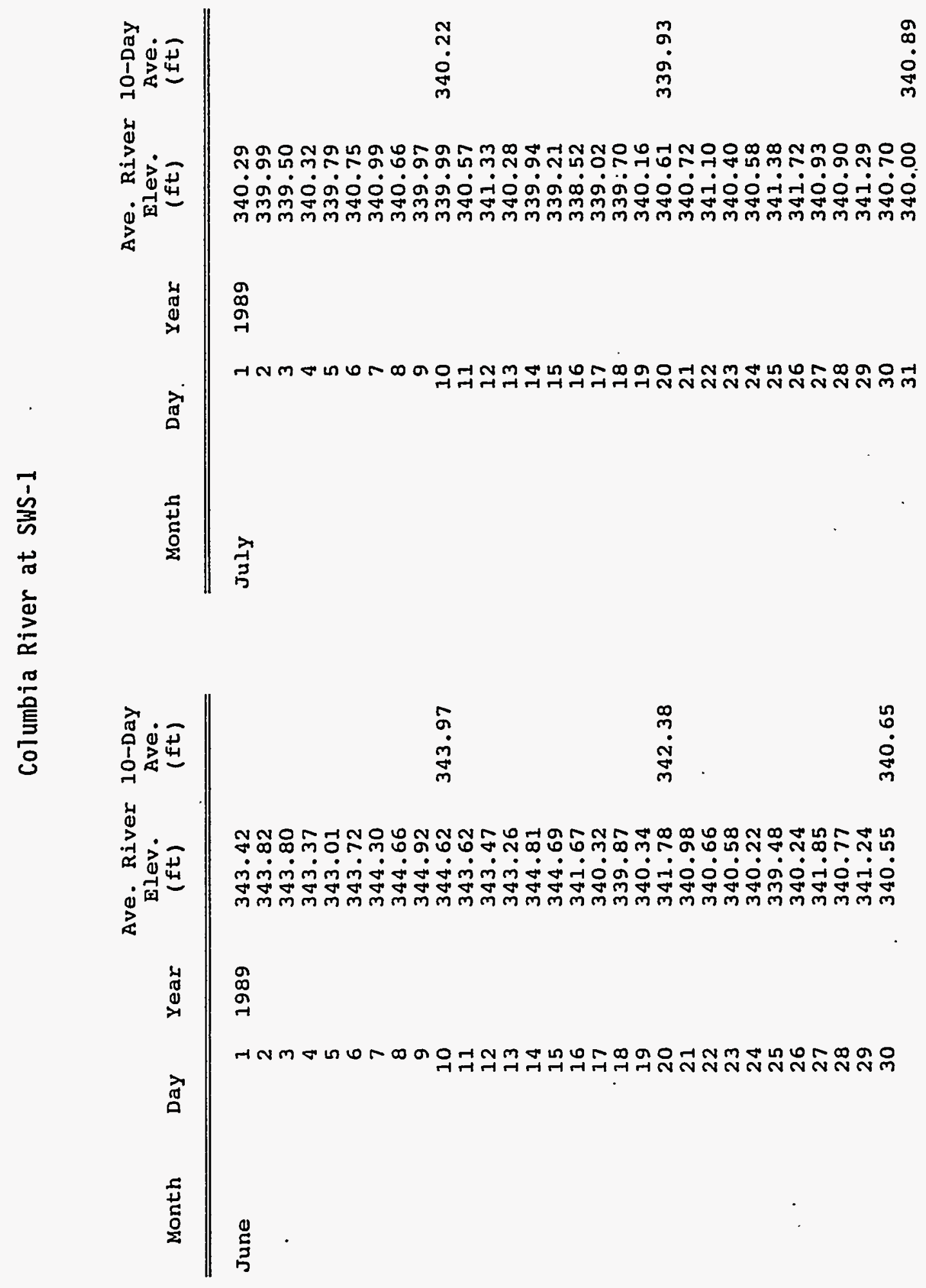

B. 47 


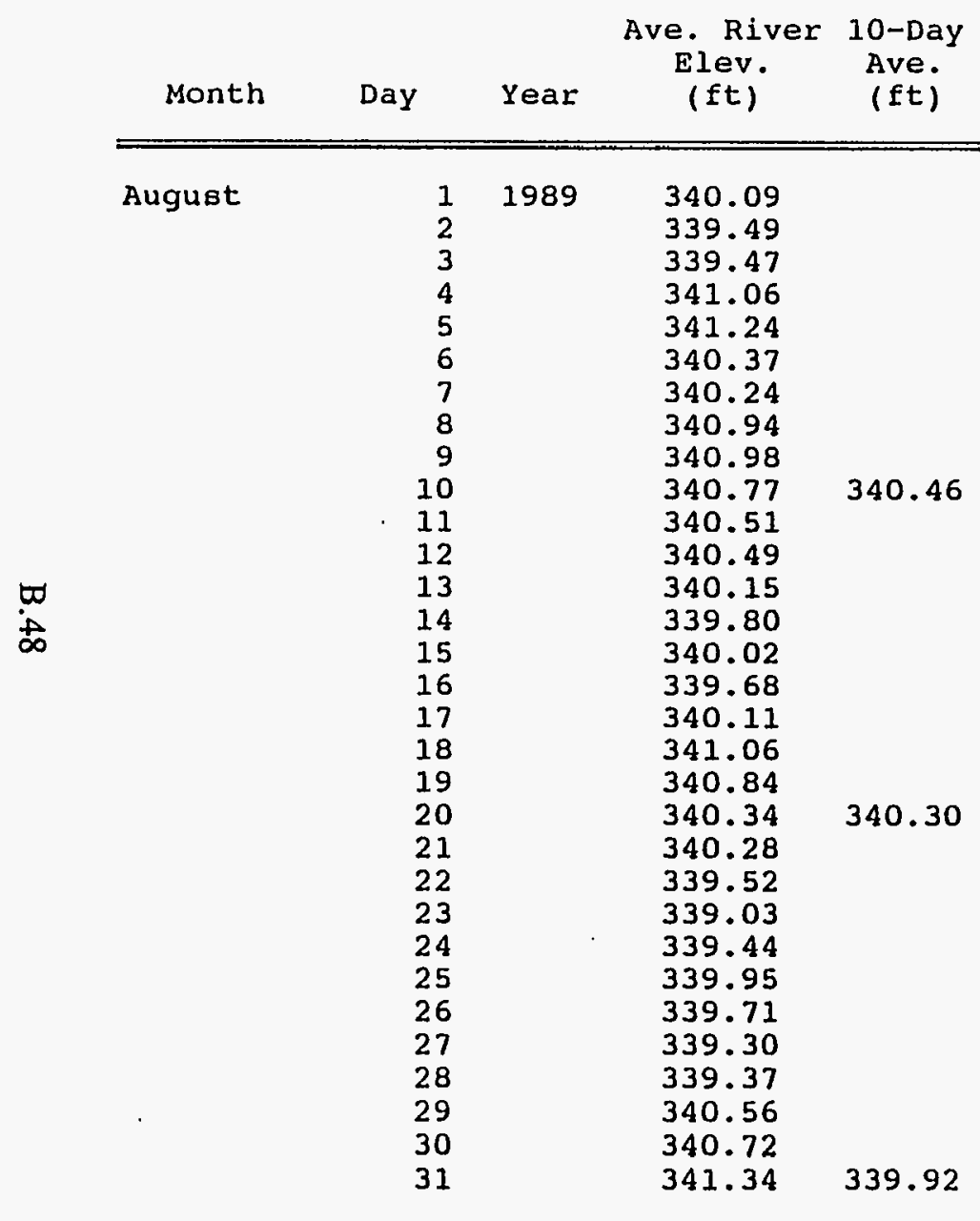

\begin{tabular}{|c|c|c|c|c|}
\hline Month & Day & Year & $\begin{array}{c}\text { Ave. River } \\
\text { Elev. } \\
\text { (ft) }\end{array}$ & $\begin{array}{l}\text { 10-Day } \\
\text { Ave. } \\
\text { (ft) }\end{array}$ \\
\hline September & $\begin{array}{r}1 \\
2 \\
3 \\
4 \\
5 \\
6 \\
7 \\
8 \\
9 \\
10 \\
11 \\
12 \\
13 \\
14 \\
15 \\
16 \\
17 \\
18 \\
19 \\
20 \\
21 \\
22 \\
23 \\
24 \\
25 \\
26 \\
27 \\
28 \\
29 \\
30\end{array}$ & 1989 & $\begin{array}{l}340.97 \\
340.76 \\
340.17 \\
340.30 \\
340.12 \\
341.72 \\
341.17 \\
340.75 \\
340.77 \\
339.93 \\
339.85 \\
339.93 \\
340.43 \\
340.59 \\
340.91 \\
340.59 \\
340.10 \\
339.75 \\
340.89 \\
341.28 \\
341.04 \\
340.61 \\
341.35 \\
340.32 \\
339.82 \\
340.81 \\
340.86 \\
341.10 \\
341.21 \\
340.55\end{array}$ & 340.67 \\
\hline
\end{tabular}




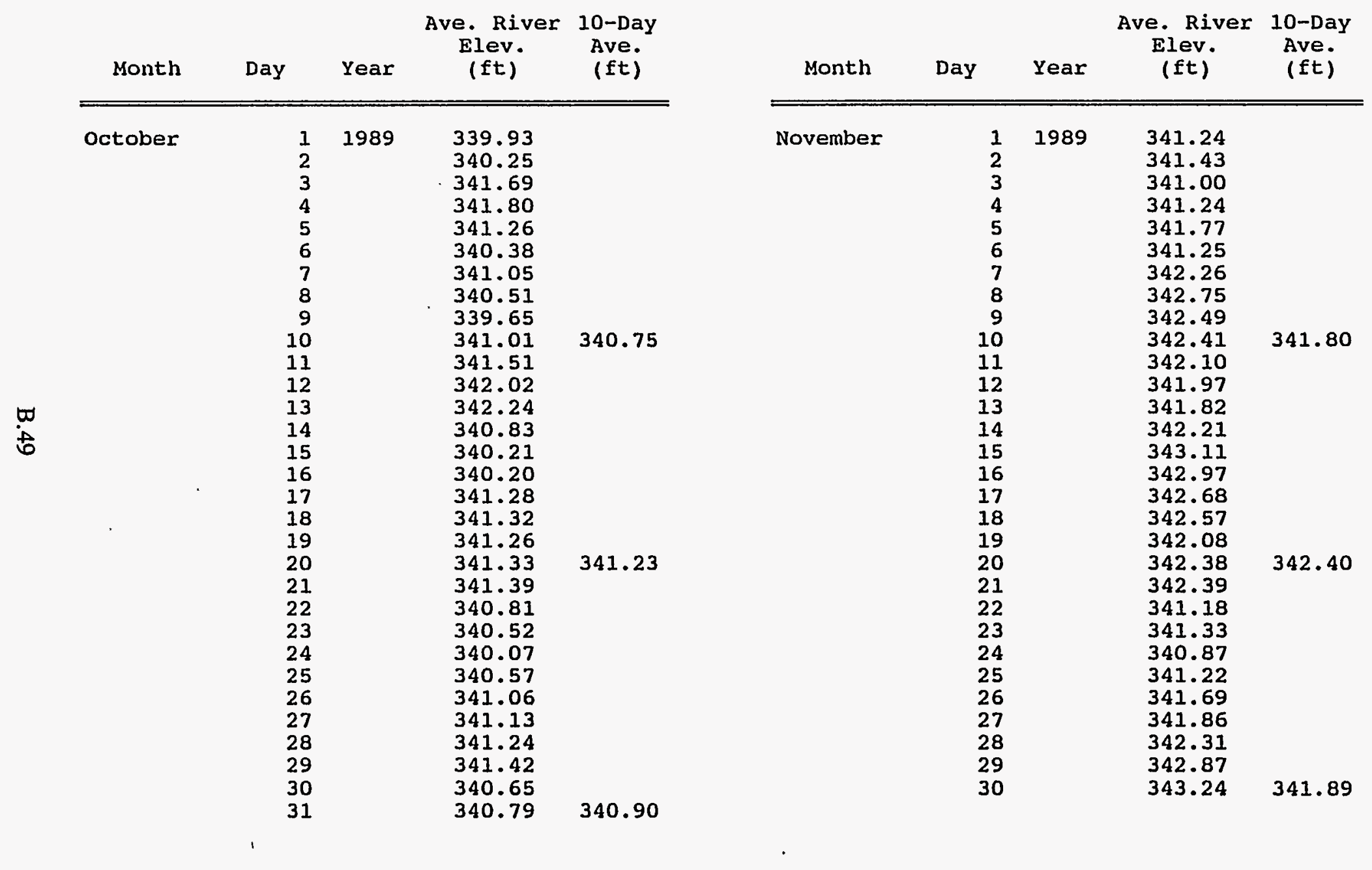




\begin{tabular}{|c|c|c|c|c|c|c|c|c|c|}
\hline Month & Day & Year & $\begin{array}{l}\text { Ave. River } \\
\text { Elev. } \\
\text { (ft) }\end{array}$ & $\begin{array}{l}\text { 10-Day } \\
\text { Ave. } \\
\text { (ft) }\end{array}$ & Month & Day & Year & $\begin{array}{c}\text { Ave. River } \\
\text { Elev. } \\
\text { (ft) }\end{array}$ & $\begin{array}{l}\text { 10-Day } \\
\text { Ave. } \\
\text { (ft) }\end{array}$ \\
\hline December & $\begin{array}{r}1 \\
2 \\
3 \\
4 \\
5 \\
6 \\
7 \\
8 \\
9 \\
10 \\
11 \\
12 \\
13 \\
14 \\
15 \\
16 \\
17 \\
18 \\
19 \\
20 \\
21 \\
22 \\
23 \\
24 \\
25 \\
26 \\
27 \\
28 \\
29 \\
30 \\
31\end{array}$ & 1989 & $\begin{array}{l}341.93 \\
342.37 \\
341.30 \\
341.22 \\
340.86 \\
341.34 \\
342.93 \\
343.17 \\
342.98 \\
342.06 \\
342.83 \\
342.81 \\
342.57 \\
343.02 \\
343.04 \\
342.60 \\
342.17 \\
342.02 \\
342.99 \\
343.17 \\
343.15 \\
342.63 \\
342.43 \\
341.47 \\
341.33 \\
341.29 \\
342.80 \\
343.22 \\
343.13 \\
342.06 \\
342.55\end{array}$ & $\begin{array}{l}342.02 \\
342.73\end{array}$ & January & $\begin{array}{r}1 \\
2 \\
3 \\
4 \\
5 \\
6 \\
7 \\
8 \\
9 \\
10 \\
11 \\
12 \\
13 \\
14 \\
15 \\
16 \\
17 \\
18 \\
19 \\
20 \\
21 \\
22 \\
23 \\
24 \\
25 \\
26 \\
27 \\
28 \\
29 \\
30 \\
31\end{array}$ & . & $\begin{array}{l}341.92 \\
342.71 \\
343.66 \\
343.51 \\
342.66 \\
342.44 \\
341.98 \\
342.61 \\
343.84 \\
343.35 \\
342.49 \\
342.98 \\
341.86 \\
342.12 \\
342.63\end{array}$ & 342.86 \\
\hline
\end{tabular}




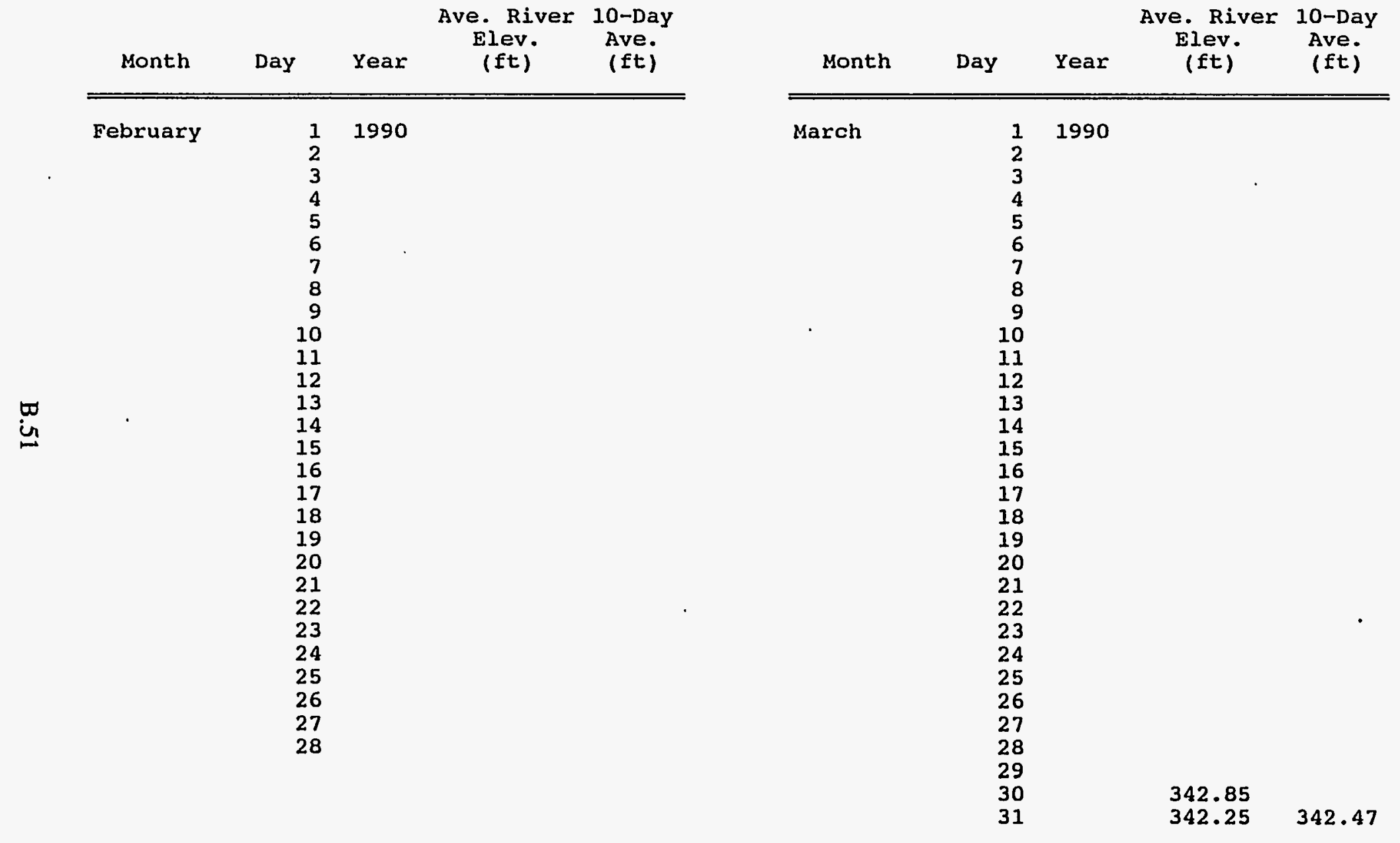




\begin{tabular}{|c|c|c|c|c|}
\hline Month & Day & Year & $\begin{array}{l}\text { Ave. River } \\
\text { Elev. } \\
\text { (ft) }\end{array}$ & $\begin{array}{l}\text { 10-Day } \\
\text { Ave. } \\
\text { (ft) }\end{array}$ \\
\hline April & $\begin{array}{r}1 \\
2 \\
3 \\
4 \\
5 \\
6 \\
7 \\
8 \\
9 \\
10 \\
11 \\
12 \\
13 \\
14 \\
15 \\
16 \\
17 \\
18 \\
19 \\
20 \\
21 \\
22 \\
23 \\
24 \\
25 \\
26 \\
27 \\
28 \\
29 \\
30\end{array}$ & 1990 & $\begin{array}{l}342.34 \\
343.72 \\
345.83 \\
344.84 \\
343.56 \\
343.13 \\
343.28 \\
345.09 \\
343.21 \\
343.89 \\
343.97 \\
343.83 \\
343.43 \\
343.61 \\
342.37 \\
341.38 \\
342.22 \\
343.20 \\
343.23 \\
344.07 \\
343.43 \\
342.23 \\
341.95 \\
344.50 \\
343.83 \\
346.13 \\
345.09 \\
343.61 \\
342.67 \\
341.30\end{array}$ & 343.89 \\
\hline
\end{tabular}

\begin{tabular}{|c|c|c|c|c|}
\hline Month & Day & Year & $\begin{array}{c}\text { Ave. River } \\
\text { Elev. } \\
\text { (ft) }\end{array}$ & $\begin{array}{l}\text { 10-Day } \\
\text { Ave. } \\
\text { (ft) }\end{array}$ \\
\hline May & $\begin{array}{r}1 \\
2 \\
3 \\
4 \\
5 \\
6 \\
7 \\
8 \\
9 \\
10 \\
11 \\
12 \\
13 \\
14 \\
15 \\
16 \\
17 \\
18 \\
19 \\
20 \\
21 \\
22 \\
23 \\
24 \\
25 \\
26 \\
27 \\
28 \\
29 \\
30 \\
31\end{array}$ & 1990 & $\begin{array}{l}343.51 \\
343.17 \\
345.17 \\
346.10 \\
345.35 \\
344.70 \\
344.53 \\
345.92 \\
345.56 \\
343.54 \\
342.37 \\
341.18 \\
341.96 \\
342.50 \\
343.07 \\
343.50 \\
343.77 \\
344.26 \\
344.22 \\
342.58 \\
342.04 \\
343.90 \\
344.28 \\
344.19 \\
344.02 \\
342.41 \\
342.40 \\
343.28 \\
342.96 \\
345.40\end{array}$ & $\begin{array}{r}344.76 \\
.\end{array}$ \\
\hline
\end{tabular}


Columbia River at Snyder Street

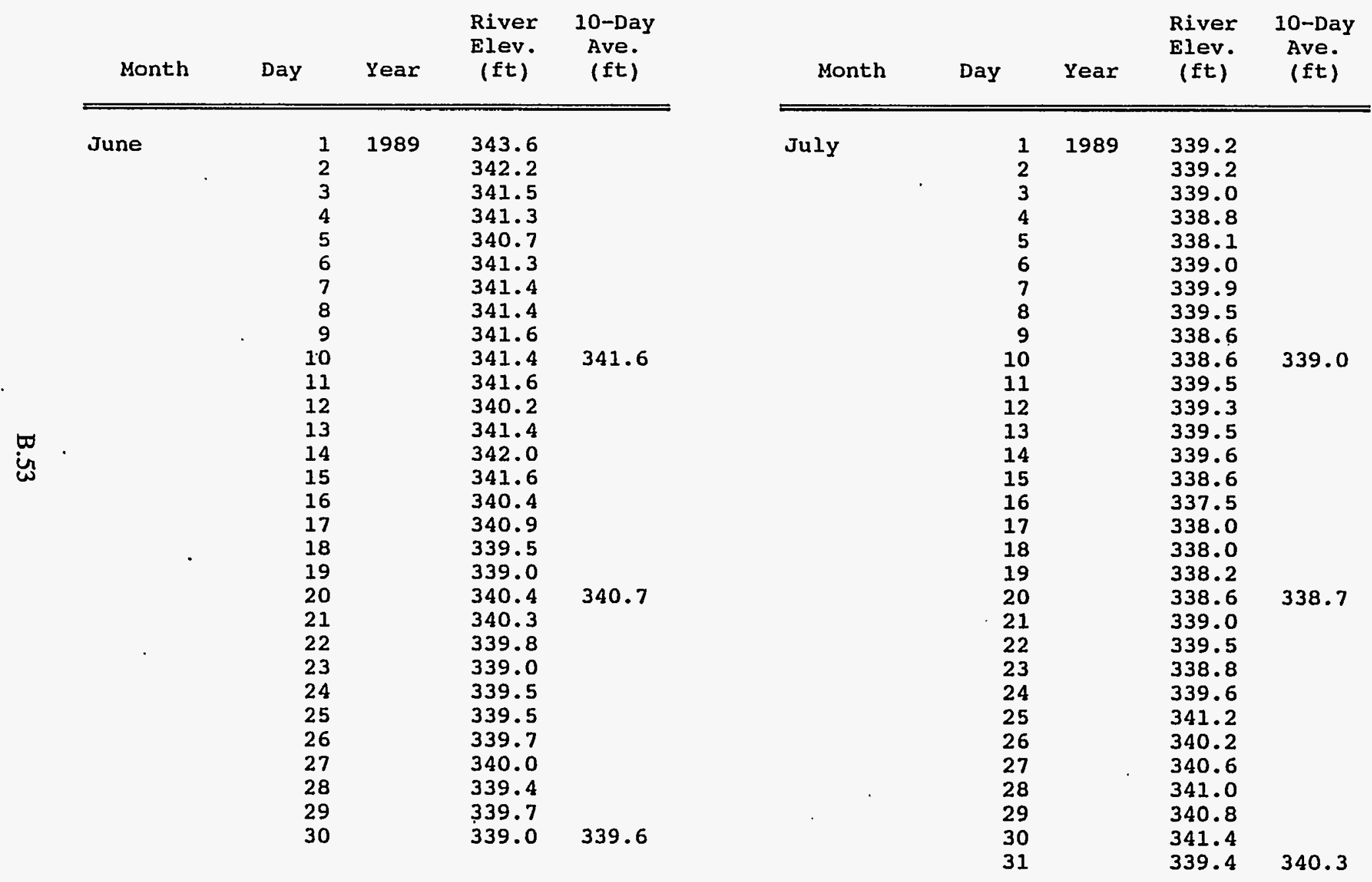




\begin{tabular}{|c|c|c|c|c|c|c|c|c|c|}
\hline Month & Day & Year & $\begin{array}{l}\text { River } \\
\text { Elev. } \\
\text { (ft) }\end{array}$ & $\begin{array}{l}\text { 10-Day } \\
\text { Ave. } \\
\text { (ft) }\end{array}$ & Month & Day & Year & $\begin{array}{l}\text { River } \\
\text { Elev. } \\
\text { (ft) }\end{array}$ & $\begin{array}{c}\text { 10-Day } \\
\text { Ave. } \\
\text { (ft) }\end{array}$ \\
\hline August & $\begin{array}{r}1 \\
2 \\
3 \\
4 \\
5 \\
6 \\
7 \\
8 \\
9 \\
10 \\
11 \\
12 \\
13 \\
14 \\
15 \\
16 \\
17 \\
18 \\
19 \\
20 \\
21 \\
22 \\
23 \\
24 \\
25 \\
26 \\
27 \\
28 \\
29 \\
30 \\
31\end{array}$ & 1989 & $\begin{array}{l}339.2 \\
338.7 \\
338.0 \\
339.4 \\
339.4 \\
338.1 \\
339.0 \\
340.9 \\
340.5 \\
340.3 \\
339.2 \\
340.6 \\
340.8 \\
339.5 \\
339.0 \\
338.4 \\
338.5 \\
340.0 \\
340.4 \\
340.1 \\
339.8 \\
340.0 \\
339.7 \\
339.7 \\
339.7 \\
339.8 \\
338.8 \\
338.6 \\
339.7 \\
339.7 \\
340.0\end{array}$ & 339.7 & September & $\begin{array}{r}1 \\
2 \\
3 \\
4 \\
5 \\
6 \\
7 \\
8 \\
9 \\
10 \\
11 \\
12 \\
13 \\
14 \\
15 \\
16 \\
17 \\
18 \\
19 \\
20 \\
21 \\
22 \\
23 \\
24 \\
25 \\
26 \\
27 \\
28 \\
29 \\
30\end{array}$ & . & $\begin{array}{l}341.0 \\
339.4 \\
340.8 \\
340.6 \\
341.4 \\
341.8 \\
341.6 \\
341.8 \\
340.6 \\
341.4 \\
341.8 \\
340.0 \\
339.8 \\
339.8 \\
339.6\end{array}$ & 340.2 \\
\hline
\end{tabular}




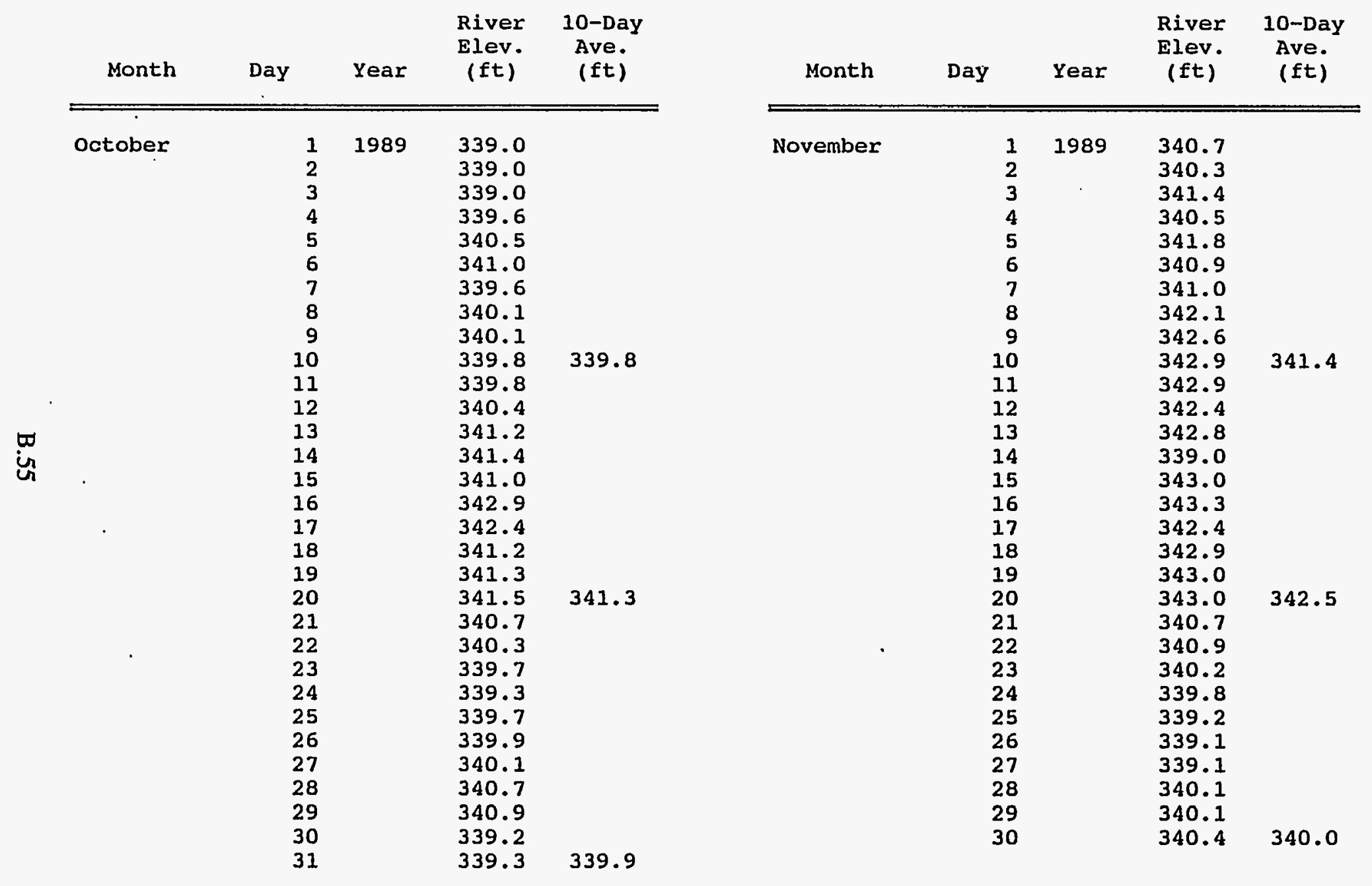




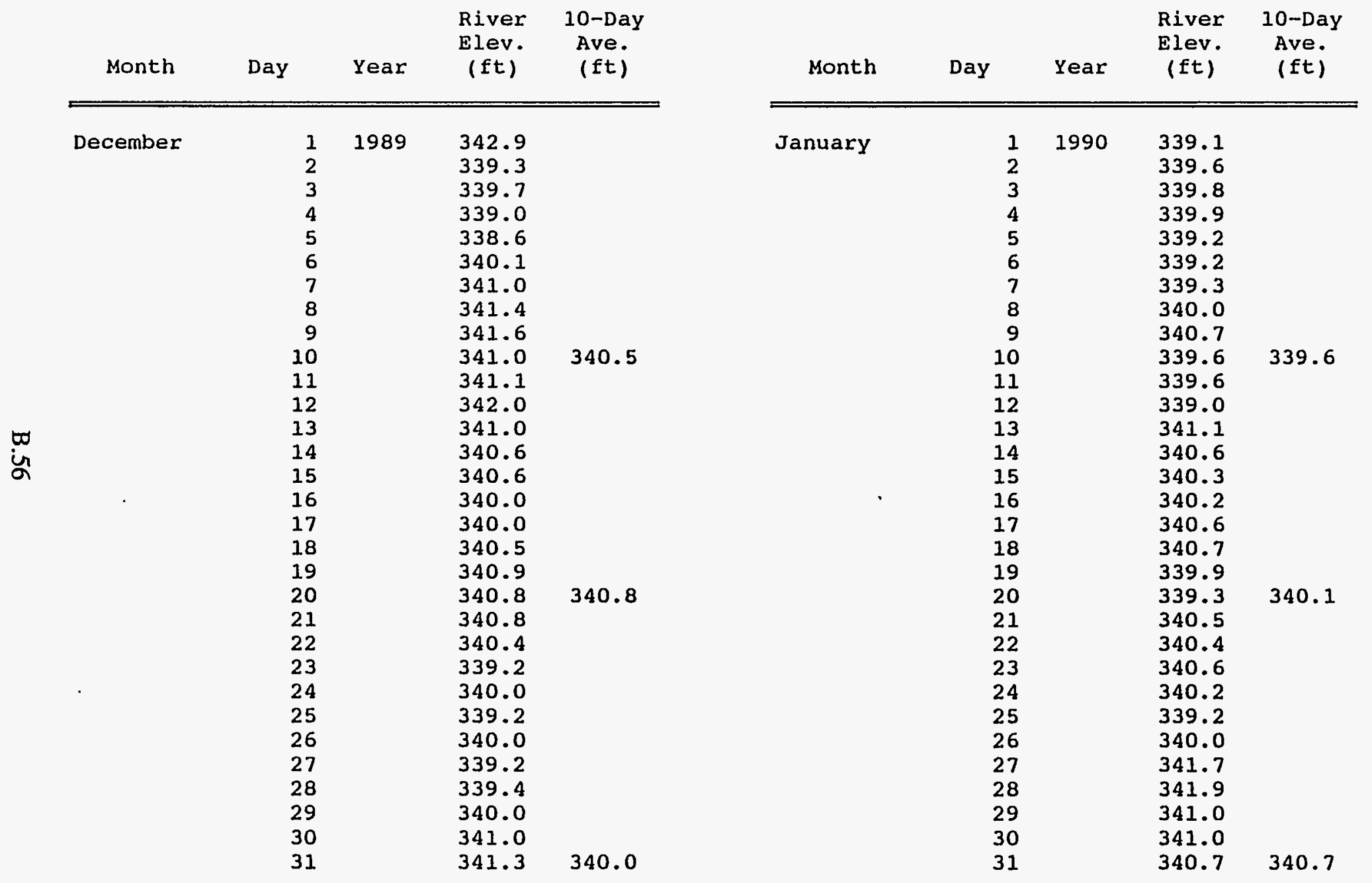




\begin{tabular}{|c|c|c|c|c|c|c|c|c|c|}
\hline Month & Day & Year & $\begin{array}{l}\text { River } \\
\text { Elev. } \\
\text { (ft) }\end{array}$ & $\begin{array}{l}\text { 10-Day } \\
\text { Ave. } \\
\text { (ft) }\end{array}$ & Month & Day & Year & $\begin{array}{l}\text { River } \\
\text { Elev. } \\
\text { (ft) }\end{array}$ & $\begin{array}{c}\text { 10-Day } \\
\text { Ave. } \\
\text { (ft) }\end{array}$ \\
\hline February & $\begin{array}{r}1 \\
2 \\
3 \\
4 \\
5 \\
6 \\
7 \\
8 \\
9 \\
10 \\
11 \\
12 \\
13 \\
14 \\
15 \\
16 \\
17 \\
18 \\
19 \\
20 \\
21 \\
22 \\
23 \\
24 \\
25 \\
26 \\
27 \\
28\end{array}$ & 1990 & $\begin{array}{l}340.0 \\
340.6 \\
341.0 \\
340.5 \\
340.6 \\
340.5 \\
341.2 \\
342.5 \\
342.8 \\
341.6 \\
341.0 \\
341.5 \\
341.2 \\
341.0 \\
342.7 \\
342.9 \\
343.0 \\
343.0 \\
341.0 \\
341.2 \\
341.6 \\
341.6 \\
342.0 \\
340.7 \\
341.0 \\
341.1 \\
341.4 \\
341.1\end{array}$ & $\begin{array}{l}341.1 \\
341.9\end{array}$ & March & $\begin{array}{r}1 \\
2 \\
3 \\
4 \\
5 \\
6 \\
7 \\
8 \\
9 \\
10 \\
11 \\
12 \\
13 \\
14 \\
15 \\
16 \\
17 \\
18 \\
19 \\
20 \\
21 \\
22 \\
23 \\
24 \\
25 \\
26 \\
27 \\
28\end{array}$ & 1990 & $\begin{array}{l}341.8 \\
341.8 \\
341.5 \\
341.0 \\
340.8 \\
342.0 \\
341.0 \\
340.8 \\
341.0 \\
340.7 \\
341.2 \\
341.8 \\
342.0 \\
341.0 \\
341.6 \\
341.2 \\
341.0 \\
340.4 \\
340.0 \\
340.7 \\
341.2 \\
341.6 \\
342.4 \\
342.1 \\
342.2 \\
342.4 \\
342.2 \\
341.4\end{array}$ & $\begin{array}{c}341.2 \\
. \\
341.1\end{array}$ \\
\hline
\end{tabular}




\begin{tabular}{|c|c|c|c|c|}
\hline Month & Day & Year & $\begin{array}{l}\text { River } \\
\text { Elev. } \\
\text { (ft) }\end{array}$ & $\begin{array}{c}\text { 10-Day } \\
\text { Ave. } \\
\text { (ft) }\end{array}$ \\
\hline April & $\begin{array}{r}1 \\
2 \\
3 \\
4 \\
5 \\
6 \\
7 \\
8 \\
9 \\
10 \\
11 \\
12 \\
13 \\
14 \\
15 \\
16 \\
17 \\
18 \\
19 \\
20 \\
21 \\
22 \\
23 \\
24 \\
25 \\
26 \\
27 \\
28 \\
29 \\
30\end{array}$ & 1990 & $\begin{array}{l}340.0 \\
341.5 \\
343.0 \\
342.8 \\
341.0 \\
341.2 \\
340.5 \\
342.2 \\
342.6 \\
342.0 \\
340.5 \\
341.6 \\
342.8 \\
340.2 \\
339.2 \\
339.4 \\
339.2 \\
341.8 \\
341.4 \\
341.6 \\
340.8 \\
339.9 \\
339.6 \\
340.8 \\
340.4 \\
340.0 \\
340.4 \\
341.0 \\
341.0 \\
340.8\end{array}$ & 341.7 \\
\hline
\end{tabular}

\begin{tabular}{|c|c|c|c|c|}
\hline Month & Day & Year & $\begin{array}{c}\text { River } \\
\text { Elev. } \\
\text { (ft) }\end{array}$ & $\begin{array}{c}\text { 10-Day } \\
\text { Ave. } \\
\text { (ft) }\end{array}$ \\
\hline May & $\begin{array}{r}1 \\
2 \\
3 \\
4 \\
5 \\
6 \\
7 \\
8 \\
9 \\
10 \\
11 \\
12 \\
13 \\
14 \\
15 \\
16 \\
17 \\
18 \\
19 \\
20 \\
21 \\
22 \\
23 \\
24 \\
25 \\
26 \\
27 \\
28 \\
29 \\
30 \\
31\end{array}$ & 1990 & $\begin{array}{l}340.5 \\
341.5 \\
342.5 \\
342.2 \\
343.2 \\
343.0 \\
342.6 \\
343.2 \\
343.0 \\
342.0 \\
342.2 \\
338.5 \\
339.0 \\
339.2 \\
341.0 \\
341.2 \\
341.1 \\
341.6 \\
341.2 \\
341.8 \\
341.9 \\
342.0 \\
342.0 \\
342.4 \\
342.2 \\
341.5 \\
342.0 \\
342.0 \\
342.5 \\
341.8 \\
342.0\end{array}$ & $\begin{array}{c}342.4 \\
.\end{array}$ \\
\hline
\end{tabular}


Average Daily Recharge and Production at the North Richland Well Field

\begin{tabular}{|c|c|c|c|c|}
\hline Month & Year & $\begin{array}{c}\text { Daily } \\
\text { Ave. } \\
\text { Total } \\
\text { Recharge } \\
\text { (mgl }\end{array}$ & $\begin{array}{l}\text { Daily } \\
\text { Ave. } \\
\text { Total } \\
\text { Production } \\
\text { (mg) }\end{array}$ & $\begin{array}{l}\text { Ratio } \\
\text { Recharge: } \\
\text { Production }\end{array}$ \\
\hline November & 1988 & 2.8 & 0.81 & 3.5 \\
\hline December & 1988 & 13.1 & 5.67 & 2.3 \\
\hline January & 1989 & 9.8 & 4.30 & 2.3 \\
\hline February & 1989 & 6.9 & 3.18 & 2.2 \\
\hline March & 1989 & 1.2 & 0.57 & 2.1 \\
\hline April & 1989 & 2.9 & 0.56 & 5.1 \\
\hline May & 1989 & 8.4 & 2.50 & 3.3 \\
\hline June & 1989 & 12.8 & 6.27 & 2.0 \\
\hline July & 1989 & 11.8 & 5.74 & 2.1 \\
\hline August & 1989 & 10.1 & 3.34 & 3.0 \\
\hline September & 1989 & 5.3 & 1.3 & 4.1 \\
\hline October & 1989 & 5.5 & 0.91 & 6.0 \\
\hline November & 1989 & 6.2 & 2.14 & 2.9 \\
\hline December & 1989 & 13.8 & 6.40 & 2.2 \\
\hline January & 1990 & 7.5 & 4.19 & 1.8 \\
\hline February & 1990 & 2.4 & 0.22 & 10.7 \\
\hline March & 1990 & 1.7 & 0.24 & 7.3 \\
\hline April & 1990 & 4.9 & 0.78 & 6.3 \\
\hline May & 1990 & 5.3 & 2.79 & 1.9 \\
\hline Total & & 132.3 & 51.91 & \\
\hline Average & & 7.0 & 2.7 & 3.7 \\
\hline \multicolumn{2}{|c|}{ Ave. (August through } & 6.8 & 1.9 & 4.0 \\
\hline
\end{tabular}


Average Monthly Recharge and Production at the North Richland Well Field

\begin{tabular}{|c|c|c|c|c|c|}
\hline Month & Yeaz & $\begin{array}{c}\text { Total } \\
\text { Recha=ge } \\
\text { (mg) }\end{array}$ & $\begin{array}{c}\text { Toeal } \\
z=\text { oduction } \\
\text { (mg) }\end{array}$ & $\begin{array}{c}\text { Net } \\
\text { Recharge } \\
\text { (mg) }\end{array}$ & $\begin{array}{l}\text { Ratio } \\
\text { Recharge: } \\
\text { Production }\end{array}$ \\
\hline November & 1988 & 34.5 & 24.4 & 60.1 & 3.5 \\
\hline December & 1988 & 407.0 & 175.3 & 231.2 & 2.3 \\
\hline January & 1989 & 304.0 & 133.4 & 170.5 & 2.3 \\
\hline Zebruary & 1989 & 192.0 & 39.0 & 103.0 & 2.2 \\
\hline Marcin & 1989 & 36.3 & 17.7 & 13.5 & 2.1 \\
\hline April & 1989 & 85.9 & 15.7 & 59.2 & $\Xi .1$ \\
\hline May & 1789 & 251.0 & 54.9 & 196.1 & 4.5 \\
\hline June & 1989 & 383.7 & 138.2 & 195.7 & 2.0 \\
\hline July & 1989 & 367.0 & 178.0 & 139.0 & 2.1 \\
\hline August & 1989 & $3: 3.1$ & 103.5 & 209.5 & 3.0 \\
\hline September & 1989 & 160.1 & 38.0 & 122.1 & 4.2 \\
\hline october & 1989 & 159.3 & 23.3 & 141.0 & J.J \\
\hline sovember & 1989 & 135.3 & 54.1 & 121.7 & 2.9 \\
\hline December & 1989 & 425.7 & 198.3 & 228.4 & 2.2 \\
\hline January & 1990 & 231.0 & 129.7 & 101.1 & 1.8 \\
\hline February & 1990 & бо. 1 & 5.2 & 59.7 & 10.7 \\
\hline Marsh & 1990 & 54.0 & 7.4 & 46.3 & 7.3 \\
\hline April & 1990 & 148.3 & 23.4 & 124.7 & 5.3 \\
\hline Kay & 1990 & 163.4 & 36.5 & 73.9 & $\dot{2} .3$ \\
\hline \multicolumn{2}{|c|}{$\begin{array}{l}\text { Average } \\
\text { Ave. (Tune } 1989\end{array}$} & $2: 2.2$ & 32.3 & 129.9 & 3.3 \\
\hline \multicolumn{2}{|c|}{$\begin{array}{l}\text { Are. (Jine } 1989 \\
\text { =hrough May 1990) }\end{array}$} & 222.5 & 37.7 & 134.7 & 4.2 \\
\hline \multicolumn{2}{|c|}{$\begin{array}{l}\text { Ave. (May through } \\
\text { Auguse } 2989 \text { ) }\end{array}$} & 328.8 & 131.2 & 197.3 & 2.7 \\
\hline \multicolumn{2}{|c|}{$\begin{array}{l}\text { Ave. (Septamber } \\
\text { th=ough November } 1989 \text { ) }\end{array}$} & $\div 7 \div .7$ & 43.5 & 123.3 & 4.4 \\
\hline
\end{tabular}




\section{Appendix C}

\section{Water-Elevation Maps for June 1989 and August 1989 Through May 1990}




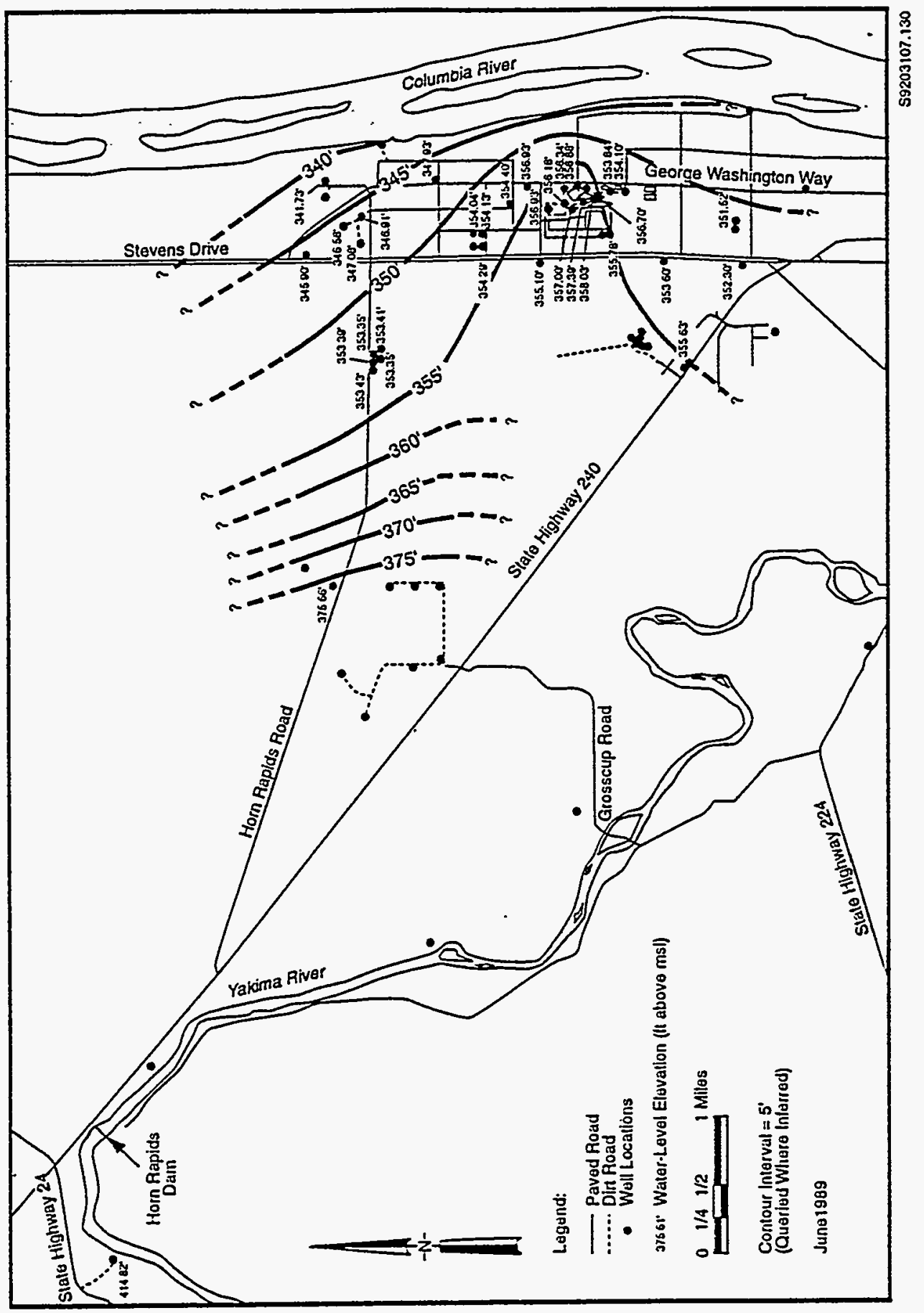

C. 1 


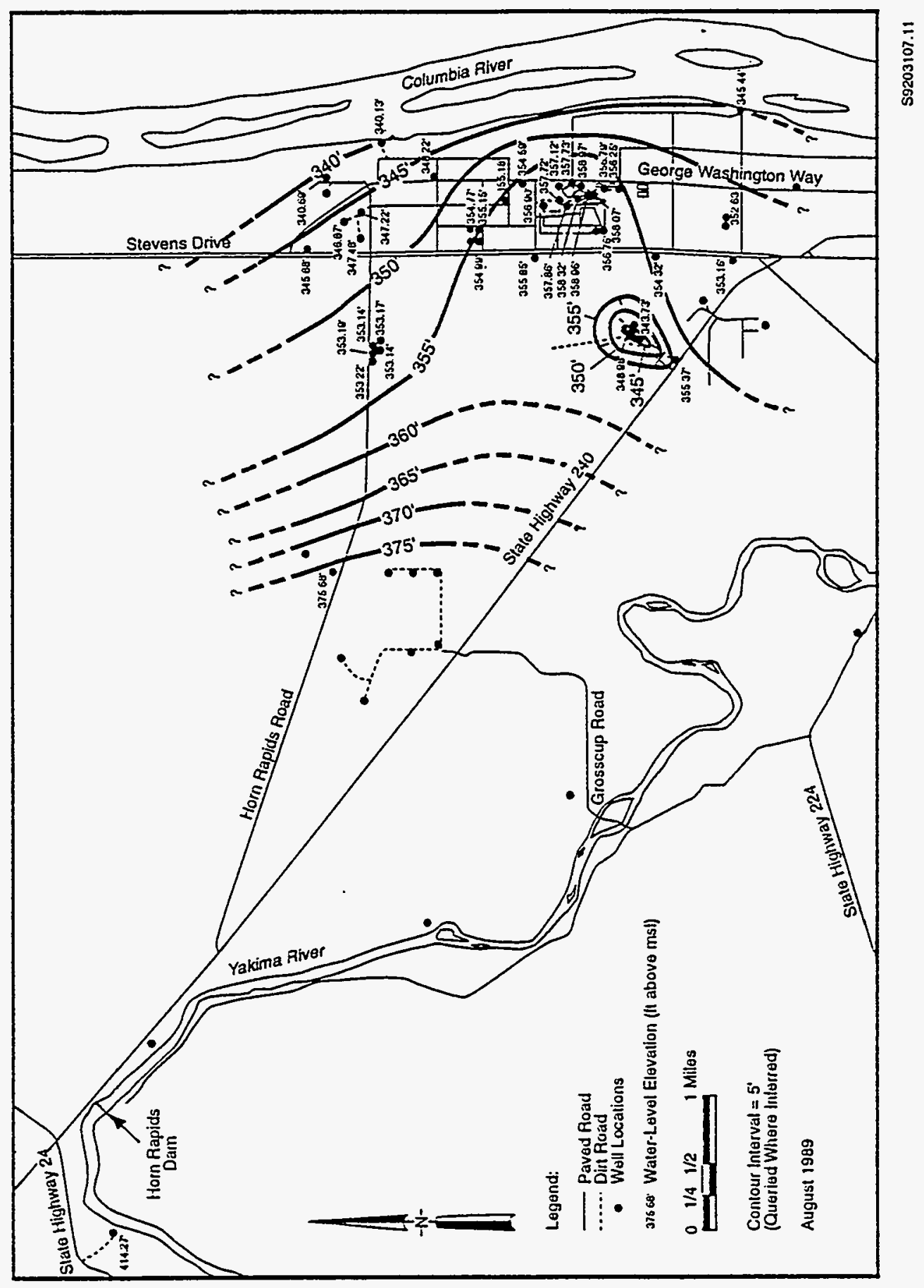

C. 2 


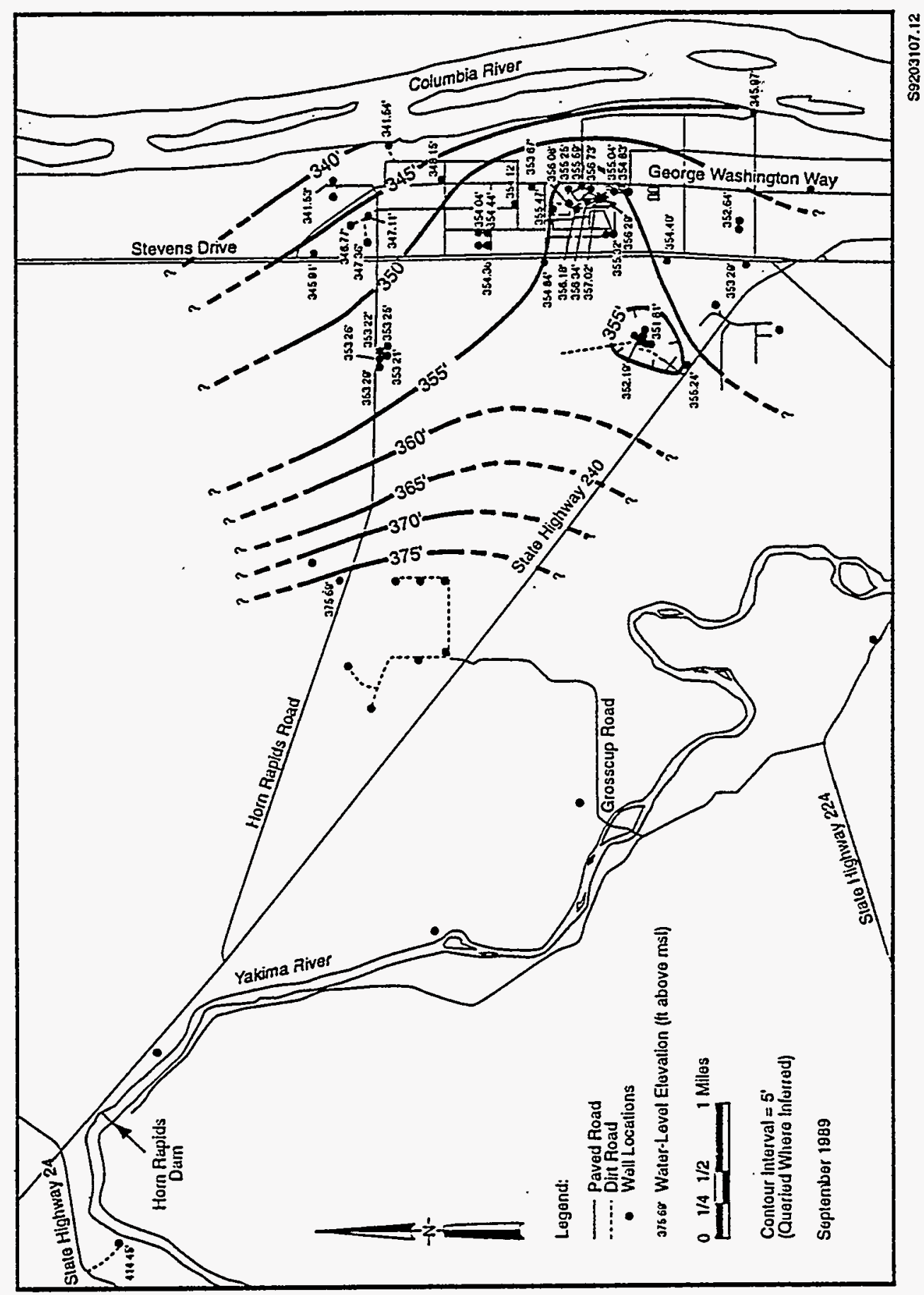

C. 3 


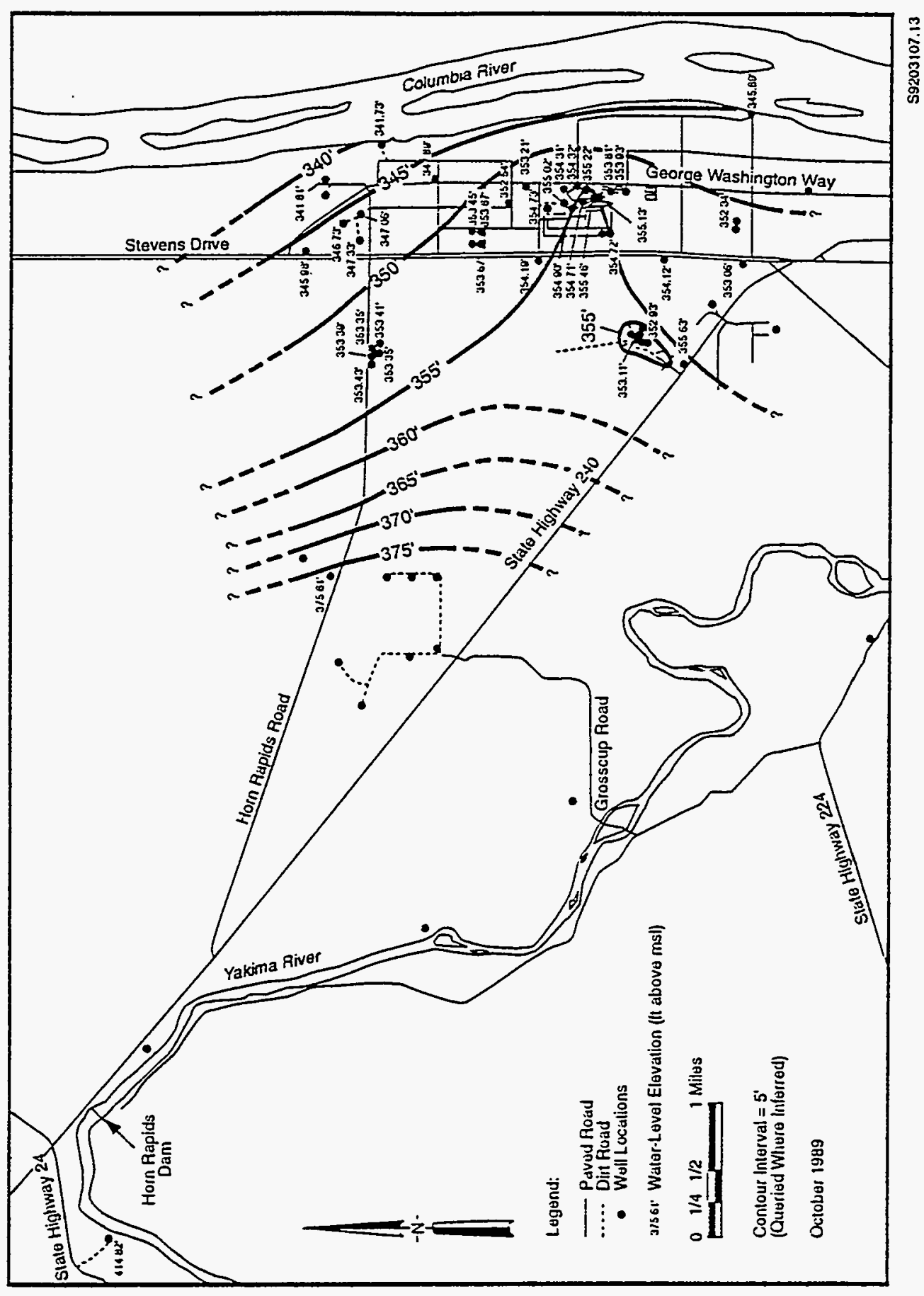

C. 4 


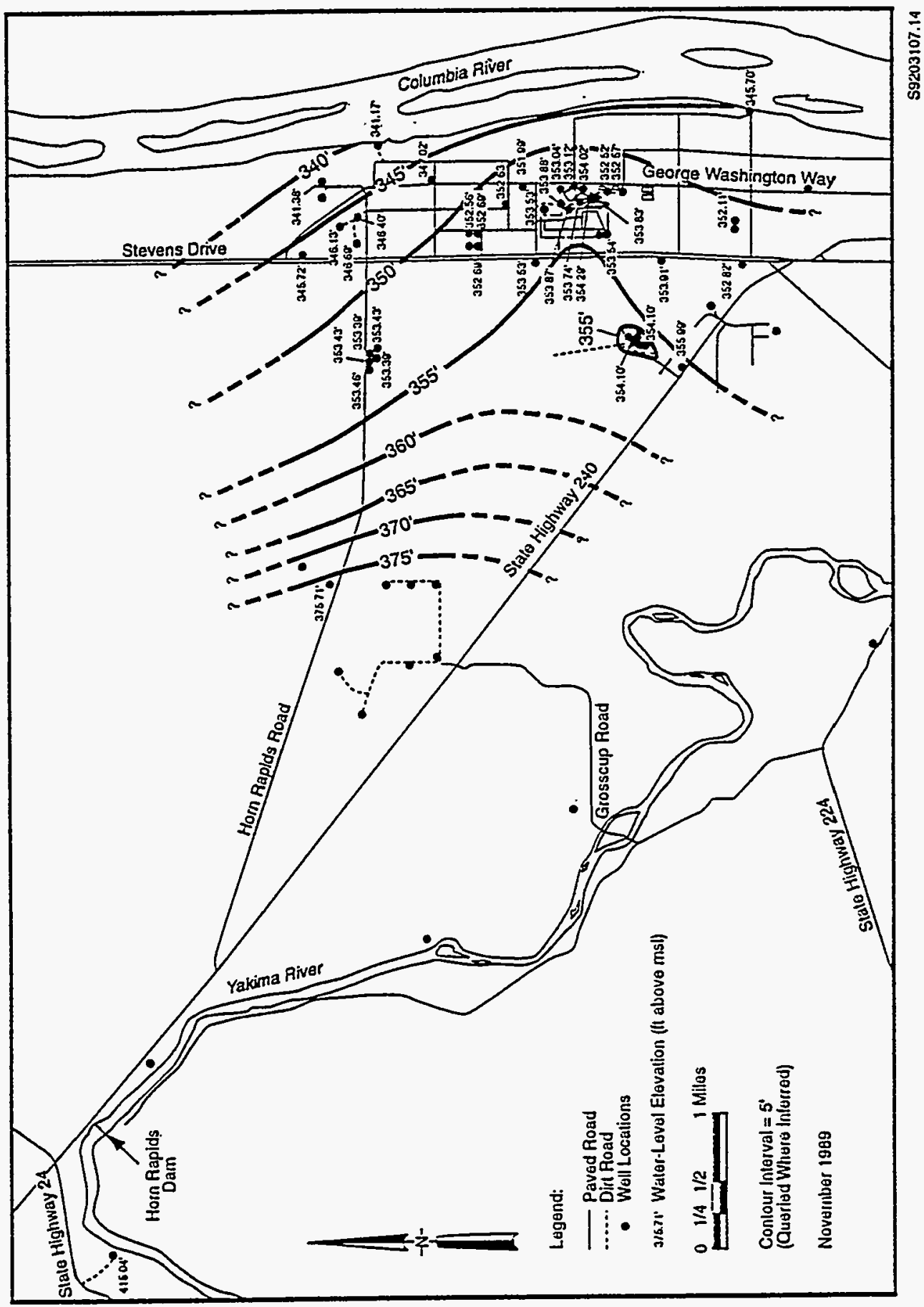

C. 5 


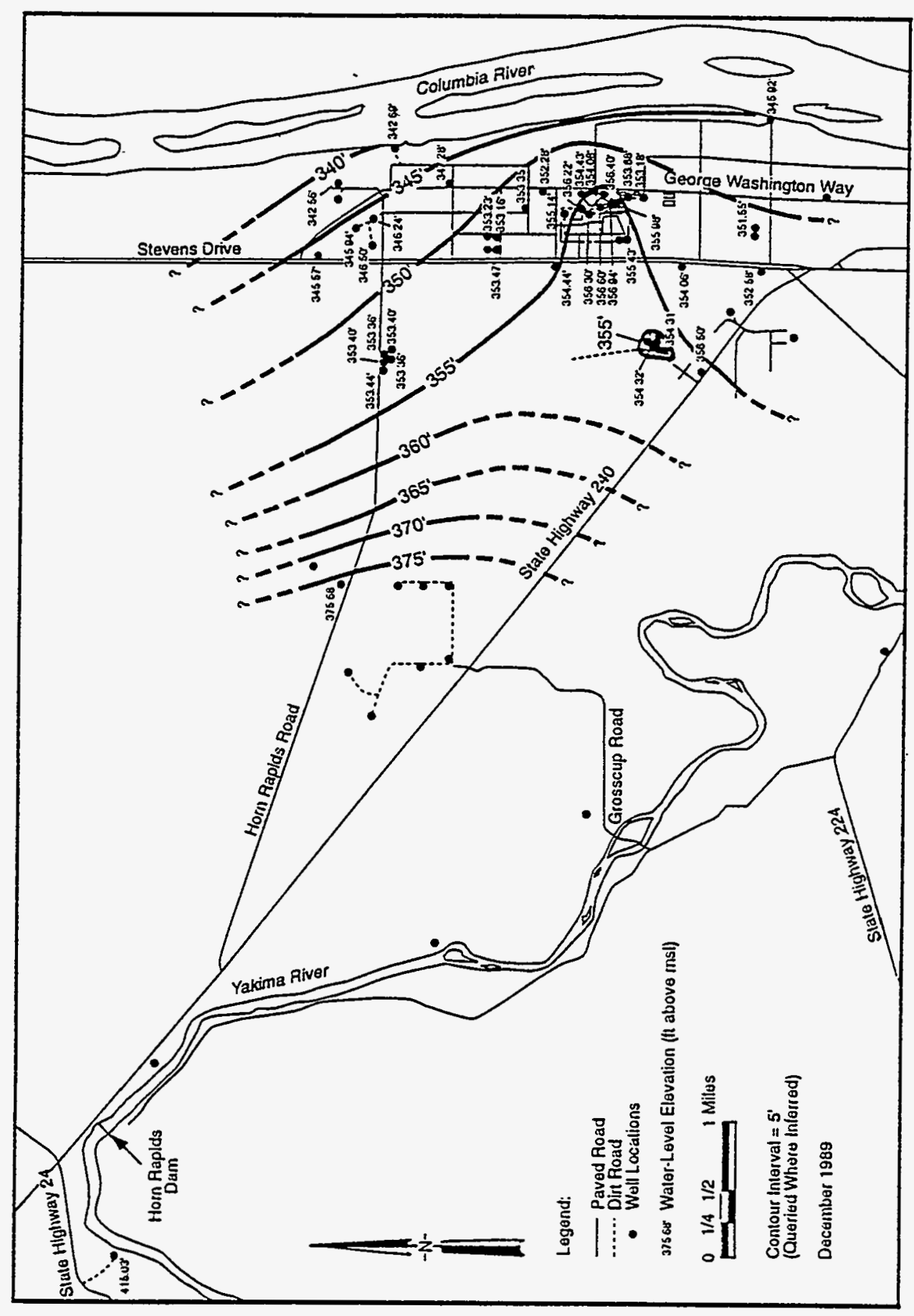

C. 6 


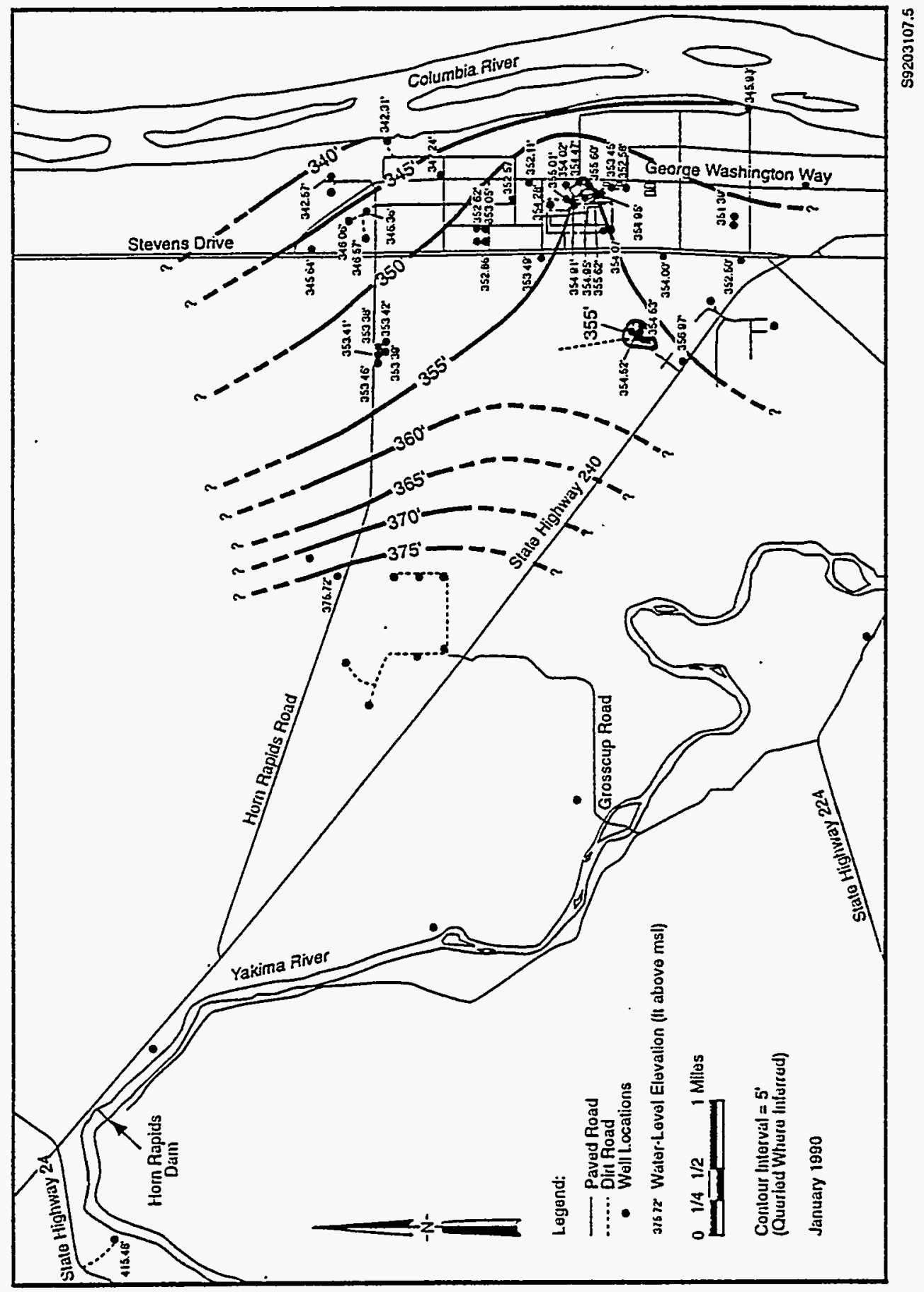

C. 7 


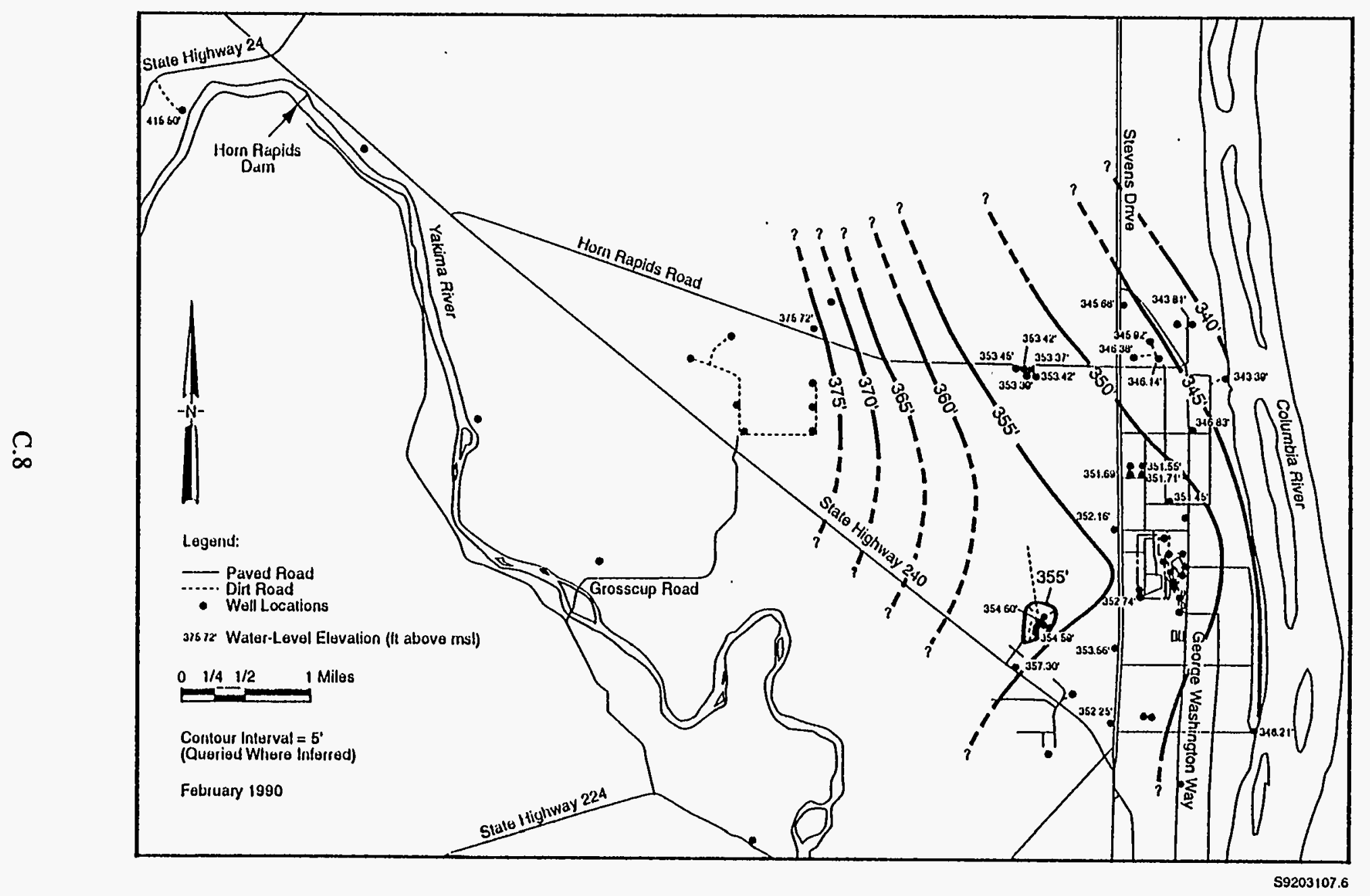




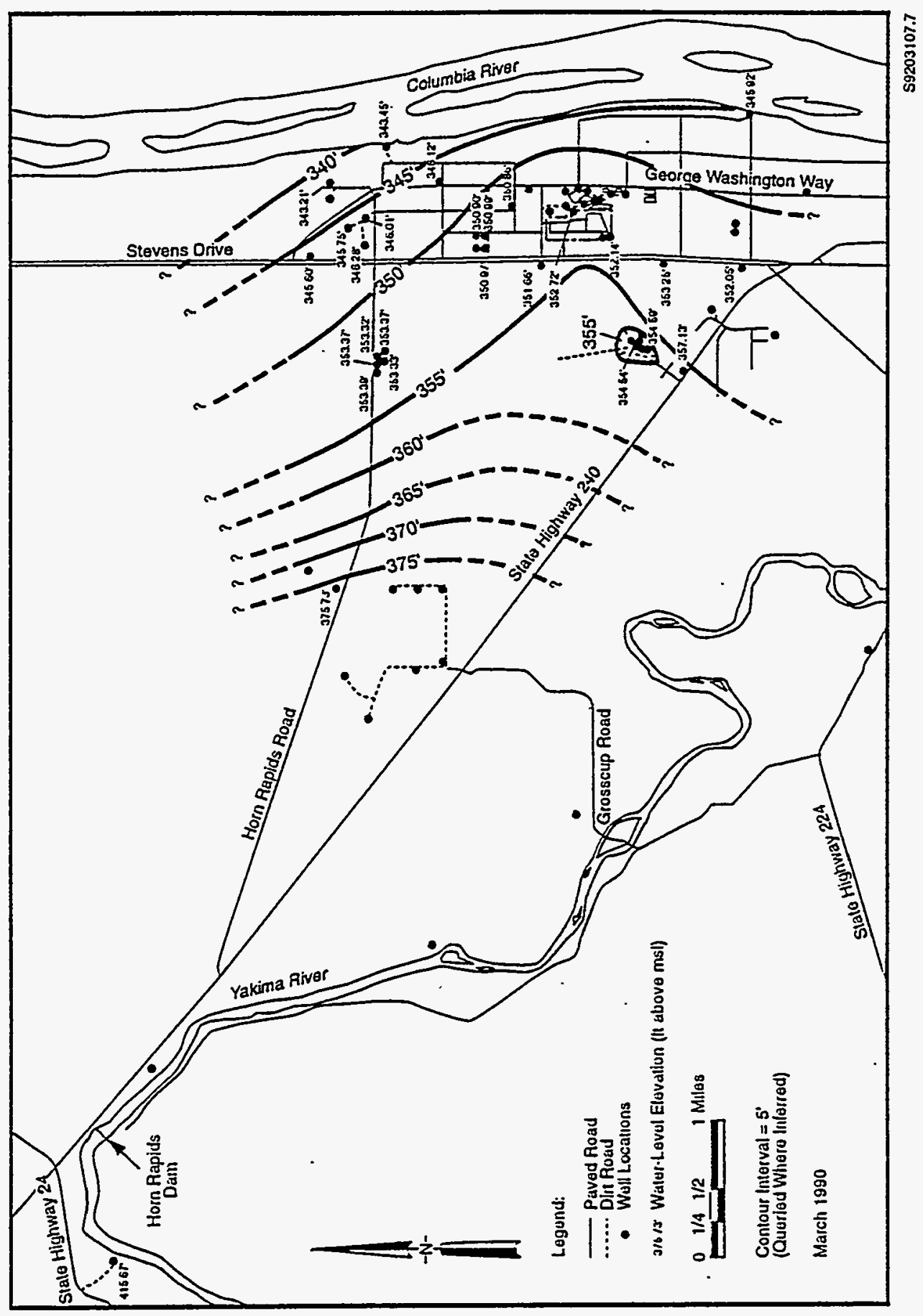

C. 9 


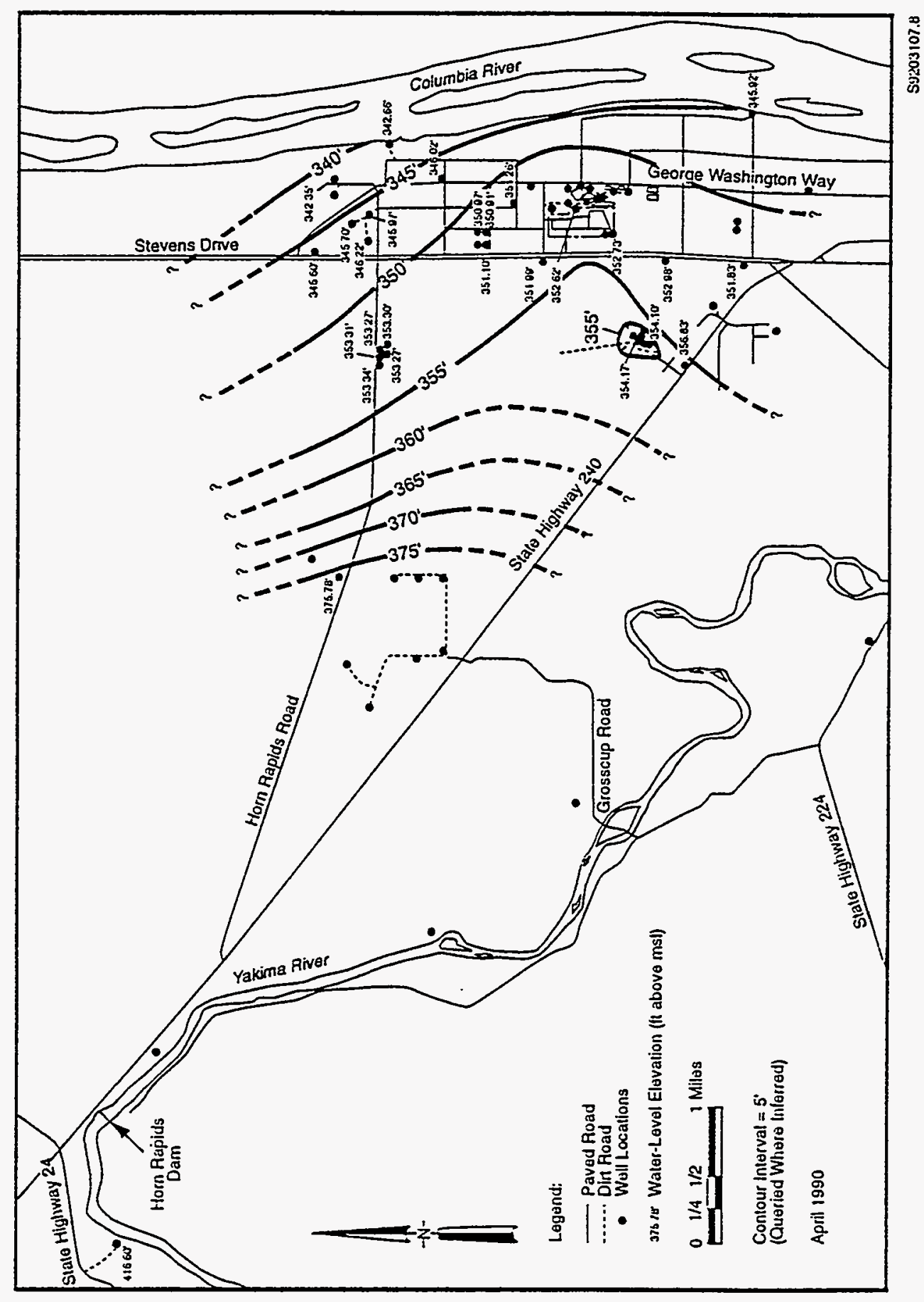

C. 10 


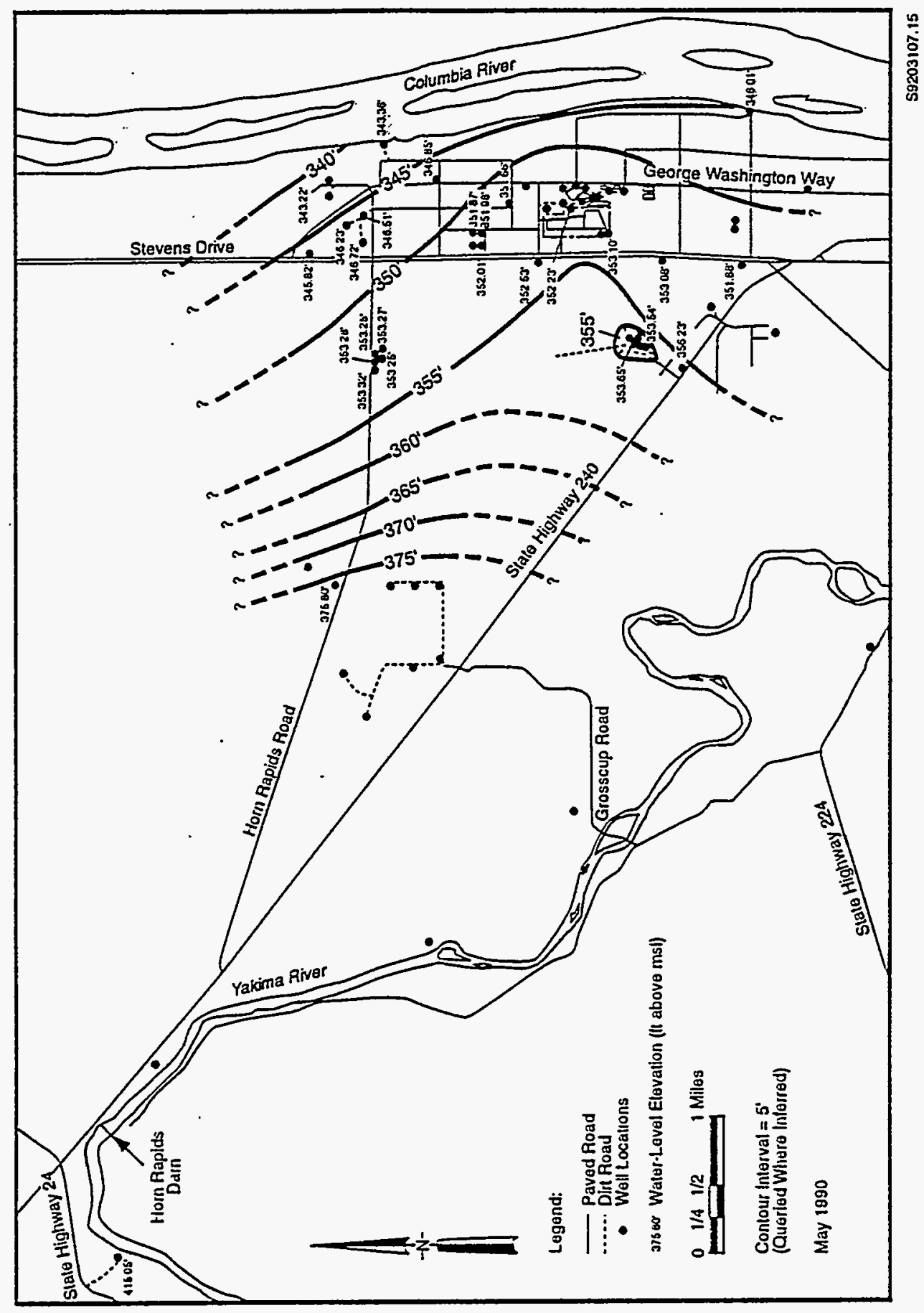

C. 11 


\section{Appendix D}

Hydrographs for the Water-Level Monitoring Network 


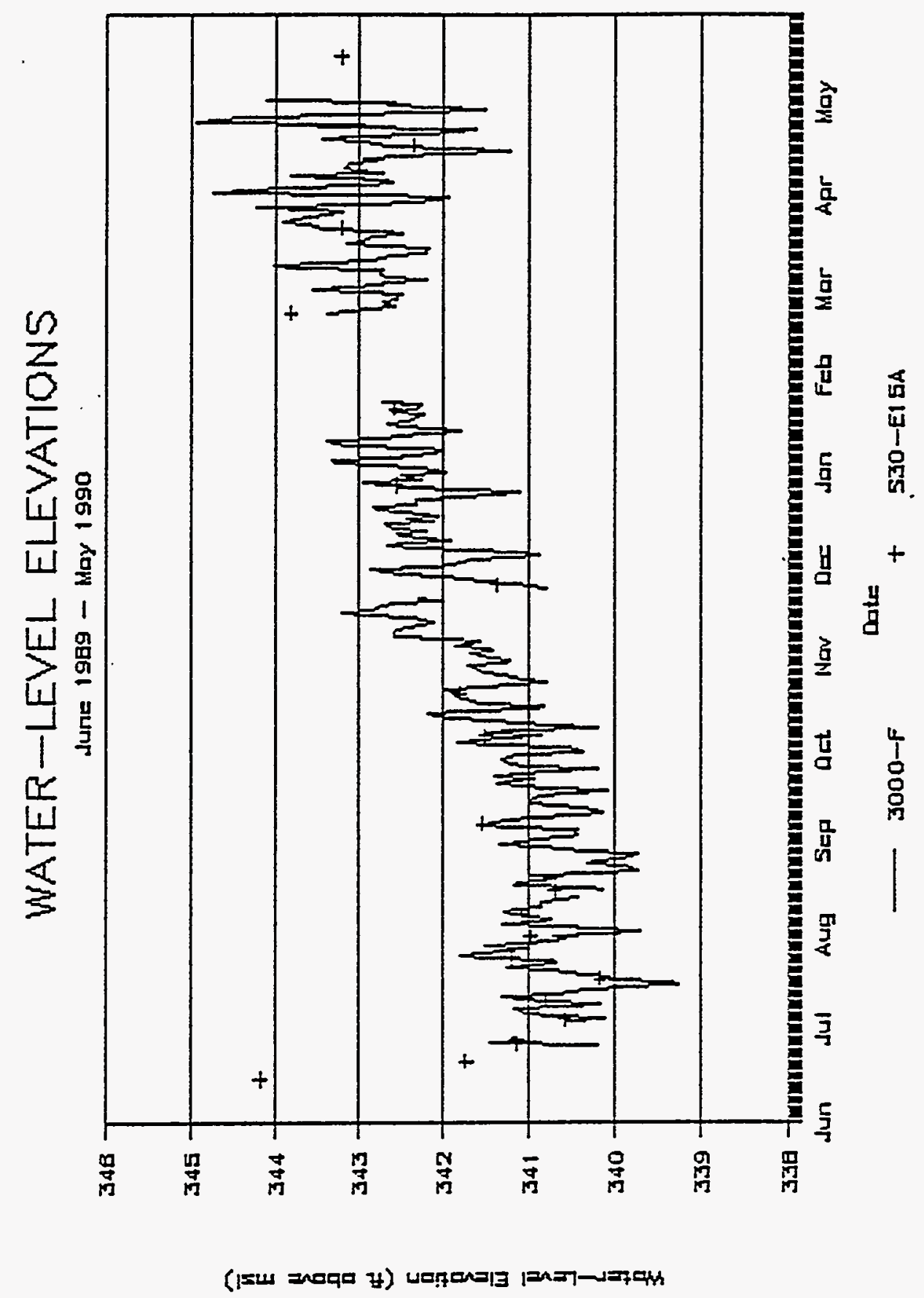

D. 1 


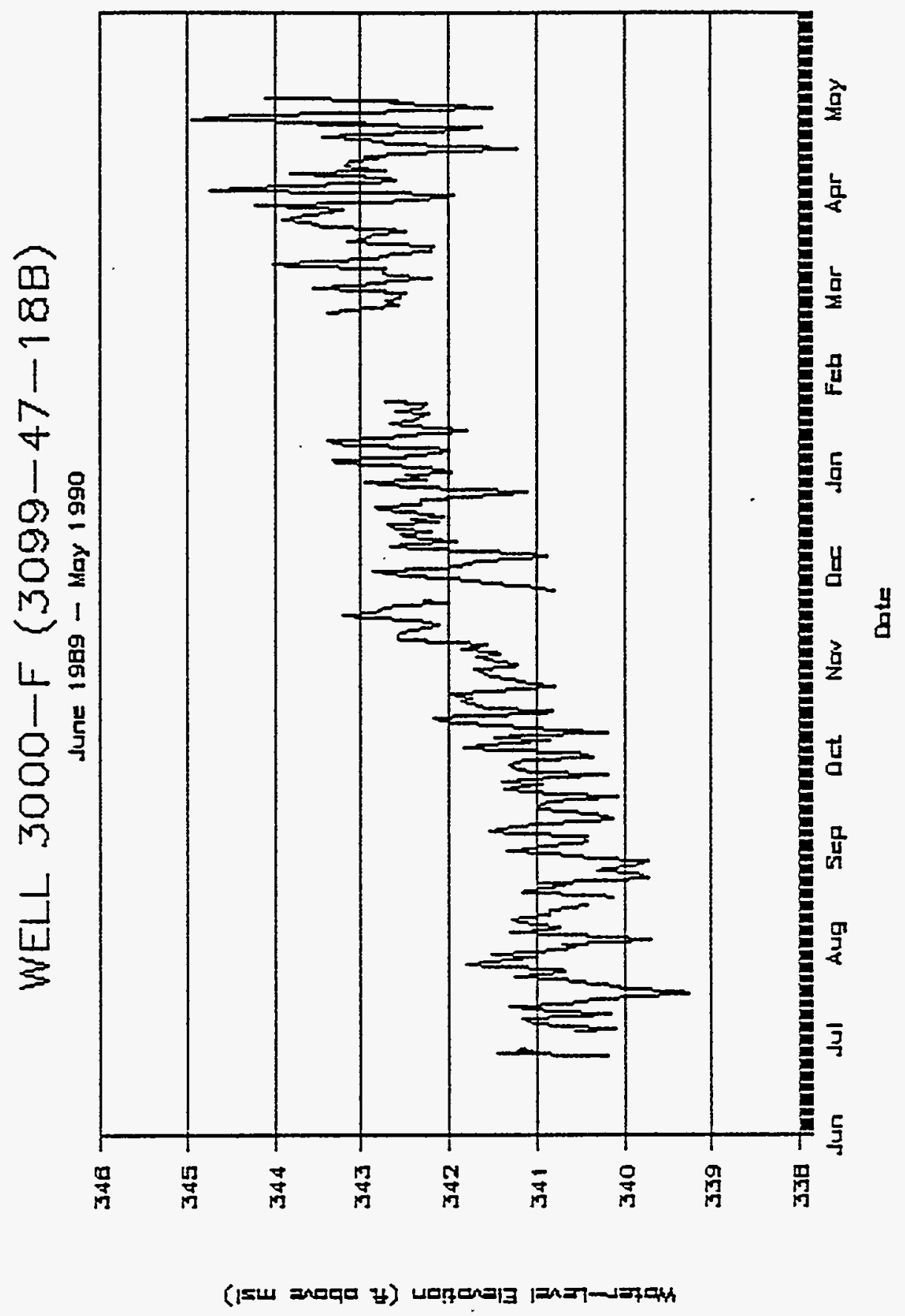

D. 2 


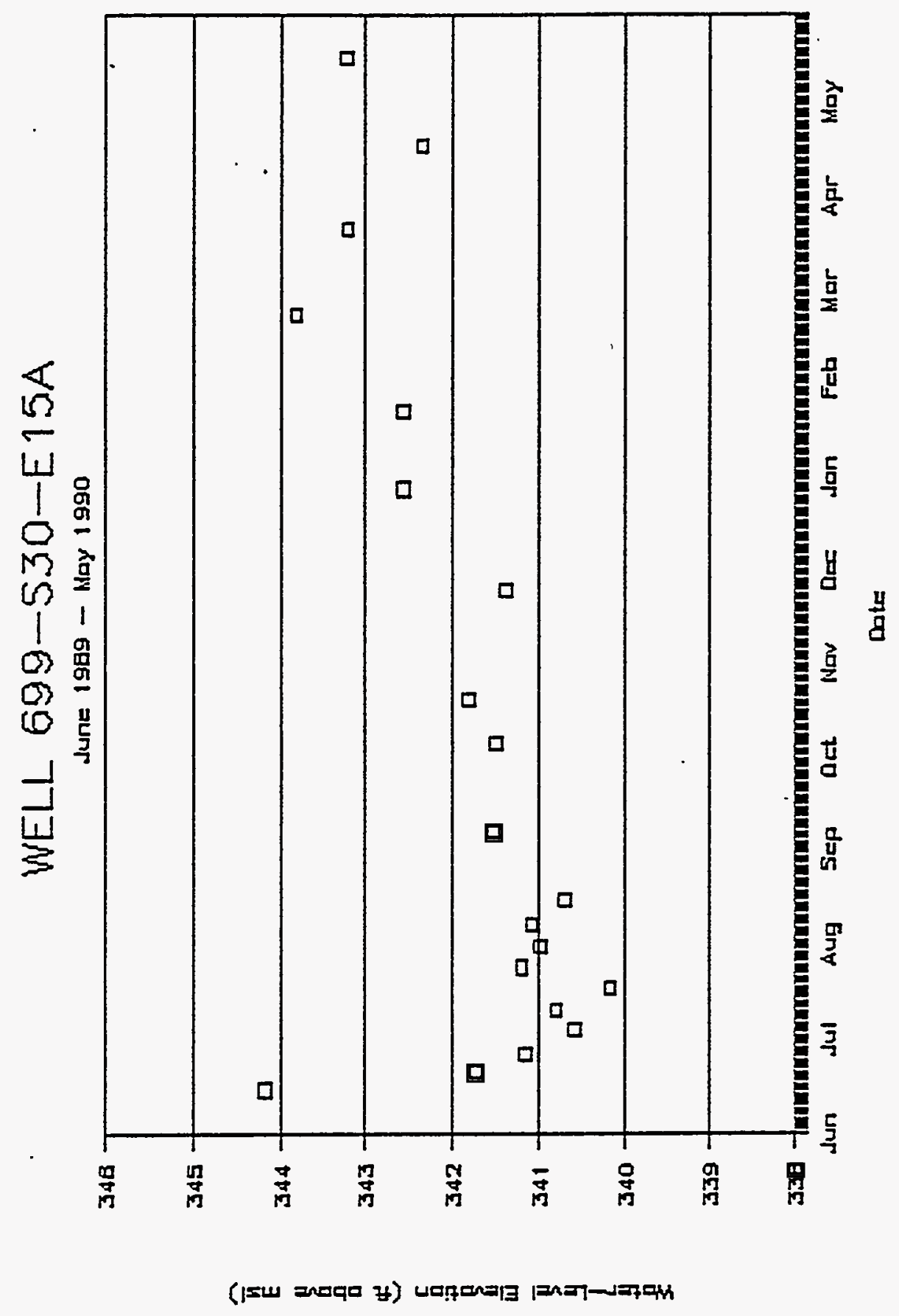

D. 3 


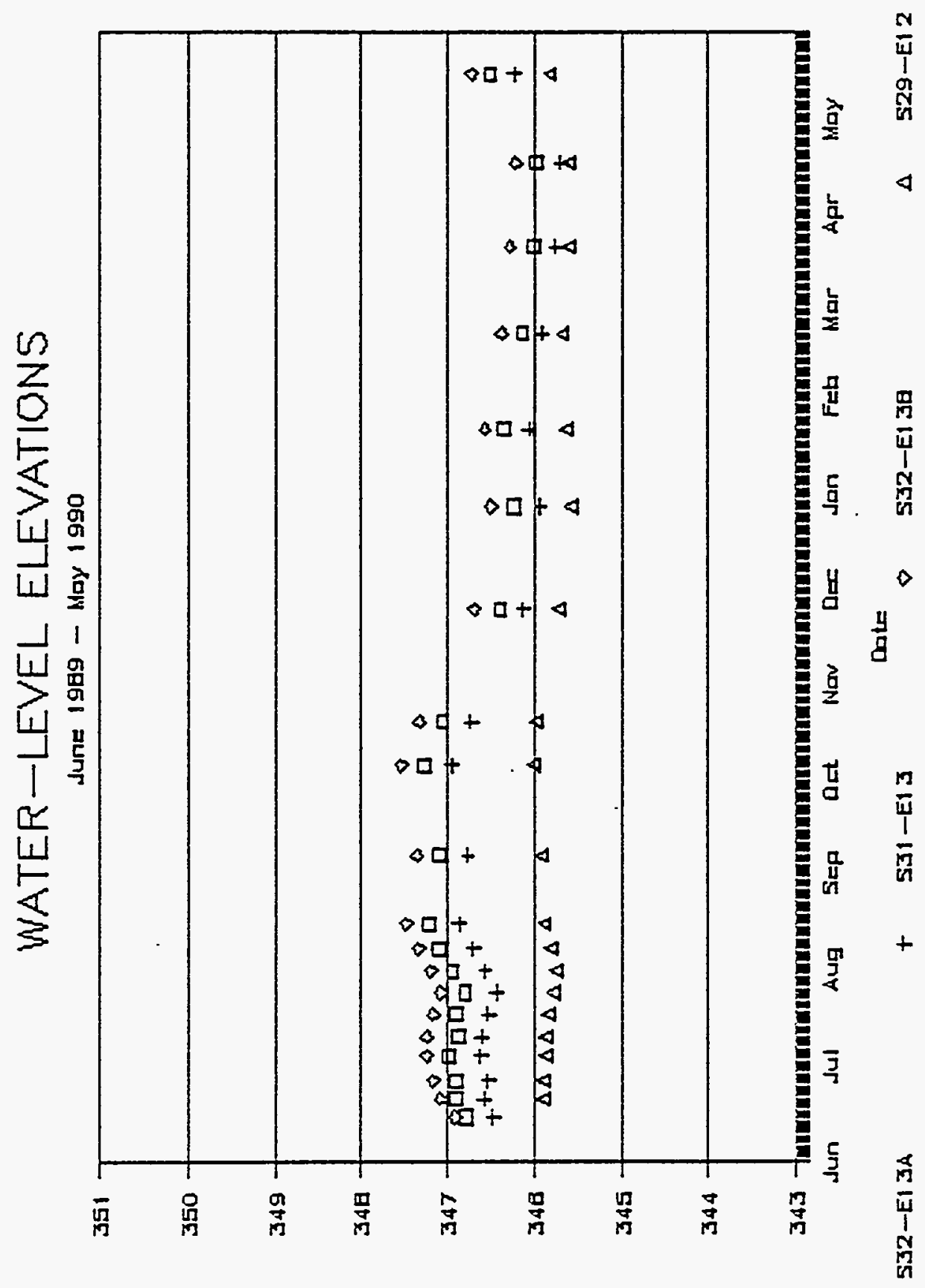

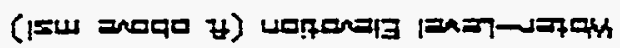

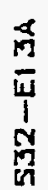

口

D. 4 


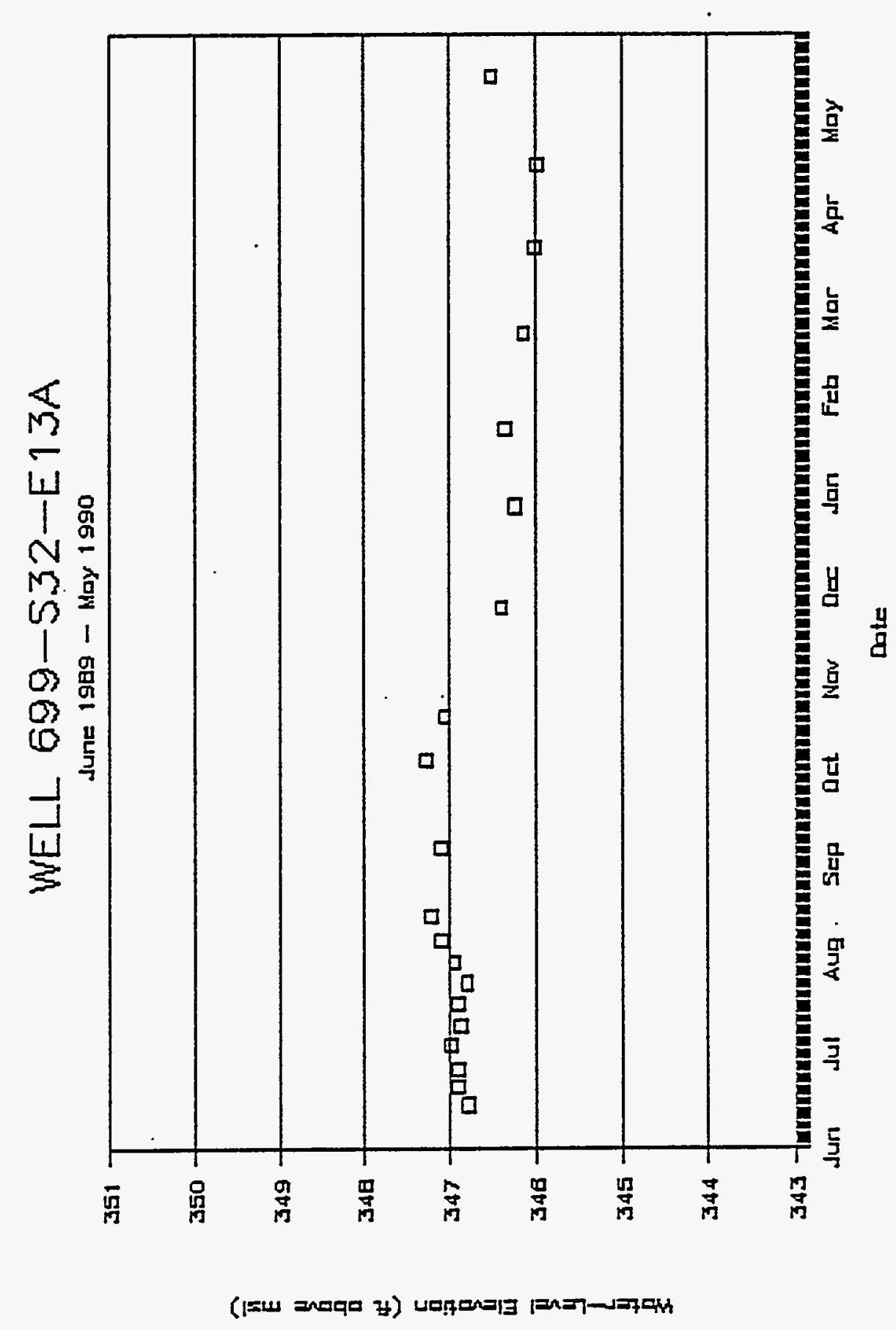

D. 5 


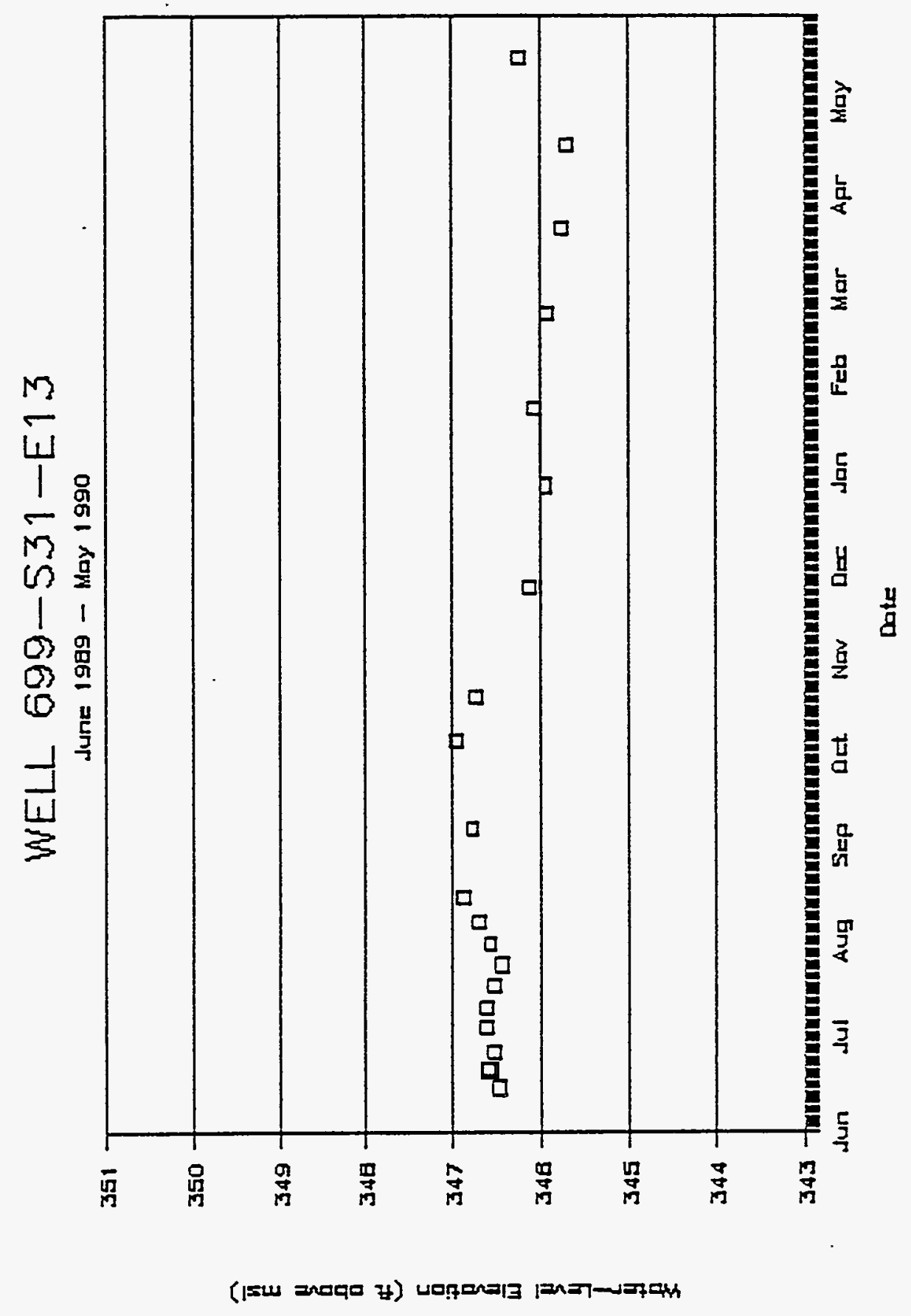

D. 6 
चाम्ण

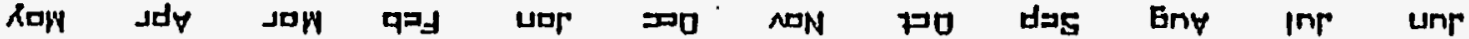
IIINMT

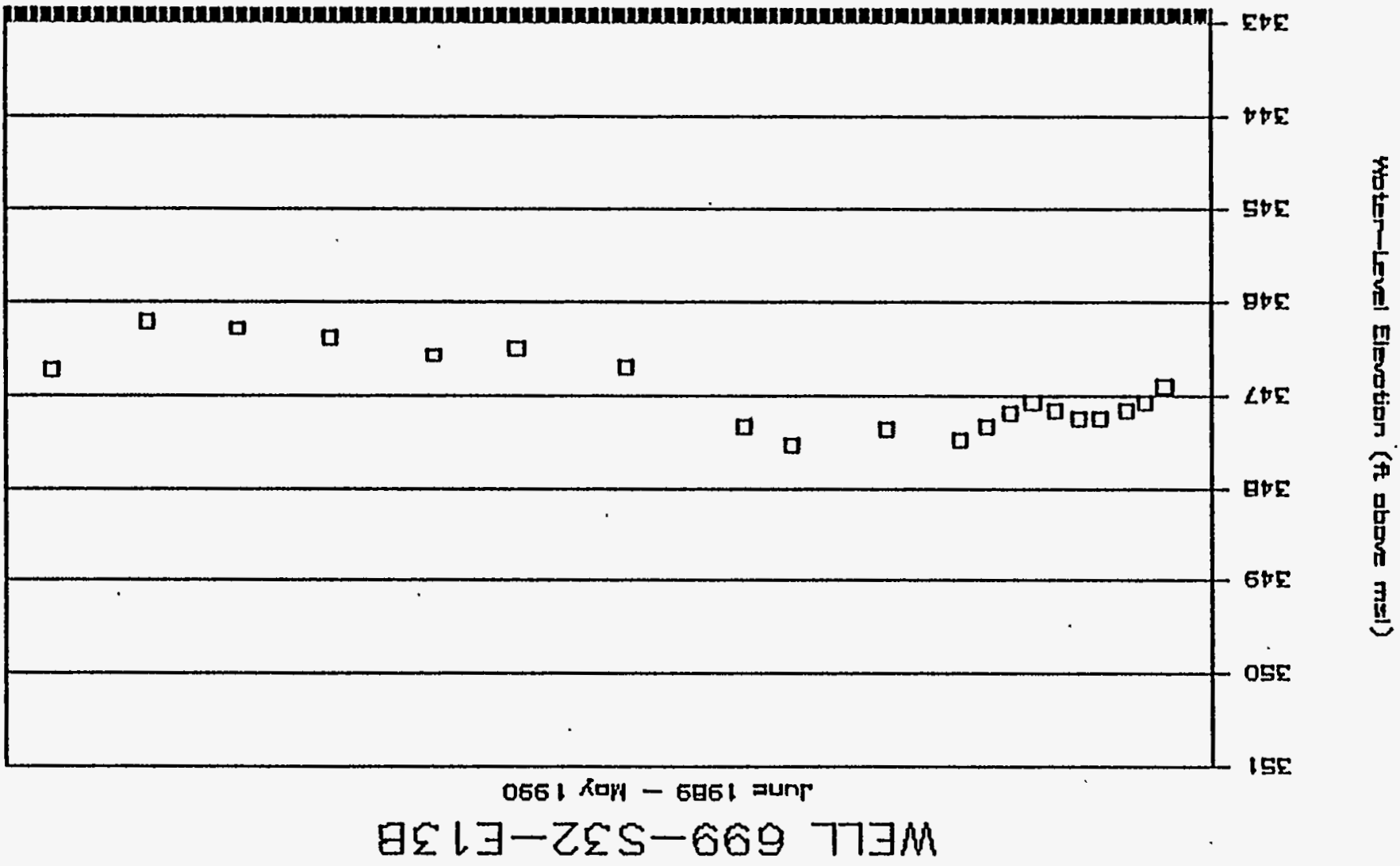




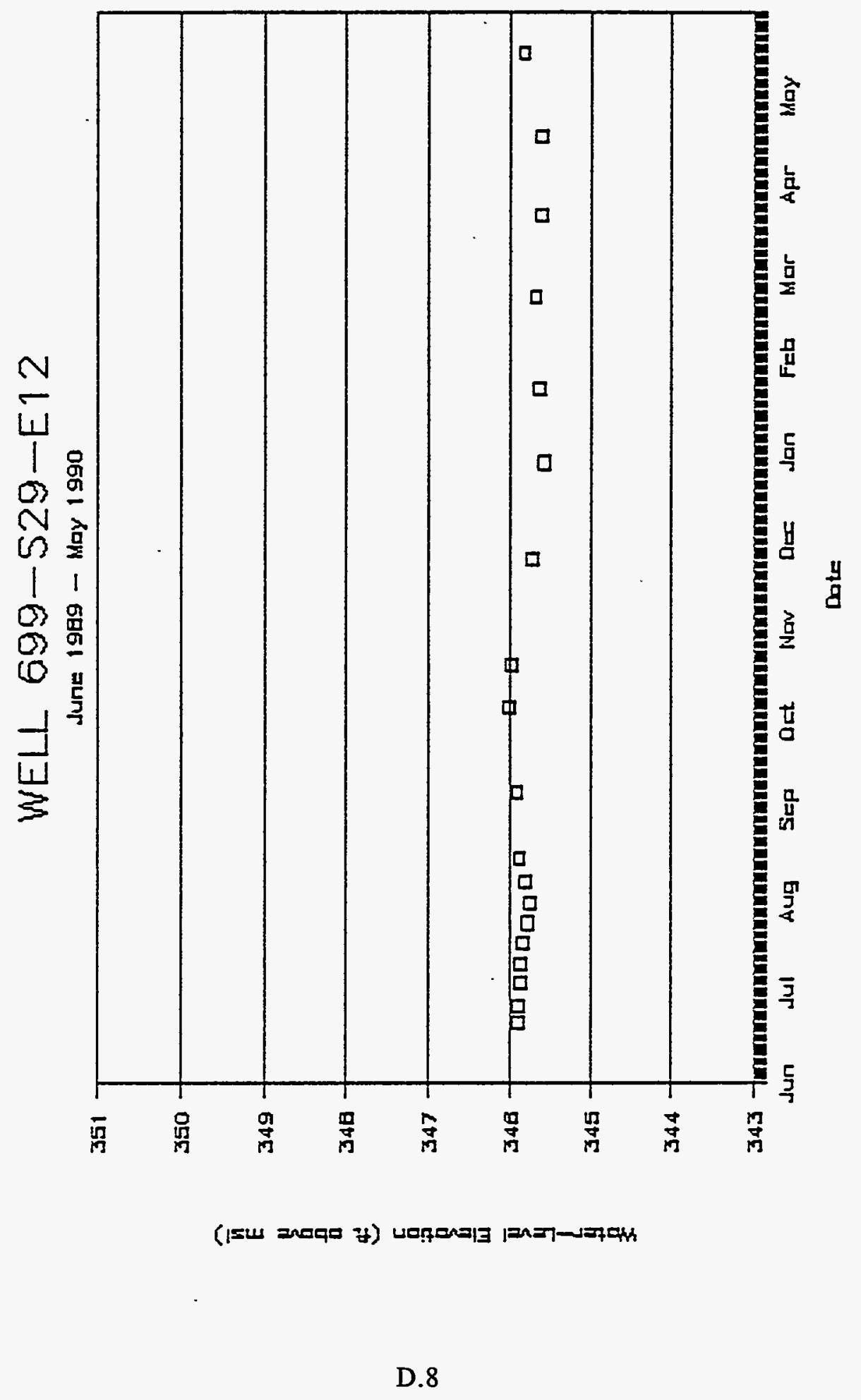




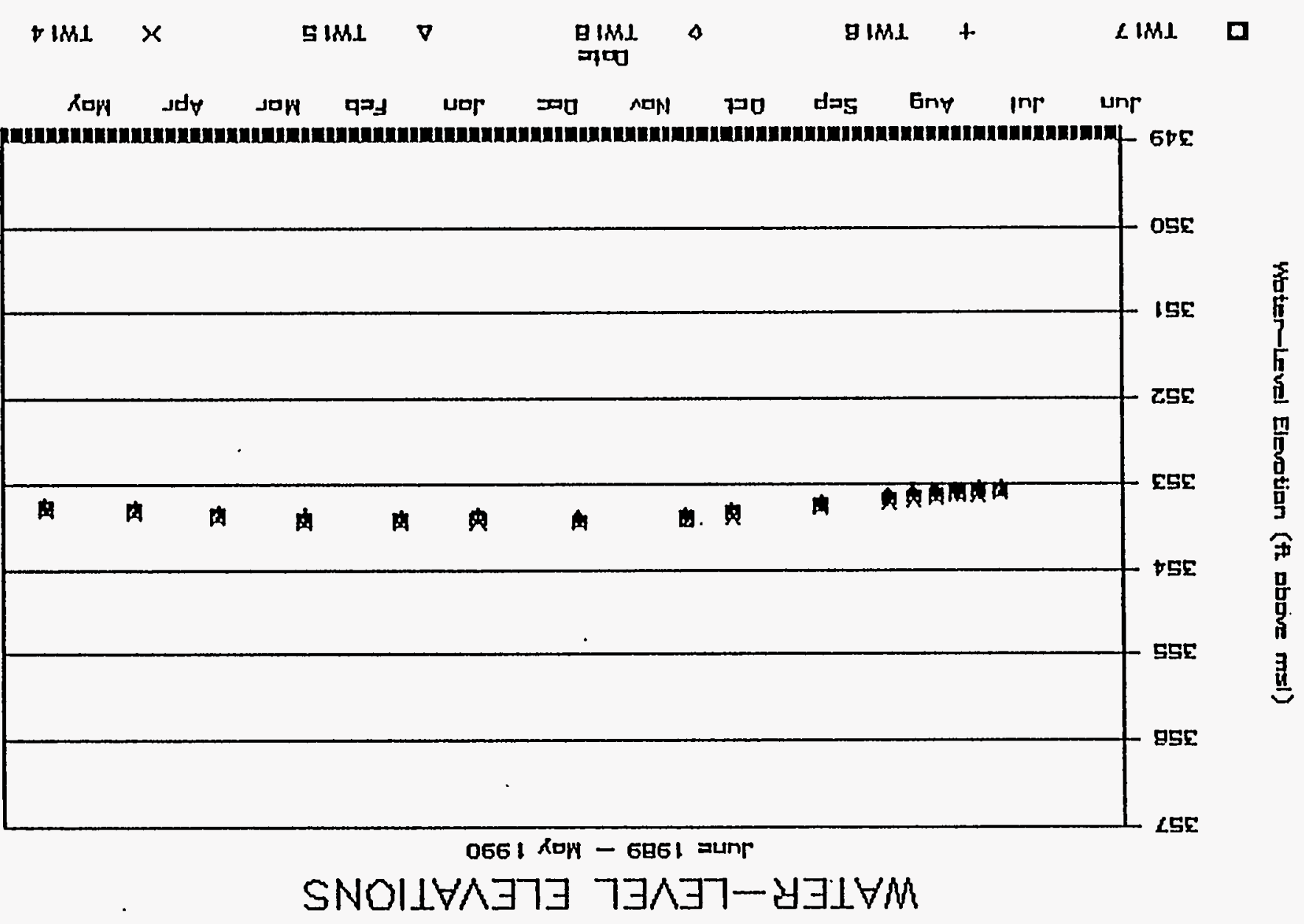




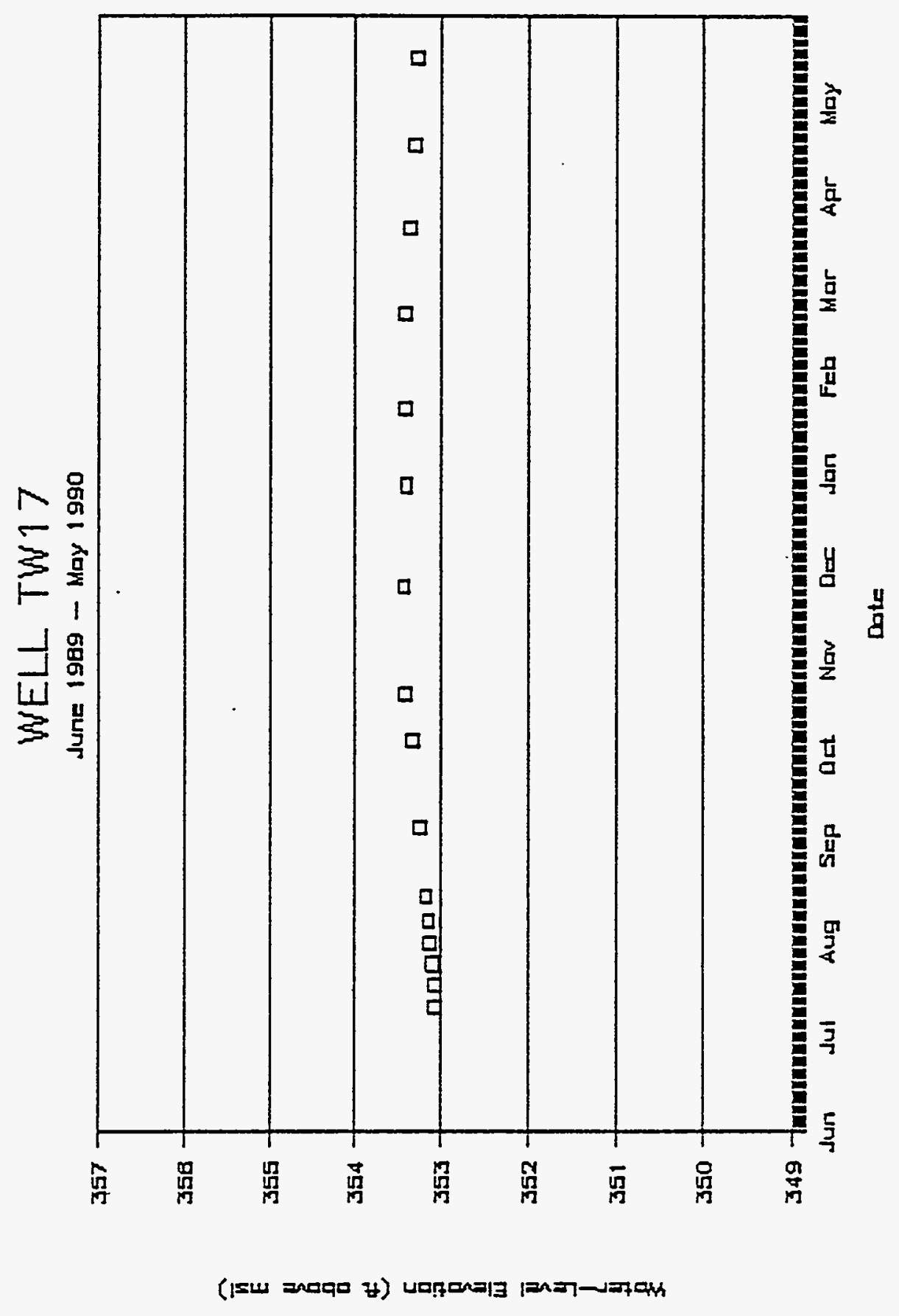

D. 10 


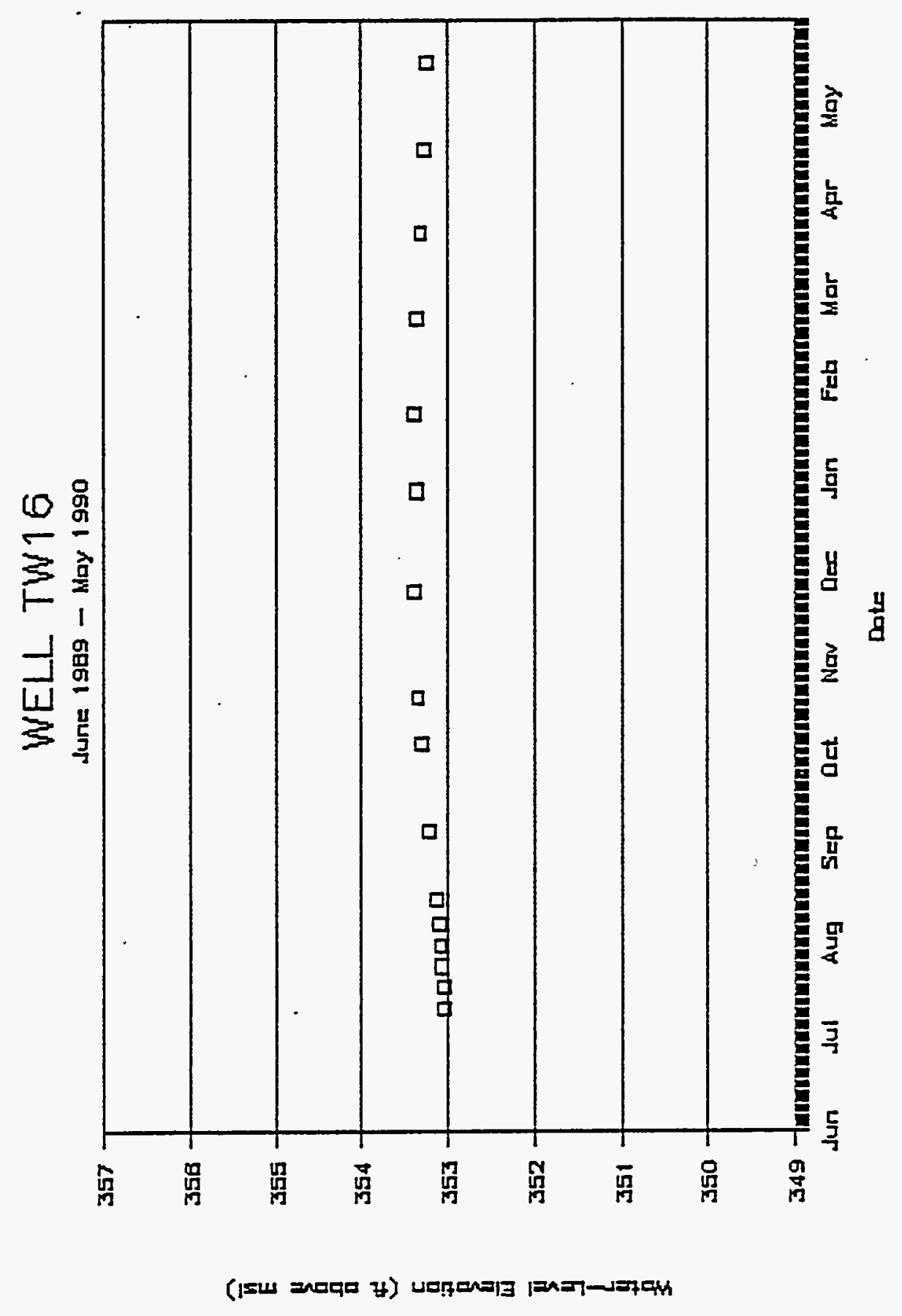

D. 11 


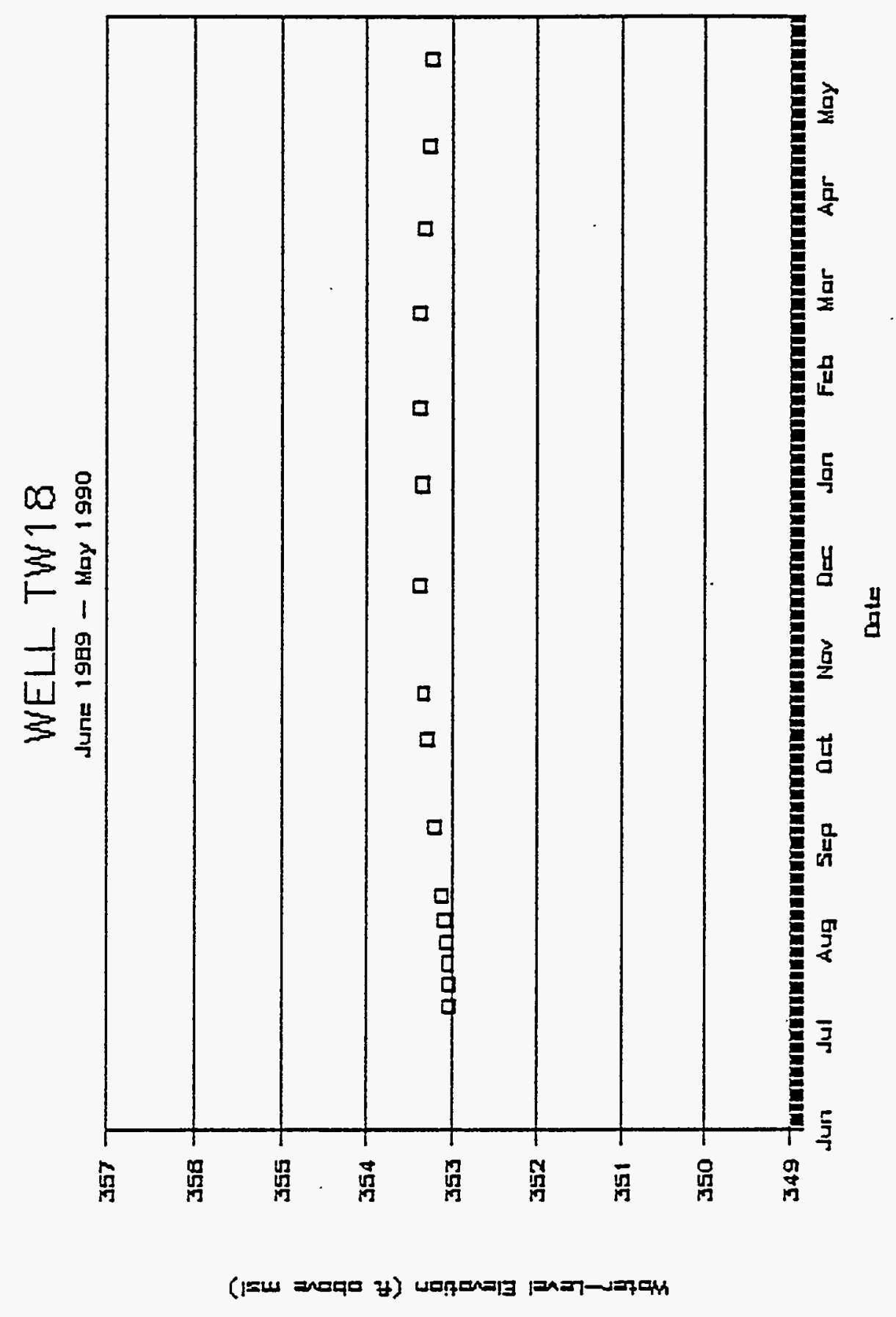

D. 12 


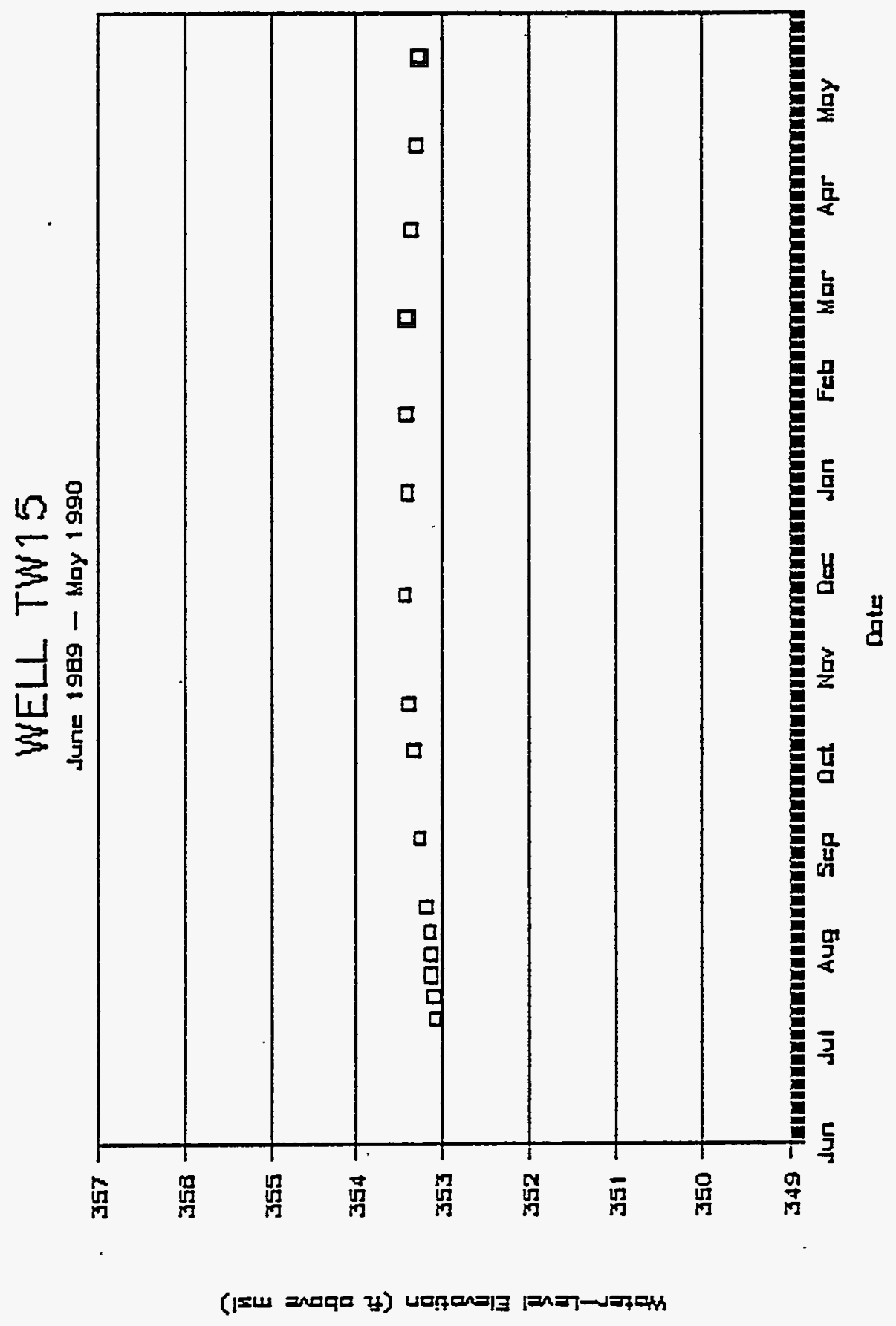

D.13 
WELL TW14

June 1989 - May 1990

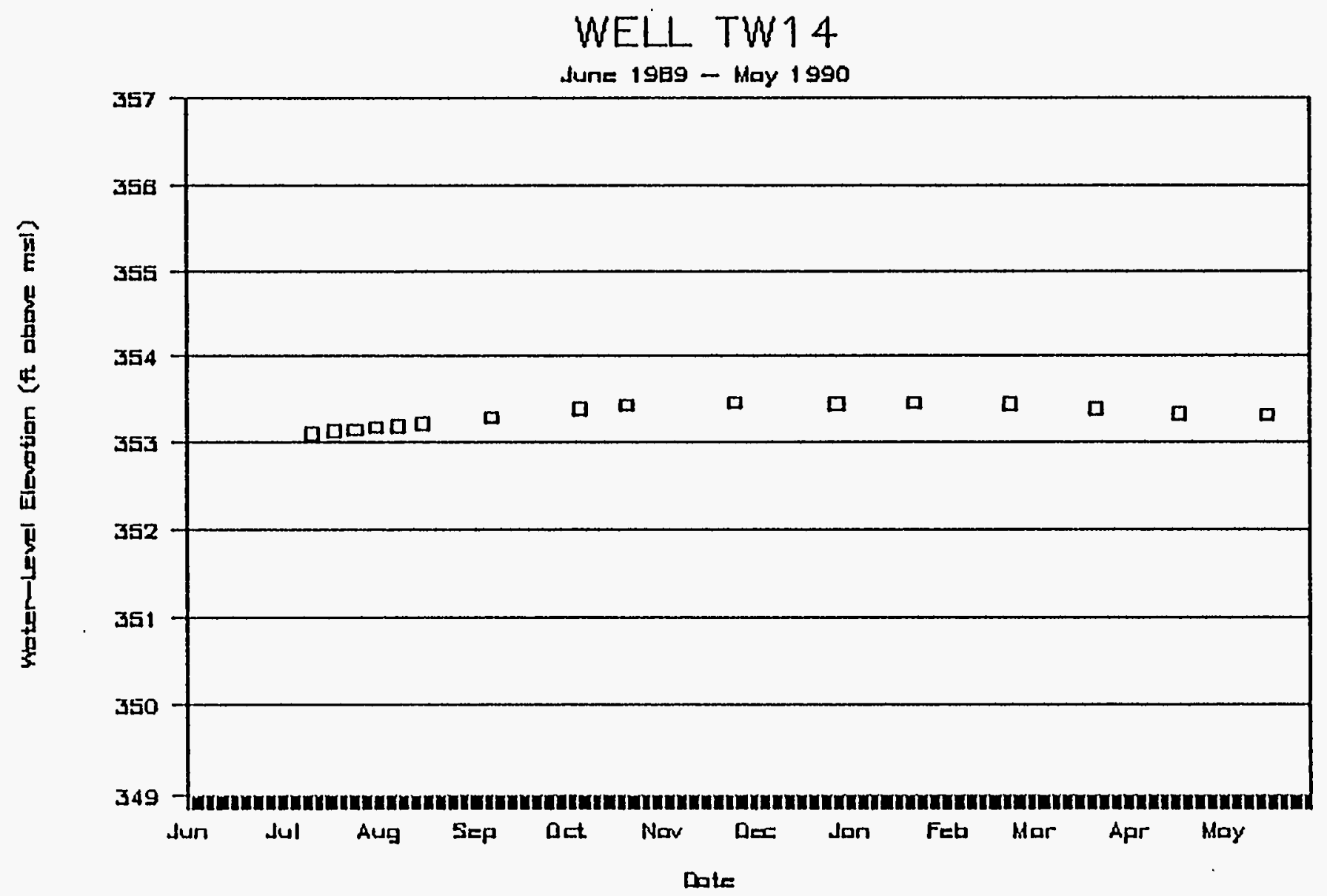




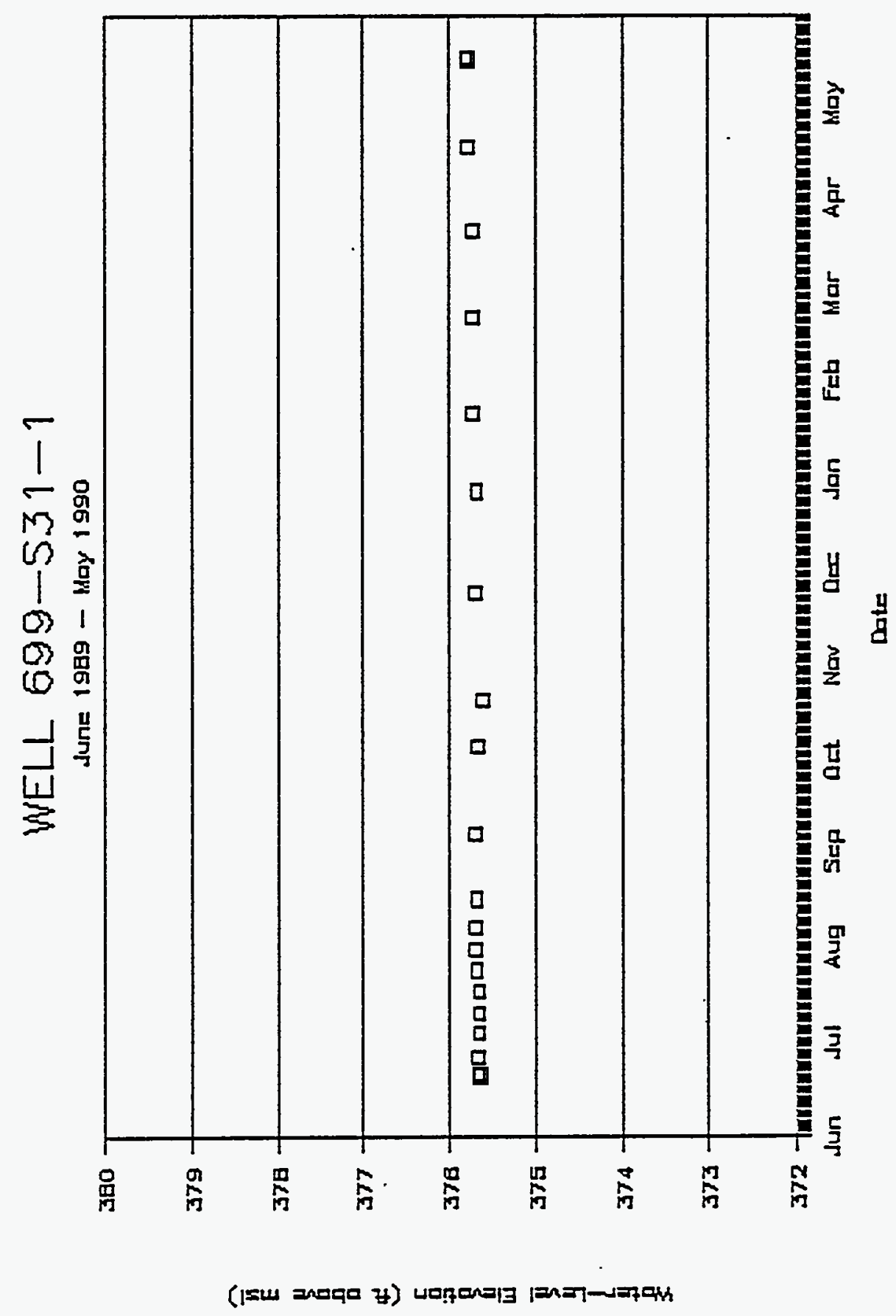

D. 15 


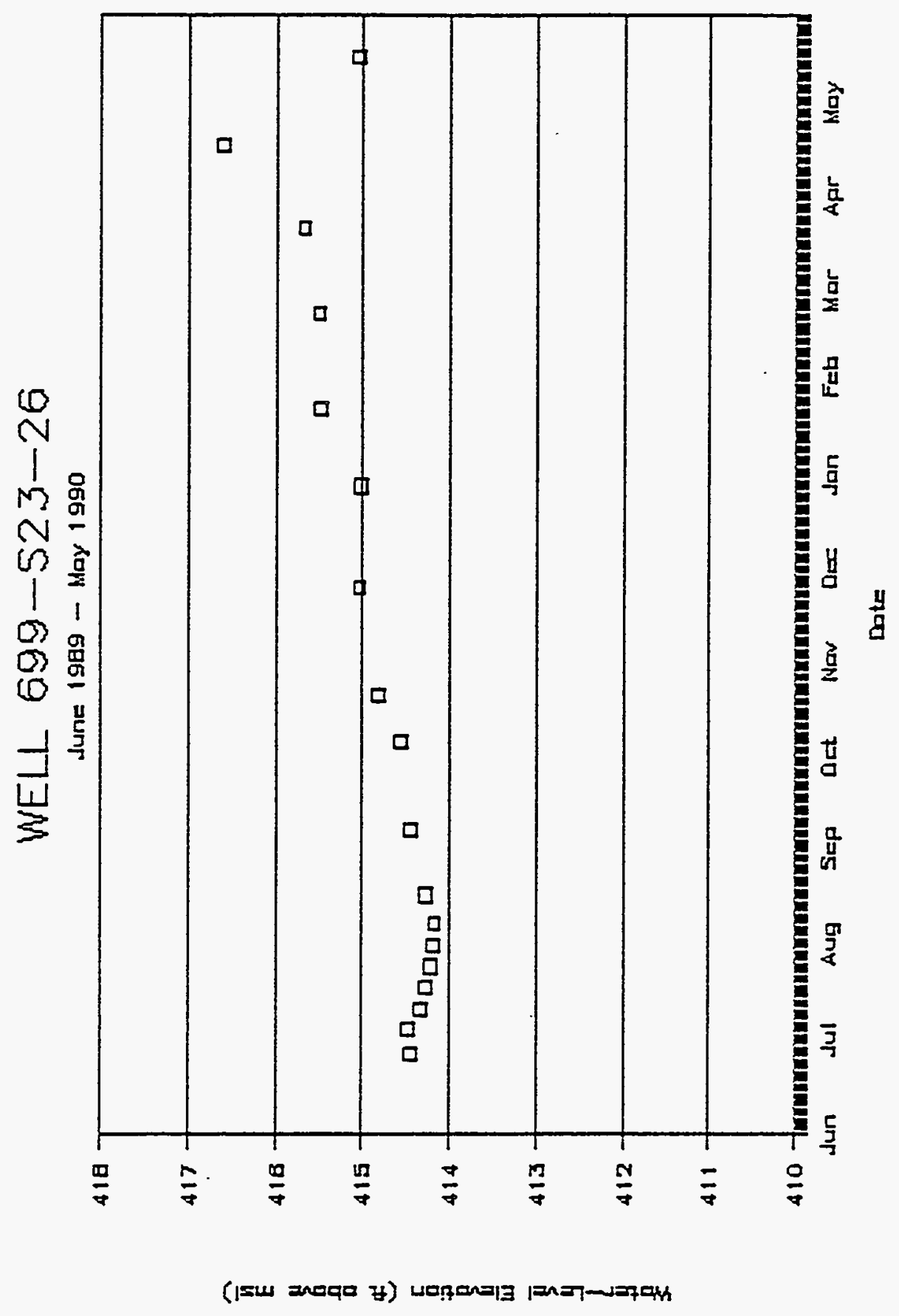

D. 16 


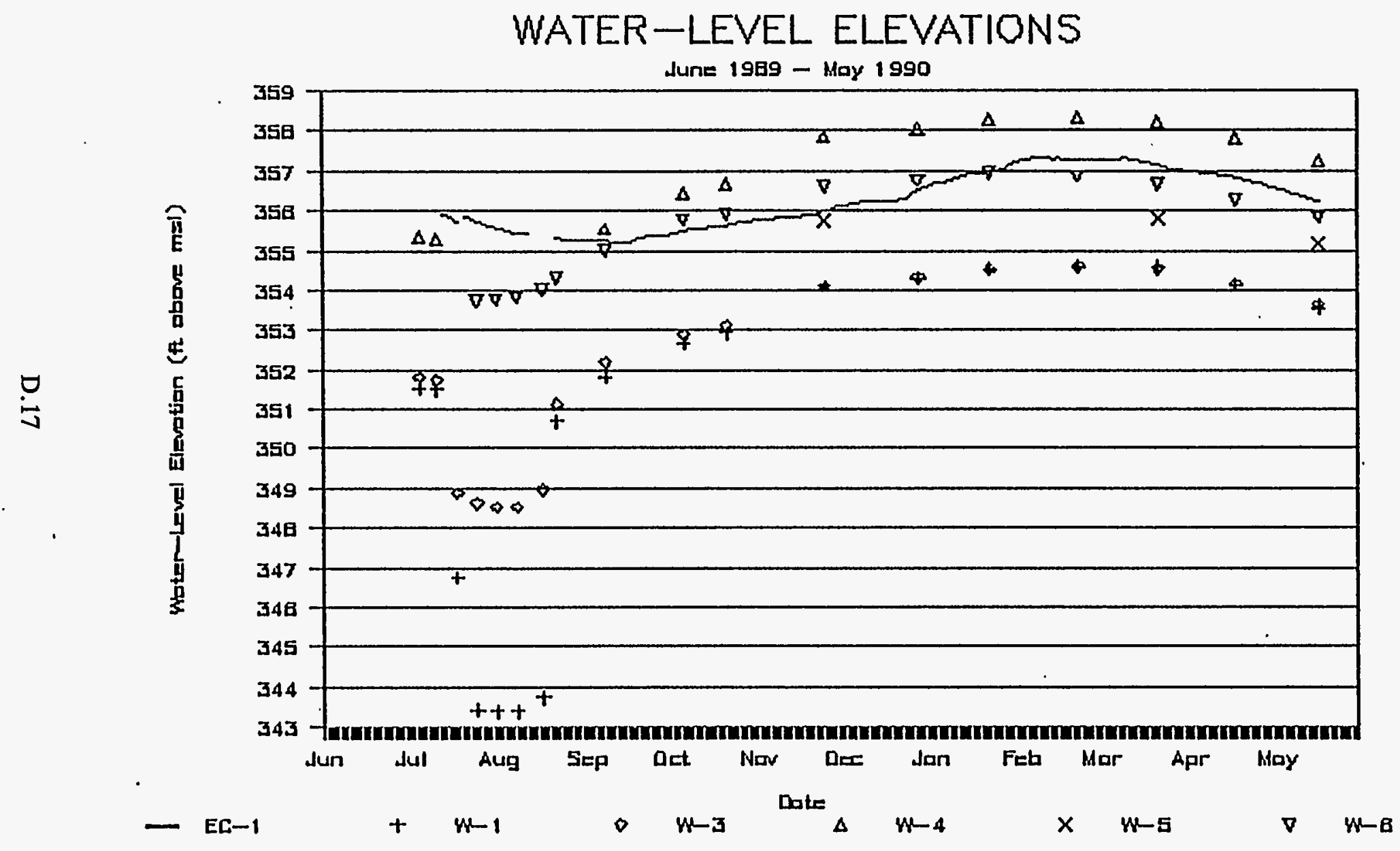




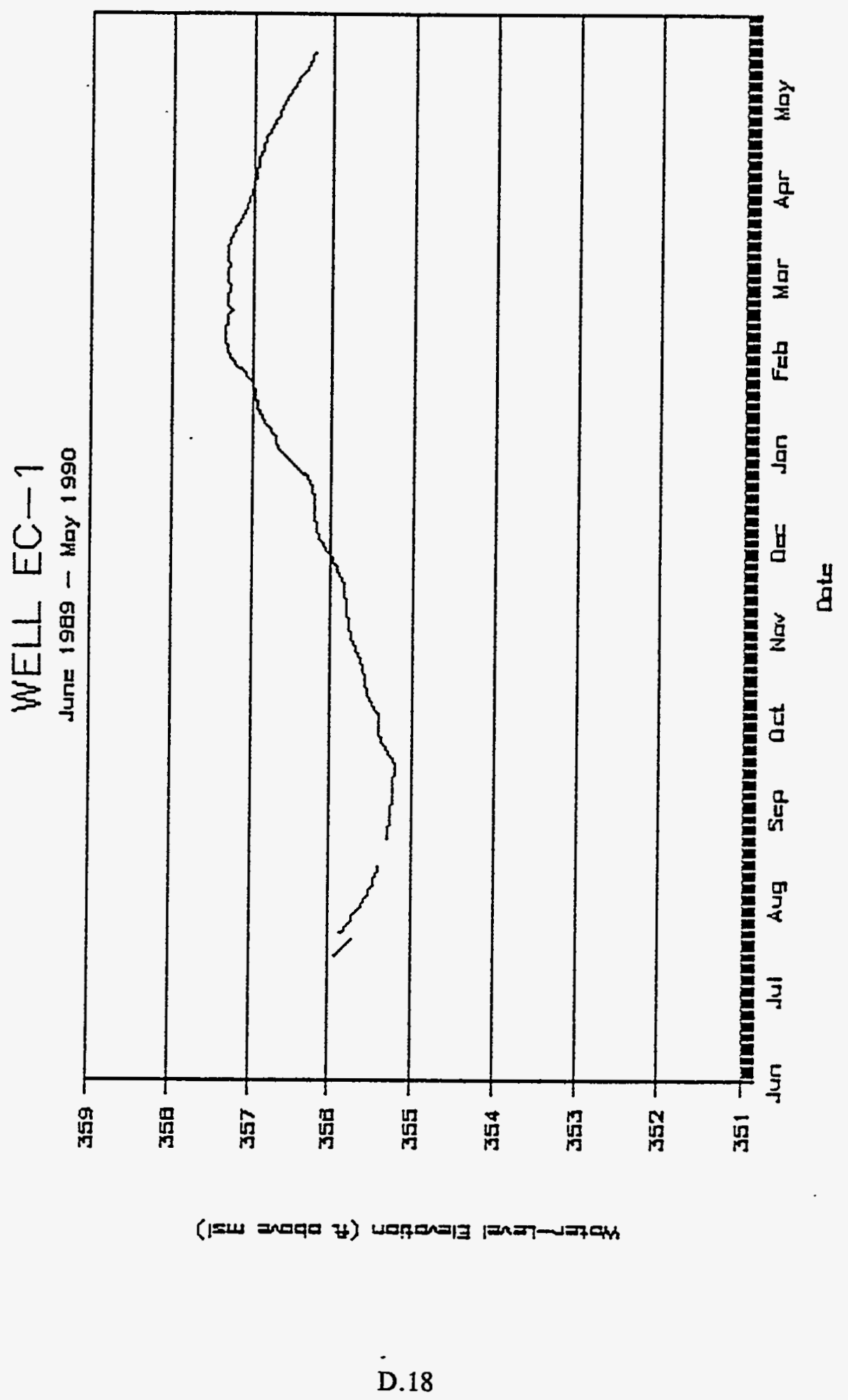


चक्ष

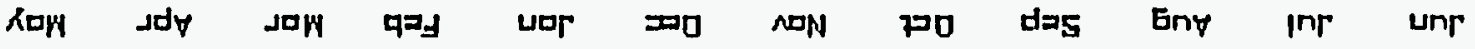

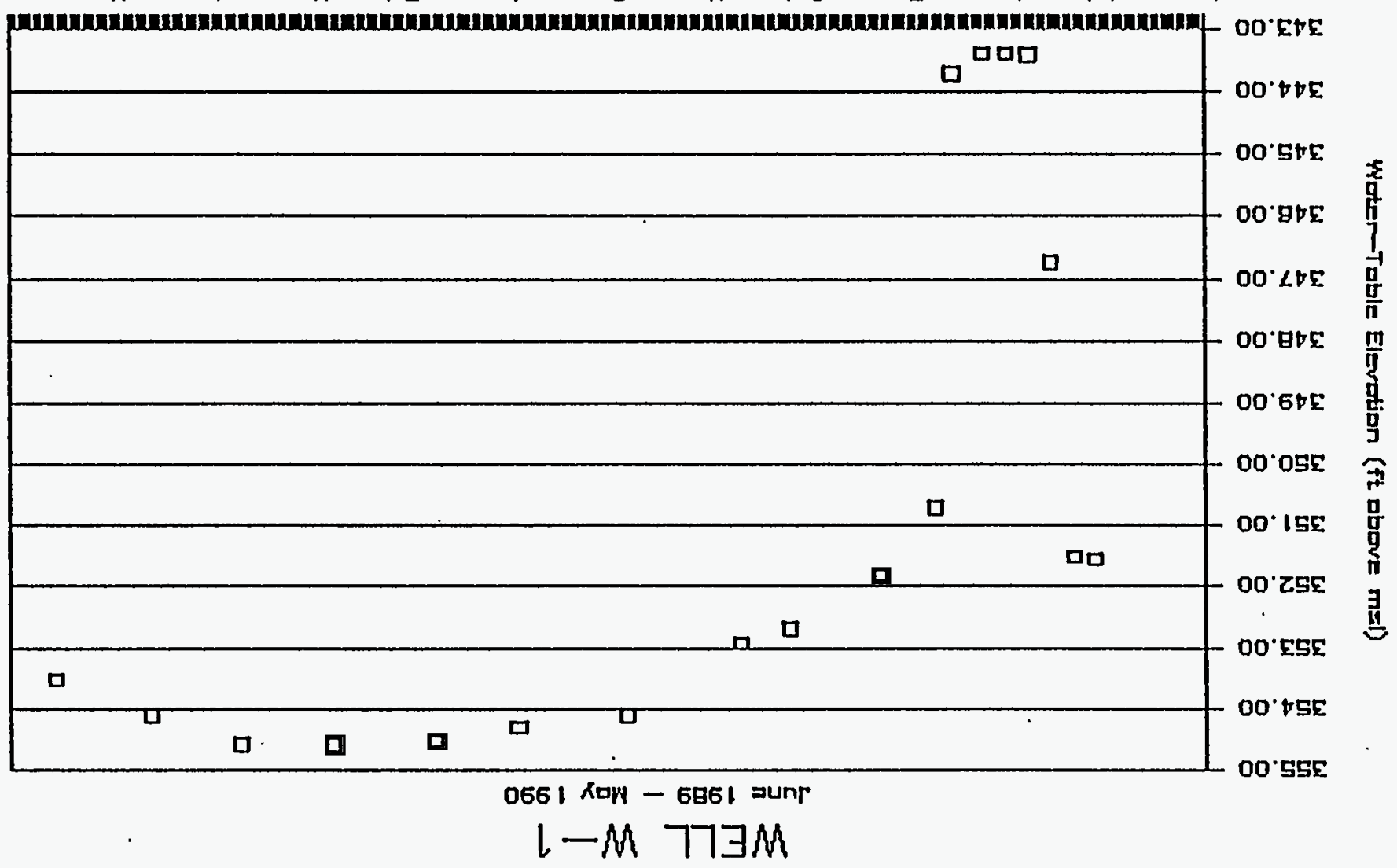




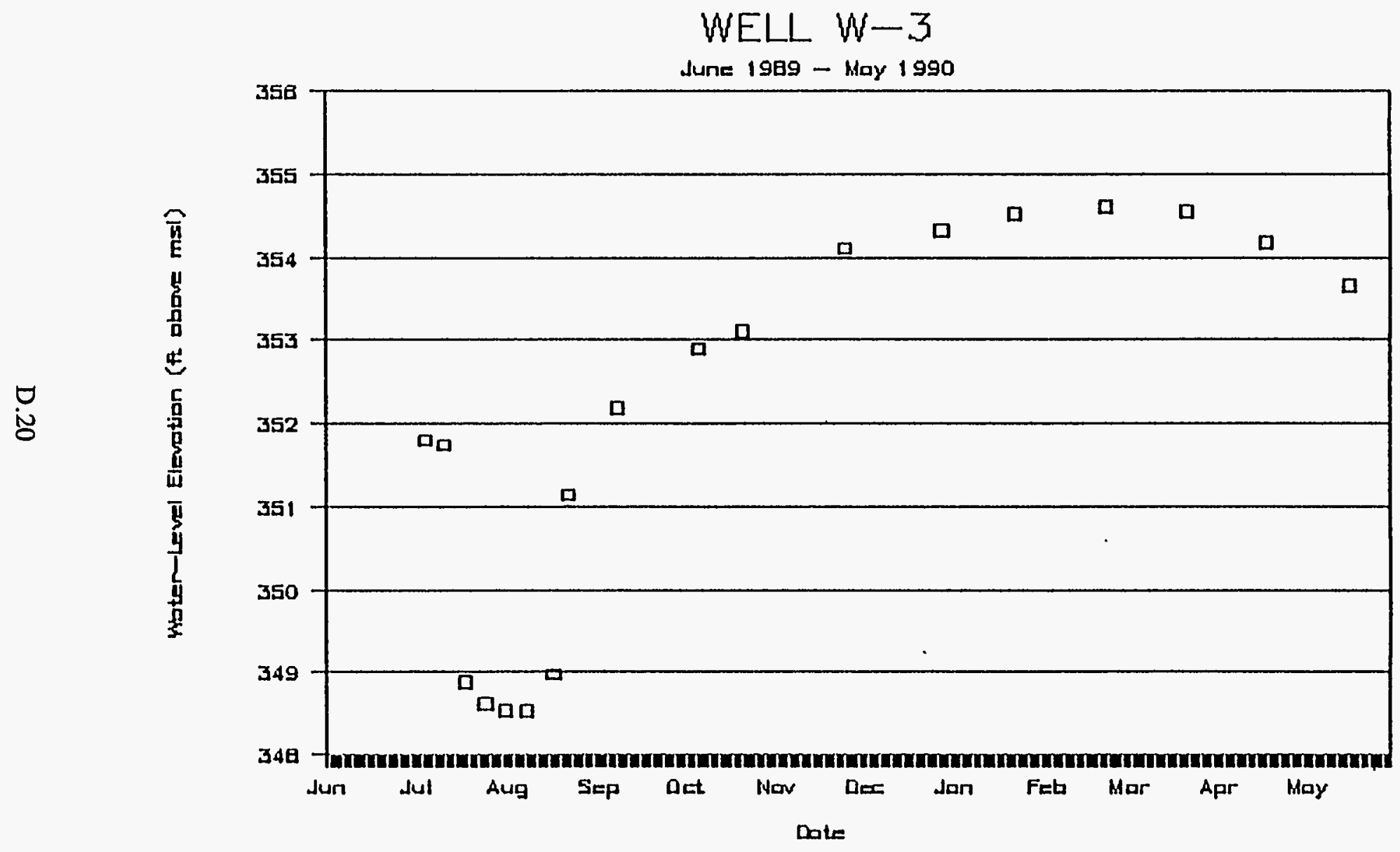




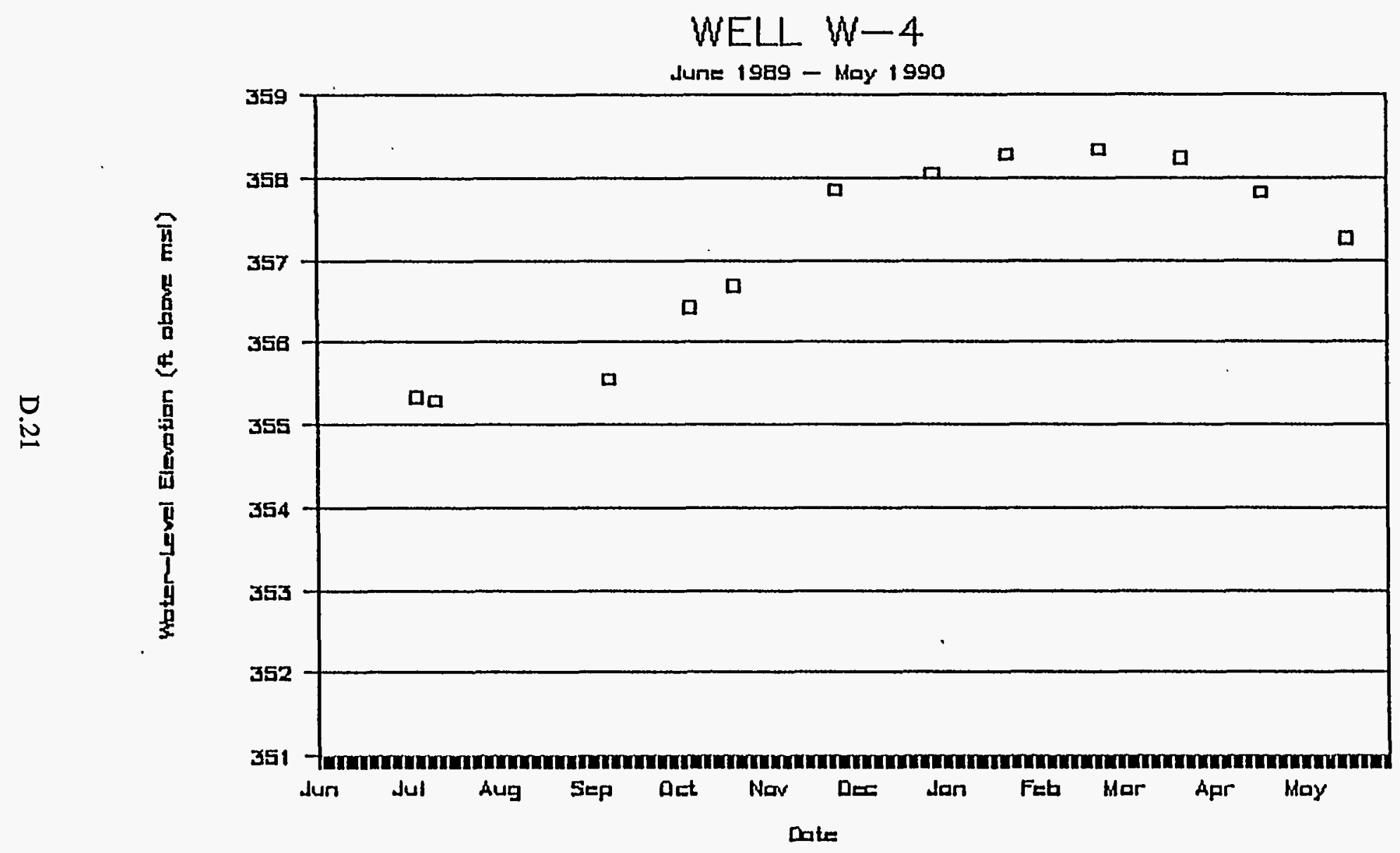




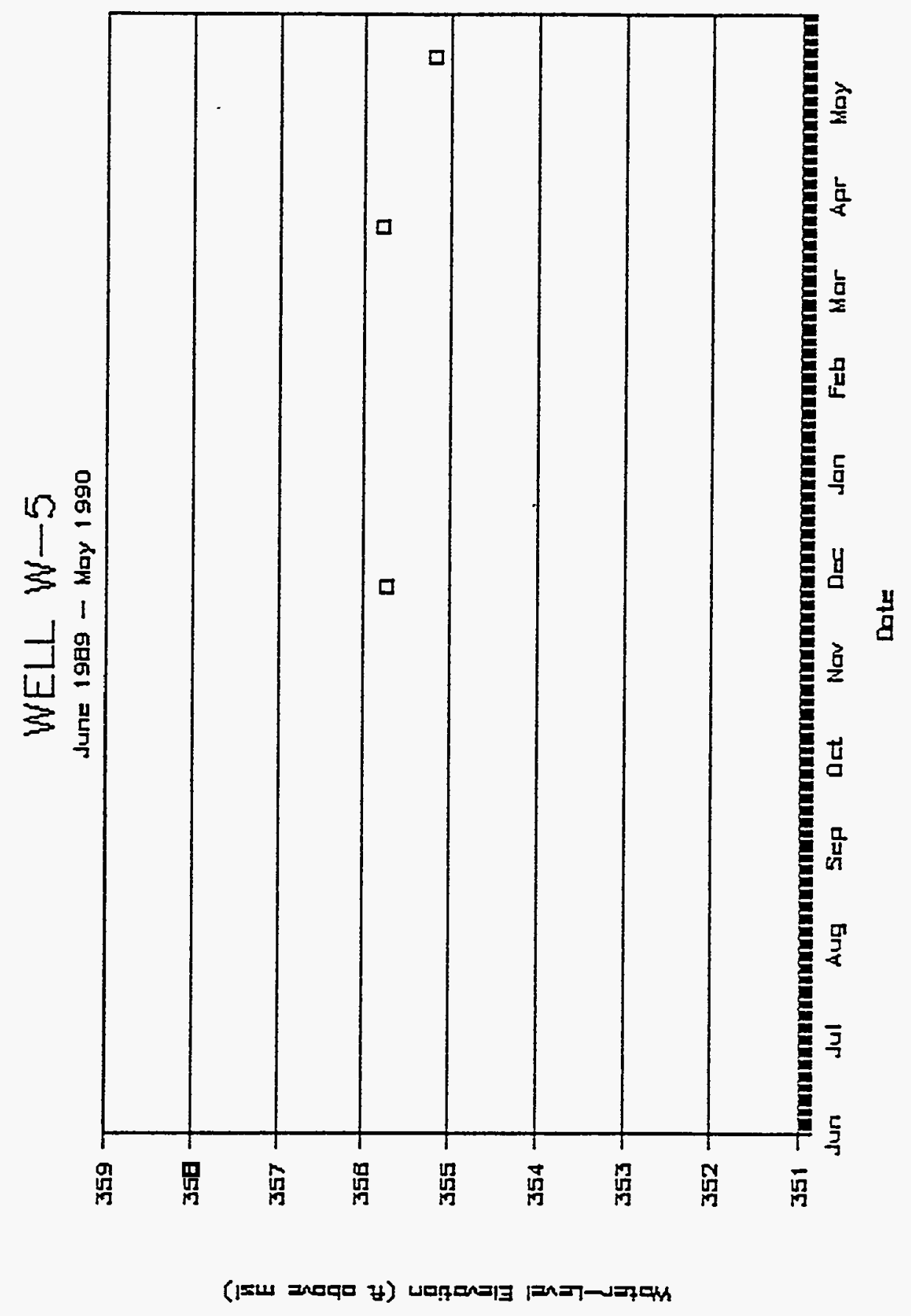

D. 22 


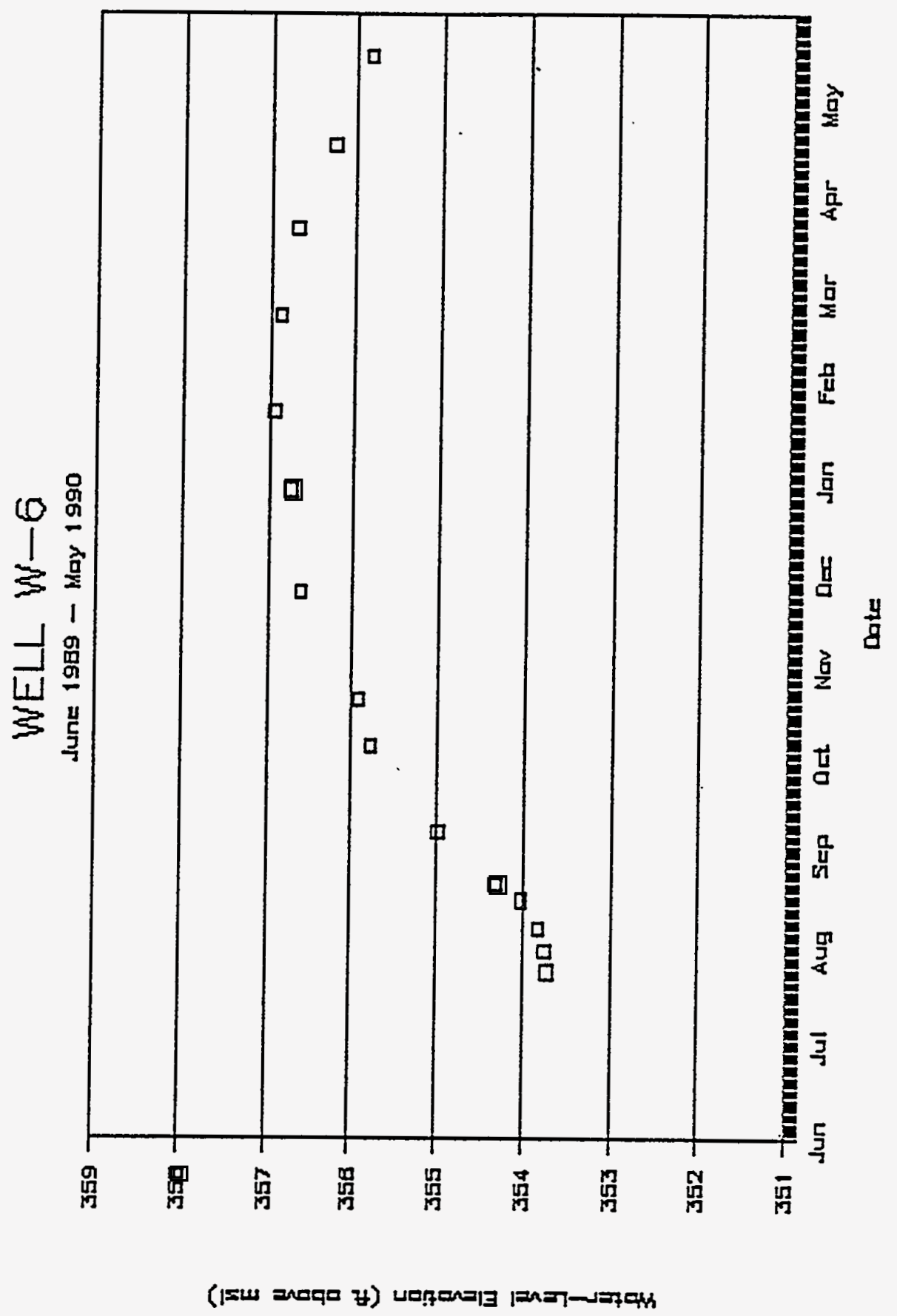

D.23 


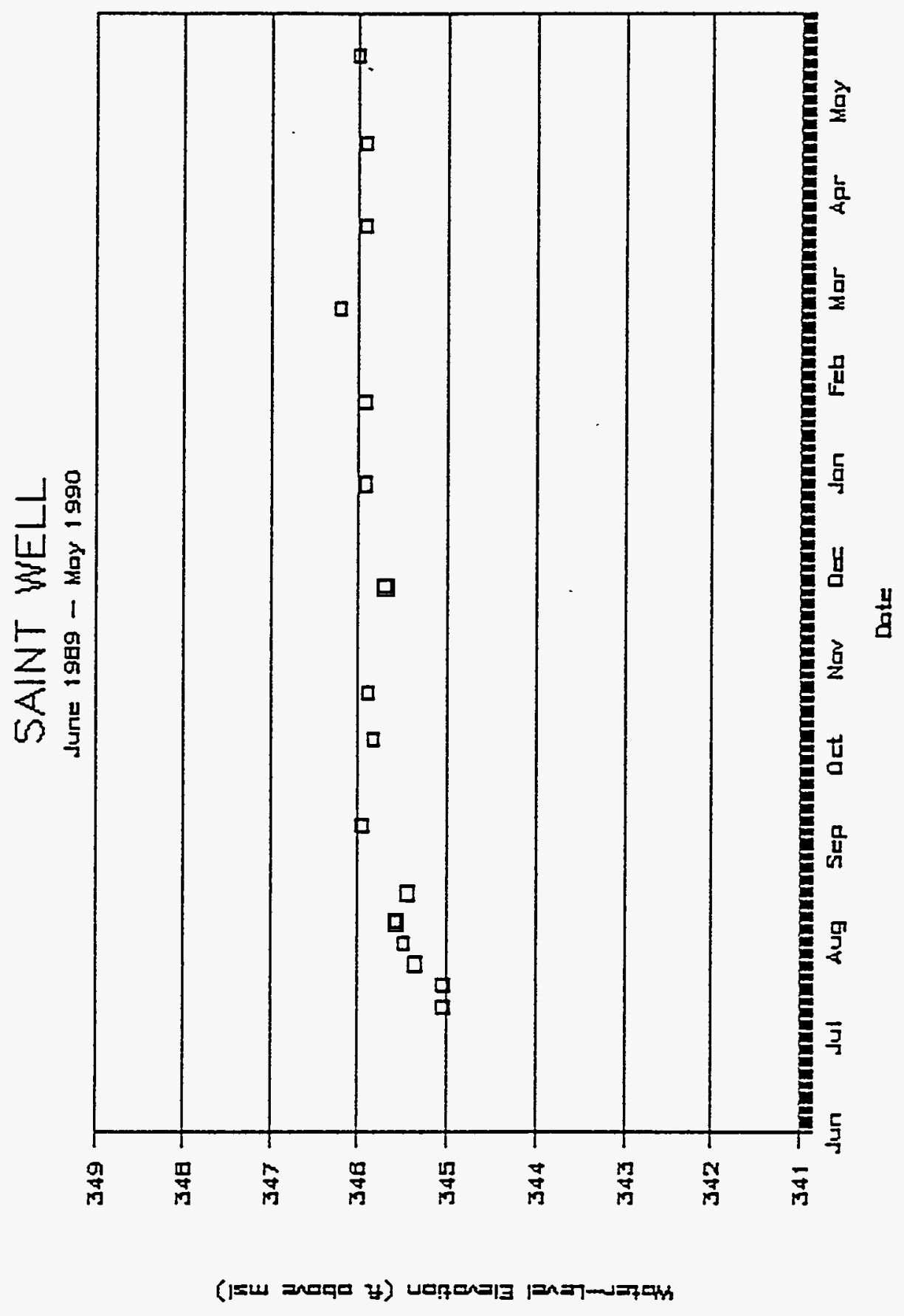

D. 24 


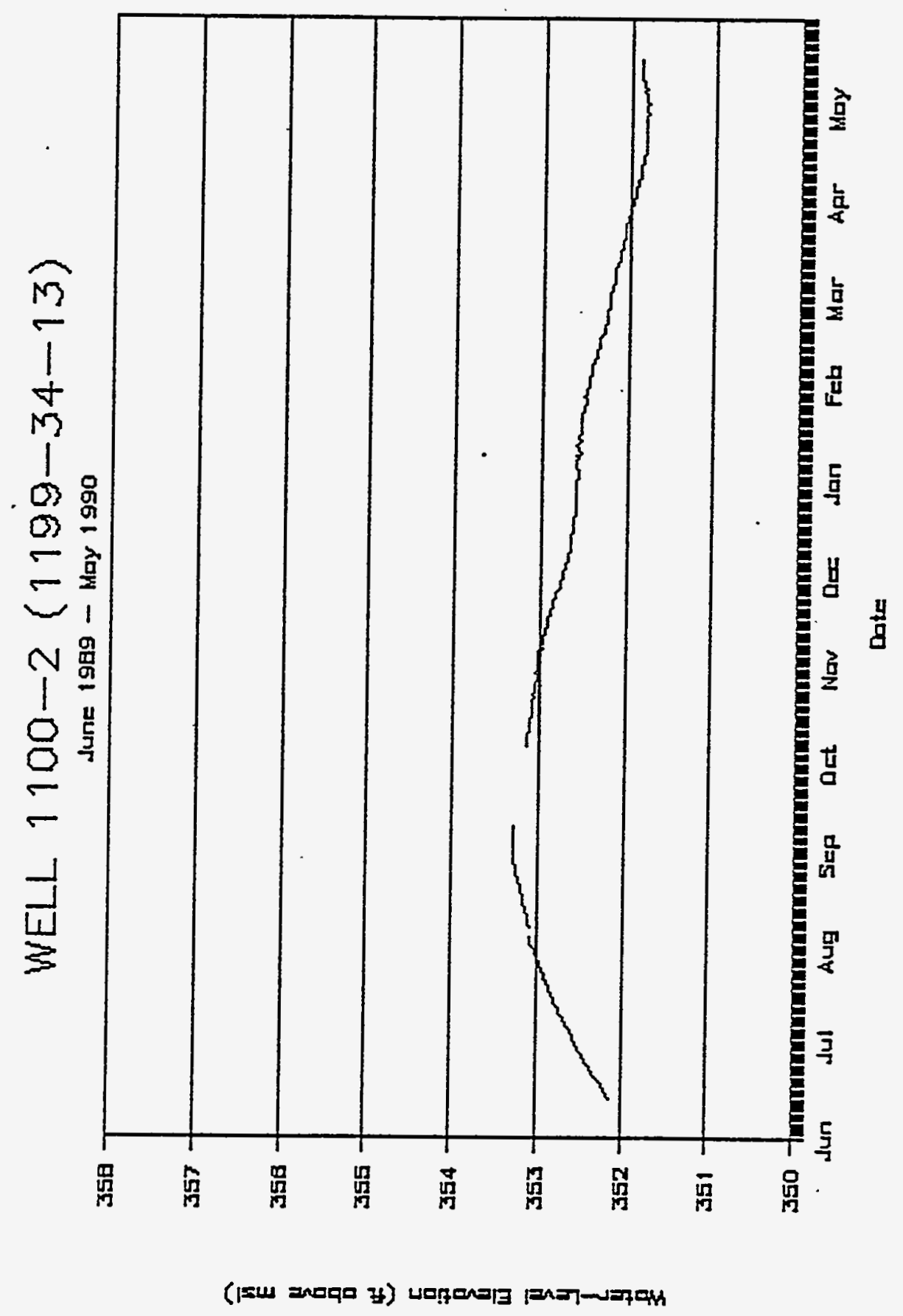

D. 25 


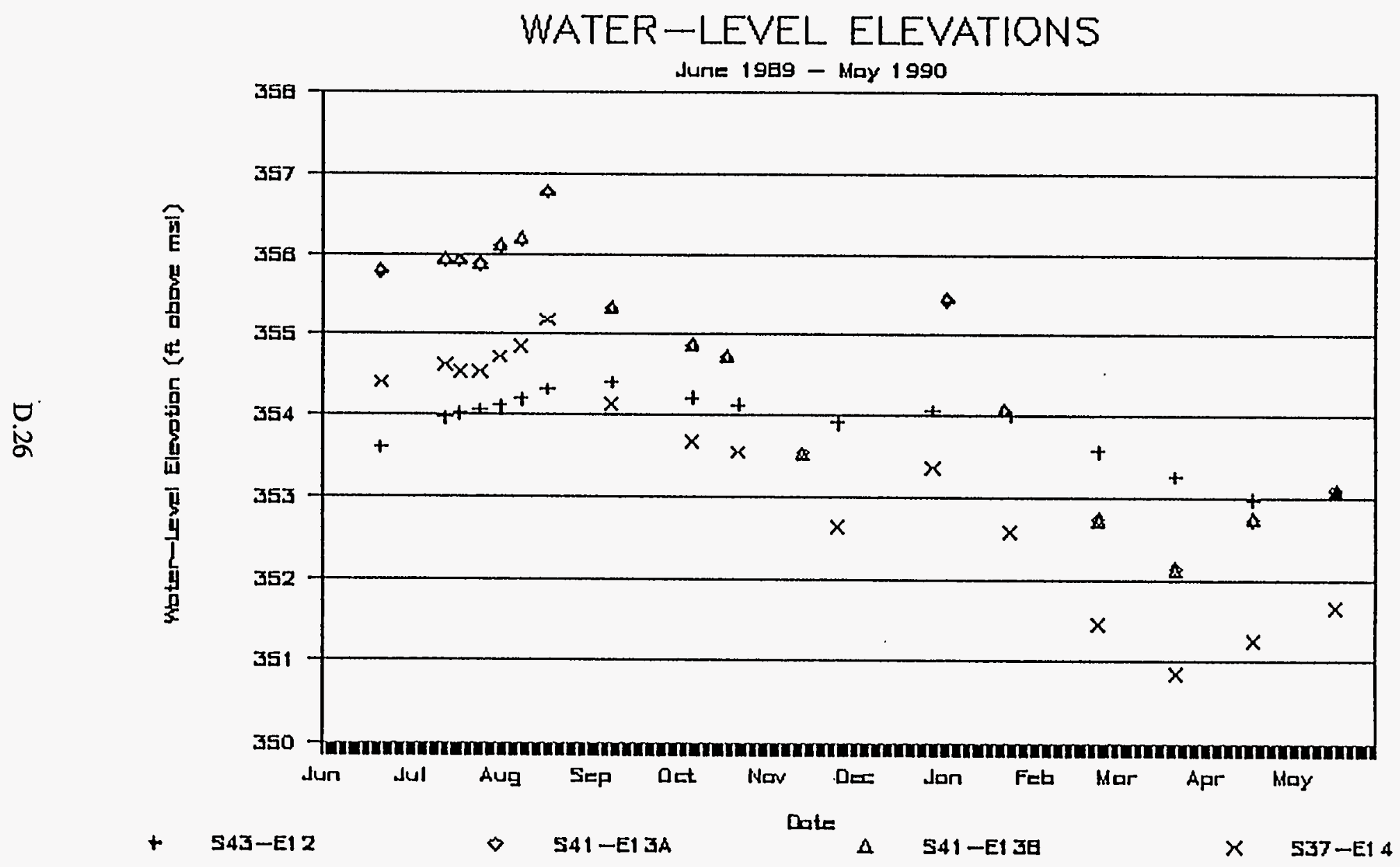




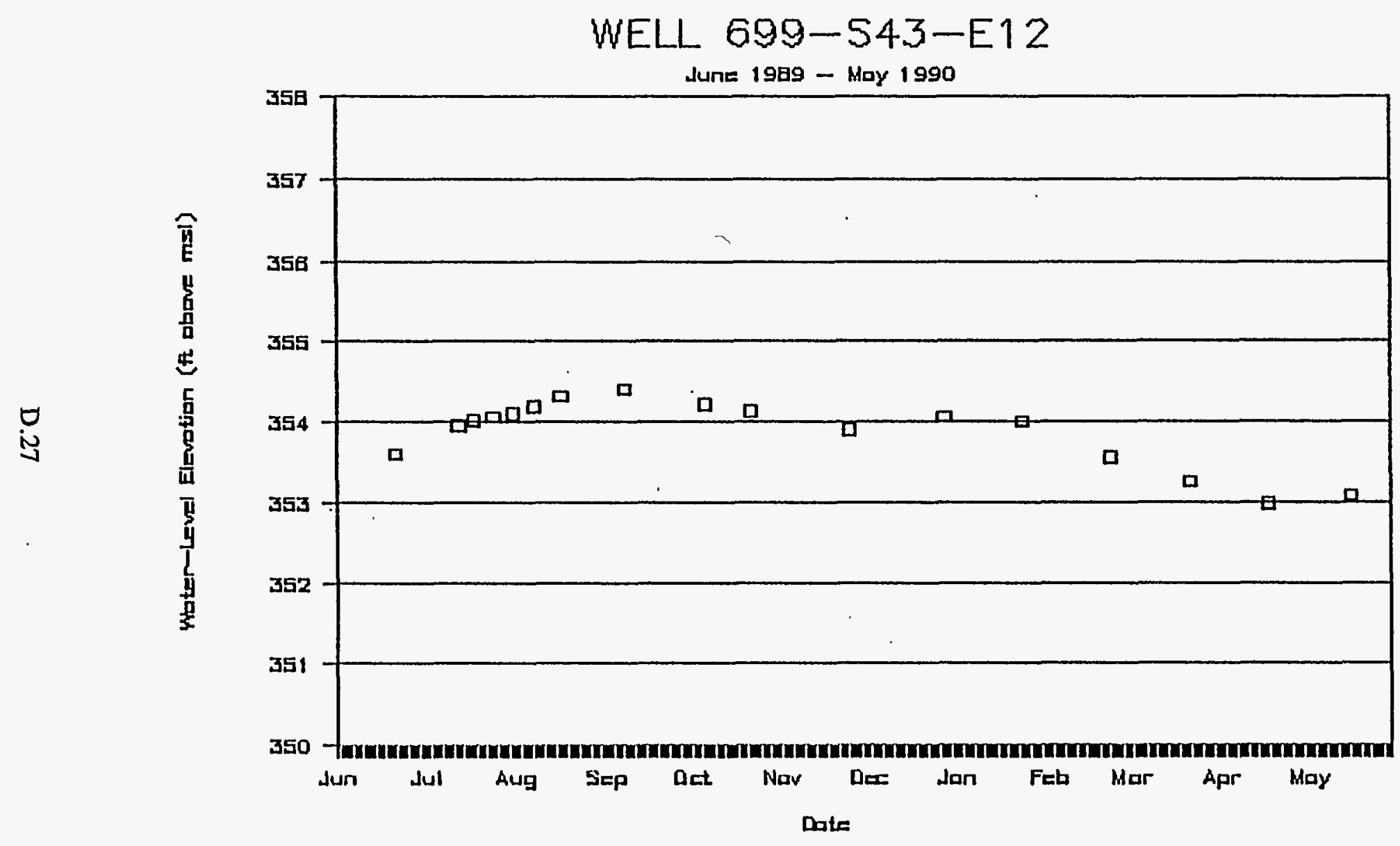


구미

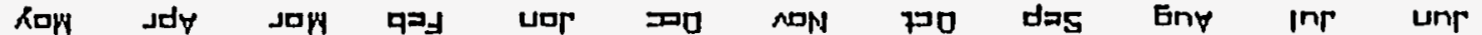

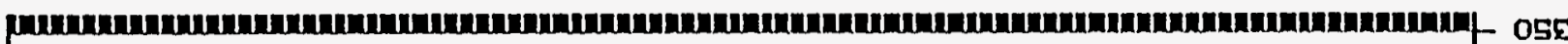

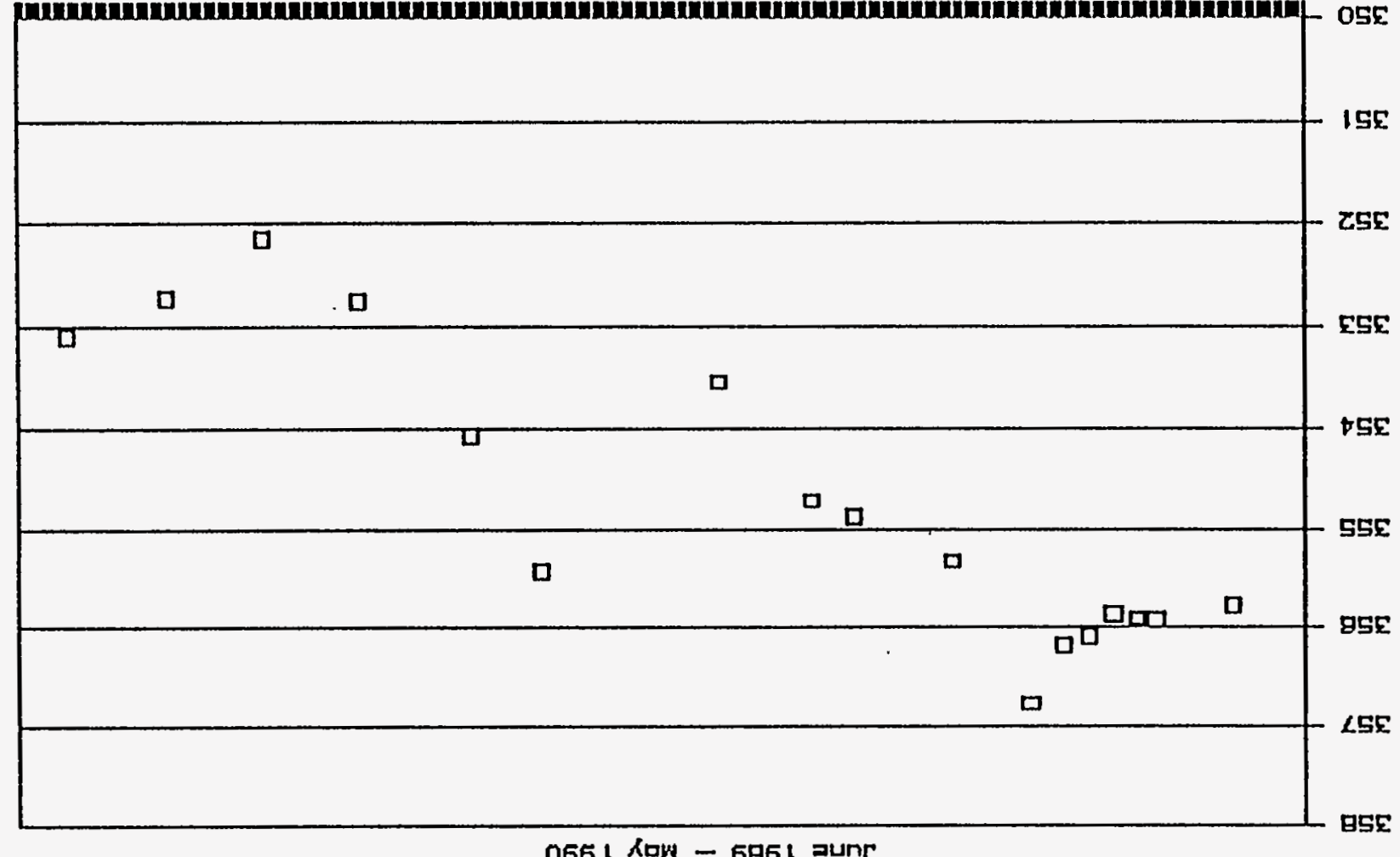

$\forall \Sigma \downarrow \exists-レ+S-66977 \exists M$ 


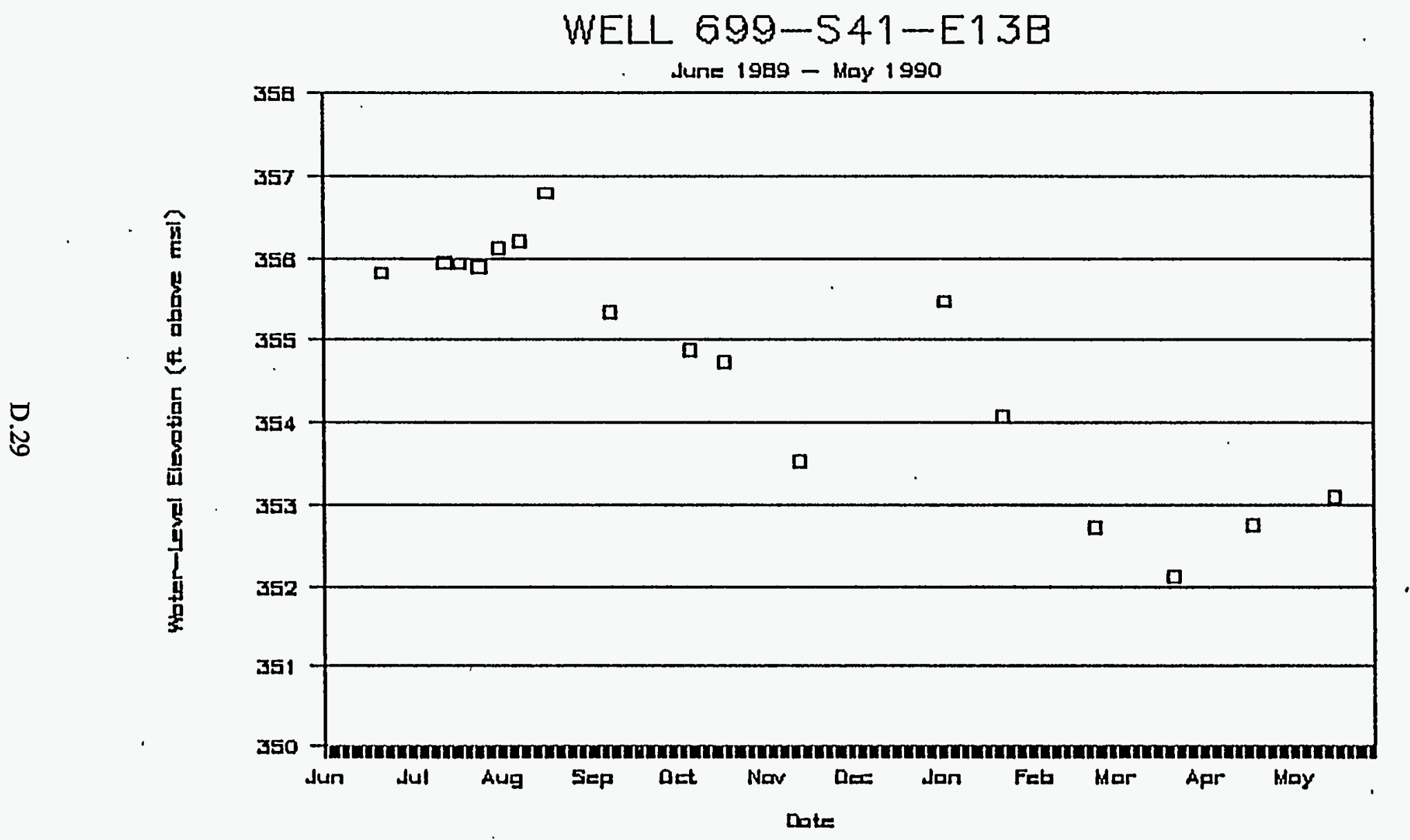




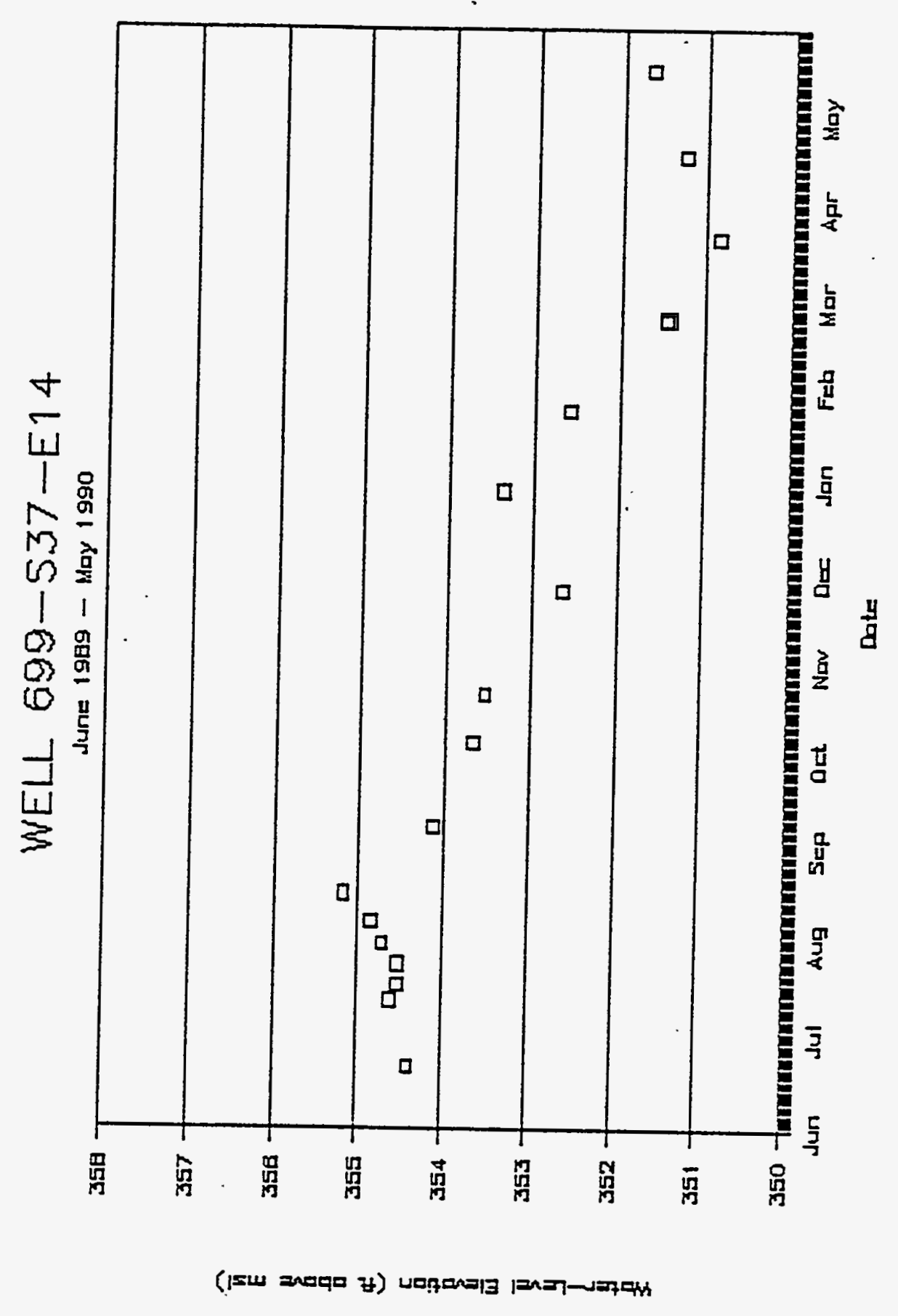

D. 30 


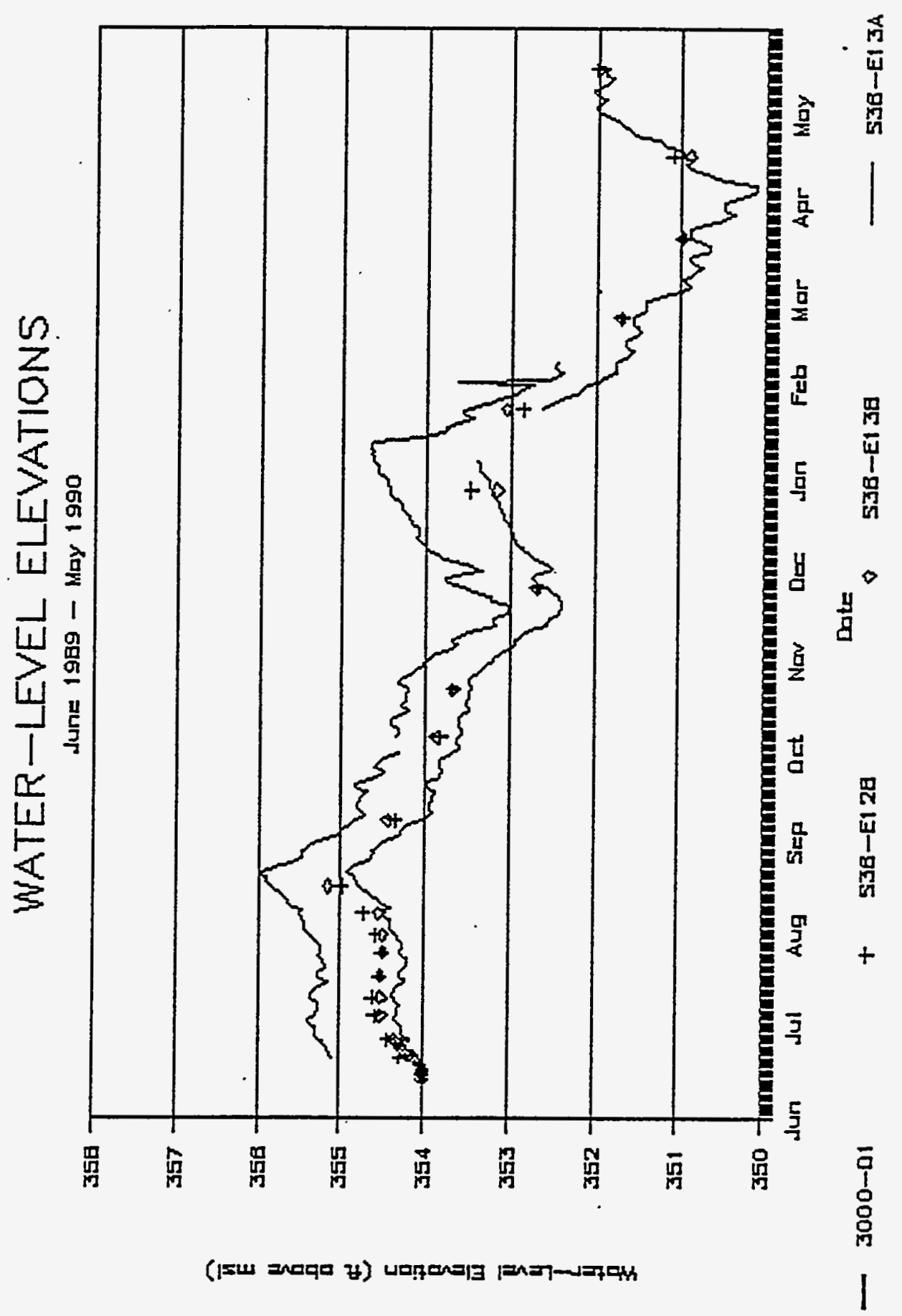

D. 31 


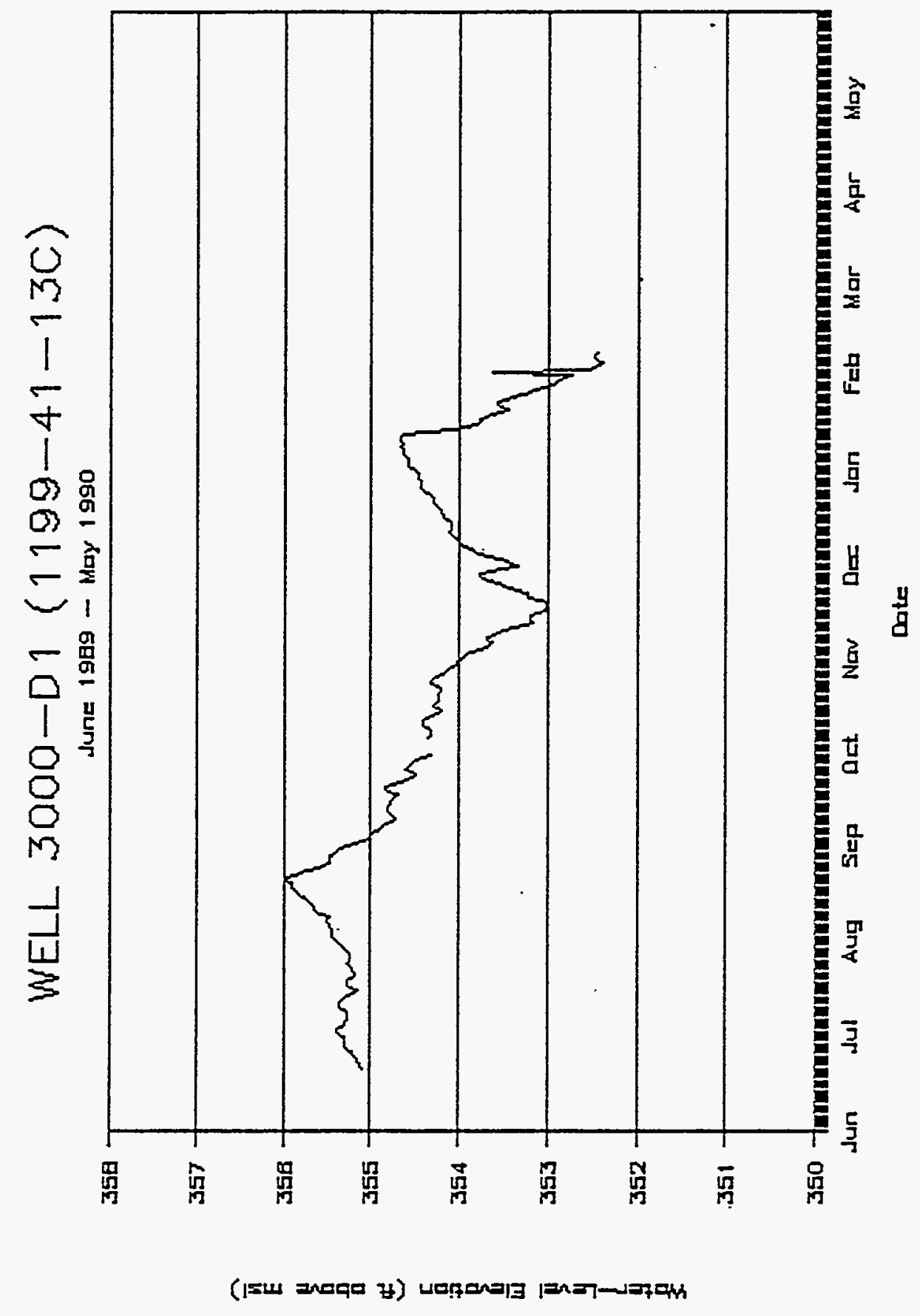

D. 32 


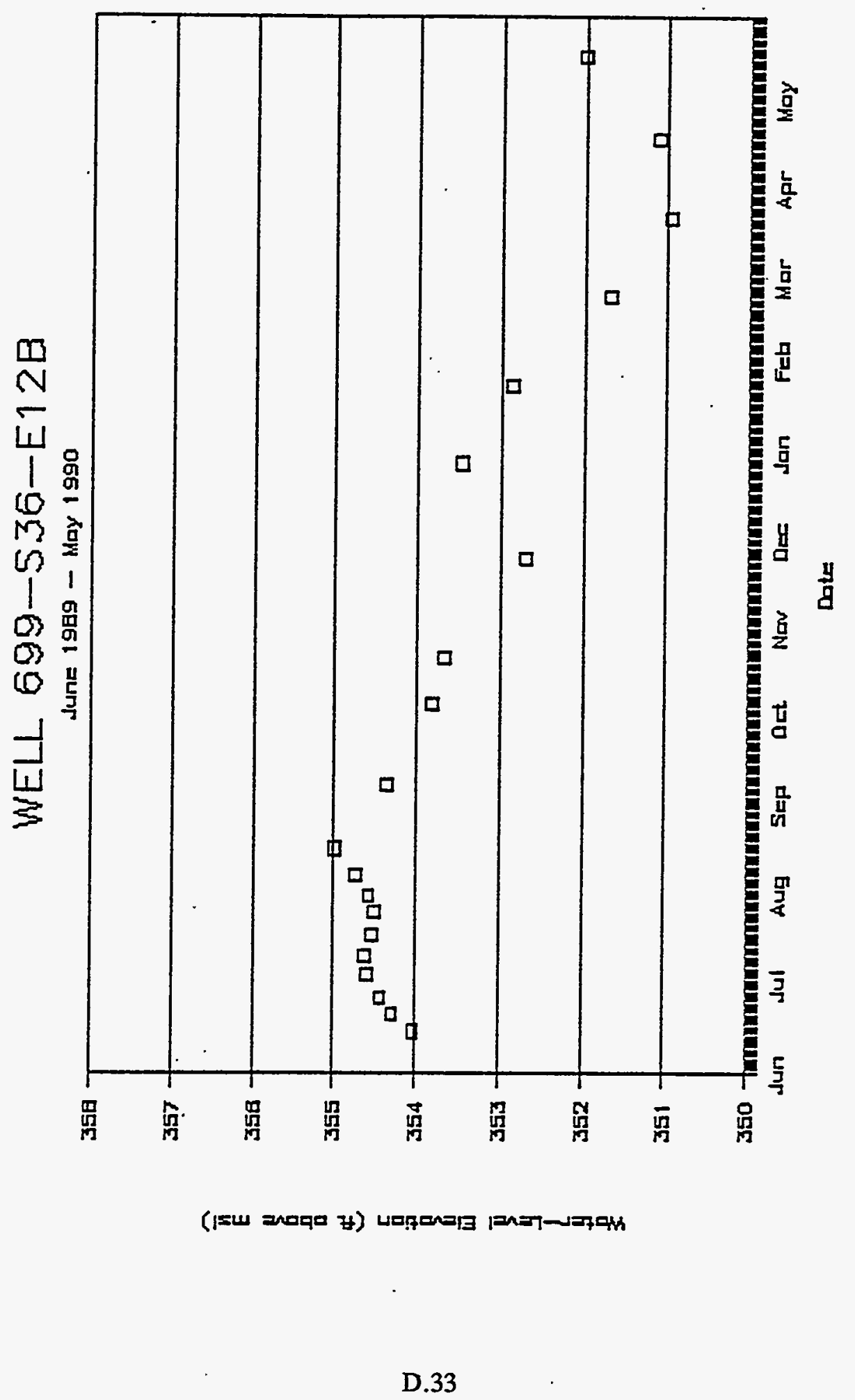


जम्प

RaW Jdy J

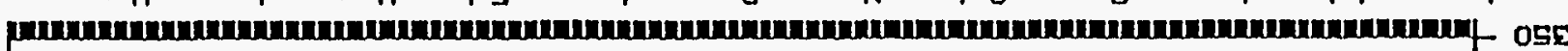

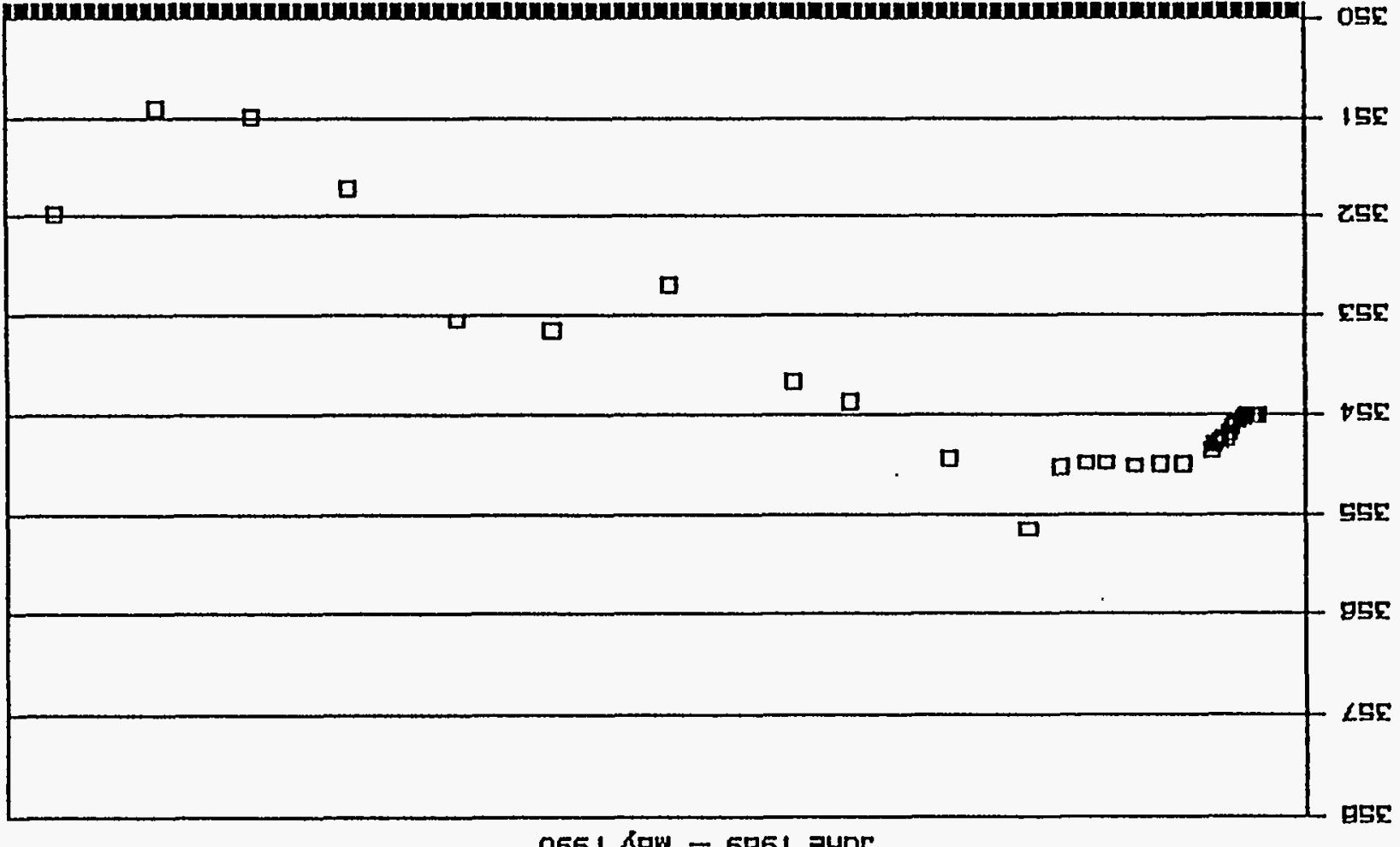

0661 kow - 6851 aunr

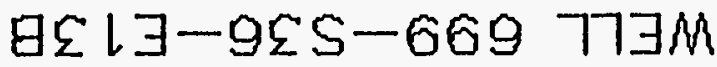




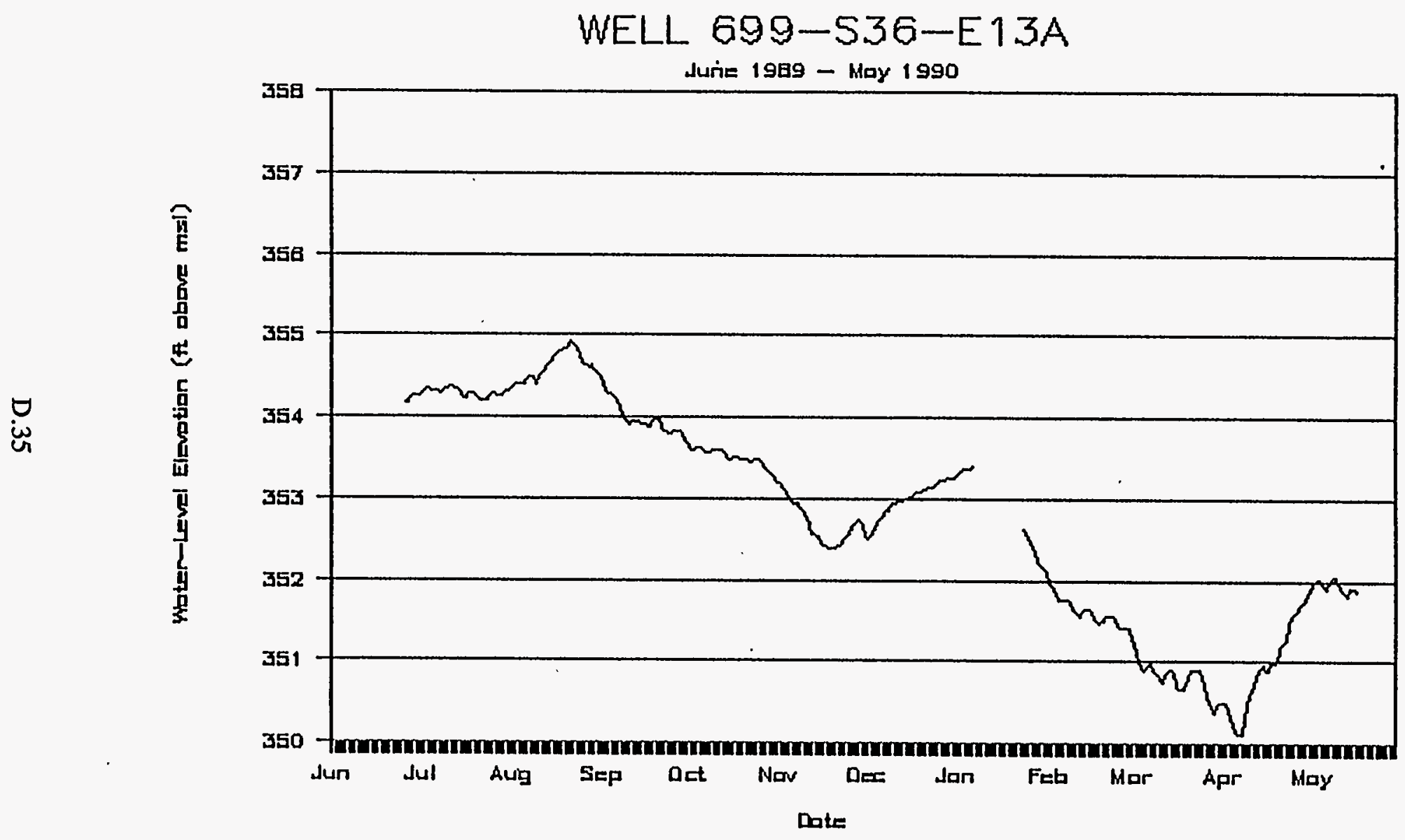




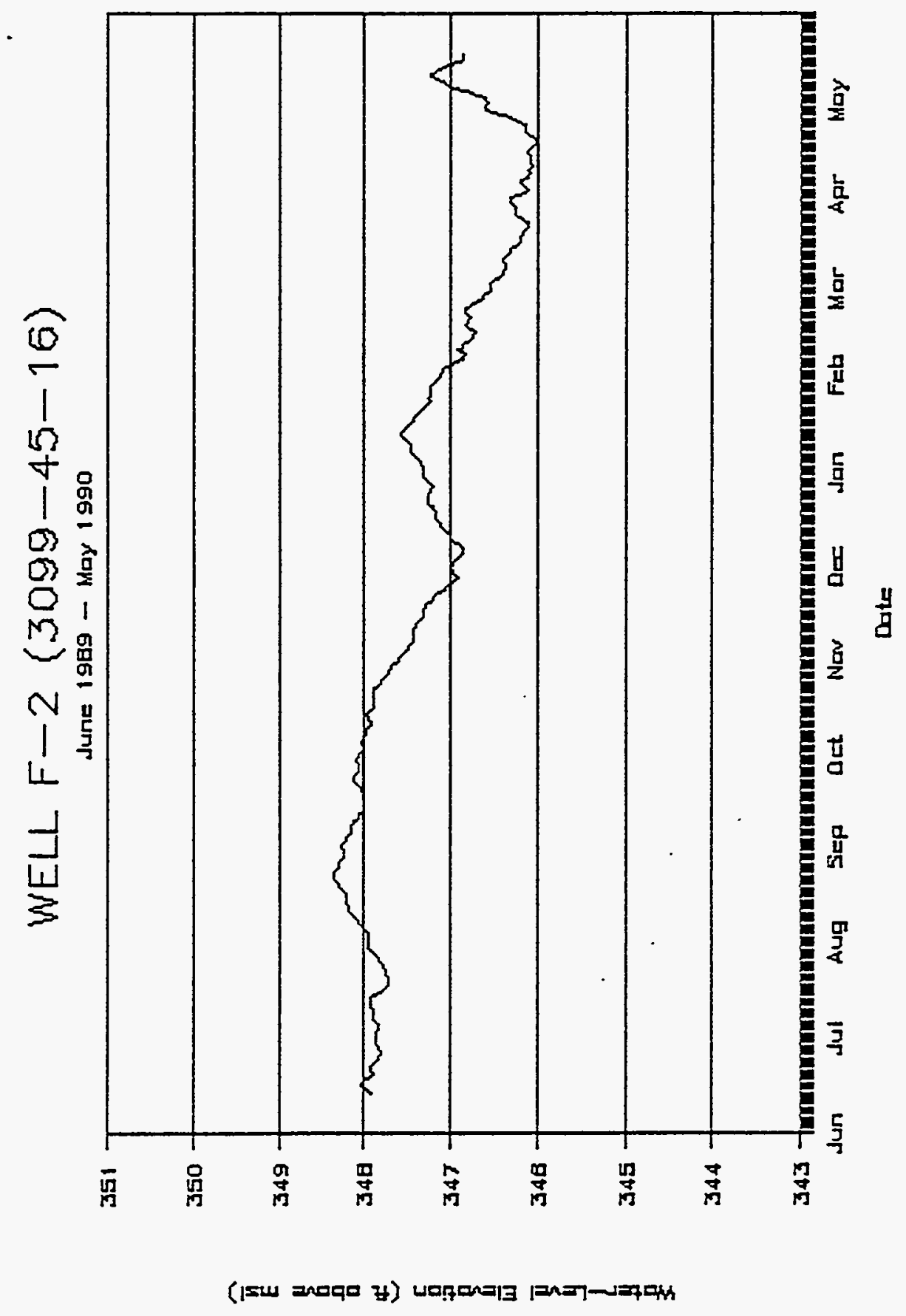

D. 36 


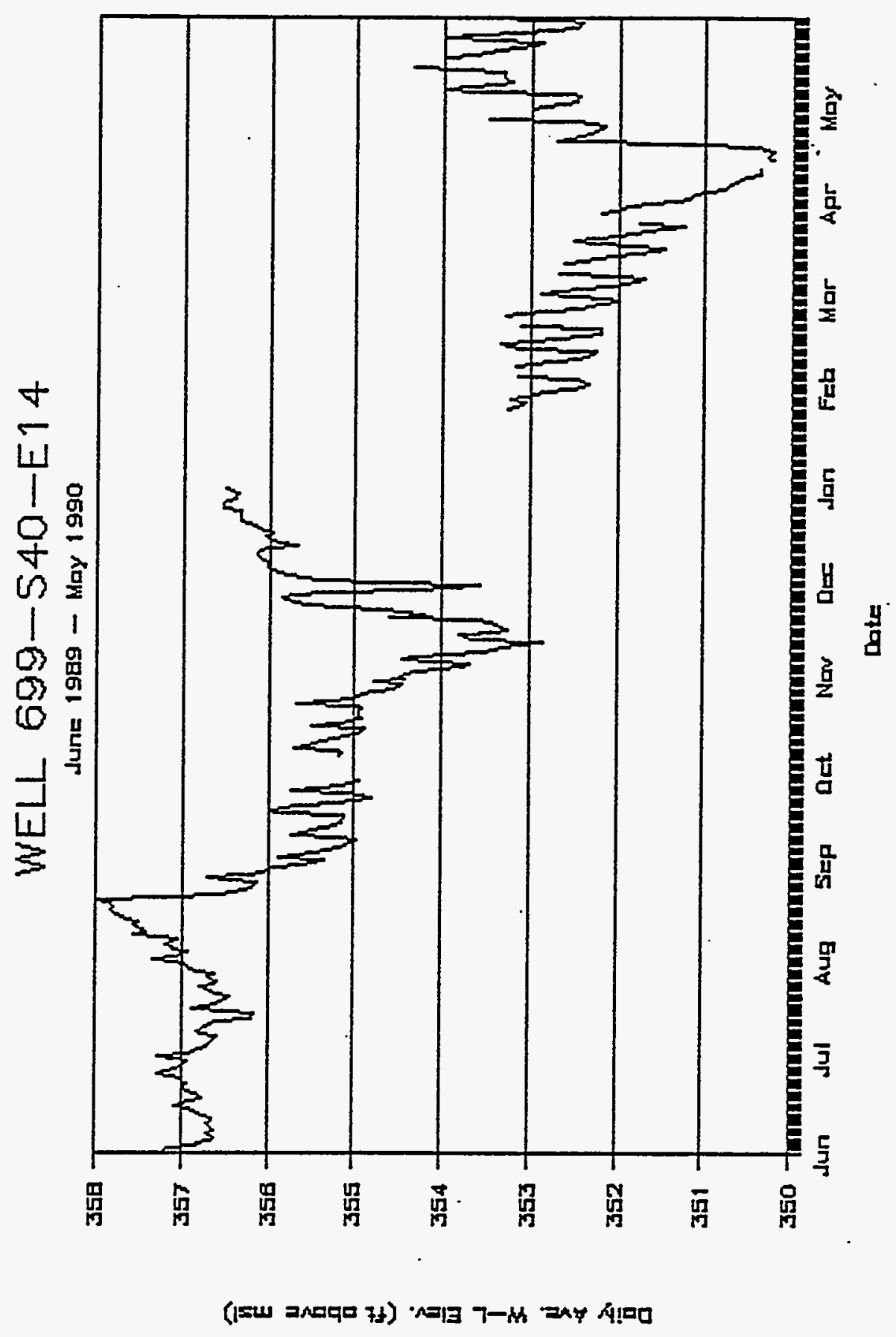

D.37 


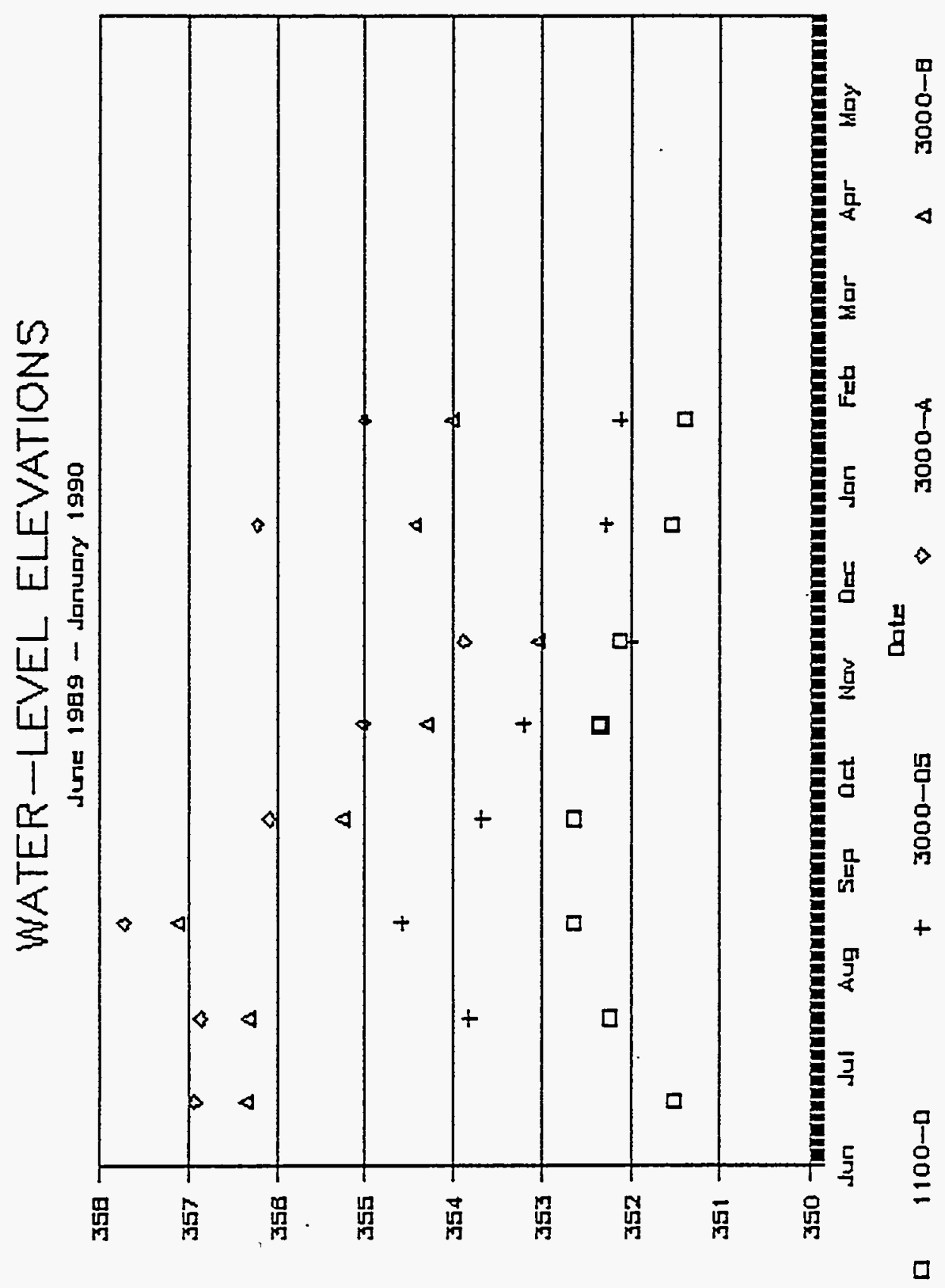

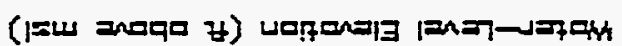




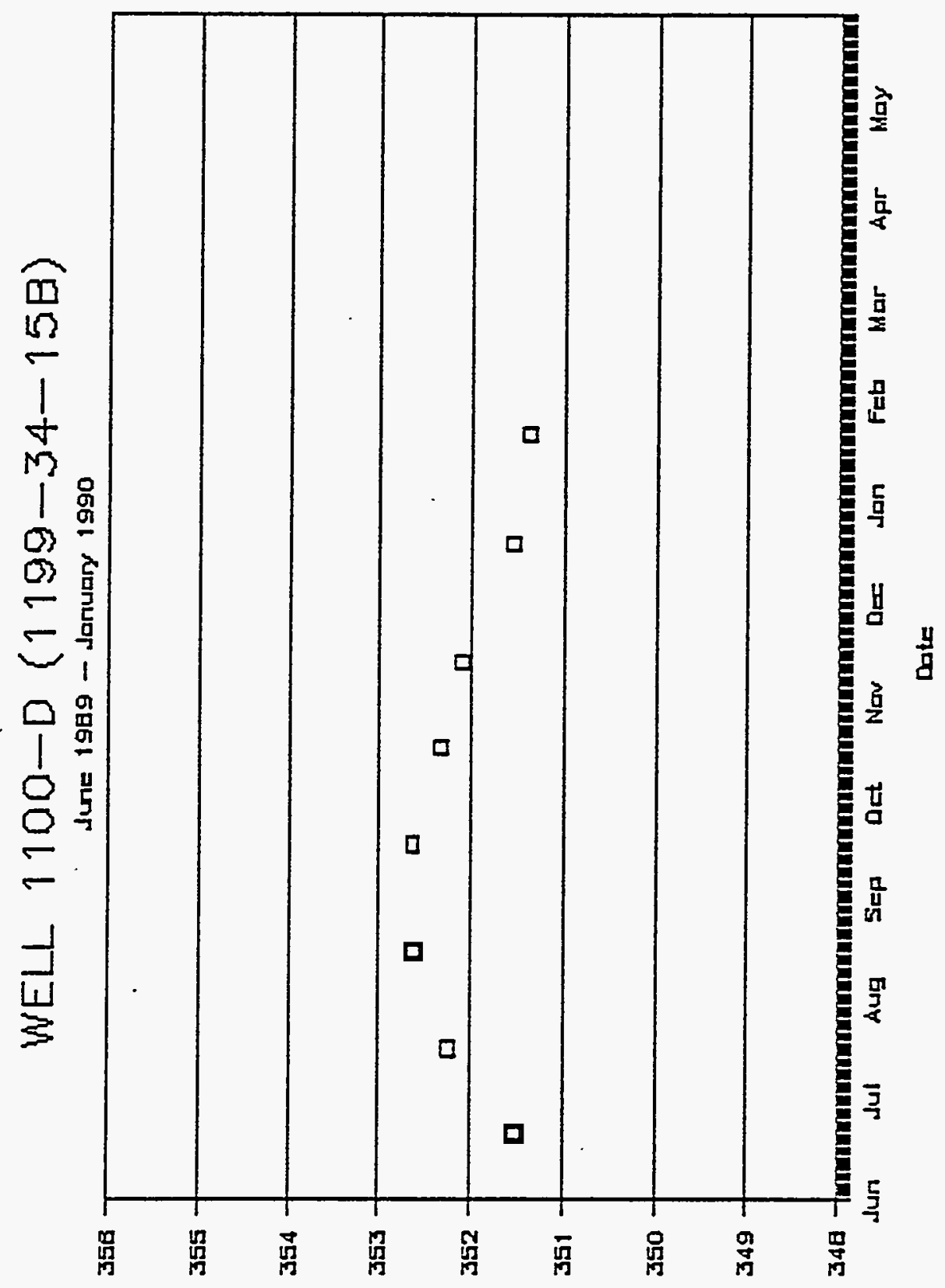

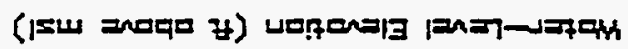

D.39 


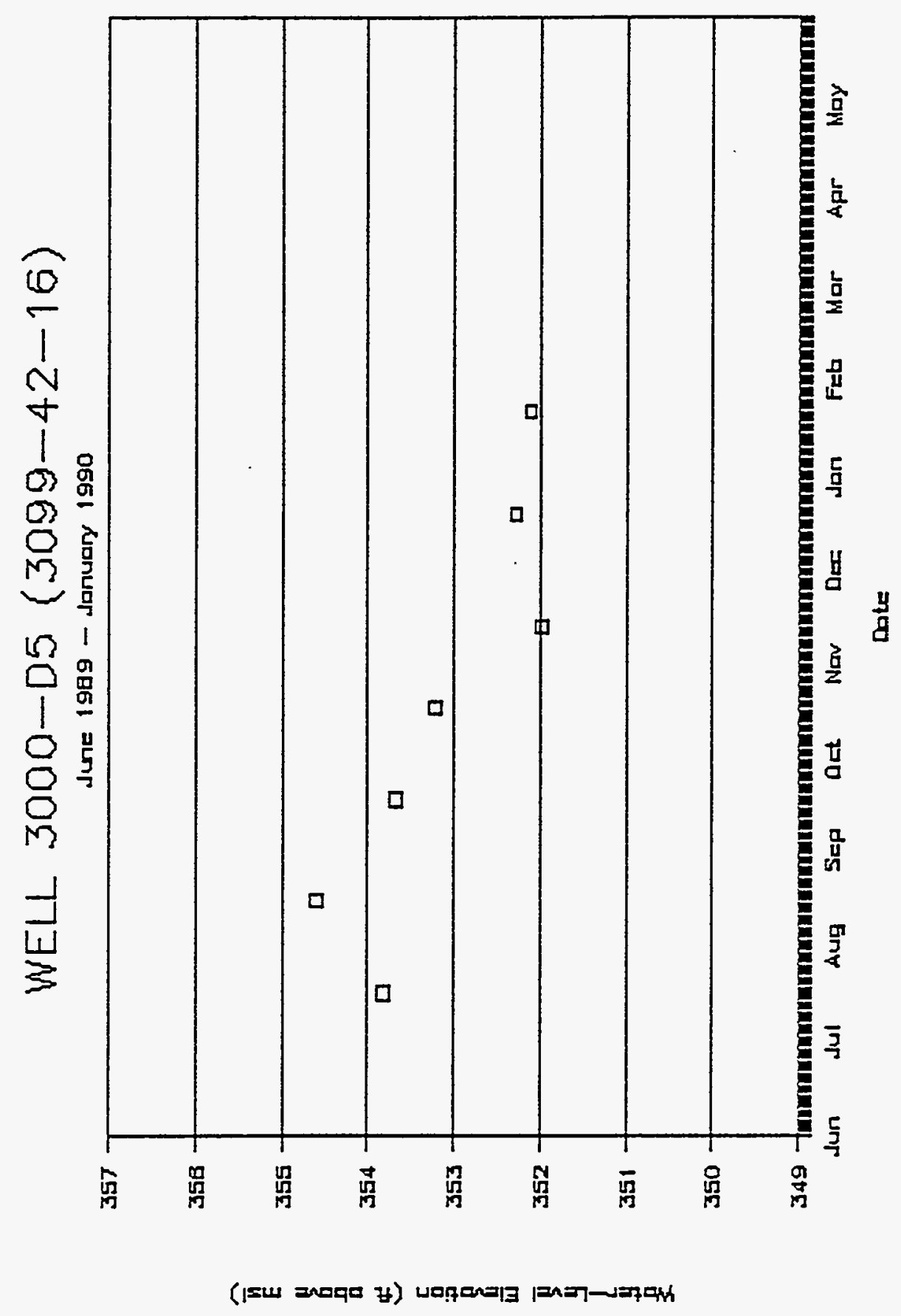

D. 40 


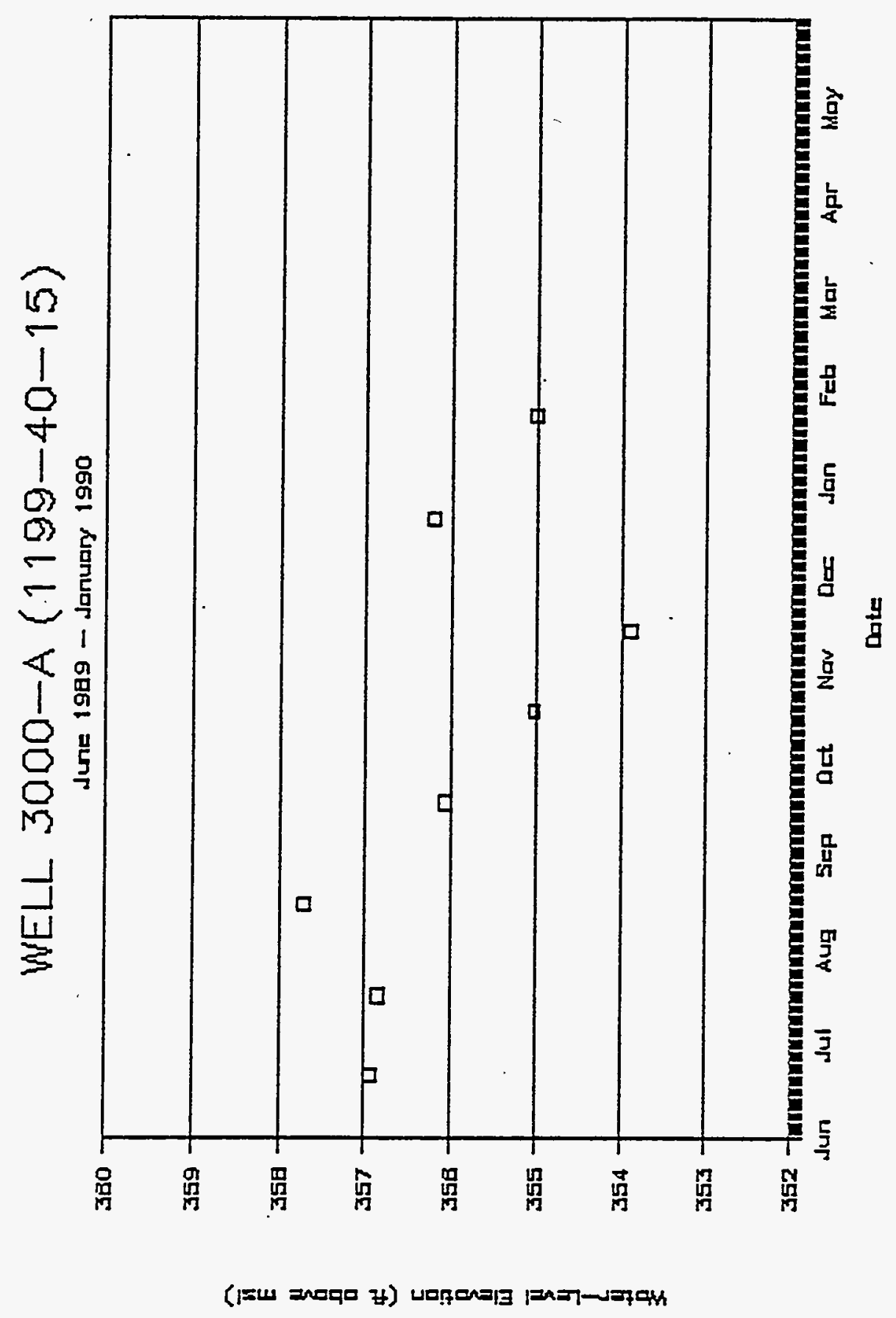

D. 41 


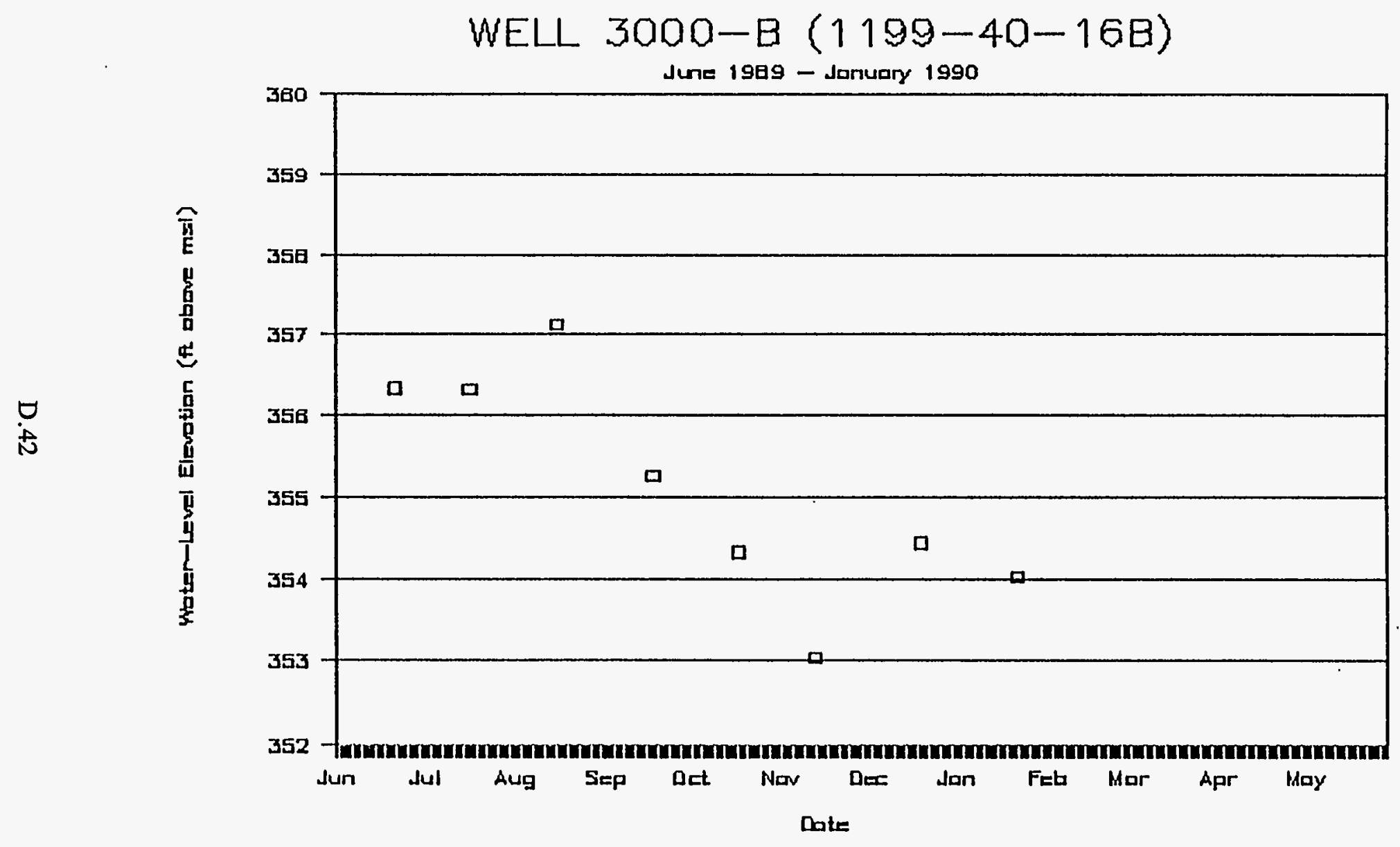




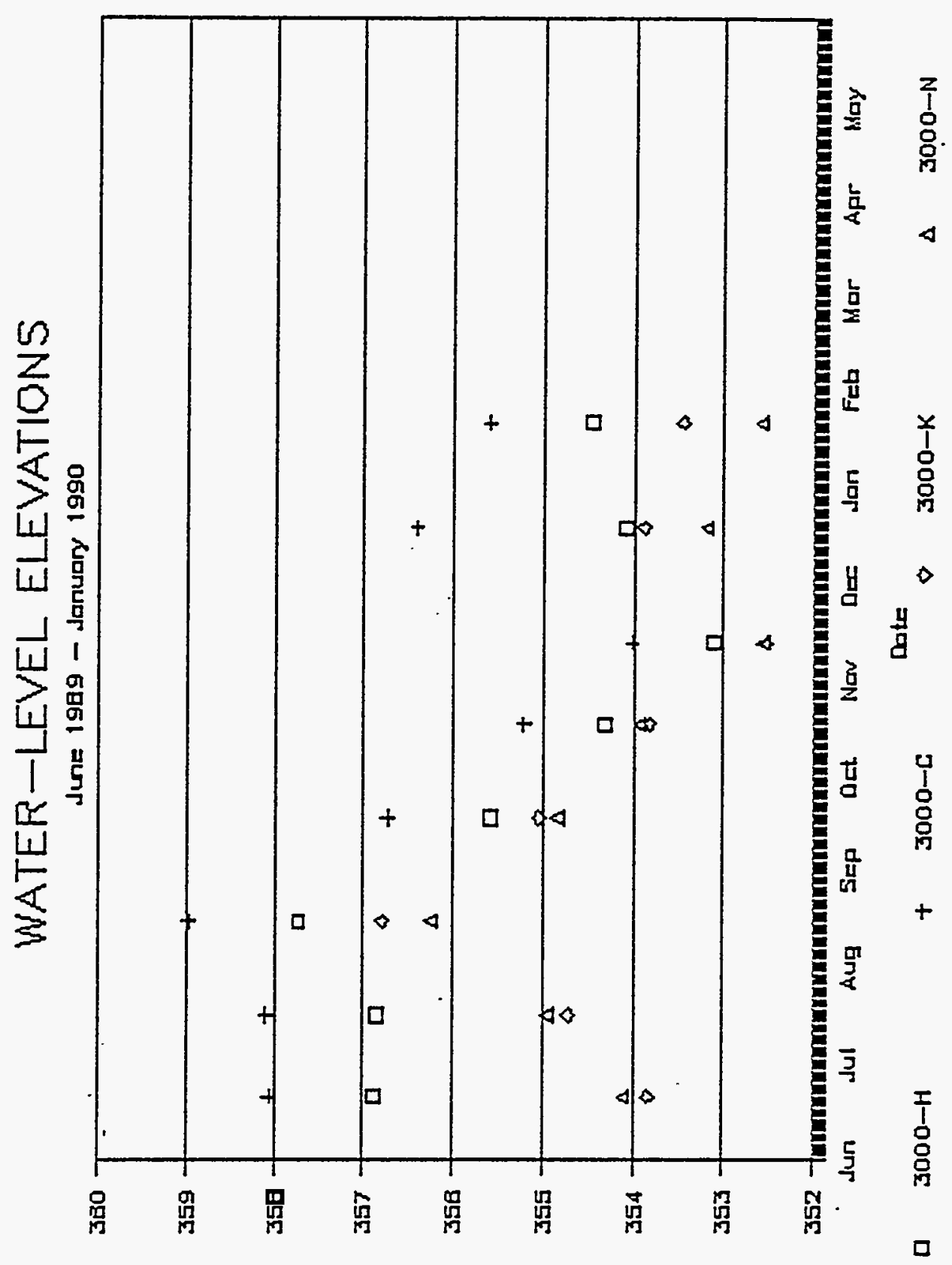

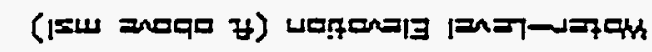

D.43 


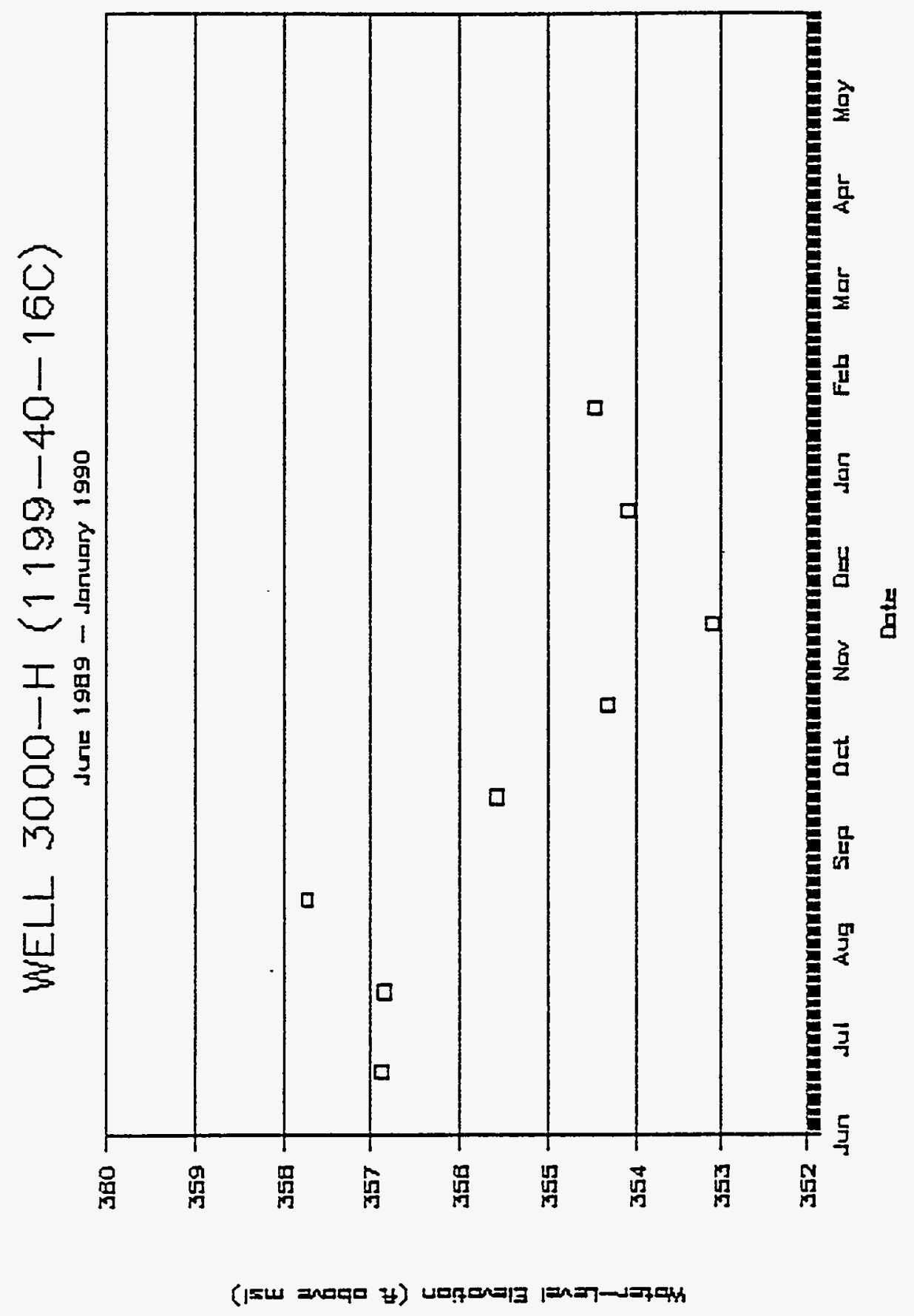

D. 44 
Ray Jdy د

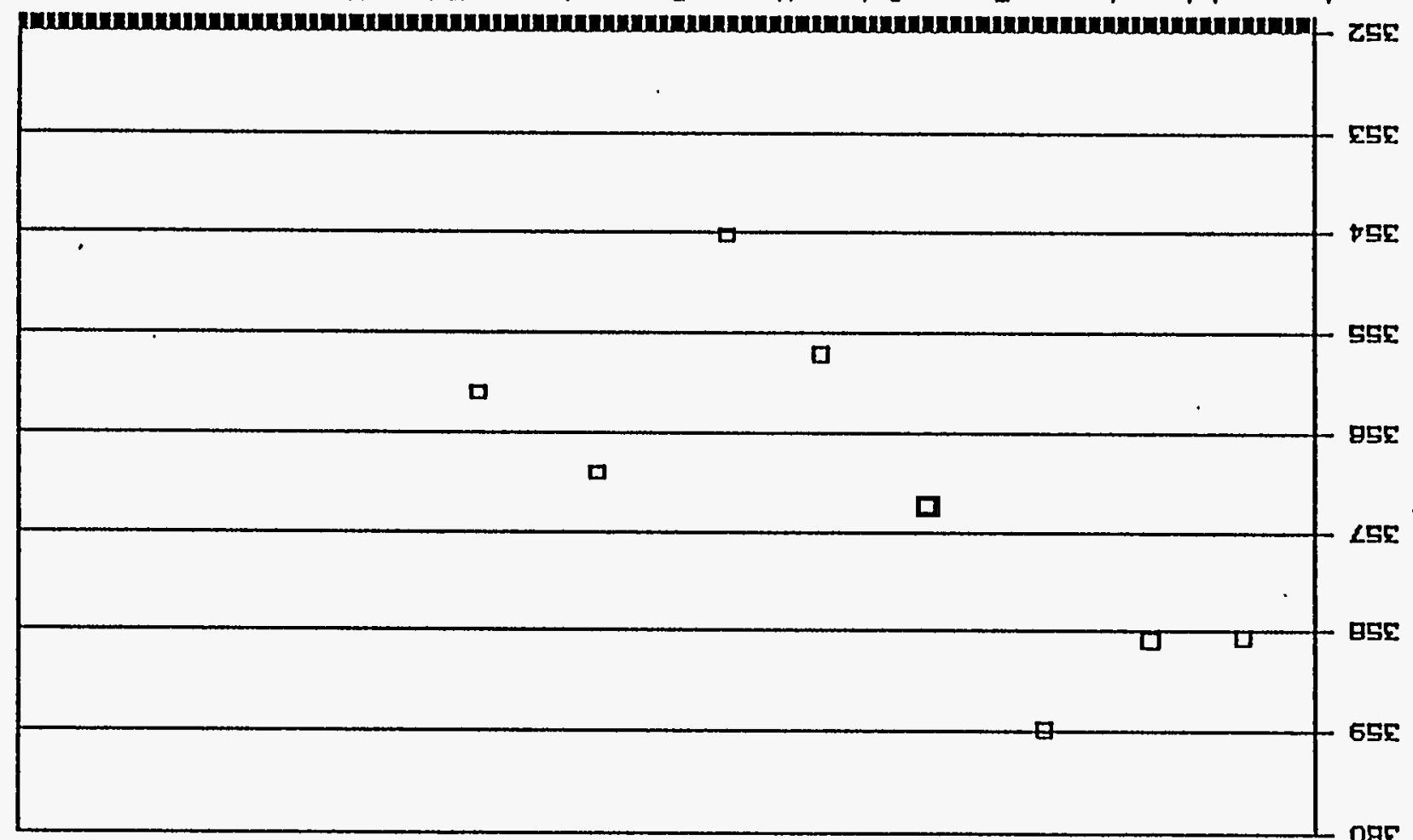




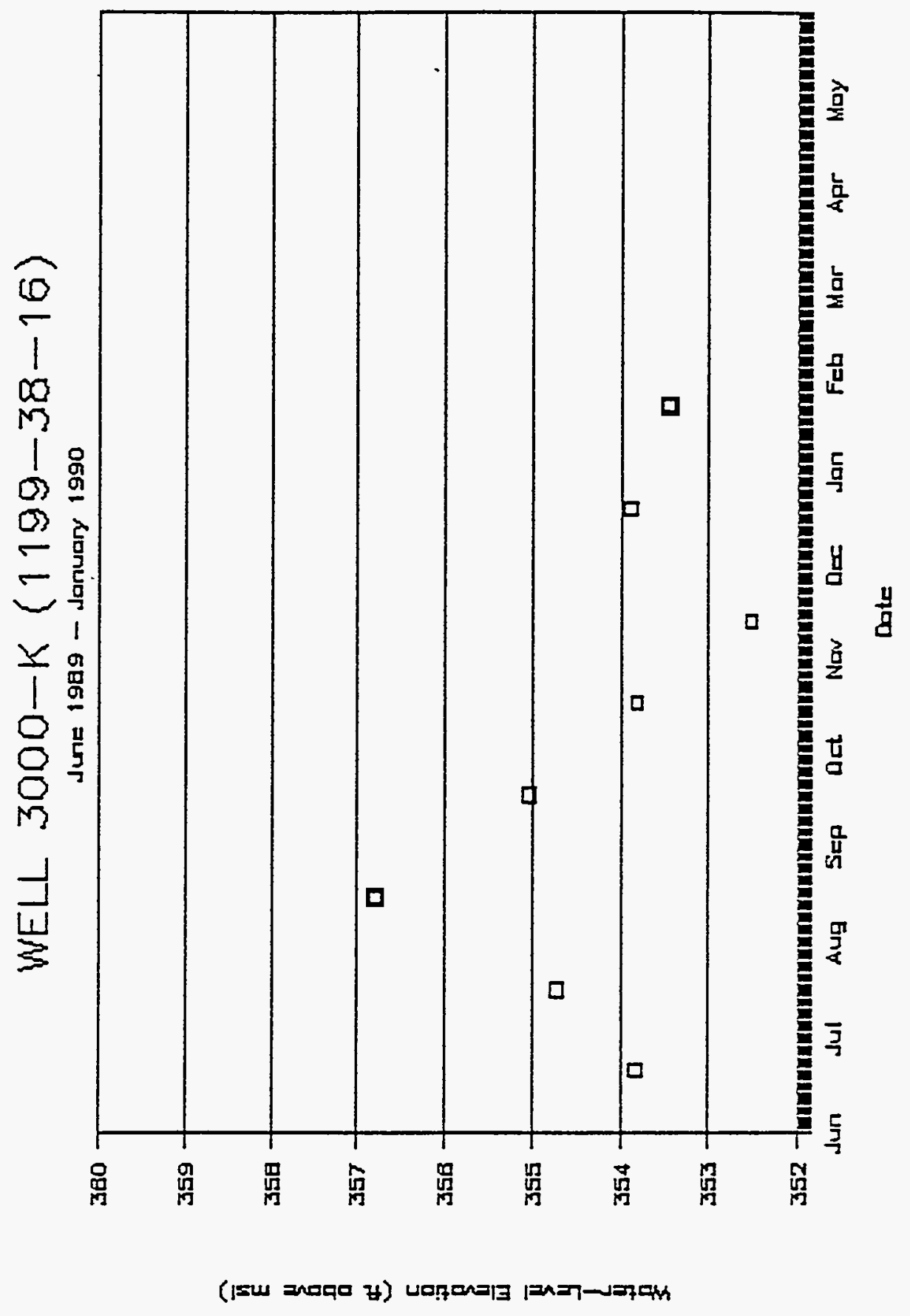

D. 46 


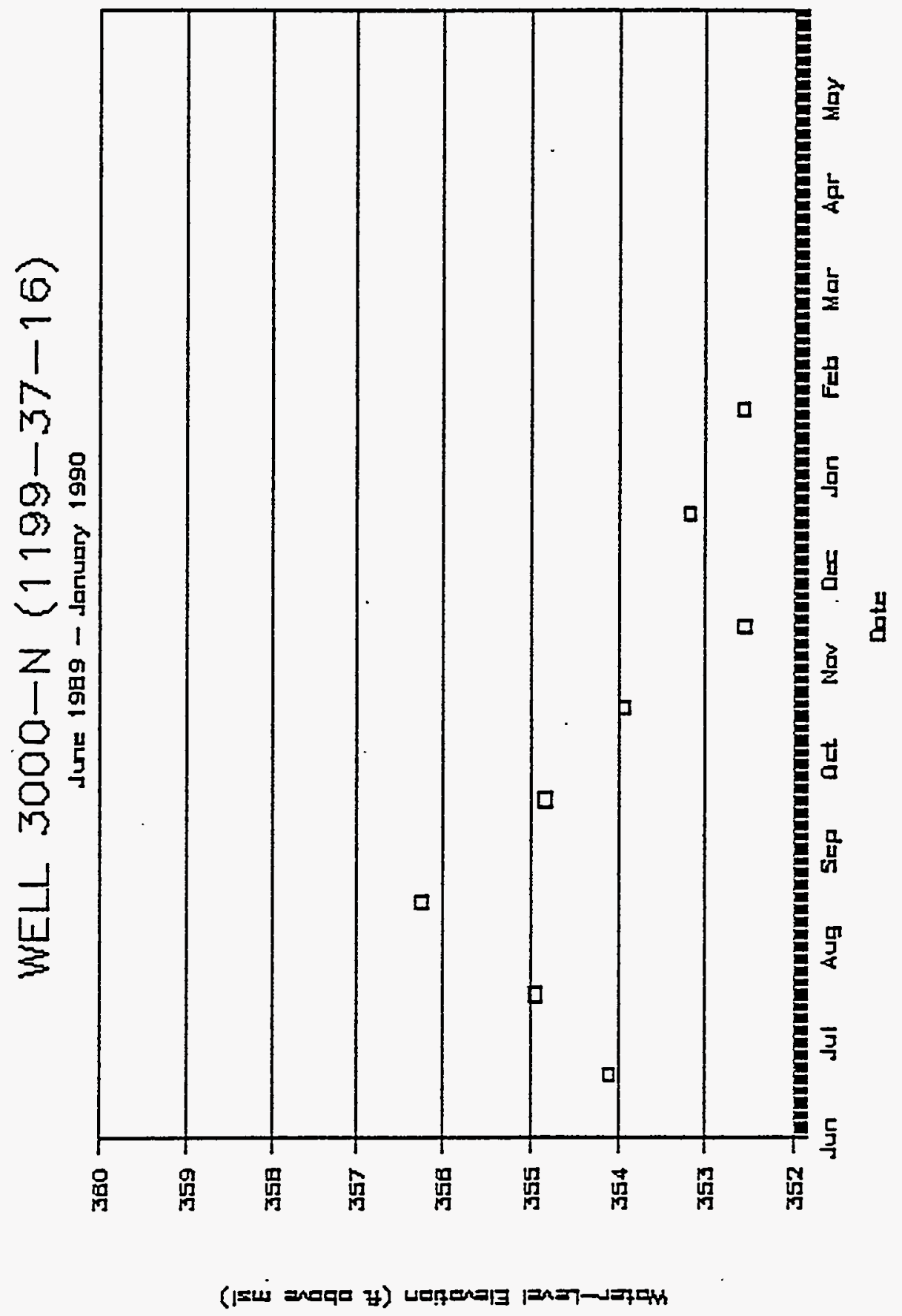

D. 47 


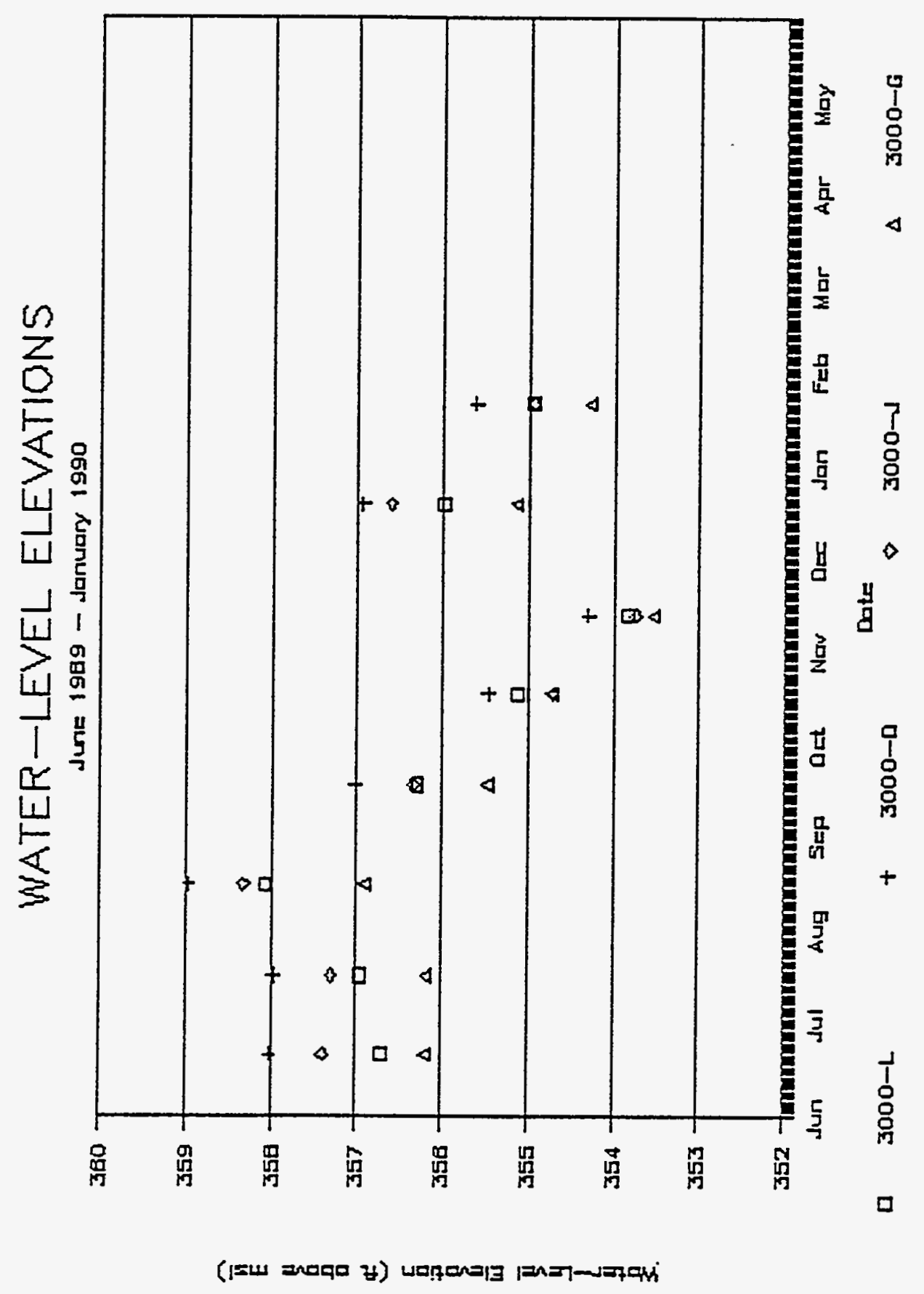

D. 48 


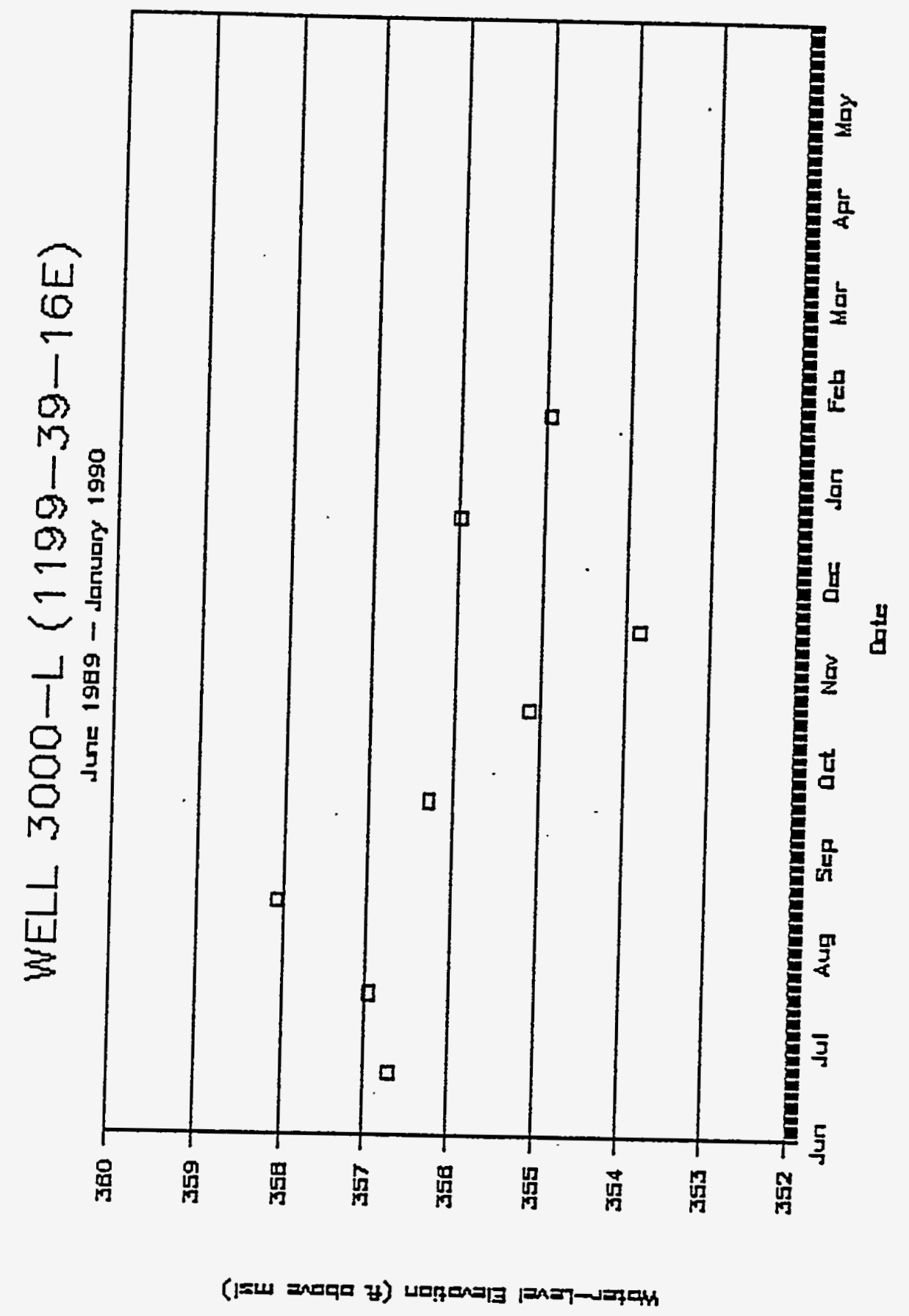

D. 49 


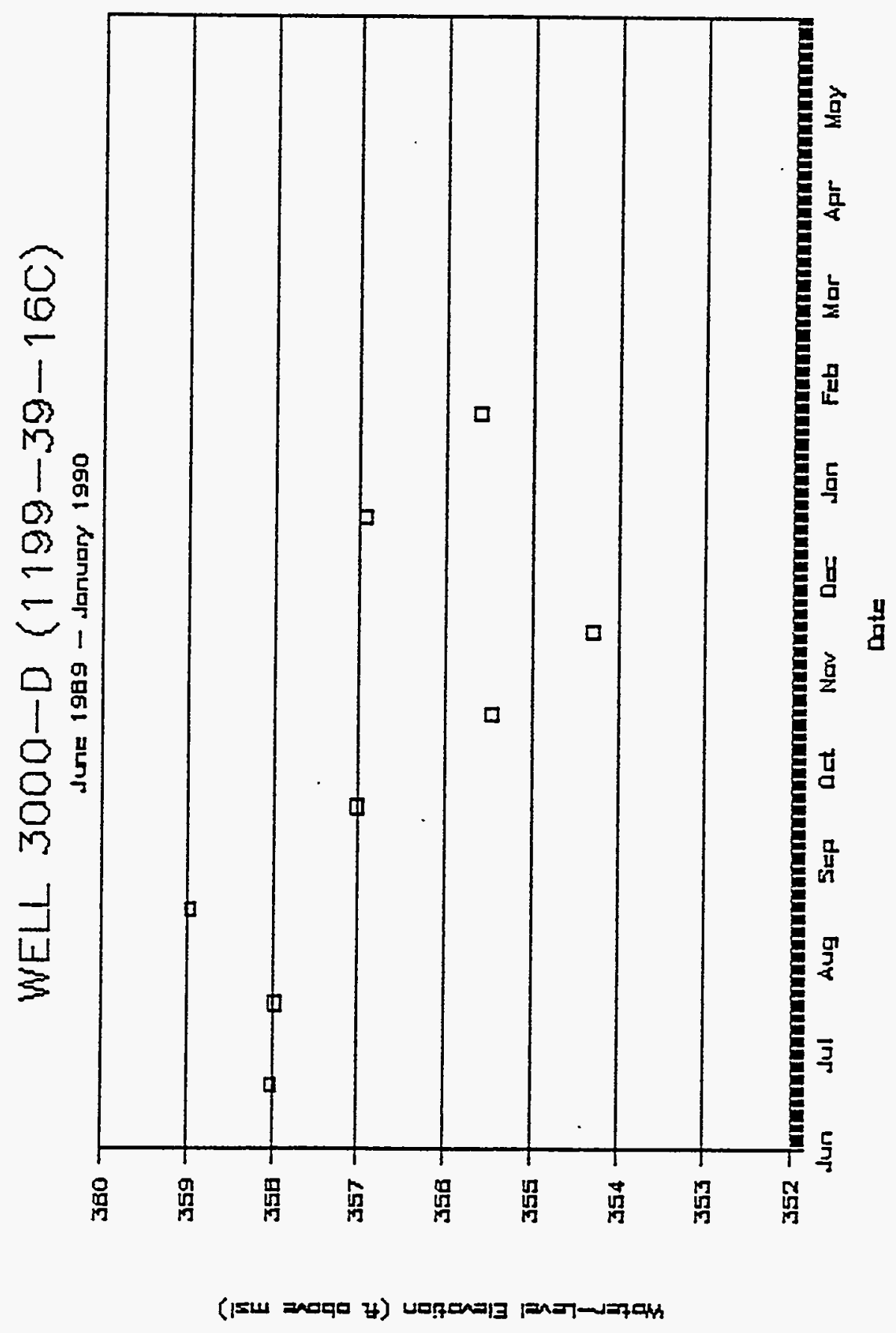

D. 50 


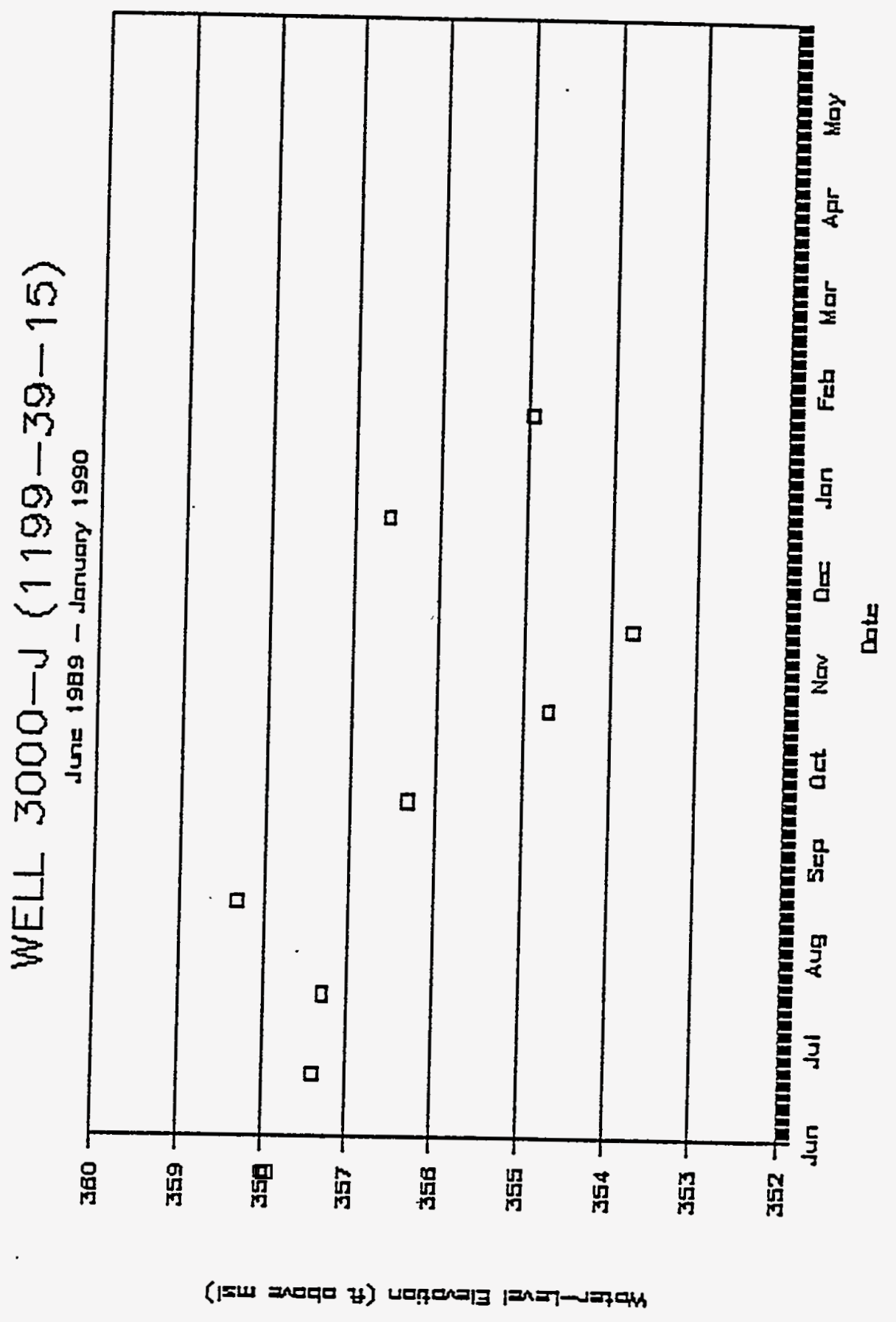

D. 51 


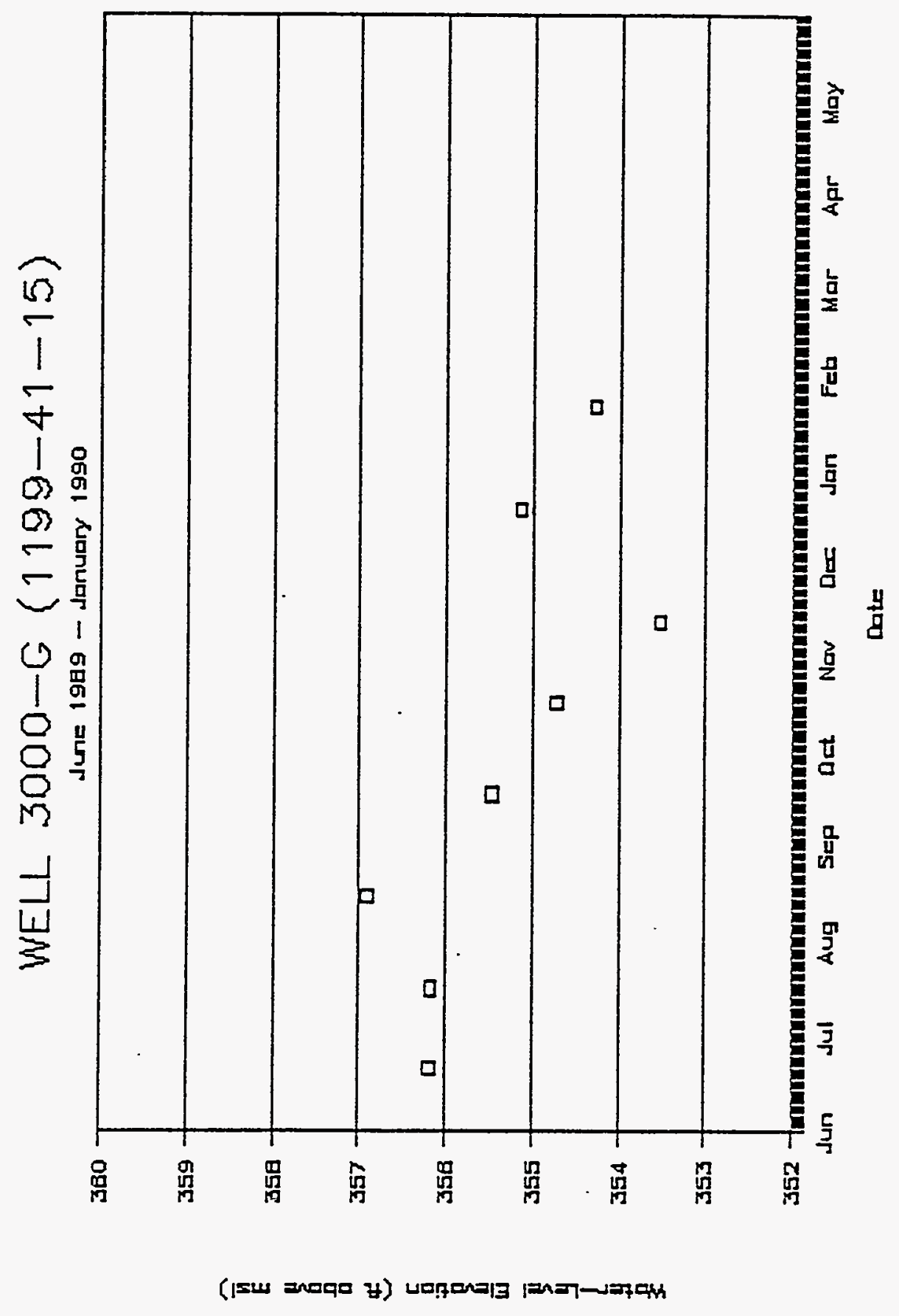

D. 52 


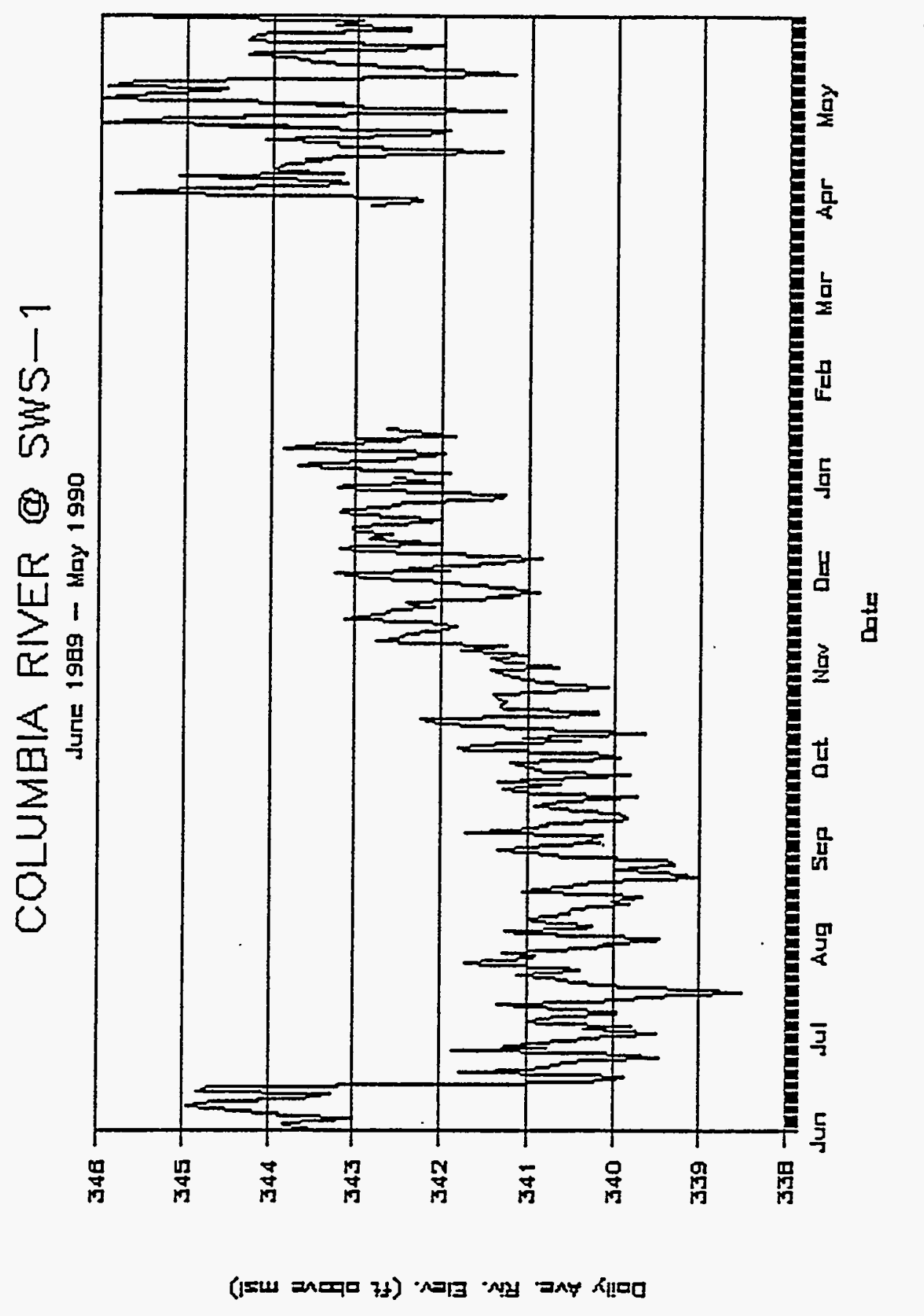

D.53 


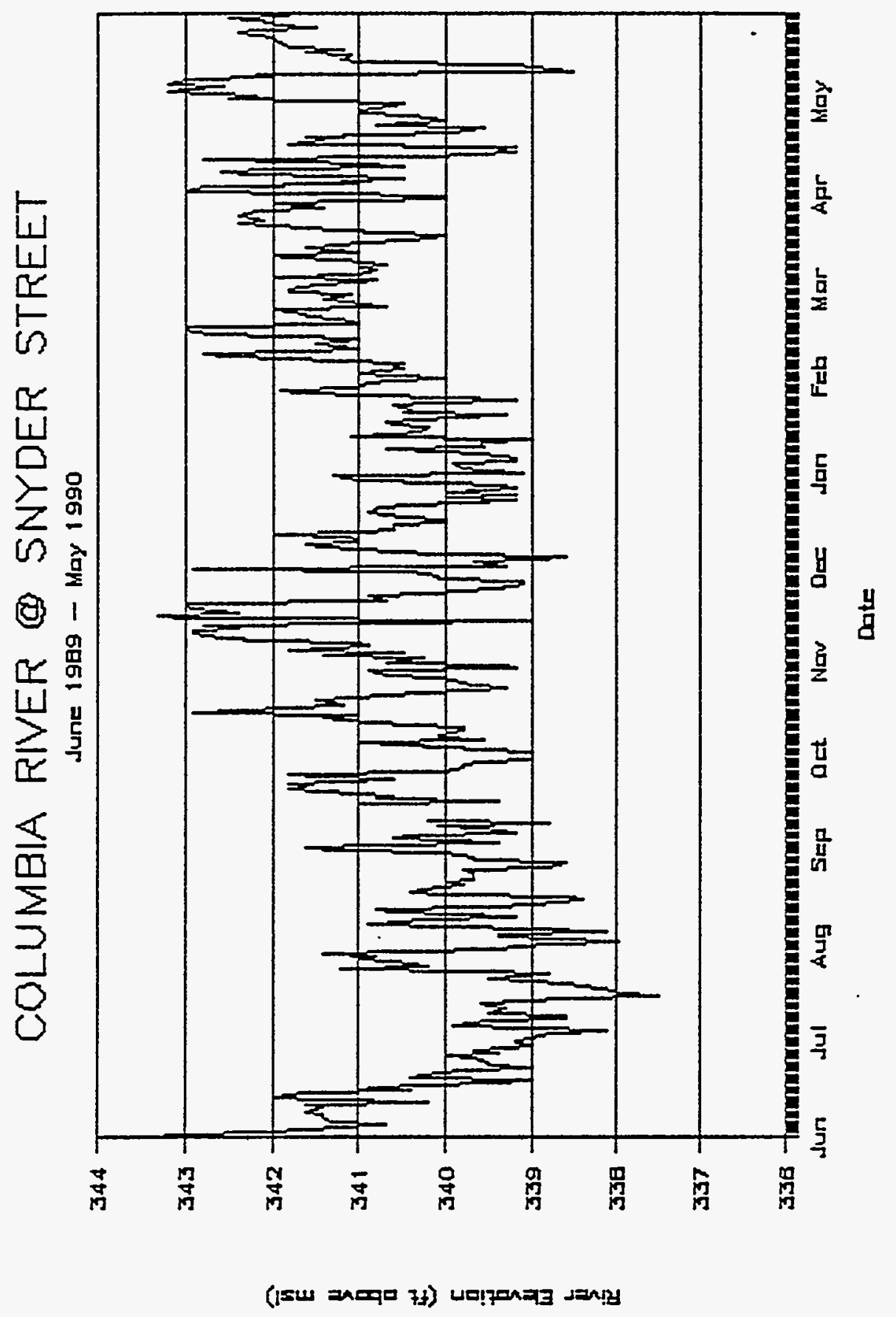

D. 54 


\section{Distribution}

No. of

Copies

$\underline{\text { OFFSITE }}$

12 DOE/Office of Scientific and Technical Information

S. Arlt

Director, Water and Waste

Utilities Department

City of Richland

505 Swift Blvd.,

Richland, WA 99352

M. Gillium

Associate Engineer, Water and Waste Utilities Department

City of Richland

505 Swift Blvd., Richland, WA 99352

S. C. Meyer

Lead Operator, Water and Waste

Utilities Department

City of Richland

110 Saint Street, Richland, WA 99352

K. F. Ferrigno

Senior Scientist

Scientific Ecology Group, Inc.

1234 Columbia Drive SE

Richland, WA 99352

S. R. Lockhaven

Industrial Hygienist

Siemens Power Corporation

2101 Horn Rapids Road,

Richland, WA 99352
No. of

Copies

ONSITE

3 DOE Richland Operations Office

E.D. Goller

A5-19

R. D. Hildebrand A5-55

R. K. Stewart .

A5-19

4 Westinghouse Hanford Company

K. R. Fecht H6-06

R. L. Jackson H6-06

A. J. Knepp H6-06

J. W. Lindberg H6-06

ICF Kaiser Hanford Company

C. J. Clement

G7-33

$2 \quad$ U.S. Army Corps of Engineers

W. L. Greenwald

A5-20

M. P. Johansen

A5-19

Associated Western Universities

R. A. Kirk

$\mathrm{H} 2-52$

39 Pacific Northwest Laboratory

B. N. Bjornstad

K6-84

J. V. Borghese

K6-96

R. W. Bryce

K6-96

M. A. Chamness

K6-84

P. G. Doctor 
No. of

Copies

P. E. Dresel

M. D. Freshley

R. E. Gephart

G. V. Last

R. E. Lewis

T. L. Liikala (15)

P. E. Long

S. P. Luttrell
No. of

Copies

K6-96

K6-77

K1-22

K6-84

K6-84

K6-84

K6-84

K6-96
Q. C. Macdonald

J. P. McDonald

D. R. Newcomer

F. A. Spane

S. S. Teel

P. D. Thorne

Publishing Coordination

Technical Report Files (5)
K6-96

K6-96

K6-96

K6-96

K6-84

K6-96 
Plate 1 - Geologic Cross Section A-A'

Plate 2 - Geologic Cross Section B-B'

Plate 3 - Geologic Cross Section C-C'

Plate 4 - Geologic Cross Section D-D'

Plate 5 - Geologic Cross Section E-E' 


\section{Plate 1}

A

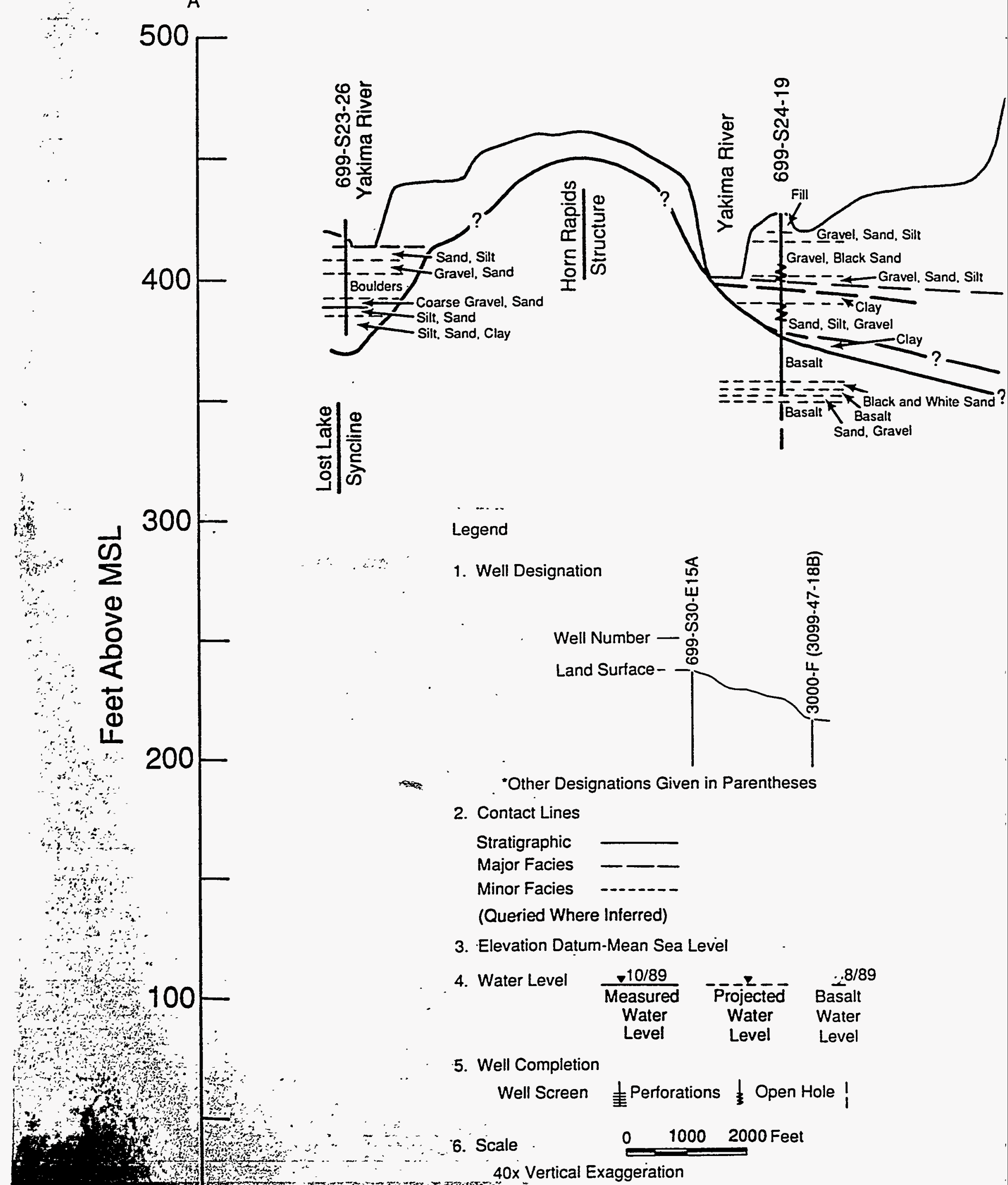




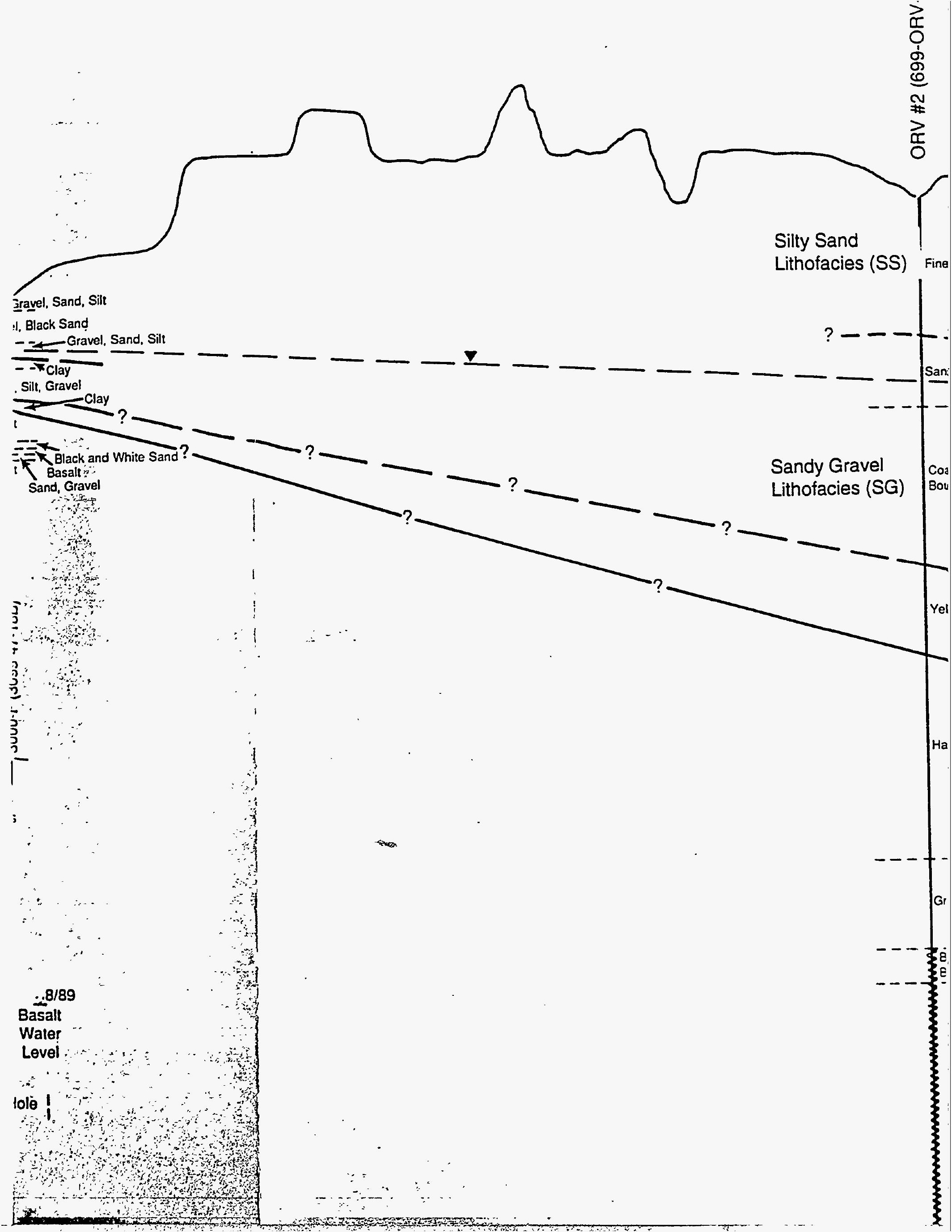




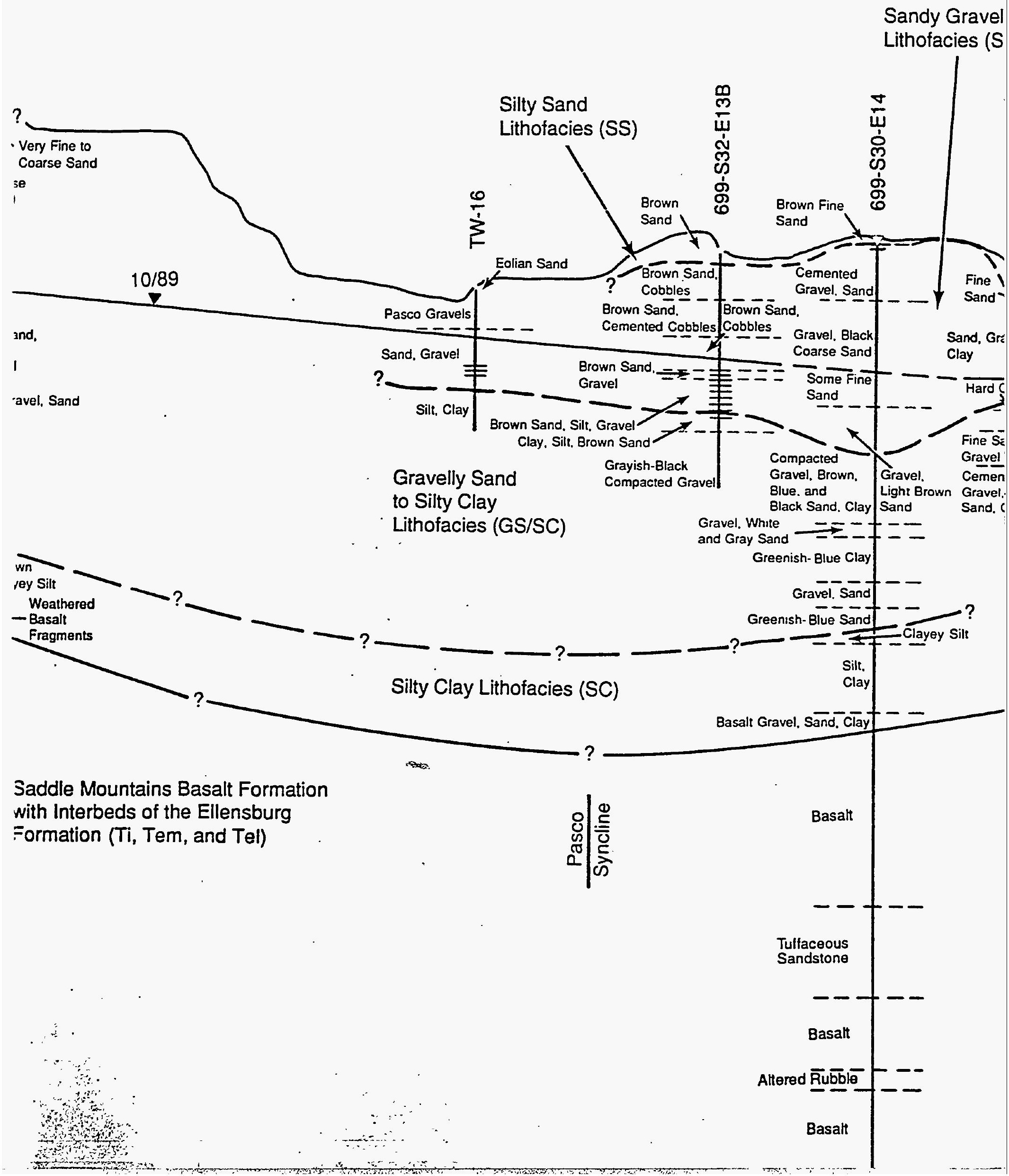




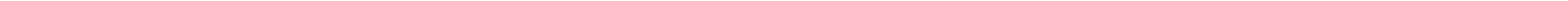




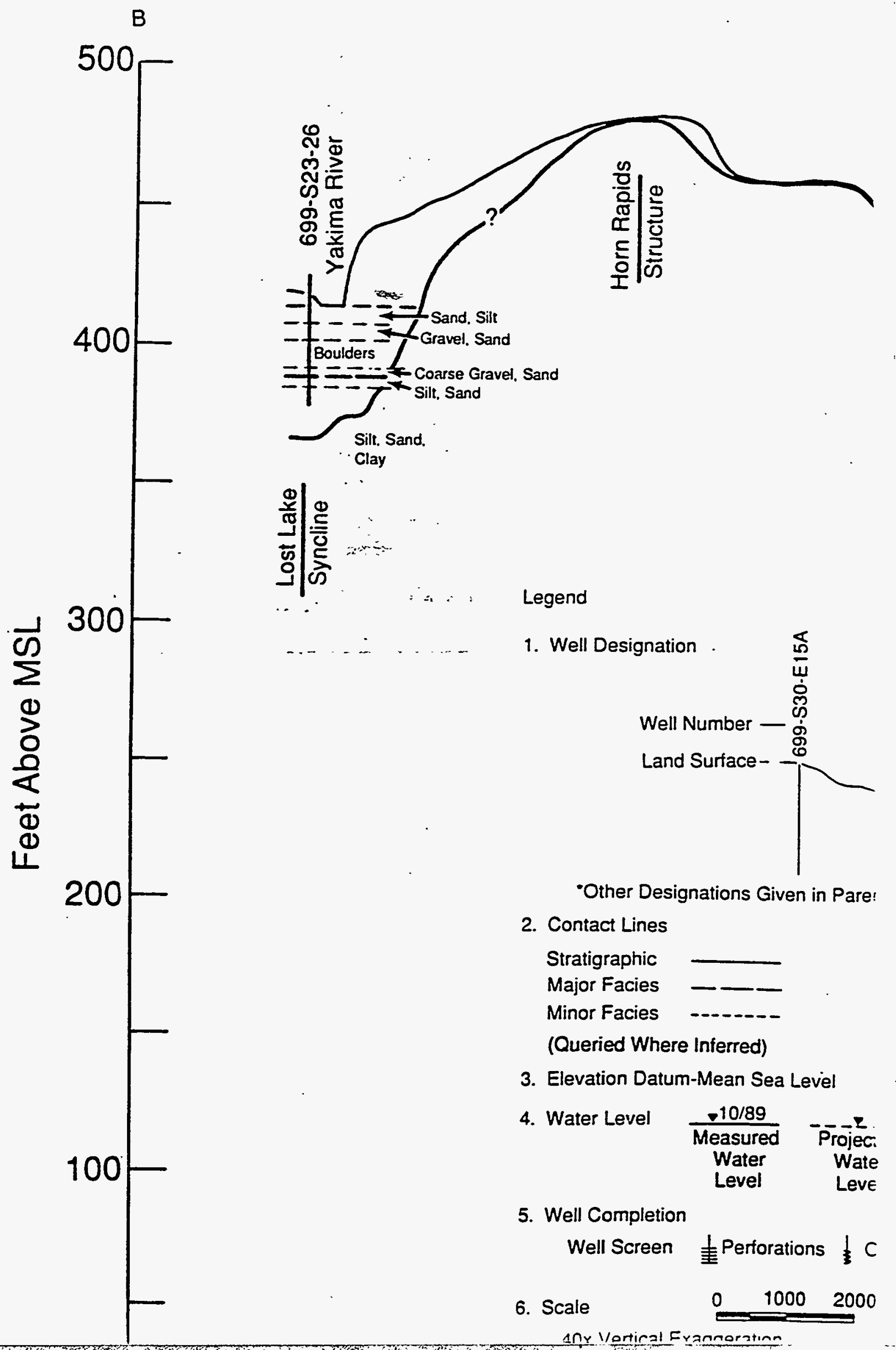




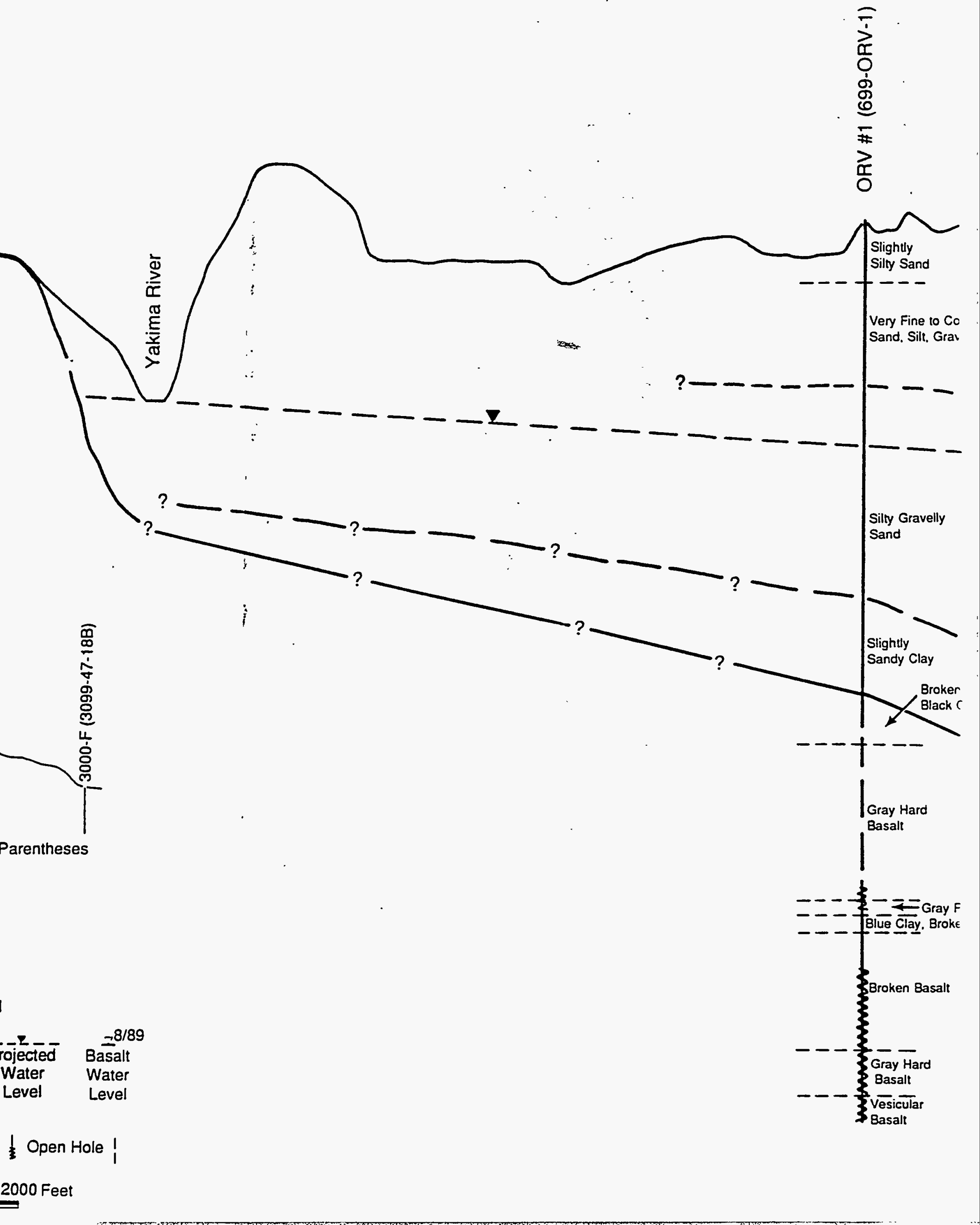




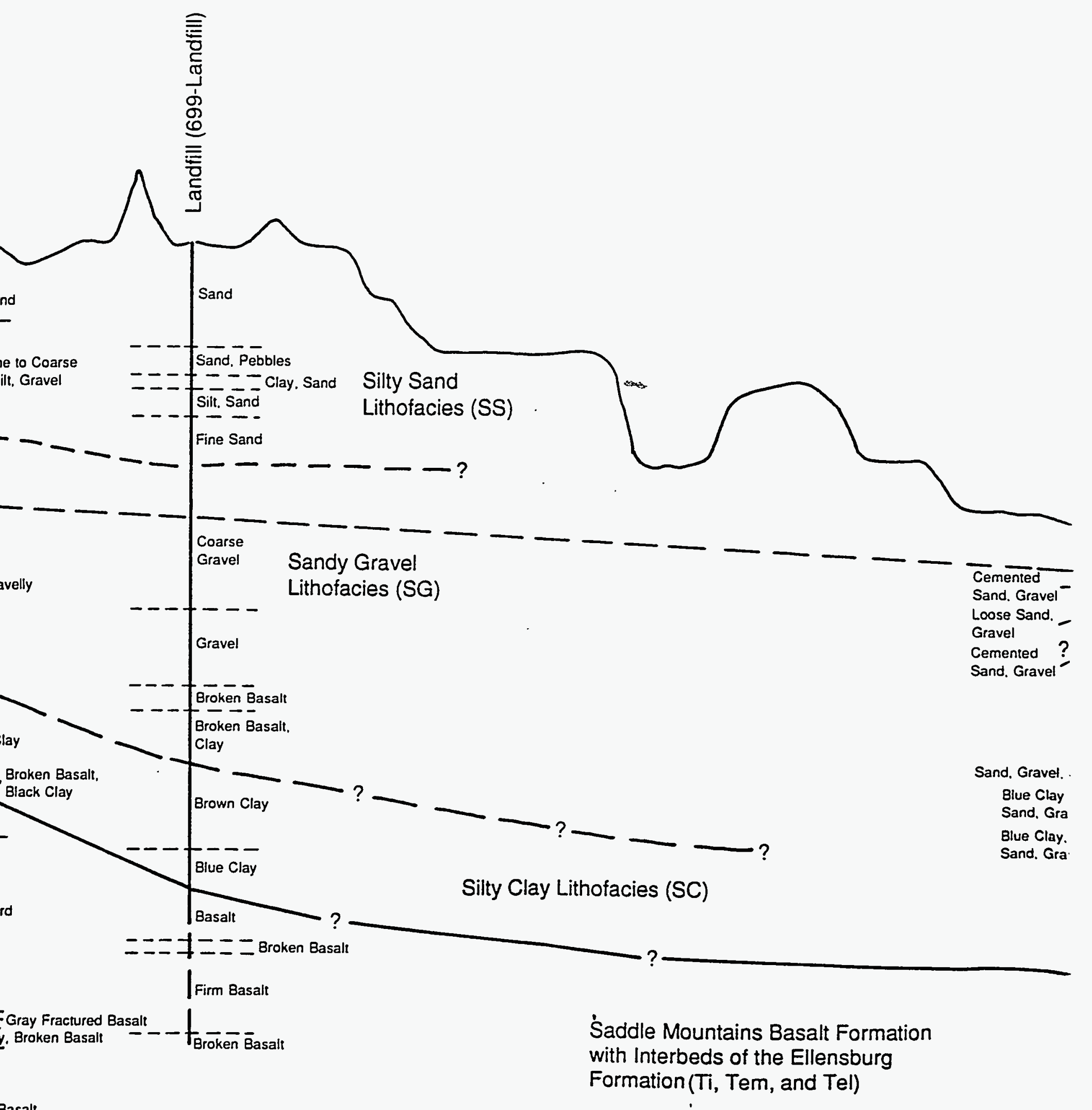


$B^{\prime}$
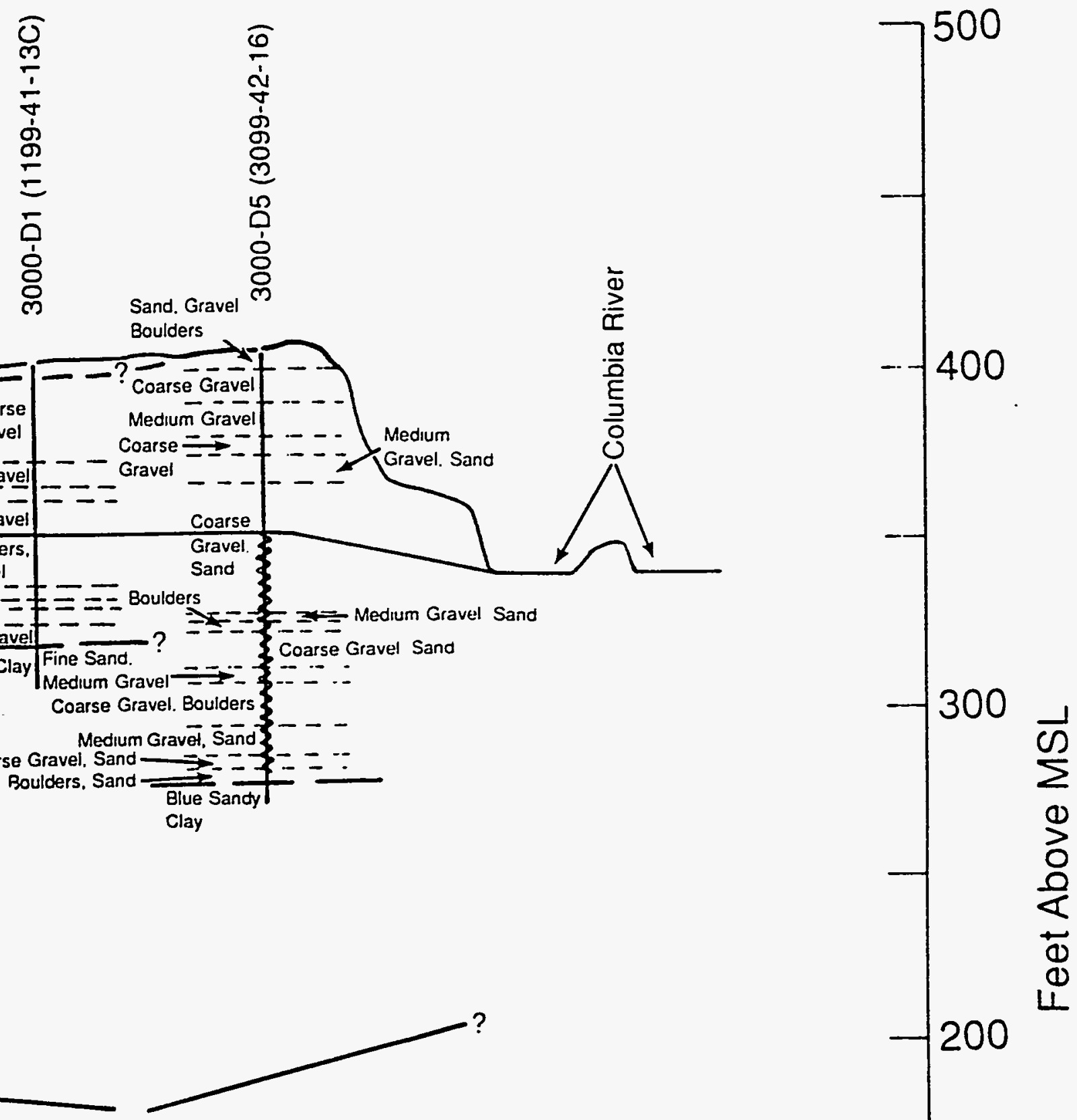

Coarse Gravel Sand

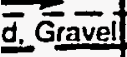

d. Gravel

Fine Sand.

Medium Gravel $=-2$

Coarse Gravel. Boulders

Medium Gravēt, S̄and

Coarse Gravel, Sand $=-3=-$

Boulders, Sand Blue Sandy

Clay

0
0
0
1
1
1
1
1

200

○| 

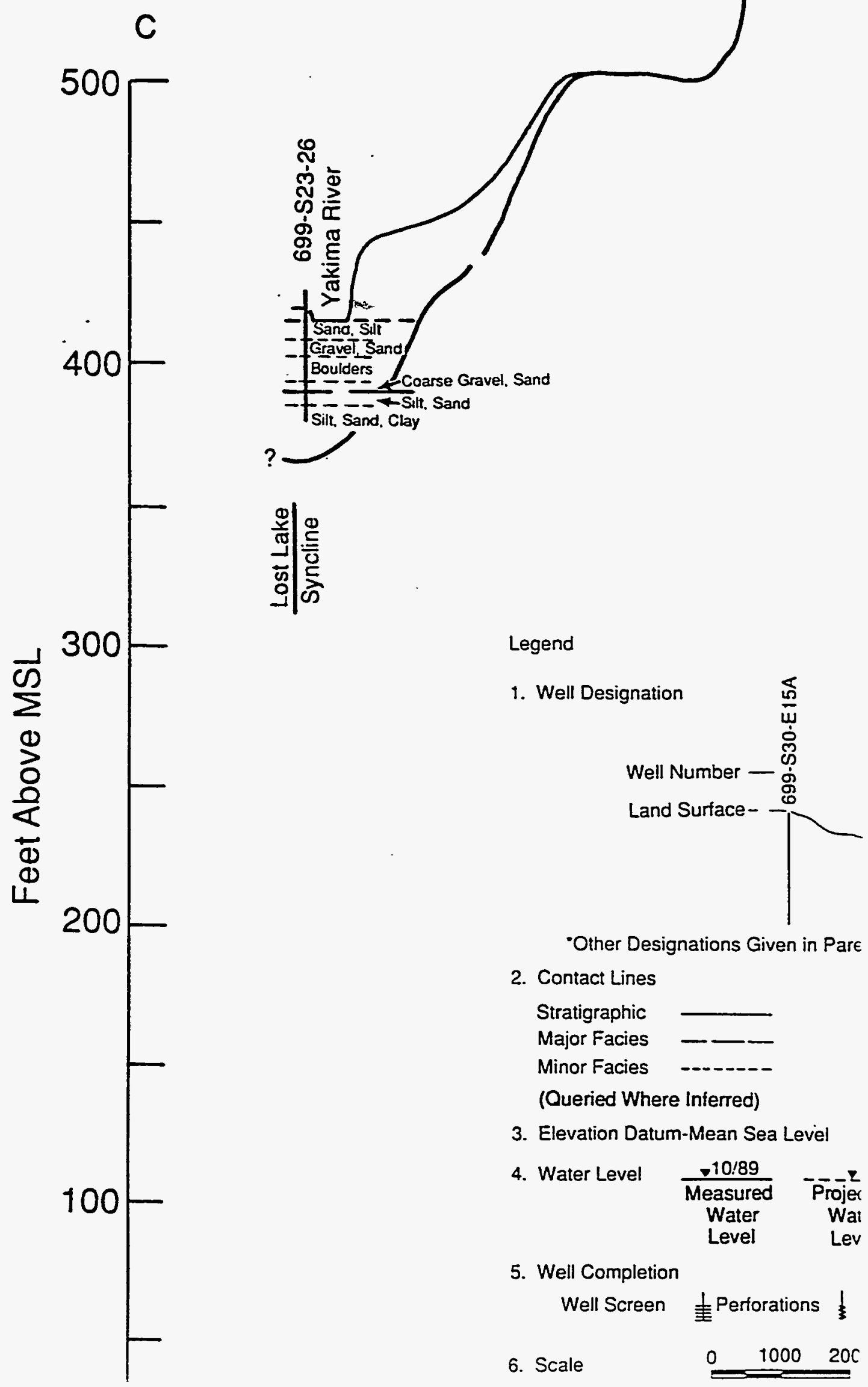

Legend

1. Well Designation

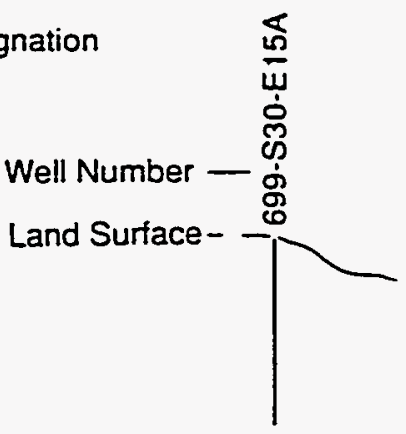

- Other Designations Given in Pare

2. Contact Lines

Stratigraphic

Major Facies

Minor Facies

(Queried Where Inferred)

3. Elevation Datum-Mean Sea Level

4. Water Level $\frac{-10.89}{\text { Measured }}-\overline{\text { Projer }}$

Water Wai

Level Lev

5. Well Completion

Well Screen Perforations

6. Scale

$0 \quad 1000 \quad 20 \mathrm{C}$ 

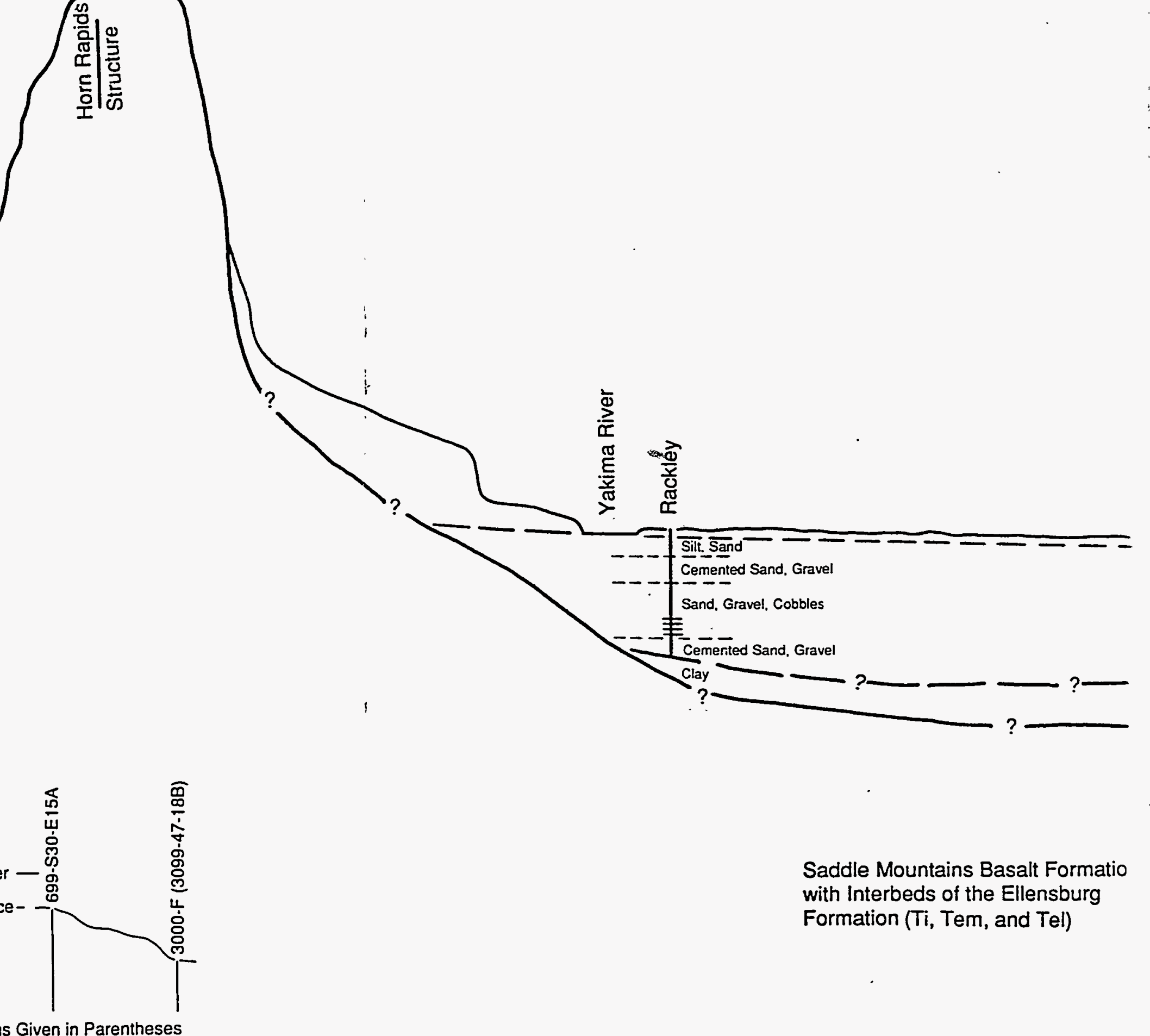

Saddle Mountains Basalt Formatio with Interbeds of the Ellensburg

Formation (Ti, Tem, and Tel)

red)

n Sea Level

185

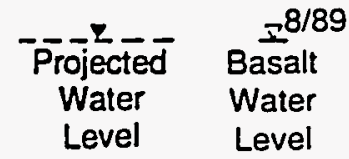

erforations $\$$ Open Hole !

10002000 Feet 


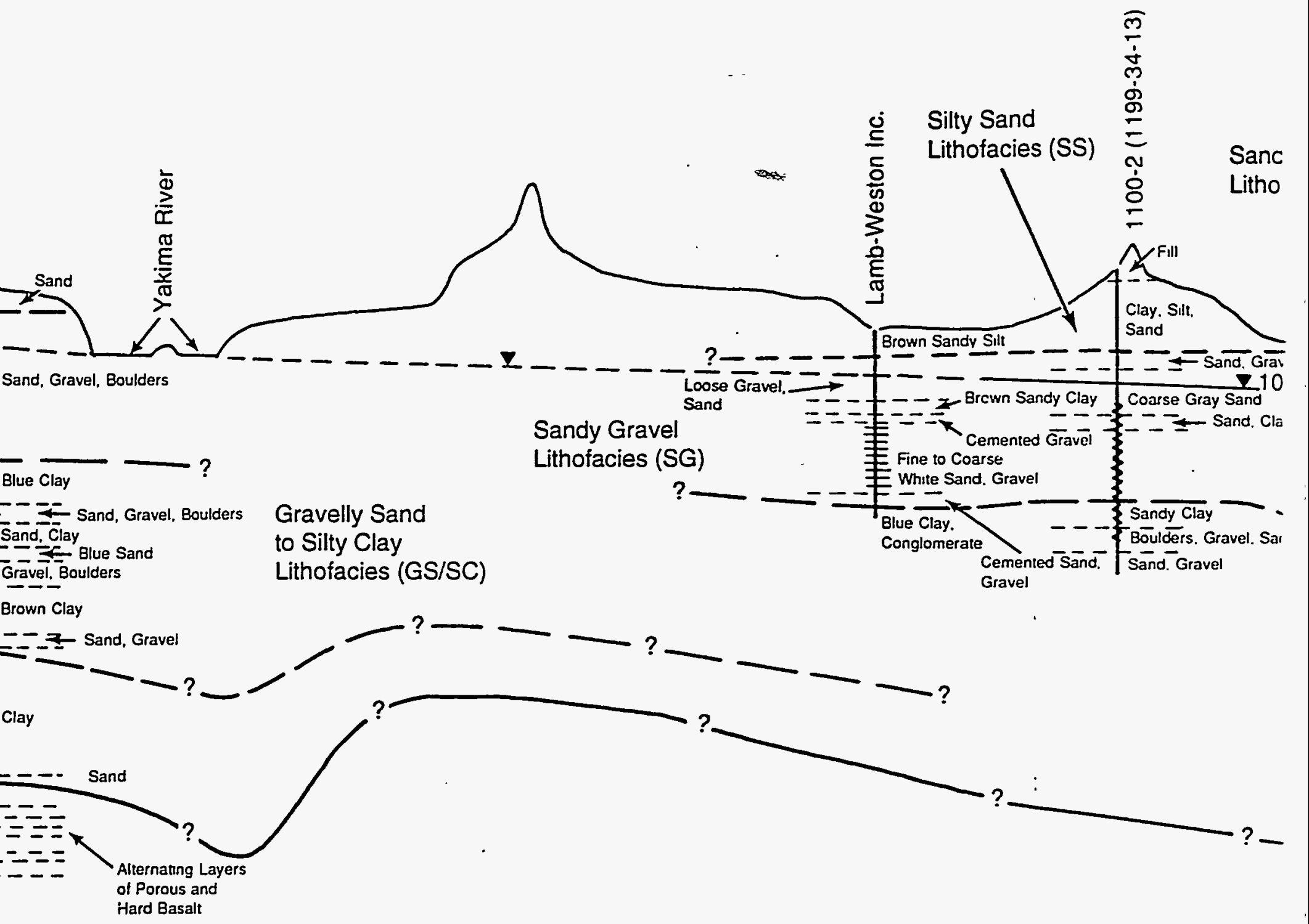

Gray Hard Basalt 


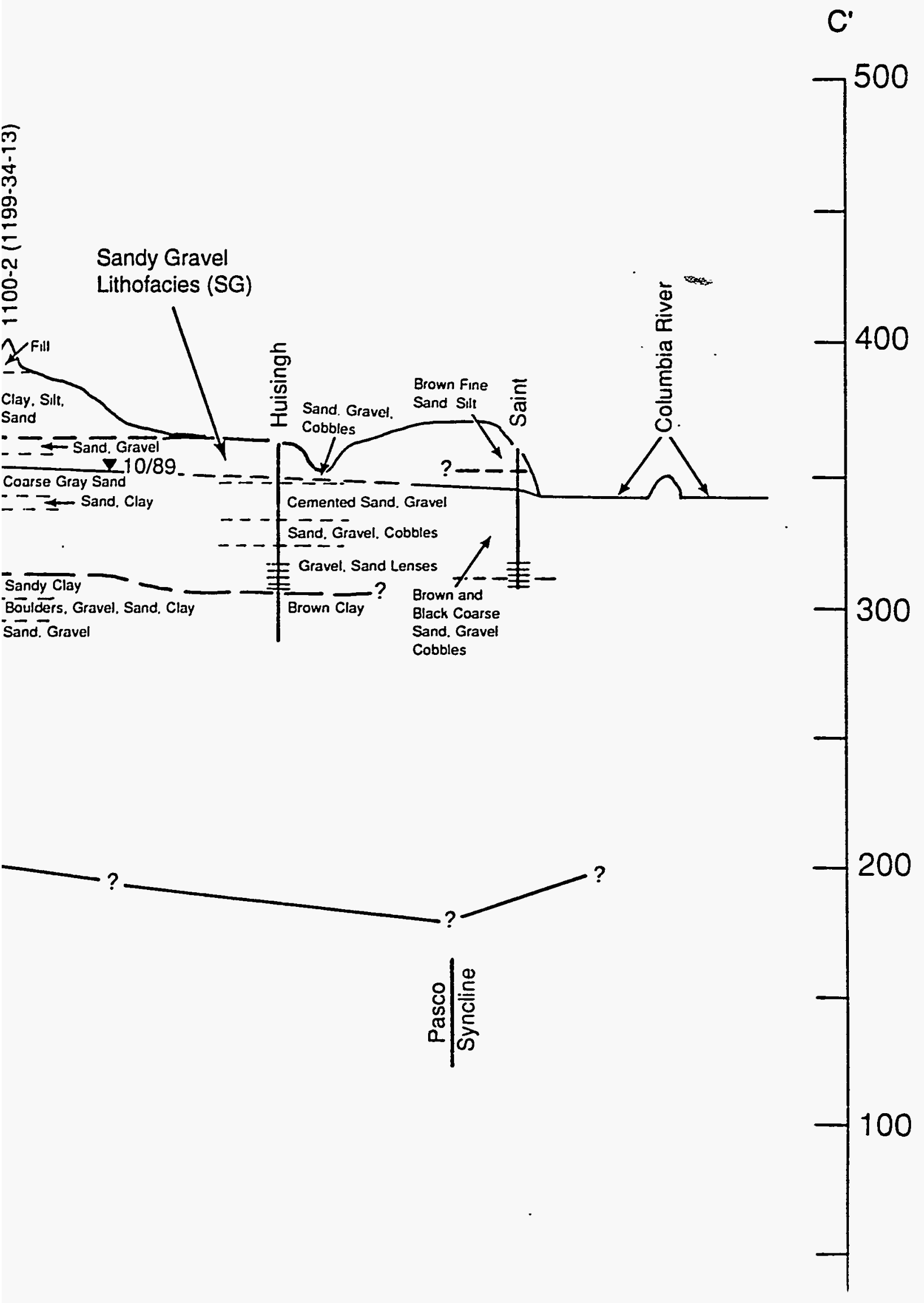




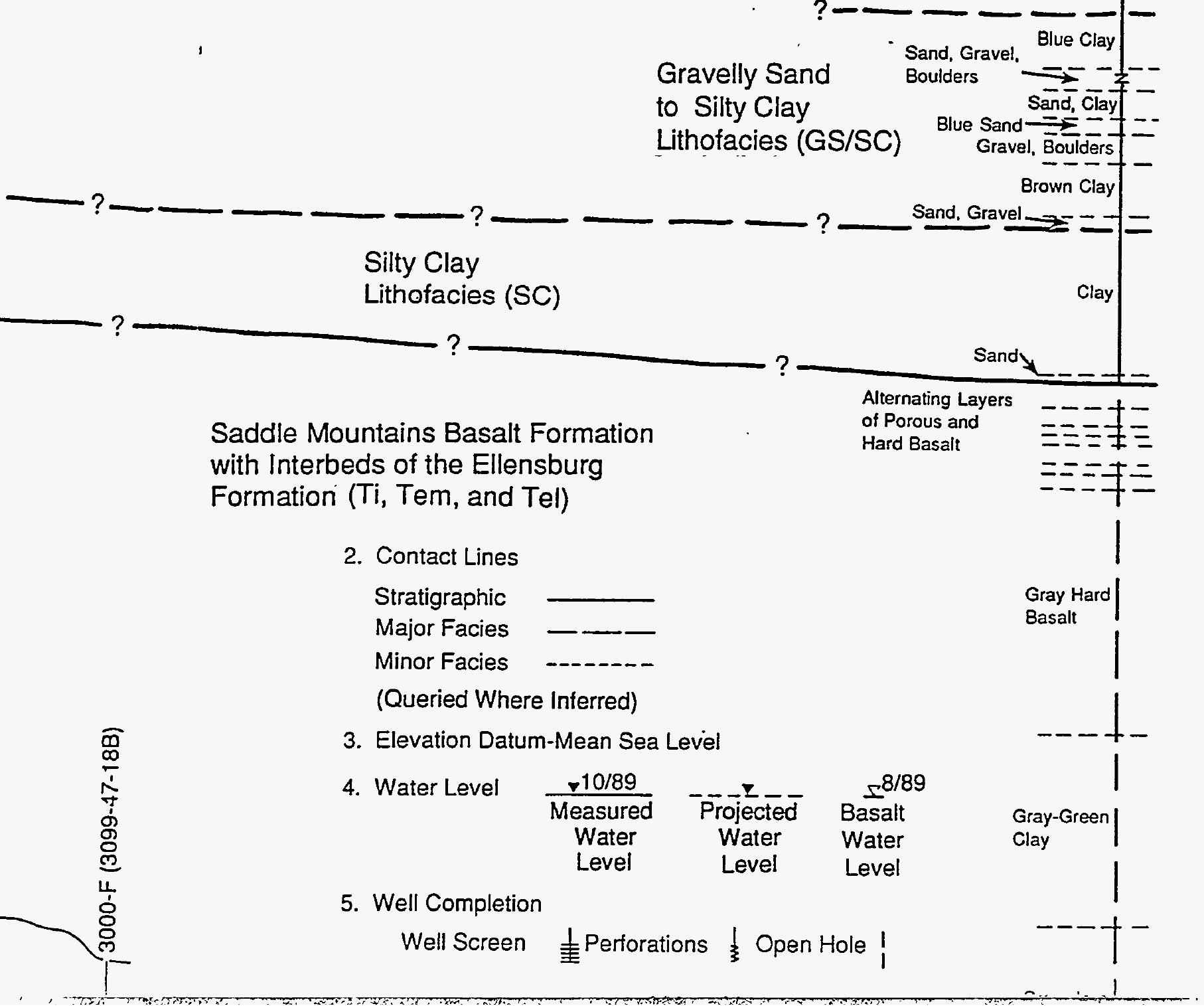




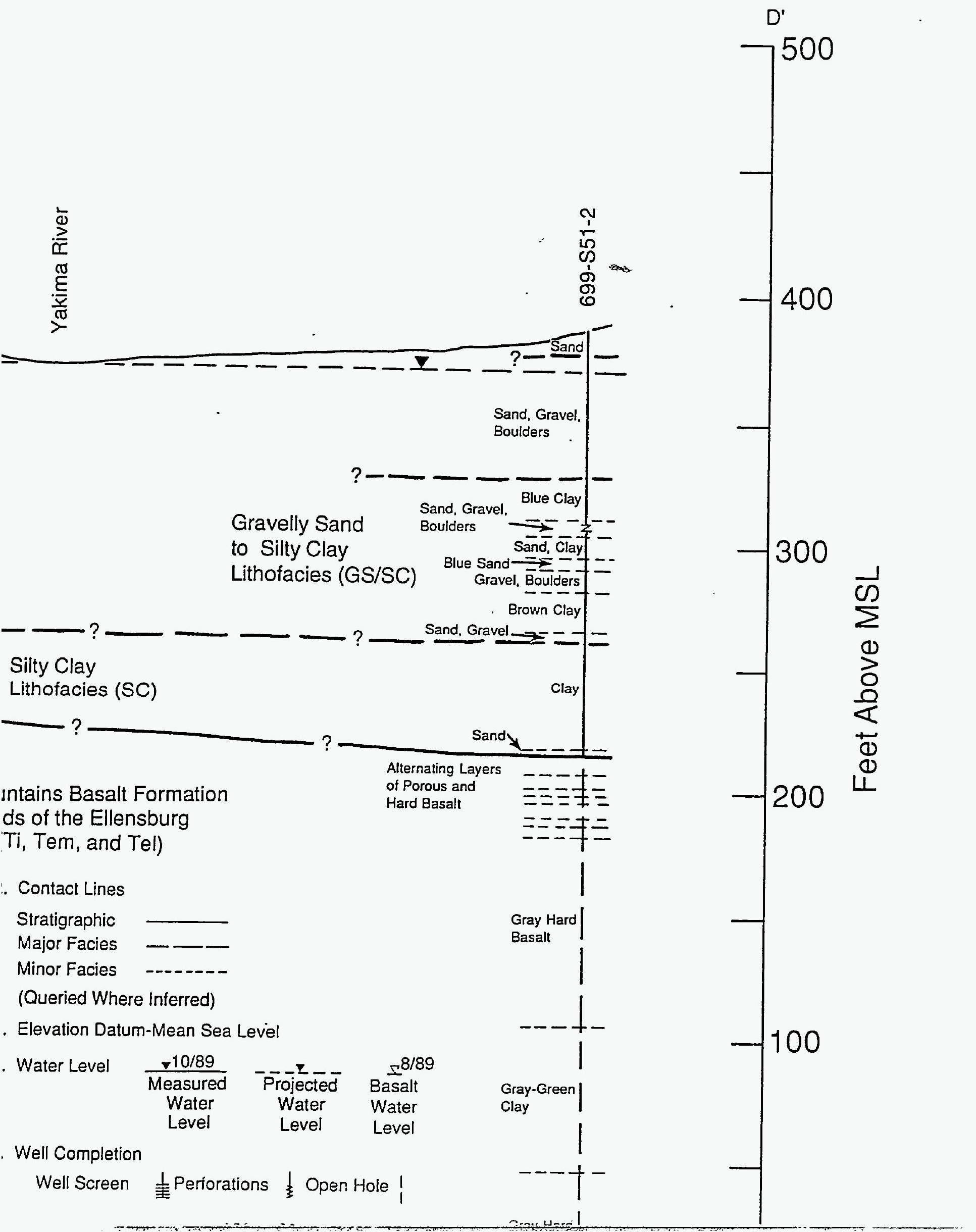




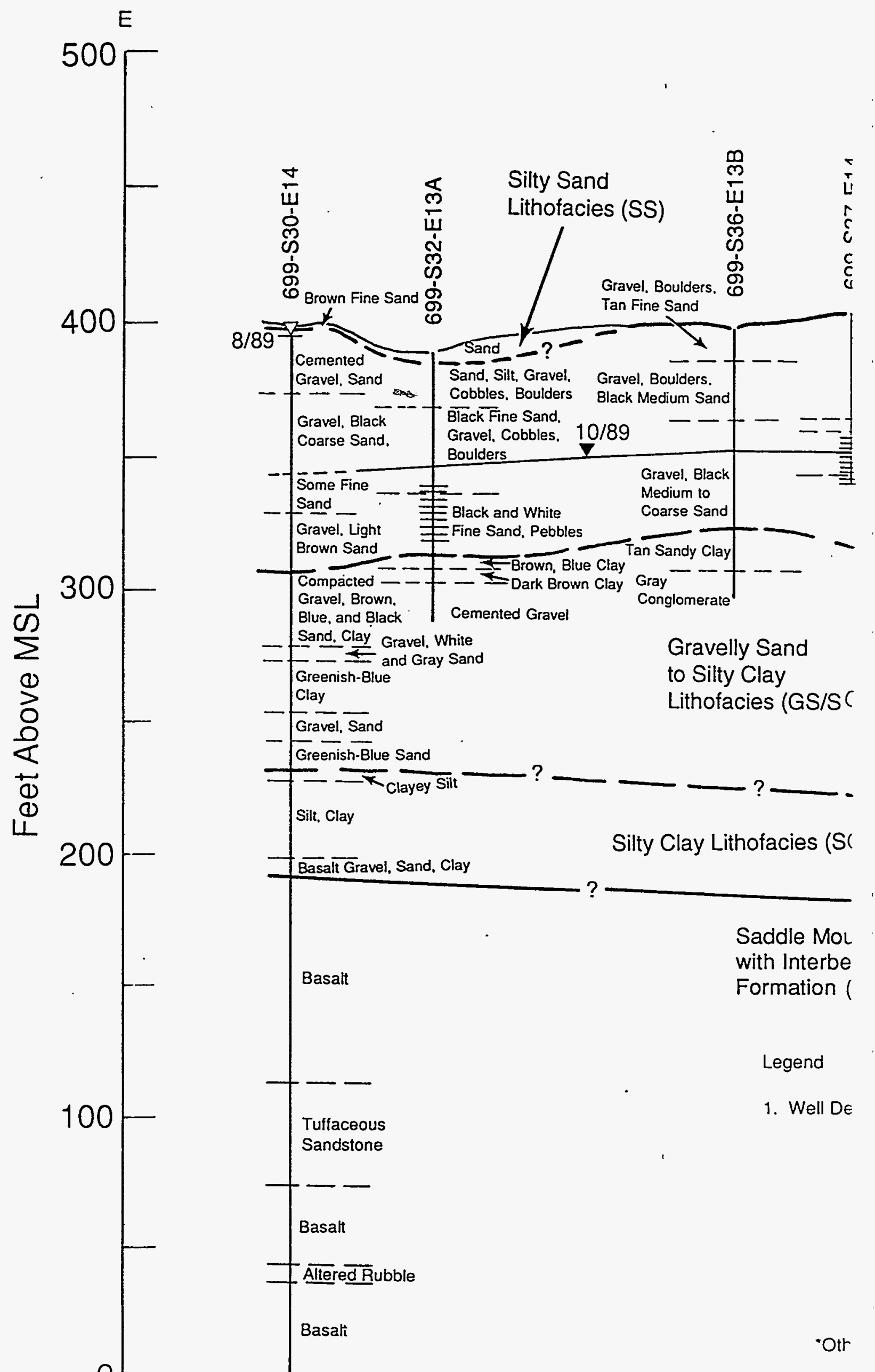




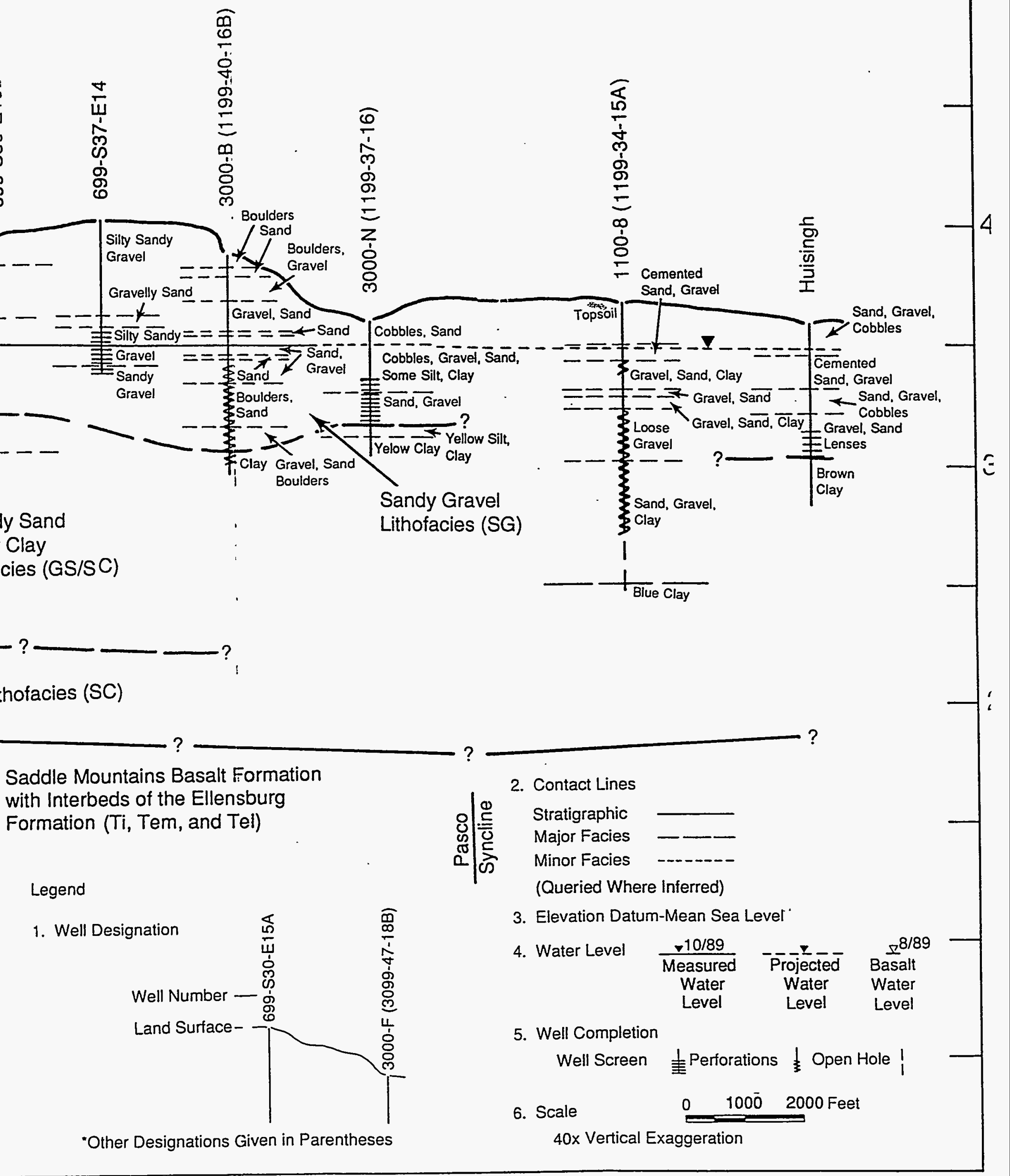




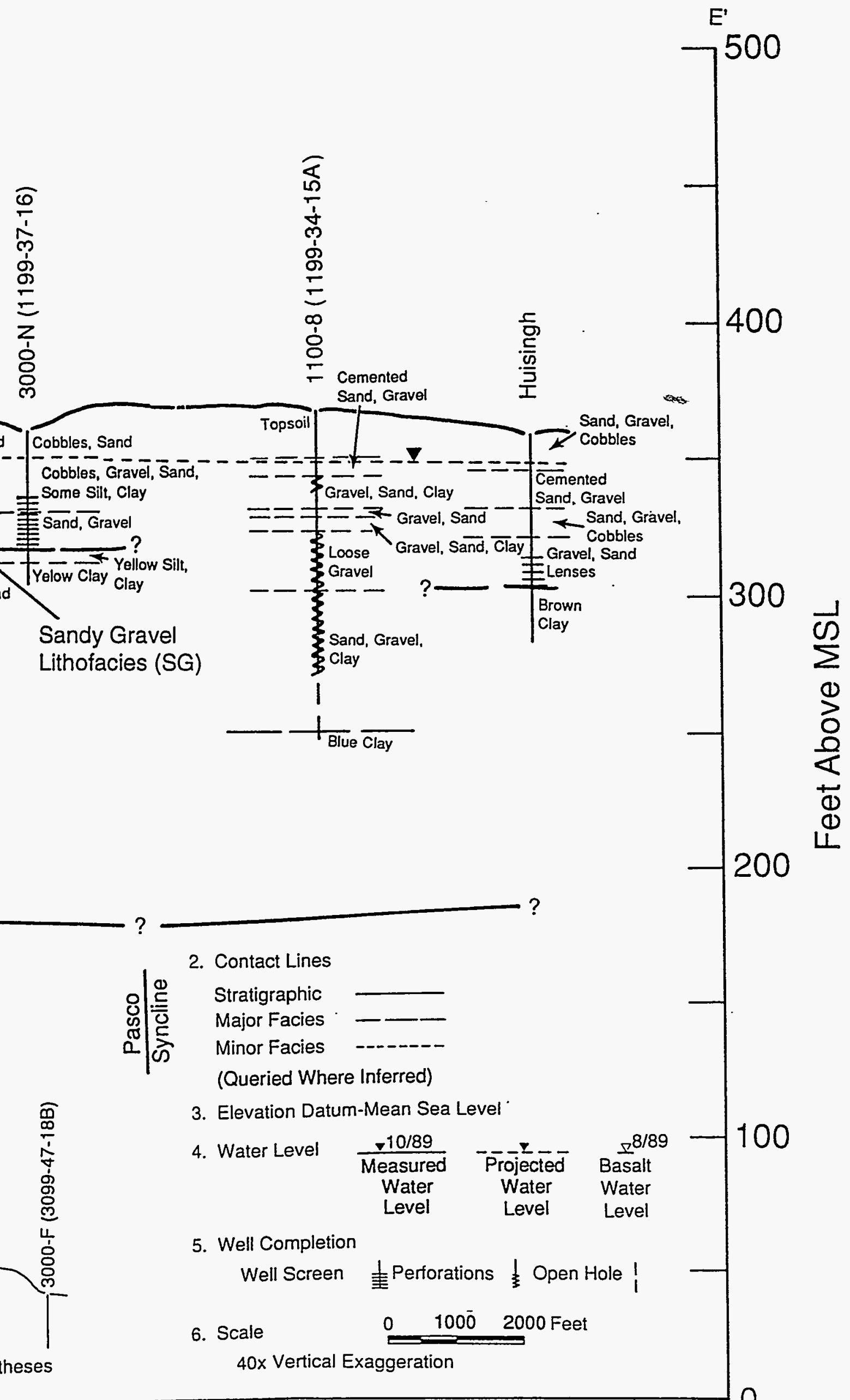

